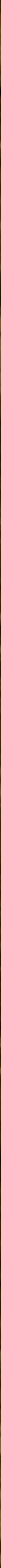




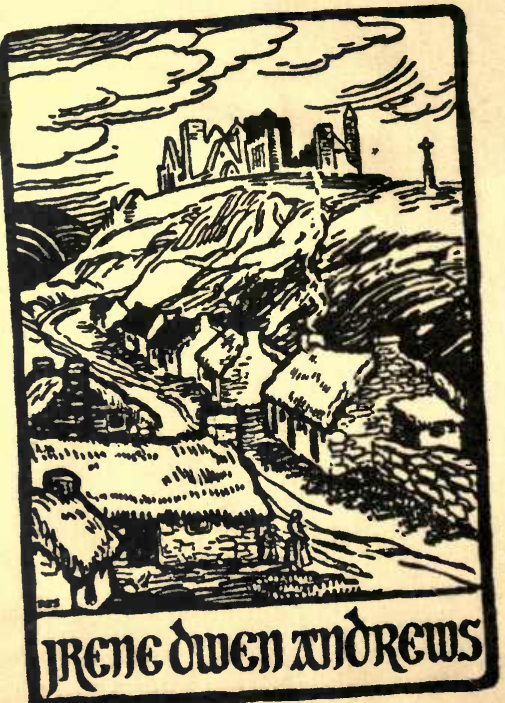



Lrene Wren Gudrews

$$
\text { may } 1927
$$





\section{$\begin{array}{llll}\mathrm{T} & \mathrm{O} & \mathrm{U}\end{array}$}

I N

I R E I A N D :

W I T H

GENERAL OBSERVATIONS

O N T H E

PRESENT STATE OF THATKINGDOM. M A DE I N

THE YEARS 1776, 1777, and 1778, A N D

BROUGHT DOWN TO THE END OF 1779.

BY ARTHUR YOUNG, Efq; F. R. S. Honorary Member of the Societies of DUBLIN, YoRK and MANCHESTER; the Oeconomical Society of BERNE; the Palatine Academy of Agriculture, at MANHeim, and the

- Phylical Society at ZURICH.

\section{O L. II. \\ D U B L I N: \\ PRINTED BX JAMEs WILLIAMS,}

For MEssRs. WHITESTONE, SLEATER, SHEPPARD, WILLIAMS, BURNET, WILSON, JENKIN, WOGAN, VALIANCE, WHITE, BEATTY, BYRN, AND BURTON, 

A

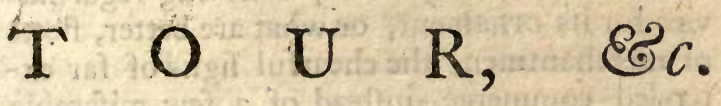

CEPTEMBER the 8 th, left Drummoland, Sir Lucius rode with me through Clonmelly, to the hill above Bunratty Caftle, for a view of the Shannon. Clonmelly is a divifion of Drumline parín, 900 acres of Corkafs land in one lot, which is cheap, at 3 os. an acre. I went into fome of the paitures, which were ftocked with very fine bullocks, at the rate of one to every acre. In this neighbourhood, Mr. Hickman has a clofe of 20 acres, which, when in his own hands, fattened him 2 cows per acre, and in winter fed him 100 wethers, to the improvement of os. each. The profit by the cows was 41 , and by the theep Il ros. per acre: in all $51.5 \mathrm{~s}$. I had this fact from his own mouth. The richnefs of thefe corcaffes, which are flat lands on the river fide, that have been gained at different times from the falt water, is very great. When in tillage, they fometimes yield extraordinary crops; 50 ftat barrels an acre of bere have been known, fixteen of barley, and from 20 to 24 of oats are VOL. II. 


\section{L L I $M$}

common crops. From Clorimelly Hill, the profpect is very noble. There is a view of the Shannon from Limerick to Foynes Illand, which is 30 miles, with all its bays, bends, iflands, and fertile thores. It is from one to three miles broad, a moft noble river, deferving regal navies for its crnament, or what are better, fleets of merchantmen, the chearful figns of far extended commerce, inftead of a few miferable firhing-boats, the only canvafs that fwelled upon the fcene: but the want of commerce in her ports is the misfortune, not the fault of Ireland. Thanks for the deficiency to that illiberal fpirit of trading jealoufy, which has at times actuated and difgraced fo many nations. The profpect has a noble outline in the bold mountains of Tipperary, Cork, Limerick, and Kerry. The whole view magnificent.

At the foot of this hill is the caftle of Bunratty, a very large edifice, the feat of the O'Brier's, princes of Thomond; it ftands on the bank of a river, which falls into the Shannon near it. About this caftle, and that of Rofmanagher, the land is the beft in the county of Clare; it is worth 1. I3s. an acre, and fats a bullock per acre in fummer, befides winter feed.

To Limérick, through a chearful country, on the banks of the river, in a vale furrounded by diftant mountains. That city is very finely fituated, partly on an ifland formed by the Shannon. The new part, called Newtown 


\section{I $M \quad \mathrm{E} \quad \mathrm{R} \quad \mathrm{I} \quad \mathrm{C} \quad \mathrm{K}$.}

Pery, from Mr. Pery, the fpeaker, who owns a confiderable part of the city; and reprefents it in parliament, is well built. The houfes are new ones, of brick, large and in right lines. There is a communication with the reft of the town by a handfome bridge of three large arches, erected at Mr. Pery's expenfe. Here are docks, quays, and a cuftom-houfe, which is a good building, faces the river, and on the oppofite banks is a large quadrangular one, the houfe of induftry. This part of $\mathrm{Li}$ merick is very chearful and agreeable, and carries all the marks of a flourining place.

The exports of this port are beef, pork, butter, hides, and rape-feed. The imports are rum, fugar, timber, tobacco, wines, coals, bark, falt, \&c. The cuftoms and excife, about 16 years ago, amounted to 16,0001 . at prefent 32,0001 . and rather more four or five years ago.

Whole revenue

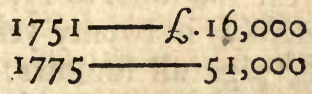

Revenue of the port of Limerick, year ending

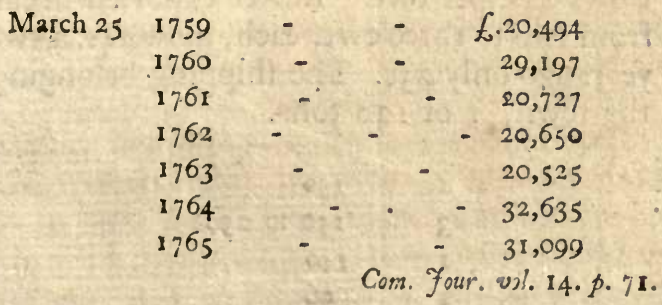




\section{$6 \quad \mathrm{~L} I \mathrm{I} \quad \mathrm{E} \quad \mathrm{R} \quad \mathrm{I}$ C K.}

Account of duties paid on goods imported and ex* ported in Limerick.

\begin{tabular}{|c|c|c|c|c|c|c|}
\hline Yers & $\operatorname{Imp}$ & ts. & & & & \\
\hline 64 & $19,86 y$ & 15 & 9 & f.2195 & & \\
\hline 765 & 21,332 & 4 & 8 & 1964 & 5 & \\
\hline 66 & 16,729 & 8 & 2 & 1815 & II & \\
\hline 67 & 16,316 & 10 & 0 & 2365 & 4 & \\
\hline 768 & $16,57 \mathrm{I}$ & 12 & 8 & 2229 & 17 & \\
\hline 1769 & 20,237 & 12 & 7 & 1855 & 0 & \\
\hline 70 & 22,138 & 0 & 4 & $194 \mathrm{I}$ & 3 & \\
\hline 771 & 20,213 & 12 & 6 & 2455 & 2 & \\
\hline 72 & 22,003 & 2 & 0 & 3046 & II & Id \\
\hline 77. & 20,606 & 15 & 7 & 2282 & I & \\
\hline 17 & 77,317 & 0 & 9 & 2150 & 13 & \\
\hline 77 & $\pm 6,979$ & 10 & 6 & 2647 & 5 & \\
\hline
\end{tabular}

Salted, laft year, 43,700 pigs; average $1 \frac{1}{2} \mathrm{lb}$. Horned cattle (of which many were cows) 12,200. The number of bullocks killed here in a year amounts to 13,000 ; increafed pretty confiderably in twenty years. They have been falting pigs all fummer. Pork now 29's. $3 \mathrm{~d}$. per cwt. was only I2s. feven years ago. The value of bullocks hides are on an average 35 s. Cows 24s. per cwt. Butter exported in canks, from two to three $\mathrm{cwt}$. each, now $44 \mathrm{~s}$. a cwt. 6 years ago only 2,5 s. The fhipping belonging to the town, I of 120 tons.

$\begin{array}{ll}I & 150 \\ 3 & 150 \text { to } 250 \\ I & 140 \\ I & 96 \\ I & 50\end{array}$




\section{I $M$ E $\quad \mathrm{R}$ I $\mathrm{C}$ K.}

but not increafed. A good deal of rape feed shipped off for Holland, and one hundred tons of rape cakes to Wells and Lynn in Norfolk, at 4 os. a ton. Till this laft year at 25 s. a ton. Many thoufand loads of dung thrown into the Shannon, both in the town and many places along the river. Within five or fix years they have taken fome away, but not much. Town parks let at 41,4 s. to 5 i. for ten miles every way the rent is $255^{\text {, to }} 30 \mathrm{~s}$. Much flour goes to Dublin from this county and Tipperary on the land-carriage bounty. There is a great increafe of tillage : thrice the corn grown that there was formerly: There has been much pafturage broken up on this account; fome bullock land, and fome theep land. Great quantities of butter made within a few miles of Limerick. Scarce any fpinning here, or in the neighbourhood, either of wool or flax. The poor live upon potatoes and milk, generally fpeaking, with fome oatmeal. They do not all keep cows; thofe who do not, buy, and pay id. for three quarts of fkim milk. The rent of their cabbins and one-fourth of an acre 15 s. to 20 s. build them themfelves. They are in a better fituation in moft refpects than twenty years ago. Pigs are much increafed, chiefly or entirely bred by the cottars, and the high price has been of prodigious confequence to them. They are much better clad than they were. Date their increafe of this from the open cattle trade to England. Population has much increafed within twenty years, and the city alfo, but was more populous fix years ago 


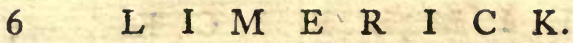

than at prefent. Emigrations were known from hence; two hips went commonly till the war. Between 1740 and 1750 , there were only four carriages in and about Limerick, the Bifhop's, the Dean's, and one other Clergyman's, and one neighbouring Gentleman's. Four years ago there were above feventy coaches and poft-chaifes in Limerick, and one mile round it. In Limerick diftrict, now 183 four wheeled carriages; I 15 two wheeled ditto.

\section{Price of Provifons.}

Wheat, is. id. a ftonet. Barley and oats, $5 \mathrm{~d}_{\frac{3}{4}}^{3}$, to $\epsilon \mathrm{d}$. Scotch coals, $18 \mathrm{~s}$. Whitehaven, 2:s. A boat load of turf, 20 tons, $45 s$.

Salmon, three halfpence

Trout, 2d. very fine, per lb.

Eels, 2d. a pound

Rabbits, 8d. a pound

Teal, rod, a couple,
Wild ducks, 2od, to 2 s.' a couple

Plover, 6d. a couple.

Widgeon, tod. ditto.

Hares, is. each, commonly

fold all the year round

Woodcocks, 2od. to 2s. 2 d.

a brace

Oyfters, 4 d, to Is, a 100

Lobfters, Is. to $x s, 6 d$, if good.

Land fells at twenty years purchafe. Rents were at the higheft in 1765 , fell fince, but in four years have fallen 8 s. to ios, an acre about Limerick. They are at a ftand at prefent, owing to the high price of provifions from pafture. The number of people in Limerick, are computed at 32,000 , it is exceeding populous for the fize; the chief ftreet quite crowded; many fedan chairs in town, and fome hackney chaifes. Affemblies the year round, 


\section{I M E R I C K.}

in a new affembly-houfe, built for the purpofe; and plays and concerts common.

Upon the whole, Limerick muft be a very gay place, but when the ufual number of troops are in town, much more fo. To fhew the general expenfes of living, I was told of a perfon's keeping a carriage, four horfes, three men, three maids, a good table, a wife, three children, and a nurfe, and all for 5001 . a year.
A footman, - $\quad \begin{aligned} & \text { 1. s. d. to s. d. } \\ & 4.0 \text { to } 60\end{aligned}$
A profeffed woman cook
A houfe-maíu
A kitchen maid
A butler,
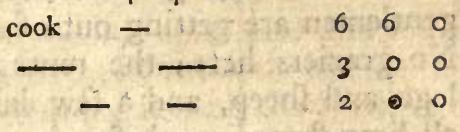

A . barrel of beef or pork, $200 \mathrm{lb}$. weight. Veffels of 400 tons can come up with fpring tides, which rife 14 feet.

September $q^{\text {th }}$, to Caftle Oliver; various country, not fo rich to appearance as the corcaffes, being fed bare: much hilly fheep-walk, and for a confiderable way, a full third of it potatoes and corn : no fign of depopulation. Juft before I got to the hills, a field of rag. wort (Jenefro jecobrea) buried the cows. The firt view of Caftle Oliver interefting. After rifing a mountain fo high that no one could think of any houfe, you come in view of a vale, quite filled with fine woods, fields margined with trees, and hedge plantations climb- 
ing up the mountains. Having engaged myfelf to $\mathrm{Mr}$. Oliver, to return from Killarney by his houfe, as he was confined to Limerick by the affizes, I thall omit faying any thing of it at prefent.

September Ioth, reached Annfgrove, the feat of Richard Aldworth, Ef́q; to whom I am obliged for the following particulars. Farms about Annfgrove, in the parifh of Caftle Town Roche, rife from 50 acres to 200 , a few fmaller. It abounds exceedingly with land jobbers, who have hired large tracts, and re-let them to tenants, and thoie to under ones, but gentlemen are getting out of this fyftem now. No graziers here; the rents are made by tillage and theep, and a few dairies; the foil is all lime-ftone, much fine hazel loam, from 4 to 18 inches deep. $A$ hill runs through this country, which is wet woodcock clay. It lets in general from 75 . to 22 s. plantation acre, average $15 \mathrm{~s}$. The barony of Orrery in this county (Cork) is as rich as Limerick; lets from 25 s. to 35 s. an acre. The next in Fermoy 1.3s. Duhallow has much mountains and unimproved; vaft tracts of it heath, but rears at prefent great numbers of young cattle, and many dairies, average rent $7 s$. Condons and Clangibon ${ }^{5}$ s. Imokilly, a very tine corn country. Barrymore, rough, 7s. Barrets mountains, with bog, $4 \mathrm{~s}$. Munherry, rough and uncultivated, $4 \mathrm{~s}$. Kinalea yields more com than any of them; lets at I 4 s. the Englifh acre. The baronies of Kerrycurihy and Courcy's upon the coaft are all high let, from fituation, Ios. the 


\section{A N N S G R O V E,}

fos the Englin acre. In Carbery, there are great quantities of wild country, and much uncultivated; provifions are extravagantly cheap, from want of communications. The whole county, upon an average, $7 \mathrm{~s}$. The courfe of crops about Annfgrove ;

I. Potatoes, 2. Wheat, 3. Oats. 4. Oats, 5. Oats. 6. Oats. 7. Leave it for three years.

1. Potatoes. 2. Bere. 3. Oats. 4. Oats, 5. Oats. 6. Oatş. 7. Leave it for three or four years.

Flax fown in patches upon lay, and fome. times after potatoes. Potatoes they plant in a moft flovenly manner, leaving the fmall ones in the ground of the firft crop, in order to be feed for the fecond, by which means they are not liced: fometimes a fharp froft catches them, and deftroys all thefe roots. They plant many on grafs without dung, on the rich land, and pay 25 s. to 5 os. an acre for liberty to do it. Of wheat they fow 20 ftone per acre, and get on an average 7 barrels. They feldom fow it till February; they think the firft dark nights in that month the beft feed time in the year. But it is in fact owing to their taking their potatoes up fo late, which they do not begin till near Chriftmas. Some, however, are earlier, and get their wheat in in November and December. They fow, of oats, a kilderkin, or 4 buthels of 32 gallons. Neither peafe, beans, nor rape in the country, but turnips and clover are creping in among gentle- 


\section{A N N S G R O V E.}

men. Flax is fown by every body for their own ufe, which they fpin, and get woven intolinen for themfelves, and what they have to fpare, fell in yarn. There are very few of thefe weavers.

Lime is the great manure; they lay 100 common barrels to the acre, lafts feven or eight gond crops, and leaves the ground the better for it ; but their principle is to exhauft as faft as poffible in confequence of liming. It cofts them $8 \mathrm{~d}$. a barrel roach. Burn with culm from the coal pits in the barony of Duhallow. This coal is only ufed for drying malt, fmiths forges, \&c. but not for common fuel. They have alfo a very rich manure, which is rotten lime-ftone, as they call it. It is a rock, and rifes very hard, like a lime ftone quarry, but when expofed to the air, falls into fand; it has a ftrong fermentation with acids, and gives great crops: they do not, however, carry it above a mile and half. Paring and burning they are very fond of for potatoes, and fome. times for bere, but the landlords prevent the practice. They get very great crops by it, and do it to chufe on wafte lands; pare with an inftument they call a graffane, and the hufbandry they call graffaning and burning. It is a very ftrong hoe with which they cut up the turf, rolling it up with their foot as they do it, and leaving it to dry in order to burn. They do it in March or April for their potatoe planting; and though it makes them very late, yet the crops never fail. Soot is thrown away, and 


\section{A N N S G R O VE.}

in general malt duft, as they do not fcreen their malt. The fences of common farmers are making banks, and fowing furze feed. Grafs lands are applied to feeding theep and cows. Their fheep fyrtem is that of breeding. They keep their lambs till they are two year old we. thers, and then fell them to thofe who fatten near the coaft. Thefe they fell at is s, to $18 \mathrm{~s}$. each; and they cull fome ewes every year, which the butchers buy at $14 \mathrm{~s}$. or $15 \mathrm{~s}$. They fheer generally on an average 4 lb. wool, which fells $13^{s}$. to 195 . $6 \mathrm{~d}$ a ftone, at which amazing price fome was fold this year. The cottars have all theep, which they milk for their families. The poor people reckon their cattle by collops, that is proportions. The heavieft collop is fix theep, the next is a horfe, the next two heifers, and laftly the cow. Flocks rife to 500 theep; no folding. Dairies are eonfiderable. They rife from 20 to 50 cows, are employed in making butter only; in fome parts of the county they make very good cheefe. An acre and a quarter maintains a cow in fummer and winter grafs and hay. The farmer generally lets them out to dairymen, at 21 . a cow, and a guinea for horn money; the 4 os. is for the butter, and the guinea for the other produce, four milk, pigs, and calf. But fometimes the rent is in butter a hundred weight per cow delivered in Cork, and the guinea is in canh. The produce is not much more than this cwt. of butter; for the dairyman's profit lies principally in having the grafs of a cow, an acre of ground, and a cabbin and garden, and 


\section{AN NSGROVE.}

they are generally very poor. They rear many pigs on account of the dairies, about a pig to every cow, and a calf to every two cows, which they feed on four milk, giving them no new milk. They are attentive to have their cows calve in May. The tillage of the farmers is all done by horfes; that of the gentlemen by oxen. Four horfes and three men ta every plough, one to drive, one to hold, and another with a pole, bearing on the beam to keep it in the ground; but they do an acre a day, by. means of leaving a great fpace untouched in the middle of each land, where they begin by lapping the fods to meet. To soo acres of tillage they keep about $f_{1} x$ horfes; they make up their teams, borrowing of one another. The chaff is thrown away as every where elfe. Hire of a car and horfe, and driver, is. 6d. a day. Price of carriage a std. per cwt. a mile. In hiring farms, they will manage to take 1oo acres without 100 pence. They will do it without teams or cattle, or any thing; by re-letting the land for potatoes, grafs for cows, \&uc. and if a fellow gets ' 51 . by a 100 acres, he is very well fatisfied. Land fells at 20 years purchafe. Rents, at prefent, at a ftand; rather upon the rife, owing to the price of butter; they fell 3 s. 0 d. in the pound in 1772 and 3 . Tythes are compounded. Wheat pays 8 s. the Englinh acre: fothe 6s. Barley and Bere 6s. Potatoes 6s. Mowing ground 2s. Sheep 3 d. Lambs 2 d, Cows 2d. Leafes are generally $3^{x}$ years, of three lives, or for ever.

The poor people in general occupy from ra to 15 acres; but the moft common way is, 


\section{A N N S G R O V E.}

hiring in partnerfhip in rundale; and they have changedale alfo. Moft of them have only a cabbin and a cabbage garden, and the fize is ufually enough for 100 plants; and their rent for it 20s: in this cafe they pay their neighbour for the grafs of their cow; but I was forry to find that fome of them have no cows. They live the year through upon potatoes, and for half the year have nothing but water with them. They have all a pig, and fome of them feveral, but kill one for themfelves at Chriftmas. Their circumftances are very generally better than twenty years ago, efpecially in cloathing, but in food no great difference. Spinning is the general bufinefs of the women: they fpin infinitely more wool than flax. All the poor keep a collop of heep; as foon as the lamb is fit to kill, they fell it, except enough to keep up the ftock, in order to have the milk. In the little towns of Donneraile, Mitchelitown, Mallow, Kilworth, Kanturk, and Newmarket, are clothiers, who buy up the wool, employ combers in their houfes, who make confiderable wages, and when combed, they have a day fixed for the poor to come and take it, in order to fpin it into worfted, and pay them by the ball, by which they earn one penny three farthings to two-pence a day. The clothier exports this worfted from Cork to Briftol and Norwich. Of late they have worked a good deal of it into ferges, which are fent to Dublin by land-carriage, and from thence to the North, from whence it is fmuggled into England by way of Scotland. The poor people's wool is 
worked into frizes for the ufe of the men. The weavers who work thefe frizes and ferges live about the country in the cabbins. Immenfe quantities of raw wool are fent to Cork from all parts; 500 cars have been feen in a line; and it is fuppofed to be fent in large quantities to France. No emigrations. All the poor people are Roman Catholics, and among them are the defcendants of the old families who once poffeffed the country, of which they ftill preferve the full memory, infomuch, that a gentleman's labourer will regularly leave to his fon, by will, his mafter's eftate.

Ireland has very few fuch farmers as $\mathrm{Mr}$. Aldworth; for above 600 acres in tillage is fuch a bufinefs as I have no where met with. In his improvements, turnips formed a confiderable article; in the year $177^{2}$ he began with them, one acre: in 1774 he had two acres: in 1775, five acres: and this year, eight. He has always hoed them, but not yet in any perfection, though improving. He fed them on the land with theep hurdles; they were chiefly fat wethers, and the benefit he found very great; being able, by no other means, to keep them fat, which the turnips did in great perfection. He alfocarted fome off for ftall-feeding bullocks and cows, which anfwered perfectly well. A very great advantage he found from turnips in the barley which fucceeded, being incomparably better than after any other preparation. Mr. Aldworth is, upon the whole, fo well perfuaded of the advantage of the culture, that he is de- 


\section{A N NSGROVE. 15}

termined to increafe the quantity every year, till he gets a fourth part of his farm under them. The effect of lime was never difplayed in a clearer manner than upon Mr. Aldworth's farm. The foil, I hould obferve, is a loam and brick clay, on a rock of lime-ftone, from nine inches to three feet deep on it; but what is remarkable, all the loofe furface ftones are grit, and all the quarries lime-ftone. Upon this foil he has found the benefit furprifingly great: where he limes he gets very good crops; and where he does not he can get no crops at all. In my life I never faw this clearer difplayed than in two of his fields this year, one wheat and the other barley; in each there was about an acre not limed, but all the reft had 100 barrels an acre; the parts limed had a very fine crop, but thofe two fpots a wretched one; literally fpeaking, not worth mowing; and another fmaller patch in the barley field the fame; the crop excellent to an inch where the lime was laid, and immediately adjoining nothing but weeds. Another experiment, hewing the great efficacy of it, was a comparifon he made of it with the fheep fold; he folded part without liming in a field, the reft of which was limed, and the fuperiority of the latter part was very great. Mr. Aldworth fpreads it on his fallows for wheat, and on his potatoe-land for barley. It is to be noted that this land was never limed before. Upon another part of his farm which had been. limed, he does not find the benefit to be equal. He burns his lime in both running and ftanding kilns; in the former with culm, and the expenfe 
expenfe to him is $8 \mathrm{~d}$. a barrel roach. In the ftanding kilns he burns without breaking the ftones, 1500 barrels at a time with faggots, and in this way it is $6 \mathrm{~d}$. a barrel. Thefe kilns, he remarks, hould be built with very great ftrength, or the extreme heat of the fire burfts the mafonry. His liming has been upon fo extenfive a fcale, that laft year he had feven kilns burning, two of them ftanding ones, and burned in all above 10,000 barrels, and as much this year, all for manuring his own farm. Mr. Aldworth has erected a bolting-mill which will grind 5000 barrels of wheat, and it is curious to obferve the effect of it as a newly-eftablifhed market: the firft year he ground 1100 barrels, being all he could get ; the next year, the prefent, it will be 5000 . He has alfo taken pains to improve the breed of Pheep, by buying Englifh ewes. The fame attention he has given to fwine and various other articles. Reynold's turnip-cabbage he has planted two years for late feeding of theep in the fpring: he finds them of excellent ufe, and is determined never to be without them. He began to plant hops in 1772 upon half an acre of land, a fine rich red loam a yard deep; they fucceeded perfectly, well; and the fecond year yielded 8 cwt. the half acre of as good hops as ever he met. In 1773 he added two acres: in 1775 he planted another acre: laft year the crop failed, not getting above 3 or $4 \mathrm{cwt}$. This year he has a very good appearance. Has not found the climate at all againft them; and is clear that it may be a very advantageous branch of culture. He, however, remarked, 


\section{A N N S G R O V E.}

marked, that they are not fo ftrong as Englim hops, owing, perhaps, to want of experience in drying, \&c. He manures them every third year. Mr. Aldworth is the only perfon in this country that folds his fheep; he finds the practice very ufeful, but not equal, as obferved before, to lime.

September I ith, accompanied Mr. Aldworth and family to his neighbour Mr. Hyde's, on the banks of the Black Water, which are very chearful, and many of the views fine, particularly from the yard, of a new church on the river: pafs many large woods in fight. . Mr. Hyde's is a place entirely of his own forming. The lawn before the houfe has a very pleafing inequality of furface, and the whole fcenery well improved and cheerful.

It was with regret I left fo agreeable and liberal a family as that of Annfgrove, nor hould I forget to mention that every thing about the place had a much nearer refemblance to an Englith than an Irifh refidence, where fo many fine places want neatne/s, and where, after great expenfe, fo little is found complete. Mrs. Aldworth has ornamented a beautiful glen, which winds behind the houfe, in a manner that does honour to her tafte; fhe has traced her paths $f_{0}$ as to command all the beauties of rock, wood, and a fweet river which giides beneath both: it is a moft agreeable fcenery.

VoL. II.

B September 
September $\mathrm{s}$ th, to Doneraile, with Mr. Aldworth. In our way called on a woollen manufacturer, Mr. Hannam, at Kilbrack, who gave me the following particulars of the trade. It confifts in buying the wool about the country, and combing it upon their own account. The combers earn ros. a week, or 40 balls at $3 \mathrm{~d}$. The fleeces he buys weighs $5 \mathrm{lb}$. on an average. To every 22 ftone of rough fleece there are 3 ftone of thort, coarfe, and wafte; 2 ftone of the 3 are worth ios. a ftone, for coarfe works, frizes, \&.c. the third ftone 13 s. 4 d. The remaining 19 ftone of combing wool give 8 balls each of 24 ounces. To each ftone there is one pound and three quarters of pinions of fhort wool that comes out in the combing. Thefe balls are given to women to fpin, and $9 d$. a ball is paid them for it; a woman can fpin the balls in two days and a half if the fticks to it all day; in three days and do trifles befides. Then the worfted, in fkains twelve to the ball, is fent to Corke or Limerick for exportation. Not above one-fixth part, to his knowledge, is woven at home. Employs feven weavers making ferges. Forty-four beer ferges fell at rs. 2 d. a yard; is 29 inches broad, and the pieces 136 yards long. Pays two-pence halfpenny a yard for weaving, and a man weaves eight in a day; he weaves a piece in three weeks, and lofes one day in that time in preparing his loom. The Connaught wool he prefers; it is of a middling length, and a fine ftaple: finds that the fhort wool is the fineft. At Charleville there are thirty looms in it. The ferges are all fent to 


\section{O N E R A I L E.}

Dublin to a factor, who fells them at 51 . per cent. commiffion. Are in general fent to Scotland. The demand for them is better than it was: it has been improving for three years. But the prices of both ferges and worfted have not rifen proportionally to that of wool.

An effimate of the cloatbing trade.

20 combers would comb in a year 5000 ftone

of wool at $16 s$. per ftone - - 4000 - 。

The faid combers would comb 8:0 balls a

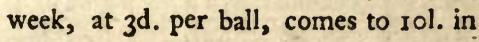
the year

300 women and girls to fpin the above, and which

would be the advantage of the clothier, to form into three houfes or factories of 100 each; their hire, at gd. a ball, comes

to

60 weavers would weave up the faid worfted, at $8 \mathrm{~d}$. each a day, $24 \mathrm{l}$. a week, the year 1248 50 little boys and girls employed in faid weaving, at $3^{\mathrm{d} .}$ a day each, comes to $31.15 \%$.

$\overline{430}$ per week, in the year - - $195 \circ 0$

Oil and foap would coft in the year $\quad-368 \circ 0$ Carriage of wool, woollen goods, \&ic. - 1000 。 Sorting wool, wanhing it, \& $x c^{-} \quad-800$ ०

807100

The year's profit I fuppofe to be -35000

The yearly fum brought into the country

where fuch trade is carried on $--f_{0} .8421 \circ 0$ 
A very important information is to be drawn from this eftimate, which is the proportion of labour to the wool in this manufactory.

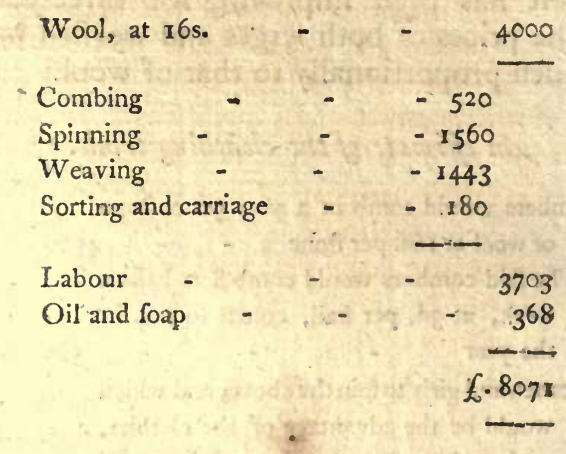

Hence therefore it appears that wool at $16 s$. labour and drugs equal it, and that labour alone is as nine one-fourth to ten.

Let me not forget here to remark, that the country, within two or three miles of Doneraile, ranks among the beft $I$ have feen in Ireland; it is varied, much improved, well wooded, and very chearful.

- To Lord Doneraile's, to whom I am indebted for a variety of ufeful intelligence; the fituation of his houfe is on a beautiful rifing ground, which flopes down to a winding vale, in which is a fmall river, accompanied by wood; from this river, on the other fide, the grounds (all lawn) rife very boldly, and are entirely margined with wood: from the higher grounds the 
the view of the houfe and park is fine, efpecially at the gate which opens to Kilbrack, there the houfe is feen furrouncled by very noble woods and a great variety of cultivated inclofures intermixed with fields and thicklyplanted hedges: the whole fcene fo pleafing, that it appeared to full advantage, though I had rode to it through a beautiful and evendreffed country in part of the way from Annfgrove. Near the houfe is a fhrubbery, through which there are paths that lead to different parts of the farm, through new plantations, and in particular to a cottage, from whence there is a fine wooded fcene, with the park lawn rifing above it, fcattered with fingle trees, and bounded by a margin of wood; the whole backed by diftant mountains. The plantations and inprovements, which lead to and furround this cottage are the work of Lady Doneraile, and do credit to her tafte.

Refpecting his Lordhip's hufbandry the following particulars deferve the attention of the reader. Three years ago he procured ewes from Leicelterhire, in order to improve the breed. The fheep which were here before took three to a ftone of wool, but now only two, and the wool is to the full as good as ever; and he finds that they are much more thriving and advantageous to keep, and eafier fed than the theep of the country: theep, his Lordfhip finds the mort advantageous ftock of all others: he keeps fix to the acre winter and fummer. This he finds much more profitable than keeping 
cows or fat cattle. Has tried many breeds of cattle, and finds that the long-horned Englin cow is the beft for fattening. The Holdernefs for giving much thin poor milk, but are too heavy for winter feeding. The Kerry cow is much the beft for milking in quantity of good milk. Hogs he has alfo tried of all forts, and finds that nothing is fo profitable as the black Indian breed with thort legs, round carcafes, and fnub nofes. For working, he finds the fmall mongrel Kerry beaft works the beft, and moves the faftert. He works them all by the horns, in the manner practifed in the fouth of France, four in a plough at the firft ploughing. He changed the manner in which Lord Shannon brought it over, from the yoke which couples them, to going fingle with double traces; this he finds much the moft beneficial manner; they move quicker and with greater power, from being free and working not in couples; befides being applicable to all forts of work which requires their going fingle. Englin waggons Lord Doneraile has tried and laid afide, from finding, on experience, that they are very much inferior to the common Irifh car in hay harveft, dung, lime, \&rc. but he ufes one-horfe carts for many forts of work. Turnips he has cultivated for fome years, hoes them, and gets good crops, but beft in the drill way, the rows two feet afunder: he ufes them in feeding theep, and alfo fattening bealts. He finds that they are not of any confiderable ufe in this country, compared to others where there is not an equal plenty of grafs, which fprings all winter; and 
that they will fatten a beaft better. When moft wanted, which is in April and the beginning of May, they are gone. Cabbages he has tried upon a large fcale three years; laft year and the year before, he had 8 or 9 acres, and ufed them in feeding and fattening cattle and heep; has found them preferable to turnips far, in all ufes in feeding cattle; but an acre of the latter will produce much more. Fern he finds is beft deftroyed by mowing it twice a year in June, and the beginning of September. He makes his tillage exceedingly profitable by the ufe of lime. His courfe of crops,

1. Wheat, yielding to barrels per acre, and has meafured 1.5 barrels, i 5 ftone per acre. 2. Barley, the produce 14,15 barrels, and of fmall barley, 6 rowed 20. 3. Oats 20 barrels. 4. Clover laid down to grafs, or for one year, and ploughed it up as foon as cleared of the hay.

Lime he fpreads on all lands for wheat or barley, \&c. 80 barrels of roach an acre colts 6d. a barrel burning. The effect is amazingly great, infomuch that it is the difference between a great and a bad crop. In general there is no ground worth 20s. an acre, that if you lime it 80 barrels, and take wheat, barley, and oats, it will then be worth 305 . This is certainly a marvellous improvement! Lord Doneraile knows, from an experiment of his brother's, that it is equally well adapted to boggy bottoms; he had five acres, which he fet for 1os, $6 \mathrm{~d}$, the whole, 


\section{4 \\ D O N E R A L E.}

whole, and was fo hard a bargain to the poor men, that an allowance was made for it. His brother took it, and limed it, and then mowed five tons of bay per Englifs acre, one of the ftrongeft proofs of the benefit of lime that can be given. In his Lordfhip's park he has a wheel for raifing water, an improvement on the Perfian, which raifes a regular ftream 28 feet; the ftream which turns it is confined by a double wall to the exact dimenfion of the boxes, which take in the water, and it works conftantly and regularly without trouble or expenfe. Lord Doneraile has erected a granary upon a new conftruction, that of a flue in the walls for a fire to air the whole building, and dry any damp corn that may happen to be in it. He dried the walls after building with it perfeetly in $a$ fhort time. This granary is fo completely built, that not a moufe can poffibly get in it: he has a thorough air, with lattice windows of wire. By the way, thefe flues are a proof, if one was wanting, how much moifter the climate of Ireland is than that of England. He has planted the clufter potatoes, called here bulls and bucks, fo much as 6 or 7 acres; gave them to horfes, cows, and fheep: the horfes that would eat them did well, and in a little time belieres would all come very well to them. Fat cows and bullocks did exceedingly well: fat Theep were put to them; but feveral dying both years, made him leave the practice off. Of other forts of potatoes, he finds the London lady and the spple to be the beft forts. The London lady is particularly valuable for one circumftance, which 


\section{O N E A I L E. $\quad 25$}

which is the ftalks withering, and the crop being ready to take up, from a month to fix weeks before any other fort; confequently, the beft fort to plant as a preparative to wheat. Hops he has planted two years ago, in order to fee how far they will anfwer; and expects to be able to get not only good hops, but a great crop. One mode of managing them he has in meditation, which is a good thought, and that is to train them horizontally inftead of perpendicularly, like efpalier, on account of the ftorms and blights which hops, in the common way, are fubject to from the height. Has compared the rotton lime-ftone and lime in a 20 acred field for wheat, 10 of the one and 10 of the other, and found the wheat equal : both very good. Has obferved the common farmers, after manuring with it, to take 12 and 14 crops of white corn running and then leaving it for grafs, which not coming, they complain that it is not good for grafs, but burns it up. But Lord Doneraile advifed a friend to lay down, after two or three crops, which being done, the grafs that followed was perfectly fine.

Lord Doneraile's lime-kiln is one of the compleateft I have any where feen; it is at bottom 36 inches diameter, leads up to 12 feet wide in the buldge, and 20 feet high from the bottom to the buldge, 7 feet from the buldge up, and at the top 9 feet diameter. Over the top, a roof and a porch to it, and it draws 44 barrels of roach lime a day, which takes 6 of culm; burns for $5 \frac{\pi}{2}$ a barrel. The culm 2 s. 5 d. a 
barrel at the kiln. Labour $4^{\text {s. Culm }}{ }^{5}$ s. a day.

September $13^{\text {th }}$, left Doneraile, and went to Colonel Jephfon's at Mallow. He was at that time confined with the gout; but his fon, Denham Jephfon, Efq; (member for Mallow) took every means for my information, in the circumftances I enquired after. About that place:

1. Potatoes on ftubbles, or grafs dunged 2. Potatoes. 3. Wheat or Bere. 4. Oats. 5. Oats. 6. Oats.

J. Fallow. 2. Wheat. 3. Oats. 4. Oats. 5. Oats. 6. Oats. The meafure the Englifh acre.

Of potatoes they plant 6 common barrels, and get 42 in the crop: fometimes take three or four fucceffive ones. Of wheat they fow 3 pecks and a half each, 3 cluggets, each clugget II quarts, and get 8 barrels. The crop of bere is 12. Of oats 12. Rents of town parks 21 . 2s. to 31 . other lands ros. to 30 s. average 125 . There are many dairies, up to 60 cows, which are all fet to dairymen, at $50 s$. to 31 . ros. of good land it will take one acre and a half to feed a cow. They make both butter and cheefe, and where the latter is made, no butter, felling the cheefe at 4 d. a pound. A cow makes one cwt. of butter in the feafon. When cows are let, none are taken that do not give 2 gallons 
of milk; good cows give 4 gallons. Colonel Jephfon had a cow half bred, between the Englin long horned and Holderneffe, that was forced to be milked three times a day and gave 12 gallons a day, many times in the prefence of various perfons. Every dairyman is allowed a houfe, a garden of one acre and a half, and grafs for a horfe, a cow, and fome a collop of fheep. Great quantities of lime are ufed: they lay 100 barrels an acre, at is. id. They plough with horfes, four or fix to a plough. The poor pay ros, rent for a cabin, and 20 . for one acre for potatoes; 21. 2s. for grafs for a cow, and Ios. for the winter's hay. They live upon potatoes generally the year through; all of them keep cows and pigs, which lacter they feed on fmall potatoes. Their circumftances are not better than 20 years ago; for though they have now $6 \mathrm{~d}$. and then had but 5 d. yet the rife is not proportioned to that of rents. Villages of cottars will take farms in partnerhip in the manner I have often defcribed. The foil of the country is in general limeftone; but from Knockerera mountain, near Mallow to Corke, there is no lime-ftone.

Leafes are thirty-one years, or three lives, and fome for three lives and thirty-one year's after; and many farms let to middle-men. who occupy no part of the land themfelves, but re-let it. Above one-third of the county is wafte land.

There are collieries about ten miles off, near Kantark, from which coal is fold at $3^{5}$. a bar. 
$\mathrm{rel}$; it is large and hard. Upon the river Blackwater, there are tracts of flat land in fome places one quarter of a mile broad; the grafs every where remarkably fine, and lets at 30 . It is the fineft fandy land I have any where feen, of a reddifh brown colour, would yield, the greatert arable crops in the world, if in tillage; it is five feet deep, and has fuch a principle of adhefion, that it burns into good brick, yet it is a perfect fand. In floods much of it is overflown. The banks of this river, from its fource to the fea, are equally remarkable for beauty of profpect, and fertility of foil.

There is but little manufacturing in Mallow; even fpinning is not general. Mr. Jephfon manures his lands very highly with all forts of dung and fullage of the ftreets of Mallow, which is conftantly bringing away; by means of this regular attention, united with the goodnefs of the foil, he has brought it into that high degree of heart, indicated by the rent, at which it would let. The whole is divided into fields, of a moderate fize, with double quick hedges, well planted with trees, and kept in the moft perfect degree of neatnefs; between the hedges are gravel walks, fo that there is a planted communication about all the. fields; the gates are neat and light, and every, attention preferved to give the whole the appearance of a ferme orne. The quantity of tillage is not confiderable, but his crops very great, barley up to twenty barrels per acre. Mules he finds more ufeful and hardy than horfes; 


\section{N E W G R O V E.}

horfes; has fome very fine ones. Mr. Jephfon has weighed to the dragoons, at the barracks, from twenty-eight acres of grafs, three and a quarter tons of hay, per Englifh acre. He has kept a particular account of his domain, and has kept his deer, horfes, cows, houfe, \&cc. and fold to the amount of $55 \mathrm{~s}$. an acre befides. I walked to the fpring in the town to drink the water, to which fo many people have long reforted; it refembles that of Briftol, prefcribed for the fame cafes, and with great fuccefs. In the feafon there are two affemblies a week. Lodgings are five fhillings a week each room, and thofe feemed to be miferably bad. Board thirteen fhillings a week. Thefe prices, in fo cheap a country, amazed me, and would, I thould fear, prevent Mallow from being fo confiderable as more reafonable rates might make it, unlefs accommodations proportionable were provided. There is a fmall canal, with walks on each fide, leading to the fpring, under cover of fome very noble poplars. If a double row of good lodgings were erected here, with public rooms, in an elegant ftyle, Mallo would probably become a place for amufement, as well as health.

September 1 $4^{\text {th, }}$ to New Grove, the feat of Robert Gordon, Ef ?; in whom I met with the greateft zeal for giving me a correct information. Paffing, at fome diftance, a very large houfe building, to the right of the road, in a good fituation, by Sir Robert Dean. New Grove is an entire new improvement of Mr.

Gordon's, 
Gordon's, the whole place, fome years ago, being a wafte moor, or mountain, as it is called in Ireland.

Mr. Gordon took it for improvement; the foil and bog five to nine fpits deep, and under it a black earth, or a reddin fand, and in fome a whitifh clayey fubftance, but not marle; many fprings in it, which were carried off by drains; and then the whole furface of turf cut out, and carried to Cork : cutting, \&cc. 30s. a 100 , and fold there at 51 . this was done in order to get lime, which is not upon the land, and by this means the line came to feven-pence halfpenny a barrel; found many ftones and great roots, and timbers, which were all cleared away, and the land ploughed with oxen, before winter; then left the winter three ploughings given in the fpring, and fifty barrels of lime, fpread and fown with oats and clover; the crop very great; could be fold however, for 41 . an acre; the clover fine. This was cut for hay, and the fecond weighed $23 \mathrm{Ilb}$. per Englinh perch fquare, and a horfe that was ftarved nine hours, eat in twenty-four hours roplb. And after thefe two cuttings, there was a third for foiling with in October; it was then fowed with a fecond crop of oats, and that with clover which was left, and has been mown every year for eleven years fince; this was one field in particular, but all in the fame manner, and would let for one pound an acre readily; all expences of the 3 crops, including the lime, coft 61.7 s. $9 \mathrm{~d}$. an acre, fo that the 


\section{NE W G R O V E.}

mere improvement was profitable, befides the increafe of rent alfo improved. At Carrickduff, 650 acres of heath, 8rc. the black foil thin, and the heath low, and under it a brown loam, with whitifh gravel, mixed. Fallowed it with ftrong ploughs, fourteen inches deep for a year; then limed it, 50 barrels an acre, at feven pence three farthings on the land, burnt on the fpot, and upon this fowed oats and clover for a meadow, the oats great, and the grafs part of it actually let at Il. Is. and all would let fo. Has profecuted this improvement with fuch fpirit, that laft year he laid on 10,000 barrels of lime, and has 73 acres oats, 34 wheat, 12 potatoes, and roo laid to grafs, and all this in two years. Has there built a farm-office, I 54 feet long, a barn, ftalls for thirty bullocks, two ftables, and a room for the fteward; and has made $175^{\circ}$ perch of ditches, planted with quicks. Thefe Mr. Gordon does in two years, half the ditch in one to leave it to fink, and the other half the year after. Turnips he has had, and got very fine crops of $6 \mathrm{lb}$. the average turnip; they thin them by hand, which he thinks upon this land is preferable to hoeing; ufed the crop in ftall-feeding 30 bullocks, which had, befides the turnips, half a hundred weight of hay to fix each day, and found that they throve exceedingly well on fuch turnips as were not above three to fix pounds weight, but upon the large ones they did not thrive. In November he cleared the field of all, ftacked them, and found them keep perfectly till April. Found that the nheep, fed at New Grove, would not take to turnips till ftarved to them. 
Imported a man from Norfolk, whom he gave forty guineas a year with board, who brought ploughs, hoes, \&cc. with him ; gave him a guinea for every boy he taught to plough, and every boy who could fairly plough, had a fhilling a day wages. By this means he has collected a fet of excellent ploughmen, who have been of infinite ufe, fo that he has to this day ploughed with Norfolk and Suffolk ploughs, worked with a pair of horfes, and no driver except the firft and fecond ploughing of frefh land, which, and dragging, he does with great drags of 18 cwt. and drawn by bullocks. This improvement is of particular confequence, as there are here twelve miles fquare of rich land, taken almoft in a fquare between Mallow and Corke, one way, and the Bagra mountains and Nagles the other; upon all which there is not a ftone to interrupt the plough, fometimes not a ftone to an acre.

$\mathrm{He}$ is convinced, from experience, that the worft of this vaft tract may be drained, inclofed, limed with fifty barrels, and tilled with a crop of oats on it, for 51: an acre. In the neighbourhood, a great improvement of 1200 acres, without lime or gravel, and badly done yet, at 12s. an acre, fix-7ths of the county of Corke at

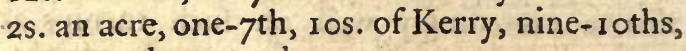
at Is. and one-1oth at ios.

Six years ago, Mr. Gordon eftablined a linen manufactory, and bleach mill, upon the completeft 


\section{B L A R NEY C A S T LE.}

completeff fcale; a factory of eleven looms for damafk, bleacher's houfe and other buildings, with a refervoir of water for turning the wheel; the whole well-built, well-contrived, and at the expence of 12001 . Kept thefe looms conftantly at work, and at the fame time bleached many pieces for the country people. Trufted to a manager for the conduct of the works, who broke, which put a ftop to them, otherwife there would have been a flourifhing manufactory eftablifhed. Spinning flax coming in; but the woollen through the country ; and from hence to the north-weft Duhallow Barony is the great country for fpinning cotton.

September 15 th, to Blarney Caftle, S. J. Jefferys, Efq; of whofe great works in building a town at Blarney, I cannot give fo particular an account as I wifh to do; for I got there juft as he and his family were on the point of fetting out for France. I did not however let lip the time I had for making fome enquiries, and found that in ${ }^{1} 76_{5}$, when Mr. Jefferys began to build this town, it confifted only of two or three mud cabins; there are now go houfes. He firft eftablifhed the linen manufactory, building a bleach-mill, and houfes for weavers, \&cc. and letting them to manufacturers from Corke, who have been fo fuccefsful in their works, as to find it neceffary to have larger and more numerous edifices, fich as a large ftamping mill for printing linens and cottons, to which is annexed another bleach-mill, and fince there has been a third erected; the work carried on is that of buying yarn, and weaving it into li-

VOL. II.

nens, 
nens, ten pence to thirty pence white; alfo diapers, Theeting, ticking, and linens and cottons of all forts printed here, for common ufe and furniture. Thefe feveral branches of the linen, employ 130 looms, and above 300 hands.

A nother of $\mathrm{Mr}$. Jefferys objects has been the ftocking manufacture, which employs 20 frames, and 30 hands, in buildings erected by him; the manager employing, by covenant, a certain number of apprentices, in order by their being inftructed, to diffufe the manufactory، Likewife a woollen manufactory, a mill for milling, tucking, \&c. broad cloths; a gigg mill for gloffing, fmoothing, and laying the grain; and a mill for knapping, which will dref's above $50^{\circ}$ pieces a year, but will be more, when fome alterations now making are finifhed. A leather mill for drefling hamoy, buck, or fkins, fully -mployed. A large bolting mill, juft finifhed, and let for 1321 . a year. A mill, annexed to the fame, juft finithing, for plating; and a blade mill for grinding edged tools. A large paper mill, which will be finifhed this year. He has been able to erect this multiplicity of inills, thirteen in all, by an uncommon command of water.

The town is built in a fquare, compofed of a large handrome inn, and manufacturers houfes, all built of excellent ftone, lime, and flate. A church, by the firft fruits, and liberal addition of above 3001 . from Mr. Jefferys. A markethoufe, in which are fold a hundred pounds worth of knit ftockings per week. Four bridges, 


\section{BLAR NE CASTLE. 35}

which he obtained from the county, and another (the flat arch) to which he contributed a confiderable fum. Much has been done, yet is not the defign near finimed.

To fhew the magnitude of thefe works, and the degree of public good refulting from them, I fhall mention the expence at which they have been executed. Refpecting the principal bleach mill, Meffrs. Foreft and Donnoghue, under the linen act, took 15 acres, at a guinea an acre, upon which they have expended 50001 . in erecting a linen mill and bleach green, twenty-five houfes for twenty-five weavers families, four looms in each houfe, a large dwelling-houfe for -them felves or their director; in each houfe, a man, his wife, three apprentices, two girls and two boys, befides young infants. In a hort time the farm was increafed, and land, which before had only brought half a guinea, then let for a guinea. The linen board advanced 500l. to this work, and Mr. Jefferys repaid them 1400 l. of the 50001 . The old rent of the premifes was 401 . a year, the new rent $7 \mathrm{Il}$. Another bleach mill, which coft Mr. Jefferys 30ol. to which the board added 3001 . and the perfon to whom it is let, 6001 . 40 acres of land, formerly let at sol. a year, go with them. The whole rent now 801 . To this mill is fince added an oatmill, which coft 3001 . two tuck-mills, 2001 . a leather mill and kilns, ${ }_{5} 01$. two dwellinghoufes, 3001. A ftamping-mill, which coft Mr. Jefferys 2,300l. to which the board added 3001 . promifing r 10001 . more when the works thould be finithed, which they bave been thefe 
two years. Twelve printing tables are kept going, and fixty-five hands employed. Twelve printers. Twelve tire boys. Three print cutters. Eighteen bleachmen. Six pencillers. Two tubmen. One clerk. One callender. One manager. Two draughtfmen. Four coppermen. Three carters. Befides the above fums, the manufacturer has laid out 500 . The quantity of land occupied is 25 acres : old rent, 61. Ios. new, 1131. 15.s.

A ftocking façtory, for which Mr. Jefferys lent 2001 . The man laid out 300 l. himfelf; he occupies 50 acres, before let at 201 . a year; now at 761 . Is. A gigg-mill, for which Mr. Jefferys lent 3001 . till repaid by the Dublin Society, who granted 300 . towards it, and the tenant laid out $200 l$. the quantity of land he has is eleven acres, let at 51 . 10s. now at 361 :

A manufactory of tape isertablifhed, by which means 6 acres of land are advanced, from $21.8 \mathrm{~s}$. to $\mathrm{gl}$. They have three looms going, which makes IO2 pieces a day of 36 yards each. The Dublin Society gave 201 . to it. A paper mill, which Thas coft Mr. Jefferys I rool. and is not yet let. A bolting mill on which he has expended I 1001 . the tenant 5001 , on adding an iron mill. Twenty acres of land, rent before 91 . 10s. rent of the whole now 321.135 . The ehurch has coft Mr. Jefferys 5001 . and the firft fruits 5001 . more. The new inn, 250l. and the tenant 3001 . more. Seventy acres of land, before at 20l. a year, now at 831 . 9 s. A dwelling-houfe, 2501 . to which the tenant added 5001 . Ninety acres. 


\section{B L A R N E Y C A S T L E. 37}

acres of land, before let at 541 . the new rent is 741. Twelve cottages, and a lime-kiln, which coft $280 \mathrm{l}$. Two dwelling-houfes and a forge, which coft him 150l. and to which parliament granted 250l. more. Upon the whole, therefore, Mr. Jefferys has expended 7,63 ol. in thefe eftablinments. Of public money there has been added 2,1 701 . and the tenants themfelves laid out 9,0501 . in all, expended here 18,8501 . befides what $M i$. Jefferys laid out on bridges, $\& c$. in the whole, very near, if not full, 20,0001 . upon matters of a public nature. In all thefe eftablifhments, he has avoided undertaking or carrying on any of the manufactures upon his own account, from a conviction that a gentleman can never do it without fuffering very confiderably. His object was to form a town, to give employment to the people, and to improve the value of his eftate by fo doing; in all which views it muft be admitted, that the near neighbourhood of fo confiderable a place as Corke very much contributed: the fame means which he has purfued would, in all fituations, be probably the moft advifeable, though the returns made might be lefs advantageous. Too much can fcarcely be faid in praife of the fpirit with which a private gentleman has executed thefe works, which would undoubtedly do honour to the greateft fortune.

To animate others to tread in fuch laudable fteps, I may remark, that even the profit of thefe undertakings is too much to be entirely forgotten; the expences are by no means barren ones; 327 acres let before thefe works at 
1671. 18s. let afterwards at $6821.8 \mathrm{~s}$. Profit 5081. Ios. without reckoning any thing for two dwelling-houfes, a forge, twelve cottages, and a lime-kiln, which may moderately be reckoned at 251 . a year, and yet let at rents of favour, in all 5331 . 10s. which from 76301 . is 7 per cent. There, however, is no agriculture - improvement that would not, with much greater certainty of continuance, pay 17. At the fame time, however, there is a greater reverfionary advantage in the benefit refulting from the increafing of the rents at the expiration of the leafes, upon undertaking thefe works, the longeft of which is for no more than three lives. Another advaniage which is felt already, is, the rife in the prices of products at Blarney; which is a direct premium to agriculture, to the farmer, and to the landlord. Dairy cows, on all the adjacent farms, arofe in two years from 3 l.to 4 l.a cow, as the weavers were happy to get milk and butter at the fame price they fold for in Corke. The fame rife took place on corn; potatoes, \&xc. Mr. Jefferys, befides the above eftablifhments, has very much improved Blarney Caftle and its environs; he has formed an extenfive ornamented ground, which is laid out with confiderable tafte; an extenfive plantation furrounds a large piece of water, and walks lead through the whole; there are feveral very pretty fequeftered fpots where covered benches are placed.

Accompanied Mr. Jefferys, Scc. to Dunkettle, the feat of Dominick Trent, Efq; who with a liberality of fentiment which renders 


\section{U N K E T T L E.}

him defervedly efteemed, took évery meafure I could wilh for my information. The road leads very beautifully on the fide of the harbour under a fhore of bold hills, on which are many villas and fome plantations. For the following particulars concerning the neighbourhood, I am indebted to Mr.'Trent.

On the fouth fide of the river, \&c. the foil is a fine lime-ftone; the country level for a mile or two, then fwelling into very gentle hills. On the north fide, which is much better planted, particularly at Lota, Dunkettle, \&c. the ground riles in bold afcents, adorned with many beautifully-fituated country-houfes. Here the ftratum is brown, or rather red ftone, and the furface fhallow ; in fome places a burning gravel. There is a good deal of arable land on the fides of the hills. The courfe of crops:

1. Potatoes. 2. Wheat. 3. Barley or oats. 4. Lay down with feeds.

Potatoes yield per acre from 10l. to 201. Average quantity fifty barrels, at eighteen ftone each. Land manured and let to labourers for planting, at four or five guineas an acre. Wheat from feven to ten barrels of twenty ftone, at 20s. a barrel ; average price from igs. to $24 \mathrm{~s}$. per barrel. The manures are Corke dung of the richeft kind, efpecially in the flaughtering feafon; fea fand for tillage, and bank fand from the river for grafs grounds. There is watercarriage to the eaftward for many miles : feveral good quays for landing manure, particular- 


\section{DUNKETTLE.}

ly one at Glanmire, near Dunkettle, from which the inland inhabitants draw the manure four or five miles in one-horfe carts. Lime is alfo much ufed at a fhilling a barrel. The meadows in this country yield from $1 \frac{1}{2}$ to 3 tons of hay per acre, at $40 \mathrm{os}$. to $45 \mathrm{~s}$. per ton on an average. Dairies are let to dairymen at 4 to 5 guineas a cow. Many theep are kept on the hills, but none folded. The diet of the poor is potatoes and milk, with fome filh in the herring and fprat feafon. Labourers houfes from 25 s. to 40 s. a year. Fuel a very little coal, the reft fupplied by bufhes, ftolen faggots, \&c. as there is no turf in this part of the country. Price of labour 6d. per day through the year, on a pinch in harveft $8 \mathrm{~d}$. fometimes more, but within the liberties of the city generally $8 \mathrm{~d}$. Women 3 d. and 4 d. a day in reeking corn: children from $1 \mathrm{~d}$. to $3 \mathrm{~d}$. in picking ftones, \&c. Moft employed in country bufinefs; a few at fome bolting irun and paper-mills in the neighbourhood. From fourteen acres of orchard Mr. Trent makes fixty hogheads a year of cyder; a clear acre of good trees about feven hogheads. His hogs he feeds on the bull potatoes, which yield great crops without dung, and for two or three years fucceffively.

September 16 th, to Cove by water, from $\mathrm{Mr}$. Trent's quay. The view of Lota is charming; a fine rifing lawn from the water, with noble fpreading woods reaching on each fide; the houfe a very pleafing front, with lawn thooting into the woods. The river forms a creek 
between two hills, one Lota, the other opening to another hill of inclofures well wooded. As the boat leaves the fhore nothing can be finer than the view behind us; the back woods of Lota, the houfe and lawn, and the high bold inclofures towards Corke, form the fineft thore imaginable, leading to Corke the city appearing in full view, Dunkettle wooded inclofures, a fine fweep of hill, joining Mi: Hoare's at Factoryhill, whofe woods have a beautiful effect. Dunkettle houfe almoft loft in a wood. As we advance, the woods of Lota and Dunkettle unite in one fine mars. The fheet of water, the rifing lawns, the houfe in the maft beautiful fituation imaginable, with more woods above it than lawns below it, the weft hore of Loch Mahon, a very fine rifing hill cut into inclofures, but without wood, landlocked on every fide with high lands, fcattered with inclofures, woods, feats, \&cc. with every chearful circumftance of lively commerce, has all together a great effect. Advancing to Paflage the fhores are various, and the fcenery enlivened by fourfcore fail of large fhips; the little port of $\mathrm{Paf}$ fage at the water's edge, with the hills rifing boldly above it. The channel narrows between the great ifland and the hills of Paffage. The fhores bold, and the Mips fcattered about them, with the inclofures hanging behind the mafts and yards, picturefque. Paffing the ftreights a new bafon of the harbour opens, furrounded with high lands. Mork's-towncaftle on the hill to the right, and the grounds of Ballybricken, a beautiful intermi, ser fcene of 
wood and lawn. The high fhore of the harbour's mouth opens gradually. The whole fcene is landlocked. The firft view of Hawlbowling-illand and Spike-ifland, high rocky lands, with the channel opening to Cove, where are a fleet of fhips at anchor, and Roftellan, Lord Inchiquin's houfe, backed with hills, a fcenery that wants nothing but the accompanyment of wood. The view of Ballybricken changes; it now appears to be unfortunately cut into right lines. Arrived at the fhip at Cove; in the evening returned, leaving Mr. Jefferys and family on board for a voyage to Havre, in their way to Paris.

Dunkettle is one of the moft beautiful places $I$ have feen in Ireland. It is a hill of fome hundred acres broken into a great variety of ground, by gentle declivities, with every where an undulating outline, and the whole varied by a confiderable quantity of wood, which in fome places is thick enough to take the appearance of clofe groves, in others fpreads into fcattered thickets and a variety of fingle groups. This hill, or rather clufter of hills, is furrounded on one fide by a reach of Corke harbour, over which it looks in the moft advantageous manner; and on the other by an irignous vale, through which flows the river Glanmire: the oppofite thore of that river has every variety than can unite to form pleafing landfcapes for the views from Dunkettle grounds; in fome places narjow glens, the bottoms of which are quite filled with water, and the fteep banks covered 


\section{DUNKE T T LE.}

with thick woods that fpread a deep Made; in others the vale opens to form the fite of a pretty chearful village, over hung by hill and wood: here the fhore rifes gradually into large inclofures, which fpread over the hills, ftretching beyond each other; and there the vale melts again into a milder variety of fields. A hilt thus fituated, and confifting in itfelf of fo mach variety of furface, muft neceffarily command many pleafing views; to enjoy thefe to the better advantage, Mr. Trent (than whom no one has a better tafte both to difcover and defcribe the beauties of natural fcenes) is making a walk around the whole, which is to bend to the inequalities of the ground, fo as to take the principal points in view. The whole is fo beautiful, that if I was to make the regular detour, the defcription might be too minute : but there are fome points which gave me fo much pleafure, that I know not how to avoid recommending to others that travel this way to tafte the fame fatisfaction : from the upper part of the orchard you look down a part of the river, where it opens into a regular bafon, one corner ftretching up to Cork, loft behind the hill of Lota, the lawn of which breaks on the fwelling hills among the woods; the houfe obfcured, and therefore feeming a part of your home fcene; the lofing the river behind the beautiful projection of Lota, is more pleafing than can be expreffed. The other reach, leading to the the harbour's mouth, is half hidden by the trees which margin the foot of the hill on which you ftand: in front a noble range of cultivated 


\section{DUNKET T L E.}

hills, the inclofures broken by flight spots of wood, and prettily varied with houfes, without being fo crowded as to take off the rural effect. The fcene is not only beautiful in thofe common circumftances which form a landfcape, but is alive with the chearfulners of fhips and boats perpetually moving. Upon the whole, it is one of the moft luxuriant profpects I have any where feen. Leaving the orchard pafs on the brow of a hill which forms the bank of the river of Glanmire, commanding the oppofite woods of Lota in all their beauty. Rife to the top of the high hill which joins the deer-park, and exhibits a fcene equally extenfive and beautiful; you look down on a vale which winds almoft around at your feet, finifhing to the left in Corke river, which here takes the appearance of a lake, bounded by wood and hills, and funk in the bottom of a vale, in a ftyle which painting cannot imitate; the oppofite hills of Lota, wood, and lawn, feem formed as objects for this point of view : at your feet a hill rifes out of the vale, with higher ones around it, the margins fcattered wood; to the right, towards Riverftown, a vale; the whole backed by cultivated hills to Kallahan's field. Milder fcenes follow; a bird's-eye view of a fmall vale funk at your feet, through which the river flows; a bridge of feveral arches unites two parts of a beautiful village, the meadow grounds of which rife gently, a varied furface of wood and lawn, to the hills of Riverftown, the whole furrounded by delicious fweeps of cultivated hills. To the left, a wooded glen 
rifing from the vale to the horizon, the fcenery fequeftered, but pleafing; the oak wood which hangs on the deer-park hill, an addition. Down to the brow of the hill, where it hangs over the river, a picturefque interefting fpot. The inclofures on the oppofite bank hang beautifully to the eye, and the wooded glen winds up the hill. Returning to the houfe I was conducted to the hill, where the grounds flope off to the river of Corke, which opens to view in noble reaches of a magnitude that fills the eye and the imagination: a whole country of a character truly magnificent, and behind the winding vale which leads between a feries of hills to Glanmire.

\section{Piciures at Dunkettle.}

A St. Michael, \&cc. the fubjeet confufed, by Michael Angelo. A St. Francis on wood, a large original of Guido. A St. Cecilia, original of Romanelli. An affumption of the virgin, by L. Carracci. A quaker's meeting, of above fifty figures, by Egbert Hemikerk. A fea view and rock piece, by Vernet. A fmall flagellation, by Sebaftian del Piombo. A madonna and child, fmall, by Rubens. The crucifixion, many figures in miniature, excellent, tho' the mafter is unknown. An excellent copy of the famous Danae of Titian, at Monte Cavallo, near $\mathrm{Na}$ ples, by Cioffi of Naples. Another of the Venus of Titian, at the tribuna in Florence. Another of Venus blinding Cupid, by Titian, at the $\mathrm{Pa}$ lazzo Borghefe in Rome. Another of great 


\section{CASTLEMART YR.}

merit of the madonna Della Sedia of Raphael, at the Palazzo Pitti in Florence, by Stirn, a German, lately at Rome. Another of an holy family, from Raphael, of which there are faid to be three originals, one at the king's palace in Naples, one in the palais royal in Paris, and the third in the collection of Lord Exeter, lately purchafed at Rome. A portrait of Sir Patrick Trent, by Sir P. Lely. An excellent portrait of a perfon unknown, by Dahl.

September 17 th, to Caftlemartyr, the feat of the earl of Shannon, one of the moft diftinguifhed improvers in Ireland, in whom I found the moft earneft defire to give me every fpecies of information, with a knowledge and ability which enabled him to do it mort effectually. Paffed through Middleton, a well built place, which belongs to the noble lord to whom it gives title. Caftlemartyr is an old houfe, but much added to by the prefent earl; he has built, befides other rooms, a dining one 32 feet long by 22 broad, and a drawing one, the beft rooms I have feen in Ireland, a double cube of 25 feet, being 50 long, 25 broad, and 25 high. The grounds about the houfe are very well laid out; much wood well grown, confiderable lawns, a river made to wind through them in a beautiful manner, an old caftle fo perfectly covered with ivy as to be a picturefque object. $A$ winding walk leads for a confiderable diftance along the banks of this river, and prefents feveral pleafing landfcapes. But let me haften to objects of more importance: Lord Shannon's 


\section{A S T LEM A R T R.}

hưfbandry confifts of many circumitances. I frall begin with

\section{T U R N I P S,}

Which Lord Shannon has cultivated upon a -very large fcale, as will appear from the following particulars. His father began the cultare many years ago, which he continued till 1770 , and then went largely into it. He had every year, from $177^{\circ}$ to 1774 both inclafive, fixteen acres, and in 1775, twenty-four. Has cultivated them in both broad caft and the drill method the rows at three feet; but finding that the roots became too large, altered his method to eighteen inches, in order to have more of them ; the fize will be feen by the following account.

Criflemartyr, December 21 ft, 1771 .

I this day meafured a fquare perch of turnips, $16 \frac{\pi}{2}$ feet, drilled in rows three feet apart; there were 84 turnips on this perch, they weighed 7 cwt. 2 qrs." which I compute to be 60 tuns to the Englifh acre; and there were vacant fpaces in the rows within this perch where the turnips had failed, that would have held at leaft ten large turnips more. I then pulled 84 turnips, the largeft I could fee, within about fifteen yards of the above perch, and they weighed 15 cwt. 5 qrs. $17 \mathrm{lb}$. which is about 125 ton, $29 \mathrm{cwt}$. 2olb. I weighed two of the above turnips feparately, one of them a white tankard, they each weighed $32 \mathrm{lb}$. The white Nor- 


\section{C A S T LE MAR T YR.}

Norfolk was three feet eight inches in circumference. N. B. I neither manured nor burned the ground; it was naturally good; I tilled it well, and hoed the crop carefully.

SHANNON.

One of the above turnips Lord Shannon took with him to the Dublin Society, where it was feen by the whole city; but from my tour through the kingdom, I am afraid it did not animate fo many as it ought. Thefe large turnips were not raifed in any peculiar fpot, but were part of a field of eight or ten acres. The application of the crop has been generally by drawing and giving them to fheep on dry paftures; all forts of theep, but particularly fat ewes, they fattened admirably. Finds that the great benefit of the culture is having them near a very dry field, in order to manage them as above-mentioned. He has found that they will do exceedingly well without manuring, efpecially if the land is an old rough pafture, or which wants to be broken up; fallowed well and thoroughly ploughed, produces great crops. Seaweed his lordinip has tried for them, fpread about the thicknefs of dung, and it gave prodigious products. Upon the whole, he is clearly of opinion, that nothing can be more beneficial to the agriculture of Ireland than introducing this culture, and fo well convinced of this, that he has always thewn his crops to farmers, weighed them before them, hewed the cattle 
cattle fed, and took every pains to make them come into the culture, but in vain. As a preparation of corn they are incomparable; he has had very great crops of barley after them, fuch as were laid with every heavy rain from luxuriance. Wheat alfo he has fown after them, and got eight barrels an acre from feven ftone of feed.

\section{A B B A G E S}

Lord Shannon cultivated alfo: generally had five or fix acres for four or five years; the fort the flat Dutch, and got very fine crops. Gave them to cattle of all forts, who eat them very greedily and did better upon them than upon turnips, but would not laft longer than Chriftmas, otherwife would have preferred them. The crops of corn after them neither better nor worfe than after turnips. Tried alfo the Scotch and other forts, but preferred the flat Dutch to any other. One great objection to both cabbages and turnips is the mildnefs of the feafon in Ireland, which is fo great as to burft the cabbages, and make the turnips run to feed before their time. As to the grafs fpringing fo faft in winter, as to prevent the neceffity of the culture, he does not find it. Cabbages muft be well manured for.

\section{P O T A T O E S.}

Lord Shannon planted eighteen acres of po. tatoes with the plough, manuring only the furVor. II. 
rows; horfe and hand-hoed them perfectly, to keep them free from weeds; did it twice, and purpofed oftener, but the growth of the crop was folux uriant that neither the horfe nor hoe could get through them. Took them up with the plough, and the crop proved exceedingly good, far better than they would have been in the common method.

\section{DRILL HUSBANDRY.}

Lord Shannon's expreffion of this mode to me was excellent, I read my felf into it, and worked myfelf out of $i t$. He tried it with wheat, horfe and hand-hoeing it perfectly, and got a very 'fine crop; an unexceptionable one for the mode, but the produce was not equal to the common way, while the expenfe, trouble, and attention, were endlefs, fo that he was convinced, even, by his fuccefs, that it could not be a beneficial mode of culture. For turnips alfo he prefers very much the broad-caft mode, and never began the drill method but as an eafe of hoeing.

\section{$S \quad O \quad I \quad L \quad I \quad N \quad G$.}

Soiling horfes, \&cc. in fummer, with grafs mown every day, Lord Shannon has practifed greatly, and finds it highly beneficial, and particularly for raifing great quantities of dung. 


\section{A S T L E M A R T YR.}

SEA-SAND AND LIME.

The manures which Lord Shannon ufes are fea-fand and lime. He prefers the latter for brown flaty ftone land, and fand for limeftone land : has ufed great quantities of it, though four to fix miles from the fea. In one month he has brought 6719 barrels of it, at 5 d. a barrel, or 139 l. 19s. 9: did. for 67 acres, at 100 barrels an acre, and afterwards 50 more for a fecond dreffing: the effect of it is very great, particularly in bringing daifies (bellis) on very poor land, and white clover when laid on good grafs lands. If a bag breaks, and fome accidentally falls on a wafte, the man gathers it up as clear as he can, yet it is fure to bring a patch of white clover. Lime his lordhip burns in a long-necked kiln, which he finds to anfwer fo well, that one barrel of culm burns ten of lime. He lets the kiln, and buys the lime at Is. 4 d. a barrel. Draws 26 balrels a day. The culm 4s, a barrel. The labourers hire Id. a barrel, for quarrying, breaking, and burning.

\section{B $O U$ U N T I E S.}

Lord Shannon's bounties to labourers amount to 501 . a year. He gives them by wity of encouragement; but only to fich as can fpeak Englith, and do fomething more than fi!t a cart. 


\section{$D$ I T C I H E S.}

His Lordfhip has made fome ditches: of an extraordinary dimenfion; the following fegment :

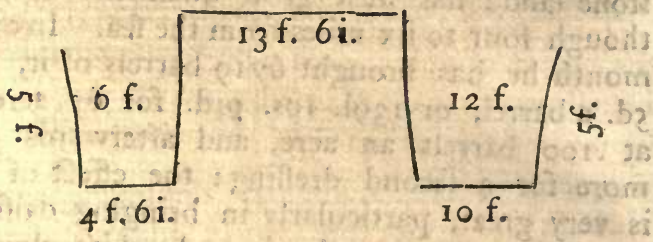
tween two ditches, broad enough to plant a hedge on each fide of it, and have a riding between them: it is moft completely done, and will anfwer the double purpofe perfectly. $\mathrm{He}$ is alfo doing a good deal in the following dimenfions:

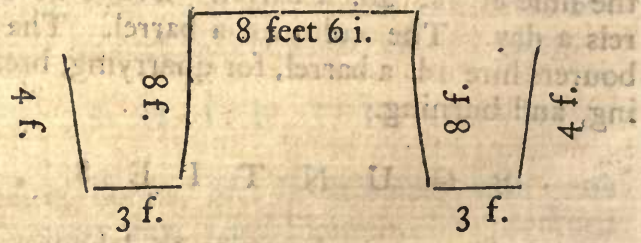

which cofts a fhilling a perch, a double row of quick, and a walk or ride between. 


\section{CASTLEM A R TYR.}

\section{LINEN MANUFACTORY.}

Lord Shannon eftablifhed a factory at Cloghnickelty, in the year 1769 , a bleach yard of feventeen acres of land, with mills, \&cc. for bleaching the pieces that are wove in the neighbourhood. There are 94 looms at work in the town, 10ol. a week laid out in yarn, and at three fairs, 1800 . the amount of which is 70001 . a year; the cloth chiefly coarfe: and this eftablifhment has had great effect in increafing the manufactures in the neighbourhood.

\section{$\begin{array}{llllllll}C & \mathrm{O} & \mathrm{M} & \mathrm{P} & \mathrm{O} & \mathrm{S} & \mathrm{T} & \mathrm{S} \text {. }\end{array}$}

$\mathrm{He}$ is exceedingly attentive in forming compofts. A river runs through Caftlemartyr, part of which is often full of fand and mud; this he empties periodically and mixes it with lime. In one field I faw larger compoft heaps of thefe materials, than I remember any where elfe to have obferved; one of thefe was 105 yards long, nine broad, and four feet high, containing cubical yards - _ 1260 Another, 78 and 8 broad, and 4 feet high 832 Another, 155 by 5 , and 4 feet high - 1033 Another, 76 by 5 , and 4 feet high - -506

$$
\text { Total - - - } 36_{3}
$$

Among thefe hills were 2000 barrels, or 8000 buhels of lime mixed : after this it is need- 


\section{CASTLEMAR T Y R.}

lefs to fay, that he manures his land with uncommon fpirit.

\section{W A S TE L A ND.}

His Lordfhip has reclaimed 109 acres of furze land, which he has eradicated, and brought to a very profitable foil.

\section{W A L L L I N G,}

Lord Shannon has inclofed 380 acres with a molt excellent wall, eight feet and a half high under the coping, and 8 inches above it. The wall is two feet thick at bottom, and 18 inches at top, and cofts 4 s. per perch, or 11 . 16 s. running meafure.

\section{B A R N.}

The beft built barn $I$ have feen in Ireland, is at Caftle Martyr. The bays and threfhing floor are fourreen feet high, and over them are two ftories for granaries, the firft eight feet two inches high, and the upper one eight feet nine jnches, befides the roof, with a door in the center of the floors, and a wheel for winding facks up. It is built in fuch a manner, the doors, \&cc. fo plated every where at the edges with iron, that it is impoffible a moufe fhould rget in or out; or that a rat fhould any where gnaw his way in. Upon clearing it laft year, about twenty mice were found, that had been carried in in the fheafs, a little ftraw was laid 
for them in a corner, and the barn fhut for a fortnight, at the end of which time they were found alive, and killed, not one being able to efcape. I have feen very fine barns built in England, on capt ftones, into which no vermin could get, unlers carried in, but when they were carried in they had a million of ways to get out.

BULLOCKS DRAWN BY THE HORNS.

Lord Shannon upon going into tillage, found that the expenfe of horfes was fo great, that it eat up all the profit of the farm; which made him determine to ufe bullocks; he did it in the common method of yokes and bows, but they performed fo indifferently, and with fuch manifeft uneafinefs, that he imported the French method of drawing by the horns; and in order to do this effectually, he wrote to a perfon at Bourdeaux to hire him a man who was practifed in that method. Upon the correfpondent being applied to, he reprefented difficulties attending it, the man who was fpoken to having been in Germany for the fame purpofe. Upon which Lord Shannon gave directions that every thing fhould be bought and fent over which the labourer withed to bring with him. Accordingly, a bullock of the beft fort, that had been worked three years, was purchafed; alfo a haycart, a plough, harrows, and all the tackle for harneffing them by the horns, which, with the man, were fent over. His falary was to be 400 livers a year, with board, \&c. The bul- 
56 CASTLEMARTYR.

lock, 218 livres; tackle for two bullocks, 36 . Two carts, 314. A plough and harrow, 123 , which, with other expenfes, came to 451.17 s. and freight $161.16 \mathrm{~s}$. Upon the whole, the experiment coft, from firft to laft, to bring it thoroughly to bear, about an hundred pounds. His Lordihip is perfuaded, that the firft year of his introducing it at large on his farm, faved him the whole. He has purfued the method ever fince, and with the greateft fuccefs. He finds the bullocks fo perfectly at their eafe, that it is a pleafure to fee them; for firft breaking up lays, and for crofs ploughing, he ufes four, but in all fucceeding earths, only two; nor more for the firft ploughing of ftibbles; I faw fix ploughs doing this in a wheat ftubble, and they did it five or fix inches deep with great eafe. Upon firf introducing it, there was a combination among all his men againft the praclice, but Lord Shannon was determined to carry his point; in this matter, he followed a courfe that had all imaginable fuccefs: one lively fenfible boy took to the oxen, and worked them readily. His Lordhip at once advanced this boy to eight pence a day: this did the bufinefs at once; others followed the example, and fince that he has had numbers who could manage them, and plough as well as the Frenchman. They plongh an acre a day with eafe; and carry yery great loads of corn and hay, coals, \&c. Four bullocks in the French cart brought twelve bairels of coals, thip neafure, each 5 cut. or three tons, but the tackle of the fore 
fore couple breaking, the other two drew the load above a mile to a forge. Two of them drew 35 cwt. of flag ftoric, three miles with eafe; but Lord Shannon does not in comman work them in this manner, three tons he thinks a proper load for four bullocks. Upon the bailiff, Mr. Bere, mentioning loads drawn by thefe oxen, that appeared to me moft extraordinarily great, I expreffed many doubts; his Lordhip immediately ordered the French harveft cart to be loaded half a mile from the reeks : it was done; 1o20 theafs of wheat were laid on it, and two oxen drew it without difficulty; we then weighed forty theafs, the weight $25 \mathrm{Ilb}$. at which rate the 1020 came to $6375 \mathrm{lb}$. or above three tons, which is a vaft weight for two oxen to draw; I am very much in doubt whether in yoaks they would have ftirred the cart fo loaded.

Lord Shannon has an excellent way of managing all his cattle in one circumftance, which is to mark them on the horn with numbers, and keeps a book ruled in columns, and engraved, by which means, on turning to the number, he fees every particular of the beaft, which are inferted in the columns. He trains them for work at three to four years old, gently breaking them in at once, without any difficulty.

The common hufbandry about Caftle Martyr, will be feen from the following account, for which particulars $\mathrm{I}$ am obliged to the attention 


\section{$5^{8}$ C ASTLEMARTYR.}

tion of this patriotic nobleman, who took every method to have me well informed. Farms rife from one hundred to three hundred acres, but fome to one thoufand, of which fize Lord Middleton has one. Farms not taken in partnerfhip fo much as in other parts; two or three will take a farm of thirty or forty acres, but it is not general. The foil is various; the vale, from Carricktowel to Killay, of ten or twelve miles long, and four over, is of lime-ftone ; the hills are brown ftone; the loam upon it is from three inches to eight feet, ftrong, rich and good; dry in winter, and good turnip land. Thefe lime-ftone rocks are full of cavities, and fubterraneous paffages, fo that if you cut a drain to carry water off, and touch upon a lime ftone rock, probably all will find its way. Rent of the barony of Imokilly, on an average, twelve fhillings an acre; Kilnatalton, eight fhillings. A third part of the county is wafte land, the price of which is rifen extremely in a few years; rent, one fhilling; the reft of the county, eight thillings. The courfe of crops:

I. Potatoes, upon clay ground, dunged and ploughed at 31 . plant fix barrels at two and a half $\mathrm{cw}$. produce 50 to 100 barrels; potatoes fell 2 s. to 4 s. a barrel.

2. Wheat, fow twelve ftone, produce five barrels.

3. Oats, on one ploughing, fow a barrel of fourteen ftone, crop eight barrels. Some poor 


\section{CASTLE M A R T Y R.}

poor people take one or two more crops of oats.

4. Lay out for grafs from two to twelve years. They fometimes burn for potatoes, efpecially on the abfentee eftates, and get as good crops, as in the other way.

\section{Expence of an acre of potatoes.}

Rent

Seed

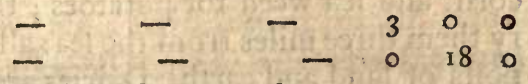

Planting and trenching, forty days of a man $\quad$ I 0

Taking up and carrying home, \&ic. _ - 100

Tythe

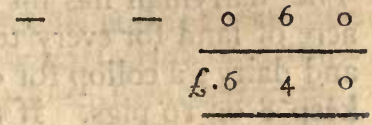

Produce.

Seventy barrels at $38 . \quad-10100$

Expences - - 640

Profit - $-\overline{6.460}$

A difpute arifing upon the produce of potatoes, Lord Shannon ordered fome fpades fquare (each $5 \frac{1}{2}$ feet) to be taken up, and weighed them; the weight, on an average, $19 \mathrm{lb}$. per fpade, or 108 barrels per acre, each $252 \mathrm{lb}$. that is, 12 weights to the barrel, each $2 \mathrm{Ilb}$. There were his own potatoes, and not an extra crop at all. Barley is fometimes put in inftead of oats, 
60 CAS T L E M R T Y R.

and bere inftead of wheat. A crop of bere produces ro barrels; barley yields 8 . No turnips or rape. A few of the better farmers fow clover, but the number very inconfiderable. Flax is fown by few of the common people in patches. Paring and burning is called graffing and burning is practifed by the common farmers, upon fuch eftates as their landlords will permit. They manure with fea fand for corn, and fea weed for potatoes; they will carry them three miles from the fea: all make comports of fand and earth. Dairies are numerous, from twenty to fifty cows fet at 31 . a cow. The dairyman has his privilege, which is an acre of Jand for every ten cows, a good houfe and dairy; a collop for every Io cows, and will kesp 8 or 10 pigs. If not paid in money, it is one cwt. of butter and $\mathrm{I} 2 \mathrm{~s}$. in money. A cow that gives two gallons a day the dairyman cannot reject : it will take three acres to a cow, but privilege and all is four acres. Very few flocks in this country; Mr. Robert Fitzgerald has 1000 to 1500 : but the number too few to be worth mentioning. The poor people all keep a collop or two of fheep, with which they clothe themielves. They plough generally with four horfes, fow with two, and ufe ploughs of fo bad a conftruction, that a man attends them with a ftrong ftick leaning on the beam to keep it in the ground.

Land fells at twenty-five years purchafe. Rents have not fallen; foi very little of it is let at more than its value. Tythes are every where 
where valued by the proctor by the acre. No emigrations from the county of Corke. The religion is almoft univerfally catholic. Building a common cabbin 51 . two of ftone, \&c. for 3il. 10s. They carry half a barrel of fea fand on horfeback, fourteen miles from Corke to the mountains of Barrymore, and to Mr. Coppinger's, twenty-four miles, and it improves much for tillage: but it is carried when not to mountains in cars : it is not found to be fo good as lime.

There is a woollen trade at Caftle Martyr : Mr: James Pratt in particular buys wool in Tipperary and at Ballynafloe. The beft is the Connaught ; it is the fineft, and is hort; the longeft is in the county of Carlow and Tipperary. In Carlow they keep the fheep fattening a year longer, after buying in Tipperary. Tipperary wool slb. Carlow 6ib. Connaught $4 \frac{1}{2} \mathrm{lb}$. In forting, the fine belly wool is feparated, the finer will make cloth of 1os. or 12s. a yard. The back and fides are laid by for combing, the other is carded; about four fifths of the fleece is combed. Combs in his own houfe, employing ' 16 to 20 hands'; pays them by the ball, $3 \mathrm{~d}$. eack of $24 \mathrm{oz}$. and they earn $8 \mathrm{~s}$. a week; thefe balls are given out to the poor people to fpin, employing above a thoufand fpinners? They fpin a ball from I I to $13 \mathrm{Akain}$ in foul days, attending their family befides. The value is $2 \mathrm{~s}$. $8 \mathrm{~d}$. per ball: are paid 9 d. a ball. In this way of doing it there are not many tricks, being in general 
very honeft. For II fkains, 8d.-12-od. 13-1od.-14-11d. They are forted and packed in packs of 180 balls, which fell at 301 . a pack. It was never known to be higher than lait year: twenty years ago it was 251 . a pack, about a fourth of what is fpun in this part of the kingdom, is worked up at home. The trade has been a rifing one for two years.

Edward Roche, Efq; of Kildining, gave me, at Caftle Martyr, the following account of fome improvements he has made. Has done $25^{\circ}$ acres of mountain, and began upon 50 of bog; the former with paring and burning with ploughs, at $7 \mathrm{~s}$. and cutting and burning, $5 \mathrm{~s} .6 \mathrm{~d}$. in June and July. Limes with the ahes, 50 barrels per acre, at 47 gallons, or 75 , at 5 d. spread and plough in April or May; then fet to poor people, at 30 s. an acre. They trench in potatoes in the common way, get on an average fixty barrels, then trench in rye or black oats, fix men to an acre; crops fix barrels of rye, 20 ftone per barrel, at $7 \mathrm{~s}$. or $8 \mathrm{~s}$. and black oats, 10 kilderkins, at 11 ftone; then white oats, 8 barrels, fow grafs feeds one barrel, with them, and $8 \mathrm{lb}$. white clover, and $2 \mathrm{lb}$. rib-grafs. The land before not $6 \mathrm{~d}$. an acre, could let it now at $7 \mathrm{~s}$. Ploughs with fix bullocks firft, and four afterwards. Potatoe ftalks he carries to his pound, but in general are left in heaps in the field, and are a nuifance to ploughing. In Wicklow, they bleed their horfes and cows, and mix the blood with meal for food.

From 


\section{A S T L E M A R Y.}

From Cartle Martyr, September zo, to Caftle Mary, the feat of — Longfield, Efq; who keeps a great quantity of land in his hands. Has cultivated the potatoes, called here bulls, that is, the Englinh cluffer, very much for cattle, but nobody will eat them; he has from fix to eleven acres yearly: plants them in the common manner, and gets 120 barrels an acre, of 20 ftone each. I faw a fpade of five feet and a half fquare, dug the produce $23 \mathrm{lb}$. on very poor land. On fand and fea weed the fame fpace of London ladies, weighed $27 \mathrm{lb}$. Manures for them with fea fand and weed, but not with dung; gives them to his horfes and bullocks: and when he gives his horfes potatoes, they have no oats. It is furprifing to fee how fond horfes are of them; they do very well on them raw, but the beft way is to boil them, as they will then fatten the horfes. The bullocks are equally fond of them, and will follow him to eat them out of his hand. Sheep are the fame, and will get into the ficlds to fcrape them up: upon the whole, Mr. Longfield is perfuaded that no root or crop in the world is more beneficial to a farmer than this potatoe, fo that he fhould have continued in turnips, which he has cultivated largely but has found this root fo perfectly ufeful, that he has experienced the abfolute dependence which may be placed on them for winter provifion of all forts. And what is of infinite confequence, the culture may be extended to what quantity you pleafe, without the affiftance of dung, without which other potatoes cannot be managed. 
64. ROSTELLAN.

Mr. Longfield eftablifhed the linen manufacture here three years ago, by building a -bleach mill and bleach green; he has 14 looms conftantly at work upon his own account, who are paid for what they manufacture by the yard. The fort generally made is from 900 to 1400 , and makes 650 pieces of 25 yards. length, annually; fells, at prefent, from 23 s. to 3 os. a piece. The factory employs $5^{\circ}$ hands; bleaches great quantities for the poor people. A great many weavers are fcattered about the country, who bring their webs, \&cc. to be bleached here. The flax is raifed, and the yarn fpun at Clanikilty and Rofs, \&cc. in the wert of the county. No woollen manufacture is carried on in this country. Mr. Longfield has always ploughed with oxen, which he has found far more advantageous than horfes. Clover he has cultivated long with very great fuccefs, and finds it highly beneficial. The county of Corke two-thirds wafte, at a very low or no rate, the other third at ${ }_{5} 5$.

September 2 ift to Roftellan, the feat of Lord Inchiquin, commanding a beautiful view of Corke harbour, the hips at Cove, the great inland, and the two others which guard the opening of the harbour. It appears here a noble bafon of feveral miles extent, furrounded with high grounds, which want no other addition but woods. This view is feen in great perfection from the windows of two very good rooms, 25 by 35 , which his Lordhip has built in addition to the old caftle. 
$\begin{array}{lllllll}C & \mathrm{O} & \mathrm{R} & \mathrm{K} & \mathrm{E} & \mathrm{6} & \end{array}$

From Roftellan to Lota, the feat of Frederick Rogers, Efq; I had before feen it in the higheft perfection from the water going from Dunkettle to Cove, and from the grounds of Dunkettle. Mrs. Rogers was fo obliging as to thew me the back grounds, which are admirably wooded, and of a fine varied furface.

Got to Corke in the evening, and waited on the Dean, who received me with the moft flattering attention. Corke is one of the moft populous places $I$ have ever been in ; it was marketday, and I could fcarce drive through the ftreets; they were fo amazingly thronged : on the other days, the number is very great. I hould fuppofe it muft refemble a Dutch town, for there are many canals in the ftreets, with quays before the houfes. The beft built part is Morrifon's Ifland, which promifes well; the old part of the town is very clofe and dirty. As to its commerce, the following particulars I owe to Robert Gordon, Efq; the furveyor general.

Average of nineteen years export, ending Marcb 24, 1773.

Hides, at Il. each

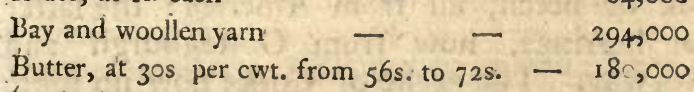

- 64,000 Beef, at 20s. a barrel

Camblets, ferges, \&c.

291,970

Candles

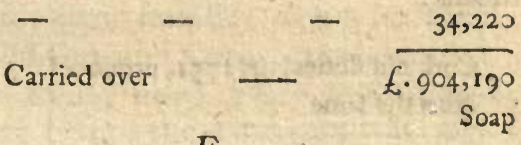

VoL. II. 
C $\quad \mathrm{O} \quad \mathrm{R} \quad \mathrm{K} \quad \mathrm{E}$.

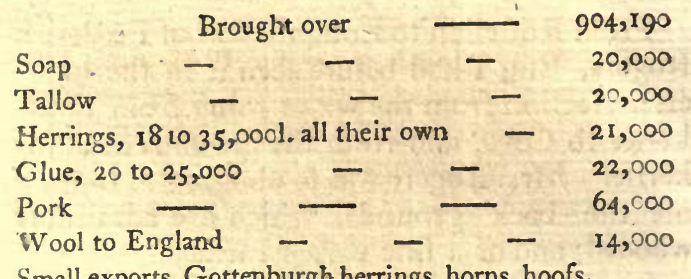

Small exports, Gottenburgh herrings, horns, hoofs,

\&ic. feather-beds, palliaffes, feathers, \&c.

35,000

f. $1,100,190$

Average prices of the 19 years on the cuftom books. All exports on thofe books are rated at the value of the reign of Charles the Second; but the imports have always ro per cent. on the fworn price added to them. Seventy to eighty fail of thips belong to Corke. Average of fhips that entered that port in thofe 19 years, 872 per annum. The number of people at Corke muftered by the clergy, by hearth-money, and by the number of houfes, payments to minifter, average of the three, 67,000 fouls, if taken before the Ift of September, after that 20,000 increafed. There are 700 coopers in the town. Barrels, all of oak or beech, all from America: the latter for herrings, now from Gottenburgh and Norway. The excife of Corke now no more than in Charles the Second's reign. Ridiculous!

Cork old duties, in $175 \mathrm{I}$, produced $f \cdot 62$,, $\mathrm{co}$ Now the fame 
C O $R \quad K \quad E$.

Bullocks 16,000 head, 32,000 barrels; 4 r,000 hogs, 20,000 barrels. Butter 22,000. Firkins of half a hundred weight each, both increafe this year, the whole being

\section{0, 000 firkins of butter \\ 120,000 barrels of beef.}

Export of woollen yarn from Corke, 300,0001 . a year in the Irifh market. No wool fmuggled, or at leaft very little. The wool comes to Corke, \&cc. and is delivered out to combers, who make it into balls. Thefe balls are bought up by the French agents at a vaft price, and exported; but even this does not amount to 40,0001 . a year.

\section{P R I C E S.}

Beef, 2 Is. per cwit. never fo high by 2 s. 6 d. Pork, 30 s. never higher than $18 \mathrm{~s}$. $6 \mathrm{~d}$. owing to the army demand. Slaughter dung, $8 \mathrm{~d}$. for a horfe-load. Country labourer $6 \mathrm{~d}$. about town rod. Milk 7 pints a penny. Coals 3 s. 8 d. to 5 s. a barrel, 6 of which make a ton. Eggs 4 a penny.

Corke labourers. Cellar ones 20,000; have I s. I d. a day, and as much bread, beef and beer, as they can eat and drink, and $7 \mathrm{lb}$. of offals a week for their families. Rent for their houfe, 40s. Mafon and Carpenters labourers rod. a day. Sailors, now, 31. a month and Mhip provifions : before the American war, $28 \mathrm{~s}$. 
Porters and coal-heavers paid by the great. State of the poor people in general incomparably better off than they were 20 years ago. There are imported 18,000 barrels annually of Scotch herrings, at $18 \mathrm{~s}$. a barrel. The falt for the beef trade comes from Lifbon, St. Ube's, \&xc. The falt for the fifh trade from Rochelle; for butter Englifh and Irifh.

Particulars of the woollen fabricks of the county of Corke received from a manufacturer. The woollen trade, ferges and camblets, ratteens, frizes, druggets, and narrow cloths, the laft they make to ros. and $12 \mathrm{~s}$. a yaid; if they might export to $8 \mathrm{~s}$. they are very clear that they could get a great trade for the woollen manufactures of Corke; the wool comes from Galway and Rofcommon, combed here by combers, who earn $8 \mathrm{~s}$. to $10 \mathrm{~s}$. a week into balls of 24 ounces, which is fpun into worfteds, of twelve fkains to the ball, and exported to Yarmouth for Norwich; the export price, 301 . a pack, to 331 . never before fo high; average of them 261. to 301. Some they work up at home into ferges, ftuffs, and camblets; the ferges at i 2 d. a yard, 34 inches wide; the ftuffs fixteen inches, at I $\delta \mathrm{d}$. the camblets at nine-pence halfpenny to thirteen pence; the finners at nine-pence a ball, one in a week; or a ball and half twelvepence $a$ week, and attend the family befides; this is done mort in Waterford and Kerry, particularly near Killarney; the weavers earn is. a day on an average. Full three-fourths 


\section{C $\mathrm{O} \quad \mathrm{R} \quad \mathrm{K} \quad \mathrm{E}$.}

of the wool is exported in yarn, and only onefourth worth worked up. Half the wool of Ireland is combed in the county of Corke.

A very great manufacture of ratieens at Carric-on-fure, the bay worfted is for ferges, fhalloons, \&c. Woollen yarn for coarfe cloths, which latter have been loft for fome years, owing to the high price of wool. The bay export has declined fince 1770 , which declenfion is owing to the high price of wool.

No wool fmuggled, not even from Kerry, not a floop's cargo in twenty years, the price too high; the declenfion has been confiderable. For every 86 packs that are exported, a licence from the Lord Lieutenant, for which 20l, is paid,

From the act of the laft feffions of Great Britain for exporting woollen goods for the troops in the pay of Ireland, Mr. Abraham Lane, of Corke, eftablifhed a new manufacture of army cloathing for that purpofe, which is the firft at Corke, and pays 401 . a week in labour only. Upon the whole there has been no increafe of woollen manufacture within 20 years. Is clearly of opinion that many fabricks might be worked up here much cheaper than in France, of cloths that the French have beat the Englifh out of ; thefe are, particularly, broad-cloths of one yard and half-yard wide, from $3^{s}$. to $6 \mathrm{~s}$. $6 \mathrm{~d}$. a yard 


\section{0 $\quad \mathrm{C} \quad \mathrm{O} \quad \mathrm{R} \quad \mathrm{K}$.}

for the Levant trade. Frizes which is now fupplied from Carcaffone in Lánguedoc. Frizes of 24 to 27 inches, at $10 d$. to 13 d. a yard. Flannels, 27 to 36 , from 7 d. to 14 d. Serges of 27 to 36 inches, at 7 d. to $12 d$. a yard; thefe would work up the coarfe wool. At Ballynafloe fair, in July, 200,00ol. a year bought in wool. There is a manufactory of knit-ftocking by the common women about Corke, for eight or ten miles around ; the yarn from $12 \mathrm{~d}$. to $18 \mathrm{~d}$. a pair, and the worfted, from I $6 \mathrm{~d}$. to $20 \mathrm{~d}$. and earn from $12 \mathrm{~d}$. to $18 \mathrm{~d}$. a week. Befides their own confumption, great quantities are fent to the north of Ireland.

All the weavers in the country are confined to towns, have no land, but fmall gardens. Bandle or narrow limen, for home confumption, is made in the weftern part of the county. Generally fpeaking, the circum. ftances of all the manufacturing poor are better than they were twenty years ago. The manufactures have not declined, though the exportation has, owing to the increafed home confumptions. Bandon was once the feat of the ftuff, camblet, and thag manufacture, but has in feven years declined above threefourths. Have changed it for the manufacture of coarie green linens, for the London market, from $6 \mathrm{~d}$. to $9 \mathrm{~d}$. a yard, 27 inches wide; but the number of manufacturers in general much leffened.

September. 


\section{O O}

September 22d, left Corke, and proceeded to Coolmore, the feat of the Rev. Archdeacon . Oliver, who is the capital farmer of all this neighbourhood; no perfon could be more defirous of procuring me the information I wifhed, nor any more able to give it me. Mr. Oliver began the culture of turnips four years ago, and found them fo profitable that he has every year had a field of them in the broad-caft method, and well hoed. This year they are exceedingly fine, clean, and well hoed, fo that they would be no difgrace to a Norfolk farmer. This is the great object wanting in Irirh tillage; a gentleman, therefore, who makes fo confiderable a progrefs in it, acts in a manner the molt deferving praife that the whole circle of his hufbandry will admit. Mr. Oliver has ufually drawn his crops for theep and black cattle; for the former he has fpread them upon grafs fields to their very great improvement; and the cattle have had them given in ftalls. All.forts have done perfectly well on them, infomuch that he is fully convinced of their great importance: he has found that they fupport the cattle much better than any thing elfe, to fuch a degree of fuperiority, he is determined never to be without a crop. He has always dunged for them, except when he has ploughed up a grafs lay, and then he has found it not neceffary. 
In bringing in furzy wafte land he has improved very extenfively. One inftance in particular I fhall mention, becaufe it, is the beft preparation for laying land to grafs that I have met with in Ireland: he firft dug it and put in potatoes, no manure, the crop middling; and after that cleared it of ftones. which were in great numbers, and fowed turnips, of which crop the following are the particulars.

"In November 1771, the Rev. Archdeacon John Oliver (at his refidence in the county of Corke) began to cultivate a field for turnips and cabbages; the field contained about 40 Englin acres, but was fo full of rocks that only about ten or eleven plantation acres could be tilled, the remainder being a limeftone quarry; the furface in the part tilled, in general, not above four inches deep, and in the deepeft part not above twelve inches over the lime-ftone quarry; this ground was planted with potatoes the fpring preceding, without any manure, and all done with the fpade, and in many parts there was not fufficient covering for them. The ploughing for turnips and cabbages was finifhed the latter end of December; it remained in that ftate till the month of March following $(1772$,$) when a large quantity of ftones were$ taken out with crows and fpades; it was then ploughed a fecond time, then harrowed with very ftrong harrows made on purpofe; about the latter end of May it was rolled 


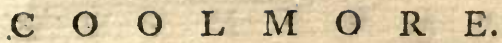

rolled with a wooden roller; on the 1 ith, 12 th, and $13^{\text {th }}$ of June, it was fowed with about one pound and a quarter of feeds to the Englin acre. When the turnips were in four leaves there appeared more fern and potatoes than turnips, which were weeded out by hand, at a great expenfe; and in about three weeks after, when the turnips began to botton), they got a fecond weeding as before, after which they were again thinned by hand; thefe different operations were continued till the turnips were about a pound weight, and then they were thinned again, and weeded as often as there was occafion, and now it is imagined they are as great a crop as any in the kingdom, fome thoufands weighing fourteen pounds per turnip. Part of the fame field is fowed in drills, thinned and weeded as the other, but they are not equal to the broad caft, but are a very good crop. Another part of the fame field is planted with 20,300 cabbages of different kinds, namely, the flat Dutch, borecole, large late Dutch cabbage, turnip-cabbage, and large Scotch cabbage, at three feet between each drill, and two feet in the rows, which is at leaft one foot too near in the drills, and half a foot in the rows, as they now touch one another this $13^{\text {th }}$ of October. All the faid cabbages and turnips were cultivated with the plough, and the cabbages hoed with the garden hoes, and manured moftly with rotten dung; part with horfe-dung, not half rotten, from the ftable; part with cow-dung, not rotten; part with fea-nlob and lime mixed; all which ma- 


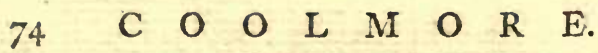

nures anfwer very well. One fmall part of the field where the cabbages were planted, was broke from the lay laft March, got fix ploughings and five harrowings; another part four ploughings and three harrowings.

The quantity of ground under turnips is $8 \mathrm{a}$. I r. ro p. Under cabbages 2a. I r. ro p.

The turnip ground got no manure of any kind, nor was it burned.

The foregoing improvements were conducted under the immediate care and management of

\section{MAURICE MURRAY."}

After thefe turnips he fowed barley, and with the barley, grafs feeds; before this improvement the land was worth Ios. an acre, but after it would let for 25 s. the grafs having fucceeded perfectly. Cabbages Mr. Oliver has alfo cultivated thefe four years, and with fuccefs, but does not find, upon the whole, they fucceed fo well as turnips, except Reynolds' turnip-rooted cabbage, which is of very great ufe late in the fpring, after other forts are gone. Beans $\mathrm{Mr}$. Oliver has alfo tried in fmall quantities, and feem to do pretty well; I faw his crop this year drilled and well managed, and a good produce, enough to give him the expectation of their being an advantageous article. Lucerne he has alfo tried, but found the trouble of kecping it clean too great to anfwer the cul- 


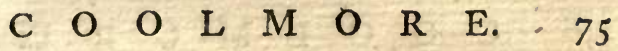

tivation. Upon manures he has tried an experiment, which promifes to be of confiderable confequence; upon fome land he took in from a creek of Corke harbour, under the flob or fea ooze he dug fome very fine blue marle; this he tried for potatoes againft dung; the crops to appearance very equal, but upon meafuring a $\int p a d e$ of each, the part marled yielded $14 \mathrm{lb}$. but that dunged only $7^{\frac{x}{2}} \mathrm{ll}$. but the dunging was not a confiderable one. It is an object of prodigious confequence to be able to get potatoes at all with marle. In the cultivation of this root $\mathrm{Mr}$. Oliver has introduced the mode of planting them in drills, two feet and a half afunder, with the plough, and found that the faving of labour is exceedingly great, but that the difference of crop is rather in favour of the common method: an acre which yielded 1005 weights, the drilled 822 , but faving in the feed of the drilled 60 weights, each weight $21 \mathrm{lb}$.

Mr. Oliver has juft taken a farm of 400 acres of land, wafte or exhaufted by the preceding tenant by inceffant crops of corn; this land was rented as is. 6d. an acre, but Mr. Oliver has tried it at 15 s. and is at prefent engaged in making very great improvements on it; draining the wet parts, grubbing furze, fallowing, liming, inclofing, and building offices, doing the whole in the moft perfect manner, and will foon make the farm carry an appearance very different from what it ever did before. His fallows for wheat had been well and often ploughed, 


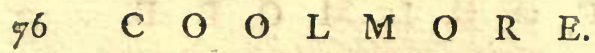

ploughed, and of a countenance very different from any lands in the neighbourhood.

A year after the date of this journey, having the pleafure of being again with this excellent improver, I had a farther opportunity of becoming better acquainted with his management. I had alfo gone over an improvement of his at Duntreleague, near Mitchelftown, where he advanced 300 acres of mountain from 50 . or 6ol. a year to 3001 . a year, having hired it on a leafe for ever; he divided the whole in fields of a proper fize by well-made ditches, doubly planted with quick and rows of trees the lands were improred with lime, laid down to grafs, and let to tenants who pay their rents well; but Mr. Oliver refiding at a diftance, the trees were very much damaged and hurt by the tenants cattle. To all appearance this improvement was as completely finifhed as any in Ireland, and the great profit arifing from the undertaking induced the archdeacon to attempt his new one I mentioned above. In that I found a very great progrefs made: befides an excellent barn of ftone and flate, there was a fteward's houfe, ftables, \&rc. and a good farmyard, walled in; and it was with particular pleafure I faw (it was in winter) a large number of cows and young cattle very well littered in it with ftraw, and feeding on turnips a thick layer of fea-fand having been fpread all over it. The improvement and cultivation of the farm went on apace, efpecially the liming; the kiln had been burning a twelvemonth, in which time the expenfe had been as follows:

364 barrels 


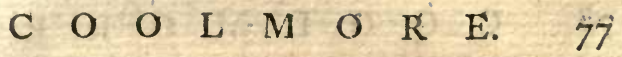

364 barrels of culm, at $4 \mathrm{~s}$.

7300

The quarry is $1 \frac{x}{4}$ mile Englifh from the kiln; two

horfes and two men drawing ftone, at $18 \mathrm{~s}$ : a

week

Two men quarrying, 5s: a week to one, and 3 s.

a week to the other

$4^{6} \quad 160$

Breaking and burning, 8s. a week

Gunpowder, rs. a month

24 waggon-load of coal cinders, bought at Corke,

at ros.

One horfe and man carries out 24 barrels a day,

at Is. 6d. 242 days $-\frac{18 \text { I }}{\text { Total }}$

The quantity of lime drawn from February

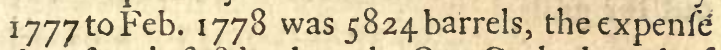
therefore juft $8 \mathrm{~d}$. a barrel. One Corke barrel' of culm, at 4 s. ufed every day, and half a barrel of antes : the kiln draws 18 barrels a day, 16 for $i$ of culm, and 10 for 1 including cinders. This barrel of culm is 6 bufhels heaped. Mr. Oliver had an old memorandum, that the price of fuel was three-pence farthing per barrel of lime. Twelve tons of lime-ftone produces 50 barrels of roach lime. Nor does the archdeacon truft to lime alone; he buys great quantities of dung and foap athes in Corke. At the fame time I viewed his turnip crops on his home farm, and found them excellent, and many oxen tied in ftalls fattening on them, a practice he finds exceedingly profitable; when other 


\section{$\begin{array}{lllllllll}7^{8} & \mathrm{C} & \mathrm{O} & \mathrm{O} & \mathrm{L} & \mathrm{M} & \mathrm{O} & \mathrm{R} & \mathrm{E} .\end{array}$}

other graziers fell their bullocks with difficulty, he puts his to turnips, and doubles and trebles their value. In 1777 he had 23 acres of turnips. Before I conclude this account of his Spirited exertions, I muft add, that if a very few improvers in Ireland have gone through more extenfive operations, I have not found one more attentive or more practical, and, upon the whole, farcely any that come near to him.

Land about Coolmore lets from 8s. to 20 . The foil lime-ftone. Farms rife from 50l. to 3001. The courfes are,

I. Potatoes, yield " 50 barrels. 2. Wheat, 3 barrels: add fometimes, 3. Oats. 4. Lay out for grafs.

The poor people have moft of them land with their cabbins, from four to fix acres, which they fow with potatoes and wheat. Not many of them keep cows, but a few forry theep for milk ; they generally have milk, either of their own, or bought, in fummer, and in winter they have herrings; but live, upon the whole, worfe than in many other parts of the kingdom. The price of labour $6 \mathrm{~d}$. a day the year round; in harvert 8d. Rent of a cabbin 20s. Many dairies here, which are generally fet at four pound a cow, fome four guineas, and near Corke, five pounds. 
C O O O L

The manures are lime, at is. 4 d. a barrel roach; if burnt by themfelves, $8 \mathrm{~d}$. to rod. lay thirty to fifty barrels. Sea fand is ufed, fixty to eighty bags, each five pecks, to the acre. Corke dung cofts $6 \mathrm{~d}$. to rs. a car load; it is all bought up very carefully; 101 . a year is paid for the cleaning of one ftreet; this argues a very fpirited hurbandry.

Rode to the mouth of Corke harbour; the grounds about it are all fine, bold, and varied, but fo bare of trees, that there is not a fingle view but what pains one in the want of wood. Rents of the tract fouth of the river Caragoline, from $5^{\text {s. to }} 3$ os. average, Ios. Not one man in five has a cow, but generally from one to four acres, upon which they have potatoes, and five or fix heep, which they milk, and fpin their wool. Labour 5 d. in winter, $6 \mathrm{~d}$. in fummer; many of them for three montirs in the year live on potatoes and water, the reft of it they have a good deal of fin. But it is remarked, at Kinfale, that when iprats are moft plentiful, difeafes are moft common. Rent for a mere cabbin, 10s. Much paring and burning; paring twenty-eight men a day, fow wheat on it and then potatoes; get great crops. The foil a fharp ftoney land; no lime-ftone fouth of the above river. Manure for potatoes, with fea weed for 26s. which gives good crops, but lafts only one year. Sea fand much ufed, no fhells in it. Farms rife to two or three hundred acres, but are hired in partnerhip. 
So C O O L $\mathrm{M}$ O $\mathrm{R}$ E.

Before I quit the environs of Corke, I muff remark, that the country on the harbour, I think preferable, in many refpects for a refidence, to any thing I have feen in Ireland. Firft, It is the moft foutherly part of the kingdom. Second, there are very great beauties of profpect. Third, by much the moft animated, bufy fcene of fhipping in all Ireland, and confequently, Fourth, a ready price for every product. Fifth, great plenty of excellent fin and wild fowl. Sixth, the neighbourhood of a great city for objects of convenience:

September $24^{\text {th, took }}$ my leave of $\mathrm{Mr}$. Oliver; I purpofed going from hence to Bandon, in the way to Carbury, and fo to Killarney, by Bantry and Nedeen, and with this view had got letters of recommendation to feveral gentlemen in that country; but hearing that the Priefts Leap between Bantry and Nedeen was utterly impaffable, the road not being finifhed, which is niaking by fubfcription. I changed my route, and took the Macroon road. Dined with $\mathrm{Co}$ lonel Ayres, who informed me that the agriculture of that neighbourhood was very indifferent, and little worth noting, except the ufe of lime as a manure, which is practifed with great fuccefs. From his houfe I took the Nedeen road.

Paffed Brockham, the place where Cornelius Townhend, Eff; eight years ago fixed two Suffex farmers, to improve a ftoney mountain. 1 faw the land, and fome of the buildings, and 


\section{C $\mathrm{O}$ O O L}

having heard feveral accounts of the tranfaction from friends to the farmers, which accounts had been received from them; I winhed to have Mr. Townfhend's, and with that view called at his houfe, but unfortunately he was not at home; as I miffed him, I hall only. mention the affair in the light it appeared to me from the particulars I received from different hands.

Mr. Townfhend wifhing to improve his eftate, a confiderable part of which confifted of mountain, but furprizingly full of rocks and ftones; he engaged two Suffex farmers, (Meffis. Crampe, and Johnfon) to come over to Ireland, to view the lands in queftion: they both came over, examined the land, and hired a tract for fome time at no rent, or a very fmall one, and after that at a rent named and agreed to. The men returned, fettled their affairs in England, bought very fine horfes, and embarked all their ftock, implements, \&c. and came over, under circumftances of great, but ufelefs expence. When they got to the land, houfes and offices were built for them, in a moft complete file, and among others, a barn 100 feet long, and 37 broad; an exceedingly illjudged expence, the refult of bringing merely Englifh (perhaps miftaken in ideas) into the climate of Ireland.

Thefe buildings being executing at the landlord's expence, but the tenants drawing the materials, they began the improvement; and

VOL. II. 


\section{$82 \quad B \quad R \quad O \quad K \quad H \quad A$.}

found the land fo exceffively ftoney, that the expence of clearing was too great to be within a poffibility of anfwering. One field of eight acres coft 10ol. in clearing: walls were buile 10 feet thick, with ftones that arofe in clearing the land. The undertaking went on for 4 years, but was then concluded in the way one might have expected. The men were ruined, and Mr. Townfhend fuffered confiderably by the expences of the undertaking, rifing infinitely beyond what he had ever thought they could amount to.

Had Mr. Townfhend met with farmers of fufficient knowledge in their profeffion, they would not probably have fixed on this fpot at all ; certainly when they found to what excers it abounded with ftones, they would have perfuaded him either to give them other land, or have hired a more favourable foil of fome other landlord : at all events to perfift in improving a fpot, the improvement of which could never be repaid, whether it was upon their own, or their landlord's account, was equally inexcufable in point of prudence, and the fure way to bring difcredit on the undertaking, and ridicule on what falfely acquired the name of Englifh bufbandry. Planting is the only proper improvement for land abounding to fuch excefs with rocks.

From hence I reached Sir John Coulthurft's at Knightrbridge, who has a very extenfive eftate here, 7000 acres of which are mountain 


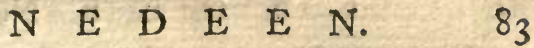

and bog. I was unfortunate in not having feen Sir John's feat, near Corke, for there he is at work upon 1000 acres of mountain, and making very great improvements, in which, among other circumftances, he works his bullocks by the horns.

September $25^{\text {th, }}$ took the road to Nedeen, through the wildeft region of mountains that $I$ remember to have feen 3 it is a dreary, but an interefting road. The various horrid, grotefque and unufual forms in which the mountains rife, and the rocks bulge; the immenfe height of fome diftant heads, which rear above all the nearer fcenes, the torrents roaring in the vales, and breaking down the mountain fides, with here and there a wretched cabbin, and a fpot of culture yielding furprife to find human beings the inhabitants of fuch a fcene of wildnefs, altogether keep the traveller's mind in an agitation and fufpence. Thefe rocks and mountains are many of them no otherwife improvable than by planting, for which, however, they are exceedingly well adapted.

Sir John was fo obliging as to fend half a dozen labourers with me, to help my chaife up a mountain fide, of which he gave a formidable account : in truth it deferved it. The road leads directly againft a mountain ridge, and thofe who made it were fo incredibly ftupid, that they kept the ftrait line up the hill, inftead of turning afrde to the right, to wind around a projection of it. The path of the

$$
\text { F } 2
$$

road 


\section{$84 \cdot \mathrm{N} E$ D E E N.}

road is worn by torrents into a channel, which is blocked up in places by huge fragments, fo that it would be a horrid road on a level; but on a hill fo fteep, that the beft path would be difficult to afcend, it may be fuppofed terrible: the labourers, two paffing ftrangers, and my fervant, could with difficulty get the chaife up. It is much to be regretted that the direction of the road is not changed, as all the reft from Corke to Nédeen is good enough. For a few miles towards the latter place the country is flat on the river Kenmare, much of it good, and under grafs or corn. Paffed Mr. Orpine's at Ardtilly, and another of the fame name at Killowen.

Nedeen is a little town, very well fituated, on the noble river Kenmare, where thips of 150 tons may come up: there are but three or four good houfes. Lord Shelburne, to whom the place belongs, has built one for his agent. There is a vale of good land, which is here from a mile and a half to a mile broad; and to the north and fouth, great ridges of mountains faid to be full of mines.

At Nedeen, Lord Shelburrie had taken care to have me well informed by his people in that country, which belongs for the greateft part to himfelf, he has above 150,000 lrifh acres in Kerry; the greatert part of the barony of Glanrought belongs to him, moft of Dunkerron and Iveragh. The country is all a region of mountains, inclofed by a vale of tat land on the ri- 


\section{N E D E E N. $\quad 85$}

ver; the mountains to the fouth come to the water's edge, with but few variations, the principal of which is Ardee, a farm of Lord Shelburne's: to the north of the river, the flat land is one-half to three quarters of a mile broad. The mountains to the fouth reach to Bear-haven, and thofe to the north to Dinglebay; the foil is extremely various; to the fouth of the river all are farid ftones, and the hills loam, ftone, gravel, and bog. To the north there is a lip of lime-ftone land, from Kilgarvon to Cabbina-cufh, that is fix miles eaft of Nedeen, and three to the weft, but is not more than a quarter of a mile broad, the reft including the mountains all fand ftone, As to its rents, it is very difficult to tell what they are; for land is let by the plough land and gineve, 12 gineves to the plough land; but the latter denomination is not of any particular quantity : for no 2 plough lands are the fame. The fize of farms is various, from 40 acres to 1000 , lefs quantities go with cabbins, and fome farmsare taken by labourers in partnerfhip. Their tillage confifts of potatoes meafured by the peck of $84 \mathrm{lb}$. manure for them with fea weed, three boat loads to an acre, each at I6s. 3 d. the poor people ufe nothing elfe : but thofe who can afford it, lay dung with it. Thefe potatoes are the firft crop. Thirty pecks plant an acre, and it takes from twenty to thirty men to fet an acre in a day.

1. Potatoes. 
I. Potatoes. 2. Potatoes. 3. Oats, or barley, good crops. 4. Lay it out for what comes, and in the firit feafon the fineft grafles appear.

Some wheat is fown, but not generally by the poor people. Oats are the common crop. This is the fhort hiftory of their arable management. There are fome dairies; from 12 to 24 cows in each, and are fet at 5 os. or one cwt. of butter and I2s. horn money, the dairymen's privilege is two collops to 20 cows; a cabbin, and three acres of land. The butter is all carried to Corke on horfes backs. Three years ago 40 s. a cow was the higheft. The common ftock of the mountains are young cattle, bred by the poor people; but the large farmers go generally to Limerick for yearlings, turn them on the mountains, where they are kept till three years old, when they fell them at Nedeen or Killarney, engaging them to be with calf. Buy at $40 \mathrm{~s}$. this year, but ufed to be from $20 \mathrm{~s}$. to $30 \mathrm{~s}$. formerly fold at $50 s$. now at 31 . The poor people's heifers fell at three years old, at 3 os. their breed is the little mountain, or Kerry cow, which upon good land gives a great deal of milk. I have remarked, as I travelled through the country, much of the Alderney breed in fome of them. The winter food, which the farmers provide, is to keep bottom lands through the fummer, which they call a nurfery, to which they bring their cattle down from the mountains when the weather becomes fevere. There are great numbers 


\section{N E D E E N.}

numbers of fwine, and many reared on the mountains by the Tormentile root, which abounds there, and from which they will come down good pork. There are few heep kept, not fufficient to cloath the poor people, who, however, work up what there is into frize.

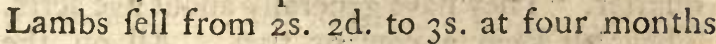
old. Three year old wethers, fat, from 5 s. to 8s. weight about glb. a quarter, and are admirable mutton. A ewe's fleece, one pound and $a$ half to two pound and a half. A lamb's, one pound. A three year old wether, two pound and a half. They have fome cows, which are fattened in the vales; and alfo fome on the mountains, weighing 2 cwt. and two and a quarter. Many goats are kept on the mountains, efpecially by the poor people, to whom they are a very great fupport; for upon the mountains the milk of a goat is equal to that of a cow; and fome of the kids are killed for meat.

Upon afking whether they ploughed with horfes or oxen, I was told there was not a plough in the whole parifh of Tooavifta, which is 12 miles long by 7 broad. All the tillage is by the Irifh loy; ten men dig an acre a day that has been ftirred before. It will take forty men to put in an acre of potatoes in a day. Rents have fallen greatly in moft parts of Kerry. Tythes in 1770 and in $177 \mathrm{I}$ were taken in kind, owing to their having been puhed up to too great a height; fince 1771 they have been lowered; the proc- 
tor every year values the tythe of the whole farm. Leafes are, fome for ever, others $3 \mathrm{I}$ years, and fome 21. The rent of a cabbin, without land, 6s. with an acre of land, 11. 2s. 9 d. The grafs for a cow is 4 os. on the mountains from is. $6 \mathrm{~d}$. to $2 \mathrm{~s}$. $6 \mathrm{~d}$. a quarter. They have generally about five acres. They all keep a cow or two. All on the mountains have goats. Swine alfo are univerfal among them. The labour of the farms are generally carried on by cottars, to whom the farmer afligns a cabbin, and a garden, and the running of two collops on the mountain, for which he pays a rent; he is bound to work with his mafter for $3 \mathrm{~d}$. a day and two meals. Their food in fummer potatoes and milk; but in fpring they have only potatoes and water. Sometimes they have herrings and fprats. They never eat falmon, The religion is in general Roman catholic,

Lime, Is. a barrel, but may be burnt for $8 \mathrm{~d}$. Fuel, all turf, 13 d. a flane, each nane four feet long, by two feet broad. Price of building a cabbin, with ftone and flate in lime mortar 201 .

There has been a confiderable fifhery upon the coaft of Kerry, particularly in the Kenmare, at Ballenfkillings in Iveragh, in the river Valentia, in Bear Haven, in Caftlemain bay, in Dingle bay, \&cc. Laft year, that in the Kenmare river was the moft confiderable: it employed twelve boats. This year none at all; the chief in Ballenfkerrings and river Valentia. 
Valentia. None in Kenmare for feveral years before : but great abundance of fprats for three years. Salmon is conftant; they export about five tons, falted. The herrings chiefly for home confumption, falted and frefh. The herring boats are of two tons, 14 foot keel, coft building $3^{1}$. 3 s. five men go in each: they are built here of bog deal. A ftring of three nets coft 31 . the poor go thares in the fifhery; build or hire the boat, and join for the nets, which are made of hemp, bought at Corke, and fpun and made here : they $\tan$ them with bark. There are many more men would go out if they had boats, but it is a very uncertain filhery. Many perfons have put themfelves to confiderable expence about it, but without fuccefs, except thirty-three years ago, when the pilchards came in, and have never been here fince,

Killarney is the principal market for wheat, which is twelve miles diftant. A floop conftantly employed upon the river Kenmare, in bringing falt and carrying lime-ftone, or whatever was wanted, would be a great improvement.

Lord Shelburne has a plan for improving Nedeen, to which he has given the name of Kenmare, from his friend the nobleman, with that title, which, when executed, muft be of confiderable importance. It is to build ten cabbins, and annex ten acres to each cabbin, 


\section{K I L L A R N E Y.}

rent free for twenty-one years; alfo to form twenty-acred allotments for the parks to the town of Nedeen, with defign to encourage fettlements in it, for which 330 acres are kept in hand. The fituation is advantageous, and hips of IQ0 tons can come up to it, with a very good landing-place. He has alfo fixed fome Englifh farmers.

Relative to the improvement of the wild regions within fight of the houfe I was in, I afked, Suppofe five acres of thofe mountains to be cleared of ftones, a fone cabbin built, at 7l. expence, and a wall raifed round the wobole, and to be let at a reafonable rent, would a tenant be found? "Tbat moment." Suppofe fix of tbem, or twelve? "You would bave tenants for all, if there were an bundred."

In the parifh of Tooavifter, they have a way of taking land by the ounce, in the arable part, which joins the fea. An ounce is the fixteenth of a gineve, and is fufficient for a potatoe garden, and they pay a guinea for it.

The climate in thefe parts of Kerry is fo mild, that potatoes are left by the poor people in the ground the whole winter through; but laft winter almoft ruined them, their crop being deftroyed.

September 26 th, left Nedeen, and rifing the mountainous region, towards Killarney, came to a tract of mountain-bog, one of the molt improvable 


\section{K I L L A $R$ R N E}

improvable $I$ have any where feen. It hangs to the fouth, and might be drained with the utmoft eafe. It yields a coarfe grafs, and has nothing in it to ftop a plough. Lord Shelburne's agent, Mr. Wray, told me, that there are vaft tracts of fuch in the barony of Iveragh. There is common gravel on the fpot, and limeftone in plenty, within half a mile of Nedeen.

Soon entered the wildeft and moft romantic country I had any where feen; a region of fteep rocks and mountains, which continued for nine or ten miles, till I came in view of Mucrufs. There is fomething magnificently wild in this ftupendous fcenery, formed to imprefs the mind with a certain fpecies of terror. All this tract has a rude and favage air, but parts of it are ftrikingly interefting; the mountains are bare and rocky, and of a great magnitude; the vales are rocky glens, where a mountain-ftream tumbles along the roughert bed imaginable, and receives many torrents, pouring from clefts, half overhung with thrubby wood; fome of thefe ftreams are feen, and the roar of others heard, but hid by vaft maffes of rock. Immenfe fragments, torn from the precipices by ftorms and torrents, are tumbled about in the wildeft confufion, and feem to hang rather than reft upon projecting precipices. Upon fome of thefe fragments of rock, perfectly detached from the foil, except by the fide on which they lie, are beds of black turf, with luxuriant crops of heath, \&c. which appeared very curious to me, having no where 


\section{K I L L L A}

feen the like; and I obferved very high in the mountains, much higher than any cultivation is at prefent, on the right hand, flat and cleared fpaces of good grafs among the ridges of rock, which had probably been cultivated, and proved that thefe mountains were not incapable from climate of being applied to ufefu! purpofes,

From one of thefe heights, I looked forward to the lake of Killarney at a confiderable diftance, and backward to the river Kenmare; came in view of a fmall part of the upper lake, fpotted with feveral iflands, and furrounded by the moft tremendous mountains that can be imagined of an afpect favage and dreadful. From this fcene of wild magnificence, I broke atonce upon all the glories of Killarney; from an elevated point of view I looked down on a confiderable part of the lake, which gave me a fpecimen of what I might expect. The wa. ter you command (which, however, is only a part of the lake) appears a bafon of two or three miles round; to the left it is inclofed by the mountains you have paffed particularly by the Turk, whofe outline is uncommonly noble, and joins a range of others, that form the thof magnificent fhore in the world: on the other fide is a rifing fcenery of cultivated hills, and Lord Kenmare's park and woods ; the end of the lake at your feet is formed by the root of Mangerton, on whofe fide the road leads. From hence I looked down on a pretty range 
$\begin{array}{lllllllllll}\text { K } & \text { I } & \text { L } & \text { L } & \text { A } & R & \mathrm{~N} & \text { E } & \text { Y. } & -93\end{array}$

of inclofures on the lake, and the woods and lawns of Mucrufs, forming a large promontory of thick wood, fhooting far into the lake. The moft active fancy can fketch nothing in addition. Inlands of wood beyond feem to join it, and reaches of the lake, breaking partly between, give the moft lively intermixture of water: fix or feven ifles and iflets form an accompanyment, fome are rocky, but with a llight vegetation, othërs contain groups of trees, and the whole thrown into forms, which would furnifh new ideas to a painter. Farther is a chain of wooded iflands, which alfo appear to join the main land, with an offspring of leffer ones fcattered around.

Arrived at Mr. Herbert's at Mucrufs, to whofe friendly attention I owed my fucceeding pleafure. There have been fo many defcriptions of Killarney written by gentlemen who have refided fome time there, and feen it at every feafon, that for a paffing traveller to attempt the like, would be in vain; for this reafon I thall give the mere journal of the remarks I made on the fpot, in the order I viewed the lake.

September $27^{\text {th }}$, walked into Mr. Herbert's beautiful grounds, to Oroch's hill, in the lawn that he has cleared from that profufion of ftones which lie under the wall; the feene which this point commands is truly delicious; the houfe is on the edge of the lawn, by a wood which covers the whole peninfula, fringes the flope at. 


\section{K I L L A R N E Y.}

your feet, and forms a beautiful thore to the lake. Tomis and Glena are vaft mountainous maffes of incredible magnificence, the outline foft and eafy in its fwells, whereas thofe above the eagle's neft are of fo broken and abrupt an outline, that nothing can be imagined more favage, an afpect horrid and fublime, that gives all the impreffions to be wifhed to aftonifh, rather than pleafe the mind. The Turk exhibits noble features, and Mangerton's huge body rifes above the whole. The cultivated tracts towards Killarney, form a hore in contraft to the terrific fcenes I have juft mentioned; the diftant boundary of the lake, a vaft ridge of diftant blue mountains towards Dingle. From hence entered the garden, and viewed Mucrufs abbey, one of the moft interefting fcenes I ever faw; it is the ruin of a confiderable abbey, built in Henry the VIth's time, and fo entire, that if it were more fo, though the building would be more perfect, the ruin would be lefs pleafing; it is half obfcured in the fhade of fome venerable afh trees; ivy has given the picturefque circumftance, which that plant alone can confer, while the broken walls and ruined turrets throw over it

\section{The laft mournful graces of decay,}

heaps of fculls and bones fcattered about, with nettles, briars and weeds fprouting in tufts from the loofe ftones, all unite to raife thofe melancholy impreffions, which are the merit of fuch fcenes, and which can fcarcely any where 
$\begin{array}{lllllllllll}K & \text { I } & \text { L } & \text { L } & \text { A } & R & N & \text { E } & \text { Y. } & 95\end{array}$

be felt more completely. The cloifters form a difmal area, in the center of which grows the moft prodigious yew tree I ever beheld, in one great ftem, two feet diameter, and fourteen feet high, from whence a vaft head of branches fpreads on every fide, fo as to form a perfect canopy to the whole fpace; I looked for its fit inhabitant-it is a fpot where.

The moping orel doth to the moon complain.

This ruin is in the true ftile in which all fuch buildings fhould appear; there is not an intruding circumftance-the hand of drefs has not touched it-melancholy is the impreffion which fuch fcenes fhould kindle, and it is here raifed moft powerfully.

From the abbey we paffed to the terrafs, a natural one of grafs, on the very fhore of the lake; it is irregular and winding; a wall of rocks broken into fantaftic forms by the waves: on the other fide, a wood, confifting of all forts of plants, which the climate can protect, and through which a variety of walks are traced. The view from this terrafs confifts of many parts of various characters, but in their different ftiles complete; the lake opens a fpreading theet of water, fpotted by rocks and illands, all but one or two wooded, the outlines of them are harp and diftinct; nothing can be more fmiling than this fcene, foft and mild, a perfect contraft of beauty to the fublimity of the mountains which form the 


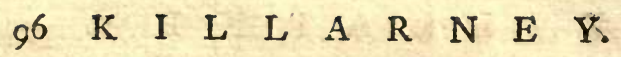

fhore: thefe rife in an outline, fo varied, and at the fame time fo magnificent, that nothing greater can be imagined; Tomys and Glena exhibit an immenfity in point of magnitude, but from a large hanging wood on the flope, and from the fmoothnefs of the general furface, it has nothing favage, whereas the mountains above and near the Eagle's-neft are of the moft broken outlines; the declivities are bulging rocks, of immenfe fize, which feem to impend in horrid forms over the lake, and where an opening among them is caught, others of the fame rude character, rear their threatening heads. From different parts of the terrals thefe fcenes are viewed in numberlefs varieties.

Returned to breakfaft, and purfued $\mathrm{Mr}$. Herbert's new road, which he has traced thro' the peninfula to Dynis ifland, three miles in length; and it is carried in fo judicious a manner through a great variety of ground, rocky woods, lawns, \&c. that nothing can be more pleafing; it paffes through a remarkable fcene of rocks, which are covered with woods; from thence to the marble quarry, which $\mathrm{Mr}$. Herbert is working; and where he gains variety of marbles, green, red, white, and brown, prettily veined; the quarry is a fhore of rocks, which furround a bay of the lake, and forms a fcene, confifting of but few parts, but thofe ftrongly marked; the rocks are bold, and broken into flight caverns; they are fringed with fcattered trees, and from many parts of 


\section{\begin{tabular}{lllllllllll}
\hline & I & L & L & A & R & N & E & Y. & 97
\end{tabular}}

then wood thoots in that romantic manner, fo common at Killarney. Full in front Turk mountain rifes with the proudeft outline, in that abrupt magnificence which fills up the whole fpace before one, and clofes the fcene.

The road leads by a place where coppermines were worked; many hafts appear; as much ore was raifed as fold for twenty-five thoufand pounds, but the works were laid afide, more from ignorance in the workmen, than any defects in the mine.

Came to an opening on the Great Lake, which appears to advantage here, the town of Killarney on the north-eaft fhore. Look full on the mountain Glená, which rifes in a very bold manner, the hanging woods fpread half way, and are of great extent, and uncommonly beautiful. Two very pleafing fcenes fucceed, that to the left is a fmall bay, hemmed in by a neck of land in front; the immediate fhore rocks, which are in a picturefque ftile, and crowned entirely with arbutus, and other wood, a pretty retired fcene, where a variety of objects give no fatigue to the eye. The other is an admirable mixture of the beautiful and fublime : a bare rock, of an aimort regular figure, projects from a headland into the lake, which with much wood and high land, forms one fide of the fcene, the other is wood from a rifing ground only; the lake open between, in a theet of no great extent, but in front is the Vol. II. 
98 K I L L L A R N N E

hanging wood of Glená, which appears in full glory.

Mr. Herbert has built a handfome Gothic bridge, to unite the peninfula to the inland of Brickeen, through the arch of which the waters of the north and fouth lake flow. It is a fpan of twenty-feven feet, and feventeen high, and over it the road leads to that ifland. From thence to Brickeen nearly finifhed, and it is to be thrown acrofs a bottom into Dynifs.

Returned by the northern path through a thick wood for fome diftance, and caught a very agreeable view of Afh Inand, feen through an opening, inclofed on both fides with wood. Purfued the way from thefe grounds to Keelbeg, and viewed the bay of the Devil's Ifland, which is a beautiful one, inclofed by a fhore, to the right of very noble rocks, in ledges and other forms, crowned in a ftriking manner with wood; a little rocky inlet rifes in front; to the left the water opens, and Turk mountain rifes with that proud fuperiority which attends him in all thefe fcenes.

The view of the promontory of Dindog, near this place, clofes this part of the lake, and is indeed fingularly beautiful. It is a large rock, which thoots far into the water, of a heigut fufficient to be interefting, in full relief, fringed with a fanty vegetation; the fhore on which you ftand bending to the right, as if to meet that rock, prefents a circular thade of dark wood:" 


\section{$\begin{array}{llllllllll}\text { K } & \text { I } & \text { L } & \text { L } & \text { A } & \mathrm{R} & \mathrm{N} & \mathrm{E} & \mathrm{Y} . & 99\end{array}$}

wood: Turk ftill the back ground, in a character of great fublimity, and Mangerton's loftier fummit, but lefs interelting outline, a. part of the fcenery. Thefe views, with others of lefs moment, are connected by a fucceffion of lawns breaking among the wood, pleafing the eye with lively verdure, and relieving it from the fatigue of the ftupendous mountain fcenes.

September 28 th, took boat on the lake, from the promontory of Dindog before mentioned. I had been under a million of apprehenfions that I fhould fee no more of Killarney; for it blew a furious ftorm all night, and in the morning the bofom of the lake heaved with agitation, exhibiting few marks but thofe of anger. After breakfaft, it cleared up, the clouds difperfed by degrees, the waves fubfided, the fun fhone out in all its fplendor; every fcene was gay, and no ideas but pleafure porfeffed the breaft. With thefe emotions fallied forth, nor did they difappoint us.

Rowed under the rocky fhore of Dindog, which is romantic to a great degree. The bafe, by the beating of the waves, is worn into caverns, fo that the heads of the rocks project confiderably beyond the bafe, and hang over in a manner which makes every part of it interefting. Following the coaft, open marble quarry bay, the thore great fragments of rock tumbled about in the wildeft manner. 
300 K I L L A R N E Y.

The ifland of rocks againft the copper-mine fnore, a remarkable group. The fhore near Cafemilan is of a different nature; it is wood in fome places, in unbroken maffes down to the water's edge, in others divided from it by fmaller tracts of rock. Come to a beautiful land-locked bay, furrounded by a woody hore, which opening in places, thews other woods more retired. Tomys is here viewed in a unity of form, which gives it an air of great magnificence. Turk was obfcured by the fun fhining immediately above him, and cafting a ftream of burning light on the water, difplayed an effect, to defcribe which the pencil of a Claude alone would be equal. Turn out of the bay, and gain a full view of the Eagle's Neft, the mountains above it, and Glená, they form a perfect contraft, the firft are rugged, but Glena mild. Here the thore is a continued wood.

Pafs the bridge, and crofs to Dynifs, an ifland $\mathrm{Mr}$. Herbert has improved in the moft agreeable manner, by cutting walks through it, that command a variety of views. One of thefe paths on the banks of the channel to the upper lake, is fketched with great tafte; it is on one fide walled with natural rocks, from the clefts of which thoot a thoufand fine arbu- tus's, that hang in a rich foliage of flowers and fearlet berries; a turf bench in a delicious fpot ; the fcene clofe and fequeftered, juft enough to give every pleafing idea annexed to retirement.

Paffing the bridge, by a rapid ftream, came prefently to the Eagle's Neft: having viewed 
K I L $L A$ A N E Y: IOI

this rock from places where it appears only a part of an object much greater than itfelf, I had conceived an idea that it did not deferve the applaufe given it, but upon coming near, I was much furprized ; the approach is wonderfully fine, the river leads directly to its foot, and does not give the turn till immediately under, by which means the view is much more grand than it could otherwife be; it is nearly perpendicular, and rifes in fuch full majefty, with fo bold an outline, and fuch projecting maffes in its center, that the magnificence of the object is complete. The lower part is covered with wood, and fcattered trees climbalmoft to the top, which (if trees can be amifs in Ireland) rather weaken the impreffion raifed by this noble rock; this part is a hanging wood, or an object whofe character is perfect beauty; but the upper fcene, the broken outline, rugged fides, and bulging maffes, are all fublime, and fo powerful, that fublimity is the general impreffion of the whole, by overpowering the idea of beauty raifed by the wood. The immenfe height of the mountains of Killarney may be eftimated by this rock, from any diftant place that commands it, it appears the loweft crag of a vaft chain, and of no account ; but on a clofe approach it is found to command a very different refpect.

Pafs between the mountains called the Great Range, towards the upper lake. Here Turk, which has folong appeared, with a figure perfectly interefting, is become, from a different pofition, 
102. K I L L A R N E Y.

pofition, an unmeaning lump. The reft of the mountains, as you pafs, affume a varied appeárance, and are of a prodigious magnitude. The fcenery in this channel is great and wild in all its features; wood is very fcarce; vaft rocks feem toffed in confufion through the narrow vale, which is opened among the mountains for the river to pafs. Its banks are rocks, in a hundred forms; the mountain fides are every where fcattered with them. There is not a circumftance but is in unifon with the wild grandeur of the fene.

Coleman's Eye, a narrow pars, opens a different fcenery. Came to a region in which the beautiful and the great are mixed without offence. The inlands are mont of them thickly wooded; Oak ifle in particular rifes on a pretty bafe, and is a moft beautiful object: Mac Gilly Cuddy's reeks, with their broken points; Baum, with his perfect cone; the Purple mountain, with his broad and more regular head; and Turk, having affumed a new and more interefting afpect, unite with the oppofite hills, part of which have fome wood left on them, to form a fcene uncommonly ftriking. Here you Jook back on a very peculiar fpot; it is a parcel of rocks which crofs the lake, and form a gap that opens to diftant water, the whole backed by Turk, in a ftile of the higheft grandeur.

Come to Derry Currily, which is a great fweep of mountain, covered partly with wood, hanging 
K I L L A R N E Y. 103

hanging in a very noble manner, but part cut down, much of it mangled, and the reft inhabited by coopers, boat-builders, carpenters, and turners, a facrilegious tribe, who have turned the Dryades from their ancient habitations. The cafcade here is a fine one, but paffed quickly from hence to fcenes unmixed with pain.

Row to the clufter of the Seven Inlands, a little archipelago; they rife very boldly from the water upon rocky bafes, and are crowned in the moft beautiful manner with wood, among which are a number of arbutus; the channels among them opening to new fcenes, and the great amphitheatre of rock and mountain that furround them, unite to form a noble view.

Into the river, at the very end of the lake, which winds towards Mac Gilly Cuddy's Reeks in fanciful meanders.

Returned by a courfe fomewhat different, through the Seven Inlands, and back to the Eagle's Neft, viewing the fcenes already mentioned in new pofitions. At that noble ruck fired three cannon for the echo, which indeed is prodigious; the report does not confift of direct reverberations from one rock to another with a paufe between, but has an exact refemblance to a peal of thunder rattling behind the rock, as if travelling the whole fcenery we had viewed and loft in tho immenfity of Mac Gilly Cuddy's Reeks. 


\section{$104 \mathrm{~K} I \mathrm{~L}$ L A R N E Y.}

Returning through the bridge, turn to the left round Dynifs ifland, under the woods of Glená ; open on the cultivated country beyond the town of Killarney, and come gradually in fight of Innisfallen and Rofs Ifland.

Pafs near to the wood of Glená, which here takes the appearance of one immenfe fweep hanging in the moft beautiful manner imaginable, on the fide of a vaft mountain to a point, fhooting into the great lake. A more glorious fcene is not to be imagined. It is one deep mafs of wood, compofed of the richert thades perfectly dipping in the water, without rock or ftrand appearing, not a break in the whole. The eye paffing upon the fheet of liquid filver fome diftance, to meet fo intire a fweep of every tint that can compofe one vaft mafs of green, hanging to fuch an extent as to fill not only the eye, but the ima: gination unites in the whole to form the moft noble fcene that is any where to be beheld.

Turn ander the North Thore of Mucruis ; the lake here is one great expanfe of water, bounded by the woods defcribed, the inlands of Innisfallen, Rors, \&c. and the peninfula. The thore of Mucrufs has a great variety ; it is in fome places rocky, huge maffes tumbled from their bafe lie beneath, as in a chaos of ruin. Great caverns worn under them in a variety of ftrange forms : or elfe covered with woods of a variety of hades. Meet the point of Ardnagluggen, (in Englifh where the water dafhes 
K I L I A R N E Y. 105

on the rocks) and come under Ornefcope, a rocky headland of a molt bold projection banging many yards over its bafe, with an old weather-beaten yew, growing from a little bracket of rock, from which the fpot is called Ornefcope, or yew broom.

Mncruls gardens prefently open among the woods, and relieve the eye, almoft fatigued with the immenfe objects upon which it has fo long gazed; thefe fofter fcenes of lawn gently fwelling among the fhrubs and trees, finifhed the fecond day.

September 29 th, rode, after breakfaft, to Mangerton Cafcade and Drumarourk Hill, from which the view of Mucrufs is uncommonly pleafing.

Pafs the other hill, the view of which I defcribed the $27^{\text {th }}$, and went to Colonel Huffy's monument, from whence the fcene is different frum the reft ; the fore ground is a gentle hill, interfected by hedges, forming feveral fmall lawns. There are fome fcattered trees and houfes, with Mucrufs Abbey, half obfcured by wood, the whole chearful, and backed by Turk. The lake is of a triangular form, Rofs ifland and Innisfallen its limits, the woods of Mucrufs and the inlands take a new pofition.

Returning, took boat again towards Rofs inle, and as Mucrufs retires from us, nothing can be more beautiful than the fpots of lawn 
106 K I L L A R N E Y.

in the terrace opening in the wood ; above it, the green hills with clumps, and the whole finifhing in the noble group of wood about the abbey, which here appears a deep hade, and fo fine a firifhing one, that not a tree fhould be touched. Rowed to the eaft point of Rors, which is well wooded, turn to the fouth coaft. Doubling the point, the moft beautiful fhore of that ifland appears; it is the well wooded environs of a bay, except a fmall opening to the caftle ; the woods are in deep fhades, and rife on the regular tlopes of a high range of rocky coaft. The part in front of Filekilly point rifes in the middle, and finks towards each end. The woods of Tomys here appear uncommonly fine. Open Innisfallen, which is compofed at this diftance of the moft various thades, within a broken outline, entirely different from the other inlands, groups of different maffes rifing in irregular tufts, and joined by lower trees. No pencil could mix a happier affemblage, Land near a miferable room, where travellers dine-Of the inle of Innisfallen, it is paying no great compliment to fay, it is the moft beautiful in the king's dominions, and perhaps in Europe. It contains twenty acres of land, and has every variety that the range of beauty, unmixed with the fublime, can give. The general feature is that of wood; the furface undulates into fwelling hills, and finks into little vales; the nopes are in every direction, the declivities die gently away, forming thofe flight inequalities which are the greateft beauty of dreffed gromnds. The little vallies let in yiews of the 


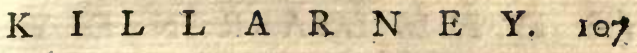
furrounding lake between the hills, while the fwells break the regular outline of the water, and give to the whole an agreeable confufion. The wood has all the variety into which nature has thrown the furface; in fome parts it is fo thick as to appear impenetrable, and fecludes all farther view; in others, it breaks into tufts of tall timber, under which cattle feed. Here they open, as if to offer to the fpectator the view of the naked lawn; in others clofe, as if purpofely to forbid a more prying examination. Trees of large fize, and commanding figure, form in fome places natural arches; the ivy mixing with the branches, and hanging acrofs in feftoons of foliage, while on one fide the lake glitters among the trees, and on the other a thick gloom dwells in the receffes of the wood. The figure of the ifland renders one part a beautiful object to another ; for the coaft being broken and indented, forms bays furrounded either by rock or wood : Night promontories thoot into the lake, whofe rocky edges are crowned with wood. Thefe are the great features of Innisfallen; the flighter touches are full of beauties eafily imagined by the reader. Every circumftance of the wood, the water, the rocks and lawn are characteriftic, and have a beauty in the affemblage from mere difpofition. I muft, however, obferve, that this delicious retreat is not kept as one could wifh.

Scenes, that are great and commanding from magnitude or wildnefs, Thould never be dreffed ; 


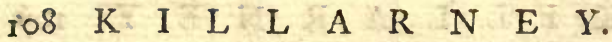

dreffed; the rugged and even the borrible, may add to the effect upon the mind : but in fuch as Innisfallen, a degree of drefs, that is cleanlinefs, is even neceffary to beauty. I have fpoken of lawn, but I fhould obferve, that expreffion indicates what it ought to be, rather than what it is. It is very rich grafs, poached by oxen and cows, the only inhabitants of the ifland. No fpectator of tafte but will regret the open grounds not being drained with hollow cuts; the ruggednefs of the furface levelled, and the grafs kept clofe thaven by many fheep inftead of beafts. The burhes and briars where they have encroached on what ought to be lawn, cleared away; fome parts of the ifle more opened : in a word, no ornaments given, for the fcene wants them not, but obftructions cleared, ruggednefs fmoothed, and the whole cleaned. This is what ought to be done; as to what might be made of the inland, if its noble proprietor (Lord Kenmare) had an inclination, it admits of being converted into a terreftial paradife, lawning with the intermixture of other fhrubs and wood, and a little drefs, would make it an example of what ornamented grounds might be, but which not one in a thoufand is. Take the inland, however, as it is, with its few imperfections, and where are we to find fuch another? What a delicious retreat! An emperor could not beftow fuch an one as Innisfallen; with a cottage, a few cows, and a fwarm of poultry, is it poffible that happinefs thould refufe to be a gueft here? 


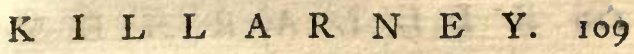

Row to Rofs Caftle, in order to coaft that ifland; there is nothing peculiarly ftriking in it; return the fame way around Innisfallen; in this little voyage the fhore of Rofs is one of the moft beautiful of the wooded ones in the lake; it feems to unite with Innisfallen, and projects into the water in thick woods one beyond another. In the middle of the channel a large rock, and from the other fhore a little promontory of a few fcattered trees; the whole fcene pleafing.

The fhore of Innisfallen has much variety, but in general it is woody, and of the beautiful character which predominates in that ifland; one bay, at taking leave of it, is exceedingly pretty, it is a femicircular one, and in the center there is a projecting knole of wood within a bay; this is uncommon, and has an agreeable effect.

The near approach to Tomys exhibits a fweep of wood, fo great in extent, and fo rich in foliage, that no perfon can fee without admiring it. The mountainous part above is foon excluded by the approach; wood alone is feen, and that in fuch a noble range, as to be greatly ftriking; it juft hollows into a bay, and in the center of it is a chafm in the wood; this is the bed of a confiderable ftream, which forms O'Sullivan's cafcade, to which all ftrangers are conducted, as one of the principal beauties of Killarney. Landed to the right of it, and walked under the thick thade of the wood, over a rocky 


\section{Ito K I L L A R N E Y.}

rocky declivity ; clofe to the torrent ftream, which breaks impetuoufly from rock to rock, with a roar that kindles expectation. The picture in your fancy will not exceed the reality; a great ftream burfts from the deep bofom of a wooded glen, hollowed into a retired recefs of rocks and trees, itfelf a moft pleafing and romantic fpot, were there not a drop of water; the firft fall is many feet perpendicularly over a rock, to the eye it immediately makes another, the bafon into which it pours being concealed; from this bafon it forces itfelf impetuoufly between two rocks; this fecond fall is alfo of a confiderable height, but the lower one, the third, is the moft confiderable, it iffues in the fame manner from a bafon hid from the point of view. Thefe bafons being large, there appears a fpace of feveral yards between each fall, which adds much to the picturefque fcenery; the whole is within an arch of wood, that hangs over it; the quantity of water is fo confiderable as to make an almoft deafening noife, and uniting with the torrent below, where the fragments of rock are large and numerous, throw an air of grandeur over the whole. It is about feventy feet high. Coaft from hence the woody fhores of Tomys and Glenà, they are upon the whole much the moft beautiful ones 1 have any where feen; Glenà woods having more oak, and fome arbutus's, are the finer and deeper thades; Tomys has a great quantity of birch, whofe foliage is not fo luxuriant. The reader may figure to himfelf what thefe woods are, when he is informed that they 


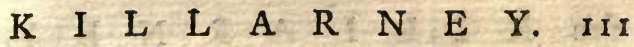

fill an unbroken extent of fix miles in length, and from half a mile to a mile and a half in breadth, all hanging on the fides of two vaft mountains, and coming down with a full robe of rich luxuriance to the very water's edge. The acclivity of thefe hills is fuch, that every tree appears full to the eye. The variety of the ground is great; in fome places great fwells in the mountain fide, with correfponding hollows, prefent concave and convex maffes; in others, confiderable ridges of land and rock rife from the fweep, and offer to the aftonifhed eye yet other varieties of fhade. Smaller mountains riferegularly from the immenfe bofom of the larger, and hold forth their fylvan heads, backed by yet higher woods. To give all the varieties of this immenfe fcenery of foreft is impolfible. Above the whole is a prodigious mafs of mountain, of a gently fwelling outline and foft appearance, varying as the fun or clouds change their pofition, "but never becoming rugged, or threatening to the eye.

The variations are beft feen by rowing near the fhore, when every ftroke of the oar gives a new outline, and frefh tints to pleafe the eye: but for one great impreffion, row about two miles from the fhore of Glenà; at that diftance the inequalities in the furface are no longer feen, but the eye is filled with fo immenfe a range of wood, crowned with a mountain in perfect unifon with itfelf, that objects, whofe character is that of beauty, are here, from their magnitude, truly magnificent, and attended with 


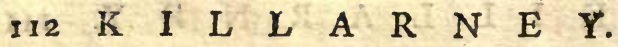

with a moft forcible impreffion.-Returned to Mucrufs.

September 30 th, this morning I had dedicated to the afcent of Mangerton, but his head was fo enihrouded in clouds, and the weather fo bad, that 1 was forced to give up the fcheme: Mir. Herbert has meafured him with very accurate inftruments, of which he has a great collection, and found his height 835 yards above the level of the fea. The Devil's punch bowl, from the defcription I had of it, muft be the crater of an exhaufted volcano: there are many figns of them about Killarney, particulary vaft rocks on the fides of mountains, in Atreams, as if they had rolled from the top in one direction. Brown ftone rocks are alfo fometimes found on lime quarries, toffed thither, perhaps in fome vaft eruption.

In my way from Killarney to Caftle Inland, rode into Lord Kenmare's park, from whence there is another beautiful view of the lake, different from many of the preceding; there is a broad margin of cultivated country at your feet, to lead the eye gradually in the lake, which exhibits her iflands to this point more diftinctly than to any other, and the back grounds of the mountains of Glenà and Tomys give a bold relief.

Upon the whole, Killarney, among the lakes that I have feen, can fcarcely be faid to have a rival. The extent of water in Loch Earne is much 


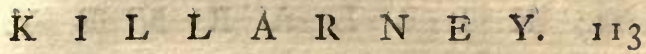
much greater; the ifland's more numerous, and fome feenes near Caftle Caldwell, of perhaps as great magnificence. The rocks at Kefwick are more fublime, and other lakes may have circumftances in which they are fuperior; but when we confider the prodigious woods of Killarney; the immenfity of the mountains; the uncommon beauty of the promontory of $\mathrm{Mu}$ crufs, and the ifle of Innisfallen; the character of the iflands; the fingular circumftance of the arbutus, and the uncommon echoes, it will appear, upon the whole, to be in reality faperior to all comparifon.

Before I quit it, I have one other obfervation to make, which is relative to the want of accommodations and extravagant expence of ftrangers refiding at Killarney. I fpeak it not at all feclingly, thanks to Mr. Herbert's hofpitality, but from the accounts given me: the inns are miferable, and the lodgings little better. I am furprifed fomebody with a good capital does not procure a large well built inn, to be erected on the immediate fhore of the lake, in an agreeable fituation, at a diftance from the town: "thére are very few places where fuch an one would anfwer better, there ought to be numerous and good apartments. A large rendezvous-room for billiards, cards, dancing, mufic, \&xc. to which the company might refort when they chofe it: an ordinary for thofe that liked dining in public; boats of all forts, nets for fifling, and as great a variety of amufements as could be colVoL. II. 
114 K I L L A $R \quad N \quad$ E

lected, efpecially within doors : for the climate being very rainy, travellers wait with great impatience in a dirty common inn, which they would not do if they were in the midft of fach accommodations as they meet with at an Englinh fpaw. But above all, the prices of every thing, from a room and a dinner, to a barge and a band of mufic, to be reafonable, and hung up in every part of the houfe: the refort of ftrangers to Killarney would then be much increafed, and their ftay would be greatly prolonged; they would not view it poft-hafte, and fly away the firft moment to avoid dirt and impofition. A man, with a good capital and fome ingenuity, would, I think, make a fortune by fixing here upon fuch principles.

In the line of agriculture, $\mathrm{Mr}$. Herbert has carried on fome important experiments, which muft deferve attention. Of 360 acres he has reclaimed 140, which, before he began, were covered with great rocks, ftones, brambles, (rubus frufficofius) and furze, (eulex europaus.) His tirft operation was to cut down and grub up the fpontaneous growth that was the ftrongeft : but the reft he fet fire to, in order to plough them up with bullocks. Then he attacked the ftones, fome of which were five or fix feet fquare; the large ones were burft in pieces by kindling fires upon them, being the brown fand-ftone. But this operation will have no effect on lime-ftone; others not fo large were drawn off the land by bullocks, to fome. 


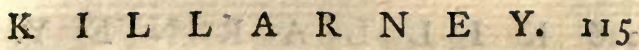

fome of which 30 were harneffed: but all ftones that could be got at were by fome means or other carried off.

This work of breaking the ftones by fire is very curious, and exceedingly ufeful: $\mathrm{Mr}$. Herbert appeared to have attended very clofely to the operation. He informed me that they firft light a good fire, which in about a quarter of an hour enables them to beat off the outward fkin of the ftone with a lledge hammer, and they then immediately light a fecond fire, which foon makes the ftone crack. The men obferve to keep it a lively brifk fire, free from afhes; when the ftone cracks, they affift it with a ftrong blow of the hammer, which then burfts it afunder, and is at once broken in pieces without difficulty.

In ploughing the land, as foon as this work was done, the remaining roots of furze, \&cc. were fo large, that he was forced to faften two ploughs together with chains, and then, with a great force of bullocks, tore up the roots, the ploughs and tackle being remarkably ftrong. The afhes of the wood, \&xc. being fpread with thole of the rubbin, numerous ploughings were given. The foil a thin gravel, of a whitifh hungry appearance, but lime changed it at once to a rich brown colour. The laft ploughing turned in the lime: upon which, Mr. Herbert, freh from Tull and Randal determined to become a driller, diilled it with wheat, the cleareft proof in the world how completely the ground had been reclaim$\mathrm{H}_{2}$ ed. 
$116 \quad \mathrm{~K}$ I L L A R N E Y.

ed. This crop he horfe hoed, following the directions of Tull and Duhamel ; the produce was trifling, and the practice found very expenfive, and the crops unprofitable: were, however, very beautiful and elegant to look at. He tried it for wheat, lucerne, fainfoine, red clover, beans, peafe, and in a word, every plant recommended by the drill writers, and continued it for fou years. Having afcertained this thorough experience, that the drill hurbandry was exceedingly difadvantageous, he gave it up, and laid down with white clover and hay feeds : and could be let at 20 . an acre. Mr. Herbert, however, going to England, they were not taken fuch care of as they ought, never being manured. Some were kaid down with burnet, which took very well in the land, but was foon overcome and choaked with natural grafs. Bird grafs he tried, got the feed from Rocque, but finds it a very coarfe poor plant of no value. Lucerne he had upon a very extenfive fcale ; having fix acres of it, found it a very good grafs, fed all forts of cattle with fuccefs, particularly. in fattening bullocks, the fat of them being warbled in the fineft manner imaginable. He had it in broad caft, and ufed Rocques harrow; but upon his foil the harrow tore up the lucerne as well as the weeds, yet the natural grafs got much a head. The drill method is the beft; but fuch is the luxuriant growth of the common graffes in Ireland, that there was the greatert difficulty in keeping it clean. Sainfoine allo did very well, 
K I I L L A $R$ R N $\quad$ E $Y$ Y. II

but the grafs had with that the fame effect as the lucerne.

Mr. Herbert has cultivated potatoes in the common lazy-bed method, upon an extenfive fcale, and he is convinced, from repeated experience, that there is no way in the world of managing that root that equals it, efpecially for bringing in wafte lands. It has been with the greateft furprife that he has read this mode condemned by feveral Englifh writers; when properly executed, it mixes the land and the manure, and by taking two crops fucceffively, and digging them out, if all the land is ftirred, it leaves it in admirable order for a fucceffive crop of any kind.

Folding theep Mr. Herbert practifes by means of a contrivance of his own; inftead of hurdles, a pole 12 feet long, and 5 inch diameter, ftruck through with perpendiculars, and having at each end two longer pieces to reft on, in form of a crofs : thofe are moveable, and eafily fet in rows. He pens the theep on his grafs lands, and finds the effect wonderful, nothing equalling them for manuring the land, and at a very fmall expence. Is clearly of opinion, that nothing would be a greater improvement to Ireland than introducing the practice generally.

An obfervation which Mr. Herbert has made on mowing land is highly deferving attention : it is, that land ought always to be mowed, though 


\section{II8 M U C R U S S.}

the value of the hay will not pay the expence. It is common in Ireland to mow parts of fields that are good, and leave the reft; but he always cuts the whole, and finds the practice very advantageous to the land.

Some bog this gentleman has improved merely by draining, and then fpreading mold upon it, without tilling or burning, brings it to a meadow as foon as poffible: and this is the method he would, in all cafes, recommend for their improvement, as there is never any neceffity of tillage in arder to bring them to grafs.

Relative to the common hufbandry of this neighbourhood, I found that the foil is divided, between lime-ftone and brown-ftone. The peninfula of Mucrufs is half the one and half the other, the one ending fuddenly where the other begins: the vale alfo to Killarney and beyond is limeftone for the extent of many miles, and in general the mountains are all brown ftone, and the vales lime-ftone. Rents here are about $8 \mathrm{~s}$. an acre on an average, including much indifferent land, but not the mountains. About three-fifths of the county of Kerry is wafte land, not rifing to above $3^{\mathrm{d}}$. an acre, and the other fifths on an average at 7 s. an acre. Farms are from 20l. a year to 13 ol. the large ones include confiderable mountain tracts. The tillage of the country is trifling. The courfe is, 


\section{$M \quad U \subset C \quad R \quad U \quad S \quad S$.}

1. Potatoes, fow eight pecks, at 7016 . and get 8 olb. at 71 . an acre. 2. Wheat, 61 . 3 . Oats. 4. Oats. (Poor crops not above 31 . Ios. an acre.) 5. Lay it out to weeds, \&uc.

Lime the manure, from 60 to 80 barrels an acre, which cofts $6 \mathrm{~d}$. to $8 \mathrm{~d}$. a barrel burning. Mr. Herbert can burn it for $4 \mathrm{~d}$. five miles off. Pafturage is applied chiefly to dairies; the common ones about 40 or 50 cows. They are all fet at 40 s. to 505 . a cow. Three acres allowed to a cow; fome paid in butter. The dairyman has his privilege, which is a cabbin, potatoe garden, liberty to cut turf, and a quantity of land proportioned to the number of cows. The butter is all fent to Corke on horfes backs in truckles, and in that way the poor horfes of the country will carry $8 \mathrm{cwt}$. the diftance 37 miles. They go in two days, and generally home in a week. Bring back rum, groceries, \&c. they are paid $9 \mathrm{~d}$. for carrying a firkin of butter of $56 \mathrm{lb}$. and for the back carriage is. $8 \mathrm{~d}$, a cwt. Very few theep kept; no flocks, except $\mathrm{Mr}$. Herbert's. It is remarkable, that no theep in the country are better fattered than many upon Mac Gilly Cuddy's Reeks, which are the wildeft and mort defolate region of all Kerry. Great herds of goats are kept on all the mountains of this country, and prove of infinite ufe to the poor people. The inhabitants are not in general well off; fome of them have neither cows nor goats, living entirely upon potatoes, yet are they better than twenty years ago, particularly in cloathing. Price of provition the 


\section{$M \quad U \quad C \quad R \quad U$ S S.}

fame as at Nedeen, but pork not common. Turkies, at $\mathrm{gd}$. Salmon, at rd. Trout and perch plentiful. No pike in Kerry. Lampreys and eels, but nobody eats the former. All the poor people, both men and women, learn to dance, and are exceedingly fond of the amufement. A ragged lad, without fhoes or ftockings, has been feen in a mud barn, leading up a girl in the fame trim for a minuet : the love of dancing and mufic are almoft univerfal amongft? tnem.

The Rev. Mr. Bland, of Wood Park, near Killarney, at whofe houfe I had the pleafure ta dine with $\mathrm{Mr}$. Herbert, has improved a great deal of boggy land; the turf fix inches deep, burnt, but would not give afhes; under it a brown gravel; reclaimed it by marking and trenching in May, lime eighty barrels per acre; fpread with green fern, then leave it until Spring following, when dunged and planted, potatoes; the crop equal to the beft : dig the potatoes, and plant a fecond crop, which will be a greater produce, but the roots not fo large; took care in the digging them to bring up the fod and manure; in the fpring dig again for turnips, or oats, the turnips will be very good, but has generally fown oats; the crop tolerable, great ftraw, but muft be fown very thin, or they will lodge; leave the oat itubble and it becomes in one year grafs to mow. Has tried turnips, and found them to anfwer perfectly, in fattening fheep infinitely better than any winter or fpring grafs.

September 
September 3 oth, took my leave of Mucrufs, and paffing through Killarney, went to Caftle Ifland. In my way to Arbella, croffed a billy bog of vaft extent, from one to fix or feven feet deep, as improvable as ever I faw, covered with bog myrtle (myricagaic) and coarfe grafs: it might be drained at very little expenfe, being almoft dry at prefent. It amazed me to fec fuch vaft tracts in a ftate of nature, with a fine road paffing through them.

To Mr. Blennerhaffet, member for the county, I am indebted for every attention towards my information. About Caftle Ifland the land is very good, ranking among the beft in Kerry. From that place to Arbella, the land is as good as the management bad, every field over-run with all kinds of rubbifh, the fences in ruins, and no appearance but of defolation: they were mowing fome fine crops of hay, which I fuppofe will be made in the fnow. The following is the ftate of hußbandry about Arbella.

The foil, from Caftle Ifland to Tralee, is from a guinea to a guinea and a half; it is all a rich lime-ftone land: fome about Tralee at 31. Ios. to 4l. 4s. About Arbella I went over fome exceeding fine reddifh fandy and gravelly loam, a prodigiounly fine foil : fern (pteris aquilina) the fpontaneous growth, which I remarked in Ireland to be a fure fign of excelient land. Two thirds of the county is mountain, which runs at no great rent, being thrown into the bargain. Six parts in feven of the whole 
A $R$ B E L L L A.

mountain and bog. The remainder at los. an acre.

J. Potatoes. 2. Potatoes. 3. Wheat, or Barley. 4. Oats. 5. Ditto. 6. Ditto. 7. Ditto. 8. Lay it out, and not a blade of grafs comes for three or four years.

The beft part of the country is under dairies. Great farmers hire vaft quantities of land, in order to ftock with cows, and let them to dairymen; one farmer, who died lately, paid 14001 . a year for this purpofe; but 3001 . or 4001 . common.

The number of cows let to one man, generally from twenty to forty. Let at one cwt. and 16s. per cow, or one-half cwt. of butter, and 16s, each, fome one cwt. 12s. and a hog, befides one fourth part of all the calves a year old. In the mountains, half cwt. and $5^{5}$. Others with all the calves to the dairymen. The dairyman's privilege, from two to four collops kept for them, and one or two acres, with a cabbin; thefe dairymen live very indifferently, their privilege being all their profit, and fometimes not that. The farmer who lets the cows, muft keep the number to fuch as give two pottles of milk. All the dairies in this county, as in others, in the bonny clobber method, that is, letting the milk ftand feveral days, till the cream comes off, by taking hold of it between the fingers, like a fkin of leather, and fome till it is moldy; the remainder. 


\section{A $R$ B E L L A.}

mainder bonny clobber. Forty acres will carry twenty cows through the year. The cows are in general of the imall breed, but not the true Kerry, for many have been brought from other countries. A cow fells at a guinea a pottle for the milk, above two or three pottles, that is 4l. $4 \mathrm{~s}$, four pottles, $5 \mathrm{l}$. 5 s. for five pottles, given at one meal. A little fattening of cows and fmall bullocks, but the number not great. No heep kept.

As to manure none is ufed in the vale, except their dung for potatoes, but upon the mountains they lime a little.

There is a colony of Palatines, that have been fixed here above thirty years; there are now fifteen or fixteen families; Colonel Haffet brought them from the county of Limerick, and fixed them here as little farmers, and thefe few people coft him above 500 l. fettling. $\mathrm{He}$ gave each a cow, a horfe, and every thing they wanted for a year, and let the land to them for half its value. Their improvements have been firft, by ploughing with a wheel plough, which with two horfes works eafily without a driver. They brought in cars with wheels, there were only fliding ones before. They alfo fow all their potatoes in drills with the plough, and alfo plough them out, and this with great fuccefs, but nobody follows them.

Years purchafe of land fixteen to eighteen. Rents three years ago fallen exceedingly, from having 


\section{A $R$ B E L L A.}

having been too high let, but of late they have. rifen again. The rife in the price of labour from three-pence and four-pence in twenty years, to five-pence and fix-pence. Oyfters, two-pence to three-pence per hundred; neat 'Tralee there is a ftrand fix miles long, which is on a bed of oyfters, and is a curious object. Lobfters, twelve years ago, one penny each, now two-pence to four-pence. Salmon three halfpence. Woodcocks, ten-pence a couple. Partridges, ten-pence a couple. A groufe, one hilling. Whitings, one penny each. Herrings, three a penny. Plaice, turbots, mullets, and fome foles. Potatoes, 1s. 6d. per cwt. the cheapeft, medium, 2s. 6d. Cabbins of ftone, mortar and flate, 251. Many orchards in this county, give, upon an average, ten hogfheads of cyder per acre, fome 15 ; they reckon young trees the beft, from 12 to 20 years old,

The ftate of the poor in the whole county of Kerry reprefented as exceedingly miferable, and, owing to the conduct of men of property, who are apt to lay the blame on what they call land pirates, or men who offer the higheft rent, and who, in order to pay this rent, muif, and do re-let all the cabbin lands at an extravagant rife, which is affigning over all the cabbins to be devoured by one farmer. The cottars on a farm cannot go from one to another, in order to find a good mafter as in England: for all the country is in the fame fyftem, and no redrefs to be found. Such being the 


\section{A R B E L L A. 125}

cafe, the farmers are enabled to charge the price of labour as low as they pleafe, and rate the land as bigb as they like. This is an evil which oppreffes them cruelly, and certainly has its origin in its landlords, when they fet their farms, fetting all the cabbins with them inftead of keeping them tenants to themfelves. The oppreffion is, the farmer valuing the labour of the poor at $4 \mathrm{~d}$. or $5 \mathrm{~d}$. a day, and paying that in land rated much above its, value. Owing to this, the poor are depreffed; they live upon potatoes and four milk, and the pooreft of them only falt and water to them, with now and then a herring. Their milk is bought; for very few keep cows, fcarce any pigs, but a few poultry. Their circumftances are incomparably worfe than they were 20 years ago; for they had all cows, but then they wore no linen : all now have a little flax. To thefe evils have been owing emigrations, which have been confiderable.

October Ift, rode over the mountain improvements which William Blennerhaffet, Efq; of Elm Grove, has made. I viewed it with very great attention; for it projecls far into a mountain of heath, that lets only at Is. an acre. I faw the progrefs of the improvement in different ftages. He has done 250 Irifh acres, and incloled 300 more, and has been offered 20s. an acre for them, but the farmhoufes were not built; at prefent he has four, to which he purpofes to throw the whole. 


\section{A $R$ B E L L A.}

The method he purfued has been firft to enclofe with double ditches, four feet deep and five broad, and the earth out of both thrown on to a parapet, ten feet broad, and fome more, planted with rows of trees, and of ofiers, the expence in labour, 2s. a perch. While this work is doing, he ploughs nine or ten inches deep, and as foon as the weather will admit, burns; then he tills it again once or twice, and burns again; and before the laft ploughing, limes 100 barrels an acre, which cofts him (burning it himfelf) fixpence a barrel, including carriage and fpreading: upon this he fows corn, has tried wheat, rye, and oats, but oats anfwer the beft; has tried potatoes, and they did pretty well, followed them with corn, and then laying it out, that is, leaving it to grafs itfelf. The other is to fow corn as long as it will yield any, when it is exhaufted, to lay it out two or three years, and then plough and lime : take two crops of corn, and lay it out again; and this way he thinks is the bert, from the experience of forty years, for fo long the improvement has been making. Trees of all forts have grown perfectly well, but the afh has done beft. A ploughing cofts 6 s. an acre. Graffaning and burning, 2l. an acre. Mr. Haffet's itock at prefent on this farm, 30 horfes, mares and foals, 100 cows, 100 meep, 100 young cattle, 8 plough bullocks : this is a moft noble ftock of cattle for a fpot which was all heath.

Mr. Blennerhaffet has alfo tried lime-ftone fand, over one part of a field, and lime upon 
the reft, fpread but lately, yet the appearance is much in favour of the fand.

October $2 \mathrm{~d}$, to Ardfert by Tralee, through a continuation of excellent land, and execrable management. Mr. Bateman tried rock falt on grafs land for a manure, half a ton to the Englin acre, but found not the leaft benefit from it. But of lime he has ufed large quantities, and with great fuccefs; burning it for 6d. a barrel, in a ftanding kiln with turf, four eyes or fires to each; lays on 50 barrels to an acre, and has advanced fome land, by draining and liming, from 5, to 20s. an acre, the foil a cold ftiff clayey gravel.

To the weft of Tralee are the Mahagree Iflands, famous for their corn products; they are rock and fand, Ptocked with rabbits; near them a fandy tract, 12 miles long, and one mile broad, to the north, with the mountains to the fouth, famous for the beft wheat in Kerry. All under the plough. Their courfe.

1. Buck potatoes. 2. Barley. 3. Wheat. Alfo corn on fome land, without any intermediate crop. Manure for every crop, if potatoes with fea weed, great crops; they get 20 for one of wheat and barley. All grain is remarkably early; they have fown Englifh barley, and made bread of the crop in fix weeks; thefe lands let at 145 . or 15 s. an acre, but fome much higher. Farms are large, one, two, or three hundred acres, but fome are taken in partnerhip. 
I28, A R D F E R T.

partnerfhip. I was affured, that in thefe if lands, they have known two crops of barley gained from the fame land in one year, and the fecond better than the firft. They fowed the firft of April, and reaped the middle of May, and immediately fowed a fecond, which they reaped the end of Auguft. This was done by John Macdonald, of Maharaghbeg.

Arriving at Ardfert, Lord Crofby, whofe politenefs I have every reafon to remember, was to obliging as to carry me by one of the fineft ftrands I ever bode upon, to view the mouth of the Shannon at Ballengary, the fite of an old fort: it is a vaft rock feparated from the country by a chafm of a prodigious depth, through which the waves drive. The rocks of the coaft here are in the boldeft ftile, and hollowed by the furious Atlantic waves into caverns in which they roar. It was a dead calm, yet the fwell was fo heavy, that the great waves tolled in and broke upon the rocks with fuch violence as to raife an immenfe foam, and give one an idea of what a ftorm would be, but fancy rarely falls thort in her pictures. The view of the Shannon is exceedingly noble; it is eight miles over, the mouth formed by two headlands of very high and bold clifts, and the reach of the river in view very extenfive: it is an immenfe fcenery. Perhaps the nobleft mouth of a river in Europe.

Croffed in the way a large bog, highly improvabie, faw fome little fpots taken in with heaps of fea fand for carrying it on. 
A $R$ D F E R T.

Lord Glandore manures his ground with lime, fea fand, and fea weed, the laft is the worft, the fand beft. Land lets at 125 . or $13 \mathrm{~s}$. an acre on an average; it rifes from 10 s: to 20 s.

Ardfert is very near the fea, fo near it, that fingle trees or rows are cut in pieces with the wind, yet about Lord Glandore's houfe there are extenfive plantations exceedingly flourifhing, many fine afh and beech; about a beautiful cirtertian abbey, and a filver fir of 48 years growth, of an immenfe height and fize.

October $3^{d}$, left Ardfert, accompanying Lord Cropy to Liftowel. Called in the way to view Lixnaw, the ancient feat of the earls of Kerry, but deferted for ten years paft, and now prefents fo melancholy a fcene of defolation, that it fhocked me to fee it. Every thing around. lies in ruin, and the houfe itfelf is going faft off by thieving depredations of the neighbourhood. I was told a curious anecdote of this eftate, which thews wonderfully the improvement of Ireland: The prefent Earl of Kerry's grandfather, Thomas, agreed to leafe the whole eftate for i $500 l$. a year, to a Mr. Collis, for ever; but the bargain went off upon a difpute, whether the money fhould be paid at Corke or Dublin. Thofe very lands are now let at 20,0001 . a year. There is yet a good deal of wood, particularly a fine afh grove, planted by the preient Earl of Shelburne's father.

Vot. II. 
I30 W $O$ O

Proceeded to Woodford, Robert Fitzgerald's, Efq; paffing Liftowel bridge, the vale leading to it is very fine, the river is broad, the lands high, and one fide a very extenfive hanging wood, opening on thofe of Woodford in a pleafing ftile.

Woodford is an agreeable fcene; clofe to the houfe is a fine winding river under a bank of thick wood, with the view of an old caftle hanging over it. Mr. Fitzgerald is making a confiderable progrefs in rural improvements; he is taking in mountain ground, fencing and draining very completely, and introducing a new hufbandry. He keeps 30 pigs, which ftock he feeds on potatoes, and has built a piggery for them. Turnips he cultivates for heep, and finds them to anfwer perfectly. Not being able to get men who underftand hoeing, he thins them by hand. He has five acres of potatoes put in drills with the plough, and defigns ploughing them out : they look perfectly wiell, and promife to be as good a crop as any in the trench way. The common courfe in this neighbourhood is,

1. Potatoes. 2. Potatoes. 3. Wheat. 4. Oats. 5. Lay it out.

Farms are very much in partnerfhip, and inprovements exceedingly backward on that account. The poor live on potatoes and milk all the year round, but are rather better off than they were twenty years ago. The labour 


$$
\text { T A } R \text { B A } T \text {. }
$$

of the country is generally done for land in the manner I have fo often defcribed, rated at an exorbitant price, $4 \mathrm{~d}$. winter; $5 \mathrm{~d}$. fummer; fome 6d. round. Three-fourths of Kerry mountain and bog, at $1 \mathrm{~s} .6 \mathrm{~d}$. the reft at $15 \mathrm{~s}$.

In $1765, \mathrm{Mr}$. Fitzgerald was travelling from Conftantinople to Warfaw, and a waggon with his baggage, heavily laden, overfet; the country people harneffed to buffaloes by the borns, in order to draw it over, which they did with eafe. In fome very inftructive converfation $\mathbf{I}$ had with this gentleman, on the fubject of his travels, this circumftance particularly ftruck me.

October $4^{\text {th }}$, from Woodford to Tarbat, the feat of Edward Lefle, Efq; through a country, rather dreary, till it came upon Tarbat, which is fo much the contrary, that it appeared to the higheft advantage; the houfe is on the edge of a beautiful lawn, with a thick margin of full-grown wood, hanging on a fteep bank to the Shannon, fo that the river is feen from the houfe over the tops of this wood, which being of a broken irregular outline, has an effect very ftriking and uncommon; the river is two or three miles broad here, and the oppofite coaft forms a promontory, which has from Tarbat exactly the appearance of a large ifland. To the eaft, the river fwells into a triangular lake, with a reach opening at the diftant corner of it to Limerick: the union of wood, water, and lawn, forms upon the whole 
a very fine fcene; the river is very magnificent. From the hill, on the coaft above the ifland, the lawn and wood appear alfo to great advantage. But the fine? point of view is from the higher hill on the other fide of the lroufe, which looking down on all thefe fcenes, they appear as a beautiful ornament to the Shannon, which fpreads forth its proud courfe, from two to nine miles wide, furrounded by highlands: a feenery truly magnificent. I am indebted to Mr. Leflie's good offices for the fols lowing particulars.

Arable land about Tarbat lets at $14^{5}$. on an average; Mr. Leflie, in 1771 , let feveral farms at $17 \mathrm{~s}$. but the fall of that period reduced the rents $3^{\text {s. }}$ Farms are from 50 acres to 3 or 400 : it is common to have the poor people hire them in partnerhip, but only the fmall ones, the large are all ftock farms. The tillage courfe ;

I. Potatoes, produce 28 barrels, at 16 pecks each, and the peck $60 \mathrm{lb}$. or $26,88 \mathrm{olb}$. in all. 2. Potatoes. 3. Oats. 4. Lay out for fereral years: The fecond crop of potatoes more numerous, but not fo large; they manure for them only with dung. The oats yield fix barrels, each 26 ftone, being double ones. Very little wheat fown but by gentlemen of large farmers, who burn the land; plough it, and burn the fod, which they call beating, and manure with lime or fea-fand; 40 barrels of lime at $1 \mathrm{~s}$. The ftone is brought from an 


\section{T A R B A $\quad$ T.}

ifland towards Limerick. They get fand at the fame place. Lime does beft for tillage, and fand for grafs. The ftock farms are either under dairies, or in the fucceffion fyftem, of buying in year olds from the county of Clare, and keeping them till three or four years old, the heifers till they calve; buy at a guinea to 3os. Fell from 31 , 5s. to 4l, sos. at four year old. There are alfo fome cows fattened: bought in in general at 31 , or 31 . sos. fell in October at 41 . 1os. to 51 . The dairies are fet to dairymen, the price is one cwt. of butter, and Ios. to I 5 s. horn money; the dairyman has all the calves, and muft fell off at Michaelmas. His privilege is a houfe and potatoe garden, and grafs for a cow for every ten. A collop here, is one cow, one horfe, two yearlings, fix fheep; two acres to feed a collop, and fome two and a half. Every cabbin has a bit of flax, which they fpin and manufacture for their own ufe, there being fome weavers difperfed about the country. A little pound yarn is fold befides to Limerick, but not much. A little wool is fpun for their own ufe, and wove into frize.

The fate of the poor is fomething better than it was twenty years ago, particularly their cloathing, cattle, and cabbins. They live upon potatoes and milk; all have cows; and when they dry them, buy others. They alfo have butter, and moft of them keep pigs, killing them for their own ufe. They have alfo herrings. They are in general in the cottar fyf- 


\section{4}

$\begin{array}{llllll}\text { T } & A & \mathrm{R} & \mathrm{B} & \mathrm{A} & \mathrm{T} \text {. }\end{array}$

tem, of paying for labour by affigning fome land to each cabbin. The country is greatly more populous than twenty years ago, and is now increafing; and if ever fo many cabbins were built by a gradual increafe, tenants would be found for them. A cabbin, and five acres of land, will let for 41 . a year. The induftrious cottar, with two, three, or four acres, would be exceedingly glad to have his time to himfelf, and have fuch an annual addition of land as he was able to manage, paying a fair rent for it ; none would decline it but the idle and worthlefs.

Tythes are all annually valued by the proctors, and charged very high. There are on the Shannon about 100 boats employed in bringing turf to Limerick from the coaft of Kerry and Clare, and in fining, the former carry from 20 to 25 tons, the latter from five to ten, and are navigated each by two men and a boy.

October 5 th, paffed through a very unentertaining country (except for a few miles on the bank of the Shannon) to Altavilla, but $\mathrm{Mr}$. Bateman being from home, I was difappointed in getting an account of the Palatines fettled in his neighbourhood. Kept the road to Adair, where Mrs. Quin, with a politenefs equalled only by her uniderftanding, procured me every intelligence I wilhed for. 


\section{A D A I R.}

Land lets about Adair from ros. to 40 . an acre, average 20s. the richeft in the country is the Corcaffes on the Maag, which lets at 30 . to $36 \mathrm{~s}$. a tract of five miles long, and two broad, down to the Shannon, which are better than thofe on that river; the foil is a kind of yellow and blue clay, of which they make bricks; but there is a furface of blue mould. The grafs of them is applied to fattening bullocks, from 7 to $8 \mathrm{cwt}$. each, and an acre fats one, and gives fome winter and fpring food for theep. When they break this land up, they fow firft oats, and get 20 barrels an acre, or 40 common barrels, and do not reckon that an extra crop; they take ten or twelve in fucceffion, upon one ploughing, till the crops grow poor, and then they fow one of horle beans, which refrefhes the land enough to take ten crops of oats more; the beans are very good. Wheat fometimes fown, and the crops very great. Were fuch barbarians ever heard of ?

In the common courfe of lands about Adair, the courfe of crops is,

I. Potatoes. 2. Ditto. 3. Wheat. 4. Oats. 5. Oats. 6. Oats, 7. Lay out.

1. Potatoes. 2. Ditto. 3. Wheat. 4. Wheat. 5. Oats. 6. Oats. 7. Oats. 8. Lay out.

I. Potatoes. 2. Ditto. 3. Wheat. 4. Oats. 5. Lay out. 


\section{A D A I R.}

Potatoes they plant on grafs without dung, a good crop, 60 barrels to an acre, at $8 \mathrm{~s}$. a barrel average. When they hire it they pay fix guineas an acre; they dung tillage land and poor lays for them. Of wheat they fow a barrel an acre, and the crop in general eight to ten of thofe barrels. Oats they fow two to an acre, and get twelve to fixteen. The low bottoms of moory and rufhy kind they plough, and burn the furrows; upon that burning they plough in the anhes and harrow in rape feed, a pottle, or three quarts to an acre; never feed, but keep it for feed, and get eight Briftol barrels an acre; it fells ufually at i4s. to 18 s. a barrel; they fow bere afterwards, the produce ten barrels an acre; then a crop of oats, twelye to fixteen barrels, and then leave it to lay. No grafs feeds fown.

Farms rife from 40 acres to 20001 . a year; fome few of the little ones are taken by cottars, in partnerfhip, but not common; the large farms are all ftock ones. Turnips have been fown many years, but by few; a little on pared and burnt land in the bottoms, inftead of rape; the crops very large; they give them all to fat fheep, in order to keep their flefh for a better market after Chriftmas; it is found to be a very advantageous practice, but not increafing. No hoeing. Hemp is fown a little by the Palatines, but by few others. Flax, by every cabbin, in order for a little fpinning for their own ufe. 


\section{A D A I R.}

The fyftem of the ftock farmers is in general dairying, but upon the beft lands they fatten bullocks, cows being only kept on lands which they think will not do for bullocks. The cows are all let, and paid for principally by butter, one cwt. to a cow, and 25 s. horn money. The dairyman's privilege is a cabbin, a garden of an acre, and the grafs of a cow or horfe to every twenty cows, and may rear half the calves, and keep them to November or Chriftmas. To 60 acres, 24 cows, I horfe, 30 fheep : this is juft two acres a head, and it is about the average of the country. The dairymen are not in good circumftances, making a mere living. The fwine here are of a large white fort, and rife to two cwt. they are moftly fattened on potatoes, but have lome oats at laft to harden the fat. A good many Theep ; the fyftem is to keep the lambs till three year old wethers, and fell them fat at 20s. each; the fleeces $7 \mathrm{ib}$. Tythes, wheat $6 s$. barley $5^{s}$. Oats 4 s. Rape no tythe. Potatoes $8 \mathrm{~d}$. to rod. mowing ground is: to 3 s. theep 2d. cach.

The poor people do not all keep cows, but all have milk; all have pigs and poultry; are pot better off than twenty years ago. Have a potatoe garden, of which one-half to threefourths of an acre carries a family through the year; they live entirely upon them, felling their pigs. They pay a guinea for a cabbin, and 1o perch ; if half an acre, 21. 2s. A whole acre, and a cabbin on poor ground, 
138: A D A I R.

31. 3 s. but not fo cheap if near a village. Labour paid in land in general. Grafs of a collop 21. 2s. if a cow hayed, $50 s$.

Palatines were fettled here by the late Lord Southwell, about feventy years ago. They have in general leafes for three lives, or 31 years, and are not cottars to any farmer, but if they work for them, are paid in money. The quantities of land are fmall, and fome of them have their feeding land in common by agreement. They are different from the Irifh in feveral particulars; they put their potatoes in with the plough, in drills, horfehoe them while growing, and plough them out. One third of the dung does in this method, for they put it only in the furrows, but the crops are not fo large as in the common method. They plough without a driver; a boy of twelve has been known to plough and drive four horfes, and fome of them have a hopper in the body of their ploughs, which fows the land at the fame time it is ploughed. Their courfe of crops is,

1, Potatoes, 2. Wheat. 3. Wheat. 4. Oats.

I. Potatoes. 2. Barley. 3. Wheat. 4. Oats.

In whicis management they keep their land many years, never laying it out as their neighbours do. They preferve fome of their German cuftoms : fleep between two beds. They appoint 


\section{A D A I R.}

appoint a burgomafter, to whom they appeal in cafe of all difputes; and they yet preferve their language, but that is declining. They are very induftrious, and in confequence are much happier and better fed, cloathed, and lodged, than the Irifh peafants. We muft not, however, conclude from hence that all is owing to this; their being independent of farmers, and having leafes, are circumftances which will create induftry. Their crops are much better than thofe of their neighbours. There are three villages of them, about feventy families in all. For fome time after they fettled they fed upon four crout, but by degrees left it off, and took to potatoes : but now fubfift upon them and butter and milk, but with a great deal of oat bread, and fome of wheat, fome meat and fowls, of which they raife many. They have all offices to their houfes, that is, ftables and cow houfes, and a lodge for their ploughs, \&c. They keep their cows in the houfe in winter, feeding them upon hay and oat ftraw. They are remarkable for the goodnefs and cleanlinefs of their houfes. The women are very induftrious, reap the corn, plough the ground fometimes, and do whatever work may be going on; they alfo fpin, and make their children do the fame. Their wheat is much better than any in the country, infomuch that they get a better price than any body elfe. Their induftry goes fo far, that jocular reports of its excefs are fpread : in a very pinching feafon, one of them -yoked his wife againft a horfe, and went in 
that manner to work, and finifhed a journey at plough. The induftry of the women is a perfect contraft to the Irifh ladies in the cabbins, who cannot be perfuaded, on any confideration, even to make hay; it not being the cuftom of the country; yet they bind corn, and do other works more laboriuus. Mrs. Quin, who is ever attentive to introduce whatever can contribute to their welfare and happinefs, offered many premiums to induce them to make hay, of hats, cloaks, ftockings, \&cc. \&rc. but all would not do,

Few places have fo much wood about them as Adair: Mr. Quin has above 1000 acres in his hands, in which a large proportion is under wood. The deer park of 400 acres is almoft full of old oak and very fine thorns, of a great fize ; and about the houfe, the plantations are very extenfive, of elm and other wood, but that thrives better than any other fort. I have no where feen finer than vaft numbers here. There is a fine river runs under the houfe, and within view are no lefs than three ruins of francifcan friaries, two of them remarkably beautiful, and one has mort of the parts perfect except the roof.

In Mr. Quin's houfe, there are fome very good pictures, particularly an annunciation, by Dominicino, which is a beautiful piece. It was brought lately from Italy by Mr. Quin, junior. The colours are rich and mellow, and the airs of the heads inimitably pleafing; the 
group of angels at the top, to the left of the piece, are very natural. It is a piece of great merit. The companion is a magdalen; the expreffion of melancholy, or rather mifery, remarkably ftrong. There is a gloom in the whole in full unifon with the fubject. There are, befides thefe, fome others inferior, yet of merit, and two very good portraits of Lord Dartry, (Mrs. Quin's brother) and of Mr. Quin, junior, by Pompeio Battoni. A piece in an uncommon ftile, done on oak, of Efther and Ahafuerus : the colours tawdry, but the grouping attitudes an effect pleafing.

October 7 th, to Caftle Oliver, by Bruff, paffing through a very fine tract of rich reddifh loam. The Right Hon. Mr. Oliver was affiduous to the laft degire to have me completely informed. About his feat, the foil is brown ftone on indifferent flate ftrata, mountainous; the mountain tops are thrown into the bargain; mountain farms, tops, bottoms and fides, is. an acre ; furze land reclaimed, and fome from 15 s: to $20 \mathrm{~s}$. Farms of all fizes, but the occupying tenants have from 15 to 100 acres, fome 300. The courfe of crops:

1. Potatoes. 2. Potatoes. 3. Potatoes. 4. Oats. 5. Oats. 6. Oats. 7. Lay out : fometimes only two of potatoes.

They manure for potatoes with all the dung they can get. Very little under tillage, and the grafs applied chiefly to dairies. In one particular 
142 C'ASTLE OLIVER.

particular they are very attentive; to conduct the mountain ftreams into their grafs lands; cutting little channels, to introduce the water as much as poffible over the whole; and though it comes from a poor mountain of brown ftone, or turf, yet the benefit they find to be very great. This is a general cuftom among all the little occupiers; and they are frequently coming to $\mathrm{Mr}$. Oliver, with complaints of each other for diverting or ftealing one another's ftreams. This is an inftance of excellent hufbandry, which I do not recollect meeting with before in Ireland. They always mow it the year they water it, and their crops of hay 2 ton, or $2 \frac{x}{2}$ an acre. They do not reclaim any mountain, but fometimes a little furze land for potatoes. They have fome lime-ftone fand; but being at a diftance, they ufe it in fmall quantities, a few barrels an acre fown for potatoes, which is effectual in preventing them from being wet or rotting. The ftate of the poor people better in thefe mountainous tracts than upon the rich flats of Limerick, both from there being more employment and greater plenty of land for them. Some few farms taken in partnerfhip. The cattle fyftem is generally dairying cows, which are all fet to dairymen. There has been a fall in rents fince $177 \mathrm{i}^{-2}$, of $2 \mathrm{~s} .3 \mathrm{~s}$. Or $4 \mathrm{~s}$. an acre, but it is not falling at prefent. Building a cabbin 41 . to $5 \mathrm{l}$. Ditto ftone, flate, \&c. 251 .

Relative to the rich lands of this country, they are principally found, firft in the barony 
LIMERICK GRAZING: 143

of Small County, which is rich; Coonagh has much; Colhlea a great deal, and much mountain; Clanwilliam, a good hare. The rich land reaches from Charleville, at the foot of the mountains, to Tipperary, by Kilfenning, a line of twenty-five miles, and acrofs from Ardpatric to within four miles of Limerick, 16 miles. Bruff, Kilmallock, and Hofpital have very good land about them; the quantity in the whole conjectured to be 100,000 acres. It is in general under bullocks, but there is fome tillage fcattered about, to the amount probably of a fifteenth of the whole; the rents are from 25 s. to $40 \mathrm{~s}$. but average $30 \mathrm{~s}$. an acre.

The county of Limerick, befides the rich grazing, has a light lime-ftone.land for fheep and cows, at 15 s. to 20s. There are alfo yellow clays, from ios. to 20 s. alfo middling land of furze and fern, from ros. 6d. to il. is. Some mountain Is. likewife fifteen miles of corcaffes on the Shannon, two to three miles broad. Average of the whole county, $20 s$. The county of Tipperary, $18 \mathrm{~s}$.

As to the foil I am able to fpeak of it particularly, for Mr. Oliver was fo kind as to ride through a great variety of it, a man with a fpade following to dig; the fineft foil in the country is upon the roots of mountains ; it is a rich, mellow, crumbling, putrid, fandy loam, eighteen inches to three feet deep, the colour a reddin brown. It is dry found land, and would do for turneps exceedingly well, for

carrots, 


\section{LIMERICK GRAZ̈ING.}

cariots, for cabbages, and in a word for every thing. I think upon the whole, it is the richeft foil I ever faw, and fuch as is applicable to every purpofe you can wih : it will fat the largeft bullock, and at the fame time do equally well for fheep, for tillage, for turneps, for wheat, for beans, and in a word, for every crop and eircumftance of profitable hufbandry.

The lower lands are wetter, and under them a yellow clay; whereas in the upper, it is fandy loam to a confiderable depth. The rent in England would be confiderably higher than this of the bullock land in Ireland.

The farms are of all fizes: The bullock farm rife to 600 acres, which quantity is a large farm; but there are many fmall ones under cottars and dairymen : the general run in ftocking is a bullock of four and a half to feven cwt: average five hundred and a half to the acre, and quarter for the fummer's grafs ; but their not generally having a bullock to an acre, is owing to their keeping theep and calves fo late, in which they do even to June. The winter's hay amounts to about a rood, befides the acre for the fummer food: Thefe beafts are bought in at autumn, at three or four years old, average price, 51 . they are fed regularly through the winter with hay every day in the fields where they are to be fattened in fum. mer ; they chufe the diry fields for it, but ftill mifchief is done by it. All the hay is ftacked 


\section{LIMER ICK GRAZING. 145}

in the fields for this purpole. The time of felling autumn. The profit they make per bullock on an average, about three guineas. The principal winter fyftem is buying calves, at Il. Is. to 21. 2s. keeping them till May, and then felling them at 20s. to $30 \mathrm{~s}$. profit, but give them a bellyful of their beft hay. A great many theep are alfo fent to be wintered from Tipperary, which is extraordinary, as their own lands are much drier than thefe of Limerick: they do this by hiring farms for the pur pofe This is one of the moft profitable articles; they bring the fpring lambs in Oetober, and keep them till May, and then fend them back to Tipperary, and they are much better than thofe they left there.

The graziers are many of them rich, but generally fpeaking, not fo much from the immediate profit, as from advantageous leafes. I wanted much to be informed of their profit, but it is exceedingly difficult to come pear it, for not a grazier in the country but denies his making any thing confiderable : this is fuppofed to be a great piece of art, but I am very apt to think the truth not fo far from the declaration, at leaft as well as I am able to judge from the information $I$ have received.

Rent of an acre and a half for a bullock 2126 County cefs, at $6 \mathrm{~d}$. Mowing and making one-third of an acre hay

Carried over

0.09

030

6.2 .163

Vot.II. 
146 CASTLE OLIVER.

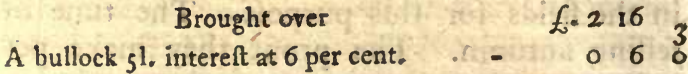

Labour -1s. 6d, an acre

$$
\begin{array}{r}
\{2163 \\
-\quad 060 \\
-\quad 023 \\
\hline 6.346
\end{array}
$$

Profit on a bullock

Winter food, two theep at 5 s.

\begin{tabular}{rrr}
-3 & 3 & 0 \\
0 & 10 & 0 \\
\hline
\end{tabular}

3. 130

Experces$$
3.45
$$

Profit

$+1,-$

$6.08 \%$

From this is to be deducted the whole of chances, the lofs of cattle, \&c. and from what $I$ was able to pick up, I have reafon to believe that it does not exceed 10s. an acre at moft. The fum neceffary to ftock 61 . an acre., I muft obferve that the profit is very low for land to yield, which is of fuch extraordinary fertility; it is of that foil which would do very well for tillage, for though it is not dry, yet it has not the wetnefs of our Englifh clays, and would in a courfe of good tillage, pay infinitely better as every perfon muft admit who are at all acquainted with the wet lands of Norfolk, Suffolk, Effex, \&x. I am however very far from recommending it, for if the Irifh tillage fhould be introduced, the very contrary would be the cafe, and the landlord fuffer exceedingly from his eftate being exhaufted. In no part of Ireland have I feen more carelefs management 


\section{CASTLE OLIVER.}

ment than in thefe rich lands. The face of the country is that of defolation; the grounds are over-run with thiftles, (carduus) ragwort, ( $(e-$ necio jacobaa) \&xc. to excefs; the fences are mounds of earth, full of gaps; there is no wood, and the general countenance is fuch, that you muft examine into the foil before you will believe that a country, which has fo beggarly an appearance, can be fo rich and fertile.

To fhew the rife of land, Sir Harry Harpfon has a farm of 400 acres, which his grandfather let in 1676 , at $4 \mathrm{~s}$. $6 \mathrm{~d}$. an acre, and thought fo dear that an offer of a fcore of theep and two goats were offered to be off; it would let now at 30 s. I had this fact from himfelf. The breed of cattle here is all long horned. There are fome cows fattened alfo, but not near fo many as oxen. Likewife fome dairies, which are fet; one cwt. butter, and 2os. horn money. The dairyman's privilege is two or three cows, a cabbin and a garden. The number of cows feldom above a fcore: but they are found fo troublefome and impofing, that they have taken a different method, and employed dairywomen on their own account.

Great quantities of flax fown by all the poor and little farners, which is fpun in the country, and a goor deal of bandle cloth made of it. This and pigs are two great articles of profit here; they keep great numbers, yet the poor in this rich tract of country are very badly

$$
\text { K } 2
$$


148 CASTLE OLIVER.

off. Land is fo valuable, that all along as I came from Bruff, their cabbins are generally in the road ditch, and numbers of them without the leaft garden; the potatoe land being affigned them upon the farm where it fuits the mafter beft. The price they pay is very great, from 4l. to 5l. an acre, with a cabbin; and for the grafs of a cow, $40 s$. to $45^{5}$. They are, if any thing, worfe off than they were twenty years ago. A cabbin, an acre of land, at $40 s$. and the grafs of two cows, the recompenfe of the year's labour : but are paid in different places by an acre of grafs for potatoes at 5 l. Thofe who do not get milk to their potatoes, eat muftard with them, raifing the feed for the purpofe. The population of the country increafes exceedingly, but moft in the higher Iands; new cabbins are building every where. The tillage in thefe rich lands confifts in,

1. Potatoes. 2. Potatoes. 3. Barley. 4. Wheat. 5. Oats. 6. Oats.

1. Potatoes. 2. Potatoes. (on fpots $\frac{x}{2}$ or $\div$ acre flax after the $2 \mathrm{~d}$ Potatoes.) 3. Wheat. 4. Barley. 5. Oats. 6. Oats. 7. Oats. 8. Oats. 9. Lay it out.

Mr. Oliver has known I 50 Briftol barrels, each four bufhels heaped of potatoes, which make fix burhels, or 900 from an acre. The weight, ftrike meafure, 15 ftone. The common crop, 150 heaped barrels, at 4 s. average price. Opinions differ much, whether the fe-

cond 


\section{CASTLE OL IVER.}

cond crop is better or worfe, but from one practice they have, I am clear which it muft be; for they truft to the fmall potatoes left in the ground as feed, which are neceffarily irregular: and I have found, by various trials, that a lice of a middling potatoe is far better than a whole fmall one.

$$
\text { POTATOES. }
$$

Rent - - - - 5138

Seed, lixteen barrels and a half, at ios. - 2150 Cutting feed

Digging

Carrying out

Trenching and fowing

Weeding

Digging out

Gathering

Carrying home

Houfing

Picking

Tythe
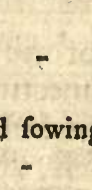
150 CASTLE OLIVER.

One hundred barrels, at 4 s. each Expences 2000

Profit $=\quad 6.41610$

The Briftol barrel, which is here charged at 4 s. is heaped, and weighs 22 ftone. The quality of the corn raifed on thefe rich lands is much better than any other in the country; the quantity- of barley per acre, 12 Briftol barrels.

Mr. Ryves, a gentleman of the neighbourhood I had the pleafure of meeting at Caftle Oliver; on $3 \frac{3}{4}$ acres fowed nine bufhels of bere, from which I I Briftol barrels; ftriked meafure. Of wheat, the crops fluct uating, but a iniddling one 12 barrels. Mr. Ryves has had 20 of oats, generally 15. All thefe ctops are with good tillage: there are many who do not get neàr fo much.

There is a bolting mill at Limerick, at Annfgrove, at Marlefield, at Clonmell, at Cartle Hyde, at Newport: hence therefore there is no want of a market in this country for corn. I was furprized to find that land, in this rich country, fells at as many years purchafe as in mountain tracts. Limerick is famous for cyder; the fineft cakaggee is at Mr. Waller's, Mr. Maffey's, Mr. Weftrope's, Mr. Monfon's, sc. The foil of the orchard's thin, on limeftone.

Mr. Oli- 


\section{CASTLE OLIVER. I5I}

Mr. Oliver has practifed hufbandry on a pretty extenfive fcale. A confiderable part of his land is improved mountain, which he grubbed and cleared of fpontaneous rubbin, and manured with lime-ftone fand; and then cultivated fome for corn, and fome for turnips: where the land is boggy, he burns, in order to get rid of that foil which he confiders as worth but little. Whatever he fows, the land runs at once immediately to thick fine grafs, even on the mountain top; fo that a ftubble will, in the firft year, yield a great crop of hay. A Atrong proof how adapted this country is to pafturage. In the breed of cattle he has been very attentive, purchafing bulls and cows, at the expence of twenty guineas each, of the long-horned Lancafhire breed, and from them has bred others. I faw two exceeding wellmade bulls of a year old of his breeding, which would have made a confiderable figure in Leicefterfhire. Turnips he has cultivated for many years, applying them chiefly to feeding deer, but he has fattened fome fheep on them with good fuccefs. Hollow draining he has practiced upon an extenfive fcale, and laid a large tract of wet land dry by it.

Mr. Oliver planted a colony of Palatines 15 years ago, from about Rathkeal, 66 families. in one year, which made 700 proteftants, on his own eftate. Fixed them upon fpots, of from thirteen to thirty acres each, charging them only two thirds of the rent, which he could get of others; built houfes for them at 
the expence of above 5001 . gave them leafes for three lives. The benefit of them has been introducing much tillage; to the proportion of their little farms, they till much more than the Irim. They drill their potatoes, and on ftubble land worn out, Houfe their cattle, feeding them with hay, and raifing thereby dung. They are cleaner and neater, and live much better : are better cloathed, and all of them have neat little kitchen gardens. Many of them labour for nobody but themfelves, and none of them conftantly for others, being employed principally on their own little farms, They live partly on four crout:

Caftle Oliver is a place almoft entirely of $\mathrm{Mr}$. Oliver's creation; from a houfe, furrounded with cabbins and rubbifh, he has fixed it in a fine lawn, furrounded by good wood. The park he has very much improved on an excellent plan; by means of feven feet hurdles, he fences off part of it that wants to be cleaned or improved, thefe he cultivates, and leaves for grafs, and then takes another fpot, which is by much the beft way of doing it. In the park is a glen, an Englifh mile long, winding in a pleafing manner, with much wood hanging on the bank. Mr. Oliver has conducted a ftream through this vale, and formed many little water-falls in an excceding good tafte, chiefly overhung with wood, but in fome places open with feveral little rills, trickling over ftones down the flopes. A path winds through a large wood and along the brow of the glen; this 


\section{CASTLE OLIVER. $\quad$ I53}

path leads to an hermitage, a cave of rock, in a good tafte, and to fome benches, from which the views of the water and wood are in the fequeftered ftile they ought to be. One of thefe little views, which catches feveral falls under the arch of the bridge, is one of the prettieft touches of the kind I have feen. The vale beneath the houfe, when viewed from the higher grounds, is pleafing; it is very well wooded, there being many inclofures, furrounded by pine trees, and a thick fine mafs of wood rifes from them up the mountain fide, makes a very good figure, and would be better, had not Mr. Oliver's father cut it into viftos for thooting. Upon the whole, the place is highly improved, and when the mountains are planted, in which Mr. Oliver is making a confiderable progrefs, it will be magnificent.

In the houfe are feveral fine pictures, particularly five pieces by Seb. Ricci, Venus and Eneas; Apollo and Pan, Venus and Achilles; and Pyrrhus and Andromache, by Lazzerini; and the rape of the Lapithi, by the centaurs: the laft is by much the fineft, and is a very capital piece; the expreffion is ftrong, the figures are in bold relief, and the colouring good. Venus and Achilles is a pleafing picture; the continence of Scipio is well grouped, but Scipio, as in evcty picture I ever faw of him, has no expreffion. Indeed, chaftity is in the countenance fo pafive a virtue as not to be at all fuited to the genius of painting; the idea is rather that of infipidity, and accordingly Scipio's 
pio's expreffion is generally infipid enough. Two fine pieces, by Lucca Jordano, Hercules and Antets; Sampfon killing the lion: both dark and horrid, but they are highly finifhed, and ftriking. Six heads of old men, by Nogari, excellent; and four young women, in the character of the feafons.

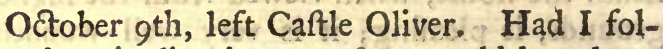
lowed my inclination, my ftay would have been much longer, for I found it equally the refidence of entertainment and inftruction. Paffed through Kilfennan and Duntreleague, in my way to Tipperary. The road leads every where on the fides of the hills, fo as to give a very diftinct view of the lower grounds; the foil all the way is the fame fort of fandy reddifh loam 1 have already defcribed, incomparable land for tillage: as I advanced, it grew fomething lighter, and in many places free from gravel. Bullocks the ftock all the way. Towards Tipperary I faw vaft numbers of heep, and many. bullocks. All this line of country is part of the famous golden vale. To Thomas-Town, where I was fo unfortunate as not to find $\mathrm{Mr}$. Mathew at home; the domain is 1500 Englifh acres, fo well planted, that I could hardly believe my felf in Ireland. There is a hill in the park, from which the view of it, the country and the Galties, are friking.

To the Earl of Clanwilliam's, where I was particularly fortunate in meeting Meffrs. Màcarthy and Keating, fons to two of the greateft farmers 
farmers that ever were in Ireland. The country is all under fheep, and the foil dry fandy loam. The theep fyftem of Tipperary is to breed and keep the lambs till three-year old wethers, fat, and fell them at 26s. at an average; keep the ewe lambs, and cull the old ftock, felling an equal number of fat ewes at three to four years old, the average price 20 . in October, the wool of all the ftock in general amounts to three fleeces, per ftone, of $\mathrm{i} 6 \mathrm{lb}$. or 6s. a head. From hence to Clonmell, there are many theep; to Cullen in Kilkenny, three or four miles beyond Thurles, within two miles of Cullen, three or four and twenty miles $N$. to $S$, and from Cullen to within three miles of Cullen, which is 30 : generally fpeaking, this is all theep, but there are many fpots in it where bullocks are fed. The ftock mixed with theep are ufually calves, bought in at fix to eight months, 305 . to 40 s. average $32 \mathrm{~s}$. and when they are three year old, fend them to the richer lands in the county of Limerick, (where every Tipperary grazier has a farm) to fat. When they have not enough of their own rearing, they buy three-year olds at Ballynafloe, and fatten them in Limerick. In general, this land will carry three to five fheep to the acre, and bear fome calves befides. One acre and three quarter's a bullock the year through, one half for hay. 
Arrangement of a flock of 2,500 ßreep.

$5 \mathrm{co}$ ewes

500 lambs

500 hoggarts

500 two-year olds

250 fat wethers

250 ewes, added to ftock, inftead of 250 older ones fole off

\section{0 at 5 to an acre 500 acres}

250 . fat wethers, at $26 \mathrm{~s}$. 250 culled ewes, at 20 . 2000 fleeces, at $6 s_{\text {: - }}$

$\begin{array}{r}-\quad 324180 \\ -\quad 250 \quad 00 \\ -\quad 600 \quad 00 \\ \hline 61174 \quad 180 \\ \hline\end{array}$

A part of the ftock of fat wethers is kept over from October to the fpring, for the Dublin market, not merely for the high price, but becaufe underlings, and not fat in autumn, and fell for lefs than the reft, feldom more than I9s. or 20s. To 3000 theep a grazier in this neighbourhood has $3^{\circ}$ acres of turnips, in order to feed this part of his wether ftock with. Mr. Macarthy with 8000 Theep, has feldom more than 30 acres. This fyftem will be further explained by Mr. Allen's ftock.

I,200 acres-2,000 fheep, befides lambsSells 200 four year-old wethers, at $26 \mathrm{~s},-200$ three 


\section{T I P P E R A R Y.}

three year-olds, at $26 \mathrm{~s}$. -200 barren ewes, at $18 \mathrm{~s}$. $-2,000$ fleeces, at $5 \mathrm{~s}-400$ two-year olds -400 year olds -500 Brood ewes- 500 lambs -Land to feed this flock, 1000 acres. Alfo 120 bullocks -40 cows and fpayed heifers and working bullocks for work, and milk breeding. -30 horfes, mares, \&c. - 30 labourers, 5 fhepherds -20 acres of wheat -10 barley10 oats-10 turnips -8 potatoes- 60 mowing ground-Rent of this large tract of heep-land from 20 to 25 s. an acre.

Farms are generally large, commonly 3 or 4000 acres, and rife up to 10,000 , of which quantity there is one farm, this is Mr. Macarthy's, of Spring Houfe, near Tipperary, and is I fuppofe the moft confiderable one in the world. Here are fome of the particulars of it :

9,000 acres in all- $-10,000$ l. rent $---8,000$ fheep----2,000 lambs---550 bullocks--- 80 fat cows---20,000l. value of ftock---200 yearlings---200 two-year olds-- 200 three-year olds ---80 plough bullocks---180 horfes, mares and foals-- -150 to 200 labourers-- 200 acres tillage.

Mr. Richard Dogherty, of Locklogher, 76 bags of wool at $500 \mathrm{lb}$. to $600 \mathrm{lb}$. this year. Lofs of heep and cattle one-half per cent. No folding. For hiring and ftocking, 51 . an acre. A thepherd is allowed four cows, a horfe, a cabbin, and three acres of garden, and as much hay as they like for their cattle.

Slaughter 
Slaughter at Corke of cows and bullocks undoubtedly much leffened. The increafe of tillage is in Tipperary owing to bolting mills.

The quantity of tillage in this country trifling, but the crops are large ; there are feveral courfes. The turnip hubbandry often upon burnt land, fome on lime and fallow, and fome on fallow alone.

1. Turnips. 2. Fallow. 3. Wheat. 4. Oats. 5. Oats. 6. Oats. 7. Oats. 8. Oats. 9. Oats. 10. Lay it out.

I. Turnips: 2. Fallow. 3. Potatoes. 4. Bere. 5. Wheat. 6. Oats. 7. Oats. 8. Oats. 9. Oats.

I. Burn for rape feed. 2. Potatoes. 3. Wheat. 4. Oats. 5. Oats. Lay out. And fometimes they take two crops of wheat. They never hoe turnips.

Mr. Dexter of Cullen, had a ram, half a guinea a leap, and great numbers of ewes were fent to him, the breed much improving.

Potatoes, average produce, 80 to 100 Briftol barrels, at 5 s. average price, and the poor people pay 5 to 6 guineas for land. They often take two crops with adding fome feed, pay the fame price for the fecond; they pay this price for turnip land burnt; grafs potatoes not generally known. The quantity 


\section{T I P P E R A R Y.}

of wheat 10 barrels to 15 .-Bere 15 to 18 .Barley 12 to 18 . - Oats 12 to 15 . Their turnips they feldom fow before the I 2 th of July. Their manures are lime and lime-ftone gravel, the gravel for crops, and lime for grafs; they ufe it on lime-ftone land, and with great fuccefs. The foil a mellow, dry fandy, or gravelly loam, on lime-ftone or limeftone gravel. Much bog in this country, that of Allen comes in a line through the Queen's County to within three miles of Cafhel. Onefifth of Tipperary, mountain, the reft 20 . an acre. Land fells at 20 years purchafe. Rents have fallen four or five Millings an acre fince 1771 and 1772 .

\section{Price of Cattle.}

Yearling bullock, 3 l. to 31 . 1os. Store bullock, 61. to 7l. Fat ditto, 10l. to 121. Profit on a bullock, 4 l. to 41 . 10 . A bullock fat of ten guineas, weighs $6 \mathrm{cwt}$.

Newtown, 250 acres, a farm of Mr. - Dogherty's, under bullocks from May to November, and r 100 lambs all winter through.

I had heard much of the late Mr. Keating's farm, of Garranlad, as the largett that ever was; his fon gave me the following particulars of it:

10,0001. a year rent. 13,800 Irifh acres. 3,000 head of black cattle. 16,300 theep. 300 horfes. 500 couple of ducks 300 
turkies. 90 hogfheads of cyder a year. He had moft of the ground from Golding to Clonmell. Collops here in order are, I horfe. 6 heep. I cow. I fat bullock. 2 yearlings. 3 calves.

To Cullen, Newtown, Palace, Carrick on Lifh, rents $3 \circ \mathrm{s}$. an acre. Refpecting the ftate of the poor in this country they are paid by a cabbin, and one acre and a half of land, for which they are reckoned 41 . and for grafs of a cow 21. 2s. They live upon potatoes and milk; generally have cows, but not all, and thofe who have not, buy, but very many of them have for the half year, only potatoes and falt. They all keep pigs. They are juft as they were 20 years ago. Prices, wheat Is. Id. per ftone. Englifh barley, 1od. Oats, 6d. Bere, 7d. Hay Il. 2s. 9d. a ton.

Rape is very commonly fown upon burnt land; they never feed it, but let it ftand for feed, of which they get 12 to 15 barrels, and it fells at 168. a barrel. Burning I fhould explain, is only the remaining turf after two ploughings, the firft in November, and after Chriftmas a crofs ploughing; harrow in March, and burn in May.

Accompanied Lady Clanwilliam in a drive through her plantations; the has planted a broad margin for feveral miles round a domain, (which his Lordfhip walled in with intention of building) and done it with equal tafte 
D U N D R U M. I6 I

tafte and fuccefs. The attention the has given to this rational amufement, and the fenfible and agreeable manner in which the renders every tree interefting by her defcriptions and remarks, are formed to fet off a female character in a light at leaft as refpectable and as amiable as the moft brilliant exhibition that a capital can witnefs. The twig which the plants with her hand, and nourimes by her care, will not difappoint her in the pleafure the expects ; it will thrive with her attention, and greet her with its friendly thade: when will Dublin prove as grateful?

October I 2th, to Lord de Montalt's at Dundrum, a place which his Lordhip has ornamented in the modern ftile of improvement: the houfe was fituated in the midit of all the regular exertions of the laft age. Parterres, parapets of earth, ftraight walks, knots and clipt hedges, all which he has thrown down, with an infinite number of hedges and ditches, filled up ponds, \&cc. and opened one very noble lawn around him, fcattered negligently over with trees, and cleared the courfe of a choaked up river, fo that it flows at prefent in a winding courfe through the grounds. $\mathrm{He}$ continues this work of dreffing the fields contiguous to him, to give them a neat appearance, and advances in it every year, even his tillage lands are all kept in the fame neat manner, with fences new done, and the whole carrying the molt cultivated appearance.

VOL. II. 


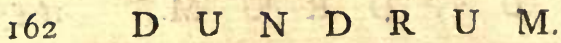

His Lordfhip's fyftem of hußbandry is an ad-: mirable one; it is in the great outline to take farms into his own hands, as the leafes expire, to keep them for improvement, and when done to relet them. This is the true agriculture for profit for a landlord; he has upon this fyftem improved near 2000 acres. Throwing down the old miferable fences which fplit the farms into little fcraps of fields, and made new ditches for drains and water-courfes, difpofed the new fields to the beft advantage, drained them with ftone drains where wet, broke up fuch of the grafs as was bad, cultivated it enough to bring it into proper order, and laid it down again to meadow; there cannot be a better fyftem, or more calculated at the fame time to ornament a country, and improve his own eftate.

His Lordhip has alfo followed feveral practices in farming, which have proved of great fervice; among others, keeping hogs upon clover. He had a mind to fhew the countryman that they might keep many hogs (a very advantageous ftock to them) by means of clover; he kept four fows and twenty-four pigs the fummer through on one acre, by which he made 10 . produce. A clear proof that the hufbandry would be highly advantageous with this view.

Turnips he cultivates upon a very large fcale; was the firft who had them here on Ifubbles; he has thirty or forty acres, and every 


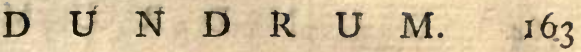

every year has a large quantity; drills them with a very cheap fimple drill, his own invention, and thins them out by hand, or hoes them. I viewed his crop, and found them very regular, and of a good fize; with the leaves of the whole of a remarkable deep green, without any yellow ones : more fo, I think, than is common in England, and I obferved the fame circumftance with the other crops I faw. He ufes them for feeding and fattening heep, giving them on dry grafs land; alfo for ftall-feeding bullocks, and finds the advantage of both ufes fo great, that he does not know what he fhould do without them.

In the winter managenent of his cattle, he proceeds on very different principles from what is common in Ireland; inftead of feeding them abroad, and for that purpore ftacking the hay about the fields, he ties them up in ftalls, of which he has many, and is erecting more: he ties up above 100 head, in which he finds the greateft advantage, both in the cattle, faving: food, and yielding dung. The breed of theep he has begun to change, from the long-legged Tipperary to the fhort legs of Leicefterfhire; has feveral tups of that breed, and finds that the change is of the higheft confequence. Folding he has practiced with the greateft fuccefs. The breed of hogs he has alfo changed to the Berkfhire, and has one of the fineft boars of that breed I have feen.

$$
\text { L } 2
$$

Cabbages 


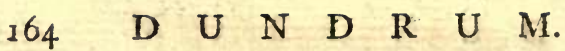

Cabbages he cultivated for feveral years, but finds them burft too foon to be of confiderable ufe; turnips much better: but Reynolds' turnip-cabbage he finds excellent for late fpring food; has eight acres of very fine ones this year, which coft him juft 201 . labour of manuring included.

Lord de Montalt keeps 2000 acres in his hands, I 500 theep, 40 plough bullocks, 12 cows, \&c. His Lordhip, for the purpofe of draining his clay lands, ploughs and thovels them up into broad highlands, fo as to form regular fegments of circles, in the manner practifed in fome counties in England; he does this that the furrows may be drains to the land, for French drains wilt not run, owing to the ftiffnefs of the clay. $\mathrm{He}$ has not much of this land, however; for in general his foil is the rich reddifh fandy loam of the golden vale. He does much of his ploughing with the plough of Warwick and Shrophire, and finds it anfwers very well.

The mountain lands of Tipperary onefeventh of the county, the reft lets at 20 . an acre on an average. There is fome woollen manufactory fcattered through it, efpecially at Thurles, Tipperary, Clonmell, \&c. Mr. John Fenning, near Colchin, employs 30 combers. The year's purchafe of land 20 , was 25 fome years ago. 'The fall owing. 


\section{A S H E L. $\quad 165$}

owing partly to the expectation of an abfentee land-tax.

October $13^{\text {th }}$, leaving Dundrum, paffed through Calhel, where is a rock and rui on it, called the rock of Cafhel, fuppofed to be of the remoteft antiquity. Towards Clonmell, the whole way through the faine rich vein of red fandy loam I have fo often - mentioned: I examined it in feveral fields, and found it to be of an extraordinary fertility, and as fine turnip land as ever I faw. It is much under fheep; but towards Clonmell there is a great deal of tillage.

The fint view of that town backed by a high ridge of mountains, with a beautiful fpace near it of inclofures, fringed with a fcattering of trees, was very pleafing. It is the beft fituated place in the county of Tipperary, on the Sure, which brings up boats of ten tons burthen. It appears to be a bufy populous place, yet I was told that the manufacture of woollens is not confiderable. It is noted for being the birthplace of the inimitable Sterne. Within two miles of it is Marletield, the feat of Stephen Moore, Efq; celebrated in Ireland for his uncommon exertions in every branch of agriculture. It was not without the greateft concern that I found him abfent. Seeing this Gentleman however in London afterwards, he was kind enough to favour me with the following particulars: 
166 C L O N M E L L.

His mill was built feven years ago, and coft I 5,0001 . the wages of the millers, including candles, coals, foap, tallow, \&c. 7 or 8001 . a year: it contains 9 ftones for wheat, and 4 for oatmeal : it has a very complete apparatus for fifting, cleaning, \&c. and granaries of uncommon magnitude, holding 10,000 barrels : began to be worked with only 3,000 barrels of wheat in a year, which has. rifen gradually to 20,000 barrels in 1776 , a very ftrong proof of the great increafe of tillage in the neighbourhood. Very much of it is between Clonmell and $\mathrm{Ca}$ (hel, in which tract there was formerly more fheep in one parift, than now in three; alfo much in the Corke road to Cloheen, but no mountain heath ground improved. The change has been from Theep and bullocks. He has a profpect of doing yet more, and at the fame time that other mills have been erected that grind much, perhaps the whole is not thort of 40,000 barrels. The farmers do not bring their wheat from a greater diffance than 16 miles. Mr. Moore finds it neceffary to kiln dry all. I mentioned to him the bad colour of all the wheat in his own, and every other mill in Ireland, he attributed it only to wet harvefts. $\mathrm{He}$ fends his flour to Dublin, on the bounty, which rather more than pays the expence of carriage 6d. per cwt. Never exports on his own account, but fends a little to Waterford. It goes to Dublin in cars, which takes each eight to ten $\mathrm{cwt}$. that is from four to five bags. 


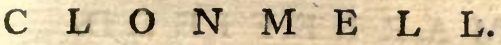

bags. He ufed to pay $3 \mathrm{~s}$. a cwt. in winter, and $3 \mathrm{s.} 6 \mathrm{~d}$. in fummer for 84 miles, but now the price is $2 s 6 \mathrm{~d}$. in fummer, and $3 \mathrm{~s}$. in winter. Mr. Moore tried Englifh broadwheeled waggons, with high priced ftrong horfes, but they did not anfwer at all: he has found the cars to carry much greater loads.

He has not found that the premium has over ftocked the Dublin market, which he attributes to there being an export from Dublin, notwithftanding fuch exported corn receives no bounty. The bran Mr. Moore applies to breeding and fattening hogs, contrary to the practice of molt other mills, who having tried it, have given that practice up. He has thirty breeding fows and fix hundred pigs, which are fed and fattened entirely on it, and the fat is firm and good. The price of bran is Is. Id. the fix ftone, and the hogs anfwer fo well, that he would contract for other bran to be delivered him at that price, in order to ufe it in this manner. He does not depend entirely on breeding his own, but buys many ftores. $\mathrm{He}$ is entirely in the Berkfhire breed, which he finds much fuperior to the Irifh. I obferved his hogs, and thought them very fine ones. His fows bring three litters each, feven pigs on an average, in a year and a quarter; fells them at half a year to two years old, putting them to fat as foon as they have done growing; but when there is a great demand, fats them young. The arerage fat pig, two cwt. 
at from 20 s. to 3 os. a cwt. medium $25 \mathrm{~s}$. The dung is a confiderable profit; he finds it beyond any other. He has given bran alfo to fatting ftore cattle, having built ftalls for that purpofe; gives them hay till when near fat, then leaves off the hay. His working horfes are fed on bran entirely, no oats.

Mr. Moore contracts for bifcuit, which he bakes in large quantities, and bread for the whole town of Clonmell. He has eight ovens going for bifcuit. Starch he alfo makes large quantities of. Adjoining his flour mill, he has erected a rape mill, for making oil; the feed is all raifed in the neighbourhood. The cake fells at $48 \mathrm{~s}$, a ton, and is exported, fome to Holland, but moft to England for manure. He has tried feeding beafts with it, but it will not do at all : they would have died. This fact has long been known in England. It is the cake of lint feed that fattens. We have, however, very florid writers of this age, who fipeak of oxen fattening on rape cake as a common thing.

$\mathrm{Mr}$. Moore's hurbandry is alfo worthy of confiderable notice. His principal attention has been given to cattle; feventeen years ago he imported Leicefterfhire rams, Northampton ftallions, and a Craven bull fiom England, and has at different times fince had bulls from Bakewell and others, and has himfelf fold yearling bull calves, from 10l. to 3 ol. a piece, and rams from rol. to 40 l. Long experience 


\section{A R L E F I E L D.}

perience has told him that the long horned Craven breed of cattle is preferable to any other. I enquired particularly into the quantity of milk, becaufe the common objection is their not giving much. Sir William Ofborne, as well as Mr. Moore, affured me that he had feen one of them milked, and the milk meafured feventeen quarts at one meal; but the average fix to ten quarts at a meal, which is neither better nor worfe than the common cows of the country: but the milk is much better and thicker, and yields more butter than that of the Holderneffe. I examined his bulls, cows, and oxen, with attention; he has a bull which deferves every commendation for fhape; and three or four out of fix or feven prime cows I faw, were very beautiful ones.

Of theep he keeps 3000 , that is 200 ewes, 200 year-olds; 200 two-year olds; 200 barren ewes, and 200 lambs. He fells every year 200 two-year old fat wethers, and 100 barren ewes; the wethers in October, at $28 \mathrm{~s}$. and the ewes in the fpring, at $25 \mathrm{~s}$. His fleeces are $7 \mathrm{lb}$. each on an average, at $\mathrm{is}$, per $\mathrm{lb}$.

Turnips he has cultivated for fome years, up to 30 acres in a year, broad caft, has not hoed, from finding them very good without. He both draws and feeds on the land. Hehas had cabbages alfo, but never more than two acres, finds them more expenfive, but do not go fo far as turnip. 
I70 MOUNTAIN IMPROVEMENT.

To Sir William Ofborne's, three miles the other fide Clonmell. From a character fo re. markable for intelligence and precifion. I could not fail of meeting information of the moft valuable kind. This gentleman has made a mountain improvement which demands particular attention, being upon a principle very different from common ones.

Twelve years ago he met with a hearty looking fellow of forty, followed by a wife and fix children in rags, who begged. Sir William queftioned him upon the fcandal of a man in full health and vigour, fupporting himfelf in fuch a manner : the man faid he could get no work: Come along witb ime, I will fhew you a spot of land upon whicb I will build a cabbin for you, and if you like it you fkall fix there. The fellow followed Sir William, who was as good as his word: he built him a cabbin, gave him five acres of a heathy mountain, lent him four pounds to ftock with, and gave him, when he had prepared his ground, as much lime as he would come for. The fellow flourifhed; he went on gradually; repaid the four pounds, and prefently became a happy little cottar : he has at prefent twelve acres under cultivation, and a ftock in trade worth at leaft 801 . his name is John Conory.

The fuccefs which attended this man in two or three years, brought others, who applied for land, and Sir William gave them as they applied. The mountain was under leafe to a tenant, 


\section{MOUNTAIN IMPROVEMENT. I 7}

tenant, who valued it fo little, that upon being reproached with not cultivating, or doing fomething with it, he affured Sir William, that it was utterly impracticable to do any thing with it, and offered it to him without any deduction of rent. Upon this mountain he fixed them; gave them terms as they came determinable with the leafe of the farm, fo that every one that came in fucceffion had fhorter and horter tenures; yet are they fo defirous of fettling, that they come at prefent, though only two years remain for a term.

In this manner Sir William has fixed twenty-two families, who are all upon the improving hand, the meaneft growing richer; and find themfelves fo well off, that no confideration will induce them to work for others, not even in harveft : their induftry has no bounds ; nor is the day long enough for the revolution of their inceffant labour. Some of them bring turf to Clonmell, and Sir William has feen Conory returning loaded with foap afhes.

He found it difficult to perfuade them to make a road to their village, but when they had once done it, he found none in getting crofs roads to it, they found fuch benefit in the firft. Sir William has continued to give them whatever lime they come for ; and they have defired 1000 barrels among them for the year 1766 , which their landlord has accordingly contracted for with his lime-burner, at I d. a barrel. Their houfes have all been built at 
his expence, and done by contract at 61 . each, after which they raife what little offices they want for themfelves.

Sir William being prejudiced againf the curtom of burning land, infifted that they fhould not do it, which impeded them for fome time; but upon being convinced that they could not go on well without it, he relaxed, and fince that they have improved rapidly. He has informed them, that upon the expiration of the leafe, they will be charged fomething for. the land, and has defired that they will mark out each man what he wifhes to have; they have accordingly run divifions, and fome of them have taken pieces of 30 or 40 acres: a ftrong proof that they find their hußbandry beneficial and profitable. He has great reafon to believe that nine-tenths of them were white boys, but are now of principles and practice exceedingly different from the mifcreants that bear that name. The lime Sir William gives them for the firft breaking up, and the quantity they chufe is 40 barrels an acre, fo that all the expenfe is 61. for the houfe, and 11. 16s. 8d. an acre for the land they improve. He has little doubt but they will take the whole mountain among them, which confifts of 900 acres. Their courfe of tillage is,

1. Potatoes on the burning, generally Turks, (cluftered) and great crops. 2. Rye. 3.Oats, and then leave it out; the grafs is, 


\section{W A T E R F O R D.}

Their cattle are feeding on the mountain in the day, but of nights they houfe them in little miferable ftables. All their children are employed regularly in their hurbandry, picking ftones, weeding, \&cc. which thows their induftry ftrongly; for in general they are idle about all the country. The women fpin.

Too much cannot be faid in praife of this undertaking. It fhows that a reflecting penetrating landlord can fcarcely move without the power of creating opportunities to do himfelf and his country fervice. It fhows that the villainy of the greateft mifcreants, is all fituation and circumftance: EMPLOY, don't bang them. Let it not be in the flavery of the cottar fyftem, in which induftry never meets its reward, but by giving property, teach the value of it; by giving them the fruit of their labour, teach them to be laborious. All this Sir William Orborne has done, and done it with effect, and there probably is not an honefter fet of families in the county than thofe which he has formed from the refufe of the white boys.

Suppore he brilds a houfe to every twenty acres, and limes that quantity of land, the expenfe would be a few hillings over 4 ol. or 40 s. an acre. If they pay him 2s. $4 \mathrm{~d}$. an acre for the land, he will make juft 61. per cent. for his money: a moft ftriking proof of the immenfe profit which attends mountain improvements of every kind, becaufe inftead of $2 s$. $4 \mathrm{~d}$. they would confider $6 \mathrm{~s}$. or $7 \mathrm{~s}$. as a rent of favour. 


\section{N E W}

4 s. $8 \mathrm{~d}$. is $\mathrm{J} 2$ per cent. for his money; $7 \mathrm{~s}$. is 18 per cent. Yet in fpite of fuch facts do the lazy,

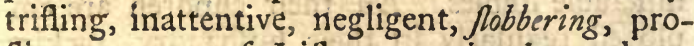
fligate awners of Irith mountains leave them, as they received them, from the hands of their anceftors, in the poffeffion of groufe and foxes. Shame to fuch a fpiritlefs conduct !

- One-third of Waterford mountain at $6 \mathrm{~d}$. an acre, and two-thirds at 75 . Twenty miles on the coaft in length, and eight or ten in breadth, is under dairies, of which the rent per acre is little known, farms being paid for by the cows they will maintain, at 50 s. each. Thefe dairies rife to 50 and even 100 cows. They all keep great numbers of hogs, which increafe every day from the high price. The ftate of the poor people much better than formerly; they ufed to have one acre of potatoes, and the grafs of one cow for their year's labour, and no more, and were much greater flaves than at prefent.

- Tillage does not thrive in the county; it has, however, increafed pretty much about Dungarvon, from whence there has been a tolerable export of corn; not only from its neighbourhood, but alfo from a diftance, owing to the mobs of Clonmell and Carrick ftopping corn going to Waterford, which has injured the latter town.

October ${ }_{1} 5^{\text {th, left New Town, and keeping }}$ on the banks of the Sure, paffed through Carrick to Curraghmore, the feat of the Earl of

Tyrone. 


\section{N E $\quad$ W $\quad T \quad O \quad W \quad N . \quad 175$}

Tyrone. This line of country, in point of foil, inferior to what I have of late gone through : fo that I confider the rich country to end at Clonmell. For the following account of the hubandry of the county of Waterford I am obliged to the attention of Lord Tyrone, who omitted no means of informing me accurately.

That county is divided into very large farms, and the renters of them keep cows generally, which they let to dairymen. One farmer, Mr. Peor, has 2000 cows, and pays 2000l. a year, but they rarely let more to one man than $5^{\circ}$ cows, ufually about 20; many of thefe men pay weekly, and others quarterly: the rent from 50 s. to 31 . 5 s, no fuch thing as hornmoney. The dairyman's privilege is a houfe and two or three acres of land, or a horfe and two cows in twenty. They make nothing but butter, and all keep hogs; but do not feed them with milk, felling it all; 1,300 to 1,500 churns full of milk, each eight gallons, goes into Waterford every day in the year, and a prodigious quantity to Carrick. The county is by far the greateft dairying one in Ireland. The breed is the common mountain cow, poor to look at, but great milkers, five or fix potthes at a meal common. Price of them 51. at an average. Average rent of all the land under cows, Ios. One-third of the county mountain; at $6 \mathrm{~d}$. the other two-thirds, at ros. Along the Blackwater, good land, and four miles round Waterford, 20s. or $25 \mathrm{~s}$. The quantity 
26

176 CURRAGHMOOR.

for a cow from two to four acres. They generally breed their own by rearing a few calves every year; the young ftock are kept on the mountains in fummer, and in the worft of the low land in winter. They never feed their cows with any hay, except in very fevere weather. No other ftock but cows.

The foils are various at this end of the county, clay and fhingly flate, with a reddifh mold upon it and gravelly loams. At the other end, they have lime-ftone lands. They have, however, about Curraghmoor lime-ftone gravel of a ftiff nature. Lime at the kiln gd. a barrel; Lord Tyrone pays is. for the ftone, and 2s. 8 d. a barrel for the culm, and pays 2 d. a barrel for breaking and burning, all which make gd. Every barrel of culm gives feven of lime; a ton of ftone produces four barrels of lime: the barrel of lime four cubical feet. Not a thirtieth part of the country under the plough. The tillage confifts only of a little patches broken up by the cabbins; it has been increafing thefe 15 years: but the principal increafe has been within thefe ten years. The courfe of crops:

1. Potatoes. 2. Potatoes. 3. Barley, or oats. 4. Oats. 5. Oats : continued while the land yields. Wheat is coming in. Some who till large fields, and do not take fo many crops. About Dungarvon, there are many potatoes planted, which are fent to Dublin in boats, with loads of birch brooms, and they are faid 


\section{UR R A H M O O R.}

to be loaded with fruit and timber. But in no part of the county do they plant grafs potatoes: they plant many of the bull or turk fort for their pigs, but they are reckoned an unwholefome fort for the people to feed on. Paring and burning land was common before the law paffed againft it, but of late very little. Upon the coaft there is a great deal of feaweed and fea-fand, efpecially beyond Dungarvon and Waterford. Flax is fcarcely any where fown. The poor people feed on potatoes and milk; moft of them have cows; many of them for a part of the year only falt: but they have oat bread when potatoes are not in feafon. They all keep pigs, but never eat them. Their circumftances are in general greatly better than they were twenty years ago, both in food and cloathing; they have now all thoes and ftockings, and are decently dreffed every Sunday. No hats among the women, and it is the fame in other parts. Their labour is valued, and they are paid the amount in land. The religion of the lower claftes is the Roman catholic.

Emigrations from this part of Ireland principally to Newfoundland, for a feafon; they have 181 . or 201 . for their pay, and are maintained, but they do not bring home more than 7l. to I11. Some of them ftay and fettle; three years ago there was an emigration of indented fervants to North Carolina, of 300 , but they were ftopped by contrary winds, \&xc. There had been fomething of this conftantly,

$$
\text { Vor.II. }
$$$$
\text { M }
$$

but. 
I78 CURRAGHOOR.

but not to that amount. The oppreffion which the poor people have moft to complain of, is the not having any tenures in their lands, by which means they are entirely fubject to their employers.

Manufactures here are only woollens. Carrick is one of the greateft manufacturing towns in Ireland. Principally for ratteens, but of late they have got into broadcloths, all for home confumption; the manufacture increafes, and is very flourilhing. There are between three and four hundred people employed by it, in Carrick and its neighbourhood.

Lord Tyrone is clear that if his eftate in Londonderry was in Waterford, or that all the inhabitants of it were to emigrate from it, fo as to leave him to new model it, he would be able to get full one-third more for it than he can do at prefent; rents in the north depending not on quality, but on price of linen.

The rife in the profperity of Ireland, about the year 1749 , owing to the higher price of provifions, which raifed rents and enforced induftry. Butter now 9 d. a lb. thirty years ago $2: \mathrm{d}$.

Tythes are ufually compounded for by the year through this county. Wheat pays Ios. Barley, 10s. Oats, 5s. Mowing ground, 4s. Sheep, id, each. Milk fells in fummer for a halfpenny 


\section{c U R R A H M O O R.}

halfpenny a quart ; five quarts of butter-milk in fummer for a halfpenny.

Lord Tyrone has improved 127 acres of hill, the foil reddifh dry loam, on a flaty bottom, over-run with French and Irifh furze, and briars and bufhes; he firft grubbed them up at a guinea an acre: then he levelled an infinite number of old ditches and mounds, at 5 ol. expenfe, ploughed in winter, and fecond ploughed in May; and 200 barrels of roach lime per acre, fpread, at 1 s. a barrel. Upon this ploughed twice more; and fowed, part with wheat at Michaelmas, and part with barley in fpring. The crops exceedingly good; 8 barrels an acre of wheat, and 18 of barley. After the wheat, barley and grafs feeds were fown; the barley as good as the other; and upon the barley, part oats were fown, the crop 15 barrels, and white clover and hay feeds. Before the improvement, it let at Ios. an acre; after the improvement it would let readily at 25 s. The grubbing the furze was not effectual, for 501 . has been fince expended in grubbing up lcattered ones. They are now completely deftroyed, is a very beautiful welllaid lawn, and fo good land, that the wool of the fheep alone that were kept there laft year, without other food, and through the year paid 20s. an acre for the whole. It would now feed 600 theep through the year. Over $9^{\circ}$ acres limed, with 250 barrels an acre, and fallowed, had 17 barrels an acre of wheat. Eight years ago, his Lordinip ftopped their burning $\mathrm{M} 2$ land; 
land; but upon receiving many complaints at it, he fold them lime at gd. a barrel, which cort him Is, in order to make up the imaginary lofs.

I had the pleafure of meeting, at Lord $\mathrm{Ty}$ rone"s, William Shanly, Efq; of Willyfield, in Leitrim, who informed me that he had twelve hundred per acre from a bad red bog, ftone of potatoes four feet deep, drained to the clay at bottom; lime-ftone fand at 31 labour, befides horfes; dunged it a common covering, and immediately planted the potatoes, dug them, and fowed barley, 15 barrels an acre. Barley again 12 barrels; barley again 8 barrels, grew too rank, laid with grafs feeds, could let at $40 s$. an acre: anfwers fo well, that he would have done any quantity of it; did 20 acres. $\mathrm{He}$ planted with a plough $29^{\frac{r}{2}}$ ftone of patatoes in rows, four feet afunder; the produce was 1,440 ftone, the quantity of land about three rood. In the county Leitrim, four-fifths of mountain, at $2 \mathrm{~d}$. or not fo much ; the remaining fifth, $6 \mathrm{~s}$. the mountains in Leitrim all wet, a boggy furface.

Curraghmoor is one of the fineft places in Ireland, or indeed that $I$ have any where feen. The houfe, which is large, is fituated upon a rifing ground, in a vale furrounded by very bold hills, which rife in a variety of forms, and offer to the eye, in riding through the grounds, very noble and ftriking fcenes. Thefe hills are exceedingly varied, fo that the detour 
CURRAGHMOOR. 18r

of the place is very pleafing. In order to fee it to advantage, $I$ would advife a traveller to take the ride which Lord Tyrone carried me. Paffed through the deer park wood of old oaks, fpread over the fide of a bold hill, and of fueh an extent, that the fcene is a truly foreft one, without any other boundary in view than what the ftems of trees offer from mere extent, retiring one behind another till they thicken fo much to the eye, under the chade of their fpreading tops, as to form a diftant wall of wood. This is a fort of fcene pot common in Ireland, it is a great extent alone that will give it. From this hill enter an evergreen plantation, a fcene which winds up the Deer-park hill, and opens on to the brow of it," which commands a moft noble view indeed. The lawns around the houfe appear at one's feet, at the bottom of a great declivity of wood, almoft every where furrounded by plantations. The hills on the oppofite fide of the vale againft the houfe, confift of a large lawn in the center of the two woods, that to the right of an immenfe extent, which waves over a mountain fide, in the fineft manner imaginable, and lead the eye to the fcenery on the left, which is a beautiful vale of rich inclofures, of feveral miles extent, with the Sure making one great reach through it, and a bold bend juft before it enters a gap in the hills towards Waterford, and winds behind them; to the right you look over a large plain, backed by the great Cummeragh mountains. For a diftind extent of view, the parts of which are all of a commanding 
182 CURRAGHOOR.

manding magnitude, and a variety equal to the number, very few profpects are finer thar. this.

From hence the boundary plantation extends fome miles to the weft and north-weft of the domain, forming a margin to the whole of different growths, having been planted, by degrees, from three to fixteen years. It is in general well grown, and the trees thriven exceedingly, particularly the oak, beech, larch, and firs. It is very well fketched, with much variety given to it.

Pafs by the garden acrofs the river, which murmurs over a rocky bed, and follow the riding up a fteep hill, covered with wood from fome breaks, in which the houfe appears perfectly buried in a deep wood, and come out, after a confiderable extent of ride, into the higher lawn, which commands a view of the fcenery about the houfe; and from the brow of the hill the water, which is made to imitate a river, has a good effect, and throws a great air of chearfulnefs over the fcene, for from hence the declivity below it is hid; but the view, which is the moft pleafing from hence, the fineft at Curraghmoor, and indeed one of the moft ftriking that is any where to be feen, is that of the hanging wood to the right of the houfe, rifing in fo noble a fweep as perfectly to fill the eye, and leave the fancy fcarce any thing to wing: at the bottom is a fmall femicircular lawn around, which flow's the river, under the immediate 


\section{CURRA G H M O R. 183}

immediate hade of very noble oaks; the whole wood rifes boldly from the bottom, tree above tree, to a vaft height, of large oak, the maffes of hade are but tints of one colour, it is not chequered with a variety, there is a majeftic fimplicity, a unity in the whole, which is attended with an uncommon impreffion, and fuch as none but the moft magnificent fcenes can raife.

Defcending from hence through the roads, the riding croffes the river, paffes through the meadow, which has fuch an effect in the preceding fcene, from which alfo the view is very fine, and leads home through a continued and an extenfive range of fine oak, partly on a declivity, at the bottom of which the river murmurs its broken courfe.

Befides this noble riding, there is a very agreeable walk runs immediately on the banks of the river, which is perfect in its ftile; it is a fequeftered line of wood, fo high on the declivities in fome places, and fo thick to the very edge in others, overfpreading the river; that the character of the fcene is gloom and melancholy, heightened by the noife of the water falling from ftone to Ptone; there is a confiderable variety in the banks of it, and in the figures and growth of the wood, but none that hurts the impreffion, which is well preferved throughout. 
I84 W A T E R F O R D.

October 17 th. accompanied Lord Tyrone to Waterford; made fome enquiries into the ftate of their trade, but found it difficult, from the method in which the Cuftom-houfe books are kept, to get the details I wifhed; but in the year following, having the pleafure of a long vifit at Ballycanvan, the feat of Cornelius Bolton, Efq; his fon, the member for the city, procured me every information I could wifh, and that in fo liberal and polite a manner, that it would not be eafy to exprefs the obligations I am under to both. In general I was informed that the trade of the place had increafed confiderably in ten years, both the exports and imports. The exports of the products of pafturage, full one-third in twelve years. That the ftaple trade of the plaçe is the Newfoundland trade; this is very much increafed, there is more of it here than any where. The number of people who go paffengers in the Newfoundland hips is amazing; from fixty to eighty hips, and from three thoufand to five thoufand annually. They come from moft parts of Ireland, from Corke, Kerry, \&cc. Experienced men will get i 8 to 251 . for the feafon; from March to November; a man who never went will have five to feven pounds, and his paffage, and others rife to 20 l. the paffage out they get, ' but pay home two pounds. An induftrious man in a year will bring home twelve to fixteen pounds with him, and fome more. A great point for them is to be able to carry out all their flops, for every thing there is exceedingly dear, one 


\section{W A T E R F O R D.}

185

or two hundred per cent. dearer than they can get them at home. They are not allowed to take out any woollen goods but for their own ufe. The fhips go loaded with pork, beef, butter, and fome falt : and bring home paffengers, or get freights where they can; fometimes rum. The Waterford pork comes principally from the barony of Iverk in Kilkenny, where they fatten great numbers of large hogs; for many weeks together they kill here three to four thoufand a week, the price 5 os. to $4 \mathrm{l}$. each; goes chiefly to Newfoundland. One was killed in Mr. Penrofe's cellar, that weighed five cwt. and a quarter, and meafured from the nofe to the end of the tail, nine feet foụr inches.

There is a foundery at Waterford for pots, kettles, weights, and all common utenfils; and a manufactory by meffieurs King and Tegent, of anvils to anchors, 20 cwt. \&cc. which employs 40 hands. Smiths earn from 6 s. to 24 s. a week. Nailors, from 10s. to 12s. And another lefs confiderable. There are two fugar-houfes, and many falt-houfes.' The falt is boiled over lime-kilns.

There is a fifhery upon the coaft of Waterford, for a great variety of fin', herrings particularly in the mouth of Waterford harbour, and two years ago in fuch quantities there, that the tides left the ditches full of them. There are fome premium boats both here and 


\section{W A T E R F O R D.}

at Dungarvon, but the quantity of herrings barrelled is not confiderable.

The butter trade of Waterford has increafed greatly for 7 years paft; it comes from Waterford principally, but much from Carlow; for it comes from 20 miles beyond Carlow, for 6d. per cwt. From the firft of January, 1774, to the firft of January, 1775, there were exported 59,856 calks of butter each on an average, one hundred weight at the mean price of 5 os. Revenue of Waterford, 175 1, 17,0001. -- $1776,52,0001$. The flaughter trade has increafed, but not fo much as the butter. Price of butter now at Waterford, $58 \mathrm{~s}$. twenty years average, 42s. Beef now to 25 s. average, twenty years, 10 s. to $18 \mathrm{~s}$. Pork now $30 s$. average, twenty years, 16s. to 22s. Eighty fail of thips now belonging to the port, twenty years ago not 30 . They pay to the captains of fhips of 200 tons, $5^{I}$. a month; the mate 31 . Ios. Ten men, at 408 . five years aga only 275 . Building hips, 101. a ton. Wear and tear of fuch a Mip, 20l. a month. Ship provifions, 20s. a month.

The new church in this city is a very beautiful one; the body of it is in the fame ftile exactly as that of Belfait already defcribed: the total length 170 feet, the breadth 58 . The length of the body of the church 92, the height 40 ; breadth between the pillars 26 . The inte (which I do not remember at Belfaft) is 58 by 45 . A room on one fide the fteeple, 
fpace for the birhop's court, 24 by 18 ; on the other fide, a. room of the fame fize for the veftry; and 28 feet fquare left for a Ateeple when their funds will permit. The whole is light and beautiful : it was built by fubfcription, and there is a fine organ befpoke-at London. But the fineft object in this city is the quay, which is unrivalled by any I have feen; it is an Englifh mile long; tbe buildings on it are only common houfes, but the river is near a mile over, flows up to the town in one noble reach, and the oppofite fhore a bold hill, which rifes immediately from the water to a height that render's the whole magnificent. This is fcattered with fome wood, and divided into paftures of a beautiful verdure; by hedges. I croffed the water, in order to walk up the rocks on the top of this hill; in one place, over againft Bilberry quarry, you look immediately down on the river, which flows in noble reaches from Granny caftle on the right paft Cromwell's rock, the fhores on both fides, quite fteep, efpecially the rock of Bilberry. You look over the whole town, which here appears in a triangular form; befides the city, the Cummeragh mountains, Slein-a-man, \&c. come in view. Kilmacow river falls into the Sure, after flowing through a large extent of well planted country; this is the fineft view about the city.

From Waterford to Paffage, and got my chaife and horfes on board the Countefs of $\mathrm{T} y$ rone pacquet, in full expectation of failing immediately 
I88 B A L L Y C A N V A N.

immediately, as the wind was fair, but I foon found the difference of thefe private veffels and the port office pacquets at Holyhead and Dublin. When the wind was fair the tide was foul: and when the tide was with them, the wind would not do; in Englifh there was not a complement of paffengers, and fo $I$ had the agreeablenefs of waiting with my horfes in the hold, by way of 'reft, after a journey of above 1500 miles:

October 18 th. after a beaftly night paffed on thip board, and finding no figns of departure, walked to Ballycanvan, the feat of Cornelius Bolton, Efq; rode with Mr. Bolton, jun. to Faithleghill, which commands one of the fineft views I have feen in Ireland. There is a rock on the top of a hill, which has a very bold view on every fide down on a great extent of country, mucli of which is grafs inelofures of a good verdure. This hill is the center of a circle of about ten miles diameter, teyond which higher lands rife, "which after spreading to a great extent, have on every fide a back ground of mountain : in a northerly direction, mount Leinfter, between Wexford and Wieklow, twenty-fix miles off, rifes in feveral heads, far above the ciouds. A littie to the right of this, Sliakeiltha (i.e. the woody mountain) at a lefs diftance, is a fine object. To the left, Tory hill, only five miles, in a regular form varies the out-line. To the eaft, there is the long mountain, eighteen miles diftant, and feveral leffer Wexford

hills. 


\section{B A L L Y C A N V A N. 189}

hills. To the fouth-eaft, the Saltees. To the fouth the ocean, and the colines about the bay of Tramore. To the weft, Monavollagh rifes 2160 feet above the level of the fea, eighteen miles off, being part of the great range of the Cummaragh mountains; and to the north-weft Slinaman, at the diftance of twenty-iour miles; fo that the out-line is every where bold and diftinct, though diftant. Thefe circumftances would alone form a great view, but the water part of it, which fills up the canvafs, is in a much fuperior ftile. The great river Sure takes a winding courfe from the city of Waterford, through a rich country, hanging on the fides of hills to its banks, and dividing into a double channel, forms the leffer ifland, both of which courfes you command diftinctly; united, it makes a bold reach under the hill on which you ftand, and there receive the noble tribute of the united waters of the barrow and the Nore, in two great channels, which form the larger ifland; enlarged by fuch an acceffion of water, it winds round the hill in a bending courfe, of the freeft and molt graceful outline, every where from one to three miles acrofs, with bold fhores, that give a fharp outline to its courfe to the ocean; twenty fail of hips at Paffage, gave animation to the fcene; upon the whole, the boldnefs of the mountain outline; the variety of the grounds; the valt extent of river, with the declivity to it from the point of view, altogether form fo unrivalled a fcenery-every object 
190 B A L L Y C A N V A N.

object fo commanding, that the general want of wood is almoft forgotten.

Two years after this account was written I again vifited this enchanting hill, and walked to it, day after day, from Ballycanvan, and with increafing pleafure. Mr. Bolton, jun. has fince I was there before, inclofed forty acres on the top and fteep flope' to the water, and began to plant them. This will be a prodigious addition; for the flope forming the bold fhore for a confiderable fpace, and having projections from which the róod will all be feen in the gentle hollows of the hill, the effect will be amazingly fine. Walks and a riding are tracing out, which will command frefh beauties at every ftep; the fpots from which a variety of beautiful views are feen are numerous. All the way from Ballycanvan to Faithleg, the whole to the amount of 1200 acres, is the property of Mr. Bolton.

Farms about Ballycanvan, Waterford, \&c. are generally fmall, from twenty and thirty. to five hundred acres, generally about two hundred and fifty, all above two hundred acres are in general dairies; fome of the dairy ones rife very high. The foil is a reddifh ftony, or flaty gravel, dry, except low lands, which are clay or turf. Rents vary much about the town very high, from 5l. $5^{\mathrm{s}}$. to $9 l$. but at the diftance of a few miles towards Paffage, \&cc. they are from 20s. to 40s. and fome higher, but the country in general does 
not rife fo high, ufually ros. to 205 . for dairying land. The courfe of crops is,

I. Potatoes; the produce 40 to 80 barrels, 20 ftones each. 2. Wheat; the crop 8 barrels, each 20 ftones. 3. Oats; the produce from Io to 14 barrels. 4. Barley; the crop 12 to 15 barrels, 16 ftone each. 5. Lay it out; the better fort clover with the barley, and leave it for meadow.

I. Oats. 2. Wheat. 3. Oats. 4. Barley. One preparation is a flight burning of the furrows for wheat, after that wheat, they will fow barley, and then feveral crops of oats. Alfo.

I. Potatoes. 2. Wheat. 3. Wheat. 4. Barley. 5. Lay out.

I. Potatoes. 2. Potatoes. 3. Wheat. 4. Oats. 5. Barley. 6. Lay out. The fecond crop to barrels. Every houfe has a little. patch of flax for making a little bandle cloth, but the quantity is not confiderable.

The principal manure is a fanci marle they raife in boats on the banks in the harbour at low water ; it is of a blueinh colour, very foapy, and ferments ftrongly with acids: a. boat load is 18 tons, and cofts 6 to 8 s. a load. Moft of it has fhells. They lay it on for barley particularly, and get great crops, can in all fee to an inch where fpread. Some- 


\section{B A L L Y C A N V A N.}

times it is laid on grafs, and the effect uncommonly great, bringing up a perfect carpeting of white clover wherever laid. They lay five or fix loads an acre, and the land is for ever the better. They repeat it on the fame band, and with great effect. They make compofts of it with lime, and alfo hedge earth with good fuccefs. Lime they ufe alfo; lay from 100 to 150 barrels roach to an acre, which has a very great effect. On the ftiffer yellow clays it does bette: than fand, but laid on all forts, and alfo on grafs land with good effect. Sea fand they ufe for potatoes, but it does not laft more than for that crop. Waterford dung, and ftreet fullage, $42 \mathrm{~s}$. the boat load of 18 tons. Clover has been introduced thefe $\mathrm{I} 2$ years; $\mathrm{Mr}$. Bolton has fown it for many years with very good effect, fo that he never lays down land without it.

The dairies are generally fet at $21.5 \mathrm{~s}$. The dairyman's privilege to 40 cows is a cow and horfe, and 2 acres and a cabbin, and he is allowed to rear one calf in ten; 100 acres to 40 cows ; they do not keep any hogs on account of cows. Price of cows, average 4l. to 51 . They are engaged to give two pottles each on an average, putting all the milk together. Meadows let at 31 . to 41 . an acre for the hay.

There are few theep kept, no great flocks. The poor people plough with four horfes, fometimes fix: gentlemen generally with fpayed heiffers or oxen. Land fells at 19 and 


\section{B A L L Y C A N V A N. 193}

20 years purchafe; it did fell at 23 , and the fall has been owing to the failure of credit in 1771 and 1772 .

Tythes, Potatoes, Wheat, Barley, and Oats, 5s. to 6s. Cows, 2d. Sheep, 6d.

The poor people fpin their own flax, but not more, and a few of them wool for themfelves. Their food is potatoes and milk; but they have a confiderable affiftance from filh, particularly herrings ; part of the year they have alfo barley, oaten, and rye bread. They are incomparably better off in every refpect than twenty years ago. Their increafe about Ballycanvan is very great, and tillage all over this neighbourhood is increafed. The rent of a cabbin Ios. an acre with it 20s. The grafs of a cow a few years ago, 20s. now $25^{\mathrm{s}}$. or 3 os.

An exceeding good practice here in making their fences is, they plant the quick on the fide of the bank in the common manner, and then, inftead of the dead hedge we ufe in England on the top of the bank, they plant a row of old thorns, two or three feet high, which readjly grow, and form at once a moft excellent fence. Their way alfo of taking in fand banks from the river deferves notice: they ftake down a row of furzes at low water, laying ftones on them to the height of one or two feet; thefe retain the mud, which every tide brings in, fo as to fill up all within 


\section{B A L L Y C A N V A N.}

the furze as high as their tops. I remarked on the ftrand, that a few boat load's of ftones laid carelefly, had had this effect, for within them I meafured 12 inches deep of rich blue mud left behind them, the fame as they ufe in inanuring, full of thells and effervefced ftrong ly with vinegar.

Among the poor people, the fifhermen are in much the beft circumitances; the filhery is confiderable; Waterford and its harbour have 50 boats each, from 8 to 12 tons, fix men on an average to each, but to one of fix ton, five men go. A boat of eight tons cofts 401 . one of twelve 601 . To each boat there is a train of nets of fix pair, which cofts from 41.4 s. to 61. 6s. $\tan$ them with bark. Their only net fithery is that of herrings, which is commonly carried on by thares. The divifion of the fifh is, firft, one fourth for the boat; and then the men and nets divide the reft, the latter reckoned as three men. They reckon 10 maze of herrings an indifferent night's work; when there is a good take 40 maze have been taken, 20 a good night; the price per maze, from is. to 7 s. average $5^{\mathrm{s}}$. Their take, in 1775 , the greateft they have known, when they had more than they could difpofe of, and the whole town and country ftunk of them, they retailed them 32 for 1 d. 1773 and 1774 good years. They barrelled many ; but in general there is an import of Swedinh. Befides the common articles I have regiftered, the following are, Pigeons, Is. a couple. A hare, Is. 


\section{B A L L Y C A N V A N. I95}

Partridges, 9d. Turbets, fine ones, 4 s. to Ios. Soals, a pair, large, 1s. 6d. to is. Lobfters, 3 d. each. Oyfters, 6s. per hundred. Rabbits, Is. to is. 4 d. a couple. Cod, IS. each, large Salmon, $x_{\frac{1}{4}} \mathrm{~d}$. to $2 \mathrm{~d}$.

A very extraordinary circumftance I was told, that within five or fix years there has been much hay carried from Waterford to Norway, in the Norway fhips that bring deals; as hay is dear here, it proves a molt backward ftate of hufbandry in that northerly region, fince the neighbourhood of fea-ports to which this hay can alone go, is generally the beft improved in all countries.

Mr. Bolton has improved a great deal of wafte land, that was under furze, heath, and wood. He firft grubs it, which colts for the woody part, 31 . or 31.3 s. and for the furze, 20s. Then levels all holes, \&cc. and clears it of rocks, at the expence of 2os. an acre. Upon this he dungs and plants posatoes in the trenching way upon a part, and upon the reft fallows and limes it, and fows wheat, 100 to 150 barrels an acre, produce feven to ten barrels an acre. Then fand it for oats or barley, 15 barrels of barley, and 12 of oats. In this way he has done 300 acres, which was not worth more than $5^{\mathrm{s}}$. an acre: now lets at $30 \mathrm{~s}$. In making this very noble improvement, he divided the land into well proportioned fields, and furrounded them with very noble fences; double ditches, with a parapet bank between,

$$
\mathrm{N}_{2} \text { planted }
$$


196 B A L L Y C A N V A N.

planted on both fides with quick, and on the top with a double row of oak; elm, afh, or fir; many of thefe were planted 36 years ago; they are now in very great perfection, fo thick and fully grown as to be impervious to the fight, and to take, when viewed at a diftance, the appearance of fpreading woods. Nothing could be done in a completer manner, and the quantity over more than 300 acres, uniting with many orchards planted at the fame time, give his domain and its envirous a richnefs of landfcape not common in Ireland. I could not help much admiring it when on the water, from fome parts of the river the effect is very beautiful.

Mr. Bolton cannot be too much commended for the humane attention with which he encourages his, poor cottar tenantry; he gives them all leafes, whatever their religion, of 2 I or 31 years, or lives: even the occupier of two acres has a leafe. It is inconceivable what an effect this has had: this is the way to give the catholics right ideas. I was for three weeks a witnefs of a molt fpirited induftry among them; every fcrap of rough rocky land, not before improved, they were at work upon, and overcoming fuch difficulties as are rarely to be found on common wartes : many fpots, not worth 5 s. an acre, they were reclaiming to be well worth 25 s. and 3 os. The improvement of this part of Mr. Bolton's eftate may be gueffed at when I mention, that on only 500 aeres of it, there have been built, in 


\section{B A L L Y C A NV A N.}

fix years, 40 new houfes, many of them handfome ones of ftone and flate. For cabbins, barns, \&cc. he gives timber for the roofs.

In I75 I, Mr. Bolton being in England, where obferving the cultivation of turnips for theep, he introduced them on his eftate on his return, and had hurdles made for penning theep on them, and did it with much fuccels; after the fame journey alfo, he introduced horfebeans for feeding his horfes, mixed with oats : he did it for twenty years together, and with the greateft fuccefs. Turnip cabbage he has tried alfo for theep, and found them to do exceedingly well. One turnip cabbage fown the beginning of April, and not tranfplanted, weighed $13 \mathrm{lb}$. top and bottom. An experiment on carrots I viewed, of which Mr. Bolton, junior, has fince favoured me with the following account.

"When you were here, 1 fhewed you a few beds of carrots, which were pulled the beginning of this month; I meafured the ground, and when the carrots were cleaned and topped, I faw them weighed. The ground meafured fifteen perches, plantation meafure, which produced 36 hundred and fix itone of carrots, befides allowing $4 \mathrm{lb}$, to every hundred for dirt, though they were very clean and dry. The produce is 156 barrels, and 16 ftones to an acre, (20 ftones to the barrel) and beyond any thing $I$ could have imagined; and $I$ am certain, had the sarrots been hoed and thinned 
198 B A L L Y C A N V A N.

as they ought, the product would have been much greater. The tops were given to pigs; they feemed to like them better than any thing elfe. Thefe fifteen perches are part of a field, which, in 1774, had been highly manured with dung for potatoes. In 1775 , the roots of the weeds (of which there were a great quantity, particularly couch grafs and crow-foot) were burnt, and the arhes and fome blue fand fpread, and it was fown with turnips. The latter end of March, thefe fifteen perches were dug, and about the 16 th of April fown with a pound of carrot-feed; they were twice hoed, to deftroy the weeds which came up very thick."

In the winter of $1775, \mathrm{Mr}$. Bolton fed 10 working horfes on bull potatoes, twice a day on oats, and once on potatoes; the potatoes given always at night; the quantity to each horfe $1 \frac{1}{2}$ peck of fmall ones; and at the other two feedings, half a peck each of oats. $\mathrm{He}$ found that they fattened the horfes very much, and did exceedingly well on them. Va-

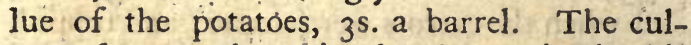
ture of rape and turnips has been tried in this neighbourhood alfo by Mr. James' Wife, merchant, of Waterford.

In the beginning of June, $1774, \mathrm{Mr}$. Wyfe ploughed lightly with a winged plough, and burned the furface of near four acres of land, which had not been tilled for many years. He fpread the afhes, and manured the ground with 


\section{B A L L Y C A.N V A N. 199}

12 boat loads of the blue fand, which is taken from the banks of the river at low water, each boat load containing 20 tons. Then ploughed and harrowed it once; and fuch of the clods as were not thoroughly burnt and pulverized after harrowing, he turned with the graffy fide down to hinder their growing. About the middle of Auguft be fowed with rape ; a little more than half a bufhel to an acre. It was cut the latter end of June, 1775, and produced 48 barrels, of fixteen ftones to the barrel, which fold for $16 \mathrm{~s}$. per barrel, and the ftraw to a tallow-chandler to burn for anes, for $48 \mathrm{~s}$. The ftraw, or haulm of rape, is fold for twelve-pence for each barrel of feed it produced. The beginning of July, 1775, Mr. Wyfe ploughed and harrowed the ground; about the 2oth of July fowed it with turnips, which on their coming up, were immediately deftroyed by the fly. About the middle of Auguft harrowed the ground, and fowed turnips again, which were alfo deftroyed by the fly. Mr. Wyfe imagines the great number of flies were occafioned by the oilinefs and richnefs of the ground, (caufed by the putrefaction of the leaves and bloffoms of the rape) and the moifture and warmth of the weather. A bout the middle of October, the grafs came up fo rich and luxuriant, (though not fown with grafs feed) that $\mathrm{Mr}$. Wyfe would not fuffer it to be ploughed for tillage, as he had intended. The latter end of June, 1776 , mowed it, and it produced three tons of hay per acre; fold for 34 s. per ton. The fand 
and carriage of it coft about thirty fhillings. per boat load; ploughing, burning, harrowing, fowing, cutting, \&c. about four guineas per acre. Rent of the land thirty fhillings an acre. In $1775 \mathrm{Mr}$. Wyfe ploughed feven acres, which he prepared in the fame manner (except fanding) and fowed it with rape; it grew very well till the great froft and fnow fell, which, was remarkably fevere, and which injured it very much, together with the moifture of the ground, occafioned by fprings in the land, and heavy rains, which fucceeded the froft and fnow; the produce per acre, about half the quantity of the former year; fold at the fame price. Mr. Wyfe recommends narrow ridges for low moift ground. He thinks a large quantity of afhes to be a chief means of enfuring a plentiful crop. The land does not require manure after rape for wheat, barley, oats, potatoes, \&c. but will not anfwer for a fecond crop of rape.

Mr. Bolton, junior, having mentioned a neighbour of his, who had drawn up a memoir upon making cyder, from confiderable experience, at my requeft wrote to him for a copy of it, which I have fince received, with his permiffion to infert it in this work.

The following is an abridgment of the account.

"Let apples of every fpecies hang till they are ripe, and begin to drop; let them be gathered 


\section{B A L L Y C A N V A N. 20 I}

thered perfectly diy, and if convenient in the heat of the day, when warmed in the fun; when gathered let them lie in heaps for one, two, three, or four weeks, according to their degrees of firmnefs, fo as to undergo a moderate fermentation; let the moifure be carefully wiped off, and each fpecies feparated (if the quantity of fruit in your orchard be fufficient to admit it) and then ground in a mill, or pounded in troughs ; but the firit the beft method, becaufe lefis of the pulp is broke, and the liquor will flow clearer from the bags; by preffing the fruit of each diftinct fpecies fo feparated, the cyder will undergo one uniform fermentation.

"When the fruit are fufficiently broke for preffing, let them lie forty-eight hours before they be preffed; this will add to that deep richnefs of colour, which to the eye is pleafing in cyder; then let the fruit fo broke, having ftood forty-eight hours, be preffed in hair cloth bags; as the juice is thus preffed out, let it be poured into large veffels, ufually called keeves, to undergo the fermentation; three of thefe veffels are neceffary in every orchard, one to contain the liquor in its ftate or courfe of fermentation, while a fecond is filling from the prefs, and the third to contain the pummage before it be preffed; three keeves, containing five or fix hogfheads each, will ferve for an orchard that yields fixty or feventy hogheads of cyder. The expence of thefe veffels made of double boards, hooped with 
iron, or ftrong afh hoops, will not be very confiderable; if the weather thould prove cold the fermenting keeves thould be covered with bags, scc in order to quicken the fermentation, which will be compleated in fix or feven days if the weather be temperate, provided no new or unfermented cyder be put into the keeve, which above all things rhould be carefully avoided; when the fermentation is over, the liquor will be fine, and thould then be racked off into yery clean hogfheads, fmoaked with brimftone matches; the hogfheads hould not be bunged or itopt clofe till all fymptoms of fermentation ceafe; and in three weeks or a month it fhould be a fecond time racked, ftill obferving to fmoak the hogfheads with brimftone, then the hogfheads fhould with the greateft care be very clofely ftopped; the keeves muft be entirely emptied before the new preffed cyder is poured into them. The great fecret in making good cyder. is to prevent or mitigate its fermentations, the firft excepted; and nothing will fo effectually do this, as repeated racking from the foul lee.

"Do not prefs wildings till Candlemas, or until they begin to rot $;$ and when the juice is preffed ovit, let it be boiled in a furnace for one hour, before it be fuffered to work or fermerit, and that will greatly foften the acrimony of its juice."

$\mathrm{Mr}$. 


\section{PASSAGE TO MILFORD HAVEN 203}

Mr. William Atkinfon, of Mount Wilkinfon, near Ballycanvan, feems to be very attentive to the orchard hufbandry; from two acres he had twenty-one hogtheads of cyder, and the fame year reaped twenty barrels of wheat under the trees, a produce little fhort of 501 . or 251 . an acre; three and an half barrels of his aples (each 6 bufhels) made a hogfhead of cyder. A common practice here in planting orchards, is to fet cuttings, three or four feet long, half way in the ground, of the cackagee, jergonelle, or any fet that grows rough and knotty in the wood ; they call them pitchers, they rarely fail, and yield well and foon.

Mr. Bolton carried me to the houfes of fome fifhermen on the harbour, one of whom had planted around his cabbin "for "fhelter, three years ago, fome willow cuttings, the growth of which amazed 'me; I' meafured them 2 I feet high, and not crooked or bending like common fort's, but ftrait as a fir. I took half a dozen cuttings with me to England to compare it with the forts common with us.

October $19^{\text {th }}$, the wind being fair, took my leave of Mr. Bolton, and went back to the lhip ; met with a frefh fcene of provoking delays, fo that it was the next morning, october 2oth, at eight o'clock, before we failed, and then it was not wind, but a cargo of paffengers that fpread our fails. ". Twelve or fourteen hours are not an uncommon paffage, 


\section{PASSAGE TO MILFORD HAVEN.}

but fuch was our luck, that after being in fight of the lights on the fmalls, we were by contrary winds blown oppofite to Arklow fands; a violent gale arofe which prefently blew a ftorm, that lafted thirty-fix hours, in which, under a reefed mainfail, the hip drifted up and down wearing, in order to keep clear of the coafts.

No wonder this appeared to me, a frefhwater failor, as a ftorm, when the oldeft men on board reckoned it a violent one; the wind blew in furious gufts; the waves ran very high; the cabbin windows burft open, and the fea pouring in fet every thing afloat, and among the reft a poor lady, who had fpread her bed on the floor. We had however the fatisfaction to find, by trying the pumps every watch, that the hip made little water. I had more time to attend thefe circumftances than the reft of the paffengers, being the only one in feven who efcaped without being fick. It pleafed God to preferve us, but we did not caft anchor in Milford Haven, till Tuefday morning the $22 \mathrm{~d}$, at one a'clock.

It is much to be wifhed, that there were fome means of being fecure of packets failing regularly, inftead of waiting till there is fuch a number of paffengers, as fatisfies the owner, and captain; with the poft-office packets there is this fatisfaction, and a great one it is; the contrary conduct is fo perfectly deteftable, 
PASSAGE TO MYLFORD HAVEN. 205

detertable, that I fhould fuppore the fcheme of Waterford ones can never fucceed.

Two years after, having been affured this conveyance was put on a new footing, I ventured to try it again; but was mortified to find that the Tyrone, the only one that could take a chaife or horfes, (the Countefs being laid up) was repairing, but would fail in five days; I waited, and received affurance after affurance that fhe would be ready on fuch a day, and then on another; in a word, I waited twentyfour days before I failed; moderately fpeaking, I could, by Dublin, have reached Turin or Milan as foon as I did Milford in this conveyance. All this time the papers had conftant advertifements of the Tyrone failing regularly, inftead of letting the public know that the was under a repair. Her owner feems to be a fair and worthy man, he will therefore probably give up the fcheme entirely, unlefs affifted by the corporation, with at leaft four hips more, to fail regularly with or withour paffengers; at prefent it is a general difappointment; I was fortunate in Mr. Bolton's acquaintance, paffing my time very agreeably at his hofpitable manfion; but thofe who, in fuch a cafe, fhould find a Waterford inn their refource, would curfe the Tyrone, and fet off for Dublin. The expences of this paffage are higher thain thofe from Dublin to Holyhead : I paid, 
$206 \quad F \quad$ U R N N E S S.

A four-wheel chaife

Three horfes

Self

$\begin{array}{lllll}\text { Two fervants } & - & \text { I } & \text { I } & 0 \\ \text { Cuftom-houfe at Waterford, hay, oats, \&c. } & \text { 2 } & \text { I } & 7\end{array}$

Ditto at Pembroke and Hubberfton

Sailors, boats, and fundry fmall charges

$\begin{array}{r}300 \\ -\quad 155 \\ \hline\end{array}$

f. $15 \quad 50$

* * * * * * * *

I777.

Upon a fecond journey to Ireland this year, I took the opportunity of going from Dublin to Mitchelftown, by a route through the central part of the kingdom which I had not before fufficiently viewed.

Left Dublin the 24th of September, and taking the road to Naas, I was again ftruck with the great population of the country, the cabbins being fo much poorer in the vicinity of the capital than in the more diftant parts of the kingdom. Mr. Nevill, at Furnefs, had, in a very obliging manner, given directions for my being well informed of the ftate of that neighbourhood. He is a landlord remarkably attentive to the encouragement of his tenantry. He allows half the expenfe of building houfes on his eftate, which has raifed feven of ftone and flate, and nine good cabbins, 35 by 16 , at 27 l. each. He gives annually three premiums of 71 . 51 . and 31 . for the greateft num- 


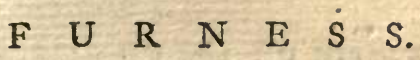

ber of trees, planted in proportion to the number of their acres, and pays the hearth money of all who plant trees. He alfo allows his tenants 40 . an acre for all the parts of their farm that want gravelling, and does the boundary fence for them, but he is paid in his rent very well for this. The following particulars I owe to him.

The foil in general, for fome miles every way, is a lime-ftone gravel, which does very well for wheat; lets at an average at 20s, that is, from ros. to 4os. There are fome tracts of green ftone land, and a little clay. Rents rofe till $177^{2}$, but have fince rather fallen: the the whole county through may be $14 \mathrm{~s}$. or $15 \mathrm{~s}$. If all now was to be let, it would be 2 os.

Farms rife from i 5 acres to $500:$ a middling fize is 250. They are now fmaller than formerly, being divided as faft as leafes fall. There are houfes in general to all, the land lets the better for them, owing to its being a tillage country. Mr. Nevill encourages his tenantry to build, by being at half the expenfe. A common farmer requires one 50 feet long, 16 wide, two ftories high; a barn, 40 by 16 ; a ftable, 40 by 16 ; a cow-houfe, 50 by 14 ; a pig-ftye, hen-houfe, \&xc. all which would coft about 300 . of ftone, the houfe nlated, and would be fufficient for 250 acres of land. The courfes of crops are; 
208 F U R N E S S.

I. Fallow. 2. Wheat. 3. Oats. 4. Wheat. 5. Clover. 6. Clover.

1. Potatoes. 2. Barley. 3. Fallow. 4. Wheat. 5. Clover. 6. Clover.

They fometimes fow wheat after potatoes; the crops are as great as after fallow; but the quality of the grain is not equal. . Their fallow they plough firft in winter; harrow in May, crofs plough in ditto and in June; ftretch it (that is, form the ridges) in Auguft, making them of two bouts; harrow, and the feed furrow, in September; and reckon the beft feed time the middle of that month. No dung in general ufed for it, but fometimes gravel. One barrel of feed to the acre; never weed the crop; the produce from five to twelve barrels, medium feven. Price of late years, 20s. a barrel. They threfh upon floors formed of lime, fand, and coal afhes, and are of opinion that they do not hurt the colour of the grain. At harvelt they do not reap till it is quite ripe, bind directly, and form it into ftacks in the field, which they leave out a fortnight. Plough the potatoe land once or twice for barley, fow a barrel an acre of 16 ftone in April; medium price of late years from 7 to izs. average ros. Of clover they fow $211 \mathrm{lb}$. per acre, generally half clover and half trefoil; do not fow it till the barley is up, bufh harrowing it ; and on wheat bull harrow it, that is, with harrows without teeth. Never mow it. For oats they plough twice if able, fow two barrels per acre 


\section{F $U$ U R N E S S.}

in March ; the produce fix to twelve barrels, and fometimes fixteen. Medium price for a few years paft 6s. 6d. Upon fome grounds that are light, are fubftituted peafe inftead of oats after wheat. Plough but once, fow 20 ftone on an acre under furrow, never weed them; the produce fix barrels per acre, and the price Ios. No flax fown.

Potatoes generally on a wheat ftubble, always well dunged; the ridge feven feet, and the trench three feet wide, and to one perch in length of it, four loads of dung. Ten facks, at twenty ftone, plant an acre. March the beft feafon; weed them, and get roo facks, at the medium price of 5s. the white Englinh and apple forts the beft. It is common for the poor to hire grafs land to plant them on, at 61. to 61. 6s. an acre or for ftubble land dunged.

Account of an acre.

Planting

Seed

Weeding

Digging out

Rent

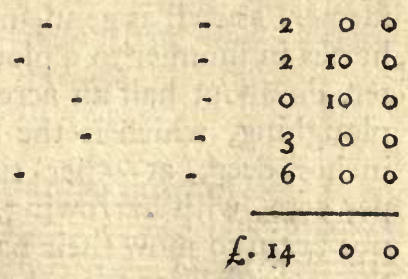

VOL. II. 
P R O D U CE.

Cne hundred facks, at 5 s.

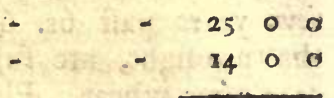

Clear profit

6. II 00

One hundred facks cofting 141 . gives the prime coft of 2s. 9 d. a fack. They are often fold as they grow, for 161 . or 181. an acre. No turnips.

Lime not generally ufed, Mr. Nevil has a kiln that draws 16 barrels a day. Burns with culm, at 2s. 8d. a barrel. Pays for quarrying, $2 \mathrm{~d}$. and burning, Id. The lime cofts him, at the kiln, rod. a barrel. Lime-ftone gravel more ufed, which lafts feven years, and on fome foils longer: twelve loads on a fquare perch may be done for 31 . an acre. Tillage is done with both horfes and oxen, and which is extraordinary, the latter are ufed by common farmers as well as gentlemen. Six oxen, or fix horfes in fummer to a plough, or four in winter, do about half an acre a day. In the crofs ploughing, which is the fecond, they go nine inches deep, at other times fhallower, price per acre, with harrowing, 1os. 6d. They do not begin to mow their hay till July, get it into the large field cock in about a fortnight, which they leave out three or four weeks longer; a medium crop 12 loads an acre, at the average price of $5^{\mathrm{s} .} 6 \mathrm{~d}$. 


\section{F U R N E S S.}

It is generally a corn country, yet are there fome graziers that buy in bullocks, but more cows. Alfo fome dairies that fatten veal for Dublin, by which they make 31 . or 41 . a cow; feeding them in winter when dry on ftraw, fome on hay. They are let out to dairymen at 41. a cow. The price of milch cows, in May, 51. to $7 \mathrm{l}$. One acre and a half will fummer feed one, and half an acre of hay for winter.

The fheep kept are generally ewe flocks for fattening, for Dublin market. Buy in at Ballinafloe, at 1os. to 15 . Sell the lamb in June or July, at $8 \mathrm{~s}$. to $14 \mathrm{~s}$. and the ewe in November, at the fame price they gave, keep them chiefly on clover. No folding. Medium price of wool, for 10 years paft, 16 s. clip three to a ftone. They are not at all fubject to the rot. A great many hogs bred; keep them for fattening on potatoes; fome are finifhed with offal corn and peafe; in fummer they feed them on clover. Mark this! one would think from more than one circumftance, that a good farmer in England was fpeaking.

In hiring and ftocking a farm of 200 acres, a man ought to employ 5001 . but fome of them will do it with $200 \mathrm{l}$. Stock for 200 acres to have 100 acres corn, and fallow: every year. 
212 F. U R R N E S S.

Twenty horfes, at 61. and ten bullocks, at 5l. I70 0 Six cows, at 5l. - - $\quad 3000$ Two fows - $-2 \quad-2100$

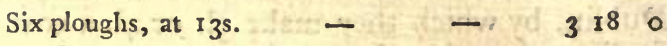
Three fets of geers Six Cars, at 25s. Sundry tools, \&c. Seed 40 acres wheat 20 oats 4 barley I potatoes ro clover

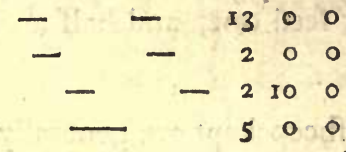

300 712 ro 00 6210

For labour he will have three cottars for ploughing, \&rc. paid by land; for other work allow $40 \quad 0$ County cels, 4 d. an acre Tythe, 40 wheat, $6 \mathrm{~s}$. 310

$$
\begin{aligned}
& 20 \text { oats } 45 . \\
& 4 \text { barley } 6 s \text {. } \\
& \text { Io hay } 4 s . \quad-200 \\
& \text { ¿...? } \\
& \text { i:: } \\
& 1940 \\
& 6.35220
\end{aligned}
$$

- In refpect of labour, every farmer has as many cottars as ploughs, whom they pay with a cabbin, and one acre of potatoes, reckoned at 3as. and a cow kept thro' the year, 3 os. more. Every cabbin has one or more cows, a pig, arrd fome poultry. Their circumftances juft the fame as 20 years ago. Their food potatoes and milk for 9 months of the year; the other three wheaten bread, and as much butter as the cow gives. They like the potatoe fare 


\section{F U $\quad R \quad N \quad E \quad S \quad S$.}

fare beft. Some have herrings; and others 6s. to 10s. worth of beef at Chriftmas. Sell their poultry, but many of them eat their pig. The fale of the fowls buys a few pounds of flax for fpinning, mort of them having fome of that employment.

They are not much given to thieving, except burhes and furze, which is all they have for fuel, there being no bog nearer than that of Allen. They bring turf eight and ten miles, the price $8 \mathrm{~d}$. a kifh of three feet and a half, by three and five long, and Is. 2d. more carriage. A kifh will laft one common fire five days.

\section{Expence of building a cabbin.}

Mud walls

Roof, 3 pair principals

4 dozen of rubberies, at $4^{s}$.

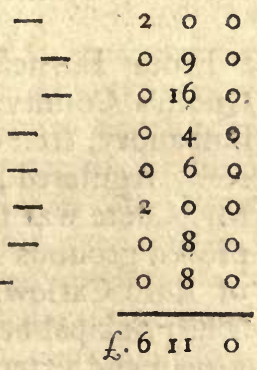

Labour

Wattles

Eight load of ftraw, 5s.

Thatching

Two doors

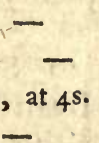




\section{$2 I 4$ CURRAGH OF KILDARE.}

ing, 6s. 6d. Mowing grafs, 2s. 6d. to $3 \mathrm{~s}$, Pigcons, 3 d. each. Rabbits, 8d. a couple.

To Kiidare, croffing the Curragh, fo famous for its turf. It is a theep walk of above 4000 Englifh acres, forming a more beautiful lawn than the hand of art ever made. Nothing can exceed the extreme foftnefs of the turf, which is of a verdure that charms the eye, and highly fet off by the gentle inequality of furface. The foil is a fine dry loam on a ftony bottom; it is fed by many large flocks, turned on it by the occupiers of the adjacent farms, who alone have the right, and pay very great rents on that account. It is the only confiderable common in the kingdom. The theep yield very little wool, not more than 3 lb. per fleece, but of a very fine quality.

From Furnefs to Shaen Caftle, in the Queen's County, Dean Coote's; but as the hiufbandry, \&c. of this neighbourhood is already regiftered, I have only to obferve, that $\mathrm{Mr}$. Coote was fo kind as to fhew me the improved grounds of Dawfon's Court, the leat of Lord Carlow, which I had not feen before. The principal beauties of the place are the well grown and extenfive plantations, which form a fhade not often met with in Ireland. There is in the back grounds a lake well accompanied with wood, broken by feveral iflands that are covered with underwood and an ornamented walk paffing on the banks, which leads from the houfe. This lake is in the feafon perfectly alive with 


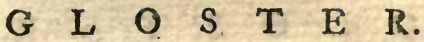

wild fowl; near it is a very beautiful fpot, which commands a view of both woods and water, a fituation either for a houfe or a temple. Mr. Dawfon is adding to the plantations, an employment of all others the moft meritorious in Ireland. Another work fcarcely lefs fo, was the erecting a large handfome inn, wherein the fame gentleman intends eftablifhing a perfon who hall be able to fupply travellers, poft, with either chaifes or horfes.

From Shaen Caftle to Glofter, in the King's County, the feat of John Lloyd, Efq; member for that county, to whofe attention I owe the following particulars, in which he took every means to have me well and accurately informed. But firft let me obferve, that I was much pleafed to remark, all the way from Naas quite to Roffcrea, that the country was amongft the fineft I had feen in Ireland, and confequently that I was fortunate in having an opportunity of feeing it after the involuntary omiffion of laft year. The cabbins, though many of them are very bad, yet are better than in fome other counties, and chimnies generally a part of them. The people too have no very miferable appearance; the breed of cattle and theep good, and the hogs much the beft I have any where feen in Ireland. Turf is every where at hand, and in plenty; yet are the bogs not fo general as to affect the beauty of the country, which is very great in many tracts, with a fcattering of wood, which makes it pleafing. 
216 G L O S T E R.

Shaen Caftle ftands in the midit of a very fine tract. From Mountrath to Glofter, Mr. Lloyd's, I could have imagined myfelf in a very pleafing part of England; the country breaks into a variety of inequalities of hill and dale; it is all well inclofed, with fine hedges; there is a plenty of wood, not fo monopolifed as in many parts of the kingdom by here and there a folitary leat, but fpread over the whole face of the profpect: look which way you will, it is cultivated and chearful.

The King's county contains the following baronies, and annexed to their names is the value per acre of each :

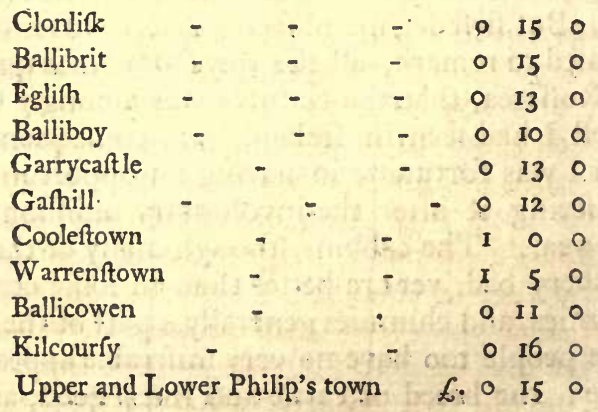

In Gafhill are 13000 acres belonging to Lord Digby; and in Warrenftown is Croghen hill, famous for the great fleeces the fheep yield that are fed upon it. A Curragh theep, from giving $3 \mathrm{lb}$. carried there, will yield $12 \mathrm{lb}$. but the quality is coarfe.

There 


\section{G L $O$ O $S$ S $T$ T E R.}

There are great tracts of bog in the county; and 153,000 acres that pay county charges; 170,000 acres at 15 . and 30,000 of bog. The fife of rents fince 1750 , more than two-thirds, but are much fallen fince $177^{2}$, in many farms 4 s. in the pound.

Eftates through the county are remarkably divided; and are in general fmall. The fize of farms varies much, 600 acres are a very large one; ufually not lefs than 100 ; very few in partnerfhip. There are many farms without buildings, which if divided and built, would let much better. The arable fyftem, when burning is permitted, is to plough in the fpring, very thin, then crofs cut it and burn the fod as foon as the feafon ferves, which will be fome time in June; plough in the afhes very lightly, and fow turnips; thefe they never hoe, which is faid to be difficult, on account of the number of Ptones; they feed the crop on the land with three-year old wethers or lambs. After this, plough it up and fallow for a fecond crop of turnips, which they manage as the firft, but feed them earlier; then plough once, and fet it to the poor for potatoes, at 61. 6s. to 61. Ios. an acre, after which they fow bere upon one ploughing; this they fucceed with wheat alfo on one ploughing; and after the wheat, oats. Then they fummer and wintei fallow, which is followed by wheat and oats as before; but by this time the land is quite exhaufted. A partial burning is fometimes ufed, which is to break up in November, and plough 


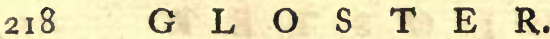

twice or thrice by May, and then to burn what the harrow does not reduce. For wheat they plough once, as before-mentioned in the burning courfe; and four times on a fallow. Sow 20 ftone to an acre; the crop five to fix and a half barrels; the medium price of late 11 . Is. a barrel. They fow a barrel of bere, of fixteen ftone, the crop 14 to 23 barrels, which great produce is from the rich preparation. Of oats two barrels, or 24 ftone, the crop Io to 16 ; of barley they fow 16 ftone, the crop ro to 16. The price of bere and barley 9 s. 6d. No clover at all fown, nor any grafs feeds, and very few peafe or beans, as they never feed their pigs or horfes with either. Very little flax. There are a few bleach yards about Clara, \&c. but the bufinefs is not much upon the increafe. Potatoes they plant in the common trenching way; the feafon from the middle of April to the middle of May; more after the firft of May than before it; eight barrels plant an acre; they always weed them. The apple fort is preferred from lafting longeft; the medium price $2 \mathrm{~d}$. a ftone; twenty ftone the barrel.

\section{Account of an acre.}

Planting, $48 \mathrm{men}$, the firft and fecond trenching at $8 \mathrm{~d}$.

Seed, at 3 s. 4 d,

Taking up, 48 men

Pịcking up, carrying home, and forting; horfeFent

hire only, as the family does the reft - $\begin{array}{lll}0 & 8 & 8\end{array}$

II 52 


\section{$\begin{array}{llllllll}G & L & O & S & T & E & R, & 219\end{array}$}

PRODU CE.

100 barrels, at 3 s. $4 \mathrm{~d}$.

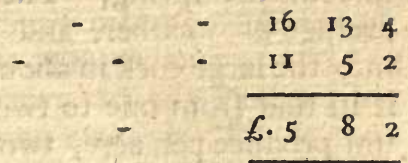

Profit

$-$

Prime coft, 2s. 3 d. a barrel. A barrel will laft a family of five perfons a week.

The turnips on the burnt land they fow from the 2oth of July to the $4^{\text {th }}$ of Auguif, but a fortnight or three weeks earlier upon a fallow, the quantity of feed $I_{\frac{1}{2}} \mathrm{lb}$. they never hoe; the price upon an average 31 . an acre, either to take away or feed on the land, but the former rarely done: they feed them off with fat Theep or lambs, very rarely with black cattle.

No lime burnt for manure, nor any limeftone gravel ufed, though plenty of it found all the country through. One farmer made an experiment of them both for corn, but neither anfwered; the general opinion is, its being bad for the grafs afterwards; there is not any marle known; the farm-yard fyftem incomplete, as every where elfe, foddering in the fields; but cows are kept in the houfe at night, and fed with hay for about five months in the winter. Their hay grounds they wilh to fhut up about the $25^{\text {th }}$ of March, but if their hay is finifhed, they are obliged to be later; mow 


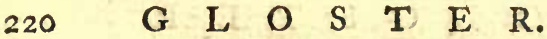

from the $15^{\text {th }}$ of July to the $15^{\text {th }}$ of September, which latenefs is owing to their feeding fo late in the fpring. They ufually upon the average of weather, and management, get it into the large cock in about ten days, and leave it in that from one to two months; the medium produce per acre, two tons and a quarter, and the price $30 \mathrm{os}, \mathrm{a}$ ton; the women here never make it.

Tillage is performed more with horfes than with horned cattle; the latter only by confiderable graziers, and they are ufually fpayed heifers. Four horfes, or four heifers to a plough, which do half an acre a day; the depth, from the thallownefs of the foil, not more than fix or feven inches; the price $7 \mathrm{s.} 6 \mathrm{~d}$. an acre. Very few hogs kept, not more than for mere convenience.

To hire and ftock a farm will, on an average, take 40 s. an acre, if a grazing one, but lefs in proportion to the tillage; but there are men who will hire on little or no capital, this however is much lefs than formerly, from feveral landlords having fuffered feverely from it. The tillage of the whole country is very inconfiderable; it is chiefly pafturage, not one acre in fifteen is tilled; the barony of Garrey caftle has much more; one reafon of there not being more, is the number of farms, from 150 to 400 acres, under leafes for ever, which are fo highly improved by the tenants, that they abftain from tillage, under the idea of its being 


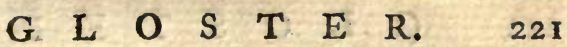

prejudicial. Refpecting the labour of a farm, the ftanding bufinefs is done by cottars; a cottar is one who has a cabbin, and an acre and a half of garden, charged at 30 s. and the grafs of one or two cows, at $25 \mathrm{~s}$. each, and the daily pay $6 \mathrm{~d}$. the year through, the account being kept by tallies, and thofe charges deducted ; the year's labour amounts to about 61. after the cottar's time for his potatoes and turf is deducted; the remaining 40 s. is paid in money, hay, or any thing elfe the man wants. The cows are fed by a field being affigned for all the cottars of the farm. No inftance of a cottar without a cow. The calves they rear till half a year old, and then fell them at $12 \mathrm{~s}$. to 2os. which will pay for the cow's hay. They keep fio theep, but every cabbin has a pig, a $\mathrm{dog}$, and fome poultry. No difference in their circumftances for the laft fifteen years. It is here thought that it would be very difficult to nurfe up a race of little farmers from the cottars, by adding land gradually to them at a fair rent ; it would be alfo very difficult, if not impoffible, to cut off the cottars from a farm; nobody would be troubled with fuch tenants, and no farmer would hire a farm with the poor on it independant of him, their cattle and all their property would be in conftant danger; as the kingdom ircreafes in profperity, fuci ideas it is to be hoped will vanith. Their food is potatoes and milk for ten months, and potatoes and falt the remaining two; they have however 2 little butter. They fell their pig, their calf, and their poultry, nor do they buy 


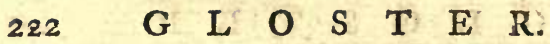

meat for more than ten Sunday's in a year. Their fuel cofts them about I4s. a year, or eighty kifh of turf, an ample allowance. There is in every cabbin, a fpinning-wheel, which is ufed by the women at leifure hours, or by a grown girl, but for twelve years 19 in 20 of them breed every fecond year. Vive le pomme de Tere!

$$
\text { Expence of a poor family. }
$$

Cabbin and garden

Labour in the garden

Two Cows

Hay for ditto

Turf

Cloathing, I5s. a head

Tools

Hearth tax

$\begin{array}{r}1100 \\ -\quad-\quad 1100 \\ -\quad 2100 \\ -\quad 1100 \\ -\quad 0140 \\ -\quad 3150 \\ -\quad 0 \quad 50 \\ -\quad 020 \\ \hline\end{array}$

The Receipt.

The year

Deduct Sundays

Bad weather

Holydays

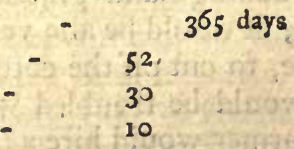

273 at $6 \mathrm{~d} . \quad 616 \quad 6$

Two calves

Pig

$$
\begin{array}{r}
1100 \\
-\quad 100 \\
-\quad 0 \quad 50
\end{array}
$$

Carried over

E. 9 II 6

$3^{\circ} 3$ days 


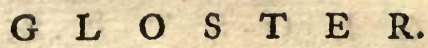

223

Brought over

$6 \cdot 9$ II 6

303 days fpinning between the wife and daugh-

ter at $3^{d}$.

Expences

Remains for whifky, \&c. \&c.

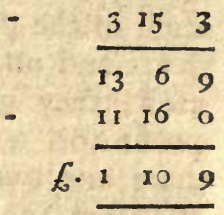

Potatoes are much more the food than formerly; there are full twice as many planted. The cottars in their gardens follow the courfe of crops firft mentioned. They are all very much addicted to pilfering: their general character idlenefs and dirtinefs, and want of attention. They are remarkable for a moft inviolable honour in never betraying each other, or even any body elfe, which refults from a general contempt of order and law, and a want of fear of every thing but a cudgel, the reader will remember that maiming cattle, pulling down, and fcattering ftacks, and burning the houfes of thofe who take lands over their heads, are very well known. I am regiftering information, and that not from one or two perfons, but feveral.

The pafturage fyftem is to buy in yearling calves, called bull cbins, at from $35^{5}$. to $55^{\mathrm{s}}$. (but twenty years ago, 22s. gd. each), which they generally fell at Banagher fair, when three years and an half, at 51 . Ios. to 61. buying and felling regularly every year. They alfo buy cows in May, and fell them fat in au- 


\section{G L}

tumn, with 40 s. profit. Sheep they either breed, or buy hoggits in May, at I2s. to I 5 s. each in the fleece, and fell them fat, at three years and an half old, from il. Is. to Il. 4s. each; they get three fleeces, worth $18 \mathrm{~s}$. the profit ros. a head, keeping them three fummers and two winters. No folding. Flocks rife from 100 to 2000 , they calculate to keep a heep to every acre of their farms. The fleeces, on an average of a running ftock, are three to a ftone of $16 \mathrm{lb}$. The price, this year, I7s. 6d. twenty years ago only 9s. or 1os. Not much alteration in the number of theep through the country; all fat ones, are in winter fed with turnips and a little hay. Their low lands rot; but being more careful than formerly, it is not fo common as it was; that, with the gid, (a fudden giddinefs) and the red water, are the chief diftempers they are troubled with.

Milch cows are kept only for convenience, a few to every farm. An acre and half neceffary to keep one the year through, but muft have $1 \geq$ ton of hay befides. One four or five years old ready for milk in the fpring, fells for five or fix guineas. A three years old heifer ready to calve, four or five guineas.

The bounty on the inland carriage of flour to Dublin has occafioned the building feveral mills, five confiderable ones, four were immediately built in confequence. The quantity of tillage has increafed double in 20 years; probably 


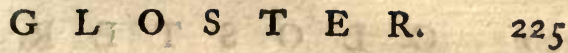

probably from this caufe, among others, has arifen the increafe of whilky, the quantity of which is three times greater than fifteen years ago. Not lefs than 30,000 barrels of barley and bere are diftilled yearly within 8 miles of Glofter.

Land fells at 25 years purchafe. Suppofe fix farms, one let for ever, at 20 years purchafe, one for three lives, let 20 year's ago, 25-one for two lives, ditto 28 -..- one for one life, ditto $30--$ one for 31 years, $30--$-one to let now, 20. Average of all, 25 years. Ten years ago it would have been twenty-fix and a half; twenty years ago, twenty-three and a half. Leafes are generally for three lives, or thirty-one years.

The country in general is much improved in moft national circumftances; buildings are much increafed, on a larger fcale, and of a far better fort than twenty years ago; there is alfo a rife in the price of almoft all commodities.

\section{Prices not minuted in the table.}

Rabbits, 8d. a couple. Roafting pigs, $2 s$. 6 d. much beyond the proportion of other things. Rife in the price of meat, Id. a lb. in twenty years, fince which bere has allo advanced, from $6 \mathrm{~s}$. to gs. 6d. the barrel of 16 ftone. Womens labour, $4 \mathrm{~d}$. Wages of a farming man, 4l. ditto a boy, 11. ditto a maid, 21. From Io VoL.II. 
$\begin{array}{lllllllll}226 & G & L & O & S & T & E & R .\end{array}$

to 14 men reap an acre of corn in a day. Mowing grafs, by the acre, $2 s .8 \frac{2}{2}$. two men do it in a day. Threrhing wheat, $6 \mathrm{~d}$. a barrel. Bere, 4d. Oats, 3d. Cutting turf, footing, \&c. 12s. the $120 \mathrm{kinh}$.

\section{B U I I D ING.}

A common cabbin, 51. Ditto of ftone, 101. to

151.

Walling, mafon's perch work - $\quad 0 \quad 07$

One barrel lime - $\quad-1006$

Seven load ftone - $\quad-\quad 0$ I I

Attendance - $\quad-0_{2} 0_{2}$

Sand and carriage $\quad-\quad 0 \quad-0$

0.34

Feet bigh

6.0168

A guinea a perch, 7 feet, 6 inches high. Slates, 9s. 6d. a thoufand. Slating, 11. 2s. 9d. a fquare, every thing included. Oak, is. 3 d. a foot. Afh and home fir, Is. Lime, fivepence halfpenny a barrel, burnt, with turf in kilns on arches; two arches burn 400 barrels, the ftone large. $400 \mathrm{kilh}$ of turf will burn 400 barrels; price of burning and filling from 21. 5s. 6d. to a guinea and half.

September 3 oth, took my leave of Mr. Lloyd, a gentleman from whofe converfation I reaped equal inftruction and amufement. Paffed by Shin- 


\section{JOH N S T O W N.}

Shinroan, Murderinny, and Graig, to Johnftown, the feat of Peter Holmes, Efq; Much of this line a very beautiful country ; near Johnftown nothing can be more picturefque, the whole well planted with hedges and little woods, and confifting of the moft fanciful variety of hill, dale, and fwelling declivities, upon which every bufh and tree is feen to advantage.

For the following particulars I am indebted to Mr. Holmes, who, notwithftanding his own ability to anfwer every queftion, trufted not to it, but called in the beft affiftance the neighbourhood could give.

\section{Baronies in the county of Tipperary.}

Lower Ormond, 20s. an acre--Upper Ormond, 20s.-Skevin, 18s.-Eliogurty, 20 s. Owen and Aira, 12s.-Clanwilliam, 11. 2s. gd. Middle third, 25 s. Befides Iffa, Offa, and Kilnemanna. The whole county on an average would now let for 2os. an acre. Rents have doubled in twenty years.

Through the whole barony of Lower Ormond, the foil is in general a dry lime-ftone land. Farms are large, fome very large, few lefs than 5 or 600 acres : the fize is rather increafed. There are many without any buildings, and it is only from particular circumftances that they let the better for them. The fmall farms are taken much in partnerfhip; a 
parcel of labourers will take 1 or 200 acres. The common courfe of tillage is,

1. Pare, and burn for turnips. 2. Turnips. 3. Potatoes. 4. Bere. 5. Wheat. 6. Oats. 7. Grey peafe. 8. Fallow. 9. Wheat. 10. Oats. i I. Lay out for grafs quite exhaufted. Alfo,

I. Fallow turnips from the turf. 2. Turnips, and then as before.

The management is to plough the fod at Chriftmas, in April or May crofs plough it, and let it dry, burn as foon as dry, which will be fometimes in May; fpread the afhes, plough once, and harrow in a pound and a half or two pounds of feed to the acre, from the 2 oth of June to the 4 th of Augurt. They never eitlier hoe or weed. Begin to feed them upon the land in December with fat Theep, giving three or four acres at a time to 2 or 300 heep; and one acre to 100 heep, giving them at the fame time hay in heep racks: a middling acre will keep 13 from Chriftmas to the firft of April, being worth from two guineas to 31 . They are alfo commonly ufed for theep and lambs in March and April. The profit upon fat theep, from turnips only, will amount to from 75 . to 10 s. a head. The land -is ploughed three times for the fecend crop; but the turnips are not fo fweet for Theep as the firft, yet they fell as well: they muft 


\section{JOH N S TOW N.}

be eaten off firft, as they will not ftand fo long as the others.

The poor people hire this turnip land at fix guineas to $7 \mathrm{l}$. 10s. for planting potatoes. About ten years ago the price was four guineas to $5 \mathrm{l}$. but the reftrictions on paring and burning have leffened the quantity of it. For this potatoe crop one ploughing is given in March or April, fix to eight barrels of feed planted; the favourite forts are the apple potatoe for late, and the early wife for early ufe, They hand weed them carefully, and take them up the middle of November or beginning of December, the average crop $9 \circ$ barrels.

\section{Expences on an acre.}

Rent

Seven barrels of feed, at $4 \mathrm{~s}$.

Planting, thirty men a day

Taking up, eighty men a day

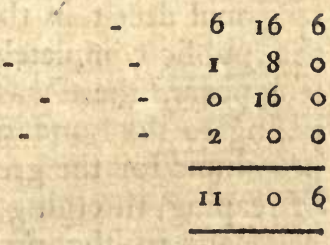

PRODUCE.

Ninety barrels, at $4 \mathrm{~s}$.

Expenfes

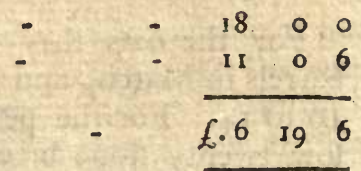

Profit

Prime coft, 2s. 5 d, a barrel.

The 
The culture has increafed very much, and been the means of reclaiming great tracts of land, which otherwife would never have been touched. The potatoe land they plough immediately for bere, and, if weather dry enough, fow 14 ftone per acre, and get 16 barrels. For the wheat they plough thrice; fow in November I4 ftone, and get 7 barrels.

It was in this neighbourhood Mr. Yelverton had his famous crop, which has been written fo often in all the books of hufbandry in Europe, but nobody here believed it. The account I had was this : that he felected the beft acre in a field of 30 , which he marked out; but his labourers knowing his intention, put many ftocks from the adjacent parts of the field into that acre. Thus without any intentional deceit in the gentleman himfelf was the public completely deceived. From hence it appears, there was fome reafon in my propofing to the London fociety, to annex to their premiums for the greatelt crops, the condition. of reaping, threfhing, and meafuring all in one day, and in the prefence of witneffes which they adopted much againft the opinion of feveral gentlemen who did not approve it.

For the oats they plough once, fow two barrels in March, and get on an average from 10 to 14. For the peafe, they plough once, fow twenty ftone broad caft, are fo far from hoeing or weeding, that they like to bave weeds among them, by way of flicks! get fix or feven 


\section{JOH NSTOWN. I3I}

barrels an acre. The fucceeding fallow is ploughed four times, the crop of wheat as good as after bere, but the following oats will not yield above eight or nine barrels.

The medium prices of the preceding products have of late years been, Wheat, 20 . Bere, 1os. Oats, 5. Peafe, 6s. There are very few threhing floors of wood: but they make the clay ones fo hard, that they think them as good. Flax is fown only by the cottars in their gardens; very few that do not fow fome. Six pottles of feed on about four perch of land. They proportion it very exactly to their own confumption; it is wove by weavers, who make it their bufinefs to weave for others; and there are very few gentlemen that do not do the fame for the coarfe linen of their families.

Marle and lime-ftone fand are the manures ufed here. They have two ways of improving wafte land with marle: they plough and fow oats, and marle the ftubble: or elfe they marle at firft upon the lay: this is moftly practifed in the Duharrow mountains, where it has worked very great improvements. It is a grey foapy marle, full of Thells, dredged from the bottom of the Shannon. The expenfe of getting it, with boats and carriage into the land, is 40s. an acre. Lime-ftone fand is laid on at the end of an exhaufting courfe, on the oat ftubble: it cofts about 5 os. an acre. Very little lime ufed. No farm-yards; the hay is 


\section{J O H N S T O W N.}

ftacked in the fields where it is defigned to be fed, and fcattered about; and thame on them, they do the fame with their ftraw; but no wonder the farm-yard fyftem is unknown, for they fell much of their corn in the ftack in the field, which gentlemen buy for ftraw. Great improvements have been made in the Duharrow mountains, infomuch that the tythes of one parifh have rifen from 701 . a year, to 4001 .

The Theep in the Ormond baronies are kept chiefly for breeding; they do not fell the lambs till they become three years old wethers; give the ewes the ram at two years old, which fupply the place of the old ewes, culled out and fattened at four years old, going five. In 170 there are 50 ewes, 40 lambs, 40 two-year olds, 20 three year old wethers fold, 20 ewes kept, and 20 old ones fold. Ten are kept for accidents. The fat wethers fell at 20 s. from grafs, and 3 os. from turnips; and the 20 culled ewes will fell at 20s. each; the wool of the whole, three fleeces to a ftone. Mr. Robert Gowen has fold a fcore of four-year old wethers at Dublin, for 59l, Their black cattle are in the fucceffion way. To 1000 acres, befides 1500 theep, they will buy in 180 year-old calves every year, at 45 s. bought in from May to September, the right time May and June; they keep them two years and an half, felling them in November, at 61. to 81. allowing three for loffes, there would be 


\section{J O H N S T O W N.}

233.

177 calves, 177 two-year olds, 177 threeyear olds- $53 \mathrm{I}$.

Alfo upon 1000 acres there would be two breeding mares, and fix colts, ten working heifers, 4 car horfes, and ten milch cows; there would alfo be 100 acres of 1000 , in tillage, ten of which under turnips every year, and fifty acres of hay mown; an inftance out of thoufands how little attention in Ireland is paid to providing a due quantity of winter food.

Mr. William Harden, thirty-two years ago, fold wool at $6 \mathrm{~s} .6 \mathrm{~d}$. a ftone; it rofe gradually for ten years to Ios. $6 \mathrm{~d}$. and did not get up to 15 s. till about four years ago; but the price was very fluctuating, rifing and falling fuddenly without. any evident reafon; the weight of the fleeces have not increafed in thirty years, but the number of theep is greater; turnips were commonly fown at that time. In black cattle however, there has been a great improvement, being much larger than formerly. Calves have rifen in price as much as wool, fuch as now coft $45 \mathrm{~s}$. might, thirty years ago, have been had at 20s. Mr. Harden's father bought a two-year old bullock for 5s. of a man now alive.

In tillage, bullocks and heifers are generally ufed, four in a plough, and they do not quite half an acre a day. Three ploughs will do an acre; they ftir five inches deep. The price 6s. Paring and burning take from twelve to 
forty men per acre, according to the drynefs of the feafon.

Labour is done by cottars, who have a cabbin and a garden of one acre, if only one man in family, but if the fon is grown, two acres. The cabbin and one acre is reckoned at 20 . alfo two collops, at 20s, each, which are generally cows. All this he works out at five pence a day, all extra labour fix-pence halfpenny a day, and eight pence in harveft. They all have from one to three pigs, and much poultry. Their food is potatoes for at leaft eleven months of the year, and one month of oat, barley or bere bread.

\section{Expences and receipt of a cottar family.}

\section{Cabbin, and one acre rent}

Two cows

One ftone of broken wool

Weaving it

Weaving their linen

Hearth money

Tools

Tythe of one acre

Hire of half an acre potatoes

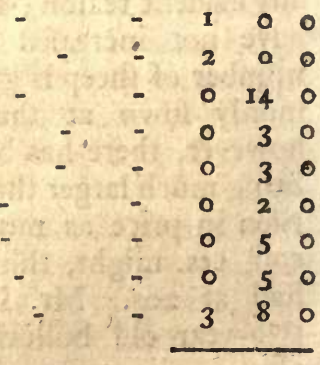

£. $8 \circ \circ$

\section{Receipt.}

Two Pigs

$\mathrm{On}$ an average of years the two cows will yield three calves in two years

Poultry 


\section{J O H S T OW N. $\quad 235$}

Brought over - $-\$ .4: 0$

Poultry

Hire -365 days

52 fundays

15 holydays

20 bad weather

48 ficknefs and their own work

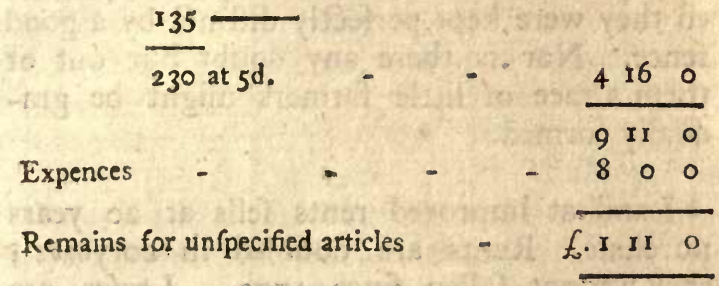

It is a general remark, that induftrious and attentive men will earn ${ }_{5} 1$. in the year. The circumftances of the poor are much better than they were twenty years ago, for their land and cabbins are not charged to them by gentlemen higher than they were 30 years ago, while all they fell bears double the price.

Potatoes are rather more cultivated and eaten than twenty years ago, and are managed better. The poor in this neighbourhood are by no means to be accufed of a general fpirit of thieving. It arifes from holding them in too much contempt, or from the improper treatment of their fuperiors. No white boys have ever arifen in thefe baronies, nor any riots that laft longer than a drunken bout at 
236 JOHNSTOWN.

a fair : nothing that has obftructed the execution of juftice.

There is no objection to cutting off the cottars from a farm, and making them tenants to the landlord, upon the fcore of difficulty in letting a farm without cottars upon it, provided they were kept perfectly diftinct by a good fence. Nor is there any doubt but out of them a race of little farmers might be gradually formed.

Land at improved rents fells at 20 years purchafe. Rents are doubled in 20 years; they are not fallen fince 1772 . Leafes are ufually for three lives, or thirty-one years.

The intereft of money has certainly rifen, and the year's purchafe of land fallen in twenty years; yet in the fame period it is undoubted that the kingdom has improved greatly, which has the appearance of a contradiction. Buildings have very much increafed in all the towns, and in a ftile far fuperior to former periods.

Tythes are very rarely taken in kind. Bere and wheat pay 6s. an acre. Barley and oats, 3s. Potatoes, 6s. They are generally let to proctors, who are fevere to the poor, and very indulgent to gentlemen. The rigour, however, does not extend beyond thofe prices. 


\section{J O H N S T OW N.}

The bounty on the inland carriage of corn has occafioned the building fome mills, which united with the turnip hurbandry, and the vaft increafe of whifky have altogether much increafed tillage.

\section{Prices not in the tables.}

Labour of a woman or boy in harvert, $4 \mathrm{~d}$. Mowing grafs, 2s. 4d. to 2s. 6d. Hire of a car, a day, Is. 3 d. to 1s. 8 d. Building a cabbin of ftone and flate, 251 . Walling the mafon's perch, 4s. Lime, per barrel, fevenpence halfpenny, at Nenagh, Is. Culm, per barrel, $3^{s}$. one burns nine of lime, in fome places only fix.

Quarrying the ftones Breaking and burning Culm

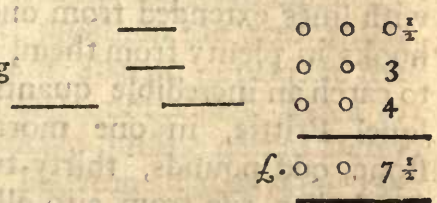

Oak timber, 50s. to 31. a ton. Fir, 40 s.

Wild fowl.-Wild ducks, 1s. 6 d. a couple. Teal, gd. ditto. Widgeon, 6d. ditto. Rabbits, 8d ditto. Trout 5 lb. for is. Salmon, 2d: perlb. Frefh water filh in general, $2 \frac{1}{2}$ d. a 1b. Oyfters, 2s. per 120.

The Shannon adds not a little to the convenience and agreeableness of a refidence fo 
$23^{8}$ JOH N T OW N.

near it. Befides affording thefe forts of wild fowl, the quantity and fize of its filh are amazing. Pikes fwarm in it, and rife in weight to 5 olb. In the little flat fpaces on its banks are fmall but deep lochs, which are covered in winter and in floods; when the river withdraws, it leaves plenty of fin in them, which are caught to put into ftews. $\mathrm{Mr}$. Holmes has a fmall one before his door at Johnftown, with a little ftream which feeds it ; a trowling rod here gets you a bite in a moment, of a pike from 20 to $40 \mathrm{olb}$. I eat of one of $27 \mathrm{lb}$. fo taken; I had alfo the pleafure of feeing a filherman bringing three trouts, weighing i $4 \mathrm{lb}$. and fell them for fix-pence halfpenny a piece. A couple of boats lying at anchor, with lines extended from one to the other, and hooks in plenty from them, have been known to catch an incredible quantity of trout. Colonel Prittie, in one morning, caught four ftone, odd pounds, thirty-two trouts: in general they rife from 3 to glb. Perch fwarm; they appeared in the Shannon for the firft time about ten years ago, in fuch plenty that the poor lived on them. Bream of 6lb. Eels very plentiful. There are many gillaroos in the river, one of $12 \mathrm{lb}$. weight was fent to $\mathrm{Mr}$. Jenkinfon. Upon the whole, thefe circumftances, with the pleafure of fhocting and boating on the river, added to the glorious view it yields, and which is enough at any time to chear the mind, render this neighbourhood one of the moft enviable fituations to live in that I have feen in Ireland. The face 


\section{J O H N S T O W N.}

of the country gives every circumftance of beauty. From Killodeernan-hill, behind the new houfe building by Mr. Holmes, the whole is feen to great advantage. The fpreading part of the Shannon, called Loch Derg, is commanded diftinctly for many miles; it is in two grand divifions of great variety. That to the north is a reach of five miles leading to Portumna. The whole hither fhore a fcenery of hills, checkered by inclofures and little woods, and retiring from the eye into a rich diftant profpect. The woods of Doras, belonging to Lord Clanrickard, form a part of the oppofite fhore, and the river itfelf prefents an inland of 120 acres. Inclining to the left, a vale of rough ground, with an old caftle in it, is backed by a bold hill, which intercepts the river there, and then the great reach of 15 miles, the bay of Sheriff, fpreads to the eye, with a magnificence not a little added to by the boundary, a tharp outline of the county of clare mountains, between which and the Dubarrowe bills, the Shannon finds its way. There hills lead the eye ftill more to the left, till the Keeper meets it, prefenting a very beautiful outline that finks into other ranges of hill, uniting with the Devil's Bit. The home feenery of the grounds, woods, hills, and lake of Johnftown, is beautiful.

Mr. Holmes has practiced agriculture upon an extenfive fcale, and not without making fome remarks, which mult be of ufe to others. 
He has not for five or fix years paft been without a fmall field of Scotch cabbages. The feed he fows both in March and autumn for ufe at different feafons; the rows he plants three feet afunder, and two feet from cabbage to cabbage. He has ufed them for fat theep and fat cattle, but principally for weaned calves : they have anfwered perfectly well in all, but remarkably fo with the calves, of which $\mathrm{Mi}$. Holmes has had the beft in the country; and fingly from being thus fed. His people were all of opinion, that a good acre of cabbages will go as far as two acres of turnips, worth each 31 . Two years ago a violent froft Itopped the ufe of turnips, and he then found the benefit of them prodigiounly great. He has always manured for them with dung or marle, the former beft.

\section{R A P E C A E,}

Mr. Holmes has ufed as a manure, with great fuccefs : in 1775, he dreffed two acres of worn out meadow, with a ton and an half an acre, at 21. 2s. per ton; and in 1776, he laid on feven tons, at $1 \frac{i}{4}$ per acre; the firft trial was made too late, and a diy feafon coming, the effect was not great. The laft year it was laid on the fifth of April, when the effect was remarkably great: it threw up a moft luxuriant crop of the fineft herbage, infomuch that he is convinced nothing can anfwer better, and is determined to extend the practice confiderably. He has tried it on low, wet, and 


\section{J O H N S T O W N.}

on upland, and the effect infinitely greater on the latter. In the fame field, Mr. Holmes fed 150 theep fome months, on the produce of feven acres of turnips, going over nine acres of grafs; the benefit to the latter did not near equal that of the rape, except in the deftruction of mofs, which was deftroyed by both methods.

\section{I O V E R.}

Mr. Holmes has ufed this grafs thefe fix years; he began with fix acres, and has extended it as far as feventeen acres laft year : he fows $24 \mathrm{lb}$. of feed per acre. The crops as good as he has feen in England; has mown it twice, but now feeds the fecond growth. $\mathrm{He}$ has tried it on dry lime-ftone hills, which are flow in coming to grafs, but anfiver well in clover. For his theep he finds it of great ufe. Ewes lamb here about the 17 th of March, and when turnips are done, want the clover very much: alfo in keeping fat heep for a late market. Courfe of crops,

r. Turnips on old turf, two ploughings and a flight burning. 2. Turnips. 3. Barley, yielding 18 barrels. 4 . Clover. 5. Clover. 6. Wheat, yielding 8 barrels. 7 . Oats, ditto I 5. Alfo,

1. Manure a ftubble for cabbages. 2. Potatoes. 3. Barley, 20 barrels. 4. Clover. 5. Clover. 6. Wheat. 7. Oats.

Vol. II.

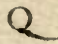

Oetober 
October 3 d, taking my leave of Johnftown and its agreeable and hofpitable family, I took the road towards Derry, the feat of Michael Head, Efq; through a country much of it bordering on the Shannon, and commanding many fine views of that river; but its nakednefs; except at particular places, takes off much from the beauty of the fcenery. Near to Derry there' are fome finer views. From one hill, the road commands the bay of Skeriff, Loch Derg, back to Johnftown; and the river turning under the hills of Achnis, a promontory of wood, which feparates them, is fully feen : there are alfo many hedges, fo well grown with fcattered trees on the higher fide as to have a pleafing effect. I found Mr. Head, on my arrival, juft going to dine with a neighbour, Mr. Parker, whofe father had worked a very fine mountain improvement, and who would probably be there: this was a fufficient inducement, had there been no other, for me to accompany him. I found Mr. Parker's houfe fo near the river, as fometimes to be wafhed by it. The improvement I had heard of is a hill of above 40 acres, which was covered with ling, furze, \&cc. and not worth 6d. an acre thirty-two years ago when the work was begun. $\mathrm{He}$ grubbed, ploughed it, and fowed oats, and marled the ftubble from the Shannon; the marle, from the fteepnefs of the hill, being carried on the backs of oxen. Upon this he took a crop of wheat, and another of oats, both exceedingly fine, and with the latter fowed the feeds for the grafs, which ftill remains, 
and has been improving ever fince; it is now worth 3 os. an acre, and a very pleafing object to the eye, efpecially fince Mr. Parker, junior, has added to the finenefs of the verdure and herbage by feeding it with many fheep.

In the fame converfation I alfo learned a few particulars of a bog of twelve acres part of one of 150 , improved by Mr. Minchin, near Nenagh. The firft operation was to cut main drains fix feet deep, and crofs ones of 18 inches or two feet, and as foon as it was a little firm, covered it with lime-ftone gravel three inches thick, before the bog would bear a car; but did it by beginning at the edge, and advancing on the part gravelled. Part was tilled, and part left for grafs without ploughing: the meadow thus formed has been exceedingly fine. One uncommon circumftance was, his having paved the bottom of the drains with gravel, in order to prevent cattle from being bogged in them. The expenfe of the whole improvement 81, an acre. 'The profit immenfe.

It is to Mr. Head's attention that I am indebted for the following particulars concerning the barony of Owna and Arra. The foil is a light gravelly loam, on a flaty rock, which is almoft general through the whole. The rent on an average $15 \mathrm{~s}$. for profitable land, and Is. for mountain; and as there is about half and half, the whole will be 8s. The rife of rent, in twenty years is about double. Eftates are generally large, fcarce any fo low as 5 or 
6ool. a year. Farms are all fmall, none above 3. or 400 acres: many are taken in partnerihip, three, four, or five families to 100 acres. They divide the land among themfelves, each man taking according to his capital. The terms runidale and changedale unknown, as is the latter practice. There are no farms without buildings upon them. Laying out money in building better houfes would pay no intereft at all, as they are perfectly fatisfied with their mud cabbins. Courfes of crops on reclaimed mountain,

I. Marle for oats: 2. Bere. 3. Bere. 4. Wheat. 5. Oats, or Englin barley. 6. Oats. 7. Oats. 8. Oats. 9. Oats. 10. Oats. The number of thefe crops of oats proportioned to the quantity of marle laid on; but the rule is to take as long as the land will yield, and then leave it to recover itfelf by weeds. Another courfe.

1. Potatoes in drills on an exhaufted ftubble. 2. Bere. 3. Oats. 4. Oats. 5. Oats. 6. Oats, and fo on till none will be got.

The quantity of wheat is very little; for that little they fow a barrel an acre, and get 8 barrels; medium price, rod. to $13 \mathrm{~d}$. a ftone. Of bere they fow a barrel, and get 15 . Of oats fow two barrels, the produce 8 to 15 , according to being early or late in the courfe. Price of bere, fix-pence to feven-pence halfpenny. Onts, four-pence to fix-pence per ftone. No peafe, 


\section{D $\quad E \quad R \quad R \quad Y$.}

peafe, beans, clover, or turnips ; but they have little patches of flax for their own confumption. Potatoes they very generally cultivate in drills; they plough the ftubble twice or thrice, and then open trenches with the plough three feet afunder; in which they put fome dung, lay the fets on it, and cover them with the plough if they have horfes, or if not with fhovels. They keep them clean by conftant earthing up with ploughs or Movels. They dig them out, the produce thirty-five barrels per acre. They find that nothing is fo good and clean as fallow for corn. Some poor people hire grafs land for them in the lazy bed way, paying 31 . to 51 . Ios. per acre.

The only manure ufed befides dung is the Shelly marle, dredged up from the bottom of the Shannon. Mr. Head's grandfather was the firf who introduced that method of getting at it by bringing men from Dublin ufed to raifing ballaft. It proved fo profitable, that the ufe has much increafed fince. It liesirregularly in banks, from 100 to 200 yards from the fhore, and under 10 or 12 feet of water in fummer which is the only time they can get it. The price of raifing it is from 1s. to 2s. according to circumftances, befides finding boat, ropes, and all tackle; a boat contains 60 bufhels, and requires $5 \mathrm{men}$. They land it on a quay, from whence it is taken in nledge carts to fome diftance for drying, nor is it dry enough for carting away till the year following. Some think it worth carrying one mile, 


\section{D E R R}

and even two. The common people do not lay on more than four or five boat loads to an acre, but Mr. Head always ten, and the whole expenfe he calculates at 4 os. Much bad land has been reclaimed by it, and to great profit. All their dung is ufed for potatoes.

The tillage of the common people is done with horfes, four in a plough, which do half an acre a day: gentlemen ufe four oxen. The price $8 \mathrm{~s}$. an acre. No paring and burning.

They thut up their meadows for hay in March or April, and rarely begin to mow till September. I hould remark, that I faw the hay making or marring all the way (October 3d) from Johnftown hither, with many fields covered with water, and the cocks forming little inlands in them. They are generally two months making it; the crop one to ope ton and a half per acre.

There is no regular fyftem of cattle in this barony, there not being above four or five graziers; but gentlemen, in their domains, have all the different fyftems. The common farmers keep a few of moft forts of cattle, except fat ones. No large flocks of theep, but every farmer a few breeding ewes. The fleeces four to a ftone. They fell either lambs, hoggits, or two or three year olds; the price of a twoyear old ewe Ios. they have no winter food but grafs, even the gentlemen have their fat mutton all winter from the low grafs lands on the Shannon, 
Shannon, without either hay or turnips. The marled land has a remarkable fpring of grafs in the winter; the rot is very little known. All keep pigs, which are much increafed of late; their pork $32 \mathrm{~s}$. a cwt. laft year at Limerick; Mr. Head has known it fo low as I4S. No proportion between cows and pigs.

In hiring and ftocking farms, many will take them in partnerfhip with no other capital than a little ftock of cattle. Difficult to fix the number of years purchafe at which land fells. None has been fold in this barony in Mr. Head's memory. Leafes to proteftants three lives.

The common mode of labour is that of cottars, they have a cabbin and an acre for 3 os. and 3 os. the grafs of a cow, reckoning with them at five pence a day the year round; other labour vibrates from four pence to fixpence. A cottar with a middling family will have two cows; there is not one without a cow. All of them keep as many pigs as they can rear, and fome poultry. Their circumftances are rather better than 20 years ago.

\section{$A$ cottar's expences.}

Rent of, a cabbin and an acre

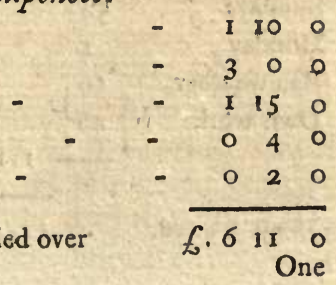

Two cows

Hay for ditto, one ton

Tythe

Hearth money

Carried over

One 
One ftone of wool a year for the man, one for the woman, and two ftones for three children; this is what they ought to have, but the fact does not exceed two ftone, one at 17s. and one at $8 \mathrm{~s}$. Tools

Turf, whether bought or in their own labour I $\quad$ a Flax feed, five or fix pottles, at 8d. - $\quad 0 \quad 36$ Breaking and fcutching, eight ftone, at rod. $\quad 0 \quad 68$ Heckling ditto, at rod. - $\quad-068$ Weaving $33^{6}$ bandles, at $1 s$. Id. a fcore $=0166$

N. B. After heckling $56 \mathrm{lb}$. flax, the reft is tow, which they fpin for bags, \&c.

Two pair of brogues, 9 s. $9 d$. and four pair foles,
Is. Iod. each, 7s. 4 d.
$0 \times 7 \div$

A pair of women's thoes, $3^{5 .} 3^{\text {d. }}$ and a pair of
foles, 16.5 d.
$-048$

A boy of fourteen, two pair, at 2s. 2d. foles,

Is. Id.

A hat, 2s. $8 \mathrm{~d}$, the boy one, $1 \mathrm{s.} 6 \mathrm{~d}$.

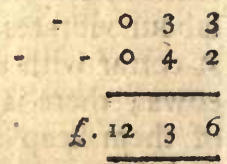

\section{His receipt.}

Deduct from

Sundays

Holiday 365 days

Bad weather 10

Own work

52

I 48

II I

Remain at $5 \mathrm{~d}$. 


\section{E $R \quad R \quad Y$.}

Brought over

The boy of twelve or fourteen, three-pence

balfpenny a day

Two pigs, one eat, the other fold for

Two calves, one zos. one ros.

$\begin{array}{r}3141 \\ -\quad 0150 \\ 1100 \\ \hline 6.11411\end{array}$

N. B. Chickens and ducks pay for falt, foap and candles, and they eat the geefe.

When my informant, who was a poor man, had finilhed, I demanded how the 20s. deficiency, with whifky, and the prieft, were to be paid; the anfwer was, that be muft not eat bis geefe and pig, or elfe not drefs fo well, which probably is the cafe. Their acre of garden feeds them the year through; nine months on potatoes, and the other three on oaten bread, from their own oats. The confumption of potatoes not increafed in twenty years. A family of five perfons will eat and wafte forty-two ftone of potatoes in a week. They are not addicted in any remarkable degree to thieving. The cottars of a farm might eafily be taken from it, and yet the farm let without difficulty, for the tenant would foon have others; but it is queftioned whether they could eafily be made farmers of.

Dancing is very general among the poor people, almort univerfal in every cabbin. Dancing-mafters of their owil rank travel through the country from cabbin to cabbin, with a piper or blind fidler; and the pay is fixpence a quarter. It is an abfolute fyifem of 
education. Weddings are always celebrated with much dancing; and a Sunday rarely paffes without a dance; there are very few among them who will not, after a hard day's work, gladly walk feven miles to have a dance. Fobn is not fo lively, but then a hard day's work with him is certainly a different affair from what it is with Paddy. Other branches of education are likewife much attended to, every child of the pooreft family learning to read, write, and caft accounts.

There is a very ancient cuftom here, for a number of country neighbours among the poor people, to fix upon fome young woman that ought, as they think, to be married; they alfo agree upon a young fellow as a proper hurband for her; this determined, they fend to the fair one's cabbin to inform her, that on the Sunday following he is to be borfed, that is carried on men's backs. She muft then provide whifky and cyder for a treat, as all will pay her a vifit after mafs for a hurling match, As foon as the is borfed, the hurling begins, in which the young fellow appointed for her hurband, has the eyes of all the company fixed on him; if he comes off conqueror, he is certainly married to the girl, but if another is victorious, he as certainly lofes her, for the is the prize of the victor. Thefe trials are not always finifhed in one Sunday, they take fometimes two or three, and the common expreffion when they are over is, that fucb a girl was goatd. Sometimes one barony hurls againft another, 
another, but a marriageable girl is always the prize. Hurling is a fort of cricket, but inftead of throwing the ball in order to knock down a wicket, the aim is to pafs it through a bent ftick, the ends ftuck in the ground. In thefe matches they perform fuch feats of activity, as ought to evidence the food they live on to be far from deficient in nourifhment.

Tythes-Potatoes, 5s. Wheat, barley, bere, 5s. Oats, 2s. 6d. Meadow, 2s. They are in the management of proctors, but the greateft hardhip attending them, is the poor man paying for his garden, while the rich grazier pays nothing, owing to the famous vote of the houfe of commons.

There is only one flour mill in the barony, and the increafe of tillage is very trifling, but the whifky ftills at Killaloe, trebled in five or fix years.

\section{Prices not in the tables.}

Wild ducks, is. a couple. Teal, 6d. Plover, 2d. Salmon, three halfpence to 3 d. per 1b. Large pike, 2s. 6d. each. Trout, of twelve inches long, id. each. Eels, is. a dozen. Eggs, ten a penny in fummer, three in winter. Women's labour in harveft, $3 \mathrm{~d}$ in winter, 2d. Maid's wages, 1l. Ios. A lad's, 11. 8s. Mowing, per acre, 2s. 4d. Women earn by fpinning, 3 d. Hire of a car, with man and horfe, 1s. 6d. Threfhing wheat, 
D $\quad E \quad R \quad R \quad$.

per barrel, 6d. Bere, 4d. Oats, two pence halfpenny. Barley, $3 \mathrm{~d}$.

\section{BUIIDING.}

A mud cabbin, 41 .

Ditto of ftone and flate, 201.

A dry wall, five feet high, building - $\quad$ I 3

Labour coping - - - - $\quad 0 \quad 06$

Dahhing - - - - 002

Lime, two barrels - - - - 014

Sand

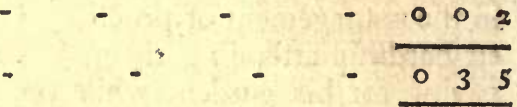

Befids carting the ftones, the mafon's perch of houfe walling, 1s. 6d.

All materials laid at the fpot.

Oak bark, 81. to 91. a ton.

Cars are made by hatchet men, at $6 \mathrm{~d} . \mathrm{a}$ day.

Timber and labour of one

tron

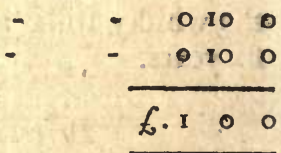

In the hills above Derry are fome very fine flate quarries, that employ 60 men. The quarrymen are paid 3 s. a thoufand for the flates, and the labourers $5 \mathrm{~d}$. a day. They are very fine, and fent by the Shannon to diftant parts of the kingdom; the price at the quarry 6 s. a thoufand, and at the more 6s. 8d. 400,000 flates are raifed to pay the rent only, from which fome eftimate may be made of the quantity.

$\mathrm{Mr}$. 


\section{D $E$ E $R \quad R \quad$ Y.}

Mr. Head has made forne confiderable improvements of wafte or rough land by means of marle. His firft was a field of I4 acres ten years ago ; the foil light, as before defcribed of the country in general; the fpontaneous growth, furze and ferns, worth 5s. an acre. He cleared it from ftones, which were ufed for building; the expence fmall, marled it, and fowed five crops of corn, and with the laft of them hay feeds: it became a meadow in two years, and is now worth 305 . an acre. The next was a field of eight acres, the fame foil; he broke it up for potatoes, then took one crop of corn, marled it on the fubble, and fowed five crops of corn, laying down with the fifth. Worth 8s. an acre before, now 3 os. Five acres and an half were alfo done, marled on the furface, the effect little; it was therefore ploughed up in four or five years ; yielded two crops of good turnips, two of Englifh barley, and then laid down. It is now worth 30 . an acre.

The next attempt was upon 16 acres, not worth 2 s. $6 \mathrm{~d}$. an acre, over-run with furze, fern and heath, with fo many ftones that clearing them away coft Ios. an acre. Ploughed and burnt it, and took two crops of turnips, then two of oats. Left it to itfelf for five or fix years, and then marled it, fince it has yielded four crops of corn, and is riow worth 11. 2s. gd. an acre. 
The laft improvement is a field of $\mathrm{II}$ acres, which has been lately marled.

Mr. Head has 400 theep, and they confift of 100 breeding ewes. -100 lambs. -84 hoggits. $\rightarrow 70$ three-year old wethers and culled ewes, fat. -46 two year old wethers. He fells annually

\section{Fifty fat wethers}

Fifty culled ewes, at $18 \mathrm{~s}$.

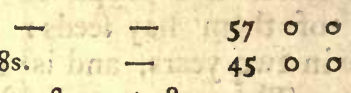

Four-hundred fleeces, I33 ftone, at I8s. II 140

$$
6.221 \times 40
$$

Mr. Head has a practice in his fences which deferves univerfal imitation: it is planting trees for gate-pofts. Stone piers are expenfive and always tumbling down; trees are beautiful, and never want repairing. Within I 5 year's this gentleman has improved Derry fo much, that thofe who had only feen it before, would find it almoft a new creation. He has built a handfome ftone-houfe, on the flope of a hill rifing from the Shannon, and backed by fume fine woods, which unite with many old hedges well planted to form a woodland fcene, beautiful in the contraft to the bright expanfe of the noble river below : the declivity, on which there woods are, finifhes in a mountain, which rifes above the whole. The Shannon gives a bend around the adjoining lands, fo as to be feen from the houfe both to the weft and north, the lawn falling gradually to a margin 
C A S T L C O N N E L. 255

of wood on the fhore, which varies the outline. The river is two miles broad, and on the oppofite fhore cultivated inclofures rife in fome places almoft to the mountain top, which is very bold.

It is a very fingular demefne; a fripe of very beautiful ground, reaching two miles along the banks of the river, which forms his fence on one fide, with a wall on the other. There is fo much wood as to render it very. pleafing, adding to every day by planting all the fences made or repaired. From feveral little hills, which rife in different parts of it, extenfive views of the river are commanded quite to Portumna; but thefe are much eclipfed by that from the top of the hill above the flate quarry. From thence you fee the river for at leaft 40 miles, from Portumna to 20 miles beyond Limerick. It has the appearance of a fine bafon, two miles over, into which three great rivers lead, being the north and fouth courfe and the bay of Skeriff. The reaches of it one beyond another to Portumna are fine. At the foot of the mountain Mr. Head's demefne extends in a fhore of rich woodland.

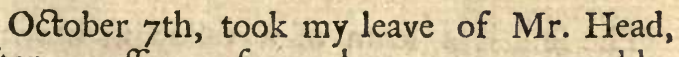
after paffing four days very agreeably, Through Killaloe, over the Shannon, a very long bridge of many arches; went out of the road to fee a fall of that river at Caftle Connel, where there is fuch an accompanyment 


\section{C U L L E N.}

of wood as to form a very pleafing feenery; the river takes a very rapid rocky courfe, around a projecting rock, on which a gentleman has built a fummer-houfe, and formed a terrace : it is a ftriking fpot. To Limerick. Laid at Bennis's, the firft inn we had flept in from Dublin. God preferve us this journey from another!

The 8th, leaving that place, I took the road through Palace to Cullen. The firft fix or feven miles from Limerick has a great deal of corn, which fhews that tillage is gaining even upon bullocks themfelves. I obferved with much pleafure, that all the cottars had their little gardens futrounded with banks well planted with ofiers. To the Rev. Mr. Lloyd's, at Caftle Lloyd, near Cullen, a gentleman whoI found as able and willing as he had been repreSented, to give me the intelligence I wifhed relative to the grazing grounds around him.-The following particulars, which I owe to him, concern more immediately the barony of Clanwilliam in Tipperary; the fame in Limerick, Small County, and the part of Coonagh next Clanwilliam. In thefe parts the foil and management are much the fame: that of Oonabeg nearly, but not quite equal.

The foil is a loam of a yellowinh brown, friable, but putrid and mixed with a fmall quantity of grit ftones upon a lime-ftone rock, at the depth of two, three, and four feet; much of it is very dry; but the richeft has what is here called a tender moift Jkin, which 


\section{A S T L E L L O Y D. 257}

yields fo much to the tread of beafts that it breaks under them : the richer and the more improved it is, the more fo. It is a great error to affert, that it would not do for tillage, for 'there is none better for the purpofe if properly managed.

The average rent of the rich parts of this tract is 3 os. an acre. In Coonagh there are $19,3^{1} 3$ acres, half of it not worth 5 s. an acre, being mountainous. In the laft twenty years, the rents of the rich lands have rifen about a fourth, and two-thirds fince the year 1748 .

Average of the county of Tipperary, 12s. 6d. Ditto of Limerick, Ios. 6d. Ditto of Corke, 5 s.

Eftates are generally very large, but fome fo low as 3001 . a year. Farms arife from fmall ones in partnerfhip to 5 or 6000 acres. The tillage acts have had the effect of leffening them evidently. The great fyftem of this diftrict is that of grazing. Bullocks are bought in at the fairs of Ballinalloe, Newport, Banagher, Toomavarra, \&c. in the months of September, October, and November, the prices from $5 l$. to 81. average, 61. Twenty years ago beafts were bought at 40 s. which now could not be got under $4 \mathrm{l}$. The prices having doubled, allowing at the fame time for the improved fize of beafts. As foon as bought, they are turned into the coarfert ground of the farm; the fattening ftock being put into the aftergrafs, the lean ones are turned after them; if

VOL. II.

$\mathrm{R}$

the 
$25^{8}$ C A S T LE L L O Y D.

the farmer has a tract of mountain, they will be turned into that at firft. They are put to hay after Chriftmas, and kept at it till May. An acre of hay for three bullocks is reckoned a good allowance, the quantity will be from three to four tons. It is given fcattered upon the ground in dry fields, till the latter end of April, or the beginning of May, when they are collected into a fmall fpace, in order for the grafs elfewhere to grow. About the 1oth of May they are put to grafs for the fummer; and in this, the method is to turn into every field the ftock which they imagine will be maintained by it, and leave the whole there till fat. The Corke butchers come in July and Auguft to make their bargains, and begin to draw in September, and continue to take them till December. Some graziers keep them with hay till the market rifes, but it is not a common practice. It is thought that they begin to lofe fleth about the 2oth of November, and that after the firft nothing is gained. Average felling price, $9 l .10$. It vibrates from 81 . to I Il. Ios:

Annexed to this bullock fyftem is that of buying in bull calves, fix months old, in September and October, from 20s. to 40 . each, fome to 31 . thefe are fed in well fheltered prights with grafs and hay, and fold in May and June with 20s. profit upon an average. One acre of hay will yield enough for nine calves; the proportion is, to buy a calf to every acre. 
Upon other parts of the farm, where calves are not fed in this manner, heep are fubftituted. Much land is hired here by Tipperary farmers, who bring their theep to it; and where this is not the cafe, the Limerick farmers have both coarfé and rich land which enables them to go into Theep. They keep ftocks of breeding ewes. If a man has 100 ewes, he will have 100 lambs, 100 yearlings, 100 twoyear olds, roo three-year olds, felling every year 50 three-year old fat wethers, and 50 culled ewes, viz.

50 wethers, at $25 \mathrm{~s}$ :

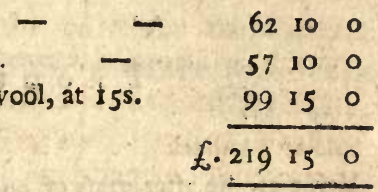

50 culled ewes, fat, at $23 \mathrm{~s}$.

400 fleeces, 133 ftoné of wool, át $15 s$.

500 Total Hock

If a man has only rich land in thore baronies, without any in Tipperary, then he keeps only bullocks regularly; but he buys in fome baggit theep, which he keeps a year, and fells fat. The Tipperary fyftem is fuppofed to be the moft profitable, for they have given more for the Limerick lands than the Limerick people themfelves. Befides thefe methods, there is another which is buying in cows in March, April, May, and June, at 31. to 61. each, and felling them fat with 4 os. profit. This is very profitable, but fubject to difficulties, for they are troublefome to pick up, and much fubject to diftempers. 


\section{C A S T L E L L O Y D.}

Calculation of the profit of grazing bullocks.

One bullock bought in at

Rent of one acre and one-third

County cefs, at 9 d.

Mowing, making, carting, and ftacking hay

Herdiman, at 12l. a year

Loffes on ftock, $\frac{x}{2}$ per cent.

Intereft, of 81 . at 6 per cent.

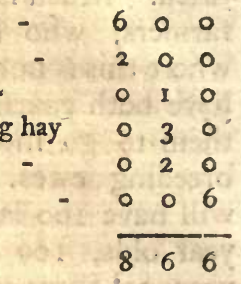

$$
-\quad \frac{097}{f^{816}}
$$

PRODUCE.

Sale of a bullock

Value of the after-grafs of one-third of an acre $\begin{array}{llll}9 & 0 & 0 \\ 0 & 3 & 4\end{array}$

Expences

$\overline{934}$
-
cre and one-third $\quad$\begin{tabular}{l}
$8 \times 1$ \\
\hline 073 \\
\hline
\end{tabular}

Profit on one acre and one-third $\quad 073$

Which is per acre

- $\quad$ f. $\quad 56$

This profit is, I think, very low, fo low that nothing but the eafe with which grazing bullocks is carried on, could induce a man to be fatisfied with it.

The fize to which oxen now come upon this rich land is $5 \frac{3}{4} \mathrm{cwt}$. twenty years ago it was $4 \frac{1}{2} \mathrm{Cwt}$. the additional $\frac{3}{4} \mathrm{cwt}$. is owing not 


\section{A S T LE LL O Y D. 26I}

to any improvement in the land, or management, but of the breed.

Particulars of a grazing farm at Cullen.

120 acres in all. 110 bullocks. 40 lambs. 4 cows. 7 acres of meadow. I $\frac{x}{2}$ acre, herdfman's garden. 2 acres of orchard. 2461. rent, or 4 Is. per acre.

The number of theep kept in this neighbourhood has decreafed, owing to the divifion into fmaller farms. The winter food for them in the rich tracts is grafs, except in fnows, when they turn them to their hay ftacks, they are very little tronbled with the rot. The rife in the price of wool, 5s. a ftone in 30 years.

There are but few dairies; the little farmers have the chief. The breed of the cows is generally half Englin, half Irin. They are kept on the pooreft grounds, $I_{\frac{1}{2}}$ acre, or $I_{\frac{3}{4}}$, keeps a cow the year round; the ufual produce is I cwt. of butter, and 20 s. horn money, or 31 . in all ; the winter food hay, $\frac{2}{4}$ of an acre to each. The calf is always reared; valued when it drops at 2 s. $6 \mathrm{~d}$. or $3 \mathrm{~s}$. the medium price of a cow, 5l. There have been many Englim bulls introduced for improving the cattle of the country, at a confiderable expence, and great exertions in the breed of fheep; fome perfons, Mr. Dexter chiefly, have brought Englifh rams, which they let out 
262 C A S T L E L L O Y D.

at feventeen guineas a feafon, and alfo at 10s. 6d. a ewe, which indicates a fpirited attention.

Hogs all the way from Limerick are of a very good breed, far fuperior to the common Irifh, and the number greatly increafed.

Refpecting tillage, the chief is done by litthe farmers, for the graziers apply themfelves folely to cattle. It is entirely connected with breaking up grafs for potatoes - the quantity fmall.

1. Grafs potatoes. 2. Potatoes. 3. Bere. 4. Oats. 5. Oats, and then leave it for grafs without fowing any feeds. With gentlemen it is,

1. Potatoes. 2. Ditto. 3. Wheat. 4. Oats, or Englifh barley. 5. Oats, left fmooth to grafs itfelf-Shame to them for being as bad farmers as the Paddies !

The grafs is let for the potatoe crop to the poor people, who pay from 51. to fix guineas an acre for it; no manure ufed; nine barrels of feed at 20 ftone, plant an acre; the ufual feafon April and the beginning of May. In planting, they dig the whole ground, except the two firit fods, and when they have got feven or eight feet, form trenches in the common manner; they weed them carefully; the produce about 120 barrels per acre; price $2 s$. 


\section{A S T LE L L O Y D. 263}

to 3 s. $6 \mathrm{~d}$. a barrel; they pay as much rent for the fecond crop as the firft, and it is as good, though they don't plant it, trufting to the little potatoes left in the ground, and which they fpread in digging; but this is a moft fovenly practice; if they were to plant the fecond crop it would be better than the firft, provided it is as good without it.

\section{Expences of an acre.}

Rent

Nine barrels of feed at 35 .

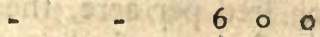

Planting, and digging, $16 \mathrm{men}$, at $8 \mathrm{~d}$. $\circ 10 \quad 8$

Planting, 12 children at $4 \mathrm{~d}$. - $\quad 040$

Trenching, 12 men - $\quad \circ 8 \circ$

$\begin{array}{lllll}\text { Cutting fets, eight women at } 4 \mathrm{~d} . & 0 & 2 & 8\end{array}$

Second trenching, fix men $\quad-\quad 0 \quad 4 \quad 0$

170

$$
0
$$




\section{$264^{\circ}$ C A S T L E L L O Y D.}

They do not plough the potatoe land for bere at all, but trench it in with fpade and fhovel, fow fix bufhels an acre, and get 20 barrels, at 75 . on an average. They then plough once for oats, fow fix bufhels, and get 16 to 20 barrels, worth 45 . a barrel on a medium, at 12 ftone. The fecond crop of oats is as good as the firft. In the gentleman's courfe the wheat is trenched in if the feafon is wet, but ploughed in if it is dry ; twenty ftone of feed per acre, the product ten barrels, at $20 \mathrm{ftone}$, and the price 20s. Plough twice for the Englifh barley; fow five of fix bufhels per açre, and get 20 barrels, 17 ftone per barjel, at 8d. a ftone. No lime, marle, or limeftone gravel ufed, nor clover, peafe, beans, or turnips fown; but enough flax is fown by every poor family for their own ufe; and fome fell it at fairs, after fcutching, at $4 \mathrm{~s}$. to $5^{\mathrm{s}}$. a ftone. There are many weavers about the country, who make bandle cloth, and fome a yard wide, for the poor people; they live both in towns and villages. All the women fpin flax. They thut up their fields for hay the be-ginning of June, generally mow in September, the crop three to four tons an acre, fometimes five or fix. It is fold ftanding for 40 os. an acre.

Tillage is done with horfes, four in a plough, and do half an acre a day, four or five inches deep; the price 75 . to Ios. In hiring and ftocking they reckon that 31 . an acre will do for a grazing farm, but much lefs for tillage. Leafes are for thirty-one years or three lives. 


\section{A S T LE L LO Y D. 265}

Land fells at twenty years purchafe: there has been a fall of rents from 1772 , to the American war, but fince that time they have been rifing. The religion all Roman catholic.

Much of the labour is done by fervants, hired into the houfe of little farmers that keep dairies, \&c. Much alfo by cottars, who have a cabbin and an acre and a half of potatoe garden, which are valued at three guineas; they have alfo two cows, at 50s. a cow. Threefourths of an acre under potatoes every year, and the reft oats and flax; they get about 120 barrels an acre, which crop, with the oats, feed them the year through; they are much more eaten than they were 20 years ago; two barrels will laft a family a week as they are ufually confumed. They all keep a pig, a dog, two cats, and fome poultry ; their circumftances are better than they were twenty year's ago; their pig they fell, but they eat fome poultry, particularly geefe. Some of them buy turf for fuel, which colts them fifteen hillings: but many depend on breaking and ftealing hedge-wood; they are much given to pilfering.

Cottar's account.

Cabbin and $\mathrm{r}_{\frac{2}{2}}^{\mathrm{r}}$ acre Grafs of two Cows Turf

$\begin{array}{rrr}3 & 8 & 3 \\ 5 & 0 & 0 \\ 0 & 15 & 0 \\ \text { Carried over } & 6.9 & 3 \\ \text { Tythe }\end{array}$


266 C A S T L E L L O Y D.

Tythe Brought over,

Seed flax, four pottles 20 Bandles of cloth for the man 20

7

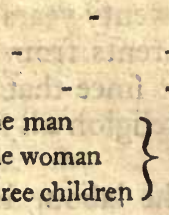

- 933

- 110

034

- 30

47 weaving, at $\frac{3}{4} \mathrm{~d}$.

N. B. Hackled, \&c. by themfelves.

One ftone of wool for the whole family - 0 I 0 Weaving ditto

Shoes

Hats

Hearth money for three children $\}$

0.34

- 100

- I 0

- 20

\section{Duties to the Prieft.}

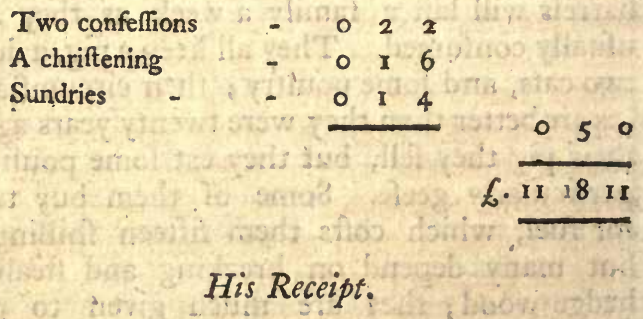

Days

Sundays

$3^{6} 5$

Holydays

52

Bad weather 10

His own garden 20 


\section{A S T L E L L O Y D. 267}

\section{Brought over $5=5-5$}

The eldeft child, 10 or 12 years old, 2 d. 2 day

for 253 days

Other earnings of the family

A pig, bought at 75 . fold at $47 \mathrm{~s}$.

Poultry

One Calf

Two cwt. of butter

Expences

Remains for unfpecified demands, cafualties, \&ic.
$-221$

$-100$

$-200$

- 0100

0150

400

$15 \quad 12 \quad 6$

II 18 II

3137

Many of the poor here have no cows; there are cabbins on the road fide that have no land; the inhabitants of them are called spalpeens, who are paid for their labour in carh, by the month, \&c. Some of them pay no rent at all, others Ios. a year; and thele are the people who hire grafs land for their potatoes; it is certain that the cottars are much better off than thefe fpalpeens, who can get but little milk, buying it part of the fummer half year only of the dairy farmers.

Tythes. Wheat, 8s. Bere, 7s. Barley, 7s. Dats, 4s. 6d. Potatoes, I Is. Meadow, 2s. 8 d.

\section{Prices not in the tables.}

Womens labour, reaping, 4d. Other work, 3 d. Making hand turf, $6 \mathrm{~d}$. Farming man's wages, 31. to 41. Farming maid's ditto, 11. 12s. Mowing, per acre, 2s. 6d. to 3 s. in 


\section{C A S T L E L L O Y D.}

1745, only 1s. 6d. Ditching, 9d.'a perch. Double ones, is. 6d. feven feet wide at top, three and a half at bottom, and four deep, and they will earn 8d. a day at it. Hire of a car, 1s. 6d, a day. In 1745 it was is. Price of a car, $11.18 \mathrm{~s} .3^{\mathrm{d}}$. Building a mud cabbin, $3^{\mathrm{l}}$. Stone and flate, 25l. Mafon's perch of ftone walls for labour, gd. fix feet high complete, I6s. Oak, 4l. a ton; twenty years ago, 21. Lime, $10 \frac{2}{2} d$. a barrel, burnt with culm, brought 25 miles.

Mr. Lloyd has worked a very great improvement of a Making morafs, which when he began was worth only $5^{5}$. an acre. The firft bufinefs was banking it, from a river fubject to floods, with a parallel back cut, to carry off the water that came over his bank. He then carried a central drain through it and a mile beyond it, to gain a fall. Next he fubdivided it into fields, from 10 to 20 acres, by ditches planted with quick. The land was over-run with much underwood and fedgy tuffocks, \&cc. thefe were all grubbed, cut up, and burnt; after which cattle were put in, the improvement being finifhed; and it has grown better and better ever fince, being now worth 305 . an acre : fome of it is actually let at $38 \mathrm{~s}$. It was a very expenfive undertaking, owing to the ftream above him belonging to a neighbour, who did not fecond his undertaking; he was obliged to make a long bank upon this account only, partly over a turf bog, which was blown up. once, bat made again with great difficulty; fourteen 
M I T C H E L S T O W N. 269

fourteen Ipits deep were cleared, and a foundation of rammed clay laid : this colt joool. it has, however, ftood well fince.

Lime Mr. Lloyd tried in a very fatisfactory experiment; he broke up one of the rich hills near Caftle Lloyd, and limed half a field; afterwards upon laying the whole down, the part limed has continued of a much deeper green and more luxuriant herbage than the other half.

October Ioth, left Caftle Lloyd, and took the road by Galbally to Mitchel's Town, through a country part of it a rich grazing tract; but from near Galbally, to the Galty mountains, there are large fpaces of flat lands, covered with heath and furze, that are exceedingly improvable, yet feem as neglected as if nothing could be made of them. The road leads immediately at the northern foot of the Galties, which form the moft formidable and romantic boundary imaginable; the fides are almoft perpendicular, and reach a height, which piercing the clouds, feem formed rather for the boundaries of two conflicting empires, than the property of private perfons. The variety of the fcenery exhibited by thefe mountains is great; the road after paffing fome miles parallel with them, turns over a hill, a continuation of their chain, and commands an oblique view of their fouthern fide, which has much more variety than the northern; it looks down at the fame time upon a long plain, bounded 
270 M I T C H E L S T O W N.

bounded by thefe and other mountains, feveral rivers winding through it, which join in the center, near Mitchel's Town. I had been informed that this was a miferable place: it has at leaft a fituation worthy of the proudeft capital.

Upon my arrival, Lord Kingfborough, who poffeffes almoft the whole country, procured me the information $I$ requefted in the moft liberal manner, and a refidence fince has enabled me to perfect it. His Lordhip's vaft property extends from Kildorrery to Clogheen, beyond Ballyporeen, a line of more than 16 Irifh miles, and it fpreads in breadth from five to ten miles. It contains every variety of land, from the fertility of grazing large bullocks to the mountain heath the cover of groufe. The profitable land lets from $8 \mathrm{~s}$. to $25 \mathrm{~s}$. an acre, but the whole does not on an average yield more than 2s. 6d. Such a field for future improvements is therefore rarely to be found. On the cold and bleak hills of Scotland eftates of greater extent may be found, but lying within twenty miles of Corke, the moft foutherly part of Ireland, admits a rational prophecy that it will become one of the firf properties in Europe.

The fize of farms held by occupying tenants is in general very fmall, Lord Kingfborough having releafed them from the bondage of the middle men. Great tracts are held in partnerfhip; and the amount held by fingle farmers rifes 


\section{I T C H E L S T OW N. 271}

from $5^{1}$. to 501 . a year, with a very few large farms.

The foils are as various as in fuch a great extent they may be fuppofed : the worft is the wet moraffy land, on a whitifh gravel, the fpontaneous growth, rufhes (juncus conglomeratus) and heath (erica vulgaris); this yields a fcanty nourifhment to cows and half-ftarved young cattle. Large tracts of wet land has a black peat or a turf furface; this is very reclaimable, and there are immenfe tracts of it. The profitable foil is in general a fandy or a gravelly loam, of a reddifh brown colour, and the principal diftinction is its being on lime or grit ftone, the former generally the beft. It declines in value from having a yellow fand or a yellow clay near the furface under it. There are tracts of fuch incomparable land that I feen very little equal to it, except in Tipperary, Limerick, and Rofcommon. A deep friable loam, moift enough for the fpontaneous growth to fat a bullock, and dry enough to be perfectly under command in tillage: if I was to name the characteriftics of an excellent foil, I Thould fay tbat upon which you may fat an ox, and feed off a crop of turnips. By the way I recollect little or no fuch land in England, yet is it not uncommon in Ireland. Quarries of the fineft lime-ftone are found in almoft every part of the eftate.

The tracts of mountain are of a prodigious extent; the Galties only are fix or feven miles 
272 M I T C H.EL S T OW N.

long, from one to four miles acrofs; and more improvable upon the whole than any land I have feen, turf and lime-ftone being on the fpot, and a gentle expofure hanging to the fouth. In every inacceffible cliff there are mountain alh, (fraxinus excelfior) oak, (quercus robur) holly, (ilex aquifolium) birch, (betula alba) willow, (Jalix) hazel, (corylus avellana) and white thorn, (cratagus oxyacantba) and even to a confiderable height up the mountain, which, with the many old itumps fcattered about them, prove that the whole was once a foreft, an obfervation applicable to every part of the eftate.

The tillage here extends no farther than what depends on potatoes, on which root they fubfift as elfewhere. They fometimes manure the grafs for them, and take a fecond crop; after which they follow them with oats, till the foil is fo exhaufted as to bear no longer, when they leave it to weeds and trumpery, which vile fyftem has fpread itfelf fo generally over all the old meadow and pafture of the eftate, that it has given it a face of defolation-furze, (eulex europaa) broom, (Jpartium fcoparium) fern, (pteris aquilina) and rufhes, owing to this and to neglect, occupy feven-eighths of it. The melancholy appearance of the lands arifing from this, which, with miferable and unplanted mounds for fences, with no gate but a furze bufh ftuck in a gap, or fome ftones piled on each other, altogether form a fcene the more dreary, as an oak, an afh, or an elm, are almoft 
MITCHE LSTOW N. 273 almoft as great a rarity, (fave in the plantations of the prefent Lord) as an olive, an orange, or a mulberry.

Of potatoes, eight barrels of feed plant an acre, which yields fixty barrels, at twenty-one ftone; the average price 4 s. 4 d.

Planting, fourteen men, at $6 \frac{x}{2} d . \quad 0 \quad 77$ Trenching, fourteen ditto $-4=140$ Leading the dung - $-1,1-0,0$ Spreading, fix men $\quad$ - 33

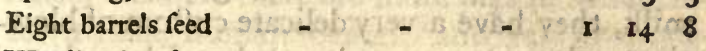
Weeding by the women $\ldots \ldots$ - rato o 0 Taking up, fixty men $\quad$ I 126 Carting home, \&c. - $\quad-\quad-0 \times 50$ trlgith ta

\section{PRODUCE.}

Sixty, at 4s. 4d.

Expenfes

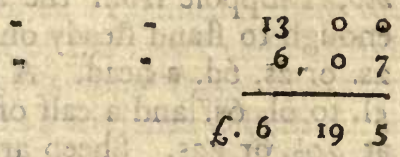

Prime coft, 2s. a barrel.

They lay them up in holes in the field. The fecond crop is generally the beft. Of oats they fow two barrels, and reap from 8 to 15 . There no wheat, and very little barley. Clover and turnips, rape, beans, and peafe, quite unknown. The rents are paid by cattle, and of VoL. II.

$$
S \text { thefe }
$$


274 M I T C H E L S T O W N.

thefe dairy cows are the chief ftock. The little farmers manage their own; the larger ones let them to dairymen for one cwt. of butter each cow, and I2s. to I 5 s. horn money; but the man has a privilege of four collops, and an acre of land and cabbin to every twenty cows. The people, moft attentive to their own intereft, are, however, getting out of this fyftem, from the innumerable rafcalities of thefe dairymen, they will play twenty tricks to keep them from taking the bull, in order to have the longer feafon; and to force them to give down their milk, they have a very delicate cuftom of blowthem where , but I have heard of this practice in other parts.

The winter food is ftraw and hay at night; not many of them are houfed. In the breeding fyftem they are very deficient. Vaft numbers of calves are killed at two or three days old for an execrable veal they call ftaggering bob, I fuppore from the animal not being old enough to ftand fteady on its legs: they fell at 2s. "or 2s. 6d. a head. A good cow fells from 51. to 61,6 s. and a calf of fix or eight months, at 20 s. or $22 \mathrm{~s}$. Sheep are kept in very fmall numbers; a man will have two, or even one, and he thinks it worth his while to walk ten or twelve miles to a fair, with a ftraw band tied to the leg of the lamb, in order to fell it for 3 s. $6 \mathrm{~d}$. an undoubted proof of the poverty of the country. Markets are crouded for this reafon, for there is nothing too trifling to carry; a yard of linen, a fleece of wool, a couple 
M I T C H E L S T O W N. 275 couple of chickens, will carry an unemployed pair of hands ten miles. In the mountains are a fmall breed of fheep, which are as delicate mutton when properly fattened as the welch, and of fo hardy a breed as to live upon heath, furze, \& cc. in winter as well as fummer. Hogs are kept in fuch numbers that the little towns and villages fwarm with them; pigs and children bafk and roll about, and often refemble one another fo much, that it is neceffary to look twice before the buman face divine is confeffed. I believe there are more pigs in Mitchelstown than human beings, and yet propagation is the only trade that flourithed here for ages.

Tillage is done by horfes; four in a plough do half an acre a day, five or fix inches deep; the price 6 s. to Ios. an acre.

Labour is chiefly done in the cottar fyftem, which has been fo often explained; there are here every gradation of the lower claffes, from the fpalpeens, many among them ftrangers, who build themfelves a wretched cabbin in the road, and have neither land, cattle, nor turf, rifing to the regular cottar, and from him to the little joint tenant, who, united with many others, takes fome large farm in partnerfhip; ftill rifing to the greater farmer.

The population is very great. It is but few diftricts in the north that would equal the proportion that holds on this eftate; the cabbins 
276 M I T C H E L S T O W N.

are innumerable, and like moft Irifh cabbins, fwarm with children. Wherever there is many people, and little employment, idlenefs and its attendants muft abound.

It is not to be expected that fo young a man as Lord King(borough, juft come from the various gaiety of Italy, Paris, and London, thould, in fo mort a fpace as two years, do much in a region fo wild as Mitchelftown; a very fhort narrative however, will convince the reader, that the time he has fpent here, has not been thrown away. He found his immenfe property in the hands of that fpecies of tenant which we know fo little of in England, but which in Ireland have flourifhed almoft to the deftruction of the kingdom, the middle man, whofe bufinefs and whofe induftry confifts in hiring great tracts of land as cheap as he can, and re.letting them to others as dear as he can, by which means that beautiful gradation of the pyramid, which connects the broad bafe of the poor people with the great nobleman they fupport, is broken; he deals only with his own tenant, the multitude is abandoned to the humanity and feelings of others, which to be fure may prompt a juft and tender conduct; whether it does or not, let the mifery and poverty of the lower claffes fpeak, who are thus afligned over. This was the fituation of ninetenths of his property. Many leafes being out, he rejected the trading tenant, and let every man's land to him, who occupied it at the rent he had himfelf received before.

During 


\section{I T C H E L S T O W N. 277}

During a year that I was employed in letting his farms; I never omitted any opportunity of confirming him in this fyftem, as far as was in my power, from a conviction that he was equally ferving himfelf and the public in it; he will never quit it without having reafon afterwards for regret.

In a country changing from licentious barbarity into civilized order, building is an object of perhaps greater confequence than may at firft be apparent. In a wild, or but half cultivated tract, with no better edifice than a mud cabbin, what are the objects that can imprefs a love of order on the mind of man? He muft be wild as the roaming herds; favage as his rocky mountains; confufion, diforder, riot, have nothing better than himfelf to damage or deftroy: but when edifices of a different folidity and character arife; when great fums are expended, and numbers employed to rear more expreffive monuments of induftry and order, it is impoffible but new ideas muft arife, even in the uncultivated mind; it muft feel fomething, firft to refpect, and afterwards to love; gradually feeing that in proportion as the country becomes more decorated and valuable, licentioufnefs will be lefs profitable, and more odious. Mitchelftown, till his Lordihip made it the place of his refidence, was a den of vagabonds, thieves, rioters, and whiteboys; but I can witnefs to its being now as orderly and peaceable as any other Irifh town, much owing to this circumftance of building, and thereby employing 
278 M I T C H E L S T O W N.

employing fuch numbers of the people. Lord Kingfborough, in a fhort fpace of time, has raifed confiderable edifices; a large manfion for himfelf, beautifully fituated on a bold rock, the edge of a declivity, at the bottom of which is a river, and commanding a large tract of country, with as fine a boundary of mountain as I have feen; a quadrangle of offices; a garden of five Englifh acres, furrounded with a wall, hot-houfes, \&cc. Befides this, three good ftone and flate houfes upon three farms, and engaged for three others, more confiderable, which are begun; others repaired, and feveral cabbins built fubitantially.

So naked a country as he found his eftate, called for other exertions, to invoke the Dryades it was neceffary to plant, and they muft be coy nymphs indeed if they are not in a few years propitious to him. He brought a fkilful nurferyman from England, and formed twelve acres of nurfery. It begins to thew itfelf; above ten thoufand perch of hedges are made, planted with quick and trees; and feveral acres, fecurely inclofed on advantageous fpots, and filled with young and thriving plantations. Trees were given, gratis, to the tenantry, and premiums begun for thofe who plant moft, and preferve them beft, befides fourfcore pounds a year offered for a variety of improvements in agriculture the moft wanted upon the eftate.

Men, 
M I T C H E L S T OWN. 279

Men, who from long poffeffion of landed property, become gradually convinced of the importance of attending toit, may at laft work fome improvements without meriting any confiderable portion of praife; but that a young man, warm from pleafure, thould do it, has a much fuperior claim. Ld d Kingfborough has, in this refpect, a great deal of merit; and for the fake both of himfelf and his country, I heartily wirh he may feadily perfevere in that line of conduct which his underftanding has once told him, and muft continue to tell him, is fo greatly for the advantage of himfelf, his family and the public.

It is not uncommon, efpecially in mountainous countries, to find objects that much deferve the attention of travellers intirely neglected by them. There are a few inftances of this upon Lord Kingfborough's eftate, in the neighbourhood of Mitchelftown; the firft I thall mention, is a cave at Skeheenrinky, on the road between Cahir and that place: the opening to it is a cleft of rock in a lime ftone hill, fo narrow as to be difficult to get into it. I defcended by a ladder of about twenty fteps, and then found myfelf in a vault of a hundred feet long, and fifty or fixty high: a fmall hole, on the left, leads from this a winding courfe of I believe not lefs than half an Irilh mile, exhibiting a variety that ftruck me much. In fome places the cavity in the rock is fo large, that when well lighted up by candles, (not flambeaux, Lord Kingfborough once lhewed 
280 MIT C H ELS T O W N.

it me with them, and we found their fmoak troublefome) it takes the appearance of a vaulted cathedral, fupported by maffy columns. The walls, cieling, floor, and pillars, are by turns compofed of every fantaftic form ; and often of very beautiful incruftations of fpar, fome. of which glitters fo much, that it feems powdered with diamonds, and in others the cieling is formed of that fort which has fo near a refemblance to a cauliflower. The fpar formed into columns by the dropping of water has taken fome vefy regular forms; but others are different, folded in plaits of light drapery, which hang from their fupport in a very pleafing manner. The angles of the walls feem fringed with ificles. One very long branch of the cave, which turns to the north, is in forne places fo narrow and low, that one crawls into it, when it fuddenly breaks into large vaulted fpaces, in a thoufand forms. The fpar in all this cave is very brilliant, and almoft equal to Briftol ftone. For feveral hundred yards in the larger branch, there is a deep water at the bottom of the declivity to the right, which the common people call the river. A part of the way is over a fort of potter's clay, which moulds into any form, and is of a brown colour : a very different foil from any in the neighbouring country. I have feen the famous cave in the Peak, but think it very much inferior to this : and Lord Kinglborough, who has viewed the Grot d'Aucel in Burgundy, fays that it is not to be compared with it. 
M I T C H E L S T O W N. 28I

But the commanding region of the Galties deferves more attention. Thofe who are fond of fcenes in which nature reigns in all her wild magnificence, fhould vifit this ftupendous chain. It confifts of many vaft mountains, thrown together in an affemblage of the moft interefting features, from boldnefs and height of the declivities, freedom of outline, and variety of parts; filling a fpace of about fix miles by three or four. Galtymore is the higheft point, and rifes like the lord and father of the furrounding progeny. From the top you look down upon a great extent of mountain, which fhelves away from him to the fouth, eaft, and weft; but to the north, the ridge is almoft a perpendicular declivity. On that fide the famous golden vale of Limerick and Tipperary fpreads a rich level to the eye, bounded by the mountains of Clare, King's and Queen's counties, with the courie of the Shannon, for many miles below Limerick. To the fouth you look over alternate ridges of mountains, which rife one beyond another, till in a clear day the eye meets the ocean near Dungarvon. The mountains of Waterford and Knockmaldown fill up the fpace to the fouth-eaft. The weftern is the moft extenfive view ; for nothing ftops the eye till Mangerton and Macgilly Cuddy's Reeks point out the fpot where Killarney's lake calls for a farther excurfion. The profpectextends into eight counties, Corke, Kerry, Waterford, Limerick, Clare, Queen's, Tipperary, King's. 


\section{M I T C HEL S T O W.}

A little to the weft of this proud fummit, below it in a very extraordinary hollow; is a circular lake of two acres, reported to be unfathomable. The defcriptions which I have read of the craters of exhaufted volcanoes, leave very little doubt of this being one; and the conical regularity of the fummit of Galtymore fpeaks the fame language." Eaft of this refpectable hill, to ufe Sir William Hamilton's language, is a declivity of about one quarter of a mile, and there Galtybeg rifes in a yet more regular cone, and between the two hills is another lake, which from pofition feems to have been once the crater which threw up Galtybeg, as the firft mentioned was the origin of Galtymore. Beyond the former hill is a third lake, and eaft of that another hill ; I was told of a fourth, with another correrponding mountain. It is only the mere fummit of thefe mountains which rife above the lakes. Speaking of them belorw, they may be faid to be on the tops of the hills; they are all of them at the bottom of an almoft regularly circular hollow. On the fide, next the mountain top, are walls of perpendicular rocks, in regular ftrata, and fome of them piled on each other, with an appearance of art rather than nature. In thefe rocks the eagles, which are feèn in numbers on the Galties, have their nefts. Suppofing the mountains to be of volcanic origin, and thefe lakes the craters, of which I have not a doubt; they are objects of the greateft curiofity, for there is an unufual regularity in every confiderable 


\section{I T C H E L S T O W N. 283}

fummit, having its correfponding crater; but without this circumftance the fcenery is interefting in a very great degree. The mountain fummits, which are often wrapped in the clouds, at other times exhibit the freeft outline; the immenfe fcooped hollows which fink at your feet, declivities of fo vaft a depth as to give one terror to look down; with the unufual forms of the lower region of hills, particularly Bull hill, and Round hill, each a mile over, yet rifing out of circular vales, with the regularity or femi-globes unite upon the whole, to exhibit a fenery to the eye, in which the parts are of a magnitude fo commanding; a character fo interefting, and a variety fo ftriking, that they well deferve to be examined by every curious traveller.

Nor are thefe immenfe outlines the whole of what is to be feen in this great range of mountains. Every Glen has its beauties; there is a confiderable mountain river, or rather torrent in every one of them; but the greateft are the Funcheon, between Sefang and Galtymore; the Limeftone river, between Galtymore and Round hill, and the Groufe river, between Coolegarranroe, and $\mathrm{Mr}$. O'Callaghan's mountain; thefe prefent to the eye, for a tract of about three miles, every variety that rock, water, and mountain can give, thrown into all the fantaftic forms which art may attempt in ornamented grounds, but always fails in. Nothing can exceed the beauty of the water, when not difcoloured by rain, 


\section{M I T C H E L S T O W N.}

its lucid tranfparency fhews; at confiderable: depths, every pebble no bigger than a pin $_{2}$ every rocky bafon alive with trout and eels, that play and dafh among the rocks, as if endowed with that native vigour which animate, in a fuperior degree, every inhabitant of the mountains, from the bounding red deer, and the foaring eagle, down even to the filhes of the brook. Every five minutes you have a waterfall in thefe glens, which in any other region, would ftop every traveller to admire it. Sometimes the vale takes a gentler declivity, and prefents to the eye at one ftroke, twenty or thirty falls, which render the fcenery all alive with the motion; the rocks are toffed about in the wildeft confufion, and the torrent burfts by turns from above, beneath, and under them; while the back ground is always filled up with the mountains which ftretch around.

In the weftern Glen is the fineft cafcade in all the Galties; there are two falls, with a bafon in the rock between, but from fome points of view they appear one : the rock over which the water tumbles is about fixty feet high. A good line in which to view thefe objects is either to take the Killarney and Mallow road, to Mitchelftown, and from thence by Lord Kingfborough's new one, to Skeheenrinky, there to take one of the Glens, to Galtybeg, and Galtymore, and return to Mitchelftown by the Wolf's track, Temple hill, and 


\section{QUEEN'S COUNTY 285}

the Waterfall : or, if the Corke road is travelling, to make Dobbin's inn, at Ballyporeen, the head quarters, and view them from thence.

* * * * * * * * * *

Having heard much of the beauties of a part of the Queen's county, I had not before feen, I took that line of country in my way on a journey to Dublin.

From Mitchelftown to Calhel, the road leads as far as Galbally in the route already travelled from Cullen; towards Cafhel the country is various. The only object deferving attention, are the plantations of Thomaftown, the feat of Francis Mathew, Efq; they confift chiefly of hedge-row trees in double and treble rows, are well grown, and of fuch extent as to form an uncommon woodland fcene in Ireland. Found the widow Holland's Inn, at Canhel, clean and very civil. Take the road to Urlingford. The rich theep paftures, part of the famous golden vale, reach between three and four miles, from Cafhel to the great bog by Botany Hill, noted for producing a greater variety of plants than common. That bog is feparated by only fmall tracts of land, from the ftring of bogs which extend through the Queen's County, from the great bog of Allen; it is here of confiderable extent, and exceedingly improvable. Then enter a low marthy bad country, which grows worfe after paffing the 66th mile ftone, and fucceflive bogs in it. Breakfan at Johnftown, a regular village on a llight 
286 QUEEN'S COUNTY.

a flight eminence, built by Mr. Hayley; it is near the Spaw of Ballyfpellin. Rows of trees are planted ; but their heads all cut off, I fuppofe from their not thriving, being planted too old. Immediately on leaving thefe planted avenues, enter a row of eight or ten new cab. bins, at a diftance from each other, which appear to be a new undertaking, the land about them all pared and burnt, and the afhes in heaps.

Enter a fine planted country, with much corn and good thriving quick hedges for many miles. The road leads through a large wood, which joins Lord Afhbrook's plantations, whofe houfe is fituated in the midft of more wood than almoft any one $I$ have feen in Ireland. Pafs Durrow; the country for two or three miles continues all inclofed with fine quick hedges, is beautiful, and has fome ręfemblance to the beft parts of Effex. Sir Robert Staple's improvements join this fine tract; they are completed in a moft perfect manner, the hedges well-grown; cut, and in fuch excellent order, that I can fcarcely believe myfelf to be in Ireland. His gates are all of iron. Thefe fylvan fcenes continue through other feats beautifully fituated, amidft gentle declivities of the fineft verdure, full grown woods, excellent hedges, and a pretty river winding by the houfe. The whole environs of feveral would be admired in the beft parts of England.

Crofs a great bog, within fight of Lord de Vefcey's plantationss. The road leads over it, being 


\section{QUEEN'S C OUNTY. 287}

ing drained for that purpofe by deep cuts on either fide. I thould apprehend this bog to be among the moft improvable in the country.

Slept at Ballyroan, at an inn kept by three animals, who call themfelves women; met with more impertinence than at any other in Ireland. It is an execrable hole. In three or four miles pafs Sir John Parnel's prettily fituated in a neatly dreffed lawn; with much wood about it, and a lake quite alive with wild fowl.

$\mathrm{Pafs}$ Monftereven, and crofs directly a large bog, drained and partly improved; but all of it bearing grafs, and feems in a ftate that might eafily be reduced to rich meadow, with only a dreffing of lime. Here I got again into the road I had travelled before.

I muft in general remark, that from near Urlingford to Dawfon Court, near Monftereven, which is completely acrofs the Queen's County, is a line of above thirty Englifh miles, and is for that extent by much the mort improved of any I have feen in Ireland. It is generally well planted, has many woods, and not confifting of patches of plantation juft by gentlemen's houfes, but fpreading over the whole face of the country, fo as to give it the richnefs of an Englifh woodland fcene. What a country would Ireland be had the inhabitanits of the reft of it improved the whole like this.

\section{END OF PART I.}




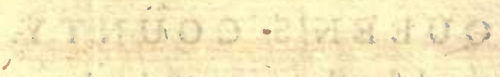

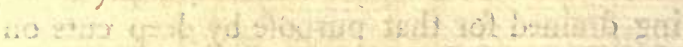

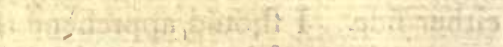

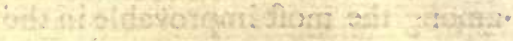

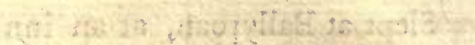

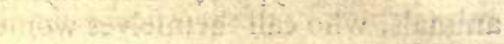

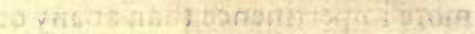

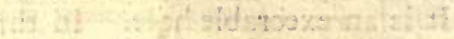

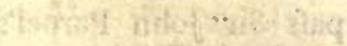

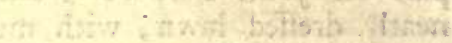

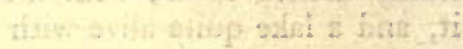

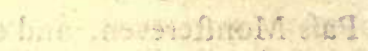

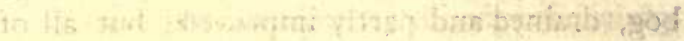

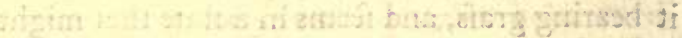

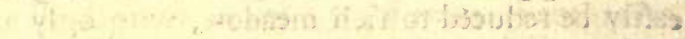

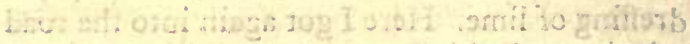
nolud tollowe bist I

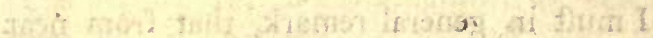

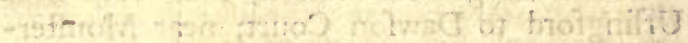

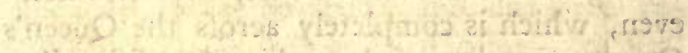

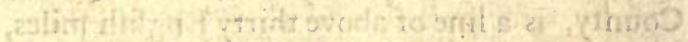

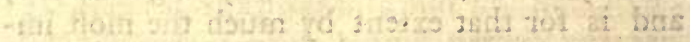

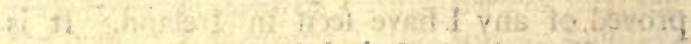

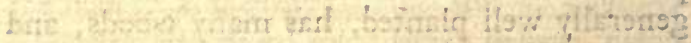

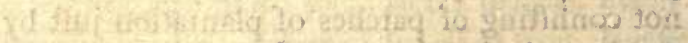

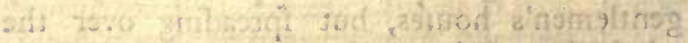

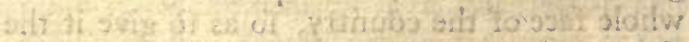

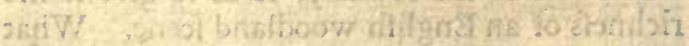

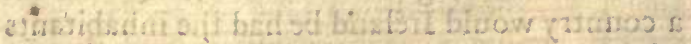

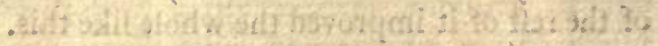

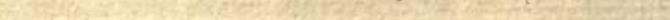

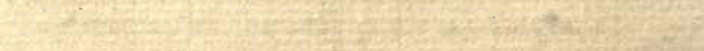

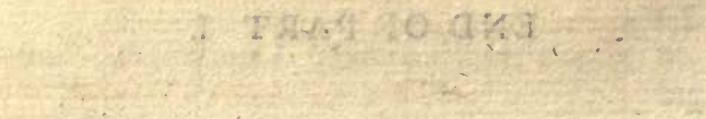


A

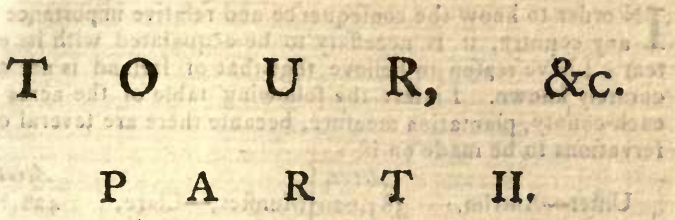

\section{Obfervations on the preceding Intelligence.}

70 regifter the minutes received upon fuch a journey as I this, and leave them fimply to fpeak for themfelves, would have its ufe; but it would leave to the inquilitive reader fo much labour and trouble in collecting general facts, that not one in five hundred would attempt it. That it is a matter of importance to have accurate general ideas of a country, inftead of erroneous ones, wili hardly be difputed; no books of geography but fpeak generally of fcil, climate, product, rental, population, E̋c. but they are too often mere gueffes; or, if founded at all, the facts that fuppert them of too old a date to yield the leaft truth at prefent in points fubjeet to change. When one country is mentioned in another it is ufually in general terms: and by comparifon, England has not fo rich a foil as Ireland. Producls in England larger than in France. Rents bigher in Ireland than in Scotland. A thoufand inttances might be produced, in which ideas of this fort are particularized, and in which general errors are often found the caufe of political meafures, even of the higheft confequence. That my Englifh tours give exat? information relative to England, I cannot affert; but I may venture to fay, that they are the oniy information extant, relative to the rental, produce, ftock of that country, which are taken from an actual examination : I wifh to offer equal information relative to our fifter inand; and I am encouraged to do it, not only from my own ideas, but the opinions of niany perfons with whom 1 have either correfponded or converfed from molt parts of Europe, including foine of the mott refpectable for abilities and rank. 


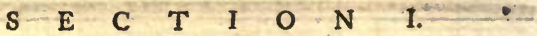

\section{Extent of Ireland.}

- $\mathrm{N}$ order to know the confequence and relative importance of 1 any country, it is neceffary to be acquainted with its extent ; I have reafon to believe that that of Ireland is not accurately known. I infert the following table of the acres of each county, plantation meafure, becaufe there are feveral obfervations to be made on it.

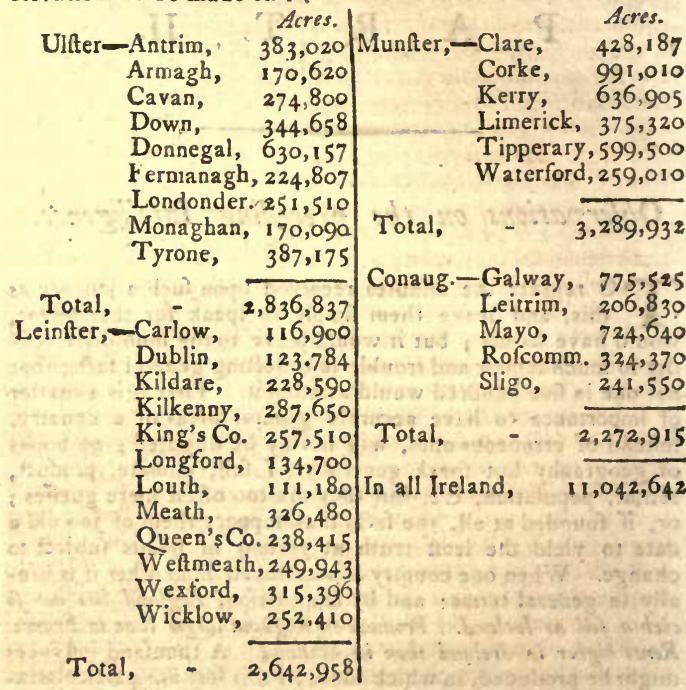

Gerard Malines makes the acres of Ireland eighteen millions: (Lex Mercatoria, part I. p. 49) I fuppofe Englifh meafure, which is eleven millions Irih ; thefe two accounts flow therefore from the fame fource. Templeman's meafurement gives it 27,457 fquare miles, or $17,572,480$ acres (Survey of tbe globe) Englifh on a fcale of 60 miles to a degree, but contequently it is profeffedly erroneous, as a degree is $69 \frac{\pi}{2}$; according to this meafure therefore, the contints in real acres would be 20,354,789 Englinh, and 12,721,743 Irin. Thefe accounts come fo nearly together, that they are all drawn from fumilar data ; that is, from old maps. Newer ones have many blunders; but as no late actual furvey has been made of the kingdom, we muft depend on the authority we find. 


\section{$\begin{array}{lllllllll}S & E & C & T & I & O & N & \text { II. }\end{array}$}

\section{Soil, Face of the Country and Climate.}

TO judge of Ireland by the converfation one fometimes hears 1 in England, it would be fuppofed that one half of it was covered with bogs, and the other with mountains filled with Irifh ready to $f y$ at the fight of a civilized being. There are people who will fmile when they hear that in proportion, to the fize of the two countries, Ireland is more cultivated tban England, having much lefs watte land of all forts. Of uncultivated mountains there are no fuch tracts as are found in our four northern counties, and the North Riding of Yorkhire, with the eaftern line of Lancafter, nearly down to the Peak of Derby, which form an extent of above an hundred miles of watte. The moft confiderable of this fort in Ireland are in Kerry, Galway, and Mayo, and fome in Sligo and Donnegal. But all thefe together will not make the quartity we have in the four northern counties; the vallies in the Irifh mountains are alfo more inbabited, I think, than thofe of Lingland, ex. cept where there are mines, and confequently foine fort of cultivation creeping up the fides. Natural fertility, acre for acre over the two kingdouns, is certainly in favour of Ireland; of this I believe there can fcarcely be a doubt entertained. when it is confidered that fome of the more beautiful, and even beft cultivated countries in England, owe almolt every thing to the capital art and induftry of the inlabitants.

The circumttance which trikes me as the greateft fingularity of Ireland, is the rockynefs of the foil, which Mould feem at firt fight againft that degree of fertility; but the contrary is the fact. Stone is fo general, that I have great reafon to believe the whole illand is one vaft rock of different ftrata and kinds rifing out of the fea. I have rarely heard of any great depths being funk witbout meeting with it. In general it appears on the furface in every part of the kingdoin, the flatteit and mott fertile parts, as Limerick, Tipperary and Meath, have it at no great depth, almoft as much as the more barren ones. May we not recognize in this the hand of bounteous providence, which has given, perhaps, the mot ftoney foil in Europe to the moittert clinate in it? If as much rain fell upon the clays of England (a foil very rarely met with in Ireland, and never without much thonel as falls upon the rocks of her fifter ifland, thofe lands could not be cultivated. But the rocks here are cloathed with verdure; -thofe of lime itone with only a thin covering of mold, have the forteit and noit beautiful turf imaginable.

Of the great advantages refulting from the general plenty of lime ftone, and lime-ftone gravel, and the nature of the 
bogs, I thall have occafion to fpeak more particularly hereafter.

The rockynefs of the foil in Ireland is fo univerfal, that it predominates in every fort. One cannot ufe with propriety, the terms clay, loam, fand, \&c. it mutt be a foney clay, a froney loam, a gravelly fand. Clay, efpecially the yellow, is much talked of in Ireland, but it is for want of proper diferimination. I bave once or twice feen almoit a pure clay upon the furface, but it is extremely rare. The true yellow clay, is ufually found in a thin fratuin under the furface mould, and over a rock; harih, tenacious, ftoney, ftrong loams, difficult to work, are not uncommon; but they are quite different from Englifh clays.

Friable fandy loams dry, but fertile, are very common, and they form the beft foils in the kingdom, for tillage and theep. Tipperary, and Rofcommon, abound particularly in them. The moft fertile of all, are the bullock paftures of Limerick, and the banks of the Shannon in Clare, called the Corcaffes. Thefe are a mellow, putrid, friable loam.

Sand, which is fo common in England, and yet more common through Spain, France, Germany, and Poland, quite from Gibraltar to Peterfurgh, is no where met with in Ireland, except for narrow lips of hillocks, upon the fea count. Nor did I ever meet with, or hear of a chalky foil.

The bogs of which foreigners have heard fo much, are very extenfive in Ireland; that of Allen extends 80 miles, and is computed to contain 300,000 acres. There are others alfo, very extenfive, and fmaller ones feattered over the whole kingdom; but thefe are not in general more than are wanted for foel. When I come to fpeak of the improvement of wafte lands, I thall deforibe them particularly.

Befides the great fertility of the foil, there are other circumftances, which come within my fphere to mention. Few countries can be better watered, by large and beautiful rivers; and it is remarkable, that by much the fineft parts of the kingdom, are on the banks of thefe rivers. Witners the Suer, Blackwater, the Liffy, the Boyne, the Nore, the Barrow, and part of the Shannon, they wath a fcenery that can hardly be esceeded. Fron the rockyneis of the country however, there are few of them that have not obftructions, which are great impediments to inland navigation.

The mountains of Ireland, give to travelling, that interefting variety, which a flat country can never abound with. And at the fame time, they are not in fuch number as to confer the ufual character of poverty, which attends them. I was either upon or very near the moft confiderable in the kingdom. Mangerton, and the Reeks, in Kerry ; the Galties in Corke; thofe of Mourne in Down; Crow Patrick and Nephin in Mayo; tbefe are the principal in Ireland, and they are of a character, in height aud fublimity, which flould reader them the objects of every traveller's attention. 
Relative to the climate of Ireland, a thort refidence cannot enable a man to fpeak much from his own experience; the obfervations I bave made myfelf, confirm the idea of its being vaftly wetter than England; from the 2oth of June, to the soth of October, I kept a regifter, and there were in 122 days, 75 of rain, and very many of them inceffant and heavy. I have examined fimilar regifters I kept in England, and can find no year that even approaches to fuch a moifture as this. But there is the regifter of an accurate diary publifhed, which compares London and Corke. The refult is, that the quantity at the latter place, was double to that of London. See Smitb's Hift. of Corke.

From the information. I received, I have reafon to believe, that the rainy feafon fets in ufually about the firn of July, and coninues very wet till September or Oetober, when there is ufually a dry fine feafon of a month or fix weeks. I refided in the county of Corke, \&c. from Oetober till March, and found the winter much more foft and mild, than ever I experienced one in England. I was alfo a whole fummer there (1778), and it is fair to mention, that it was as fine a one, as ever I knew in England, though by no means fo hot. I think hardly fo wet, as very many I have known in England. The rops of the Galty Mountains, exhibited the only fnow we faw ; and as to frofts, they were fo Dight and rare, that I believe niyrtles, and yet tenderer plants, would have furvived without any covering. But when I fay that the winter was not remarkable for being wet, I do not mean that we had a dry 2 to noofphere. The inches of rain which fell, in the winter I fpeak of, would not mark the moifture of the climate. As many inches will fall in a fingle tropical thower, as in a whole year in England, See Mitcbel's Prefent State of Great Britain, and Nortb America. But if the clouds prefently difperfe, and a bright fun thines, the air may foon be dry. The wort circumftance of the climate of Ireland, is the conftant moifture without tain. Wet a piece of leather, and lay it in a room, where there is neither fun nor fire, and it will not in funmer even, be dry in a month *. I have known gentlemen in Ireland deny their climate being moifter than England;-but if they have eyes let them open them, and fee the verdure that cloathes their rocks, and compare it with ours in Ergland-where rocky foils are of a ruffet brown however fweet the food for theep.

Does

* I have bad tbis bappen myfelf with a pair of avet gloves.

The myriads of fies alfo whicb buz about one's ears, and are ready to go in Boals into one's mouth at equery wird-and thofe almoft imperceptible fies called midges, wbich perfecily dewour one in a queod, or near a river; prove the fame tbing. 
Does not their ifland lye more expofed to the great Atlantic, and does not the weft wind blow three-fourths of a year? If there was another inand yet more to the weftward, would not the climate of Ireland be improved? Such perfons fpeak equally againt $f_{a} \varepsilon$, reafon, and philofophy. That the moifture of a climate does not depend on the quantity of rain that falls, but on the powers of aerial evaporation, Dr. Dobfon has clearly proved. Pbil. Tranf. Vol. Ixvii. part' i. p. 244.

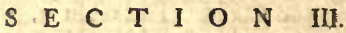

\section{Rental.}

Jo country can ever be held in a juft eftimation when the I rental of it is unknown. It is not the only circumitance which a political arithmetician fhould attend to, but it is a moft important one. The value of a country is rarely the fubject of a converfation without gueffes at its rental being made, and comparifons between different ones. I contend for nothing more through this and the enfuing tables, than the fuperiority of aetual information on the fpot, drawn into one point of view, over any gueffes whatever. I hall therefore proceed at once to lay it before the reader.

\begin{tabular}{|c|c|c|c|c|c|c|}
\hline Places. & $\begin{array}{c}\text { Rentper } \\
\text { Acre. }\end{array}$ & $\left|\begin{array}{c}\text { Rentat } \\
\text { Irigh } \\
\text { Acre }\end{array}\right|$ & Rife. & Fall. & $\begin{array}{l}\text { Year's } \\
\text { purchafe } \\
\text { of land. }\end{array}$ & $\begin{array}{l}\text { Leajes, } \\
\text { years or } \\
\text { lives. }\end{array}$ \\
\hline County of Dublin, & & & & s. d. & 22 & \\
\hline Celbridge, & 1100 & & & & 22 & \\
\hline Dolleftown, & $\begin{array}{lll}1 & 1 & 0\end{array}$ & & & 50 & & \\
\hline $\begin{array}{l}\text { Summerhill, } \\
\text { Slain Caftle, }\end{array}$ & $\begin{array}{lll}1 & 0 & 0 \\
1 & 5 & 0\end{array}$ & & & & 23 & \\
\hline $\begin{array}{l}\text { Slain Caftle, } \\
\text { Headfort, }\end{array}$ & 150 & & & & $22 \div$ & \\
\hline $\begin{array}{l}\text { Headfort, } \\
\text { Drueftown, }\end{array}$ & $\begin{array}{l}10 \\
160\end{array}$ & & & & 21 & \\
\hline Fore, & 0150 & & & & & \\
\hline $\begin{array}{l}\text { Packenham Hall, } \\
\text { Mullingar to Tul- }\end{array}$ & 0176 & & & 44 & 21 & \\
\hline lefpace, & 100 & & & & & \\
\hline Charleville, & 0160 & & & 40 & 20 & \\
\hline Shaen Caftle, & 0130 & & & 50 & 20 & \\
\hline $\begin{array}{l}\text { Athy to Carlow, } \\
\text { Kilfaine, }\end{array}$ & $0 \begin{array}{lll}0 & 18 & 0 \\
0 & 15 & 6\end{array}$ & & & 20 & & \\
\hline Rofs to Taghmon, & $\mid \begin{array}{lll}0 & 15 & 0 \\
0 & 15 & 0\end{array}$ & & & & 21 & 21 \\
\hline Bargie and Forth, & 1. 29 & & a little & & $23 \frac{2}{2}$ & \\
\hline Wexford to Wells, & 0110 & & & & & \\
\hline Wells to Gowry, & 0170 & & & & & \\
\hline $\begin{array}{l}\text { Courtown, } \\
\text { New 'Tewn M. }\end{array}$ & 0176 & & none & & 2 & 311 \\
\hline Kennedy, & 200 & & 80 & & $19 \frac{1}{2}$ & $31 \mathrm{~L}$. \\
\hline $\begin{array}{l}\text { Ditto Mountain, } \\
\text { Kilrue. }\end{array}$ & 080 & & & & & \\
\hline & 1120 & & & & & \\
\hline
\end{tabular}


$R \quad N \quad T A L$.

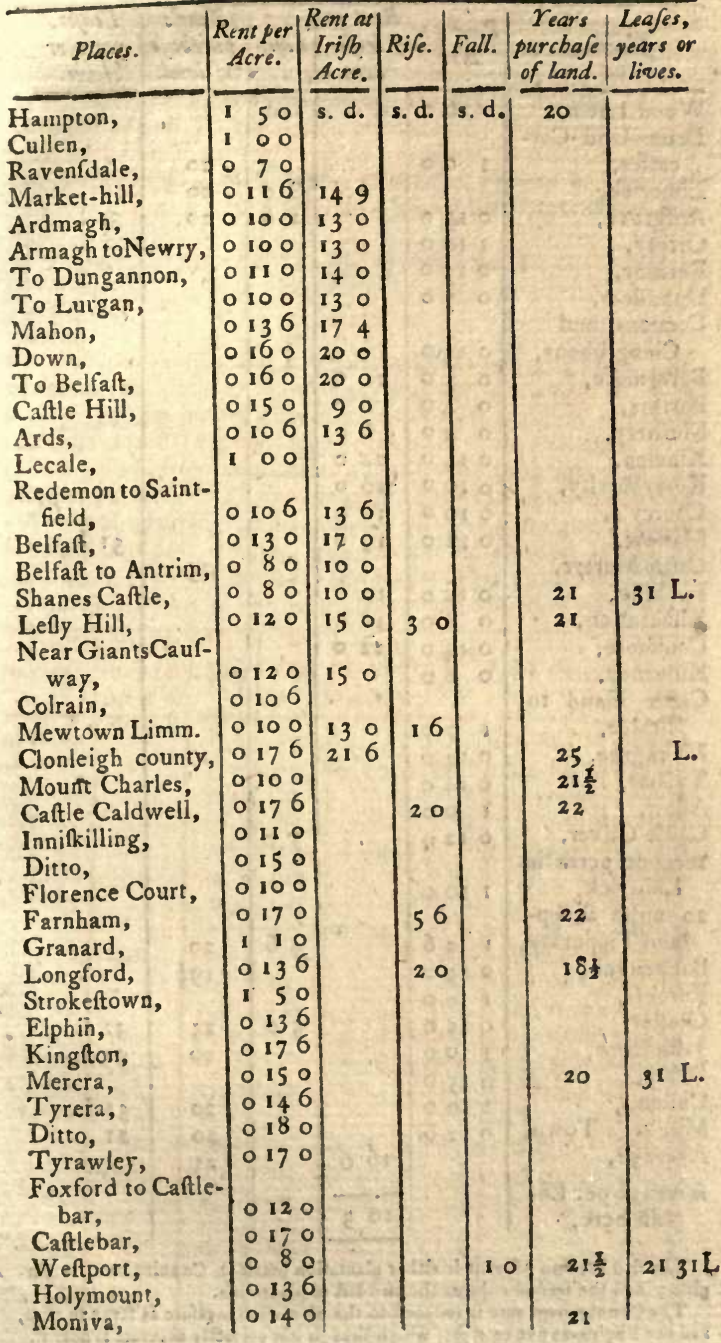

Wood 


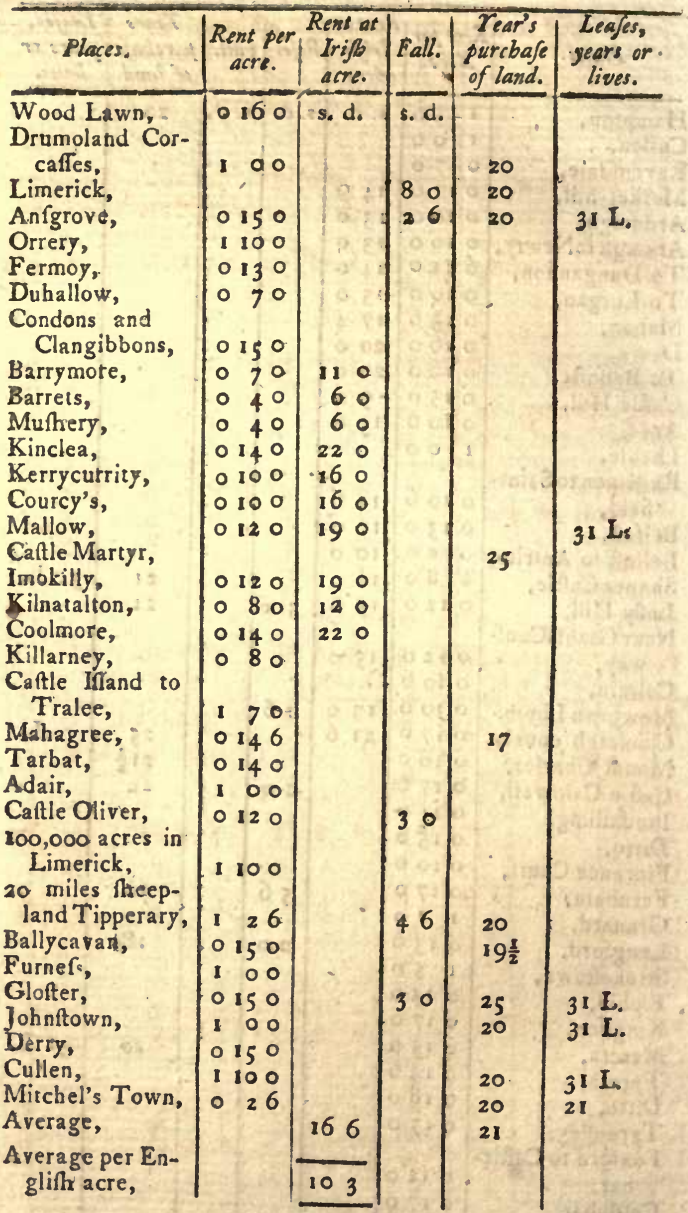

The firft column of rent is either plantation meafure, Cunniogham, or Estglith; and the fecond reduoes the two laft to plantation.

The Conningham acre is reduced to the plantation meafure as feven to nine, and the English as fire to eight, which though not perfeetly aceurate is near it. 
The following table contains the information I received relative to the general average rental of whole counties; and as there are feveral with more than one account, the medium of thofe different accounts is given in a feparate column.

\section{Counties. Different Average. Reduced to Total rental minutes. plantation. of tbe County.}

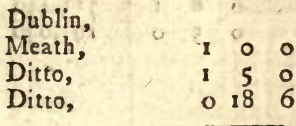

Weftmeath,

$\begin{array}{llll}\text { King's County, } & 0 & 13 & 0 \\ \text { Ditto, } & 0 & 12 & 6\end{array}$

$$
1116 \quad 1116 \quad \text { L.194,959 }
$$

Carlow,

Wexford,

Wicklow,

Louth,

Ardmagh, $\quad 080$

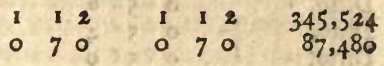

Ditto,

0140

Down,

$0129 \quad 0129 \quad 164,168$

$0150 \quad 0150 \quad 87,675$

$0150 \quad 0150 \quad 236,547$

$0150 \quad 0150 \quad 189,307$

$110 \quad 10 \quad 116,739$

Ditto, 0 10 0

Ditto,

$010 \quad 0$

Antrim, : $\quad 56$

$0110 \quad 0140 \quad 119,434$

Ditto, - 049

Derry,

Ditto,

o 46

04.

Donnegal, $0 \geq 0$

Ditto, 010

Ditto, $\quad 0^{2} 6$

$0100 \quad 01210 \quad 221,154$

- $51 \frac{x}{4} \quad 066,124,481$

$\begin{array}{lllll}0 & 43 \quad 0 & 56 \quad 69,164\end{array}$

$\begin{array}{llllll}0 & 16 & 0 & 16 & 47,260\end{array}$

Cavan, $\quad 060$ o 55 94,603

Ditto, $\quad 076$

Longford, $\quad 669$ ० 69 92,745

Ditto, 020

Ditto, $\quad 0$ - 14

Rofcommon, 0 ir 0

$\begin{array}{llll}0 & 25 & 0 & 25\end{array}$

Ditto, 0100

0 $106 \quad 0106 \quad 170,294$ 
10

$$
\text { R E N T A L. }
$$

Counties. Different Average. Reduced to Total rental minutes. plantation. of tbe County.

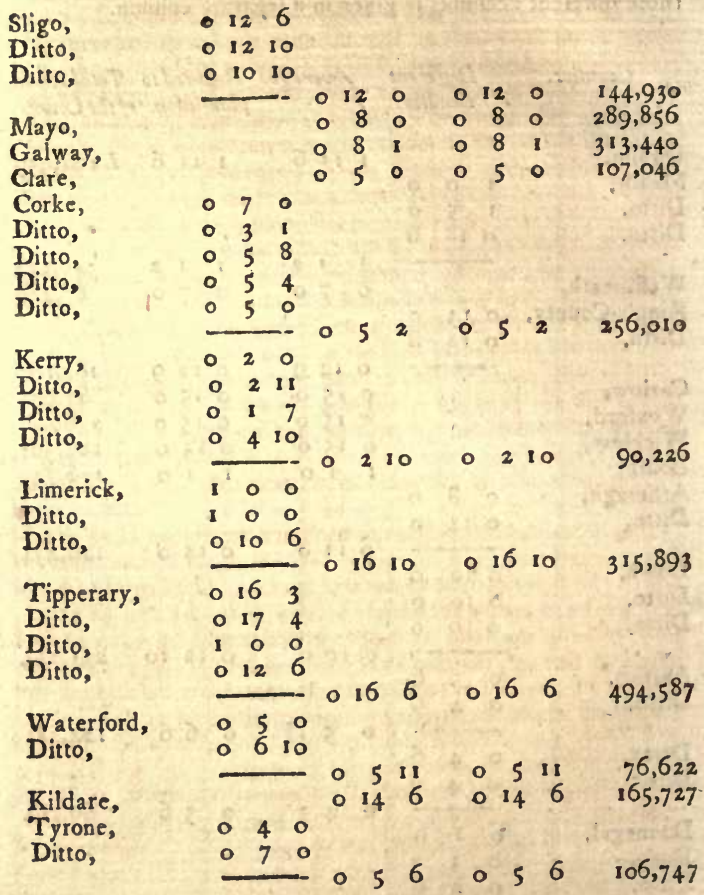

Since the journey I have procured the information for the following :

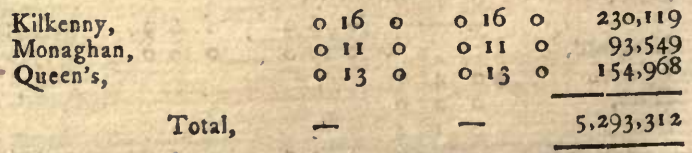


$11,042,642$ plantation acres, giving the rent of $5,2,93,3121$. is at the rate of $9 \mathrm{~s} .7 \mathrm{~d}$. per acre. The average of all the minutes made it $16 \mathrm{~s}$. $6 \mathrm{~d}$. from hence there is reafon to imagine, that the line travelled was better than the medium of the kingdom; or on the contrary, that the fuppofitions of the rents per county are under the truth, the real rent of the kingdom, if it could be afcertained, would probably be found rather to exceed than fall fhort of fix millions. Efpecially as the rents upon which thefe particulars are drawn, were not thofe paid by the occupying tenant, but a general average of all tenures; whereas the object one would afcertain is the fum paid by the occupier, including confequently, not only the landlords rents, but the profit of the middle men.

But farther, as the computation that makes the total of $11,042,642$ acres is profeffedly erroneous above a feventh, being drawn from geographic miles, there thould be added above 700,0001 . to this renial on that account.

The difference of noney and meafure included 353 . Irifh makes juft 20s. Englifh. Suppofe therefore the rental of Ireland 9s. 7d. per acre, it makes 5s. 6. Englith.

If Ireland is ros. it would be 5s. 9d. Englifh.

Suppofe it is or the total of fix millions, it is per Englifh acre 6 s. 4 d.

It is a curious difquifition to compare the rent of land in different countries, and to mark the various circumftances to which the fuperiority may be attributed. The rental of England has been pretty accurately afcertained to be 13 s. an acre*. Poor rates in the fame 1s. $10 \frac{1}{2} \mathrm{~d}$. in the pound, or is. $2 \frac{1}{2} \mathrm{~d}$. per acre. $\|$ The information I received in Ireland concerning the amount of the money raifed for prefentments throughout the kingdom, made the total 140,000 l. or 3 d. an acre.

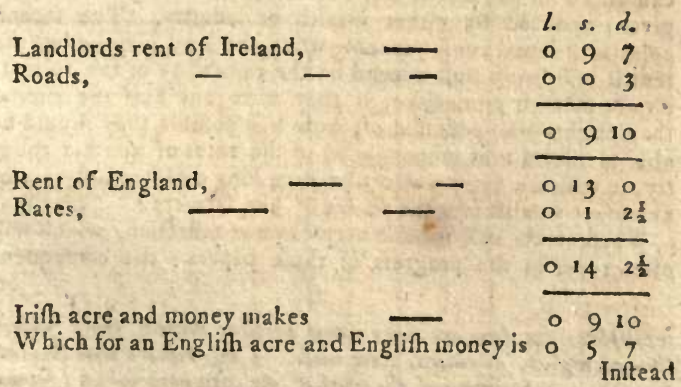

* Eaftern Tour through England. Vol. iv. p. 229.

11 The average of the Eaftern and Nortbern Tours which make a total of $1,926,666 l$. By tbe returns laid before parlicment it ap. peared to be culually $1,720,3161.14 \%, 7 d$; but tbat return sias 
Inftead of which is 14 s. $2 \frac{1}{2} \mathrm{~d}$. confequently the proportion between the rent of land in England and Ireland is nearly as two to five : in other words, that fpace of land which in Ireland lets for 2s. would in England produce 5s.

In this comparifon the value of land in England appear 10 be fo mucb greater than it is in Ireland, that feveral circumitances thould be confidered. The idea $J$ found common in Ireland upon that matter was, that rents there were bigber than in England; but tbe extreme abfurdity of the notion arofe from the difference of meafure and money, the exact par being, as 20 to 35. As far as I can form a general idea of the foil of the two kingdams, Ireland bas much the advantage; and if $I$ ans accurate in this, furely a ftronger argument cannot be ufed, to Shew the immenfe importance of CA BITAL firt in the hands of the landlords of a country, and then in that of the farm mers. I have reafon to believe that five pounds fterling per Englith acre, expended over all Ireland, which amounts to $88,34^{1}, 1361$. would not more than build, fence, plant, drain, and improve that country to be upon a par in thole refpects: with England. And farther, that if thofe 88 millions were fo expended, it would take much above 20 millions more for above 20s. an acre) in the hands of the farmers in ftock of hufbandry, to put them on an equal footing with thofe of her fiter kingdom; nor is this calculation fo vagne as it might at firt fight appear, fince the expences of improvements and ftock are very eafily eftiniated in both countries. This is the refolution of that furprifing inferiority in the rent of Jreland: the Englifh farmer pays a rent for his land in the ttate he finds it, which includes, not only the natural fertility of the foil, but the immenfe experditure which national wealth has in the progrefs of time poured into it; but the Irithman finds nothing he can afford to pay a rent for, but what the bounty of God has given, anaided by either wealth or induftry. The fecond point is of equal confequence-when the land is to be let, the rent it will bring muft depend on the capability of the cultivators to make it productive, if they have but half the capital they ought to be poffeffed of, how is it poffible they flould be able to offer a rent proportioned to the rates of a nother country, in which a variety of c? ufes bave long directed a ftream of abundant wealth into the purfes of her farmers?

Thefe facts call for one very obvious reflection, which will often recur in the progrefs of thefe papers : the confequen-

ces

incomplete, for there are very many parifies named, from which, tbrough negleq, no returns were made. I may remark that tbis fact is a frong confirmation of the truth of the data upon which I formed thefe calculations, tbe above fum coning vaftly nearer to the trutb afserwards afcertained by parliament, than any oiber calculation or conjeliure which over found its way into print.

The roads of England are a very beavy article; I conjecture much beavier then in Ireland, but I bave no data whereby to afcertain the amount. 
ces of it are felt in Ireland; but I am forry to lay, very ill underftood in England : that portion of national wealth which is employed in the improvement of the lands of a ftate is the beft employed for the general welfare of a courtry; while trade and manufactures, national funds, banking, \&c. fwallow up prodigious fums in England, but yield a profit of not above 5 to to per cent, the lands of Ireland are unimproved, upon which money would pay $\$ 5$ to 20 per cent. exclufive of a variety of advantages which muft ftrike the mott fuperficial reader.-Hence the vaft importance to England of the improvement of her Irifh territory. It is an old obfervation, that the wealth of Ireland will always center in England; and the fact is true, though not in the way commonly afferted:- No employment of 100 millions, not upon the actual foil of Britain, can ever pay her a tenth of the advantage which would refult from Ireland being in the above refpeets upon that par which I have defcribed with England: The more attentively this matter is confidered, I am apt to think the more clearly this will appear; and that whenever ofd illiberal jezloufies are worn out, which, thanks to the good fenfe of the age, are daily difappearing, we fhall be fully convinced, that the benefit of Ireland is fo intimatel $\neq$ connected with the good of England, that we thall be as forward to give to that hitherto unhappy country, as the can be to receive, from the firm conviction, that whatever we thus fow will yield to us a moft abundant harveft.

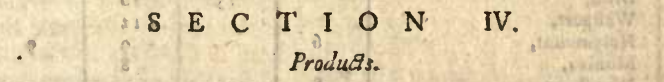

THE produets per acre were, in every place; an object of 1 my enquiries. The following table will at one view thew what they are in moft parts of the kingdom.

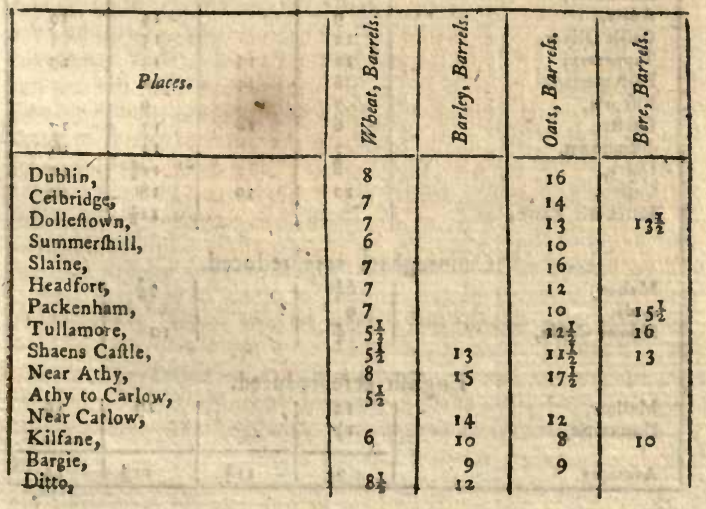


Bargy and Eorth, Wells,

Courtown,

M. Kennedy,

Kilrue,

Hampton,

Louth,

Mahon,

Ards,

Lecale,

Shaen: Caftle,

Newtown Limm.

Innifhoen,

Clonleigh,

Caftle Caldwell,

Belleifle,

Florence Court,

Farnham,

Longford,

Strolkeftown,

Ballymioat,

Mercra,

Tyrera,

Ditto,

Weftport,

Holymount,

Moniva,

Woodlawn,

Drumoland,

Anfgrove,

Mallow,

Dunkettle,

Adair,

Caftle Oliver,

Tipperary,

Ballycanvan,

Furnefs,

Glofter,

Johnftown,

Derry,

Cullen,

Mitchel's Town,

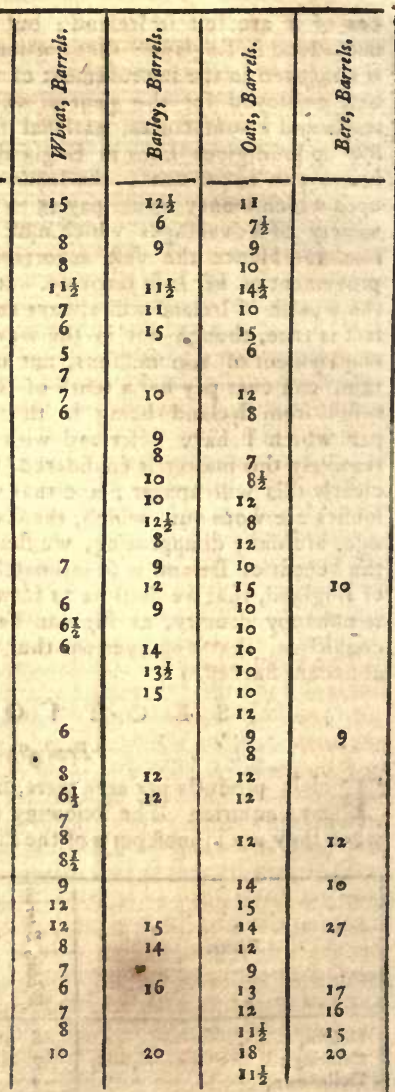

Mahon,

Ards,

Sbrens Calle,

Cunningham acre reduced.

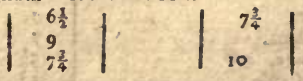

Englifh scre reduced.

Mollow,

Dunketile,

Averages,

\begin{tabular}{|l|l|l|l|}
12 & 19 & 19 \\
\hline $7 \frac{1}{2}$ & $-11 \frac{1}{2}$ & & \\
\hline $11 \frac{1}{2}$ & 14 \\
\hline
\end{tabular}




\section{T I L L A A G E.}

Thefe quantities per. Englifh acre are :

$\begin{array}{lccc} & \text { 2rs. } & \text { Bujp. } & \text { Pecks. } \\ \text { Wheat } & 2 & 2 & 3 \\ \text { Barley } & 3 & 4 & 3 \\ \text { Oats } & 3 & 4 & 3 \\ \text { Bere } & 4 & 3 & 0\end{array}$

The averages of the Farmer's Tour through the Eaft of England were:

$\begin{array}{cccc} & \text { 2rs. } & \text { Bufb. } & \text { Pecks. } \\ \text { Wheat } & 3 & 0 & 0 \\ \text { Barley } & 4 & 0 & 0 \\ \text { Oats } & 4 & 6 & 0\end{array}$

Of the Six Months Tour through the North of England:

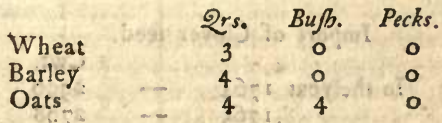

The produets upon the whole are much inferior to thofe of England, though not more fo than I fhould have expected; not from inferiority of foil, but the extreme inferiority of management. They are not to be confidered as points whereon to found a full comparifon of the two countries ; fince a fmall crop of wheat in England, gained after beans, clover, \&c. would be of much more iimportance than a larger one in Ireland by a fallow: And this remark extends to other crops.

Tillage in Ireland is very little underftood. In the greateft corn counties, fuch as Louth, Kildare, Carlow and Kilkenny. where are to be feenn many very fine crops of wheat, all is under the old fyitein, exploded by good farmers in England, uf fowing wheat upon a fallow, and fucceeding it with as many crops of fring corn as the foil will bear. Where they do bett by their land, it is only iwo of barley or oats before the fallow returns again, which is fomething worfe than the open field management in England, of 1 . fallow; 2. wheat; 3. oats; to which, while the fields are open and common, the farmers are by cruel neceffity tied down. The bounty on the inland carriage of corn to Dublin has increafed tillage very confiderably, but it has no where introduced any, other fystem. And to this extreme bad nanagement of adopting the exploded practice of a century ago, inftead of turneps and clover, it is owing. that Ireland, with a foil, acre for asre, much better than England, has its produets inferior. 
But keeping cattle of every fort, is a bufinefs fo much more adapted to the lazinefs of the farmer, that it is no wonder the tillage is fo bad. It is every where left to the cottars, or to the very pooreft of the farmers, who are all utterly unable to make thofe exertions, upon which alone a vigorous culture of the earth can be founded; and were, it not for potatoes, which neceffarily prepare for corn, there would not be half of what we fee at prefent. While it is in fuch hands, no wonder tillage is reckoned fo unprofitable; profit in all undertakings depends on capital, and is it any wonder that the profit fhould be fmall when the capital is pothing at all? Every man that has one gets into cattle, which will give him an idle, lazy, fuperintendence, inftead of an active attentive one.

That the fyftem of tillage has improved very little, much as it has been extended in the lalt fourteen years, there is great reafon to believe, from the very fmall increafe in the import of clover feed, which would have doubled and trebled, had tillage got into the train it ought. This the following table proves.

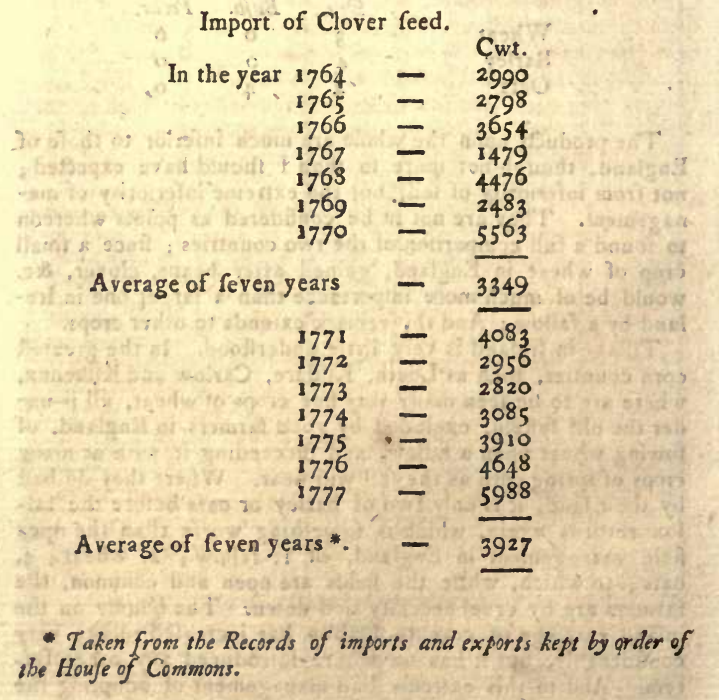




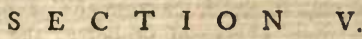 \\ Of the Tenantry of Ireland.}

$T$ has been probably owing to the fmall value of land in 1 Ireland before, and even through a confiderable part of the prefent century, that landlords became fo carelefs of the interelts of pofterity, as readily to grant their tenants leafes for ever. It might alfo be partly owing to the unfortunate civil wars, and other inteftine divifions, which for fo long a fpace of time kept that unhappy country in a ftate rather of devaftation than improvement. When a caftle, or a fortified houfe, and a family ftrong enough for a garrifon, were effentially neceffary to the fecurity of life and property among proteftants, no man could occupy land unlefs he had fubftance for defence as well as cultivation; thort, or even determinable tenures were not encouragement enough for fettling in fuch a fituation of warfare. To increafe the force of an eftate leafes for ever were given of lands, which from their wafte ftate were deemed of little value. The practice once become common, continued long after the motives which originally gave rife to it, and has nor yet ceafed entirely in any part of the kingdom. Hence, therefore, tenants holding large tracts of land under a leafe for ever, and which have been relet to a variety of under-tenants, muft in this enquiry be confidered as landlords.

The obvious diftinetion to be applied is, that of the occupying and unoccupying tenantry : in other words, the real farmer, and the middle man. The very idea, as well as the practice, of permitting a tenant to relet at a profit rent, feems confined to the diftant and unimproved parts of every empire. In the highly cultivated counties of England the practice has no exiftence, but there are traces of it in the extremities; in Scotland it has been very common; and I am informed that the fame obfervation is parily applicable to France. In proportion as any country becomes improved the practice neceffarily wears out.

It is in Ireland a queftion greatly agitated, whether the fyftem has or has not advantages, which may yet induce a landlord to continue in it. The friends to this mode of letting lands contend, that the extreme poverty of the lower claffes renders them fuch an infecure tenantry, that no gentleman of fortune can depend on the leaft punctuality in the payment of rent from fuch people; and therefore to let a large farm to fome intermediate perfon of fubftance, at a lower rent, in order that the prefit may be his inducement and reward for becoming a collector from the immediate occupiers, and anfwerable for their punctualiy, becomes neceffary to any perfon. who will not fubnit to the drudgery of fuch a minute attention. Alfo, that fuch a man will at leaft improve a fot around Vor.II. 
his own refidence, whercas the mere cottar can do nothing. If the internediate tenant is, or from the accumalation of feveral farms becomes, a man of property, the fame argument is applicable to his reletting to another intermediate man, giving up a part of his profit to efcape that trouble, which induced the landlord to begin this fyitem, and at the fame time accounts for the number of tenants, one under another, who have all a profit out of the rent of the occupying farmer. In the variety of converfations on this point, of which I have partook in Ireland, I never heard any other arguments that had the leaf foundation in the actual fate of the country; for as to ingenious theories, which relate more to what might be, than to what is, little regard fhould be paid to them.

That a man of fubftance, whofe rent is not only fecure, but regularly paid, is in many refpects a more eligible tenant than a poor cottar, or little farmer, cannot be difputed, if the landlord looks no farther than thofe circumftances the queftion is at an end, for the argument nut be allowed to have its full weight even to victory. But there are many other confidera. tions: I was particularly attentive to every clafs of tenants throughout the kingdom, and thall therefore defcribe thefe middle men, from whence their merit may be the more eafily decided. Sometimes they are refident on a part of the land, but very often they are not. Dublin, Bath, London, and the country towns of Ireland, contain great numbers of them; the merit of this clafs is furely afcertained in a moment; there cannot be a fhadow of a pretence for the intervention of a man, whofe fingle concern with an eftate is to deduct a portion from the rent of it. They are however fometimes refident on a part of the land they hire, where it is natural to fuppofe they would work fome improvements; it is however very rarely the cafe. 1 have in different parts of the kingdom feen farms juft fallen in after leafes of three lives, of the duration of fifty, fixty, and even feventy years, in which the refidence of the frincipal tenant was not to be diftinguifhed from the cottared fields furrounding it. I was at firft much furprized at this, but after repeated obfervation, I found thefe men very generally were the mafters of packs of wretched hounds, with which they wafted their time and money, and it is a notorious fact, that they are the hardeft drinkers in Ireland. Indeed the clafs of the finall country gentlenzen, chiefly confiting of thefe profit renters, feem at prefent to monopolize that drink. ing fpirit, which was, not many years ago, the difgrace of the kingdom at large: this I conjecture to be the reafon why thofe who might improve are fo very far from doing it; but there are ftill greater objections to them.

Living upon the fpot, furrounded by their litle undertenants, they prove the noft oppreffive fpecies of tyrant that ever lent affiftance to the deftruction of a ccuntry. They selet the land, at fhort tenures, to the occupiers of fmall farms; and often give no leafes at all. Not fatisfied with ferewing 
up the rent to the uttermott farthing, they are rapacious and relentlefs in the collection of it. Many of them have defended themfelves in converfation with me, upon the plea of taking their rents, partly in kind, when their undertenants are much diftreffed: "What," fay they, " would the head landlord, " fuppofe hin a great nobleman, do with a miferable cottar, "who, difappointed in the fale of a heifer, a few barrels of " corn, or firkins of butter, brings his five inftead of his ten "guineas? But we can favour him by taking his commodities " at a fair price, and wait for reimburfement until the market " rifes. Can my lord do that ?" A very common plea, but the moft unfortunate that could be ufed to any one whoever remarked that portion of human nature which takes the garb of an Irith land jobber ! For upon what iffue does this remark place the queftion? Does it not acknowledge, that calling for their rents, when they cannot be paid in cafh, they take the fubftance of the debtor at the very moment when he can not fell it to another Can it be neceffary to ank what the price is? It is at the option of the creditor and the miferable culprit meets his oppreflion, perhaps his ruin in the very action that is trumpeted as a favour to him. It may feem harih to attribute a want of feeling to any clafs of men; but let not the reader milapprehend me; it is the fruation, not the man, that I condemn. An injudicious fyftem piaces a great number of perfons, not of any liberal rank in life, in a ftate abounding with a variety of opportunities of oppreffion, every act of which is profitable to themfelves. I am afraid it is human nature for men to fail in fuch poits; and I appeal to the experience of mankind, in other lines of life, whether it is ever found advantageous to a poor debtor to fell his products, or wares, to his richer creditor, at the moment of demand.

But farther; the dependance of the occupier on the refident middle man goes to other circumftances, perfonal fervice of themfelves, their cars and horfes, is exacted for leading turf, hay, corn, gravel, \&c. infomuch that the poor undertenants often lofe their own crops and turf, from being obliged to obey thefe calls of their fuperiors. Nay, I have even heard thefe jobbers gravely affert, that without undertenants to furnifh cars and teams at half or two-thirds the common price of the country, they could carry on no inprovements at all; yet taking a merit to themfelves for works wrought out of the fweat and ruin of a pack of wretches, affigned to their plunder by the inhumanity of the landholders.

In a word, the cafe is reducible to a fhort compafs; intermediate tenants work no improvements; if non-refident they cannot, and if refident they do not; but they opprers the occupiers, and render them as incapable as they are themfelves unwilling. The kingdom is an aggregate proof "of thefe facts; for if long leafes, at low rents, and profit incomes 
given, would have improved it, Ireland had long ago been a garden. It remains to enquire, whether the landlord's fecurity is a full recompence for fo much mifchief.

But here it is proper to obferve, that though the intermediate man is generally better fecurity than the little occupier; yet it is not from thence to be concluded, as I have often heard it, that the latter is beyond all comparifon beneath him in this refpect: the contrary is often the cafe; and 1 have known the fact, that the landlord, difappointed of his rent, has drove (diftrained) the undertenants for it at a time when they had actually paid it to the middle man. If the profit rent is fpent, as it very generally is in claret and hounds, the notion of good fecurity will prove vifionary, as many a landlord in Ireland has found it : feveral very confiderable ones have affured me, that the little occupiers were the beft pay they had on their eftates; and the intermediate gentlemen tenants by much the wor $f$.

By the minutes of the journey it appears, that a very confiderable part of the kingdom, and the moft enlightened landlords in it, have difcarded this injurious fyftem, and let their farms to none but the occupying tenantry; their experience has proved, that the apprehenfion of a want of fecurity was merely ideal, finding their rents much better paid than ever. At the laft extremity, it is the occupier's ftock which is the teal fecurity of the landlord. It is that he diftrains, and finds abundantly more valuable than the laced hat, hounds ard piftols of the gentleman jobber, from whom he is more likely in fuch 2 cafe to receive a me $\int a g e$, than a remittance.

And here let me obferve, that a defence of intermediate tenants has been founded upon the circumftance of leffening the remittance of abfentee rents; the profit of the middle man was fpent in Ireland; whereas upon his difmiffion the whole is renitted to England. I admit this to be an evil, but it appears to be in no degree proportioned to the mifchiefs I have dwett on. It is always to be remembered, that in the arrangement of landed property, the produce is the great objeet; the fyitem of letting, which encourages moft the occupying tenant, will always be the mot advantageous to the comnunity. I think $\mathbf{I}$ have proved that the middle man oppreffes the cottar, inconiparably more than the principal landlord; to the one he is ufually tenant at will, or at leaft under fhort terms, but under the other has the moft advantageous tenure. This fingle point, that the perfon moft favoured is in one inftance an idle burthen, and in the other the induftrious occupier, fufficiently decides the fuperiority. To look therefore at the rent, after it is paid, is to put the queftion on a wrong iffue; the payment of that rent, by means of ample products, arifing from animated induftry, is the only point deferving attention; and I had rather the whole of it thould go to the antipodes, than exact it in a manner that thall cramp that induftry, and leffen thofe products. 
When therefore it is confidered, that no advantages to the eftate can arife from a non-refident tenant, and that a refident intermediate one improves no more than the poor occupiers who are prevented by his opprefisons, that the landlord often gains little or nothing in fecurity from employing them, but that he fuffers a prodigious deduction in his rental for mere expectations, which every hour's experience proves to be delufive. When thefe faets are duly weighed, it is prefumed, that the gentlemen in thofe parts of the kingdom, which yet groans under fuch a fyftem of abfurdity, folly and oppreffion, will follow the example fet by fuch a variety of intelligent landlords, and be deaf to the deceitful afleverations with which their ears are affailed, to treat the anecdotes retailed of the cottar's poverty, with the contempt they deferve, when coming from the mouth of a jobber; when thefe bloodfuckers of the poor tenantry boaft of their own improvements, to open their eyes and view the ruins which are dignified by fuch 2 term, and finally determine, as friends to themfelves, to their pofterity and their country, TO LET THEIRESTATES TO NONE BUT THE OCCUPYING TENANTRY.

Having thus defcribed the tenants that ought to be rejected, let me next mention the circumftances of the occupiers. The variety of thefe is very great in Ireland. In the North, where the linen manufacture has fpread, the farms are fo fmall, that ten acres in the occupation of one perfon is a laige one, five or fix will be found a good farm, and all the agriculture of the country fo entirely fubfervient to the manufacture, that they no more deferve the name of farmers than the occupier of a mere cabbage garden. In Limerick, Tipperary, Clare, Meath and Waterford, there are to be found the greateft graziers and cow-keepers perhaps in the world, fome who rent and occupy from $3000 \mathrm{l}$. to 10,0001 . a year: thefe of courfe are men of property, and are the only occupiers in the kingdom, who have any confiderable fubitance. The effects are not fo beneficial as might be expected. Rich graziers in England, who have a little tillage, ufually manage it well, and are in other refpects attentive to various improvements, though it mutt be confeffed not in the fame proportion with great arable farmers; but in Ireland thefe men are as errant Dovens as the moft beggarly cottars. The rich lands of Limerick are in refpect of fences, drains, buildings, weeds, \&c. in as wafte a fate as the mountains of Kerry ; the fertility of nature is fo little feconded, that few tracts yield lefs pleafure to the fpectator. From what I obferved, I attributed this to the idlenefs and diffipation fo general in Ireland. Thefe graziers are too apt to attend to their claret as much as their bullocks, live expenfively, and being enabled, from the nature of their bufinels, to pals nine-tenths of the year without any exertion of induftry, contract fuch a habit of eafe, that works of improvement would be nortifying to their noth. 
In the arable counties of Louth, part of Meath, Kildare, Kilkenny, Carlow, Queen's, and 'part of King's, and Tipperary, they are much more induftrious. It is the nature of tillage, to raife a more regular and animated attention to bufinefs; but the farms are too finall, and the tenants too poor, to exhibit any appearances that can ftrike an Englifh traveller. They have a great deal of corn, and many fine wheat crops; but being gained at the expence and lofs of a fallow, as in the open fields of England, they do not fuggett the ideas of profit to the individual, or advantage to the ftate, which worfe crops in a well appointed rotation would do. Their manuring is trivial, their tackle and implements wretched, their teams weak, their profit imall, and their living little better than that of the cottars they employ. Thefe circumftances are the neceffary refult of the fmallnefs of their capitals, which even in thefe tillage counties do not ufually amount to a third of what an Englifh farmer would have to manage the fame extent of land. The leafes of thefe men are ufually three lives to proteftants, and thiriy-one years to catholics.

The tenantry in the more unimproved parts, fuch as Corke, Wicklow, Longford, and all the nouncainous counties, where it is part tillage, and part pafturage, are generally in a very backward ftate. Their capitals are finaller than the clafs I juft mentioned, and among them is chiefly found the practice of many poor cottars hiring large farms in partnerihip. They make their rents by a little butter, a little wool, a little corn, and a few young cattle and lambs. Their lands at extreme low rents, are the moft unimproved, (mountain and bog excepted;) in the kingdom. They have, however, more induftry than capital; and with a very little management, might be brought greatly to improve their hußbandry. I think they hold inore generally from intermediate tenants than any other fet; one reafon why the land they occupy is in fo wafte a ftate. In the mountainous traets, I faw inftances of greater induftry than in any other part of Ireland. Little occupiers, who can get leafes of a mountain fide, make exertions in improvement, which, though far enough from being complete, or accurate, yet prove clearly what great effests encouragement would have among them.

In the King's county, and allo in fome other parts, I faw many tracts of land, not large enough to be relet, which were occupied under leafes for ever, very well planted and improved by men of fubftance and induftry.

The poverty, common among the fmall occupying tenantry, may be pretty well afcertained from their general conduet in hiring a farm. They will manage to take one with a fum furprizingly finall; they provide labour, which in England is fo confiderable an article, by affigning portions of land to cottars for their potatoe gardens, and keeping one or two cows 
for each of them. To leffen the live ftock neceffary, they will, whenever the neighbourhood enables them, take in the cattle at fo much per month, or feafon, of any perfon that is deficient in pafturage at home, or of any labourers that have no land. Next, they will let out fome old lay for grafs potatoes to fuch labourers; and if they are in a county where corn acres are known, they will do the fame with fome corn land. If there is any meadow on their farm, they will fell a part of it as the hay grows. By all thefe means the neceflity of 2 full ftock is very much leffened, and by means of living themfelves in the very pooreft manner, and converting every pig, fowl, and even egg into carh, they will make up their rent, and get by very low degrees into fomewhat better circumftances. Where it is the cuftom to take in partnerfhip, the difficulties are eafier got over, for one man brings a few theep. another a cow, a third a horfe, a fourth a car and fome feed potatoes, a fifth a few barrels of corn, and fo on, until the farm among them is tolerably ftocked, and bands upon it in plenty for the labour.

But it is from the whole evident, that they are uncommon mafters of the art of overconing difficulties by patience and contrivance. Travellers, who take a fuperficial view of them are apt to think their poverty and wretchednefs, viewed in the light of farmers, greater than they are. Perbaps there is an impropriety in confidering a man merely as the occupier of fuch a quantity of land, and that inftead of the land, his capital fhould be the object of contemplation. Give the farmer of twenty acres in England no more capital than his brother in Ireland, and I will venture to fay he will be much poorer, for he would be utterly unable to go on at all.

I Thall conclude what I have to fay upon this fubject, with fating, in few words, what I think would prove a very advantageous conduct in landlords towards the poor tenantry of the kingdom, and I thall do this with the greater readinefs, as I fpeak not only as a paffing traveller, but from a year's refidence among feveral hundred tenants, whofe circumftances and fituation I had particular opportunities of obferving.

Let me remark, that the power and influence of a refident landlord is fo great in Ireland, that whatever fyftem he adopts be it well or ill imagined, he is much more able to introduce and accomplifh it than Englifhmen can well have an idea of; confequently, one may fuppofe him to determine more authoritatively than a perfon in a fimilar fituation in this kingdom could do. The firftobjeet, is a fettled determination never to be departed from, to let his farms only to the immediate occupier of the land, and to a void deceit not to allow a cottar, herdfman, or fteward, to have more than three or four acres on any of his farms. By no means to reject the little occupier of a few acres from being a tenant to himfelf, rather, than annex his land to a larger fpot. Having by this previous ftep, eafed thefe inferior tenantry of the burden of the interme- 
diate man, let him give out, and fteadily adhere to it, that he fhall infift on the regular and punctual payment of his rent, but thall take no perfonal fervice whatever. The meaneft occupier to have a leale, and none fhorter than twenty-one years, which I am inclined alfo to believe is long cnough for his adyantage. There will arife, in fpite of his tendernefs, a neceflity of fecuring a regular payment of rent: I would advife him to diftrain without favour or affection, at a certain period of deficiency. This will appear harfh only upon a fuperficial confideration. The object is to eftablifh the fyftem, but it will fall before it is on its legs, if founded on a landlord's forgiving arrears, or permitting them to encreafe. He need not be apprehenfive, fince they, who can under difadvantages, pay the jobber, can certainly pay the landlord himfelf, when freed from thofe incumbrances. At all events, let him perfift in this firmnefs, though it be the ruin of a few ; for he muft remember, that if he ruins five, he affuredly faves ten: he will, it is true, know the fall of a few, but many with an intermediate tenant might be deftroyed without his knowing it. Such a fteady regular conduct would infallibly have its effect, in animating all the tenantry of the eftate to exert every nerve to be punctual; whereas favour thewn now and then would make every one, the leaft inclined to remiffnefs, hope for its exertion towards himfelf, and every partial good would be attended with a diffufive evil; exceptions however to be made for very great and unavoidable misfortunes, clearly and undoubtedly proved. This ftern adminiftration on the one hand fhould be accompanied on the other with every fpecies of encouragement to thofe, who fhewed the leaft difpofition 10 improve; premiums fhould be given, rewards adjudged, difficulties impothed, and notice taken, in the moft flattering manner, of thofe whofe conduct merited it. I fhall in another part of thefe papers point out, in detail, the advantageous fyftems; it is here only requifite to obferve, that whatever novelties a landlord wifhes to introduce, he hould give feed gratis, and be at a part of the expence, promifing to be at the whole lors, if he is well fatistied it is really incurred. From various obfervations I am convinced, that fuch a conduct would very rarely prove unfuccefsful. The profit to a landlord would be immenfe; he would in the courfe of a leafe find his tenartry paying a bigh rent, with greater eafe to themfelves, than they before yielded a low one.

A few confiderable landlords, many years ago, made the experiment of fixing, at great expence, colonies of palatines on their eftates. Some of them I viewed, and made many enquities. The fcheme did not appear to me to anfwer. They had houfes built for them; plots of land affigned to each at a rent of favour, affifted in ftock, and all of them with leafes for lives from the head landiord. The poor Irifh are very rarely 
treated in this manner; and when they are, they work much greater improvements than common among thefe Germans : witnefs Sir William Obborne's mountaineers! a few beneficial practices were introduced, but never travelled beyond their own farms; they were viewed with eyes too envious to allow them to be patterns, and it was human nature that it fhould be fo: but encourage a few of your own poor, and if their practices thrive they will fpread. I am convinced no country, whatever ftate it may be in, can be improved by colonies of foreigners, and whatever foreigner, as a fuperintendant of any great improvement, afks for colonies of his own countrymen to execute his ideas, manifefts a mean genius and but little knowledge of the human heart; if he has talents he will find tools wherever he finds men, and make the natives of, the country the means of encreafing their own happinefs. Whatever he does then, will live and take root; but if effected by foreign hands, it will prove a fickly and fhort lived exotic; brilliant perhaps, for a time, in the eyes of the ignorant, but of no folid advantage to the country that employs him.

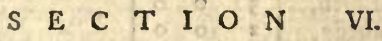 of Of the Labouring Puor.}

SUCH is the weight of the lower claffes in the great fcale $S$ of national importance, that a traveller can never give too much attention to every circumftance that concerns them; their weliare forms the broad bafis of public profperity; it is they that feed, cloath, enrich, and fight the battles of all the other ranks of a coinmunity; it is their being able to fupport thefe various burthens without oppreffion, which conftitutes the general felicity ; in proportion to their eafe is the ftrength and wealth of nations, as public debility will be the certain attendant on their mifery. Convinced that to be ignorant of their ftate and fituation, in different countries, is to be deficient in the firft rudiments of political knowledge. I have upon every occafion, made the neceffary enquiries, to get the beft information circumftances would allow me. What paffes daily, and even hourly, before our eyes, we are very aps entirely to overlook ; hence the furprizing inattention of $\mathrm{va}$. rious people to the food, cloathing, poffeffions and ftate of the poor, even in their own neighbourhood; many a queftion have I put to gentlemen upon thefe points, which were not anfwered without having recourfe to the next cabbin; a fource of information the more neceffary, as I found upon various occafions, that fome gentlemen in Ireland are infelled with the rage of adopting fyfems as well as thofe of England: with one party the poor are all ftarving, with the other they are deemed in a very tolerable fituation, and a third, who look with an evil eye on the adminiftration of the Britih government, are fond of exclaiming at poyerty and rags, as proofs of the cruel 
ment of Ireland. When truth is likely to be thus warped, a traveller muft be very circumfpect to believe, and very affiduous to fee.

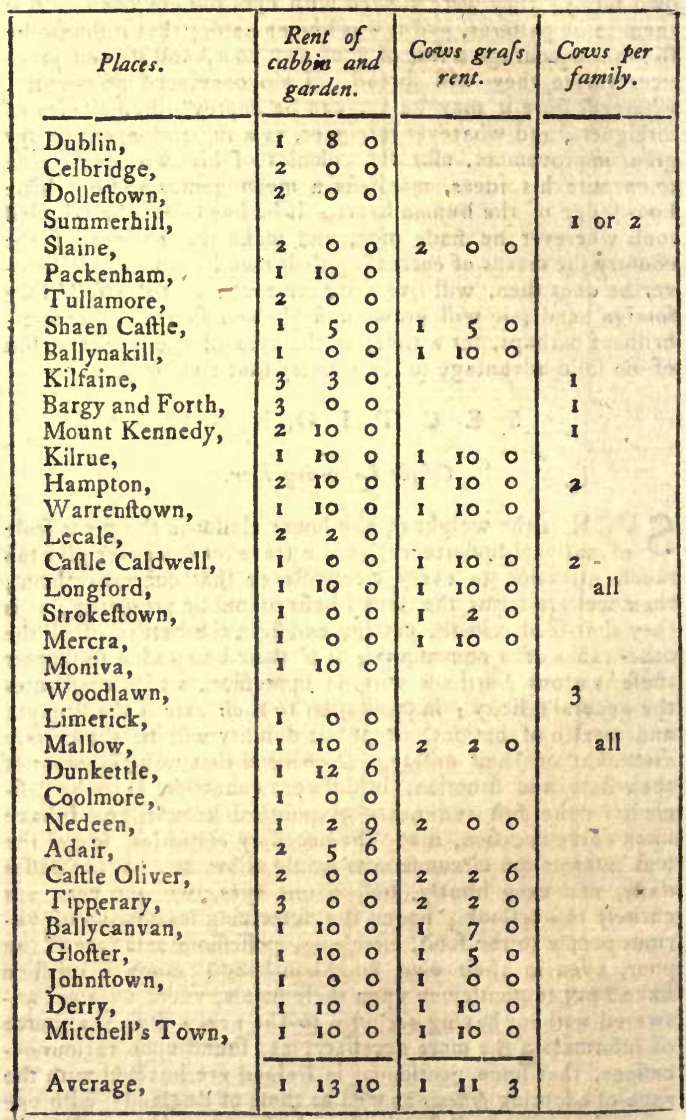


From the minutes of the journey it will be found, that there is no determinate quantity of land for the potatoe garden; it is ufually an acre; fometimes half an acre, and fometimes one acre and a half; but according to the foit, that quantity which is underttood (right or wrong) to be neceffary, is called the garden. The grafs for a cow is for the green food only, the cotter himfelf finds or buys hay. From the blanks in the number of cows it is not to be implied that they have none, but that the information was not receired.

But it is neceffary here to explain the common cottar fyitem of labour in Ireland, which much refembles that of Scotland until very lately, and which was probably the fame all over Europe before arts and commerce changed the face of it. If there are cabbins on a farm they are the refidence of the cottars, if there are none the farmer marks out the potatoe gardens, and the labourers, who apply to him on his hiring the land, raife their own cabbins on fuch fpots; in fome places the farmer builds ; in others he only afiits them with the roof, $\&$ c. a verbal compaet is then made, that the new cotter fhall. have his potatoe garden at fuch a rent, and one or two cows kept him at the price of the neighbourhood, he finding the cows. He then works with the farmer at the rate of the place, ufually fixpence halfpenny a day, a tally being kept (half by each pariy) and a notch eut for every day's labour : at the end of fix months, or a year, they reckon, and the balance is paid. The cotter works for himfelf as his potatoes require.

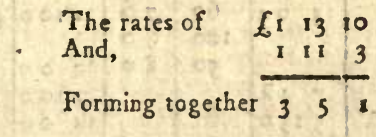

for milk and potatoes appear to be very reafonable; if two cows are kept, it is only 4 l. $16 \mathrm{~s}$. $4 \mathrm{~d}$. from whence it is evident, as far merely as this charge goes, there is no oppreffion upon them which can ever amount to ftarving. In particular inftances, where therc is much inhumanity in the greater tenants, they are made to pay too high a rent for their gardens; and though the price, at which their cows are fupported, may not appear high, yet they may fo poorly kept as to make it very unreafonable. I believe, from what I faw, that fuch infances are not uncommon. 


\begin{tabular}{|c|c|c|c|c|c|c|}
\hline Places. & $\begin{array}{l}\text { Expence } \\
\text { per acre. }\end{array}$ & $\begin{array}{l}\text { Produc } \\
\text { Barrels. }\end{array}$ & $\begin{array}{c}\text { Price } \\
\text { per } \\
\text { Barrel. }\end{array}$ & $\begin{array}{l}\text { Produce } \\
\text { value. }\end{array}$ & $\begin{array}{l}\text { Prime } \\
\text { coft. }\end{array}$ & $\begin{array}{l}\text { Rent } \\
\text { potatoe } \\
\text { ground. }\end{array}$ \\
\hline bhlin & & & ta & & & \\
\hline Ige, & & 100 & 50 & & & 800 \\
\hline Dolleftown, & 15150 & $\begin{array}{l}60 \\
80\end{array}$ & $F^{\prime}$ & 15150 & 50 & $\begin{array}{lll}5 & 12 & 6 \\
6 & 3 & 0\end{array}$ \\
\hline in Caftle, & $12 \quad 40$ & 64 & 36 & II 40 & 40 & 4100 \\
\hline $\begin{array}{l}\text { dfort, } \\
\text { renhar }\end{array}$ & 10100 & $\begin{array}{l}85 \\
80\end{array}$ & & & 26 & $\begin{array}{lll}4 & 10 & 0 \\
5 & 0 & 0\end{array}$ \\
\hline allingar to Tul- & & & & & & \\
\hline $\begin{array}{l}\text { lefpace, } \\
\text { Tullimore, }\end{array}$ & & 60 & & & & 600 \\
\hline eral Walfh, & & 176 & & & & \\
\hline $\begin{array}{l}\text { Near Aiby, } \\
\text { Ballynakill, }\end{array}$ & 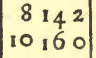 & $\begin{array}{l}80 \\
60\end{array}$ & $\begin{array}{l}34 \\
46\end{array}$ & 1370 & $\begin{array}{ll}2 & 2 \\
3 & 6\end{array}$ & \\
\hline$e$ & 540 & $\begin{array}{l}40 \\
80\end{array}$ & & & & \\
\hline dpect, & & 45 & 50 & & & \\
\hline $\begin{array}{l}\text { nftown, } \\
\text { Caftle, }\end{array}$ & & $\begin{array}{l}40 \\
87\end{array}$ & & & & \\
\hline Lefy Hill, & $7 \quad 70$ & 80 & 40 & 1600 & 110 & \\
\hline North of ditto, & 856 & 75 & 40 & 1500 & $20 \frac{1}{2}$ & \\
\hline $\begin{array}{l}\text { Newton Lir } \\
\text { dy, }\end{array}$ & & & & 1000 & & \\
\hline Florence court, & $\begin{array}{lll}7 & 7 & 5\end{array}$ & & & 12160 & & \\
\hline $\begin{array}{l}\text { ham, } \\
\text { gford, }\end{array}$ & $13 \circ 4$ & $\begin{array}{r}60 \\
120\end{array}$ & $\begin{array}{l}70 \\
80\end{array}$ & 22100 & 144 & \\
\hline tov & & 50 & 80 & 2000 & & 550 \\
\hline Apert, & $\begin{array}{rrr}7 & 4 & 4 \\
5 & 13 & 0\end{array}$ & & 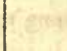 & 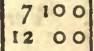 & & 500 \\
\hline sount, & & & & & & 3150 \\
\hline awn. & & $\begin{array}{l}50 \\
60\end{array}$ & $\begin{array}{l}40 \\
40\end{array}$ & $\left|\begin{array}{lll}10 & 0 & 0 \\
12 & 0 & 0\end{array}\right|$ & & \\
\hline land. & & 100 & & & & \\
\hline Ifgrove, & & & & & & 1176 \\
\hline itle, & & $\begin{array}{l}42 \\
50\end{array}$ & & & & 4150 \\
\hline e Martyr, & 640 & $\begin{array}{l}70 \\
50\end{array}$ & 30 & 10100 & 19 & \\
\hline , & & 60 & 80 & 2400 & & 6.66 \\
\hline $\begin{array}{l}\text { Caftle Oliver, } \\
\text { Tipperary, }\end{array}$ & $15 \quad 32$ & $\begin{array}{r}150 \\
90 \\
60\end{array}$ & $\begin{array}{l}40 \\
50\end{array}$ & 3000 & 20 & $\begin{array}{lll}4 & 10 & 0 \\
6 & 0 & 0\end{array}$ \\
\hline & 1400 & 100 & 50 & 1500 & & \\
\hline Ater, & 1152 & 100 & 34 & 16134 & 23 & \\
\hline town, & 1106 & 90 & 40 & 1800 & 25 & 700 \\
\hline & & 35 & & & & 450 \\
\hline $\begin{array}{l}\text { Cullen, } \\
\text { Michelftown, }\end{array}$ & $\mid \begin{array}{rrr}10 & 11 & 8 \\
6 & 07\end{array}$ & $\begin{array}{r}120 \\
60\end{array}$ & $\begin{array}{l}30 \\
44\end{array}$ & $\begin{array}{lll}18 & 0 & 0 \\
13 & 0 & 0\end{array}$ & $\mid \begin{array}{ll}1 & 2 \\
2 & 0\end{array}$ & \\
\hline
\end{tabular}


P O T A T O E S.

Cunninghan Acre reduced.

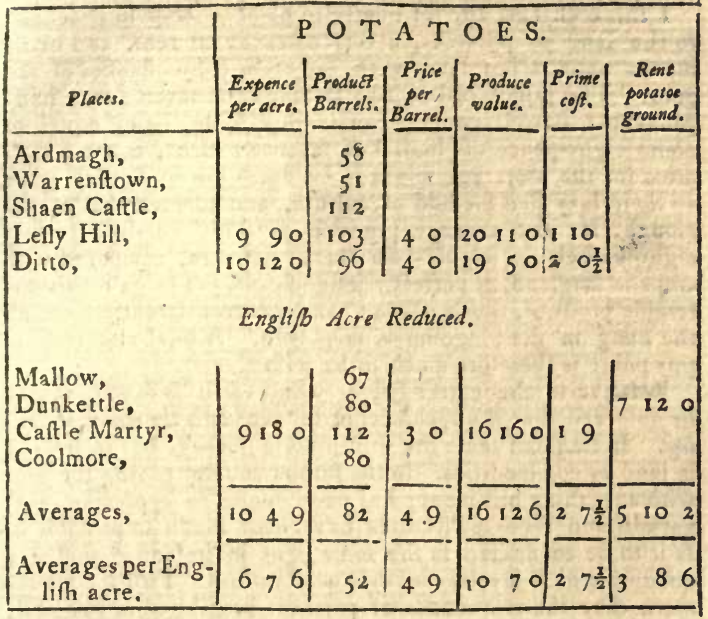

Thefe tables together will enable the reader to have a pretty accurate idea of the expences at which the poor in Ireland are fed. The firit column is the total expence of an acre of potatoes, the third is the price at which potatoes are bought and fold, for feed, or food. The prime coft is the price formed by the firt and fecond columns, being the rate at which they are eaten by thofe who raife them. The laft column requires rather more explanation to thofe who were never in that country. There are a great many cabbins, ufually by the road fide, or in the ditch, which have no potatoe gardens at all. Ireland being free from the curfe of Englifh poor.laws, the people move about the country and fettle where they will. A wandering family will fix themfelves under a dry bank, and with a few fticks, furze, fern, \&c. make up a hovel much worfe than an Englifh pigftie, fupport theinfelves how they can, by work, begging and ftealing; if the neighbourhood wants hands, or takes no notice of them, the hovel grows into a cabbin. In my rides about Mitchelitown, I have paffed places in the road one day, without any appearance of a habitation, and next morning found a hovel, filled with a man and woman, fix or eight children, and a pig. Thefe people are not kept by any body as cottars, but are taken at bufy feafons by the day or week, and paid in money, confequently having no potatoe garden, they are neceffitated every year, to hire a fpot of fome neighbouring farmer, and of the preceding table, the laft column, is the rent per acre paid 
for it. The cabbins in little towns are in the fame fituation.

I think 5l. 1 os. -2 d. for liberty to plant a crop fo beneficial to the land as potatoes, a very extravagant rent, and by no means upon a fair level with the other circumftances of the poor. The prime coft of two thillings and feven prence halfpenny per barrel, generally of twenty ftone, being equal to about eight-pence the bufhel of feventy pounds, is not a high price for the root, yet might it be much lower, if they gave up their lazy bad method of culture, and adopted that of the plough, for the average produce of three hundred twenty eight bufhels, or eighty-two bariels per acre, compared with crops in England, is perfeetly infignificant, yet to gain this miferable produce, much old lay, and nineteen-twentieths of all the dung in the kingdom is employed. A total alteration in this point is therefore much to be wilhed.

Relative to the cottar fyftem wherever it is found, it may be obferved that the recompence for labour is the means of living. In England thefe are difpenfed in money, but in Ireland in land or commodities. In the former country paying the poor with any thing but money has been found fo oppreflive, that various and repeated ftatutes have been made to prohibit it. Is it to be confidered in the fame light in Irtiand? this is a queftion which involves many confiderations. Firft let me remark that the two modes of payment prohibited in England, but common in Ireland, are not exactly the fame, though upon fimilar principles. In England it is the payment of manufacturing labourers in neceftaries, as bread, candles, foap, \&c. In Ireland it is a quantity of land for the fupport of a labourer a year. The former, it muft ftrike every one, is more open to abufe, involving more complex accounts than the latter. The great queftion is, which fyftem is moft advantageous to the poor family, the payment to be in land for potatoes and milk, or in money, fuppofing the payment to be fairly made: here lies the difcuffion.

On one band the Irifh labourer in every circumftance which gives him any appearance of plenty, the poffeffion of cattle is fubjected to chances which muft be heavy in proportion to his poverty; ill fed cattle, we know from the experience of Englith commons are very far from being fo advantageous to a man as they firft feem; accidents happen without a refource to fupply the lofs, and leave the man much worfe than him who being paid in money is independant of fuch events. But to reverfe the medal, there appear advantages, and very. great ores by being paid in land, he has plenty of articles of the utmoft importance to the fuftenance of a family, potatoes and milk. Generally fpeaking the Irifh poor have a fair belly full of potatoes, and they have milk the greateit part of the year. What I would particularly infift on here is the value of his labour being food not money; food not for himfelf only, but for his wife and children. An Irifhman loves whilkey as well 
as an Englifhman does ftrong beer; but he cannot go on $\mathrm{Sa-}$ turday night to the whikey houfe, and drink out the week's fupport of himfelf, his wife and his children, not uncommon in the ale-houfe of the Englifhman. It may indeed be faid that we thould not argue againft a mode of payment becaufe it may be abufed, which is very true, but we certainly may reafon againt that which carries in its very principles the feed of abufe. That the Irifhman's cow may be ill fed is admitted, but ill fed as it is, it is better than the no cow of the Englithman; the children of the Irifh cabbin are nourifhed with milk, which, fmall as the quantity may be, is far preferable to the beer or vile tea which is the beverage of the Englifh infant, for no where but in a town is milk to be bought. Farther, in a country where bread, cheefe or meat are the common food, it is confumed with great ceconomy, and kept under lock and key where the children can have no refort; but the cafe with potatoes is different, they are in greater plenty, the children help themfelves; they are fcarce ever feen about a cabbin-without being in the act of eating them, it is their employment all day long. Another circumitance not to be forgotten, is the regularity of the fupply. The crop of potatoes, and the inilk of the cow is more regular in Ireland than the price at which the Englifhman buys his food. In England complaints rife even to riots when the rates of provifions are high; but in Ireland the poor have nothing to do with prices, they depend not on prices, but crops of a vegetable very regular in its produce. Attend the Englifh labourer when he is in ficknefs, be mutt then have refort to his favings, but thofe will be nought amang nine-tenths of the poor of a country that have a legal dependance on the parifh, which therefore is the beft off, the Englifhman fupported by the parifh, or the Irithman by his potatoe-bed and cow?

Money I am ready enough to grant has many advantages, but they depend almoft entirely on the prudence with which it is expended. They know little of the human mind who fuppofe that the poor man with his feven or eight fhillings on a Saturday night has not his temptations to be imprudent as well as his fuperior with as many hundreds or thoufands a year. He has his alehoufe, his brandy thop, and'fkittle ground, as nuch as the other his ball, opera or mafquerade. Examine the ftate of the Englioh poor, and fee if facts do not co-incide here with theory; do we not fee numbers of half ftarved, and half cloathed families owing to the fuperfluities of ale and brandy, tea and fugar. An Irihman cannot do this in any degree, he can neither drink whifkey from bis potatoes, nor milk it from his cow.

But after all that can be faid on this fubject, the cuitom of both countries is confiftent with their refpective circumftances and fituations. When great wealth from immenfe branches of induftry has brought on a rapid circulation, and much of 
what is commonly called luxury, the more fimple mode of paying labour with land can fcarcely hold. It does not, however, follow that the poor are in that refpect better off, othet advantages of a different kind attend the evils of fuch a fituation, among which, perhaps, the employment of the wife and all the children, are the greateft. In fuch a country, alfo markets and thops will be eftablifhed in every corner, where the poor may buy their neceffaries without difficulty; but in Ireland there are neither one nor the other; the labourer there with his pay in his pocket would find nothing readily but whilky.

I have gone into this enquiry in order to fatisfy the people of Ireland, that the mode there common of paying the labouring poor is confiftent with the fituation of the kingdom: whether it is good or bad, or better or worfe than that of England, it is what will neceffarily continue until a great encreafe of national wealth has introduced a more general circulation of money, they will then have the Englifh mode with its defects as well as its advantages.

\section{F O O D.}

The food of the common Irifh, potatoes and milk, have been produced more than once as an inftance of the extreme poverty of the country, but this I believe is an opinion embraced with more alacrity than reflection. I have heard it ftigmatized as being unhealthy, and not fufficiently nourifhing for the fupport of hard labour, but this opinion is very amazing in a country, many of whofe poor people are as athletic in their form, as robuft, and as capable of enduring labour as any upon earth. The idlenefs feen among many when working for thofe who opprefs them is a very contraft to the vigour and activity with which the fame people work when themfelves alone reap the benefit of their labour. To what country mutt we have recourfe for a ftronger inftance than lime carried by little miferable mountaineers thirty miles on horfes backs to the foot of their hills, and up the fteeps on their own. When I fee the people of a country in fpite of political oppreffion with well formed vigorous bodies, and their cottages fwarming with children; when I fee their men athletic, and their women beautiful, I know not how to believe them fubfifting on an unwholefome food.

At the fame time, however, that both reafon and obfervation convince me of the juftice of thefe remarks, I will candidly allow that I have feen fuch an excefs in the lazinefs of great numbers, even when working for themfelves, and fuch an apparent weaknefs in their exertions when encouraged to work, that I have had my doubts of the heartinefs of their food. But here arife frefh difficulties, were their food ever fo nourifhing I can eafily conceive an habitual inactivity of exertion would give them an air of debility compared with 2 
more induftrious people. Though my refidence in Ireland was not long enough to become a perfeet mafter of the queftion, yet I have employed from twenty to fifty men for feveral months, and found their habitual lazinefs or weaknefs fo great, whether working by meafure or by day, that I am abfoluteiy convinced is. 6d. and even 2s. 2 day in Suffolk or Hertfordfhire much cheaper than fixpence halfpenny at Mitchelftown : It would not be fair to confider this as a reprefentation of the kingdom, that place being remarkably backward in every fpecies of induftry and improvement ; but I am afraid this oblervation would hold true in 2 lefs degree for the whole. But is this owing to habit or food ? Granting their food to be the caufe, it decides very little againit potatoes, unlefs they were tried with good nourifhing beer inftead of their vile potations of whifky. When they are encouraged, or animate theinfelves to work hard, it is all by whifky, which though it has a notable effeet in giving a perpetual motion to their tongues, can haye but litle of that invigorating fubitance which is found in ftrong beer or porter, probably it has $2 \mathrm{n}$ effe $\theta$ as pernicious, as the other is beneficial. One circumitance I hould mention, which feems to confirm this: I have known the Irifh reapers in Hertfordithire work as laboriounly as any of our own men, and living upon potatoes which they procured from London, but drinking nothing but ale. If their bodies are weak I attribute it to whinky, not potatoes; but it is ftill a queftion with me whether their miferable working arifes from any fuch weaknefs, or from an habitual lazinefs. A friend of mine always refufed Irithmen work in Surrey, faying his bailiff could do nothing but fettle their quarrets.

But of this food there is one circumftance which muft ever recommend it, they have a belly full, and that let me add is more than the fuperfluities of an Englifhrnan leaves to his family : let any perfon examine minutely into the receipt and expenditure of an Englith cottage, and he will find that tea, fugar and ftrong liquors, can come only from pinched bellies. I will not affert that potatoes are a better food than bread and cheefe; but I have no doubt of a bellyfull of the one being much better than balf a bellyfull of the other; ftill lefs have I that the milk of the Irithman is incomparably better than the fmall beer, gin, or tea of the Englihman; and this even for the father, how much better muft it be for the poor infants; milk to them is nourifhment, is healtb, is life.

If any one doubts the comparative plenty, which attends the board of a poor native of England and Ireland, let him attend to their meals: the fparingnefs witb which our labourer eats his bread and cheefe is well known; mark the Irifhman's potatoe bowl placed on the floor, the wbole family upon their hams around it, devouring a quantity almoft incredible, the beggar feating himfelf to it with a bearty welcome, the pig taking his thare as readily as the wife, the cocks, hens, tur-

$$
\text { C kies, }
$$


kies, geefe, the cur, the cat, and perhaps the cow-and all partaking of the fame difh. No man can often have been a witnefs of it without being convinced of the plenty, and I will add the chearfulnefs, that attends it.

-Is it, or is it not a matter of confequence, for the great body of the people of a country, to fubfift upon that ipecies of food which is produced in the greateft quantity by the fmalleft fpace of land? One need only to ftate, in order to anfwer the queftion. It certainly is an object of the higheft confequence, what in this refpect is the comparifon between wheat or cheefe, or meat and potatoes?

The minutes of the journey will enable as to thew this.

No. 1. At Shaen caftle, Queen's county, a barrel of potatoes lafts a family of fix perfons a week.

No. 2. At Shaen caftle, Antrim, fix people eat three bufhels, and twenty pounds of oatmeal befides, in a week, twenty pounds of meal are equal to one bufhel of potatoes; this therefore is a barrel alfo.

No. 3. Leflie hill, a barrel of four bufhels fix perfons a week.

No. 4. Near Giant's caufeway, a barrel fix people eight days.

No. 5. Caftle Caldwell, a barrel of eighteen ftone fix people a week.

No. 6. Glofter, a barrel five perfons a week.

No. 7. Derry, five perfons eat and wafte two barrels a week.

No. 8. Cullen, two barrels fix perfons a week.

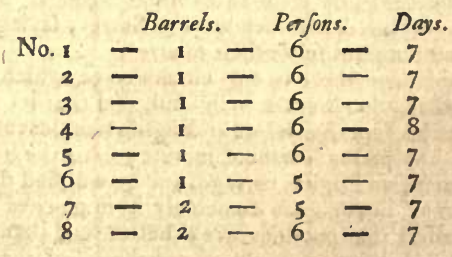

A barrel is twenty ftones, or two hundred and eighty pounds, which is the weight of four Englifh buthels : the average of thefe accounts is nearly that quantity lafting a family of fix people fix days, which makes a year's food fixiy barrels. Now the average produce of the whole kingdom being eightytwo barrels per acre, plantation meafure, one acre does rather more than fupport eight perfons the year through, which is five perfons to the Englifh acre. To feed on wheat, thofe eight perfons would require eight quarters, or two lrifh acres, which at prefent, imply two more for fallow, or four in all.

When, however, I peak of potatjes and buttermilk being the food of the poor, the tables already inferted hew, that in fome parts of the north that root forms their diet but for a part 
of the jear, much oatmeal and fome meat being confumed. I need not dwell on this, as there is nothing particular to attend to in it, whereas potatoes, as the ftaple dependance, is a peculiarity met with in no country but the other parts of Ireland.

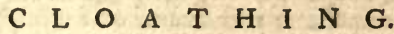

The common Irifh are in general cloathed fo very indifferently, that it impreffes every ftranger with a ftrong idea of univerfal poverty. Shoes and ftockings are fcarcely ever found on the feet of children of either fex; and great numbers of men and women are without them : a change however, in this refpect as in moft others, is coming in, for there are many more of them with thofe articles of cloathing now than ten years ago.

An Irithman and his wife are much more folicitous to feed than to cloath their children : whereas in England it is furprizing to fee the expence they put themfelves to, to deck out children whofe principal fubfiftence is tea. Very many of them in Ireland are fo ragged that their nakednefs is fcarcely covered; yet are they in health and active. As to the want of thoes and ftockings I confider it as no evil, but a much more cleanly cuftom than the beaftiality of ftockings and feet that are wafhed no oftener than thofe of our own poor. Women are oftener without thoes than men; and by wafhing their cloaths no where but in rivers and ftreams, the cold, efpecially as they roaft their legs in their cabbins till they are fire. fpotted, mutt fwell them to a wonderful fize and horrid black and blue colour always met with both in young and old. They ftand in rivers and beat the linen againft the great ftones found there with a beetle.

I remarked generally, that they were not ill dreffed of fundays and holidays, and that bläck or dark blue was almott the univerfal hue.

\section{H A}

The cottages of the Irifh, which are all called cabbins, are the moft miferable lnoking hovels that can well be conceived: they generally confit of only one room: mud kneaded with ftraw is the common nuaterial of the walls; thefe are rarely above feven feet high, and not always above five or fix ; they are about two feet thick, and have only a door, which lets in light inftead of a window, and flould let the fmoak out inftead of a chimney, but they had rather keep it in : thefe two conveniencies they hold fo cheap, that I have feen them both ftopped up in ftone cottages, built by improving landlords; the fmoak warms them, but certainly is as injurious to their eyes as it is to the complexions of the women, which in general 
in the cabbins of Ireland has a near refemblance to that of a fmoaked ham. The number of the blind poor 1 think greater there than in England, which is probably owing to this caufe.

The roofs of the cabbins are rafters, raifed from the tops of the mud walls, and the covering varies; fome are thatched with ftraw, potatoe italks, or with heath, others only covered with fods of turf cut from a grafs field; and I have feen feveral that were partly compored of all three, the bad repair thefe roofs are kept in, a hote in the thatch being often mended with turf, and weeds fprovting from every part, gives them the appearance of a weedy dungtill, efpecially when the cabbin is not bailt with regular walls, but fupported on one, or perhaps on both fides by the banks of a broad dry ditch, the roof then feems a hillock, upon which perhaps the pig grazes. Some of thefe cabbins are much lefs and more miferable habitations than I had ever feen in England. I was told they were the worft in Connaught, but I found it an error; I faw many in Leinfter to the fall as bad, and in Wicklow, fome worfe than any in Connaught. When they are well roofed, and built not of ftones, ill put together, but of mud, they are much warmer, independently of fmoke, than the clay, or lath and mortar cottages of England, the walls of which are fo thin, that a rat hole lets in the wind to the annoyance of the whole family. The furniture of the cabbins is as bad Is the architecture ; in very many, confifting only of a pot for boiking their potatoes, a bit of a table, and one or two broken ftools; beds are not found univerfally, the family lying on ftraw, equally partook of by cows, calves and pigs, though the luxury of fties is coming in in Ireland, which excludes the poor pigs from the warmth of the bodies of their mafter and miftrefs : I remarked little hovels of earth thrown up near the cabbins, and in fome places they build their turf ftacks hollow, in order to afford fhelter to the hogs. This is a general defcription, but the exceptions are very numerous I have been in a multitude of cabbins that had much afeful furniture, and forne even fuperfluous; chairs, tables, boxes, cheft of drawers, earthen ware, and in fhort moft of the articles found in a middling Englifh cottage; but upon enquiry, I very generally found that thefe acquifitions were all made within the laft ten years, a fure fign of a rifing national profperity. I think the bad cabbins and furniture the greateft inftances of Irifh poverty, and this muft flow from the mode of payment for labour, which makes cattle fo valuable to the peafant, that every farthing they can fpare is faved for their purchafe : froin bence alfo refults another obfervation, which is, that the apparent poverty of it is greater than the reel; for the houfe of a man that is mafter of four or five cows, will bave fcarce any thing but deficiencies; nay, I was in the cabbins of dairymen and farmers, not fmall ones, whofe cabbins 
were not at all better, or better furnifhed than thofe of the pooreft labourer: before, therefore, we can attribute it to abfolute poverty, we muft take into the account the cuftoms and inclinations of the people. In England a man's cattage will be filled with fuperfluities before he poffeffes a cow. I think the comparifon much in favour of the Irifhman; 2 hog is a much more valuable piece of goods than a fet of tea things; and though bis faout in a crock* of potataes is an idea not fo poetical as

Broken tea cups, wifaly kept far foew, Rang'd ''er the cbimney, gliflen'd in a row.

Yet will the cotter and his family, at Chrifmas, find the folidity of it an ample recounpence for the prnament of the other.

\section{I V E $S$ T O C K.}

In every part of the kingdom the common Irish have all forts of live ftock: the tables already inferted thew this in refpect of cows. I thould add here that pigs are yet more general, and poultry in many parts of the kingdom, efpecially Leinter, are in fuch quantities as amazed me, not only cocks and hens, but alfo-geefe and turkies; this is owing probably to three circumitances; firft, to the plenty of potatoes with which they are fed; fecondly, to the warmth of the cabbins; and thirdly, to the great quantity of fpontaneous white clover (trifolium repens) in almoft all the fields, which much exceeds any thing we know in England; upon the feeds of this plant the young poultry rear themfelves; much is fold, but a confiderable portion eaten by the family, probably becaufe they cannot find a market for the whole. Many of the coclss, hens, turkies and geefe, have their legs tied together to prevent them, from trefpaffing on the farmers grounds. Indeed all the live ftock of the poor mas in Ireland is in this fort of thraldom; the horfes are all hopping about, the pigs have a rope of ftraw from around their necks to their hind legs. In the county of down they have an ingenious contrivance for a fheep jutt to feed dow a the grals of a ditch, a rope with a ftake at each end, and the fheep tied to a ring, through which it paffes, fo that the animal can move from one end of the rope, to the other, and eat whatever grows within two or three feet of it,

- The iron pot of an Irifb cabbin. 


\begin{tabular}{|c|c|c|c|c|}
\hline Places. & $\begin{array}{l}\text { Hay ana } \\
\text { barveft. }\end{array}$ & $\mathbf{R}$ & $\begin{array}{l}\text { rear } \\
\text { round }\end{array}$ & Rife in Labour. \\
\hline $\begin{array}{l}\text { Dublin, } \\
\text { Celbridge, } \\
\text { Kilcock, } \\
\text { Slaine, } \\
\text { Headfort, } \\
\text { Packenham, } \\
\text { Tullamore, } \\
\text { Shaen Caftle, } \\
\text { Carlow, } \\
\text { Kilfain, } \\
\text { Taghmon, } \\
\text { Forth, } \\
\text { Profpect, } \\
\text { Mount Kennedy, } \\
\text { Balbriggin, } \\
\text { Marker-hill, } \\
\text { Ardmagh, } \\
\text { Warrenftown, } \\
\text { Portaferry, } \\
\text { Shaen Caftle, } \\
\text { Lefly Hill,: } \\
\text { Limmavady, } \\
\text { Innifhoen, } \\
\text { Clonleigk, } \\
\text { Mount Charles, } \\
\text { Caftle Caldwell, } \\
\text { Caftle Cool, } \\
\text { Belle Ille, } \\
\text { Florence Court, } \\
\text { Farnham, } \\
\text { Strokeftown, } \\
\text { Ballyna, } \\
\text { Mercra, } \\
\text { Sortland, } \\
\text { Killala, } \\
\text { Weftport, } \\
\text { Moniva, }\end{array}$ & 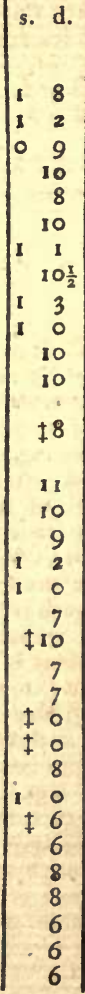 & $\begin{array}{r}8 \\
8 \\
8 \\
8 \\
8 \\
6 \\
6 \\
7 \\
7 \\
+0 \\
6 \\
6 \\
6 \\
4 \\
6 \\
4 \frac{\pi}{2} \\
4 \\
5\end{array}$ & $\begin{array}{c}7 \\
7 \\
+6 \\
8 \\
6 \\
6 \\
5 \\
6 \\
5^{\frac{x}{2}} \\
5^{\frac{x}{2}} \\
5\end{array}$ & $\begin{array}{l}\text { Twopence in zo years. } \\
\text { Threepence in } 10 \text { years. } \\
\text { None. } \\
\text { None. } \\
\text { Very little. } \\
\text { One-fifth in } 20 \text { years. } \\
\text { One-fourth in } 20 \text { years. } \\
\text { A little in } 20 \text { years. } \\
\text { Twopence in } 20 \text { years. } \\
\text { One-third in } 20 \text { years. } \\
\text { One-half in } 20 \text { years. } \\
\text { Near double in } 20 \text { years. } \\
\text { One fourth in } 20 \text { years. } \\
\text { A little. } \\
\text { One-third in } 20 \text { years. } \\
\text { Near double in } 20 \text { years. } \\
\text { None. } \\
\text { One-third in } 20 \text { years. } \\
\text { One penny in } 20 \text { years. } \\
\text { One-third in } 20 \text { years. } \\
\text { One-fixth in } 20 \text { years. } \\
\text { None. } \\
\text { One-fixth in } 20 \text { years. } \\
\text { Oyence a day in } 20 \\
\text { Onears. }\end{array}$ \\
\hline
\end{tabular}

Drumoland, 


\begin{tabular}{|c|c|c|c|c|}
\hline Placer. & $\begin{array}{l}\text { Hay and } \\
\text { barveft. }\end{array}$ & Winter. & $\begin{array}{l}\text { Year } \\
\text { round. }\end{array}$ & Rife in Labour. \\
\hline $\begin{array}{l}\text { Drumoland, } \\
\text { Doneraile, } \\
\text { Caftle Martyr, } \\
\text { Nedeen, } \\
\text { Tarbat, } \\
\text { Adair, } \\
\text { Caftle Oliver, } \\
\text { Tipperary, } \\
\text { Curraghmore, } \\
\text { Waterford, } \\
\text { Furaefs, } \\
\text { Glofter, } \\
\text { Jahoftowo, } \\
\text { Derry, } \\
\text { Caftle Loyd, } \\
\text { Mitchel's Town, }\end{array}$ & $\begin{array}{r}d \\
6 \\
+8 \\
8 \\
6 \\
6 \\
6 \\
6 \\
6 \\
6 \\
6 \frac{1}{2} \\
8 \\
8 \\
6 \frac{1}{2} \\
6 \frac{1}{2}\end{array}$ & $\begin{array}{l}d . \\
6 \\
6 \frac{1}{2} \\
6 \\
6 \\
6 \\
5 \\
5 \\
5 \\
5 \\
6 \frac{\pi}{2} \\
7 \\
6 \frac{\pi}{2} \\
5 \\
6 \frac{\pi}{2}\end{array}$ & $\begin{array}{l}d . \\
6 \\
6 \frac{\pi}{2} \\
6 \\
6 \\
6 \\
6 \\
6 \\
6 \frac{1}{2} \\
6 \\
5 \\
5 \frac{1}{2} \\
6 \frac{1}{2}\end{array}$ & $\begin{array}{l}\text { None. } \\
\text { One-third in } 20 \text { years. } \\
\text { One-third in ditto. } \\
\text { One-third in ditto. } \\
\text { One-penny in ditto. } \\
\text { One-third in ditto. } \\
\text { One-penny a day in ditto. } \\
\text { One penny a day. } \\
\text { One third in } 20 \text { years. } \\
\text { Confiderable. } \\
\text { None. } \\
\text { One penny a day. } \\
1 \frac{1}{2} \text { d. a day in } 5 \text { years. }\end{array}$ \\
\hline Average, & $8 \frac{3}{4}$ & $6 \frac{x}{2}$ & $5 \frac{1}{2}$ & \\
\hline
\end{tabular}

The rife is very near a fourth in twenty years; and it is remarkable that in my Eaftern Tour through England (vol. 4. p. 338.) I found the rife of labour one fourth in eighteen years; from which it appears, that the two kingdoms, in this refpect, have been nearly on a par.

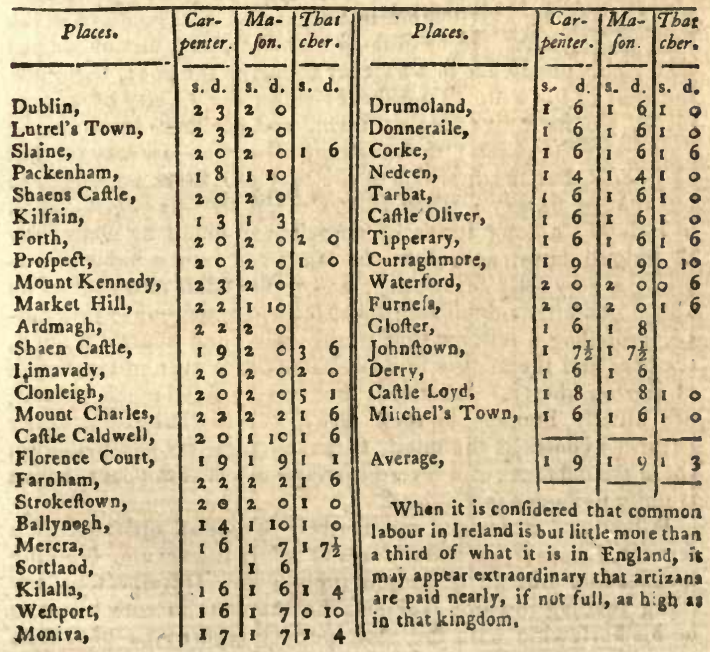




\section{O P P R E S S I O N.}

Before I conclude this article of the common labouring poor in Ireland, I muft obferve, that their happinefs depends not merely upon the payment of their laboux, their cloaths, or their food; the fubordination of the lower claffes, degene+ rating into oppreffion, is not to be overlooked. The poor in all countries, and under all governments, are borh paid and fed, yet is there an infinite difference between them in different ones. This enquiry will by no means turn out fo favourable as the preceding articles. It muft be very apparent to every traveller, through that country, that the labouring poor are treated with harhnefs, and are in all refpects fo little confidered, that their want of iniportapce feenis a perfeet contraft to their fituation in England, of which country, comparatively fpeaking, they reign the fovereigns. The age has improved fo much in humanity, that even the poor Irifh have experienced its influence, and are every day treated better and better ; but ftill the remnant of the old manners, the abomi. thable diftinction of religion, united with the oppreflive conduct of the little country gentlemen, or rather vermin of the king. dom, who never were out of it, altogether bear ftill very hea$v y$ on the poor people, and fubject them to fituations more mortifying than we ever behold in England. The landlord of an Irifh ettate, inhabited by Roman catholics, is a fort of defpot who yields obedience in whatever concerns the poor, to no law but that of his will. To difcover what the liberty of a people is, we mutt live among them, and not look for it in the itatutes of the realm : the language of written law may be that of liberty, but the fituation of the poor may fpeak no language but that of Aavery; there is too much of this contradiction in Ireland; a long feries of oppreffions, aided by many very ill judged laws, have brought landlords into a habit of exerting a very lofiy fuperiority, and their vafials into that of an alinolt unlimited fubmifion : fpeaking a language that is defpifed, profeffing a religion that is abhorred, and being difarmed, the poor find thenifelves in many cafes flaves even in the botom of written liberty. Landlords that have reficed much abroad, are ufually humane in their ideas, but the habit of tyranny naturally contracts the inind, fo that evell in this polithed age, there are inftances of a fevere carriage towards the poor, which is quite unknown in England.

A landlord in Ireland can fearcely invent an order which a fervant, labourer, or cottar dares to refufe to execute. Nothing fatisfies him but an unlimited fubmiffion. Difrefpect or any thing tending towards faucinefs he may punith with bis cane or his horfewhip with the molt perfect fecurity, a poor man would have his bones broke if be offered to lift his hand in his 
own defence. Knocking down is fpoken of in the country in a manner that makes an Englifh man ftare, Landlords of confequence have affured me that many of their cortars would think themtelves honoured by having their wives and daughters fent for to the bed of their mafter; a mark of liavery that proves the oppreffion under which fuch people mutt live. Nay, I have heard anecdotes of the lives of people being made free with without any apprehenfion of the juttice of a jury. But let it not be iniagined that this is conmon; formerly it happened every day, but law gains ground. It mult ftrike the moft carelefs traveller to fee whole ftrings of cars whipt into a ditch by a gentleman's footman to make way for his carriage; if they are overturned or broken in pieces, no matter, it is taken in patience, were they to complain they would perhaps be horfewhipped. The execution of the laws lies very much in the hands of juftices of the peace, many of whom are drawn from the moft illiberal clafs in the kingdom. If a poor man lodges a complaint againtt a gentleman, or any animal that chufes to call itrelf a gentleman, and the juftice iffues out a fummons for his appearance, it is a fixed affront, and he will infallibly be called out. Where MANNERS are in confpiracy againit LA $\mathrm{W}$, to whom are the oppreffed people to have recourfe? It is a fact that a poor man having a conteft with a gentleman muf-but I am talking nonienfe, they know their fituation 200 well to think of it ; they can have no defence but by means of protection from one gentleman againt another, who probably protects his vaffal as he would the fheep he intends to eat.

The colours of this picture are not charged. To affert that all thefe cafes are common, would be an exaggeration, but to fay that an unfeeling landlord will do all this with inpunity is to keep ftrictly to truth: and what is liberty but a farce, and a jeft if its bleflings are received as the favour of kindnefs and humanity, inftead of being the inheritance of RIGHT ?

Confequences have flowed from thefe oppreffions which ought long ago to have put a ftop to them. In England we have heard much of whiteboys, fteelboys, oakboys, peep-of-dayboys, \&c. But thefe various infurgents are not to be confounded, for they are very different. The proper diftinction in the difcontents of the people is into proteftant and catholic. All but the whiteboys were among the manufacturing proteftants in the north. The whiteboys catholic labourers in the fouth: from the beft intelligence I could gain, the riots of the manufacturers had no other foundation, but fuch variations in the manufaeture as all fabrics experience, and which they had themfelves known and fubmitted to before. The cafe, how ever, was different with the whiteboys; who being labouring catholics met with all thofe oppreffions I have defcribed, and would probably have continued in ful! fubmiffion had not very fevere treatinent in refpect of tythes united with a great fpecu- 
lative rife of rents about the fame time, blown up the flame of refiftance; the atrocious acts they were guilty of made them the object of general indignation, acts were paffed for their punifhment, which feemed calculated for the meridian of Barbary; this arofe to fuch a height, that by one they were to be hanged under certain circumftances without the common formalities of a trial, which though repealed the following feffions marks the fpirit of punifhinent; while others remain yet the law of the land, that would if rxecuted tend more to raife than quell an infurrection. From all which it is manifeft that the gentlemen of Ireland never thought of a radical cure from overlooking the real caufe of the difeafe, which in fact lay in themfelves, and not in the wretches they doomed to the gallows. Let them change their own conduct intirely, and the poor will not long riot. Treat them like men who ought to be as free as yourfelves: put an end to that fyftem of religious perfecution which for feventy years has divided the kingdom againft itfelf; in thefe two circumftances lies the cure of infurrection, perform them completely, and you will have an affectionate poor, inftead of oppreffed and difcontented vaffals.

A better treatment of the poor in Ireland is a very material point to the welfare of the whole Britifh empire. Events may happen which may convince us fatally of this trutb-If not; oppreffion muft have broken all the Ipirit and refentment of men. By what policy the government of England can for fo many years have permitted fuch an abfurd fyftem to be matured in Ireland, is beyond the power of plain fenfe to difcover.

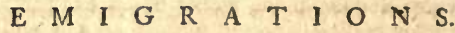

Before the American war broke, the Irifh and Scotch emigrations were a conftant fubject of converfation in England, and occafioned much difcourfe even in parliament. The common obfervation was, that if they were not ftopped, thofe countries would be ruined, and they were generally attributed to a great rife of rents. Upon going over to Ireland I deter. mined to omit no opportunities of difcovering the caufe and extent of this emigration, and my information, as may be feen in the minutes of the journey, was very regular. I have only 2 few general remarks to make on it here.

The fpirit of emigrating in Ireland appeared to be confined to two circumftances, the prefbyterian religion, and the linen manufacture. I heard of very few emigrants except among manufacturers of that perfuafion. The catholics never went, they feem not only tied to the country but almoft to the parifh in which their anceitors lived. As to the emigration in the north, it was an error in England to fuppofe it a novelty which arofe with the increafe in rents. The contra. of was the fact, it had fubfifted, perhaps, forty years, infomuch 
that at the ports of Belfatt, Derry, \&c. the pafenger trade as they called it, had long been a regular branch of commerce, which employed feveral fhips, and cónfifted in carrying people to America. The increafing population of the country made it an increafing trade, but when the linen trade was low, the paffenger trade was always high. At the time of Lord Donnegall's letting his eftate in the North the linen bufinefs fuffered a temporary decline, which fent great numbers to America, and gave rife to the error that it was occafioned by the increafe of his rents: the fact, however, was otherwife, for great numbers of thofe who went from his lands actually fold thofe leafes for confiderable fums, the hardihip of which was fuppofed to have driven them to America. Some emigration, therefore, always exifted, and its increafe depended on the fluctuations of linen ; but as to the effect, there was as swach error in the conclufions drawn in England as before in the caufe.

It is the misfortune of all manufactures worked for a foreign market to be upon an infecure footing, periods of declenfion will come, and when in confequence of them great numbers of people are out of employment, the beft circamftance is their enlifting in the army or navy; and it is the common refult, but unfortunately the manufacture in Ireland (of which I thall have occafion to fpeak more hereafter), is not confined as it ought to be to towns, but fpreads into all the cabbins of the country. Being half farmers, half manufacturers, they have too much property in cattle, \&c. to enlift when idle; if they convert it into cafh it will enable them to pay their paffage to America, an alternative always chofen in preference to the military life. The confequence is, that they muft live without work till their fubftance is quite confumed before they will enlift. Men who are in fuch a fituation that from various caufes they can not work, and won't enlift, thould enigrate, if they ftay at hoime they muft remain a burthen upon the community; enigration fhould not, therefore, be condemned in ftates fo ill governed as to poffefs many people willing to work, but without employment.

\section{S E C C $\quad \mathrm{T}$ I}

Of Religion.

THE hittory of the two religions in Ireland is too generally

known to require any detail introductory to the fubjec. The confliet for two centuries occafioned a fcene of devaftation and bloodfhed, till 'at laft by the arms of King William the decifion left the uncontrouled power in the bands of the proteftants. The landed property of the kingdom had been greatly 
greatly changed in the periad of the reigns of Elizabeth and James I. Still more under Cromwell, who parcelled out an immenfe proportion of the kingdom to the officers of his army, the anceftors of great numbers of the prefent poffeffors : the colonels of his regiments left eftates which are now eight and ten thoufand a year, and I know feveral gentlemen of twa and three thoufand pounds a year at prefent which they inherited from captains in the fame fervice. The laft forfeitures were incurred in that war which fripped and banifhed James 1I. Upon the whole nineteen-twentieths of the kingdom changed hands from catholic to proteftant. The lineal defcendants of great families, once poffeffed of vaft property, are now to be found all over the kingdom in the loweft fituation, working as cottars for the great great grandfons of men, many of whom were of no greater account in England than thefe poor labourers are at prefent on that property which was ance their own. So entire an overtbrow, and change of landed poffeffion, is within the period to be found in fcarce any country in the world. In fuch great revolutions of property the ruined proprietors have ufually been extirpated or banifhed; but in Ireland the cafe was otherwife : families were fo numerous and fo united in clans, that the heir of an eftate Was always known; and it is a faet that in moft parts of the kingdom the defcendants of the old land owners regularly tranfmit by teftamentary deed the memorial of their right to thofe eftates which oncé belonged to their families. From hence it refults taat the queftion of religion has always in Ireland been intimately connected with the right to and poffeffion of the landed property of the kingdom; and has probably received from this fource a degree of acrimony, not at all wapting to influence the fuperftitious prejudices of the human mind.

Fluthed with fuccefs after the victory of the Boyne, and animated with the recollection of recent injuries, it would not have been furprizing if the triumphant party had exceeded the bounds of moderation towards the catholic, but the amazing circumftance is that the great category of perfecuting laws was not framed during the life of that monarch who wifely was a friend to toleration: if ever fuch a fyftem as would crufh the minds of a conquered people into a Ravifh fubmiffon was neceffary, it muft have been under that new, and in many refpects weak eftablifhment, when the late conflict might have been an apparent juftification: but why fuch a fyitem fhould be embraced fix or feven years after the death of King William is not fo eafy to be accounted for.

By the laws of difcovery as they are called:

1. The whole body of Roman catholics are abfolutely difarmed.

2. They are incapacitated from purchafing land.

3. The entails of their eftates are broken, and they gavel among the children. 
4. If one child abjures that religion, he inherits the whole eftate, though he is the youngeft.

5. If the fon abjures the religion, the father has no power over his eftate, but becomes a penfioner on it in favour of fuch fon.

6. No catholic can take a leafe for more than thirty-ore years.

7. If the rent of any catholic is lefs than two-thirds of the full improved value, whoever difcovers takes the benefit of the leafe.

8. Priefts who celebrate mals to be tranfpotted, and if they retura to be hanged.

9. A catholic baving a horfe in his polfeflion above the value of five pounds, to forfeit the fame to the difcoverer.

10. By a conftruation of lord Hardwick's, they are incapacitated from lending noney on mortgage*.

The preceding catalogue is very impetfeet, but here is an exhibition of oppreffion fully fufficient. The great national objects in framing laws againft the profeffion and practice of any religion, may be reduced to three heads. Ift. The propagation of the dominant faith. $2 \mathrm{~d}$. Internal fecurity. $3 \mathrm{~d}$. National profperity : the faireft way to judge of the laws of Ireland will be to enquire how far they have anfwered any or all of thefe ends.

That it is a defirable object in fome refpects to have a people if not all of one perfuafion, at leaft in good friendip and brotherhood, as to religion, is undeniable. Though I think there are reatons againft wifhing a whole kingdom to profefs only one fimilai faith. It excludes a variety of difquifitions which exercife and animate the talents of mankind; it encourages the priefts of the national religion to a relaxation of their it:adies, their activity and even their morals, and tends to introduce a lazy, wretched, vicious, and ignorant clergy : it is oppofition and contraft that fharpen the wits of men.

But waving thefe objections, and confidering the queltion only in a political view, I admit that fuch a fimilarity of worthip as is followed by laws equal to the whole community to be an advantage, tet us therefore examine whether the Irifh intolerant laws have had the effect or not.

That they have leffened the landed properiy in the hands of the catholics is certain; their violence could not have had any other effect, but not, however, to fuch a degree as might have been imagined. There are principles of homour, religion, and ties of blood too powerful for tyrannic laws to overcome, and which have prevented their full effect. I am not cunvinced that the converfion of the land owners while all the rabble retained their religion, was an advantage to the kingdour.

* Same mitigation of thofe penal lates bas taken place, by an act of the legiflature in 1778 , in fuvour of tho $\int e$ who take and fubfcribe an oath framed on tbe occafion. 
kingdom. Great poffeffions gave thofe landlords an intereft in the public welfare; which in emergencies of danger might induce them to ufe their influence to keep their dependants quiet; but when none are connected with them richer than themfelves, and the whole party confifting of a poor and half ruined peafantry, and priefts almoft as poor as themfelves, what tie, or what call is there upon them to reftrain the dictates of refentment and revenge ? At this day the beft fubjects among the catholics, and many there are very much to be depended on, notwithftanding all their oppreffions, are the men of landed property: how impolitic to with to leffen the number ! to be defirous of cutting off two millions of peafantry, fom every poffible connection that can influence their fubmiffion. The fame obfervation is applicable to mortgages, and in thort to all inveftments of money within the kingdom. Surely the obedience of a man who bas property in the realm is much fecurer than if all he is worth is in the Englifh or Dutch funds ! While property lay expofed to the practices of power, the great body of the people who had been ftripped of their all were more enraged than converted: they adhered to the perfuafion of their forefathers with the fteadieft and moft determined zeal; while the priefts actuated by the fpirit of a thoufand inducements, made profelytes among the common proteftants in defiance of every danger. And the great glaring faet jet remains, and is even admitted by the warmeft advocates for the laws of difcovery, that the eftablifhed religion has not gained upon the catholic in point of numbers, but on the contrary that the latter bave been rather on the increafe. Public lifts bave been returned in the feveral diocefes which confirm this fact; and the intelligence I received on my journey fpoke the fame language.

Now as it is the great body of the common people that form the ftrength of a country when willing fubjects, and its weaknefs when ill-affected, this fact is a decifion of the queftion : after feventy years undifturbed operation, the fyitem adopted in Queen Anne's reign has failed in this great end and aim; and meets at this day with a more humerous and equally determined body of catholics as it had to oppofe when it was firt promulgated. Has not the experience of every age, and every nation proved that the effeet is invariable and univerfal? Let a religion be what it may, and under whatever circumftances, no fyftem of perfecution ever yet had any other effect than to confirns its profeffors in their tenets, and fpread their dostrines inftead of reftraining them. Thus the great plea of the Roman catholic priefts, and their merit with their congregations are the dangers they hazard; and the perfecutions they fuffer for the fake of their faith; arguments that ever had and ever will have weight while human nature continues formed of its prefent materials.

The queltion of internal fecurity is decided almoft as foon as named: the fubmiffion of the catholics is yet felt to be fo 
much conftrained that no idea has been formed, that their being trufted with arms is confiftent with the fafety of the kingdom. Laws founded in the very fpirit of perfecution, and receiving an edge in their operation from the unlimited power affumed by the proteftant landlord, are ttrangely calculated to conciliate the affection, or fecure the loyalty of a people. All the emotions of the heart of man revolt at fuch an idea. It was the opinion of a valt majority of the gentlemen I converfed with on the fubject, that no people could be worfe affected; all Ireland knows and agrees in the fact, nay, the arguments for a continuation of the laws of difcovery are founded on the principle, that the lower claffes of the catholics are not to be trufted. Is not this declaring that the difarmed, difgufted multitude, have not loft in their misfortunes the importance of their numbers? The fears of an invafion fpeak the ftrength of the cppreffed, and the extent of the oppreffion.

The difturbances of the whiteboys, which lafted ten years in fpite of every exertion of legal power, were in many circuinftances very remarkable, and in none more fo than the furprizing intelligence among the infurgents where ever found: it was univerfal, and almoft inftantaneous : the numerous bodies of them at whatever diftance from each other feemed animated with one foul; and not an inftance was known in that long courfe of time of a fingle individual betraying the caufe; the fevereft threats, and the moft fplendid promifes of reward had no other effect but to draw clofer the bands which connected a multitude, to all appearance fo defultory. It was then evident that the iron rod of oppreffion had been far enough from fecuring the obedience, or cruthing the fpirit of the people. And all reflecting men who confider the value of religious liberty, will wifh it never may have that effeet; will truft in the wifdom of Almighty God for teaching man to refpect even thofe prejudices of his brethren that are imbibed as facred rights from their earlieft infancy, that by dear bought experience of the futility and ruin of the attempt, the perfecuting fpirit may ceafe, and TOLERATION eftablifh that harmony and fecurity which fourfore years experience has told us is not to be purchafed at the expence of $\mathrm{HUMA-}$ NIr Y !

But if thefe exertions of a fucceffion of ignorant legillatures have failed continually in propagating the religion of government, or in adding to the internal fecurity of the kingdom, much more have they failed in the great object of national profperity. The only, confiderable manufacture in Ireland which carries in all its parts the appearance of induftry is the linen, and it ought never to be forgotten that this is folely confined to the proteftant parts of the kingdom; yet we may fee from the example of France and other countries that there is nothing in the Roman catholic religion itfelf tbat is incompatible with manufacturing induftry. The poor catholics in 
the fouth of Ireland fpin wool very genetally, but the ptrchafers of their labour, and the whole worited trade is in the bands of the quakers of Clonmell, Carrick, Bandon, \& $c$. The fact is, the profeffors of that religion are under fuch difcouragements that they cannot engage in any trade which requires both induftry and capital. If they fucceed and make a fortune what are they to do with it ? They can neither buy land, hor take a mortgage, nor even fine down the rent of 2 leafe. Where is there a people in the world to be found induftrious under fuch a circumftance ? But it feems to be the meaning, wifh, and intent of the difcovery laws, that none of them thould ever be rich. It is the ptinciple of that fyf tem that wealthy fubjects would be nuifances, and therefore every means is taken to reduce, and keep them to a ftate of poverty. If this is not the intention of the laws they are the noft abominable heap of felf-contradictions that ever were iffued in the world. They are framed in fuch a manner that no catholic thall have the inducement to become rich. But if in fpite of thefe laws he fhould accidently gain wealth, that the whole kingdom thould not afford him a poffibility of invefting it. Take the laws and their execution into one view, and this ftate of the cafe is fo true, that they actually do not feem to be fo much levelled at the religion, as at the property that is found in it. By the law a prieft is to be tranfported and hanged for reading mafs, but the mais is very readily left to them with impunity. Let the fame prieft, however, make a fortune by his mass, and from that moment he is the object of perfecution. The domineering ariftocracy of five hundred thoufand proteftants feel the fweets of having two millions of Caves; ther have not the leaft objection to the tenets of that religion which keeps them by the law of the land in fubjeeti= on s but property and flavery are too incompatible to live together. Hence the fpecial care taken that no fuch thing thould arife among them.

I muft be free to own that "when I have heard gentlemen who have favoured the laws as they now ftand, urge the dangerous tenets of the church of Rome, quote the cruelties which have difgraced that religion in Ireland, and led them into the comnion routine of declamation on that fide the queftion; (I cannot call it argument, for I never yet heard any thing that deferved the name) when 1 have been a witnefs to fuch converfations I could not but fmile to fee fubfcriptions handed about for building a mafs houfe, at the very time that the beavieft vengeance of the law fully executed fell on thofe who poffelfed a landed property, or ventured a mortgage upon it.

It is no fuperficial view I have taken of this matter in Ireland, and being at Dublin at the time a very trifling part of thefe laws was agitated in parliament, I attended the debates, with my mind open to conviktion, and auditor for the niere 


\section{R E L I G I O N.}

purpole of information: I have converfed on the fubject with fome of the moft diftinguifhed characters in the kingdom, and I cannot after all but declare that the fcope, purport, and aim of the laws of difcovery as executed are not againft the catholic religion which increafes under them, but againt the induftry, and property of whoever profeffes that religion. In vain has it been faid, that confequence and power follow property, and that the attack is made in order to wound the doctrine through its properiy. If fuch was the intention, I reply, that feventy years experience prove the folly and futility of it. Thofe laws have crufhed all the induitry, and wrefted mott of the property from the catholics; but the religion triumphs; it is thought to encreafe. Thofe who have handed about calculations to prove a decreafe, admit on the face of them that it will require $F O U R$ THOUSAND YEARS to make converts of the whole, fuppofing that work to go on in future, as it has in the patt time. But the whole pretence is an affront to common fenfe, for it implies that you will leften a religion by perfecuting it : all hiftory and experience condemn fuch a propofition.

The fyftem purfued in Ireland has had no other tendency but that of driving out of the kingdom all the perfonal wealth of the catholics, and prohibiting their induftry within it. The face of the country, every object in fhort which prefents itfelf to the eye of a traveller, tells him how effectually this has been done. I urge it not as an argument, the whole kingdom fpeaks it as a faet. We have teen that this conduct has not converted the people to the religion of government; and inftead of adding to the internal fecurity of the realm it has endangered it, if therefore it does not add to the national profperity, for what purpofe but that of private tyranny could it have been embraced and perfifted in ? Miftaken ideas of private intereft account for the actions of individuals, but what could have influenced the Britifh government to permit a fyftem which mut inevitably prevent the inand from ever becoming of the importance which nature intended.

Relative to the national welfare it muft appear extremely evident to the unprejudiced, that an ariftocracy of five hundred thoufand proteftants, crufhing the induftry of two millions of poor catholics, can never advance the public intereft. Secure the induftry of your people, and leave their religion to itfelf. It is their hands not their faith you want; but do not tie thefe behind them, and then afk why they are not better employed. How is agriculture to fourifl, nianufåures to be eftablifhed, or commerce to extend in a dependant country labouring under great difadvantages, if the united capitals, induftry, activity and attention of the whole community be not emplored for fuch purvoles? When the territory of an ifland lies in fuch a wretched ftate, that though bleffed with a better foil it yiclds on comparifon with England as only two to five :

VoL.II.

whes 
when manufactures are of fo fickly a growth as to be confined almoit to one province, and when trade is known to exift only by the fhips of other countries appearing in the harbours, while a kingdom is in fuch a fituation, is it wifdom to perfitt in a fyftem which has no other effect than to clog, defeat, or exterminate the capical and induftry of four-fifths of the inhabitants! Surely the gentlemen of that country when they complajn of reftricted commerce, and the remittance of the rentals of the abfentees to England, cannot be thought ferious in lamenting the fituation of their country while they continue wedded to that internal ruin which is the work of their own hands, and the favourite child of their molt active exertions. Conplain not of reftrictions while you yourfelves inforce the moft enormous reffriction; and what are the body of abfentees when sompated with the abfence of induftry and wealth from the immenfe mafs of two millions of fubjects. I fhould be well founded in the affertion that both thefe evils, great and acknowledged as they are, are trifles when compared with the poverty and debility which refults from the oppreffion of the Roman catholics. Encourage the induftry of thore two millions of idle people, and the wealth arifing from it, will make ample amends for mioft of the evils complained of in Ireland. This remedy is in your hands; you have no rivals to fear; no minifters to oppofe you.

Think of the lofs to Ireland of to many catholics of finall property, reforting to the armies of France, Spain, Sardinia and Auftria, for einployment. ' $C_{a n}$ it be imagined, that they would be fo ready to leave their own country, if they could Itay in it with any profpect of promotion, fuccefsful induftry, or even liberal protection? It is known they would not; and that under a different fyftem, inftead of adding ftrength to the enemies of this empire, they would be annong the foremoft to exrich and defend it. Upon the whole it appears fufficiently clear, that in thefe three great objects, of making the religion of government general, internal fecurity, and national profperity, the laws of difcovery have totally failed; a long feries of experience enables us to difcufs the fubject by a reference to facts, inftead of a reliance on theory and argument; the fanguage of thofe facts is fo uniform, that private intereft muft nite with habitual prejudice, to permit it for a moment to be mifunderftood.

Upon the general queftion it has been afferted by the friends of the law, that gentlemen in England are apt very much to mittake the point from being ignorant of Iriff popery, which from the ignorance of the people, is more bigoted than any thing known in the fitter kingdoin; alfo that the papits in England are not clamants of all the landed property, which is the cafe in Ireland.

Both thefe obfervations are too fhallow to bear the leaft examination; oppreflion has seduced the major part of the lrifts catiolics 
catholics to a poor ignorant rabble; you have made them ignorant, and then it is cried your ignorance is a reafon for keepigg you fo; you thall live and die, and remain in ignorance, for you ate too wretched to be enlightened. Take it as argument, or humanity, it is of a moft precious kind. In all other parts of Europe the catholic religion has grown mild and even tolerant; a rofter humanity is teen diffufed in thofe countries, once the moft bigoted; Spain and Portugal are no longer what they were. Had property taken its natural courfe in Ireland, the religion of the catholics there would bave improved with that of their neighbours. Ignorance is the child of poverty, and you cannot expect the modern inprovements, which have refulted from diffeminated induftry and wealth, fhould fpread among a feet, whofe property you have detached, and whofe induftry you have crufied : to ftigmatize them with ignorance and bigotry, therefore, is to reproach them with the evils which your own conduct has entailed; it is to bury them in darknefs, and villify them becaufe they are not enlightened.

But they claim your eftates; they do fo, as fteadily at this moment as they did fourfcore years ago; your fyftem therefore has utterly failed even in this refpeet. Has the rod of oppreffion obliterated the memory or iradition of better days ? Has feverity conciliated the forgivenefs of paft, perhaps neceffary injuries ? Would protection, favour, and encouragement add frefr ftings to their refentments? None can aftert it. Ample experience ought to have convinced you, that the harihnefs of the law has not annihilated a fingle claim; if claims could have reftored their eftates, they would have regained them before now: but here, as I fliewed before, the laws have weakened inftead of ftrengthening the proteftant intereft; had a milder fyftem encouraged their induftry and property, they would have had fomething to lofe, and would, with an enemy in the land, have thought twice before they joined him, in fuch a cafe whatever they had got would be endangered, and the hope of being reinftated in antient poffeflions, being diftant and hazardous, prefent advantage might have induced thens not only to be quiet, but to have defended the government, under whofe humanity they found protection and happinefs. Compare fuch a fituation with the prefent, and then determine whether the fyttem you have perfifted in, has added a jot to the fecurity of your poffeflions.

But let me ank, if thefe catholic claims, on the landed property, were not full as ftrong an argument in the reign of King William as they are at prefent? The moment of conflia was then but juft decided ; if ever rancour and danger could arite from then, that certainly was the feafon of apprehenfion: but it is curious to obferve, that that wife monarch, would pernit few ats to pafs to opprefs the catholics. It was not until the reign of Anne, tbat the great fyptem of oppreffion 
was opened : if therefore thefe laws were unneceffary from the revolution to the death of King William, and the experience of that reign tells us they were not, moft certainly they cannot be fo at prefent.

The enlightened fpirit of TOLIRATION, fo well underftood and practifed in the greateft part of Europe, is making progrefs every day, fave in Iteland alone: while the proteftant religion enjoys peace and protection in catholic countries; why fhould a nation, in all other refpets fo generous and liberal as the Irish, refufe at bome what they receive and enjoy abroad.

As the abfurdity of the prefent fyftem can no longer be doubted, the queftion is, in what degree it hould immediately be changed? Would it be prudent directly to arm, and put upon a level with the reft of the community, fo large and neceffarily, fo difgufted a body of the people? Great fudden changes are rarely prudent; old babits are not immediately laid afide; and the temper of men's minds, nurfed in ignorance, fhould have time to open and expand, that they may clearly, comprehend their true intereits : for this reafon the alteration of the laws fhould be gradual, rather than by one or two repealing claufes, at once to overthrow the whole. But all things confidered, there ought not to be a fingle feffions without doing fomething in fo neceffary a work. For inftance, in one feffions to give them a power of taking mortgages; in another of purchafing lands; in a third, to repeal the abominable premiums on the divifion of a family againft itfelf, by reftoring to parents their rights; in a fourth, mafs to be rendered legal; in a fifth, a feminary, to be eftablished by law, for the education of prietts, and a bifhop to be allowed, with thofe powers which are neeeffary for the exercife of the religion; by which means the foreign intereft from a priefthood, entirely educated abroad, would be at once cut off. Thus far the moft zealous friends to the proteftant religion could not object upon any well founded principles. When once the operations of the new fyftem had Faifed a fpirit of induftry, and attendant wealth among the lower claffes of them, no evil confequences would flow from permitting them the ufe of arms. Give them an intereft in the kingdom, and they will ufe their arms, not to overturn, but to defend it. Upon firt principles, it is a miferable government, which acknowledges itfelf incapable of retaining men to their cbedience that have arms in their hands; and fuch an one as is to be found in Ireland alone. In like manner 1 fhould apprehend that it might be proper to give them a voice in the election of members of parliament. There is great reafon to believe, that they will not be treated by gentemen in the country in the manner they ought to be, until this fort of importance is given them. 
Let it in general be remembered, that no country in the world has felt any inconveniences from the moft liberal fpirit of toleration: that on the contrary, thofe are univerfally acknowledged to be the moft profperous, and the moft flourishing, which have governed their fubjects on the moft tolerating principles. That other countries, which have been actuated by the fpirit-of bigotry, have continued poor, weak, and helplefs: thefe are circumftances which bear fo immediately upon the queftion, that we may determine, without any hazard of extravagance, that Ireland will never profper to any great degree until the profits by the example of her neighbours. Let her difmifs her illiberal fears and apprehenfions; let her keep pace with the improvement of the age, and with the mild fpirit of European manners, let her transfer her anxiety from the faith to the induftry of her fubjects; let her embrace, cherifh, and protect the catholics as good fubjects, and they will become fuch; let her, defpifing and detefting every fpecies of religious perfecution, confider all religions as brethren, employed in one great aim, the wealth, power, and happinefs of the general community; let thefe be the maxims of her policy, and the will no longer complain of poverty and debility. the will be at home profperous, and abroad formidable.

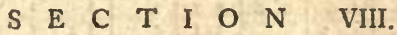

\section{Price of Provifions.}

IN the fpeculations of modern politicians, fo many conclu1 fions have been drawn from the prices of provifions in different countries, and fome of them with fo much reafon, that every one muft readily admit a confiderable degree of importance to be annexed to fuch information : with this view, I was as particular in thefe enquiries as I had been before in my Englilh journies. The following table fhews the refult.

Piaces. 


\begin{tabular}{|c|c|c|c|c|c|c|c|c|c|c|}
\hline Places. & & eef. & $\begin{array}{l}\text { Mutt } \\
\text { per l }\end{array}$ & & $\begin{array}{l}\text { Veal } \\
\text { per lb. }\end{array}$ & $\begin{array}{l}\text { Park. } \\
\text { per lb. }\end{array}$ & $\begin{array}{l}\text { Butter. } \\
\text { per lb. }\end{array}$ & Cbick & Turkey. & Googe. \\
\hline & & - $f$ & d. & f. & d. $f$. & d. f. & d. $f$. & d. $\delta_{0}$ & d. $f$. & d. $f$ \\
\hline Dublin, & & 2 & & & 5 & 32 & 8 & 12 & 30 & 18 \\
\hline Luthelftown, & & & & 2 & 4 & 3 & 8 & & & \\
\hline Kilcocks & & 2 & 3 & 1 & 31 & 22 & 62 & 22 & 12 & 83 \\
\hline Slane, & 3 & 1 & 3 & 2 & 4 & 13 & 6 & 3 & 10 & 6 \\
\hline $\begin{array}{l}\text { Packenham, } \\
\text { Tullamore. }\end{array}$ & 2 & 2 & 3 & 2 & 4 & 3 & 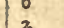 & 3 & 12 & 8 \\
\hline $\begin{array}{l}\text { Tullamore, } \\
\text { Shaen Caftle, }\end{array}$ & & $\begin{array}{l}3 \\
2\end{array}$ & $2^{2}$ & & 3 & 21 & $5_{2}^{2}$ & 2 & & 8 \\
\hline $\begin{array}{l}\text { Shaen Caftle, } \\
\text { Carlow, }\end{array}$ & & 2 & 2 & $\begin{array}{l}2 \\
3\end{array}$ & $\begin{array}{l}3 \\
3\end{array}$ & $\begin{array}{ll}2 & 1 \\
3 & \end{array}$ & $6^{52}$ & 22 & $\begin{array}{l}13 \\
12\end{array}$ & $\begin{array}{l}7 \\
8\end{array}$ \\
\hline Kilfaine, & 2 & 2 & 2 & 2 & 3 & $\begin{array}{l}3 \\
2\end{array}$ & 62 & 2 & 8 & 62 \\
\hline Taghmon, & 2 & & 2 & 2 & 2 & 2 & & 2 & 8 & 72 \\
\hline Fortb, & 2 & & 2 & 2 & 22 & 2 & 7 & & & \\
\hline Profpect, & 2 & 2 & 2 & 2 & & & 5 & 2 & 6 & 12 \\
\hline Mount Kennedy, & 3 & 2 & 3 & 2 & 5 & 32 & 8 & & & \\
\hline Market Hill, & 3 & & 3 & 2 & 4 & 22 & 6 & $\begin{array}{l}22 \\
2\end{array}$ & 38 & II \\
\hline $\begin{array}{l}\text { Ardmagh, } \\
\text { Warrenftown, }\end{array}$ & $\begin{array}{l}2 \\
2\end{array}$ & 3 & 3 & & 31 & 31 & 52 & 22 & 16 & 13 \\
\hline $\begin{array}{l}\text { Wartenftown, } \\
\text { Portaferry, }\end{array}$ & $\begin{array}{l}2 \\
2\end{array}$ & 3 & 3 & & 3 & 22 & 5 & 23 & 15 & 18 \\
\hline $\begin{array}{l}\text { Portaferry, } \\
\text { Shaen Caftle, }\end{array}$ & $\begin{array}{l}2 \\
2\end{array}$ & 3 & 2 & 2 & 3 & 2 & 5 & $\begin{array}{ll}1 & 3 \\
1 & 2\end{array}$ & 13 & 13 \\
\hline Belfaft, & $\begin{array}{l}2 \\
2\end{array}$ & 2 & 2 & 2 & $\begin{array}{ll}3 & 1 \\
2 & 2\end{array}$ & $\begin{array}{ll}2 & 2 \\
2 & 2\end{array}$ & 5 & $\begin{array}{ll}1 & 2 \\
2 & 2\end{array}$ & 12 & 14 \\
\hline eny Hill, & 2 & 3 & 3 & & 32 & 22 & 42 & 2 & 12 & 12 \\
\hline Limavaddy, & 2 & 3 & 3 & I & 31 & 2 & 51 & 12 & 12 & 12 \\
\hline Innifhoen, & 2 & I & 2 & 2 & 3 & 22 & 42 & 2 & & \\
\hline Clonleigh, & 3 & & 2 & 2 & 32 & 22 & 52 & 2 & 12 & 13 \\
\hline Mount Charles, & 2 & & 2 & 2 & 32 & 2 & 4 & 1 & 12 & 6 \\
\hline Caftle Caldwell, & 2 & $?$ & 3 & & 31 & $2^{-}$ & 32 & & 10 & 52 \\
\hline Belle Ifle, & 2 & & 2 & & & 13 & 5 & 12 & 6 & 6 \\
\hline Florence Court, & 2 & 2 & 3 & & 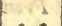 & 2. & 42 & 2 & 12 & 6 \\
\hline Farnbam, & 2 & 2 & 3 & & 33 & I 3 & 5 & 13 & 12 & 8 \\
\hline Ballynogh, & 2 & 2 & 2 & I & & 22 & 4.2 & 2 & 9 & 6 \\
\hline Strokeftown, & 2 & & 2 & 3. & 4 & 12 & 4 & 2 & 72 & 32 \\
\hline Macry, & 3 & I & 4 & & 32 & 13 & 5 & 2 & 8 & 8 \\
\hline Sostland, & 3 & & 3 & & 4 & 2 & & 12 & .8 & 6 \\
\hline Kilalla, & 2 & I & 2 & 2. & $12=0$ & 2 & 43 & 2 & 13 & 8 \\
\hline Wefport, & 2 & 2 & 3 & & ing & 2 & $\frac{6}{6}$ & 3 & 10 & $3 !$ \\
\hline Moniva, & 3 & & 3 & 2 & 128 & $2_{2}^{2}$ & 6 & $x_{2}^{2}$ & $\begin{array}{r}10 \\
6\end{array}$ & $\begin{array}{l}9 \\
6\end{array}$ \\
\hline $\begin{array}{l}\text { Drumoland, } \\
\text { Limerick, }\end{array}$ & 2 & $\begin{array}{l}2 \\
3\end{array}$ & & 2 & & 2 & $\begin{array}{l}7 \\
5\end{array}$ & $\begin{array}{ll}1 & 2 \\
2 & 2\end{array}$ & 5 & 6 \\
\hline Donneraile, & 2 & 2 & 2 & 2 & & 22 & 7 & 23 & 8 & 47 \\
\hline Corks, & 3 & & 3 & & 3 & 22 & 72 & 26 & 10 & 6 \\
\hline Niedeen, & $I$ & 3 & 2 & & & 13 & 6 & 2 & & 6 \\
\hline Arbella, & 2 & 3 & & 2 & & & $4^{1 / 2}$ & 122 & 102 & 6 \\
\hline Tarbat, & 2 & 2 & 2 & 2 & & 22 & $S$ & & & \\
\hline Caffle Oliver, & 3 & & 3 & & & 22 & & & & \\
\hline Tipp & 3 & & 3 & & & 22 & & ${ }^{2} 3$ & 12 & 12 \\
\hline $\begin{array}{l}\text { Curraghmore, } \\
\text { Wuterford. }\end{array}$ & 3 & & 3 & & 33 & 21 & $\begin{array}{l}6 \\
7\end{array}$ & 3 & & 10 \\
\hline $\begin{array}{l}\text { Waterford, } \\
\text { Furnefs, }\end{array}$ & 3 & & 3 & & 32 & 22 & $\begin{array}{l}7 \\
8\end{array}$ & $\begin{array}{l}3 \\
3\end{array}$ & $\begin{array}{l}12 \\
12\end{array}$ & $\begin{array}{l}10 \\
12\end{array}$ \\
\hline Glofter, & & 3 & 2 & 3 & $\begin{array}{ll}4 & 3 \\
2 & 3\end{array}$ & $2^{2} 3$ & 52 & $\begin{array}{lll}3 & 3\end{array}$ & $\begin{array}{l}12 \\
12\end{array}$ & 12 \\
\hline Johnfown, & 3 & & $\begin{array}{l}2 \\
3\end{array}$ & $\begin{array}{l}3 \\
2\end{array}$ & $3_{3}^{23}$ & 3 & 6 & 3 & 11 & 6 \\
\hline Derry & 2 & 2 & 3 & & $\overrightarrow{6}$ & 3 & 5 & 2. & 10 & 12 \\
\hline CaAle Lloyd, & 3 & & 2 & 3 & 22 & 22 & 6 & 2 & 72 & 5 \\
\hline Mitchel': Town, & 2 & 2 & 2 & 2 & 22 & 22 & 6 & 22 & 8 & 8 \\
\hline Average, & 2 & 2 & 2 & 3 & 32 & 21 & 53 & 22 & 103 & 82 \\
\hline
\end{tabular}




\section{PRICE OF PROVISION 6.}

In order for a comparifon, I thall add the prices of my Englin tours.

\begin{tabular}{|c|c|c|c|c|c|}
\hline & ڤัँ & בั่ & ๙ั. & ปे & एं \\
\hline $\begin{array}{l}\text { The Southern Tour } 1767,- \\
\text { The Nortbern Tour } 1768, \\
\text { The Eaftern Tour } 1770,\end{array}$ & $\begin{array}{l}6 \frac{x}{2} \\
6 \frac{x}{2}\end{array}$ & $\begin{array}{l}4 \frac{x}{4} \\
3 \\
3 \frac{1}{2}\end{array}$ & \begin{tabular}{l|}
4 \\
3 \\
$3 \frac{1}{2}$
\end{tabular} & $\begin{array}{l}3 \frac{3}{4} \\
3 \\
3 \frac{1}{2}\end{array}$ & $\begin{array}{l}3 \frac{x}{2} \\
3 \frac{1}{2}\end{array}$ \\
\hline verage of the three, & $6 \frac{x}{4}$ & $3 \frac{1}{2}$ & $3 \frac{1}{2}$ & $3 \frac{3}{4}$ & $3 \frac{1}{2}$ \\
\hline$d$ in 1776 & $5 \frac{3}{4}$ & $2 \frac{3}{4}$ & $2 \frac{1}{2}$ & $3 \frac{1}{2}$ & $2 \frac{1}{4}$ \\
\hline
\end{tabular}

Average of the four meats in England, - $3 \frac{1}{2} d$.

Ditto in Ireland $-\quad-3 \frac{3}{4} \mathrm{~d}$.

Ireland to England as it to 14.

I hould remark, that there has been very little variation in the prices of meat in England fince the dates of thofe journies : the rates in Ireland are higher than I conceived them, and do not from cheapners afford any reafon to conclude that country, as far as cattle extends, to be in a ftate of backwardnefs. The whole of thefe minutes, however, concerns the home confumption only, for as to the immenfe trade in beef and pork (of which hereafter) their rates are confiderably under thefe, as may be fuppofed from the greatnefs of the fcale, in like manner as the confumption prices in England are near double thofe of the victualling office.

Poultry being fo extremely cheap is owing to feveral caufes: Firn, The fmallnefs of the demand; the towns are few, finall, and poor; and all genilemen's families raife a quantity for themfelves. Second, The plenty of potatoes, upon which they are fed, being vaftly greater, and difpenfed with lefs cconomy than the corn in England, upon which poultry is there reared. Third, the extreme warmth of the cabbins, in in which the young broods are nourifhed. Fourth, The na. tural produce of white clover, which is much greater than in England, and upon the feeds of which, young turkies, in particular, are advantageounly fed. I know a gentleman in England, who reared an amazing number of turkies and peachicks the year his lawn was fown with white clover, but the foil being inproper it lafted but one year, and he neither before nor afier bad fuch faccefs with thofe broods. 


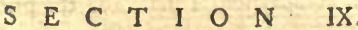

\section{Roads-Cars,}

HOR a country fo very far behind us as Ireland, to have I got fuddenly fo much the ftart of us in the article of roads, is a fpectacle that cannot fail to ftrike the Englifh traveller exceedingly. But from this commendation the turnpikes in general muft be excluded, they are as bad as the buy roads are admirable. It is a common complaint, that the tolls of the turnpikes are fo many jobs, and the roads left in a fate that difgrace the kingdom.

The following is the fyitem on which the crofs roads are made. Any perfon wißhing to make or mend a road, has it sneafured by two perfons, who fwear to the meafurement before a juftice of the peace. It is defcribed as leading from one market town to another (it matters not in what direction) that it will be a public good, and that it will require fuch a fum, per perch of twenty-one feet, to make or repair the fame; a certificate to this purpofe (of which printed forms are fold) with the blanks filled up, is figned by the meafurers, and alfo by two perfons called overfeers, one of whom is ufually the perfon applying for the road, the other the labourer he intends to employ as an overfeer of the work, which overfeer fwears alfo before the juftice the truth of the valuation. The certificate, thus prepared, is given by any perfon to fome one of the grand jury, at either of the aflizes, but ufually in the fpring. When all the common bufinefs of trials is over, the jury meets on that of roads; the chairman reads the certificates, and they are all put to the vote, whether to be granted or not. If rejeeted, they are torn in pieces and no farther notice taken, if granted they are put on the file.

This vote of approbation, without any farther form, enables the perfon, who applied for the prefentment, imniediately to confruet or repair the road in queftion, which he muft do at his own expence, he muft finifh it by the following afizes, when he is to fend a certificate of his having expended the money purfuant to the application; this certificate is figned by the foreman, who alfo figns an order on the treafurer of the county to pay him, which is done immediately. In like manner are bridges, houfes of correction, gaols, \&c. \&c. built and repaired. If a bridge over a river, which parts two counties, half is done by one, and the other half by the other county.

The expence of thefe works is raifed by a tax on the lands, paid by the tenant; in fome counties it is acreable, but in others it is on the ploughland, and as no two plough lands are of the fame fize, is a very unequal tax. In the county of Meath it is acreable, and amounts to one flilling per acre, 
being the higheft in Ireland; but in general it is from threepence to fixpence per acre, and amounts of late years, through the whole kingdom, to one hundred and forty thoufand pounds a year.

The juries will very rarely grant a prefentment for a road, which amounts to about fifty pounds, or for more than fix or feven fhillings a perch, fo that if a perfon wants more to be made than fuch a fum will do, he divides it into two or three different meafurements or prefentments. By the act of parliament all prefentment roads muft be twenty-one feet wide at leaft from fence to fence, and fourteen feet of it formed with ftone or gravel.

As the power of the grand jury extends in this manner to the cutting new roads, where none ever were before, as well as to the repairing and widening old ones, exclufive, however, of parks, gardens, \& $\dot{c}$. it was neceffary to put a reftriction againft the wanton expence of it. Any prefentment may be traverfed that is oppoled, by denying the allegations of the certificate; this is fure of delaying it until another affizes, and in the mean time perfons are appointed to view the line of road demanded, and report on the neceffity or hardihip of the cafe. The payment of the money may alfo be traverfed after the certificate of its being laid out; for if any perfon views, and finds it a manifeft impofition and job, he has that power to delay payment until the caufe is cleared up and proved. But this traverfe is not common. Any perfons are eligible for afking prefentments; but it is ufually done only by refident gentlemen, agents, clergy, or refpectable tenantry. It follows neceffarily, that every perion is defirous of making the roads leading to his own houfe, and that private intereft alone is confidered in it, which I have beard objefted to the meafure; but this I muft own appears to me the great merit of it. Whenever individuals act for the public alone, the public is very badly ferved; but when the purfuit of their own intereft is the way to benefit the public, then is the public good fure to be promoted; fuch is the cafe of prefentment of roads; for a few years the 'good roa(is were all found leading from houfes like rays from a center, with a furrounding fpace, without any communication; but every year brought the remedy, until in a fhort time, thofe rays, pointing from fo many centers, met, and then the comnunication was complete. The original act paffed but feventeen years ago; and the effect of it in all parts of the kingdom is fo great, that I found it perfecly practicable to travel upon wheels by a map; I will go here. I will go there; I could trace a route upon paper as wild as fancy could dietate, and every where I found beautiful roads without break or hindrance, to enable me to realize my defign. What a figure would a perfon make in England, who thould atteinpt to move in that. manner, where the roads, as Dr. Burn has very well obferved, are almolt in as bad a ttate as in the time of Philip and Mary. In 2 few years there will not be a piece of bad road except turn- 
pikes in all Ireland. The money raifed for this firt and molt mportant of alf national purpofes, is expended among the people who pay it, employs themfelves and their teams, enceurages their agriculture, and facilitates fo greatly the improvement of wafte lands, that it ought always to be confidered as the firft ftep to any undertaking of that fort.

At firt, roads in common with bridges, were paid out of the general treafure of the county, but by a fublequent act, the road tax is now on baronies; each barony pays for its own roąds. By another act, juries were enabled to grant prefentments of narrow mountain roads, at two hillings and fixpence a perch. By another, they were empowered to grant prefentments of footpaths, by the fide of roads, to one thilling a perch. By a very late ast, they are alfo enabled to contract, 2t three halfpence per perch per annum, from the firt making of a road, for keeping it in repair, which before could not be done without a fref prefentment. Arthur French, Efq; of Moniva, whofe agriculture is defcribed in the preceding minutes, and who at that time reprefented the county of $\mathrm{Gal}_{\text {way, }}$ was the worthy citizen who firt brought this excellent meafure into parliament: Ireland, and every traveller that ever vifits it, ought, to the lateft time, to revere the memory of fuch a diftinguifhed benefactor to the public. Before that time the roads, like thofe of England, remained impaffable, under the miferable police of the fix days labour. Similar good effects would here flow from adopting the meafure, which would eafe the kingdom of a great burthen in its public effee? abfolutely conteniprible; and the tax here, as in Ireland, ought to be fo laid, as to be borne by the tenant, whofe bufinefs it is at prefent to repair.

Upon the imperfections of the Irifh fyitem I have only to remark, that juries thould, in fome cafes be more ready than they are to grant thefe prefentments. In general, they are extremely liberal, but fometimes they take filly freaks of giving none, or very few. Experience having proved from the general goodnefs of the roads, that abufes cannot be very great, they thould go on with firit to perfect the great work throughout the kingdom; and as a check upon thofe who lay out the money, it might perbaps be advifeable to print county maps of the prefentment roads, with correfponding lifts and tables of the names of all perfons who bave obtained prefentments, the fums they received, and for what roads. Thefe thould be given freely by the jurymen, to all their acquaintance, that every man might know, to whore careleffnefs or jobbing, the public was indebted for bad roads, when they had paid for good ones. Such 2 practice would certainly deter many.

At 1,142,642 acres in the kingdom, ne hundred and forty thoufand pounds a year amounts to juft threepence an acre for the whole territory, a very trifling tax for fuch an improve- 
ment, and which almolt ranks in public eafe and bezefit with that of the poit-office.

It is not to this fyftem fingly, that Ireland is indebted for the goodnefs of her roads; another circumftance calls materially for obfervation, which is the vehicle of carriage : all land-carringe in that kingdom is performed with one-horfe cars or carts. Thofe of the poor people are wretched things, formed with a view to cheapnefs alone; and the loads they carry on them when working by the day, are fuch as an Englifhman would be ainanied ro take in a wheelbarrow, yet they fuffer their horfes to walk fo flow with thefe burthens, that I am confident. work of this fort, done by hire, is five hundred per cert. dearer than in England. Even when they wark for themfelves, their loads are contemptible, and not equal to what their garrens, nifferable as they are, would draw: Cars, however, which work regularly for mills in carrying flour to Dubtin, do better; the common load is from fix to ten hundred weight, which, confidering the horfes, is very well; eighteen hundred weight has been often carried thither from Slane mills. The lownefs of the wheels fuits a mountainous country; but if there is truth in the mechanic powers, is in general a great difadvantage to the animak Great numbers of thefe cars confift only of a fiat bottom orer the axletree, on which a few facks, logs, or ftones, may be laid, or a little heap of gravel in the center. Others have fide-boards, and fome bafkets fixed. But fuch an imperfect and niferable machine deferves not a moment's attention; the object of importance arifing only from one horfe for draught.

Some gentlemen have carts very well made in refpect of ftrength, but fo heavy, as to be almoft as faulty as the common car. Others have larger and heavier two-horfe carts; and a few bave been abfurd enough to introduce Englifh waggons. The well-made roads preferving themfelves for fo many years, is owing to this practice of ufing one-horfe carriages, which is worthy of univerfal imitation. Notwithftanding the expence beftowed on the turnpikes in England, great numbers of them are in a moft wretched ftate, which will con- tinue while the legiflature permits fo many horfes to be harneffed in one carriage. A proof how little one-horfe carriages wear roads, is the inethod ufed in Ireland to conttruet them; they throw up a foundation of earth in the niddle of the fpace from the outfides, on that they immediately form a layer of limeftone, broken to the fize of a turkey's egg; on this a thin feattering of earth to bind the itones together, and over that a coat of gravel, where it is to be had. Their carriages confidered, no fault is to be found with this mode, for the road is beautiful and durable, but being all finifhed at once, with very little or no time for fettling, an Englifh waggon would prefently cut through the whole, and demolifh the road as, foon as made, yet it is perfeclly durable under cars and coaches. 
1 have weighed common cars in Ireland, and find the lighteft weigh $2 \mathrm{C}$. 2qrs. 34 lb. good carts for one horfe at Mr. O'Neil's, 4 C. 2qrs. $211 \mathrm{lb}$. and Lord Kingtoorough had larger carts from Dublin, with five-feet wheels, which weighed $7 \mathrm{C}$. but thefe are much too heavy, in the lightnefs of the machine confifts a great part of the merit. A common Englith waggon with nine-inch wheels from $55 \mathrm{Cwt}$. to three tons. I built a narrow wheeled one in Suffolk for four horfes, the weight of which was $25 \mathrm{Cut}$.

Every horfe in the Irifh car draws, weight

Cwt. qrs.lb.

\begin{tabular}{lllll}
\multicolumn{1}{c}{ of carriage, } & - & 2 & 2 & 14 \\
In Mr. O'Neil's carts, & - & 4 & 2 & 21 \\
In Lord Kingtborough's, & - & 7 & 0 & 0 \\
In a broad wheeled waggon, & - & 7 & 1 & 0 \\
In a narrow ditto, & - & 6 & 1 & 0
\end{tabular}

The extreme lightnefs of the common car is not to be taken into the queftion, as it is inapplicable to a profitable load of any thing, except a fingle block, or facks. It is abfolutely neceffary a cart fhould be capacious enough for a very light but bulky load, fuch as malt duft, bran, dry aihes, \&c. as well as for bay and ftraw. The Suffolk waggon for four horfes is twelve feet long. four broad, and two deep in the fides and ends, confequently, the body of it contains juft 96 cubical feet; the end ladders extended for hay or ftraw four feet more, and there was a fixed fide one, which added two feet to the breadth, confequently the furface on which hay was built, extended juft ninety-fix fquare feet. In a great variety of ufes, to which $I$ applied that waggon, I found four middling horfes, worth about twelve pounds each, would draw a full load of every thing in it; viz. from fifty to fixty hundred weight of hay, twelve quarters of wheat, or fifty-five hundred weight, and the fullage of Bury fheets by computation, judging by the labour of the horfes to a much greater weight, perhaps above three tons. I have more than once taken thefe ineafures as a guide for a one-horfe cart, to give one horfe an exact proportion of what four did in that waggon, the dimenfions of the cart muft be as follow : the body of it muft be juft four feet long, three feet broad, and two feet deep; the end ladders each one foot, and the fide ones fix inches. This will be upon a par with the waggon; but I gave the carts the advantage, by end ladders being each eighteen inches, and the fide ones twelve, which inade the whole furface thirty-five fquare feet, four times which is one hundred and forty inftead of ninety-fix. The weight of thefe carts complete were from four to five hundred; the wheels five feet high, and the axletree iron, which is effential to a light draft; fuch carts coft in England, complete and painted, from nine pounds to ten guineas. Whoever tries them will find a horfe will draw in them, far more than the fourth of the load of a four horfe team, or 
than the eighth of an eight-horfe one, for he will in a tolerably level country draw a ton.

I have often converfed with the drivers of carriers waggons, as well as with intelligent carters in the fervice of farmers, and their accounts have united with my own obfervation, to prove that one horfe in eight, and to the amount of half a horfe in four, are always ablolutely idle, moving on without drawing any weight; a molt unremitting attention is neceffary even for a partial remedy of this, but with carelefs drivers the evil is greater; hence, the fuperiority of horfes drawing fingle, in which mode they cannot fail of performing their thare of the work. The expence, trouble and difappointment of an accident, are in proportion to the fize of the team; with a broad wheeled waggon and eight horfes, they are very great, but with eight carts they are very trifling; if one breaks down, the load and cart are eafily diftributed among the other feven, and little time loft. When bufinefs is carried on by means of fingle horfe carts, every horfe in a ftable is employed; but with waggons, he who keeps one, two, or three horfes, mutt ftand Atill; and what is to be done with five, fix, or feven? It is only four or eight horfes that form an exact team; but the great object is the prefervation of the roads; to fave thefe the legilature has prefcribed wheels, even fixteen inches broad, but all fuch machines are fo enormounly heavy, that they are ruinous to thofe who ufe them; befides, they form fuch exact paths for the following teams to walk in, that the hardeft road is prefently cut into ruts, the moft folid materials ground into duft, and every exertion in repairing bafled as faft as tried. Roads, which are made annually at a vaft expence, are found almoft impaffable from the weights carried in waggons. It may be afferted, wishout exaggerasion, that if there were nothing but one-horfe carriages in England, half the prefent highway expence might be faved, and the roads at the fame time incomparably better.

It mult be admitted, that the expence of drivers would at firt be greater, for a man would not drive above three of them; a man and two boys would do for nine : but why they thould not be as well managed here as in lreland I cannot fee; a man there will often drive five, fix, or even eight cars. I have myfelf feen a fingle girl drive fix. Even in this refpect there is an advantage which does not attend waggons, a boy could any where manage one or two, but twenty boys would not be trufted to drive a waggon. Granting, however, that the expence under this head was fomething greater, ftill is it vaftly more than counterbalanced by the fuperior advantages ftated above, which render it an equal object to individuals and the public. 


\section{S E C T I O N $\mathrm{N}$. \\ Timber-Planting.}

THROUGH every part of Ireland, in which 1 have been, 1 one hundred contiguous acres are not to be found without evideat figns, they were once wood, or at leaft very well wooded. Trees, and the roots of trees of the largeft fize, are dug up in all the bogs; and in the cuitirated countries, the ftumps of trees deftroyed inew that the deftruction has not been of any antient date. A vaft number of the Irith names for hills, mountains, vallies and plains, have forefts, woors, groves, or trees for the fignification; Lord Kingfborough bas an bundred thoufand acres about Mitchelftown, in which you mutt take a breathing gatlop to find a ftick large enough to beat a dog, yet is there not an enclofure without the remnants of trees, many of them large; nor is it a peculiarity to that eftate: in a word the greateft part of the kingdom exbibits a naked, bleak, dreary view for want of wood, which has been deftroyed for a century paft, with the mott thoughtlefs prodigality, and ftill continues to be cut and wafted, as if it was not worth the prefervation. The Baltic fir fupplies all the ufes of the kingdom, even thofe for which nothing is proper but oak; and the diftance of all the ports of Ireland from that fea, makes the fupply much dearer than it is in England.

In converfation with gentlemen, I fourd they very generally laid the deftruction of timber to the common people; who, they fay, have an averfion to a tree; at the earliett age they fteal it for a walking-ftick; afterwards for a fpade bandle; later for a car thaft; and later ftill for a cabbin rafter; that the poor do fteal it is certain, but I am clear the gentlemen of the country may thank themfelves. Is it the confuruption of fticks and handles that has deftroyed millions of acres? Abfurdity! The profligate, prodigal, worthlels landowner cuts down his acres, and leaves them unfenced againft cattle, and then he has the impudence to charge the fcarcity of trees to the walking-fticks of the poor, goes into the houfe of commons and votes for an act, which lays a penaliy of forty flillings on any poor man having a twig in his porfefion, which he cannot account for. This act, and twenty more in the fame fpirit, ftands at prefent a monument of their felf-condemnation and oppreflion. They have made wood fo fcarce, that the wretched cottars cannot procure enough for their neceffary confumption, and then they paifs penal laws on their ftealing, or even polfefling, what it is impolible for them to buy. If by another at you would hang up all the landlords who cut woods without fencing, and deftroy trees without planting, you would lay your axe to the root of the evil, and rid the kingdom of fome of the greateft pefts in it; but in the name of humanity and common fenfe, let the poor alone, for whofe ftealing in this, as in moft other cafes, nobody ought to 
be anfwerable but yourfelves. I was an eye-witnefs in various parts of the kingdom, of woods cut down and not copfed. The bonefteft poor upon earth, if in the fame fituation as the Irifh, would be ftealers of wood, for they muft either fteal or go without what is an abfolute neceffary of life. Inftead of being the deftroyers of trees, I am confident they may be made prefervers of them; recollect Sir William Oborne's mountaineers, to whom he gave a few Lombardy poplars, they cherifhed them with as much care as his own gardener could have done. At Mitchelftown, I had opportunities of making obfervations which convinced me of the fame thing; I faw in every refpect, indeed all over Ireland, the greateft readinefs to do whatever would recommend then to their landlord's favour. I had three plans relative to wood, which I have reafon to believe would anfwer in any part of the kingdom: Firft, To give premiums to the cottars who planted and preferved trees, and not to let it depend on the premium alone, but to keep a lift of thofe who appeared as candidates, and upon every ollier occafion to let them be objects of favour. Second, To force all the tenantry to plant under the following claufe in their leafes:

"And alfo, that the faid A. B. bis beirs and affgns, fball and " will, every year, during the continuance of tbis demife, well and " truly plant, and tborougbly fecure until the end of tbe faid term, "from all injury or damage by caule, or otberwife, one timber tree "for every acres tbat are contained in tbe berein demifed "prenifes, provided that fuch trees foall be fupplied gratis, on de" mand, by the faid C. D. bis beirs and affgns; and in cafe any "trees jall die or fail, that in fucb cafe the faid $A$. B. Jball and " will plant in tbe year next after fucb deatb or failure, an equal " number of timber trees in the faid demijed premijes, in the placs " or flead of fuch tree or trees fo dying or failing as aforefaid; and "s in caje, at the expiration of the fuid demife, the proper number of - trees, of a due age, according to the meaning and intent of ibefe "premifes, be not left growing and fanding upun the faid demijed "s premijes, or fome part tbereof, that then tbe faid A. B. lis beirs or " alfigns, fhall forfeit and pay unto the faid C.D. bis heirs and "afligns, the fum of five foillings for every tree fo deficient by death, " failure, injury, or negligence."

The proportion of acres per tree to be according to circumftances. It fhould always be remembered, that the claufes of a leafe rarely execute themfelves; it is the landlord or his agent's attention that mutt make them efficient. A tenantry every where is very much dependent, unlefs leafes for lives are given, but I fuppofe them for twenty-one years. In Ireland their poverty makes this dependance ftill greater. They afk time for the paynerit of their rent: they run in arrears; they are threatened or driven; if they pay wetl, Atitl they have fome favour to afk, or expect; in a word, they are in fuch a fituation, that attention would fecure the nott eatife 
compliance with fuch a claufe. If once, or twice, upon an eftate, a man was drove for his rent, who neglected the trees, while another in the fame circumftances had time given him, becaufe he preferved them, the effect would prefently be feen. 'T bird, To have a magazine of fticks, fpade handles, pieces for cars, and cabbins, \&c. laid in at the cheapeft rate, and kept for felling at prime coft to whoever would buy them. Thefe would want to be purchafed but for a few years, as fmall plantations of the timber willow would in four years furnith an ample fupply.

That thefe three circumftances united, would prefently plant a country I am convinced; I faw a willingners among Lord Kingfborough's little tenants do it, fome even who made a beginning the very firft year; and bundreds affured me of their moft affiduous compliance. Such a plan moft certainly Should not preclude large annual plantations on the land which a gentleman keeps in hand; but the beauty of the country depends on trees, fcattered over the whole face of it. What a figure would Ireland make on a comparifon with its prefent ftate, if one tree now ftood by each cabbin! but it is the fpirit of the Irifh nation to attempt every thing by laws, and then leave thofe laws to execute themfelves, which indeed with many of them is not at all amifs. It is by no means clear, whether the act which gives to the tenant a property in the trees he plants, to be afcertained by a jury at the end of the leafe, and paid by the landlord, has any great tendency to encreafe the quantity of wood. It has unfortunately raifed an undecided queftion of law, whether the act goes to trees, which were originally furnithed from the landlord's nurfery, or planted in confequence of a claufe in a leafe. If it thould fo interfere with fuch plantations, it would be highly mifchievous: Alfo, for a man to be forced eitber to buy or to fell bis property, at the price fixed by a jury, is a harfh circumitance. To this caufe it is probably owing, that the plantations made in confequence of that act, are perfectly infignificant.

I have made many very minute calculations of the expence, growth, and value of plantations in Ireland, and am convinced from them that there is no application of the beft land in that kingdom will equal the profit of planting the wort in it. A regard for the intereft of poiterity call for the oak and other trees which require more than an age to cone to maturity, but with other views the quick growing ones are of profit much fuperior, thefe come to perfection fo fpeedily that three-fourths of the landlords of the king: dom might expect to cut where they planted, and reap thofe great profits, which moft certainly attend it. There are timber willow (fallies as they are called in Ireland) which rife with incredible rapidity. I have meafured them at Mr. Bolton's near Waterford twenty-one feet high in the third year from the planting, and as ftrait as a larch. With this willow, woods would arife as it were by enchantment, and 
all forts of farm offices and cabbins night be built of it in feven years from planting. Is it not inexcufable to complain of 2 want of wood when it is to be had with fo much eafe? Larch and beech thrive wonderfully wherever I have feen them planted; and the Lombardy poplar makes the fame luxuriant thoots for which it is famous in England; and though a foft wood yet it is applicable to fuch a multiplicity of purpofes, and fo eafily propagated, that it deferves the greateft attention.

As to oak they are always planted in Ireland; from a nurfery I have feen very handfome trees as old as fifteen years, fome perhaps older, but even at that age they run incomparably more into head than plants in England which have never been tranfplanted. It is a great misfortune that a century at leaft is neceffary to prove the mifchief of the practice: We know by moft ample experience that the noble oaks in EngJand applicable to the ufe of the large fhips of war, were all forwn where they remained. That tree puhes its tap root fo powerfully that I have the greateft reafon to believe the future growth fuffers effentially from its being injured, and I defy the moft fkilful nurferyman to take them up upon a large fcale without breaking, if it is broke in the part where it is an almoft imperceptible thread, it is juft the fame as cutting it off in a larger part, the fteady perpendicular power is loft, and the furface roots muft feed the plant, thefe may do for a certain growth, and to a certain period, but the tree will neyer become the fovereign of the foreft, or the waves. I know feveral plantations of fown oak in England from twelve to thirty, and fome forty years growth, which are truly beautiful, and infinitely beyond any thing I have feen in Ireland.

The woods yet remaining in that kingdom are what in England would be called copfes. They are cut down. at various growths, fome being permitted to ftand forty years. Attentive landlords fence when they cut to preferve the future thoots, others do not. But this is by no means the fyttem with a view to which I recommend planting, timber of any kind cut as fuch will pay double and treble what the fhoots from any fubs in the world will do. They may come to a tolerable fize, and yield a large value; but the profit is not to be compared with. To explain this, permit me one or two remarks.

If willow, poplars, alh, \&c. are planted for timber to be cut at whatever age, ten, twenty or thirty years; when cut the ftools will throw out many fhoors, but let it not be imagined that thefe fhoots will ever again become timber; they will never be any thing but copfe wood, and attended in future with no more than the copfe profit, which is not half that of timber, in fuch a cafe the land flould be new planted, and the old tools either grubbed up for fuel, or elfe the growth from them cut very often for faggots till the new timber gets up enough to drip on and deftroy it. The conmon practice in Ireland is cutting young trees down when they do not fhoot well, this is converting timber to copfe vood; attention 10 cutting VOL. II. E. 
off all the fhoots but one will train up a ftem, but I queftiost whether it will ever make a capital tree: if the other fhoots are not annually cut it will never oe any iree at all; and yet it is certainly a fact that the new thoot is much finer than the old one, which perhaps would have cone to nothing ; but better remove it entirely than depend on new thoots for making timber. The gentlemen in that kingdons are much too apt to think they have got timber, when in faet they have nothing but fine large copfe wood. A trong proof of this is the great double ditches made thirty or forty years ago, and planted with double rows of trees, generally aih, thefe for two reafons are ufually (for the age) not half fo good as trees of the fame growth in England; one is, many of them were cut when young, and arofe from ftools; the other is their growing out of a high dry bank, full of the roots of four rows of white thorn or apple quick, befides thofe of the trces themfelves. It is a fact that I never faw a fingle capital tree growing on thefe banks : all hedge trees are difficult to preferve, and therefore muft have been cut when young. Afh in England growing from a level are generally worth in forty years frcm forty thillings to three pounds. And I know many trees of fifty to fixty years growth that would fell readily at from four to eight pounds, yet the price in Ireland is higher. Another practice which is common in that kingdom is pruning timber trees, and even oaks. I was petrified at feeing oaks of ten and fifteen feet high with all the fide fhoots cut off. There are treatifes upon planting which recommend this practice as well as cutting down young trees to make the better timber. There are no follies which are not countenanced, and even prefcribed in fome book or other, but unbappy is it for a kingdom when they are liftened to. Burn your looks, and attend to nature; come to England and view our oak, our afh, and our beech all felf fown, and never curfed with the exertions of art. Shew me fuch trees from the hands of nurferyman and pruners before you wafte your breath with fhallow reafoning to prove that the moft common of the operations of nature mult be affited by the axe or pruning hook.

Ore reafon why both fences and trees in Ireland which have once been made are now neglected and in ruin, is owing to the firt planting being all that is thought of ; the hedges are fuffered to grow for thirty or forty years without cutting; the confequence of which is their being ragged, and cpen at botton, and full of gaps whole perches long. But all fences fhould be cut periodically, for the fame reafon that trees ought never to be touched, their pufhing out many fhoots for every one that is taken off; this fhould be ropeated every ffteen years; a proper portion of the thorns fhould be plaflied down to forin an impenetrable live hedge, and the reft cut off, and made into faggots. But in the Irith way the fences yield no fuel at all. Topermit a hedge to grow too long without cutting, not only suins it for a fence, but fpoils the trees that are planted with it. 


\section{A N U R, E S.}

Lafty, let me obferve, that the amazing neglect in not planting ofier grounds for making bafkets and fmall hoops, is unpardonable throughout the kingdom, they no where thrive better; a fmall one I planted in the county of Corke grew fix feet the finft year, yet at that port there is a confiderable importation of them from Portugal.

\section{S E C C T I O \\ Manures-Wafe Lands.}

THE manure commonly ufed in Ireland is lime; inexhauttible 1 quarries of the fineft lime-itone are found in molt parts of that inand, with either turf, or culm at a moderate price to burn it. To do the geritemen of that country juftice, they underftand this branch of hufbandry very well, and practice it with uncommon fpirit. Their kilns are the beft I have any where feen, and great numbers are kept burning the whole year through, without a thought of ftopping on account of the winter. Their draw kilns burn up to forty barrels a day; and what they call French kilns, which burn the ftone without breaking, have been made even to five thoufand barrels in a kiln. Mr. Lellie laying ten thoufand barrels on his land in one year, and Mr. Aldworth as much, are initances which I never heard equalled. The following table will thew the general practice.

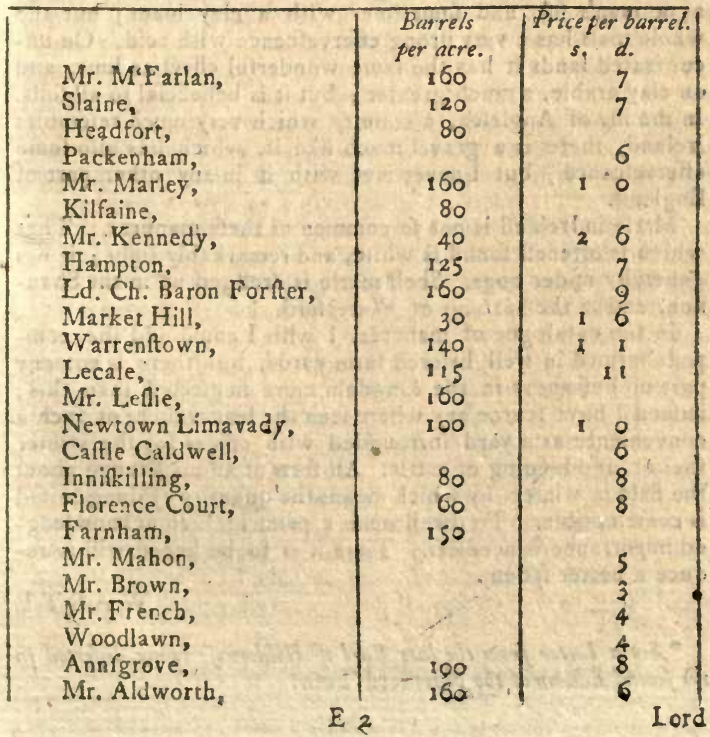




\begin{tabular}{|c|c|c|}
\hline $\begin{array}{l}\text { Lord Donneraile, } \\
\text { Mallow, } \\
\text { Mr. Gordon, } \\
\text { Coolmore, } \\
\text { Nedeen, } \\
\text { Mucrus, } \\
\text { Mr. Blennerhaffet, } \\
\text { Mr. Bateman, } \\
\text { Tarbat, } \\
\text { Lord Tyrone, } \\
\text { Average, }\end{array}$ & $\begin{array}{c}\text { Barrels } \\
\text { per acre. } \\
80 \\
100 \\
50 \\
40 \\
70 \\
100 \\
50 \\
40 \\
200\end{array}$ & 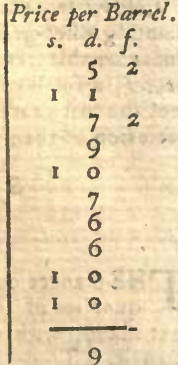 \\
\hline
\end{tabular}

Thefe quantities are upon the whole confiderable. The price thews the plenty of this manure in Ireland. To find any place where it can be burnt for three pence and four pence is truly wonderful, but can only be from the union of turf and limeftone at the fame place.

I no where heard of any land that had been over limed, or on which the repetition of it had proved fo ditadvantageous as it has fometimes been found in England*.

Limeftone gravel is a manure peculiar to Ireland; and is moft excellent. It is a blue gravel, mixed with ftones as large as a man's fift, and fometimes with a clay loam; but the whole mafs has a very ftrong effervefcence with acid. On uncultivated lands it has the fame wonderful effect as lime, and on clay arable, a much greater; but it is beneficial to all foils. In the ifle of Anglefea, a country which very much refembles Ireland, there is a gravel much like it, which has alfo fome effervefcence; but Inever net with it in any other part of England.

Marle in Ireland is not fo common as thefe manures. That which is ofteneft found is white, and remarkably light; it lies generally under bogs. Shell marle is dredged up in the Shannon, and in the harbour of Waterford.

In the catalogue of manures, I wifh I could add the compoits formed in well listered farm yards, but there is not any part of hubandry in the kingdom more neglected than this; indeed I have fcarce any where feen the lealt veftige of fuch a convenience as a yard furrounded with offices for the winter thelter, and feeding of cattle. All forts of animals range about the field in winter, by which means the quantity of dung raifed is contemptible. 'To dwell upon a point of fuch acknowledged importance is needlels. Time it is to be hoped will introduce a better fyftem.

W A S T E

- See a Letter from the late Earl of Holdernefs $10 \mathrm{me}$, inferted in the fecond Edition of abe Northern Tour. 


\section{W A S T E L A N D S.}

Although the proportion of wafte territory is not, I apprehend, fo great in Ireland as it is in England, certainly owing to the rights of commonage in the latter country which fortunately have no exiftence in Ireland; yet are the tracts of defart mountains and bogs very confiderable. Upon thefe lands is to be practifed the moft profitable hufbandry in the King's dominions; for fo I am perfuaded the improvement of mountain land to be. By that expreffion is not to be underftood only very high lands, all wafte in Ireland that are not bog they call mountain; fo that you hear of land under that denomination where even a hillock is not to be feen. The largeft tracts, however, are adjoining to real inountains, efpecially where they flope off to a large extent gradually to the fouth. Of this fort Lord Kingtborough has a very extenfive and moft unprofitable range. In examining it, with many other mountains, and in about five months experience of the beginning only of an improvement under nyy direction there, I had an opporiunity of afcertaining a few points which made me better acquainted with the practicability of thofe improvernents than if I had only paffed as a traveller through the kingdom. By ftating a few of the circumitances of this attempt, others who have mountains under fimilar circumitances may judge of the propriety of undertaking their inprovement. The land has a very gentle declivity from the Galty mountains towards the fouth, and to a new road Lord King borough made leading from Mitchelftown towards Cahir, which road he very wifely judged was the firit ftep to the inprovement of the wafte parts of his effate as well as a great public benefit. The South fide of this road limeftone is found, and on the North fide, the improvement $w$ as begun in a fpot that included fome tolerable good land, fome exceeding rough and ftoney, and a wet bottom where there was a bog two, three, and four feet deep ; the land yielded no other profit than being a commonage to the adjoining farm, in which way it night pay the rent poffibly of a hilling an acre: Twenty thoufand acres by eftimation joined it in the fame fituation which did not yield the fourth of that rent. In June I built a lime kiln which burnt twenty barrels a day, and cut, led, and ftacked turf enough to keep it burning a whole tweivenionth, Retched the fences of four inclofures, making thirty-four acres, and finifhed the firt work of thetn, leaving the reft, and planting till winter*. I cleared two inclofures of ftones; pared and burnt them; burnt eight hundred barrels of lime, limed

one

* Where fences muft be done by the day and not the perch, which will generally be the cafe in the beginning of an improvienent in a very wild country, from the labourers being totally ignorant of taking work by meafure; all ithat is pojfible pould be executed in fung- 
one inclofure, and fowed one third with wheat, a third with rye, and the other with bere, as an experiment; the other field with turneps, which from the continual drought, failed. Two cabbins were built. And the whole expence in five months, including the price of all ploughing, and carriage, (the latter from the miferable cars and garrens at a molt extravagant rate) buying timber, ftewards wages, Src, amounted to one hundred and fifty pounds. The moment the neighbours underftood the works were at an end, fome of them offered me ten fhillings an acre for the land to take it as it was, which is juft eleven per cent. for the money, but I could have got more. The following were the only data gained : lime burnt for fivepence a barrel. Paring with the graffan in ftoney land 305 . to 40 s. an acre, and done by the plough at eight thillings much betier, burning and fpreading the afhes depends on weather, one piece coft above twenty fhillings an acre, the other not five, but on an average I fhould calculate it at ten fhillings. The whole operation may be very well done with the plough at twenty thillings. Clearing from ftones and carting away, various; I found a very ftoney piece could be cleared at twelve hillings an acre. A fingle ditch feven feet broad, and from three to five deep, the bank nine feet high from the botton of the ditch, coft one fhilling and fixpence; but this expence would haveleffened when they were more accuftomed to it : confequently a double fence with a fpace between left for planting, three fhillings.

My defign was to purchafe a flock of mountain theep in the following fpring, and keep them through the fummer in the mountains, but folding them every night in the improvement, in which work I could have inftructed the people, and when once they had feen the benefit, I do not think the practice would ever have been loft. To have provided plenty of turneps for their winter fupport, and improved the breed by giving them fome better tups, but to have done this gradually in proportion as their food improved. Turneps to be for fome years the only crop, except fnall pieces by way of trial. To have laid down the land to grafs after a proper courfe of turneps in the manner and with the feeds I practifed in Hertfordhire, which would have fhewn what that operation is. There is not a complete meadow in the whole country. To haye proportioned the theep to the turneps at the rate of from twenty to thirty an acre according to the goodnefs of the crop: there is a power in fuch wafte tracts of keeping any number in fummer; the common people keep them all the year round on the mountains.

The

mer, efpecially in fo wet a climate as Ireland; and wben no more is paid for a day in July than in December. Some of my banks fell with the Autumn rains, owing to two caujes: fir $\beta$, tbe men, infiead of knowing borv to make a ditch were mountaineers, who fcarcely knew the right end of a Spade; and fecondly, it proved the dryef Seafon that ever was known in Ireland. 
The annual product of the improved land is in this fyftem very eafily afeertained. Suppofe only twenty * theep per acre, and no more than fifteen lambs from them, worth two fhillings and fixpence each, it is thirty-feven fhillings and fixpence, and the twenty fleeces at one hilling make ffty-feven fhillings and fixpence : about three pound therefore may be reckoned the loweft value of an acre of turneps at firt ; but as fucceffive crops on the fame land improve greatly, they would winter more than twenty, and both lambs and wool be more valuable, fo that from a variety of circumftances I haye attended to in that country, I am clear the common value of the turneps might be carried to four pounds, and in the courfe of a few years perhaps to five pounds an acre. And to ftate the expence of fuch an improvement completely finifhed at ten pounds an acre, including every article whatever; three crops of turneps amply repay the whole, and the future produce or rent of the land, neat profit. This would be twenty fhillings an acre; twentyfive thillings are commonly paid for much worfe land. The real fact of fuch improvements is a landlord's accepting an eftate gratis, or at leaft paying nothing but trouble for it. Nearly fuch conclufions muft be drawn froul lord Altamont's mountain works, of which an account is given in the minutes. I thould remark that the people I employed, though as igno. rant as any in the kingdom, and had never feen a turnep hoe, hoed the turneps when I fhewed them the manner, very readily, and though not flilfully, well enough to prove their docility would not be wanting; it was the fame with the paring mattock, and the Norfolk turnep fower. They very readily execute orders, and feem to give their inclination to it.

There are feveral reafons which make thele improvenents more profitable and eafy in Ireland than they are in England. There are nocommon rights to encounter, which are the curfe of our noors. Buildings, which in England form one of the heavieft articles, are but a trifing expence; make the land gond, and you will let it readily without any at all; or at leaft with an allowance of a roof towards a cabbin; and laftly, the proportionate value of improved land compared with that of unimproved is much higher than it is with us, owing to the want of capital, rendering all improvements forare, and to the common people fo difficult. Three hundred pounds a year fteadily einployed in fuch an undertaking, would in a fow years create an eftate fufficient for the greateft undertakings : but fuccefs depends. on a regular unbroken exertion, a point I found very few perfons in Ireland thoroughly underftood, owing to their not being accultomed to large flocks of theep regularty depending on turneps. At the fame time that this work was carrying on, his lordhip, by my advice, encouraged the pea-

It is to be noted that fock Beep are onty baited, and that rbiefly in bad weatber. The winters in Ireiand are much mildes. shar, in England. 
fantry to take in fmall patts of thefe mountains themfelves. The adjoining farms being out of leafe, he had a power of coing what he pleafed; I marked a road, and afligned portions of the wafte on each fide to fuch as were willing to form the fences in the nanner prefcribed, to cultivate and inhabit the land, allowing each a guinea tow ards his cabbin, and promifing the beft land rent free for three years, and the wort for five; the eagernefs with which the poor people came into this fcbeme, convinced me that they wanted nothing but a little encouragement to enter with all their might and fpirit into the great work of improvement. They trufted to iny affurance enough to go to work upon the ditches, and actually made a confiderable progrefs. In all undertakings of this fort in Ireland it is the poor cottars, and the very little farmers, who are the beft tools to employ, and the beft renants to let the land to; but this circumftance raifes many enemies to the work; the better fort who have been ufed to tread upon and opprefs, are ill pleafed to fee any importance or independancy given to them : and the whole race of jobbing gentlemen, whofe converfation for ever takes the turn of ridiculing the poverty of the cottar tenants, will always be ready with an equal cargo of fallhood and ignorance to decry and depreciate any undertaking which is not to conduce to their own benefit : if a landlord does not fteadily refolve to laugh at all this trafh, he had better never think of improvements.

Trifling as they have been on the Irifh mountains, yet are the bogs itill more negleeted. The minutes of the journey thew that a few gentlemen have executed very meritorious works even in thefe, but as they, unfortunately for the public, do not live upon any of the very extenfive bogs, the inhabirants near the latter deny the application of their remarks. Bogs are of two forts, black and red. The black bog is generally very good, it is folid almoft to the furface, yields many athes in burning, and generally admitted to be improveable though at a heavy expence. The red fort has ufually a reddifl fubftance five or fix feet deep from the furface, which holds water like a fpunge, yields no afhes in burning, and is fuppofed to be uttcrly irreclaimable.

In the variety of theories which have been farted to account for the formation of bogs, difficulties occur which are not eafily folved: yet are there nany circumftances which affit in tracing the caufe. Various forts of trees, fome of them of a great fize, are very generally found in them, and ufually at the bottom, oak, fir, and yew the moft common; the roots of thefe. trees are faft in the earth; fome of the trees feem broken off, others appear to be cut, but mare with the miarks of fire on them. Under fome bogs of a confiderable depth there are yet to be feen the furrows of land once ploughed. The black bog is a folid weighty mafs which cuts almott like butter, and upon ezamination apfears to refemble rotten wood. Under the red 
bogs there is always a ftratum if not equally folid with the black bog, nearly fo, and inakes as good fuel. There is upon the black as well as the red ones a furface of that fpungy vegetable mafs which is cleared away to get at the bog for fuel, but it is Shallow on thefe. Sound trees are found equally in both forts. Both differ extremely from the bogs $I$ have feen in England in the inequality of the furface; the Irith ones are rarely level but rife into hills. I have feen one in Donnegal which is a perfect fcenery of hill and dale. The fpontaneous growth moft common is heath ; with fome bog myrtle, rufhes and a little fedgy grafs. As far as I can judge by roads, laying gravel of any fort, clay, earth, \&c. improves the bog, and brings good grafs. The depth of them is various, they have been fathomed to that of fifty feet, and fome are faid to be ftill deeper.

From thefe circumftances it appears, that a foreft cut, burnt, or broken down, is probably the origin of a bog. In all countries where wood is fo common as to be a weed, it is deftroyed by burning, it is fo around the Baltic, and in America at prefent. The native Irifh might cut and burn their woods enough for the tree to fall, and in the interim between fuch an operation, and fucceflive culture, wars and other inteftine divifions might prevent it in thofe fpots, which fo neglected afterwards became bogs. Trees lying very thick on the ground would become an impedinent to all ftreams and currents, and gathering in their branches, whatever rubbifh fuch waters brought with them, form a mals of a fubitance which time might putrefy, and give that acid quality to, which would preferve fome of the trunks though not the branches of the trees. The circumftance of red bogs being black and folid at the bottom, would feem to indicate that a black bog has received lefs acceffion from the growth and putrefaction of vegetables after the formation than the red ones, which from fome circumftances of foil or water might yield a more luxuriant furface vegetation, till it.produced that mafs of fpunge which is now found on the furface. That this fuppofition is quite fatisfactory I cannot affert, but the effect appears io be at leaft polfible, and accounts for the diftinction between the two kinds. That they receive their form and increafe from a coriftant vegetation appear from their rifing into hills, if they did not vegetate the quantity of water they contain would keep them on a level. The places where the traces of ploughing are found, I thould fuppofe were cnce fields adjoining to the woods, and when the bog rofe to a certain height it flowed gradually over the furrounding land.

But the means of improving them is the mot important confideration at frefent. Various methods have been prefcribed, and fome finall improvements have been effected by a few gentlemen, but at fo large an expence that it is a queftion how far their operations anfwered. Here, therefore, one muft call in theory to our aid from a deficiency of practice. Fortunately for 7 bog improver, drains are cut at fo fmall an expence, in them, 
that that neceffary work is done at a very moderate coff. But in fpungy ones it muft be repeated annually, according to the fubftance of the bog, and no other work attended to but finking the drains lower and lower, by no means till you come to the bottom, (the neceffity of which is a vulgar error) but till the fpaces between them will bear an ox in boots. Then the furface thould be levelled and burnt, and I would advife nothing to be done for a year or two but rollers as heavy as might be, kept repeatedly going over it, in order to prefs and confolidate the furface. Before any thing elfe was attempted I would fee the effect of this; probably the draining and rolling would bring up a frefh furface of vegetables not feen before, in that cate I thould have very few doubts of fipilining the work with the feeding, treading, and fold of theep which would encourage the white clover and graffes to vegetate ftrongly; fortunately for any operation with theep they can be kept fafely, as they never rot in a drained bog. A very ingenious friend of mine thinks the whole might be done with theep with little or no draining, but from viewing the bogs I am clear that is impofible. During the time of rolling and theep feeding, the drains I would have kept clean and open, the labour of which would regularly be lefs and lefs. When the furface was fo hard as to bear cars, marle, clay, gravel, or earth, night be carried on according to diftance, which with the theep feeding would convert it into good meadow. But as carting in a large improvement would probably be too expenfive; I hould think it worth while to try the experiment whether it would not be practicable to fink a thaft through the bog into the gravel or earth beneath it, boarding or walling, and plaftering with terrafs or cement, in order to be able to draw up the under ftratum, as all the chalk in Hertfordfhire is raifed, that is, wound up in buckets; chalk is fo raifed and wheeled on to the land for the price of eight-pence the load of twenty bufhels, and is found a cheap improvement at that price, yet the chalk drawers, as they call themfelves, earn two flillings and two and fixpence each day. Whatever the means ufed, certain it is that no meadows are equal to thofe gained by improving a bog; they are of a value which fcarcely any other lands rife to: in Ireland I Thould fuppofe it would not fall thort of forty fhilings an ase, atd tife in inany eafes to three pounds. 


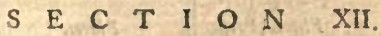

\section{Cattle-Wool-Winter Food.}

THE cattle in Ireland are much better than the tillage ; 1 in the management of the arable ground the Irith are five centuries behind the beft cultivated of the Englifin counties. but the moifture of the climate, and the richnefs of the foil have reared, affifted with importations from England, a breed of cattle and theep, though not equal to ours, yet not fo many degrees below them as might be expecled from other circunftances. The following table will thew the prices and profic on fattening bullocks and cows.

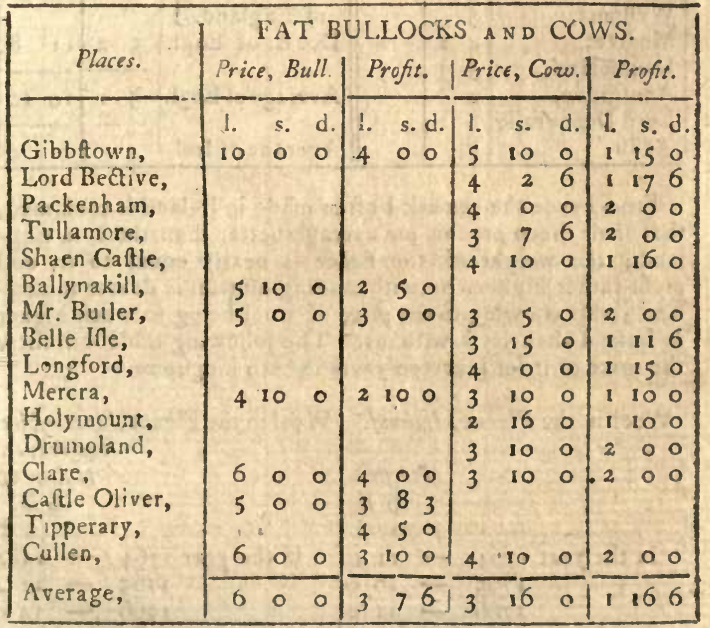

The fyitem purfued in fatting thefe beafts is explained fully in the minutes of the journey. I think the profit remarkably fntall. The exporration of beef, and its prices, will be given under the article Trade, as it forms a principal branch of the commerce of Ircland. 


\begin{tabular}{|c|c|c|c|c|c|}
\hline Places. & Flece. & Profit. & Places. & Flesce. & Profit. \\
\hline & |lb.grs. & s. & & grs. & \\
\hline & & & Tipper & & 100 \\
\hline $\mathrm{T}$ & 6 & & 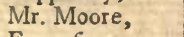 & & \\
\hline & 4 & & & $\begin{array}{ll}5 & 3\end{array}$ & \\
\hline & 62 & 1 & & 53 & \\
\hline & 53 & & & 53 & 10 \\
\hline & 53 & & & $\begin{array}{ll}5 & 3\end{array}$ & 9 \\
\hline urt, & $\begin{array}{l}8 \\
3\end{array}$ & & in & 3 & - \\
\hline 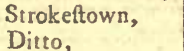 & 5 & $\begin{array}{ll}17 & 0 \\
10 & 0\end{array}$ & Avera & 5 & 110 \\
\hline & 5 & 100 & f 7 & & \\
\hline & 4 & & & 5 & 10 \\
\hline & 5 & & & & \\
\hline & 42 & & Do. E. of Engl. & 52 & 11 \\
\hline , & $\begin{array}{l}53 \\
4\end{array}$ & & Average of Engl. & $7 \overrightarrow{51}$ & 1010 \\
\hline & 8 & & & 8. & \\
\hline & 7 & & & 5 & II \\
\hline
\end{tabular}

From hence the remark $I$ often made in Ireland is confirmed, that their theep are on an average better than thofe in England; the weight of the fleece is nearly equal to it, and profit rather higher, notwithftanding mutton is dearer in England; this is owing to the price of wool being fo much higher in Ireland than it is with us. The following table will thew the price of it for fourteen years in both kingdoms.

Wool in the Fleece, Ireland. Wool in the Fleece, Lincolnfire.

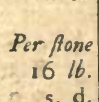

Tod reduced

In the year $176_{4}-2$ is 0

$1765=100$
$1766-110$
$1767-130$
$1768-136$
$1769-136$
$1770-140$
$1771=140$
$1772^{*}-00$
$1773^{*}-00$

to fone of $16 \mathrm{lb}$.

s. d:

In the year $1764-114$

$1765-114$

$1766-120$

$1767-108$

$1768-80$

$1769-80$

$1770-83$

$1771-80$

$1772-83$

$1773-84$

* Unfetiled but very bigh. 
Wool in the Fleece, Ireland. Wool in the Fleece, Lincolnfbire.

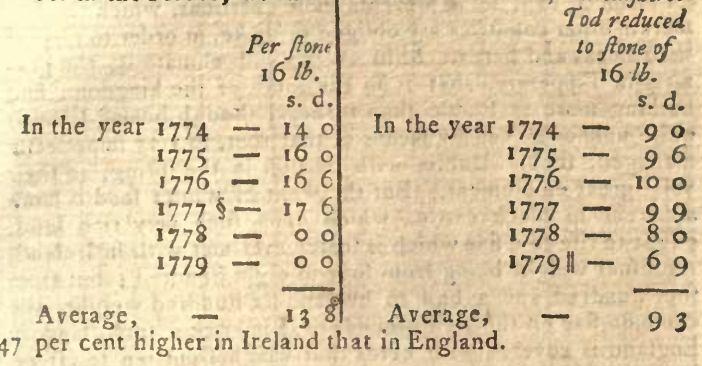

From hence it appears, that wool has been amazingly higher in Ireland, which accounts for the fuperiority in the profit of theep. There are feveral reafons for their height of price, but the principal are a decreafe in the quantity produced, and at the fame tine an encreafe in the confumption. The bounty on the inland carriage of corn, as I thall thew hereafter, has occafioned the ploughing up great tracts of theep walk; and at the fame time the poor people have improved in their cloathing very much : thefe reafons are fully fufficient to account for that rire in the price of wool, which has brought it to be higher than the Englifh rate. There is, however, another very fowerful reafon, which has had a conftant operation, and which is the cheapnefs of fpinning; in Ireland this is twopence halfpenny and threepence, but in England fivepence and fixpence. Great quantities are therefore fpun into yarn in Ireland, and in that ftate exported to England, for the price of the labour is fo low, that a yarn manufacturer can afford to give a much higher price for wool than an Englifh one, and yet fell the yarn itfelf, after the expence of freight is added, as cheap as Englifh yarn. The quantities of yarn, \&c. exported, will be feen hereafter.

Many gentlemen have made very fpirited attempts in improving the cattle and fieep in Ireland, fo that the mixture of the Englith breed of cattle has fpread all over the kingdom; Englifh theep are atfo extending. The minutes of the journey thew that the fize of the bullocks is much encreafed in the laft twenty years.

But profitable as theep are in Ireland, they are not near fo as they might be, if turneps were properly attended to: and the reafon why oxen and cows yield ftill lefs is the fame deficiency. The mildnefs of the climate enables the ftock-maiter to do with but little winter food, and this natural advantage proves

$\$$ Communicated by Mr. Jolbua Pine in the woollen trade, Dublin.

II Comnunicated by Mr. Fanies Oaks in the rooollen trade, Bury, suffolk. 
an artificial evil, for it prevents thofe exertions, which the farmers in other countries are obliged to make, in order to fupport their flocks and herds. Mild as the Jrith climate is, the graziers in Tipperary, that is in the louth of the kingdom, find nothing more profitable than turneps, though hoeing them is quite unknown, and by mieans of that root, fo very imperfectly managed, fupply Dublin with mutton in the fpring, to their very great enolument. But the want of winter food is more apparent in black cattle, which upon fuch very rich land, ought to rife to a fize which is farce ever met with in Ireland, the ufual weight being from four to eight hundred; but from four hundred and a half to five and fix hundred weight, the common fize on the rich grounds of Limerick; fuch land in. England is covered with herds that weigh from ten to fifteen hundred weight each; this vaft difference is owing to their being reared the two firt winters with fuch a deficiency of fond, that their growth is itinted, fo that when they come upon the fine bullock land, they are of a fize which can never be fatrened to the weight of Englifh oxen. The deficiency in turneps, \&c. renders hay very valuable in Ireland, which occafions its being given fparingly to cattle; but if they had while young, as many turneps as they would eat in addition to their prefent quantity of hay, and were protected in warm yards againt the wind and rain, they would rife to a fize unknown at prefent in that kingdom. Upon this and a variety of other accounts, there is farcely any objeet in its agriculture of fo much importance as the introduction of that plant under the right cultivation.

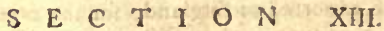

\section{Tythes-Cburch Lands.}

UR fitter kingdom labours under this heavy burden as well as her neighbours, to which is very much owing the uncultivated ftate of fo great a part of her territory. The following are the minutes of the journey: 


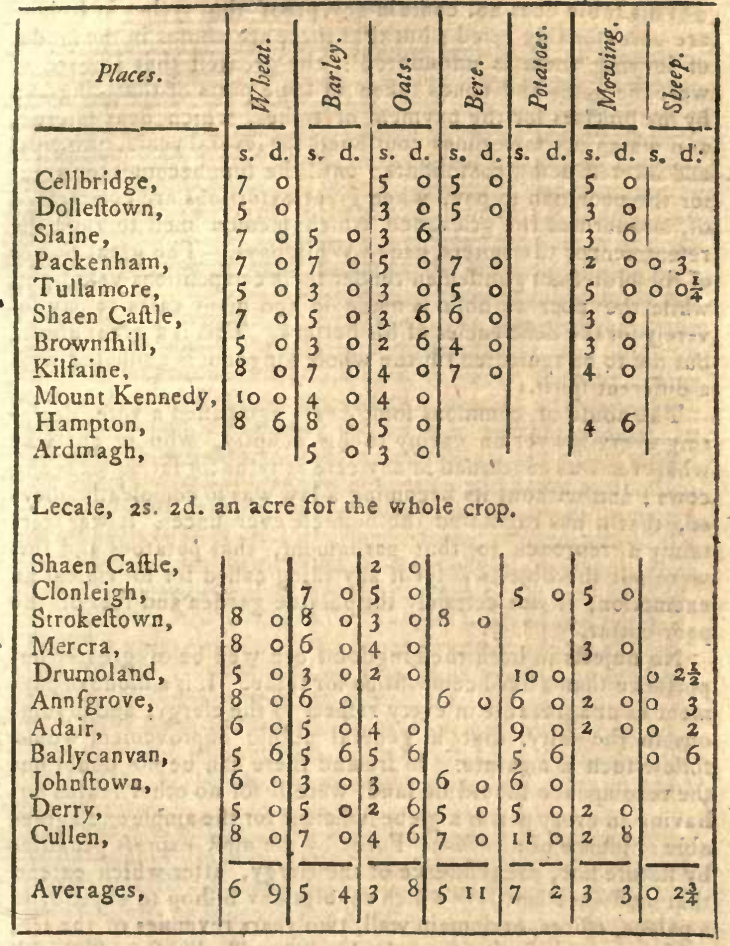

\begin{tabular}{|c|c|c|c|c|}
\hline & Wbeat. & Barley. & Oats. & Hoy, \\
\hline $\begin{array}{l}\text { Average of the Tourthruugh } \\
\text { the North of England, } \\
\text { Eaftern ditto, }\end{array}$ & $\begin{array}{ll}5 & 2 \\
4 & 8\end{array}$ & $\begin{array}{ll}3 & 11 \\
4 & 0\end{array}$ & $\begin{array}{ll}3 & 4 \\
2 & 8\end{array}$ & 1.10 \\
\hline Average, & 411 & $311 \frac{1}{2}$ & 30 & 10 \\
\hline Ireland, per Englifh acre & 4 & 34 & $2 \quad 3 \frac{1}{2}$ & 2 \\
\hline
\end{tabular}


This table does not contain any proof that tythes in Ireland are unreafonably rated, but that there are abufes in the modes of levying them is undoubted: the greateft that I heard of were the notes and bonds taken in fome parts of that kingdom by the proctors for the paynient of tythes, which bear intereft, and which are fometimes continued for feveral years, principal and intereft being confolidated until the fum becomes too great for the poor man to pay, when great extortions are complained of, and formed the grievance which feemed moft to raife the refentnient of the ripters, called Whiteboys. The great powet af the proteftant gentlemen render their compofitions very light, while the poor catholic is made in too many cafes to pay feverely for the deficiencies of his betters. This is a great abufe, but not to be remedied till the whole kingdom is animated with a different fpirit.

The houfe of commons fome years ago paffed a vote, declaring every lawyer an enemy to his country, who in any way whatever was concerned in any cafe of tythe for fat bullocks and cows; and without its becoming a law was fo compleatly obey. ed, that it has regulated the bufinefs ever fince; it was certainly a reproach to that parliament, that potatoes and turf were not the objects; for if any thing called for fo violent an exemption; it was certainly the potatoe garden and fuel of the poor cottar.

No objects in both the kingdoms can well be of greater importance than a fised compofition for tythe. It is a mode of payment fo difagreeable in every refpect to the clergy, and fo ruinous to the laity, that a general public improvement would follow fuch a meafure. In Ireland there can be'ro doubt bue the recompence fhould be land, were it for no other reafon but having in every parith a glebe fufficient for the ample and agreeable refidence of a reetor. Force by the moft exprefs penalries by ftatute law, the refidence of the clergy, after which extend that moft excellent law which enables any bifhop to expend, in a palace, offices, or domain wall, two years revenues of the fee, with a power of charging, by his laft will, his fucceffor with the payment of the whole of the fum to whatever ufes he leaves it, who in like manner is enabled to charge his fucceffor with three fourths, and fo on; this law fhould be extended to parIonage boufes, with this affitance, that wherever the reetor or vicar proved the expenditure of two years revehue in a houfe, he flould receive a permit from the grand jury, for expending half as much more for offices, walling, \&c. and when in like manner he brought his certificate of fo doing, the money to be paid him by the county treafurer in like manner as the prefentment roads are done at prefent, not however to leave it at the option of the jury. A refident clergy fpending in the parifh the whole of their receipts, would in all refpects be fo advantageous and defirable, that it is fair the county fhould affit in enabling them to do it in a liberal manner. The expence would 
would be gradual, and never amount very high, if churches, when greatly wanted, were built at the fame time. If the expence was for a time confiderable, ftill it would be laid out in 2 manner amply to repay it. Decent edifices rifing in all parts of the kingdom, would alone, in the great bufinefs of civilization, be advantageous; it would ornament the country, as well as humanize minds, accuftomed to nothing better than cabbins of mud; and fecuring one refident gentleman of fome learning and ideas in every parifh of the kingdom, living on a property in which he had an intereft for life, could fcarcely fail of introducing improvements in agriculture and planting; the whole county would profit by fuch circumftances, and ought to affift in the expence. I muft obferve, however, that fuch plans fhould depend entirely on the clergy accepting a perpetual recompence in lieu of tythes; for as to a pnblic expence, to introduce refident rectors, whofe bufinefs, when fixed, would be an extenfion and feverity in that tax, and prove a premium on taking them in kind to the ruin of agriculture, common fenfe would certainly dictate a very different expenditure of the public money. So burthenfome is this mode of payment, that where their refidence is followed by tythes being paid in kind, the clergyman, who ought to be an object beloved and revered, lives really upon the ruin of all his parifhioners, fo that initead of giving public money to bring him into a parifh, no application of thofe funds would be inore beneficial in fuch a cafe, than to purchafe his abfence. If ever fuch plans came in agitation, it would certainly be right to eftablifh a provifion for parifh clerks, to teach the children of all religions to read and write.

The revenues of the clergy in Ireland, are very confiderable. Here is a lift of the bifhoprics with the annual value, which I have had corrected fo often in the neighbourhood of each that I believe it will be found nearly exact.

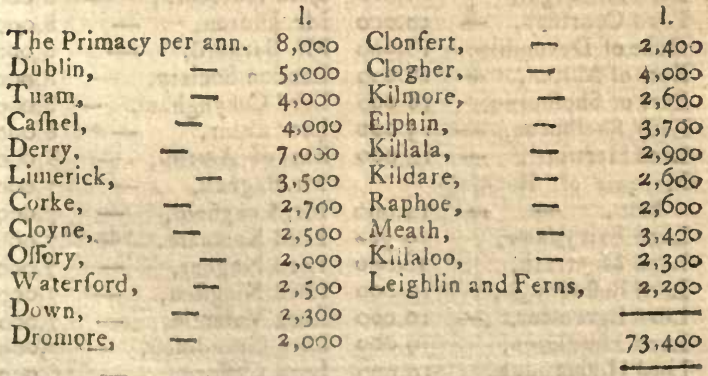


This total does not, however, mark the extent or value of the land which yields it. I was informed in converfation that the lands of the prinacy would, if lett as a private eftate, be worth near one hundred thoufand a year. Thefe of Derry balf as much, and thofe of Cafhel near thirty thoufand a year. Thefe circumftances taken into the account will fhew that feventy-four thoufand pounds a year include no inconfiderable portion of the kingdom. I have been alfo informed, but not on any certain authority, that thefe fees have the patronage of an ecclefiaftical revenue of above one hundred and fifty thoufand pounds a year more.

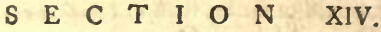

\section{Abfentees.}

THERE are very few countries in the world that do not 1 experience the difadvantage of remitting a part of their rents to landlords who refide elfewhere; and it muft ever be fo while there is any liberty left to mankind of living where they pleafe. In Ireland the amount proportioned to the territory is greater probably than in moft other inftances; and not having a free trade with the kingdom in which fuch abfentees fpend their fortunes, it is cut off from that return which Scotland experiences for the lofs of her rents.

Some years ago Mr. Morris publifhed a lift of the Irifh abfentees, and their rentals, but as every day makes confiderable alterations, it is of courfe grown obfolete, this induced me to form a new one, which I got corrected by a variety of perfons living in the neighbourhood of many of their refpective eftates: in fuch a detail, however, of private property, there mult neceffarily be many mittakes.

1.

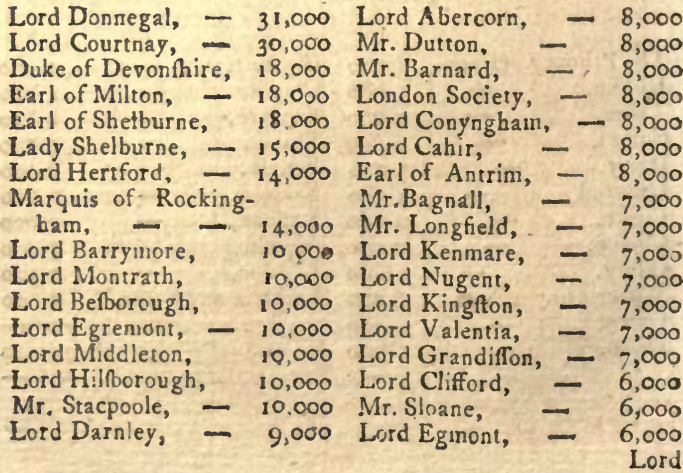


1.

1.

Lord Upper Offory, - 6,000 Mr. John Barry, - 3,000

Mr. Silver Oliver, - 6,000 Mr. Edwards, - 3,000

Mr. Dunbar, - 6,000 Mr.Frceman, - 3,000

Mr. Henry Obrien, - 6,000 Lord Newhaven, - 3,000

Mr. Mathew, - 6,000 Mr. Wellh, (Kerry) . 3,000

Lord Irnham, _ 6,000 Lord Palmeritown, - 2,500

Lord Sandwich, - 6,000 Lord Beaulieu, - 2,500

Lord Vane, - 6,000 Lord Verney, - 2,500

Lord Dartry, - 6,000 Mr. Bunbury, - 2,500

Lord Fane, - - 5,000 Sir George Saville, 2,000

Lord Claremont, - 5,000 Mrs. Newman, - 2,000

Lord Carbury, - 5,000 Col. Shirley, - 2,000

Lord Clanrickard, - 5,000 Mr. Campbell, - 2,000

Lord Farnham, - 5,000 Mr. Minchin, 2,000

Lord Dilton, - 5,000 Mr. Burton, 2,000

Sir W. Rowley, - 4,000 Duke of Dorfet, - 2,000

Mr. Palmer, - 4,000 Lord Powis, - 2,000

Lord Clanbraffi, - 4,000 Mr. Whithead, - 2,000

Lord Maffareen, - 4,000 Sir Eyre Coote, - 2,000

Lord Corke, - 4,000 Mr. Upton, 2, 2,000

Lord Portfinouth, - 4,000 Mr. John Baker Holroyd, 2,000

Lord Afhbrook, - 4,000 Sir N. Bayley, - 2,000

Lord Villiers, - 4,000 Duke of Chandois, 2,000

Lord Bellew, - 4,000 Mr. S. Campbell, - 2,000

Sir Laurence Dundafs,' 4,000 Mr. Afhroby, - 2,000

Allen family, - 4,000 Mr. Damer, - 2,000

Mr. O Callaghan, - 4,000 Mr. Whitelead, - 2,000

General-Montagu, - 4,000 Mr. Welbore Ellis, 2,000

Mr. Fitzmaurice, - 4,000 Mr. Folliot, - 2,000

Mr. Needham, - 4,000 Mr. Donellan, - 2,000

Mr.Cook, - 4,000 Mrs. Wilfon, - 2,000

Mr. Annefley, - 4,000 Mr. Forward, - 2,000

Lord Kerry, - 4,000 Lord Middlefex, — 2,000

Lord Fitzwilliam, - 4,000 Mr. Supple, - 2,000

Vifcount Fitzwilliam, 4000 Mr. Nagles, - 2,000

Englith Corporation, 3,500 Lady Raneleigh, - 2,000

Lord Bingley, - 3,500 Mr. Addair, - 2,000

Lord Dacre, - 3,000 Lord Sefton, - '2,000

Mr.Murray of Broughton,3,000 Lord Tyrawley, - 2,000

Lord Ludlow, - 3,000 Mr. Woodcock, - 2,000

Lord Weymouth, - 3000 Sir Jobn Millar, - 2,000

Lord Digby, - 3,000 Mr.Baldwyn, - 2,000

Lord Fortefcue, - 3.000 Dr.Moreton, - 1,800

Lord Derby, - 3.000 Dr. Delany, - 1,800

Lord-Fingall, - 3,000 Sir William Yorke, - 1,700

Blundenheireffes, - 3.000 Mr. Arthur Barry, - 1,600

Lady Charleville, - 3000 Lord Dyfart, - 1,600

Mr.Warren, - 3,000 Lord Clive, _ 1,600

Mr. St. George, - 3,000 Mr. Bridges, $-\quad 1,500$ 


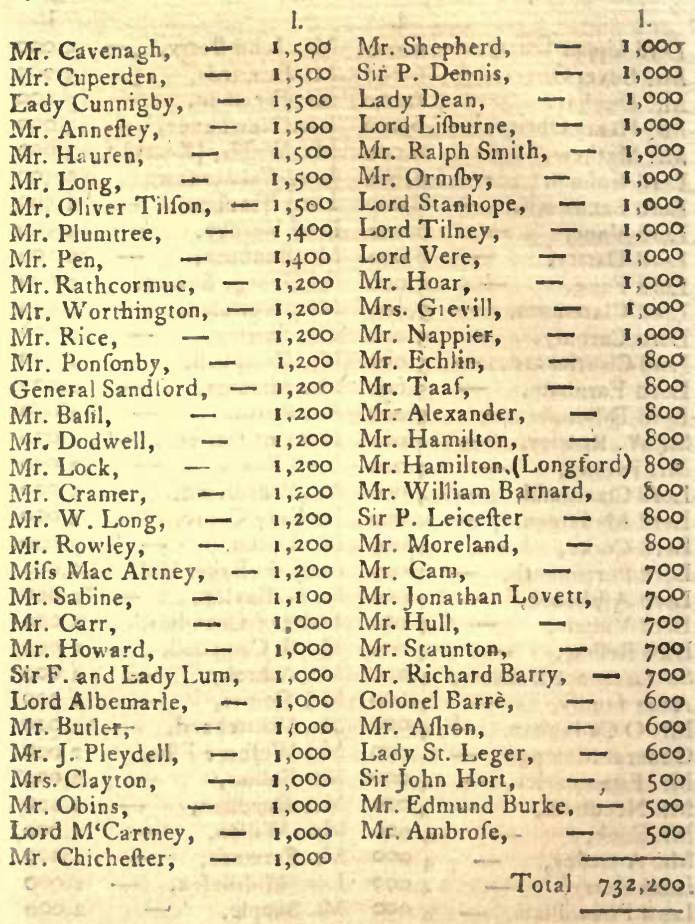

This total, though not equal to what has been reported, is certainly an amazing drain upon a kingdom cut off frcm the re-action of a free trade, and tuch an one as uuft have a very confiderable effect in preventing the natural courfe of its proiperity. H is not the fiuple amount of the rental being remitted into another country, but the damp on all forts of iuprovements, and the total want of countenance and encouragement which the lower tenantrv labour under. The landlord at fuch a great diftance is out of the way of all complainis, or which is the fane thing, of examining into, or renedying erils; miferies of which he can fee notbing, and probably hear as lixtle of, can make no impreffion. All that is required of the agent is to be punctual in his temittances, and as to the people who pay him, they arctoo often welcome to go to the devil, provided their rents could be paid from his 
territories. This is the general picture. God forbid it fhould be univerfally true! there are ablentees, who expend large fums upon their eftates in Ireland; the earl of Shelburne has made great exertions for the introduction of Englifh agriculture. Mr. Fitzmaurice has taken every means to eftablifh a manufacture. The bridge at Lifmore is an inftance of liberal magnificence in the duke of Devonhire. The church and other buildings at Belfaft do lionour to lord Donnegall. The church and town of Hilfborough, are ftriking monuments of what that nobleman performs. Lord Conyngham's expenditure in his abfence in building and planting merits the higheft praife, nor are many other inftances wanting, equally to the advantage of the kingdom, and the honour of the individuals.

It will not be improper here to add, that the amount of the penfion lift of Ireland, the 29th of September, 1779, amounted to $84,59 \mathrm{l}$. per annum; probably therefore, abfentees, penfions, offices, and intereft of money, amount to above A MILLION!

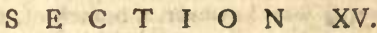

\section{Population.}

$T T$ is very aftonifhing that this fubject fhould be fo little un1 derftood in moft countries; even in England, which has given birth to fo many treatifes on the ftate, caufes and contequences of it, fo little is known, that thofe who have the beft means of information, confers their ignorance in the variety of their opinions. Thofe political principles which fhould long, ere this time, have been fixed and acknowledged, are difpu. ted; erroneous theories ftarted, and even the evidence of facts denied. But thefe mifchievous errors ufually proceed from the rage of condemnation, and the croaking jaundiced fpirit, which determines to deduce public ruin from fomething; if not from a king, a minifter, a war, a debt, or a peftilence, from depopulation. In fhort, if it was not to be attributed to any thing, many a calculator would be in bedlam with difappointment. We have feen thefe abfurdities carried to fuch a length as to fee grave treatifes publifhed, and with refpectable naines to them, which have declared the depopulation of England itfelf to take place even in the moft productive period of her induitry and her wealth. This is not furprifing, for there are no follies too ridiculous for wife men fometimes to patronize, but the amazing circumftance is that fuch tracts are believed, and that harmleis politicians figh in the very hey day of propagation, left another age thould fee a fertile land without people to eat the fruits of it. Let population alone, and there is no fear of its taking care of itfelf. but when fuch fooleries are made a pretence of recommending laws for the regulation of landed property, which has been the cafe, fuch fpeculations fhould be treated with contempt and deteftation; while merely fpeculative, thev are 
perfectly harmlefs, but let them become active in parliament, and common fenfe fhould exert her power to kick the abfurdity out of doors. To do juftice to the Irifh, I found none of this folly in that kingdom : many a violent oppofer of government is to be found in that country, ready enough to confefs that population increafes greatly; the general tenour of the information in the minutes declare the fame thing.

There are feveral circumftances in Ireland extremely favourable to population, to which inuft be attributed that countrybeing fo much inore populous than the ftate of manufacturing induftry would feem to imply. There are five caufes, which may be particularized among others of lefs confequence. Firft, There being no poor laws, Second, the habitations. Third, The generality of marriage. Fourtb, Children not being burthenfome. Fifth, Potatoes the food.

The laws of fettlement in England, which confine the poor people to what is called their legal fettlements, one would think frained with no other view than to be a check upon the national induftry, it was, however, a branch of, and arofe from thofe moruments of barbarity and mifchief, our poor rates, for when once the poor were made, what they ought never to be confidered a burthen, it was incumbent on every parifh to leffen as unuch as poffible their numbers; thefe laws were therefore framed in the very fpirit of depopulation, and moft certainly have for near two centuries proved a bar to the kingdom's becoming as populous as it would otherwife have done. Fortunately for Ireland, it has hitherto kept free from thefe evils, and from thence refults a great degree of her prefent population. Whole families in that country will move from one place to another with freedom, fixing according to the demand for - their labour, and the encouragement they receive to fettle. The liberty of doing this is certainly a premium on their induftrv, and confequently to their increafe.

The cabbins of the poor Irifh being fuch apparently miferable habitations, is anothervery evident encouragement to population. In England, where the poor are in many refpects in fuch a fuperior ftate, a couple will not marry unlefs they can get a houfe, to build which, take the kingdom through, will coft from twenty-five to fixty pounds; half the life, and all the vigour and youth of a man and woman are paffed, before they can fave fuch a fum; and when they have got it, fo burthenfome are poor to a parifh, that it is twenty to one if they get permifion to ereet their cottage. But in Ireland the cabbin is not an object of a moment's confideration; to poffefs a cow and a pig is an earlier aim; the cabbin begins with a hovel, that is crected with two days labour, and the young couple pafs not their youth in celibacy for want of a neft to produce their young in. If it comes to matter of calculation, it will then be but as four pounds to thirty. 
Marriage is certainly more general in Ireland than in England: I fcarce ever found an unmarried farmer or coitar, but it is feen more in other claffes, which with us do not marry at all; fuch as fervants ; the generality of footmen and maids, in gentlemen's families, are married, a circumftance we very rarely fee in England.

Another point of importance is their children not being burthenfome. In all the enquiries 1 made into the ftate of the poor, I found their happinefs and eafe generally relative to the number of their children, and nothing confidered as fuch a mlsfortune as having none: whenever this is the fact, or the general idea, it muft neceffarily have a confiderable effect in promoting early marriages, and confequently population.

The food of the people being potatoes is a point not of lefs importance: for when the common food of the poor is fo dear as to be an object of attentive ceconomy, the children will want that plenty which is effential to rearing them; the article of milk, fo general in the Irifh cabbins, is a matter of the firit confequence in rearing infants. The Irifh poor in the catholic parts of that country are fubfifted entirely upon land, whereas the poor in England have fo little to do with it, that they fubfitt almott entirely from thops, by a purchafe of their neceflaries; in the former cafe it mult be a inatter of prodigious confequence, that the product fhould be yielded by as fmall a fpace of land as poffible; this is the cafe with potatoes more than with any other crop whatever.

As to the number of people in Ireland I do not pretend to compute them, becaufe there are no fatisfactory data whereon to found any computation. I have feen feveral formed on the hearth tax, but all computations by taxes muft be erroneous, they may be below, but they cannot be above the truth. This is the cafe of calculating the number in England from the houfe and window tax. In Ireland it is ftill more fo, from the greater carelefinefs and abufes in collecting taxes. There is, however, another reafon, the exemptions from the hearthmoney, which in the words of the act are as follow: "Thofe "who live upon alms and are not able to get their livelihood " by work, and widows, who hall procure a certificate of " two juftices of the peace in writing yearly, that the houfe " which they inhabit is not of greater value than eight thill" ings by the year, and that they do not occupy lands of the "v value of eight thillings by the year, and that they have not "goods or chattles to the value of four pounds *" It muft be very manifeft from hence, that this tax can be no rule whereby to judge of the population of the kingdon. Captain South's account is drawn from this fource in the lat century, which made the people $t, 034,102$ in the year $1695 t$; the

* A Treatife of the Excliequer and Revenue of Irelund. By G. E. How A R D, ESq; Vol. 1. p. 90 .

+ Abridgment of Pbil. Tranj. Vol. iii. P. $66_{5}$. 
number was computed by Sir W. Petty, in the jear 1657 to 850,000 ; in 1688 at $1,200,000$; and in 1767 the houfes taxed were 424,046 . If the number of houfes in a kingdom were known, we fhould be very far from knowing that of the people, for the computation of four or five per houfe, drawn from only a thoufandth part of the total, and perhaps deduced from that of a family rather than a houfe, can never fpeak the real fact. I cannot conclude this fubject without earneftly recommending to the legillature of Ireland, to order an actual enumeration of the whole people, for which purpore I thould approhend a vote of the houfe of commons would be fufficient. Such a meafure would be attended with a variety of beneficial effeets, would prevent the rife of thofe errors which have been mifchievous in England, and would place the great inportance of Ireland to the Britifh empire, in that truly confpicuous light in which it ought ever to be viewed, and in which it could not fail to be confidered, while we bave theorifts, who infift that the people of England do not amount to five millions.

The common idez is, that there are fomething under three millions in Ireland.

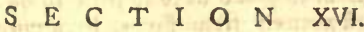

\section{Public Works-Dublin Society.}

A BOUT twenty years ago Ireland inftead of being bur$A$ thened with a national debt, had at the end of every feffions of parliament from fifty to fixty thonfand pounds, furplus revenue in the Exchequer, at the difpofition of parliament : this money was voted for public works. The members of the the houfe of commons, at the conclufion of the felfions, met for the purpofe of voting the ufes to which this money fhould be applied; the greater part of it was among themfelves, their friends, or dependants; and though fome work, of apparent ufe to the public at large, was always the plea, yet under that fanction, there were a great number of very fcandalous private jobs, which by degrees brought fuch a difcredit an this mode of applying public money, that the conclufion of it, from the increafe of the real expences of the public, was not much regretted. It muft, however, be acknowledged, that during this period, there were fome excellent works of acknowledged utility executed, fuch as harbours, piers, churches, fchools, bridges, \&c. built and executed by fome gentlemen, if not with oconomy, at leait without any difhonourable mifapplication; and as the whole was fpent within the kingdon, it certainly was far from being any great national evil.

But of all public works, none have been fo much favoured as inland navigations; a navigation board was eftablifhed many years ago for directing the expenditure of the fums, granted by parliament for thoic purpoies, and even regular funds fixed 
for their fupport. Under the adminiftration of this board, which confifts of many of the moft confiderable perfons in the kingdom, very great attempts have been made, but I am forry to obferve, very little completed. In order to examine this matter the more regularly, it will be proper to lay before the reader the fums which have, from time to time, been granted for thefe objects.

An account of money, granted for public works by parliament, or the navigation board, from 1753 to 1767 , inclufive*.

Newry river, - $\quad 9,000$

Drumglafs colliery and navigation, - - 112,2i8 Dromreagh, - - 3,000 Lagan River, - - 40,304 Shannon River, - 31,500 Grand Canal, - - 73,646 Blackwater River, - 11,000 River Lee, - - 2,000 River Barrow, - - 10,500 River Sule \& Waterford, 4,500 River Nore, - - 25,250 River Boyne, - - 36,998 Pier at Skerries, - - 3,500 Pier at Envir, - 1,870 Pier at Dunleary, - 18,500 Pier at Balbriggen, - 5,252 Pier at Bangor, - - 500 Pier at Killyleagh, - 1,200 Pier at Sligo, - - 1,300 Antrim River, - - I,359 Ballaft-office Wall, - 43,000 Widening Dublin ftreets $4 \mathbf{I}, 986$ Trinity College, - 31,000 Baal's Bridge Limerick quays,

Cork $\quad 7,773$ Cork Workhoufe, - 1,500 Derry Quay, - - - 2,900 Shandon Street, Corke, 1,500 Wicklow harbour, - 6,850 St. Patrick's Hofpital, , 6,000

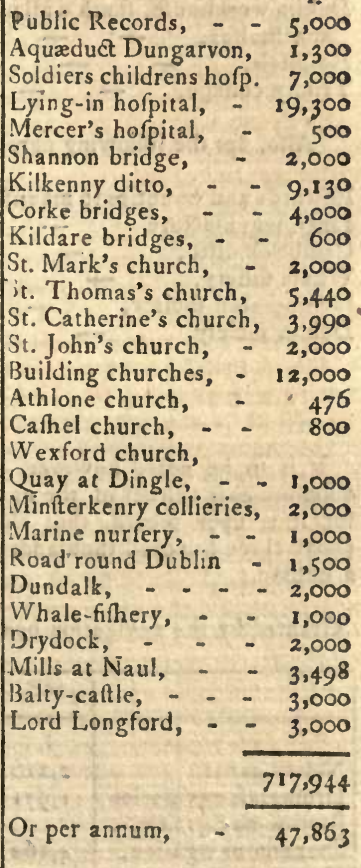

1.

300 300 500 $(1000$ , 600 , 000 $990^{\circ}$ , 00 476 800 ,$\infty 00$ 
This period of fifteen years, I believe was that of the furplus of the revenue, during which the objects were as various as the inclirations of thofe individuals who had any intereft in parliament. It appears from the lift, that the article of navigations fwallows up the greateft proportion of it.

Sums paid out of the revenues at large for certain public works, purfuant to the feveral bills of fupply, from 1703 to 1771 , inclufive.

Navigations, collieries, docks, Sx. - - 379,388 To build churches, - - - - 17,706 Parliament houfe, - $\quad$ - $-16,270$ Dublin workhoufe, fouth u all paffages, new road and

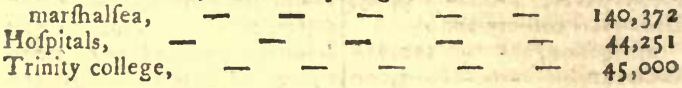

Alfo, for the following purpofes during the fame period.

Rewards and bounties to manufacturers, Linen manufacture Whale fifhery, - $\quad$ - $\quad$ - 1,500 Incorporated fociety, - _ _ _ _ 96,000 Dublin fociety,

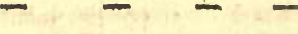

64,000

$£_{1}, 018,86_{2}$

It is to be noted however, that this account includes the difburfements neither of the navigation, nor the linen board, for it is upon record, that the grand canal alone has coft above three hundred thoufands pounds, by fome accounts half 2 million.

Granted by the navigation board only, from 1769 , to 1771 .

\begin{tabular}{|l|r|r|r|r|r|}
\hline & 1768 & 1769 & 1770 & 1771. & Total. \\
\hline Newry canal, & 1. & 1. & 1. & 1. & 1. \\
Drumglafs navigation, & 2,216 & 130 & & 88 & 2,434 \\
Barrow navigation, & 1,971 & 244 & 2,151 & 1,200 & 5,566 \\
Shannon navigation, & 4,162 & 162 & 3,000 & 100 & 3,100 \\
Grand canal, & 550 & 1,280 & 755 & 2,000 & 7,660 \\
Boyne navigation, & 2,143 & 2,860 & 2,000 & 2,504 & 9,507 \\
Fergus navigation, & 500 & & 350 & & 850 \\
\hline
\end{tabular}


Incomplete as thefe data are, we find from them, that great fums of money have been granted for inland navigations, and are to this day given for the fame purpore; let us therefore enquire how this money has been expended, and what has. been the effect of it,

I made fome enquiries, and trayelled many miles to view fome of the navigations, and the only one which appeared to me really completed, is the canal from the town of Newry to the fea, on which I faw a brig of eighty or one hundred tons burtben. The fame canal is extended farther than that town, but Atops thort of the great objeet for which it was begun and made, viz. the Drumglafs and Dungannon colleries; this may therefore be claffed as incomplete relative to the object. but as Newry is a place of confiderable trade, finifhing it fo far has merit. The great Uefign was to furnifh Dublin with Irith coals, which was probably feafible, for the feams of coals in thofe collieries are afferted to be of fuch a thicknefs, and goodnefs, as proved thein more than equal to the confumption of balf a dozen fuch cities as Dublin; but two great difficulties were to be overcome : firt, to make the navigation fo, that all land carriage might be faved, which was properly a public work; and fecondly, to work the collicries, which was properly private bufinefs, but from the utter deficiency of capital in the bands of the individuals concerned, could never have been done without public affiftance. To get over thefe difficulties, parliament went very eagerly into the bufinefs; they granted fo liberally to the canal, that I think it has been finifhed to within two or three miles of the collieries; at the fame time a private company was formed for working the mines, to whom confiderable grants were made to enable them to proceed. The property in the works changed hands feveral times; among others, the late archbifhop of 'Tuam (Ryder) was deeply concerned in them, entering with great fpirit into the defign; but what with the impolitions of the people employed; the lofs of fome that were able and honeft; the ignorance of others; and the jobbing fpirit of fome proprietors, parliament, after granting enormous funs, both to the canal and collieries, bad the morrification, inftead of feeing coals come to Dublin, sothing but gold fent from Dublin, to do that which fate feensed determined fhould never be done, and fo in defpair abandoned the defign to the navigation board, to fee if their leffer exertions would effect what the mightier ones had failed in. $\Lambda \mathrm{Mr}$. Dularte, an Italian engineer, and very ingenious architect, has had for a few years the fuperintendance of the works, but the temper of the ration has been fo foured by difappointments, that he bas not the fupport which he thinks neceffary to do any thing effectual. 
The following $T_{2}$ ble of the Import of Coal to Ireland, will thew the Importance of the Object.

\begin{tabular}{|c|c|c|c|c|}
\hline In the year & $\begin{array}{l}1764 \\
1765 \\
1766 \\
1767 \\
1768 \\
1769 \\
1770\end{array}$ & $\begin{array}{l}161,970 \\
185,927 \\
186,612 \\
172,276 \\
185,554 \\
171,323 \\
197,135\end{array}$ & $\begin{array}{r}\text { In the year } 1771 \\
1772 \\
1773 \\
1774 \\
1775 \\
1776 \\
1>77\end{array}$ & $\begin{array}{l}\text { Tons. } \\
182,973 \\
211,438 \\
186,057 \\
189,237 \\
203,403 \\
217,938 \\
240,893\end{array}$ \\
\hline Average 0 & & 180,113 & Average of 7 years & 204,566 \\
\hline
\end{tabular}

From this table it appears, that not only the quantity itfelf is great, but that it is a very rifing import, owing to the increafe of Dublin, which has arofe with the increaring profperity of the kingdons.

The little effeet of all attempts to fupply Dublin with Irifh coals will be feen by the following table of the bounties paid for that purpofe.

1. 5. d.

In the year

$\begin{array}{rrrr}1762 & 220 & 3 & 10 \\ 1763 & 125 & 14 & 9 \\ 1764 & 218 & 19 & 3 \\ 1765 & 135 & 13 & 3 \\ 1766 & 81 & 13 & 0 \\ 1767 & 75 & 4 & 0 \\ 1768 & 150 & 18 & 4 \\ 1769 & 164 & 15 & 4\end{array}$

1. s. d.

In the year $3770 \quad 169$ il 4

$1771 \quad 105 \quad 410$

1772113110

1773209 11 8

$\begin{array}{llll}1774 & 204 & 7 & 2\end{array}$

$\begin{array}{llll}1775 & 213 & 14 & 4\end{array}$

$\begin{array}{lllll}1776 & 86 & 0 & 0\end{array}$

$1777 \quad 88$ o 0

Before I entirely difmifs this undertaking, I cannot but remark, that nothing can more clearly prove the amazing want of capital in Ireland than the prefens ttate of thefe works. The navigation is complete except two or three miles; I will venture to affert, that parliament would grant the mosey for finifhing it without hefication, provided men of undoubted fubftance engaged for working the collieries at their own expence : we may therefore affert, there is water carriage from fome of the finet feams of coal in the world, and at a very flight depth, directly into the heart of the fecond market in the Britiin dominions, with the advantage of a parliamentary bounty per chaldron on their import into Dublin. Yet, with all thefe advantages, nobody has capita! enough to undertake the work. This fact feems to call alio tor another obiervation. I remember in the Englifh Houfe of Commons, in the feffion 1777-8, when the friends of the Irith trade bills urged, that the want 
of capital in Ireland was fuch that the could never rival the manufactures of. Great Britain : it was repiied, that Englifh, capitals would go over to do it for them; - but what I have juft recited, proves that this remark is perfectly unfounded. If capitals were fo readily moved from one country to another, the Drumglafs collieries would have attracted them, efpecially as an intereft for ever is to be purchafed in them, but the fact is, that removeable capitals are in the hands of men who have been educated, and perhaps have made them locally in fome trade or undertaking which they will not venture to remove. Prejudice and habit govern mankind as much even as their intereft, fo that no apprehenfion can be fo little founded as that of a country lofing the capital the has made, by tranf. ferring it in to another for greater feeming advantages in trade. But this point 1 thall have occalion hereafter to dwell more. particularly on.

The grand canal, as it has been ridiculoufly termed, was. a nother inland navigation which has coft the public ftill greater funs. The ciefign, as the maps of Ireland thew, was to form a communication by water between Dublin and the Shannon. by this cut, mott of the way through the immenfe bog of $\mathrm{Al}$ len. The former plan of bringing coals to Dublin was a very. wife one, but this of the grand canal had fcarcely any object. that feemed to call for fuch an exertion. If the country is examined, through which the intended canal was to pafs, and alfo that through which the Shannon runs, it will be found, confidering its extent, to be the leaft productive for the Dublin market, perhaps of the whole kingdom. Examine Leitrim, Rofcommon, Longford, Galway, Clare, Limerick, and thofe parts of Weft Meach and Kings, which the line of the canal and Shanron lead through, there are fcarcely any commodities in them for Dublin. Nay, the prefent bounty on the inland carriage of corn to Dublin, proves to a demontration, that the quantity of corn raifed in all thefe counties for that market is contemptible: What other products are there? Raw wool takes another direction, it goes at prefent from Rofcommon to Corke. Manufactures in that line are very infignificant; there are fome in Galwav, but the ports of Limerick and $\mathrm{Gal}$ way are perfectly fuflicient for the finall exportation of them. There remains nothing.but turf; and who at Dublin would burn that while Whitehaven coals are at the prefent price?

Mott of the inland navigations in. England have been executed with private funds; the intereft paid by the tolls-one. ftrong reafon for this mode, is the prevention of unneceffary and idle fchemes; the manufactures mutt be wrought, or the products raifed, and feel the clog of an expenfive carriage before private perfons will fubfcribe their money towards a cheaper conveyance; in which cafe, the very application to parliament is generally proof fufficient that a canal ought to be cut. Having fomething to carty before you, feek the means of carriage. I will venture to fay, that if the grand canal was 
entirely complete, the navigation of it, including whatever the country towns took from Dublin, would prove of fuch a beg garly account, that it would then remain a greater monument of folly if poffible, than at prefent. Some gentlemen I have talked with on this fubject, have replied it is a job; 'twas meant as a job; you are not to confider it as a canal of trade but as a canal for public money; but even this, though advanced in Ireland, is not upon principle. I anfwer that fomething has been done, fourteen niles with innumerable locks, quays, bridges, \&c. are abfolutely finifhed, though only for the benefit of eels and ikating: Why throw this money a way? Half what thefe fourteen miles have coft would have finifhed the Newry canal, and per. fected the Dungannon collieries. Admit your argument of the job; I feel its weight; I fee its force; but that does not account for the funs actually expended. Might not the fame perfons have plundered the public to the fame amount, in executing fome work of real utility; from which fomething elfe migh: have refulted than difgrace and ignominy to the uation?

As to the other navigations, there is in general this object:on to be made to then all, however neceffary they might be, they are ufelefs for want of being completed; three-fourths are only begun. The gentlemen in the neighbourhood of them have had intereft enough in the navigation board to get a part only voted, and from the variety of undertakings going on at the fame time, and all for the fame reafon incomplete, the public utility has been more trifling from all, than from a fingle one finithed. Sorry I am to fay, that a hiftory of public works in Ireland would be a hittory of jobs, which has and will prove of much worfe confequence, than nay be at firft apparent: it has given a confiderable check to permitting grants of money. Adminiftration feeing the ufes to which it has been applied, have viewed thefe mifapplications, as they term them, of the public money with a very jealous eye. They have curtailed much : until another very queftionable meafure, the bounty on the inland carriage of corn to Dublin demanded fo much as to leave nothing for jobs of another fort; that meafure may be repealed, and the money applied to it will be at the difpofal of parliament, either for the common purpofe of government, or applicable to fome national improvenent of a more decifive nature; the latter may, after fo many intances, be rejected for fear of jobs : how melancholy a confideration is it, that in a kingdom which from various caufes had been fo fortunate as to fee a great portion of public treafure annually voted for public purpofes, fo abominably mifapplied, and pocketed by individuals, as to bring a ridicule and reproach upon the very idea of fuch grants. There is fuch a want of public fpirit, of candour and of care for the interefts of poiterity in fuch a conduet, that it cannot be branded with an expreffion too harfh, or a condemnation too pointed: nor lefs deferving of feverity is it, if flowing from political and fecret motives of burthening 
the public revenues to make private factions the more impor$\operatorname{tant.}$

Great honour is due to Ireland for having given birth to the DUBLIN SOCIETY, which has the undifputed merit of being the father of all the fimilar focieties now exitting in Europe. It was eftablifhed in 1731, and owed its origin to one of the moft patriotic individuals which any country has produced, $D_{R}$. SA MUEL MADAN. For fome years it was fupported only by the voluntary fubfcriptions of the members, forming a fund much under a thoufand pounds a year; yet was there fuch a liberality of fentiment in their conduct, and fo pure a love of the public intereft apparent in all their tranfactions, as enabled them with that fmall fund to effect much greater things than they have done in later times fince parliament has granted them regularly ten thoufand pounds a feffions. A well written hiftory of their tranfactions would be a work extremely ufeful to Ireland; for it would explain much better than any reafoning could do, the proper objects for the patronage both of the fociety and patliament. I thall confine myfelf to a few general opfervations. It was inftituted, as their charter expreffes, for the improvement of agriculture, and for many years that material objeet poffeffed by far the greateft part of their attention; but when their funds by the aid of parliament grew more confiderable, they deviated fo far into manufactures, (in which branch they have been continually increafing their efforts, ) that at prefent agriculture feems to be but a fecondary object with them. During the life time of that ingenious but unfortunate man, Mr. Fohn Wynn Baker, his fupport drew fo many friends of agriculture to their meetings, that the premiums in its favour were very numerous; fince his death, the nobility and gentry not having the fame inducement to attend the tranfactions of the fociety, they were chiefly directed by fome gentlemen of Dublin, who underftand fabrics much better than lands, and being more interefted in them, they are attended 10 , perhaps, in too exclufive a manner. It would be tedious to enter into an examination of many of their meafures, there are fome, however, which demand a few reniarks.

In order to encourage the manufacture of Irifh woollen cloths, and Irith, filks, the fociety have two warehoufes*, in one of which filk is fold on their account, wholefale and retait, and in the other cloth; both are fent to them by the-weaver, whofe name is written on the piece, and the price peryard on it: nothing but ready money is taken; the ftock of filks generally amounts to the value of twelve or thirteen thoufand pounds in hand; and of woollens to ten or eleven thoufand more; and the expences in rent and falaries of thefe warehoufes

* The woollen wareboufe was opened May 29, 1773; that for filk $F_{e} b .18,1755$. 
houfes amount to five huridred pounds a year each. Call the ftock twenty-five thoufand pounds at fix per cent. the total expence of this meafure is juft two thoufand five hundred pounds a year; or four times over the whole revenue of the fociety for the encouragement of arts, manufactures, ard commerce at London. I have examined their fales in the weekly returns publifhed, and find that from June 23,1777 , to February 7 , 1778 , their average weekly receipt was

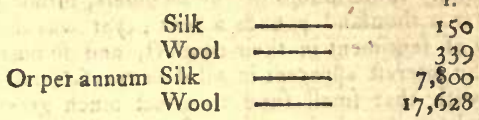

as the fociety give a premium of 31 . per cent. on all the Irifh wrought filk bought in the kingdom by wbolefale for the purpofe of retailing, that is abore four foillings a yard, it will help us to form an idea of the filk manufacture. From the firt of June 1776 , to the firt of June 1777 , the amount was 34,0231 . 8s. 2d. including Corke, Limerick, Belfaft, \&c. and they paid fix hundred and fifty pounds premium on it, from hence we find that their own filk fales muft be a large proportion of the wholefale in Dublin. This has been the greateft exertion of the Dublin Society of late years.

The intention of the meafure is evidently to take the weavers, both of filk and wool, out of the hands of mercers and drapers, and let their manufactures come to market without any intermediate profit on them. There is one effect certain to refult from this, which is taking a great part of the ready money cuftom from the draper and mercer, which being the moft beneficial part of their trade, is to all intents and purpofes laying a beavy tax on them: now upon every principle of common fenfe as well as commerce, it will appear a ftrange mode of encouraging a manufacture to lay taxes upon the mafter manufacturers. But all taxes laid upon a tradefman in confequence of his trade, muft be drawn back in the fale of his commodities, and this tax muft be fo as well as oihers; whatever he does fell muft be fo much the dearer, or he can carry on no trade at all; here therefore is a frefh tax, that of enhancing the prices paid by all who do not buy with ready money, a very great majority of the whole : the dearer a commodity is the lefs is confumed of it, fo the confumption on credit is undoubtedly leffened, in order that thofe who have ready money in their hands may be ferved fomething the cheaper: here is a manifett and felf evident mifchief, in order to attain a very doubiful and queftionable benefit.

Is there under the fun, an inftance of a manufacture made to flourith by fuch meafures? Mafter manufacturers with that vigour, attention, fkill and invention, which are the refult of a profitable bufinefs, are in all parts of the world, the very foul of profperous fabrics. It is their profit which aninates them to thofe fpirited exertions, upon which the advance of 
manufactures depends. If the Dublin fociety's conduet is right in part it is right in the whole, which would be attracting all the demand to their own warehoufes; in which cafe there would not be a mercer or draper left in Dublin. Their comwittees, and gentemen, and weavers, may choofe and pay clerks, and dificharge their rent, but where are the diretors of finer fabrics to come from? Where the men of tafte who are to invent? Where the quicknefs and fagacity to mark and follow the caprice of fathion? Are thele to come from weaver's? Abfurd the idea! It is the active and intelligent mafter that is to do all this. Go to the weavers in Spitalfelds, and fee theu mere tools directed by their mafters. Go to any other fabric upon earth, and fee vihat would become of it if the heads were confidered as ufelefs, and rivalled in their profits with public money. If the manufacture is of fuch a fickly growth, that it will not fupport the mafter as well as the man, it is not worth a country's notice. What is it that induces individuals to embark in a fabric their capital and induftry ? Profit. The greater this is, the greater the capital that will be attracted; but eftablint a fyittem that fhall rival, leffen and deAtroy this profit, who will bring their capital to fuch a trade? And can any people be fo fenfelefs as to unagine, that a manufacture is to be encourazed by banithing capital from it ?

There is another effect, which I thould fuppofe muft flow from this extraordinary idea, which is, that of raifing great heart-burnings and jealoufies among the trade; the drapers, and mercers are not probably at all pleafed with the weavers, who work for the fociety's warehoufes ; this muft be very detrimental to the bufinefs at large. I may alfo obferve, that mafter-manufacturers have more ways of encouraging Rilful and induftrious workmen, than the mere buying their goods and employing them; there are a thoufand little points of $\mathrm{fa}_{\mathrm{a}}$ vour in their power, which the fociety cannot practice; but how can they be inclined to fuch things, while fteps are taken to deprive them of every workman that can do without their affiftance?

Fortunately for the kingdom, it is at Dublin as in other cities, the ready money trade is by no nieans equal to that of credit, confequently the pernicious tendency of this meafure cannot fully be feen. The drapers and mercers do and will fupport their trade in fpite of this formidable rival, backed with a premium of two thoufand five hundred pounds a year, appropriated to their ruin, in order to encourage their trade! The tendency of the meafure is evidently the deftruction of both the manufactures.

This is a fast, whichappears fo obvious, that I flould apprehend it muft have done mifchief, in direct proportion to the amount of the operation. It is extremely difficult to difcoverfacts that can prove this from the nature of the cafe; no wonder if the import of toreign filk and woollens flould have encreafed from fuch a meafure. Let us examine this point.

VOL.II. 
Account of Silk imported into Ireland in Twenty-fix Years."

\begin{tabular}{|c|c|c|c|c|c|c|c|}
\hline$r_{\text {ears. }}$ & $\begin{array}{c}\text { Manu- } \\
\text { factur- } \\
\text { ed. }\end{array}$ & Rave. & $\begin{array}{l}\text { Rib- } \\
\text { band. }\end{array}$ & $r_{\text {OB }}$ & $\begin{array}{l}\text { Manu- } \\
\text { faciur- } \\
\text { ed. }\end{array}$ & Rav. & $\begin{array}{l}\text { Rib- } \\
\text { band. }\end{array}$ \\
\hline & $l b$. & lb. & 16. & & 16 & lb. & $l b$. \\
\hline 1752 & 14,654 & 53,705 & 160 & 1765 & $21,5^{82}$ & 54,655 & 1,543 \\
\hline 1753 & 13,360 & 60,155 & 184 & 1766 & 17,260 & 54,418 & $s, 724$ \\
\hline 1754 & $15,44^{1}$ & 42,665 & 361 & 1767 & 19,104 & 46,067 & 1,527 \\
\hline 1755 & 9,874 & 43,947 & 265 & 1768 & $23,44^{6}$ & 52,062 & 1,646 \\
\hline 1756 & 13,715 & 32,948 & 140 & 1769 & 17,522 & 57,001 & 1,401 \\
\hline 1757 & 7,709 & 41,354 & 17 & 1770 & $20,5^{8 \mathrm{I}}$ & 44,273 & 1,183 \\
\hline 1758 & 17,292 & $51,3 \odot 3$ & 271 & 1771 & 14,095 & $3^{8,107}$ & 650 \\
\hline 1759 & 13,836 & 44,493 & 118 & 1772 & 15,804 & 512 & 644 \\
\hline 1760 & 21,878 & 55,905 & 365 & 1773 & & 562 & $37^{8}$ \\
\hline 1761 & $14,8 I_{5}$ & $5^{1}, 34^{8}$ & iso & 1774 & 14,665 & $3^{8,811}$ & 553 \\
\hline $17 \sigma_{2}$ & 21,054 & 70,292 & 306 & 1775 & $13,65^{8}$ & $29,57^{8}$ & 355 \\
\hline 1763 & 17,741 & 41,021 & 469 & 1776 & 17,326 & 41,594 & 717 \\
\hline 1764 & $23,5 \times 1$ & $3^{6,58 \mathrm{r}}$ & 746 & 1777 & 24,187 & 54,043 & 1,574 \\
\hline Aver & 15,760 & $4^{8,1} 3^{2}$ & 275 & Aver. & 18,200 & 45,990 & $p, 000$ \\
\hline
\end{tabular}

Confidering the extept of the period, I will not affert that this table is very decifive; whatever conclufions, however, that are to be drawn from it, are as far as they go againf the late meafures that refpeet the Irifi filk manufacture, for the imported fabrics have increafed, while the raw material worked up. in Ireland has decreafed; a proof that the manufagture has noo been of any very healthy growth.

* MS. Communicted by Mr. Forfler. 
An Account of the Import of Woollen Goods for it Years $\$$.

\begin{tabular}{|c|c|c|c|c|c|}
\hline Years. & $\begin{array}{c}\text { Hewe Dra } \\
\text { pery. }\end{array}$ & $\begin{array}{l}\text { Old Dra- } \\
\text { pery. }\end{array}$ & rears. & $\begin{array}{c}\text { Nerw Dra } \\
\text { pery. }\end{array}$ & $\begin{array}{c}\text { Old Dra- } \\
\text { pery. }\end{array}$ \\
\hline & $\begin{array}{c}Y_{\text {ards }} . \\
248,002\end{array}$ & & & & \\
\hline $\begin{array}{l}1765 \\
1765\end{array}$ & $\begin{array}{l}240,002 \\
239,365\end{array}$ & 176,161 & $\begin{array}{l}1771 \\
1772\end{array}$ & $\begin{array}{l}302,096 \\
314,703\end{array}$ & $\begin{array}{l}217,395 \\
153,566\end{array}$ \\
\hline 1766 & 313,216 & 197,316 & 1773 & 387,143 & $210,06_{5}$ \\
\hline 1767 & $325,5^{85}$ & 189,882 & 1774 & 461,407 & 282.317 \\
\hline 1768 & $337,55^{8}$ & $198,66_{4}$ & 1775 & $465,6 \mathrm{II}$ & 281,379 \\
\hline 1769 & 394,553 & 207,117 & 1776 & $676,4^{85}$ & 290,2 I 5 \\
\hline $177^{\circ}$ & 462,499 & 249,666 & 1777 & 731,819 & 381,330 \\
\hline \multirow[t]{4}{*}{ Average } & $331,54^{8}$ & 205,662 & Average & 485,609 & 259,466 \\
\hline & 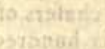 & & Latt 7 years & $4^{8} 5,609$ & 259 \\
\hline & 1.3 & & $\mathrm{~F}$ & 33 & 22 \\
\hline & & & Increafe, & 154,061 & 53,804 \\
\hline
\end{tabular}

The increafe is fo great that it might juftify conclufions againft all the late mealures, none of which are near fo much to be condemned as the eftablifhment of the focieties wareboufe.

Import of Linen, Cotton, and Silk, Britih Manufacture.

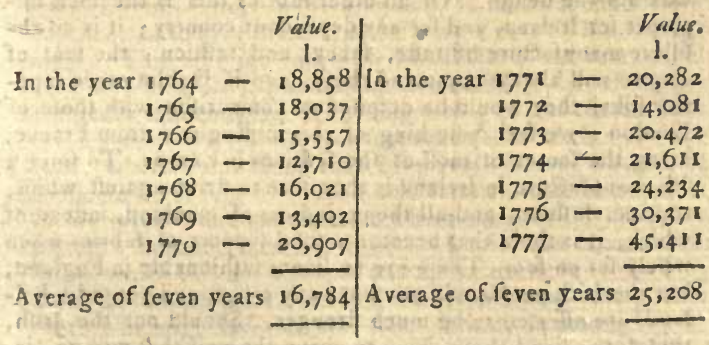

t Parl. Rec. of Exp and Inp. MS. 
When it is confidered, that the undoubted nifchief of this fyttem is not fubmitted to as an unavoidable evil, but purcha. fed with great expence, attention and anxicty; and that the two thoufand five Kundred a year thus beftowed, as the price of to ut:ich barm, might be expended in objects of great confequence to the public, it will furely teem unpardonable in parliament 10 appear fo little folicitous for the welfare of their manutactures, as to give ten thoufand pounds a feffion, at large, and not lianit the application of fuch a liberal grant to purpoies of certain advantage. And it furely behoves the fociety itfelf to recommit this natter; to extend their views; to confider the principles upon which all the manufactures in the world are carried on, fupported and increafed; and if they fee no vertige of fuch a policy, as they patronize and practice, in any country that has pufhed her fabrics to a great height, at leaft to be dubious of this favourite meafure, and not perfitt in forcing it at fuch a confiderable expence.

Ancther meafure of the fociety, which 1 hinted at before, is to give three per cent. to the wholefale purchafers of Irifh filks for retailing, and this cofts them above fix hundred pounds a year. Upon what found principles this is done I cannot difcover; if the mercers have not a demand for thefe Irifh filks, five times the fociety's premiuns will not make them purchafers; on the contrary, if they have a demand for them, they mott undoubtedly will buy them without any premium for fo doing. It apsears therefore to me, that the only end which fuch a meafure could anfwer, was to difcover the abfolute infignificance of the whole Irifh filk manufacture, which is proved through the whole kingdom to be to the amount only of thirty-four thoufand pounds a year, of four fhillings a yard and upwards , but the repetition of the premiun fliews that this was not the defign. Of all other fabrics this is the moft improper for Ireland, and for anyidependant country; it is an abfolute manufacture of tafte, fancy, and fafhion; the feat of empare will always command there, and if Dubtin made fuperior filks, they would be defpifed on comparifon with thofe of London : we feel fomething of ibis in England from France, being the fource of moft of the fafhions in Europe. To force a filt manufactare in Ireland is therefore to Atrive againft whim, caprice, fathion, iand all the prejudices of mankind, inftead of which, it is thefe that become a folid fupport of fabrics when wifely fet on foot. There are no linens fafhionable in England, but the lrifh penple will not wear any other, and yet gulie hollandsare afferied to be much Atronger. Should not the Irifh, therefore, bend their voice to drive the nail that will go. inftead of plaguing then:felves with one which never will. This is a general cofervation, but the particular meafure of the fociety, fuppofing the object valuable, is perfectly infignificant, $i t$ is throwing away fix husdred founds a year to anfwer no Ore purpofe whatever. 
The fociety offers a great number of other premiums for nanufactures, many of which are very exceptionable; but it would take up too much room to be particular. in an examination of them. In agriculture they have a great number offered to poor renters feparately.

Upon the general fpirit of thefe $I$ have to remark, that the defign of encouraging poor renters is very meritorious, and does honour to the humanity of the fociety; but from a great variety of inftances which were pointed out to me, as I travelled through the kingdom, I have too much reafon to believe, that abufes and deceptions are numerous, that the fociety has astually paid premiums per acre, to great numbers of claimants, who have, as foon as they received the money, let the land run wafte again, fo that no perfon could diftinguifh it from the adjoining bog or moor. There are two reafons why thefe preniums mut very much fail of their withed-for fuccefs; the extreme difficulty, not to fay impoffibility, of :afcertaining the merit of the candidates, or the facts alledged; and the utter impoffibility that fuch very poor fellows flould work any improvements worthy the fociety's patronage. The London fociety have found, by repeated experience, their vitter incapacity of doing any thing by weight of money; in bounties per acre for any object; I am convinced the fame fact will hold true with that of Dublin; the funds even of the latter are much too inconfiderable for this mode. The object ought to be to infpire thofe men, who have the neceffary capital to employ it in the way the fociety thinks for the public good: the premiums hould be honorary but confiderable, with that degree of variety and noveliy that fhould attraet the attention of men of fortune.

But nothing was ever better imagined, than the plan of fixing an Englifh farmer in the kingdom, fo much at the fociety's expence, as to give them a power over a part of his management. This was the cafe with Mr. Baker; and it was alio a very wife meafure to enable him to eftablifh a manufactory of hufbandry implements. The only errors in the execution of this fcheme were : Firf, Not fupporting hin much more liberally, when it was found that his private fortune was too inconfiderable to fupport himfelf and family; had he been eafy in his private circumftances, his hußandry would have been perfect. Second, The not directing him in the choice of his farm, which was not a proper one for an example to the kingdom; it lhould have been in fome mountainous tract, where there was bog, and tolerable foil. Third, In permitting him to make and publifh fmall and trifling experiments, objects of curiofity to a private fpeculatif, but quite unworthy of the Dublin Society; befides, fuch a perfon thould be brought to eftablith what a previous experience has convinced him is right, not to gain his own knowledge at the focicty's expence.

The fcheme, had it, in the cafe of Mr. Baker, bcen exectrted in this thanner, or was fuch an one now to be adopted, 
would tend more to fpreading a true practical knowledge of agriculture than any other that could be executed; and the union of a manufactory of implements unites with it perfectly. To inform a backward country. of right fyltems has its ufe, but it is very weak compared with the actual practice and exhibition of it bèfore their eyes ; fuch an object in full perfection of managenent, with an annual publication of tharefult, fimply related, would tend oiore to the improvement of the national hafbandry than any otber fyftem. The farm thould not be lefs than five hundred acres, it fhould have a tract of bog and another of mountain ; one thoufand pounds fhould be applied in the neceffary buildings; five hundred pounds inmeciately in fences; one thoufand pounds a year for five years in ftocking it; one thoufand pounds for eftablifhing a manufactory of implements, not to be fold but given away by the fociety as premiuns ; five hundred pounds a year allowed to the fuperintendant for his private emolumest, that 1:o diftreffes of bis own might interfere with the public views; and in addition, to animate his attention, ten per cent. upon the grofs product of the farm. The fociety to delegate their power over it to a felect committee, and no member to be eligible to that committee, who bad not in his own occupation one hugdred acres of tand, or more. The firt expence would be feven thoufand five hundred pounds, and the annual charge five hundred pounds; this would be an effective eftablifhurent that could not fail, if the manager was properly chofen. He fhould be an active, fpirited man, not fo low as to have no reputation to lofe, but at the fame time more a practical than a fpeculative farmer, and who could teach the common Irifh, with his own hands, the opera. tions he wifhed them to perform. The annual charge of only ore of the fociety's wareboufes is equal to this, and the capitad appropriated to it near twice as large; how much more beneficial would this application of the money be ?

Relative to the premiums for the encouragement of agriculture, I thall venture to hint fome which $I$ apprehend would be of great advantage; and by throwing them into the words common in offering premiums, any meaning will be better explained.

1. TUR NE P HSBANDRY, 1779. 'To the perfon who Anall cultivate the moft land, not lefs than twenty acres, in the following courfe of crops during four years, viz. 1. Turneps. 2. Barley or oats. 3. Clover. 4. Wheat. The turneps to be twice thoroughly hand-hoed and eaten where they grow by Sheep, and to make a full report of the cultivation, expences, produce, and effect of the turneps on the theep fed, a piece of plate of the value of one bundred pounds, with a fuitable infcription. Accounts to be delivered in in the year 1784 .

z. For the next greateft quantity of land, not lefs than ten acres fo cultivated, a piece of plate of the value of fifty pounds, with a fuitable infcription. 
3. To the perfon who fhall in the year 1780 , have the moft acres of turneps, not lefs than twenty, twice thoroughly handhoed; to report the effect, a piece of plate of the value of one bundred pounds, with a fuitable infeription.

4. For the next greateft quantity, not lefs than ten acres, a piece of plate of the value of fifty pounds, with a faitable infeription.

5. BEAN HUSBANDRY, 1779. To the perfon who frall cultivate the moft land, not lefs than twenty acres, in the following courfe of crops during four years, viz. 1. Beans, 2. Wheat. 3. Beans. 4. Wheat. The beans to be in rows, eighteen inches afunder, and three times thoroughly hoed, and to report the effeet to the fociety. A piece of plate of the value of one hundred pounds, with an infcription. Accounts to be laid in in the year 1784 .

6. For the next greateft quantity, not lefs than ten actes, a piece of plate of the walue of fifty pounds, with an infoription.

7. To the perfon who fall cultivate the greatef quantity of land, not lefs than twenty acres, in the following courfe of crops during four years, viz. 1. Beans. 2. Barley or oats. 3. Clover. 4. Wheat. The beans as before, and to report the effect. A piece of plate of the value of one hundred pounds, with an infeription.

8. Next greateft quantity, not lefs than ten acres. The value of 501 . with an infeription.

9. FLA X HUSBANDRY, 1779. To the perfon who thall cultivate the moft land, not lefs than twenty acres, in the following courfe of crops during four years, viz. Turneps. 2. Flax. 3. Clover. 4. Wheat. The turneps to be twice handhoed, and the flax to be feeded, ftacked and threfthed like corn, and then watered and dreffed, and to report the effect to the fociety. A piece of plate of the value of one hundred and fifty pounds, with a fuitable infeription.

10. For the next greateft quantity, not lefs than ten acres. The plate eighty pounds. Accounts to he delivered in in 1784 .

11. MOUN TAIN IMPROVEMENT, 1779. To the perfon who fhall improve the largeft traet of mountain land, not lefs than one hundred acres, at prefent waite, and not let at one flailing an acre, and make a full report of the cultivation, expences and produce to the fociety in the year 1787. A piece of plate of the value of five hundred pounds, with a fuitable infcription. Conditions.

The improvement at the time of the certificates being figned to be completely enclofed; to be divided into fields of not more than ten acres each; the rences to be either walls in mortar, or double ditches well planted with white thorns and timber, the gates, piers, \&c. to be perfect. The land to have had four crops in the following courfe : 1. Turneps. 2. Oats, bere or rye. 3. Turneps. 4. Oats, the uurneps twice hand- 
hoed, and eaten when green by theep, and one half of the improvement to be in grafs laid down with the laft crop of oats. Not lefs than one hundred barrels of lime per acre to have been fpread on the whole. An orchard of two acres to be well planted; and a fally garden of as much. One good farm houfe, with a barn, ftable, cowhoufe, \& c. and four cabbins to be built and inhabited, the whole of ftone or mortar, and covered with tlate. And the tract to be actually let on leafe to one or more tenants, not occupying any other land, and refiding on the premifes. Whoever intends to be claimants to give notice to the fociety that they may appoint infpectors.

12. To the next greateft quantity, not lefs than fixty acres, on the like conditions, the plate three hundred pounds:

13. Bog IMPROVEMENT, 1779. To the perfon who fhall drain and improve into rich meadow, the greateft quantity of bog, not lefs than 50 acres, being part of a bog not Jefs than 100 acres, and nuke a full report to the fociety of the mode, expences and produce in the year 1788 , a piece of plate of the value of 400 . with an honorary infeription. The fociety leaves to the claimant to purfue whatever mode he pleafes, but the land mut have a good houfe, cowhoufe and neceffary offices, witb two cabbins built all of ftone and flate, and the improvement let to refident tenants occupying no other land.

14. For the next greatef quantity, not lefs than thirty acres, the plate two hundred pounds.

15. PLANTING. To the perfon who fhall inclofe with a wet wall, not lefs than fix feet high, and plant, the greateft quantity of land, not lefs than fifty acres, in the year 1780 , a piece of plate of the value of four hundred pounds, with a fuitable infcription. The trees to be afh, elm, poplar, beech, larch, fcotch, fpruce or filver fir, to be not more than four years old, nor more than four feet afunder, and in the centre of everv fuch fpace, acorns to be fown and covered.

16. For the next greateft quantity, not lefs than thirty acres, the plate two hundred pounds.

17. To the perfon who thall in the year 1780 , plant and fence fo as to be completely fecured from catile, the greateft quantity of land with the common bafket fallow in beds fix feet broad, and four rows on each bed, not lefs than thirty acres, a piece of plate of the value of one hundred pounds, with a - fuitable infcription.

18. For the next greateft quantity, not lefs than fifteen acres, the plate fifty pounds. All to be continued by previous notice, every year when once they came into turn.

I have to obferve upon them, that the courfes of crops here recommended can only lave fair juftice done them in the infancy of the hufbandry by gentlemen, or men of confiderable cepital ; confequently, it is the wifeft to offer a premium that Shall atrraet their notice, and not vary it for leffer tenants, who at firt would be incapable of executing the conditions. The mountain and bog improvement are great objects, and therefore 
therefore well deferve ample encouragement; I have added the condition of being let by way of fatisfactory proof, that the improvement is completely finifhed, for if it was kept in hand, it would be 2 matter of opinion and valuation, which is never fatisfactory. The planting premiums would in all probability have many claimants. The ftone wall is effential; planting without prefervation is trifling.

As to the nature of the premiums, I recommend, viz. pieces of plate, I think they would have a greater effect than. any thing elfe; money would be out of fight and forgotten; a medal that has been proftituted to all forts of trifles, would be a contemptible reward for fuch exertions, but a handfome cup, vaze, tray, table, \&c. would be always in fight, and on every occafion a fubject for converfation to animate others to gain the fame. The experience of a few years would prove whether the quantities of land required were too high or not. An infpector to view all proceedings would be abfolutely neceffary, whofe reward fhould be devifed in fuch a manner as to fecure his integrity; unlefs fome gentlemen of confiderable confequence in the neighbourhood took that office voluntarily upon them.

Some premiums upon thefe principles, united with fuch a plan as I have ftated for the eftablifhunent of a farm, would be attended with all the advantage to the national agriculture, in the power of any fociety to effect. The expence would not be fo large as not to leave a confiderable portion of the fociety's funds for trade and manufactures, and confequently to pleafe thofe who wifhed fuch objects not to be neglected,

\section{S E $\quad$ C $T$ T I O Manners and Cuftoms. \\ حuid legis fine moribus, Vana proficiunt!}

$T T$ is but an illiberal bufinefs for a traveller, who defigns to 1 publifh remarks upon a country, to fit down coolly in his clofet and write a fatire on the inhabitants. Severity of that fort nuft be enlivened with an uncommon flare of wit and ridicule, to pleafe. Where very grofs abfurdities are found, it is $f a i r$ and manly to note them; but to enter into character and difpofition is generally uncandid, fince there are no people but might be better than they are found, and none but have virtues which deferve attention, at leaft as much as their failings; for thefe reafons this fection would not have found a place in my obfervations, had not fome perfons of much more flippancy than wifdom, given very grofs mifreprefentations of the Irifh nation. It is with pleafure, therefore, that I take up the pen, on the prefent occafion; as a much longer refidence 
there enables me to exhibit a very different pieture; in doing this, I thall be free to remark, wherein I think the conduct of certain glaffes may have given rife to general and confequently injurious condemnation.

There are three races of people in Ireland, fo diftinet, as to ftrike the leaft attentive traveller : thefe are the Spanith which are found in Kerry, and a part of Limerick and Corke, tall and thin, but well made, a long vifage, dark eyes, and long black lank hair. The time is not remote when the Spaniards had a kind of fettlement on the coaft of Kerry, which feemed to be overlooked by government. There were many of them in Queen Elizabeth's reign, nor were they entirely driven out till the time of Cromwell. There is an inland of Valentia on that coaft, with various other names, certainly Spanifh. The Scotch race is in the North, where are to be found the features which are fuppofed to mark that people, their accent, and many of their cuttoms. In a diftriet, near Dublin, but inore particularly in the baronies of Bargie and Forth in the couniy of Wexford, the Saxon tongue is fpoken without any misture of the Irifh, and the people have a variety of cuftons mentioned in the minutes, which diftinguifh them from their neighbours. The reft of the kingdom is made up of mongrels. The Milefian race of Irifh, which may be called native, are fcattered over the kingdom, but chiehy found in Connaught and Munfter; a few confiderable families, whofe genealogy is undoubted, remain, but none of them wiih confiderable poffeffions, except the O'Briens and Mr. O'Neil, the former have near twenty thoufand pounds a year in the family; the latter half as much, the reninant of a property once his anceftors, which now forms fie or feven of the greateft eftates in the kingdom. O'Hara and M'Dermot are great names in Connaught, and O'Donnohue a confiderable one in Kerry; but 1 heard of a family of O'Drifchal's in Corke, who claim an origin prior in Ireland to any of the Milefian race.

The only divifions which a traveller, who paffed through the kingdom, without making any refidence, could make, would be into people of confiderable fortune and mob. The internediate divifion of the fcale, fo numerous and refpectable in England, would hardly attract the leaft notice in Ireland. A refidesce in the kingdom convinces one, however, that there is another clais in general of fmall fortune,-country gentlemen and renters of land. The manners, habits and cuftoms of people of confiderable fortune, are much the fame every where, at leaft there is very little difference between England and Ireland, it is among the common people one mut look for thofe traits by which we difcriminate a national character. The circumftances which ftruck me mott in the common Irifh were, vivacity and a great and eloquent volubility of fpeech, one would think they could take fnuff and talk without tiring till doomfday. They are infinitely more chearful and lively 
than any thing we commonly fee in England, having nothing of that incivility of fullen filence, with which fo many Engliftumen feen to wrap themfelves up, as if retiring within their own importance. Lazy to an excefs at work, but fo fpiritedly aetive at play, that at burling, which is the cricket of favages, they thew the greateft feats of agility. Their love of fociety is as remarkable as their curiofity is infatiable; and their hofpitality to all comers, be their own poverty ever fo pinching, has too nuch merit to be forgotten. Pleafed to enjoyment with a joke, or witty repartee, they will repeat it with fuch expreffion, that the laugh will be univerial. Warm friends and revengeful enemies; they are inviolable in their fecrecy, and inevitable in their refentment; with fuch a notion of honour, that neither threat nor reward would induce them to betray the fecret or perfon of a man, though an oppreffor, whofe property they would plunder without ceremony. Hard drinkers and quarrelfome; great liars, but civil, fubmitive and obedient. Dancing is fo univerfal among them, that there are every where itinerant dancing-mafters, to whom the cottats pay fixpence a quarter for teaching their families. Befides the Irifh jig, which they can dance with a moft luxuriant expreffion, miuuets and country dances are taught; and $I \mathrm{evcn}$ heard fome talk of cotillons coming in.

Some degree of education is alfo general; hedge fchools, as they are called (they might as well be termed ditcb ones, for I ha ve feen many a ditch full of fcholars) are every where to be met with, where reading and writing are taught; fchools are alfo common formen; I have feen a dozen great fellows at fchool, and was told they were educating with an intention of being prietts. Many ftrokes in their character are evidently to be afcribed to the extreme oppreffion under which they live. If they are as great thieves and liars as they are reported, it is certainly owing to this caufe.

If from the loweft clafs we rife to the higheit, all there is gaiety, pleafure, luxury and extravagance; the town life at Dublin is formed on the model of that of London. Every night in the winter there is a ball or a party, where the polite circle weet, not to enjoy but to fweat each other; a great crowd crammed into twenty feet fquare gives a zeft to the agriments of fimall talk and whift. There are four or five houles large enough to receive a company commodioufy, but the reft are fo fmall as to nake parties deteftable. There is however an agreeable fociety in Dublin, in which a man of large fortune will not find his time heavy. The ftile of living may be gueffed from the fortunes of the refident nobility and great comnoners; there are about thirty that poffefs incomes from feven to twenty thoufand pounds a year. The court has nothing remarkable or fplendid in it, but varies very much, according to the private fortune or liberality of difpofition in the Lord Lieutenant. 
In the country their life has fome circumftances which are not commonly feen in England. Large tracts of land are kept in hand by every body to fupply the deficiencies of markets, this gives fuch a plenty, that, united with the lownefs of taxes and prices, one would fuppofe it difficult for them to fpend their incomes, if Dublin in the winter did not lend affiftance. Let it be confidered, that the prices of meat are much lower than in England; poultry only a fourth of the price; wild fowl and fifh in vaftly greater plenty; run and brandy not half the price; coffee, tea and wines far cheaper; labour not above a third; fervants wages upon an average thirty per cent, cheaper. That taxes are inconfiderable, for there is no land tax, no poor rates, no window tax, no candle or foap tax, only half a wheel tax, no fervants tax, and a variety of other articles heavily burthened in England, but not in Ireland. Confidering all this, one would think they could not fpend their incomes; they do contrive it however. In this bufinefs they are affitted by two cuftoms that have an admirable tendency to it, great numbers of horfes and fervants. The excefs in the latter are in the lower fort : owing, not only to the general lazinefs, but alfo to the number of attendants every one of a higher clafs will have; this is common in great families in England, but in Ireland a man of five hundred pounds a year feels it. As to horfes the number is carried quite to a folly ; in order to explain this point, I thall infert a table of the demefnes of many of the nobility and gentry, which will thew not only the number of horfes, but of other cattle, the quantity of land they keep, and other circumftances explanatory of their country life. 
D E M E S N E S .

\begin{tabular}{|c|c|c|c|c|c|c|c|c|c|}
\hline Names. & Acre & $W_{00}$ & Corn. & $\mid \begin{array}{l}T u r n \\
\text { Cabb. }\end{array}$ & Rent. & Lab & $\begin{array}{l}\text { Hor, } \\
\text { fes. }\end{array}$ & Plou & $\mid S b$ cep $\mid$ \\
\hline Mr. Clements, & 240 & & 14 & & $\begin{array}{l}1 . \\
420\end{array}$ & 20 & 22 & 6 & 163 \\
\hline Col. Marley, & 200 & & 31 & I $\frac{1}{2}$ & 300 & & 8 & 4 & 40 \\
\hline Mr. Rowley, & 700 & 100 & & 3 & 700 & & 90 & & 250 \\
\hline Lord Conyngham, & 447 & 120 & 32. & 3 & & & 37 & & 44 \\
\hline Lord Bective, & 1600 & & 84 & & 2000 & 140 & 100 & 20 & 500 \\
\hline Mr. Gerard, & 1200 & & 64 & & 1300 & & 12 & & 1300 \\
\hline Lord Longford, & 320 & & 32 & 5 & 300 & 20 & 26 & 12 & 100 \\
\hline Mr. Johnfon, & 410 & 110 & io & 5 & 320 & 9 & 8) & 4 & 200 \\
\hline Dcan Coote, & 500 & & 35 & 8 & 350 & 30 & 35 & 8 & 200 \\
\hline General Walth, & 700 & & $7^{1}$ & 5 & & 50 & & & 150 \\
\hline Mr. Brown, & 300 & & & & 460 & & 8 & & 800 \\
\hline Mr. Buthe, & 170 & $3^{\circ}$ & 50 & 2 & 330 & & is & 8 & 70 \\
\hline Lord Courtown, & 300 & & $3^{\circ}$ & 7 & 315 & 30 & 21 & 12 & 70 \\
\hline General Cuninghame, & 150 & & 34 & & 375 & 20 & 16 & 5 & 70 \\
\hline 1.ord Gosfort, & 300 & & 25 & 3 & $45^{\circ}$ & 30 & 43 & 4 & 46 \\
\hline Mr. Clofe, & 100 & & 23 & & 135 & 9 & 10 & & 40 \\
\hline Mr. Leny, & 350 & 100 & $3^{2}$ & & $35^{\circ}$ & 30 & 37. & 20 & 150 \\
\hline Mr. Savage, & 190 & & 35 & 2 & 250 & & 32 & & 40 \\
\hline Mr. O'Niel, & 733 & & 57 & 17 & 549 & 40 & 68 & 24 & 500 \\
\hline Mr. Leflie, & 1026 & 60 & 101 & & 790 & 50 & $4^{6}$ & 24 & 80 \\
\hline Sir J. Caldwell, & .700 & 300 & $4 \mathrm{I}$ & $\mathbf{u}$ & 900 & & 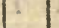 & & \\
\hline Mr. Corry, & 1000 & & 68 & & 900 & 120 & & & 500 \\
\hline Lord Rols, & $95^{\circ}$ & 125 & & & & $3^{\circ}$ & 30 & & 120 \\
\hline Lord Farnham, & 1000 & 200 & 55 & 10 & 800 & 100 & 108 & 22 & $28 ;$ \\
\hline Mr. Newcomen, & 400 & & 40 & & & & & 18 & \\
\hline Mr. Mahon, & 1100 & 100 & 60 & & 840 & 20 & 30 & & 500 \\
\hline Mr. Cooper, & 1000 & 300 & 22 & 8 & tets & 60 & 25 & 12 & 130 \\
\hline Mr. Brown, & 370 & & 18 & & tes & 10 & 30 & & 300 \\
\hline Mr. Gore, & 3300 & & 160 & & 2310 & 120 & 170 & & 5000 \\
\hline Lord Altamont, & 1500 & & 120 & 6. & 1000 & 100 & 70 & 20 & 200 \\
\hline Mr. French, & 1790 & $25^{2}$ & 55. & & & 100 & 20 & 14 & 424 \\
\hline Mr. Trench, & 1046 & 100 & 13 & & 600 & 80 & 45 & 10 & 980 \\
\hline Sir Lucius O'Brien, & 399 & 30 & 47 & & 560 & 60 & 26 & 11 & $13^{8}$ \\
\hline Mr. Fit & 3000 & & & & 2000 & 26 & 54 & 18 & 1800 \\
\hline th, & 1270 & 600 & 550 & 12 & 1010 & & 33 & 16 & 500 \\
\hline Lord Donneraile, & 1200 & 200 & 200 & 5 & 1500 & 60 & 54 & $4^{\circ}$ & 400 \\
\hline Colonel Jepfon, & 300 & & 35 & & .900 & & 24 & & 120 \\
\hline Mr. Gordon, & 915 & & 114 & & 700 & 45 & 13 & 15 & 187 \\
\hline Mr. Jeffries, & 304 & & 20 & & 300 & & 32 & & 200 \\
\hline Mr. Trent, & $23^{8}$ & 24 & 21 & & & & 13 & 5 & 200 \\
\hline Lord Shannon, & 1600 & 268 & 81 & & 1500 & ${ }^{1} 32$ & Ii) & 36 & 470 \\
\hline Mr. Longfield, & 1100 & & $7^{8}$ & & 800 & 20 & 65 & 14 & 200 \\
\hline Rev. Archd. Oliver, & 900 & & $13^{6}$ & 16 & 650 & 50 & 25 & 21 & 100 \\
\hline Mr. Herbert, & 1300 & 780 & & & 400 & & 18 & 30 & 300 \\
\hline Mr. Bate & 250 & & 5 & & $25^{\circ}$ & & 30 & (2) & 60 \\
\hline Lord Glendour, & 1000 & 100 & 55 & & 1000 & & 50 & & 200 \\
\hline Mr. Fitzgerald, & 200 & & 23 & 3 & 200 & & $2: 1$ & 8 & 60 \\
\hline Mr. Leflie, & 250 & 50 & 27 & & $23^{\circ}$ & & 24 & 6 & 60 \\
\hline Mr. Oliver, & 500 & 100 & 24 & 10 & 500 & 50 & $30 \mid$ & 10 & 125 \\
\hline Mr. Ryves, & 300 & & 25 & & $45^{\circ}$ & 61 & 20 & the & 300 \\
\hline Clan & $64^{\circ}$ & & 34 & 8 & 600 & 30 & 40 & & 600 \\
\hline Mr. Macartney & 9000 & & & & 10,000 & 170 & 180 & 80 & 8000 \\
\hline Lord de Montal & 1300 & 300 & & & & 75 & 40 & 40 & 1500 \\
\hline Mr. Moore, & 600 & & 17 & & 1255 & & & & 1000 \\
\hline Lord Tyrone, & 2100 & 1500 & 64 & & 1200 & 200 & 36 & 48 & 400 \\
\hline Mr. Bolton, & 200 & & 28 & & 300 & $4^{\circ}$ & 25 & 6 & 70 \\
\hline Mr. Nevill, & 220 & 2 & & & 350 & & $2=$ & & 100 \\
\hline Mr. Lloyd, & 200 & & & & 150 & & 12 & 7 & 182 \\
\hline Mr. Holmes, & 540 & 49 & 25 & is & $54^{\circ}$ & 40 & so! & 14 & 590 \\
\hline & $45^{\circ}$ & 16 & 27 & & 675 & 20 & & & 400 \\
\hline ord King $\mathrm{K}$ & 6001 & $100 !$ & 30 & 5 & 4001 & $1: 00^{\prime}$ & 401 & & 200 \\
\hline
\end{tabular}


The intelligent reader will colleet fomeihing more thas mere curiofity from this table; it will neceffarily otrike him, that a country refidence in Ireland demands a much larger quantity of land in hand than in England, from which might be dedaced, if not from any thing elie, how much backwarder the former is than the latter; where markets are wanting every thing muft be had at home, a cafe fronger fill in America. In England fuch extenfive demefnes would be parks around the feats for beauty as much as ufe, but it is not fo in Ireland; the words deer-park and demefne are to be dittinguifhed; there are great deniefnes without any parks, but a want of tafte, too common in Ireland, is having a deer-park at a diftance from the houfe; the refidence furrounded by walls, or bedges, or cabbins; and the lawn enclofure fcattered with animals of various forts, perhaps three miles off. The fmall quantity of corn proportioned to the total acres, fhews how little tillage is atiended to even by thore who are the beft able to carry it on; and the column of turneps proves. in the cleareft manner, what the progrefs of improvement is in that kingdom. The number of horfes may aluoit be efteemed a fatire upon common fenfe; were they wcll fed enough to be ufeful, they would not be fo ounerous, but 1 have found a good hack for a common ride farce in a boufe, where there were a hundred. Upon an average, the borfes in gentlemen's ftables, throughout the kingdom, are not fed half fo well as they are in England by men of equal fortune; jet the sumber makes the expence of them very heary.

Another circumftance to be remarked in the country life is the miferablenefs of many of their houfes; there are men of five thoufand a year in Ireland, who live in habitations that a man of feven hundred a year in England would difdain; an air of neatnefs, order, drefs, and proprete, is wapting to a furprizing degree around the manfion; even new and excelient houfes have often nothing of this about thein. But the badnefs of the houfes is remedying every hour througheur the whole kingdom, for the number of new ones juft built, or building, is prodigioully great. I flould fuppofe there were not ten dwellings in the kingdom thirty years ago that were fit for an Englioh pig to live in. Gardens were equally bad. but now they are running into the contrary extreme, and wall in five, fix, ten, and even twenty Irifin acres for a garden, but generally double or trebie what is necelfary.

The tables of people of fortune are very plentifuliy fpread; many elegantly, differing in nothing from tho?e of England. I think I remarked that venifon wants the flavour it has with us, probably for the fame reafon, that the produce of rich parks is never equal to that of poor ones; the moifture of the climate, and the richnefs of the foil, give fat but not fiavour. Anotber reafon is the fmaltnefs of the parks, a man who has three or four thoufand acres in his hands, has not, perhaps, above three or four hundred in his deer park, and range 
is a great point for good venifon, Nor do I think that garden vegetables have the flavour found in thofe of England, certainly owing to the climate; green peas I found every where perfectly infipid, and lettuce, \&c. not good. Claret is the common wine of all tables, and fo much inferior to what is drank in England, that it does not appear to be the fame wine, but their port is incomparable, fo nuch better than the Englifh, as to prove, if proof was wanting, the abominable adulterations it muft undergo with us. Drinking and duelling are two charges which have long been alledged againft the gentlemen of Ireland, but the change of manners which has taken place in that kingdom is not generally known in England. Drunkennefs ought no longer to be a reproach, for at every table I was at in Ireland I faw perfect freedom reign, every perfon drank juft as little as they pleafed, nor have I ever been afked to drink a fingle glafs more than I had an inclination for; I may go farther, and affert that bard drinking is very rare among people of fortune; yet it is certain that bliey fit nuch longer at table than in England. I was much furprized at firt going over to find no fummons to coffee, the company often fitting till eight, nine, or ten o'clock before they went to the Iadies. If a gentleman likes tea or coffee, he retires without faying any thing, a ftranger of rank may propofe it to the mafter of the houfe, who from cuftom contrary to that of England, will not ftir till he receives fuch a hint, as they think it would imply a defire to fave their wine. If the gentlemen. were generally defirous of tea I take it for granted they would have it, but their flighting is one inconvenience to fuch as defire it, not knowing when it is provided, converfation may carry them beyond the time, and then if they do trifle over the coffee it will certainly be cold. There is a want of attention in this, which the ladies fhould remedy, if they will not break the old cuftom and fend to the gentlemen, which is what they ought to do, they certainly fhould have a falver frefh. I muft however remark, that at the politeft tables, which are thofe of people who have refided much out of Ireland, this point is conducted exactly as it is in England.

Duclling was once carried to an excefs, which was a real reproach and fcandai to the kingdom; it of courfe proceeded from exceffive drinking; as the caufe has difappeared, the effeet has nearly followed: not, however. entirely, for it is yet far more common among people of faftion than in England. Of all practices a man who felt for the honour of his country, would wifh fooneft to banifh this, for there is not one favourable conclufion to be drawn from it: as to courage nobody can queftion that of a polite and enlightened nation, entitled to a thare of the reputation of the age; but it implies uncivilized manners, an ignorance of thole forms which govern polite focieties, or elfe a brutal drunkennefs; the latter is no longer the caufe of the pretence. As to the former, they would place the national charaker fo backward, would take 
from it fo nuch of its pretence to civilization, elegance and politenefs of manners, that no true Irifhman would be pleafed with the imputation. Certain it is, that none are fo captious as thofe who think themfelves negleeted or defpifed; and none are fo ready to believe themfelves either one or the other, as perfons unufed to good company. Captious people, therefore, who are ready to take an affront, nuft inevitably have been accuftomed to ill company, unlefs there fhould be fomething uncommonly crooked in their natural difpofitions, which is not to be fuppofed. Let every man that fights his one, two, three, or half a dozen duels, receive it as a maxim, that every one he adds to the number is but an additional proof of his being ill educated, and having vitiated his manners by the contagion of bad company; who is it that can reckon the moft numerous rencounters? who but the bucks, bloods, landjobbers, and little drunken country gentlemen? Ought not people of fafhion to blufh at a practice which will very foon be the diftinction only of the moft contemptible of the people? the point of honour will and mutt remain for the decifion of certain affronts, but it will rarely be had recourfe to in polite, fenfible, and well bred company. The practice among real gentlemen in Ireland every day declining is a ftrong proof, that a knowledge of the world correets the old manners, and confequently its having ever bcen prevalent was owing to the caufes to which I have attributed it. There is another point of mianners fonewhat connected with the prefent fubject, which partly induced me to place a motto at the head of this fection. It is the conduct of juries; the criminal law of Ireland is the fame as that of England, but in the execution it is fo different, as fcarcely to be known. I believe it is a faet, at leaft I have been affured fo, that no man was eyer hanged in Ireland for killing another in a duel: the fecurity is fuch that nobody ever thought of removing out of the way of juftice, yet there have been deaths of that. fort, which had no more to do with bonour, than ftabbing in the dark. I behieve Ireland is the only country in Europe. I am fure it is the only part of the Britifl dominions, where affociations among men of fortune are neceffary for apprehending ravilhets. It is fcarcely credible how many young women, have eved of late years been ravihed, and carried off in order (as they generally have fortunes) to gain to appearance a voluntary marriage. Thefe actions it is true are not committed by the clats $I$ ain confidering at prefent; but they are tried bythem, and A C QU,IT TED. I think there has been only one man executed for that crime, which is fo common as to occafion the aftociations I nentioned; it is to this fupine execution of the law that fuch enorinities are owing. Another circumftance which has the effect of fcreening all forts of offenders, is mien of forcune protecting them, and making interett for their acquittal, which is attended with a variety of evil confequences. I heard it boatted in the cousty of Fermanagh, that there had not been a man hanged in it for two and twenty years: all I concluded from this was, that there had been many a jury who deferted it richly. 
Let me, however, conclude what I have to obferve on the conduct of the principal people refiding in Ireland, that there are great numbers among them who are as liberal in all their ideas as any people in Europe; that they have feen the errors which have given an ill character to the manners of their country, and done every thing that example could effect to produce a change: that that happy change has been partly effeeted, and is effecting every hour, infomuch that a man may go into a vaft variety of families which he will find actuated by no other principles than thofe of the moft cultivated politenefs, and the moft liberal urbanity.

But I muit now come to another clafs of people, to whofe conduct it is almot entirely owing, that the character of the nation has not that luftre abroad, which I dare affert, it will foon very generally merit : this is the clafs of little country gentlemen * t tenants, who drink their claret by means of profit rents; jobbers in farms; bucks; your fellows with round hats, edged with gold, who hunt in the day, get drunk in the evening, and fight the next morning. I fhall not dwell on a fubject fo perfectly difagreeable, but remark that thefe are the men among whom drinking, wrangling, quar reling, fighting, ravifhing, \&c. \&zc. \&c. are found as in tneir native foil; once to a degree that made them the pelt of fociety ; they are growing better, but even now, one or two of them got by accident (where they have no bufinels) into better company are fufficient very much to derange the pleafures that refult from a liberal converfation. A new fpirit; new fafhions; new modes of politenefs exhibited by the higher ranks are imitated by the lower, which will, it is to be hoped, put an end to this race of beings; and either drive their fons and coufins into the army or navy, or fink them into plain farmers like thofe we have in England, where it is common to fee men with much greater property without pretending to be gentlemen. I repeat it from the intelligence I received, that even this clafs are very different from what they were twenty years ago, and improve fo falt that the time will foon come when the national character will not be degraded by any fet.

That character is upon the whole refpectable: it would be unfair to attribute to the nation at large the vices and follies of only one clafs of individuals. Thofe perfons from whom it is candid to take a general eftimate do credit to their country. That they are a people learned, lively and ingenious; the admirable authors they have produced will be Vol. II.

* This exprefion is not to be taken in a general fenfe. God forbid I Sould give this character. of all country gentlemen of finall fortunes in Ireland: 1 have myfelf been acquainted with exceptions. -I mean only that in general they are not the mof? liberal people in the kingdon. 
an eternal monument, witnefs their Swift, Sterne, Congreve, Boyle, Berkeley, Steele, Farquhar, Southern, and Goldímith. Their talent for eloquence is felt, and acknowledged in the parliaments of both the kingdoms. Our, own fervice both by fea and land, as well as that (unfortunately for us) of the principal monarchies of Europe fpeak their fteady and determined courage. Every unprejudiced traveller who vifits them will be as much pleafed with their chearfulnefs, as obliged by their hofpitality : and will find them a brave, polite, and liberal people.

\section{S E C T I O N XVIII.}

\section{Corn Trade of Ireland.—Bounty on inland Carriage.}

THE police of corn in Ireland is almolt confined to one 1 of the moft fingular meafures that have any where been adopted, which is giving a bounty on the inland carriage of corn from all parts of the kingdom, to the capital. Before it is fully explained it will be neceffary to ftate the motives that were the inducement to it.

Dublin, it was afferted from the peculiarity of its fituation, on the eaftern extremity without any inland navigations leading to it, was found to be in point of confumption more an Englifh than an Irifh city, in corn almoft as much as in coals. The import of corn and flour drained the kingdom of great fums at the fame time that the fupply was uncertain and precarious. It was farther afferted that tillage was exceedingly neglected in Ireland, to the impoverifhment of the kingdom, and the mifery of the poor. That if fome meafure could be ftruck out at once to remedy thofe two evils, it would be of fingular advantage to the community.

This reafoning furnifhed the hint to a gentleman of very confiderable abilities, now high in office, there to plan the meafure I am fpeaking of. It has been perfected by repeated acts giving a bounty on

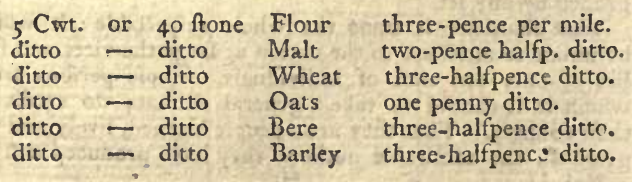

Oatmeal the fame as oats; the ten firft miles from Dublin deducted, it amounts, as has been found by experience, to near twenty per cent. more for flour than the real expenfe of carriage, and one and a half per cent. more for wheat. In confequence of this act many of the fineft mills for grinding 
corn that are to be found in the world were erected, fome of which have been built upon fuch a fcale, as to have coft near $20,000 \mathrm{l}$. The effeet has been confiderable in extending tillage, and great quantities of the produce are carricd to Dublin. Before I offer any obfervations on this fyftem, it will be neceffary to infert fuch tables as are neceifary to explain the extent, effect, and expenfe of the meafure which took place in 1762 , and in 1776 and 7 , arofe to above 60,0001 . In order to fee what the import was before that period, and alfo what it was before the bounty was in full fway, as well as fince, the following table will have its ufe.

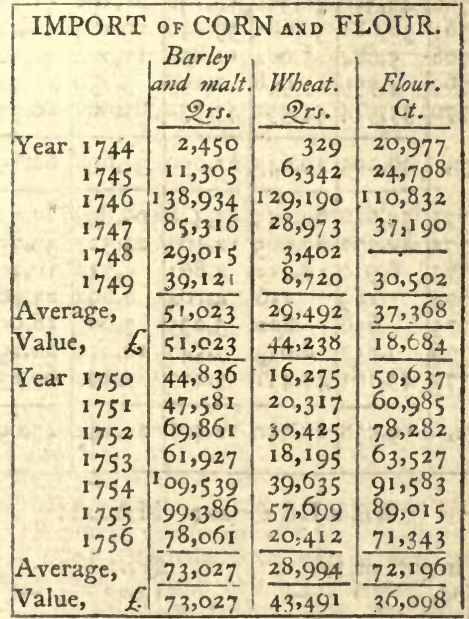

\begin{tabular}{|c|c|c|c|c|c|c|c|}
\hline & & Barley a & d Malt. & $\overline{W b}$ & & & sur. \\
\hline & & Quantity. & Value. & 2uantity & | Value. & 2uantity. & I Value. \\
\hline & & qrs. & 1. & qrs. & 1 . & C. & 1. \\
\hline Year & 1757 & 59,354 & 59,354 & 31,711 & 47,567 & 55,975 & 27,978 \\
\hline & $175^{8}$ & 38,123 & & 27,850 & 41,775 & 72,490 & 36,245 \\
\hline & 1759 & 6,071 & 6,071 & 4,718 & 7,078 & $27,25^{8}$ & 13,629 \\
\hline & 1760 & 34,678 & 34,678 & 3,697 & 5,546 & 30,093 & 15,046 \\
\hline & 1761 & 30,208 & 30,208 & 2,427 & 3,641 & 30,982 & 15,491 \\
\hline & 1762 & 237,500 & 37,500 & $0,17,129$ & 25,694 & 51,522 & $25,76_{1}$ \\
\hline & 1763 & 44 & 44,264 & 6 & & 8 & $29,5^{24}$ \\
\hline Aver & age, & 35,742 & 35,74 & 15,741 & 23,6 & 46,48 & $23,3^{82}$ \\
\hline
\end{tabular}




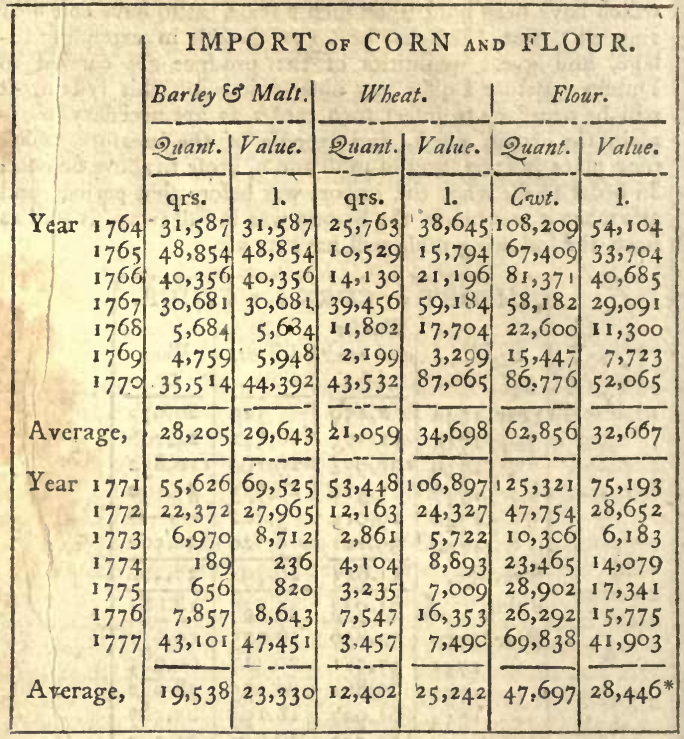

BARLEY AND MALT.

Average import of the

Firft period,

Second ditto,

Third ditto,

Fourth ditto,

Fifth ditto,
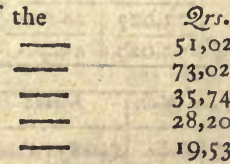

Value.

51,023

51,023

73,027 - 73,027

$35,742 \quad-\quad 35,743$
$28,205 \quad-\quad 29,643$

$19,53^{8}-23,330$

W H E A T.

Average of the

Firft period,

Second ditto,

Third ditto,

Fourth ditto,

Fifth ditto,

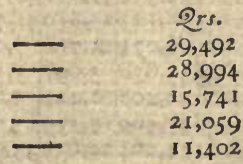

Value.

1.

44,238

43,491

23,612

34,698

25,242

* MS. Communicated by the Right Hon. John Beresford, firfz commifioner of the revenue in Ireland. 


\section{F I O U R.}

Average of the

Firft period,

Second ditto,

Third ditto,

Fourth ditto,

Fifth ditto,

$$
\text { F L O U R. }
$$


been minutely examined. But in order that we may have the whole corn trade before us, let me infert the import of other forts of corn.

\begin{tabular}{|c|c|c|c|c|c|c|c|c|c|}
\hline \multirow{2}{*}{\multicolumn{2}{|c|}{ i }} & \multicolumn{2}{|c|}{ Wheat Meal. } & \multicolumn{2}{|c|}{ Oatmeal. } & \multicolumn{2}{|c|}{ Beans \&ै Peafe. } & \multicolumn{2}{|c|}{ Oats. } \\
\hline & & Quant. & Value. & 2uant. & Volue. & Qtant. & Value. & Qmant. & Value. \\
\hline & & Barrels. & 1. & Ber-els. & I. & 2rs. & 1. & Qrs. & L. \\
\hline Year & $\begin{array}{l}1757 \\
1758\end{array}$ & & & 4,677 & 1,559 & $\begin{array}{l}425 \\
647\end{array}$ & 382 & 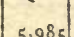 & \\
\hline & $\begin{array}{r}1759 \\
\end{array}$ & & & $\begin{array}{r}4,030 \\
10\end{array}$ & $\begin{array}{r}1340 \\
-\quad 3\end{array}$ & $\begin{array}{l}047 \\
269\end{array}$ & $\begin{array}{l}502 \\
242\end{array}$ & & 35 \\
\hline$\therefore$ & 1760 & 9 & II & & & 410 & 369 & 72 & \\
\hline & 1761 & & & & & 85 & 256 & 56 & \\
\hline & $\begin{array}{l}1762 \\
1763\end{array}$ & 95 & 119 & $1,18 \mathrm{I}$ & $\begin{array}{r}393 \\
632\end{array}$ & $\begin{array}{r}497 \\
366\end{array}$ & 447 & 9) & J \\
\hline 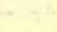 & .1763 & 23 & 29 & 7,912 & 2,637 & 366 & 329 & & \\
\hline Avera & ge, & 18 & 22 & 2.545 & 848 & 414 & 373 & 883 & $5^{29}$ \\
\hline Year & 1764 & 1,136 & 1,420 & 55 & 18 & 543 & $4^{89}$ & 139 & 83 \\
\hline & $\begin{array}{l}1705 \\
1766\end{array}$ & $\begin{array}{r}46 \\
417\end{array}$ & $\begin{array}{r}57 \\
52.1\end{array}$ & 520 & 173 & 579 & $\begin{array}{l}78 \mathrm{I} \\
521\end{array}$ & 744 & \\
\hline & 367 & 9,659 & 12,074 & 740 & 246 & 089 & 620 & 2,854 & 1,712 \\
\hline & 1768 & 5,351 & 6,689 & & & 389 & $35^{\circ}$ & $95^{\circ}$ & 570 \\
\hline & 1769 & 23 & 1,278 & & & 453 & 453 & 115 & 74 \\
\hline+1 & 1770 & 1,854 & 2,781 & 104 & 36 & $75^{2}$ & 752 & 44 & 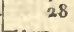 \\
\hline Avera & age, & 2,355 & 3,546 & 202 & 67 & 610 & 566 & $69^{2}$ & 416 \\
\hline Year & 1773 & 3,696 & 529 & $14,62,5$ & 119 & 2,356 & 2.356 & $5.1,820$ & 1,274 \\
\hline & 1772 & 2,904 & 356 & 13.599 & 759 & 836 & 836 & 351 & 246 \\
\hline & 1773 & 782 & 173 & 1,495 & $5^{2} 3$ & 428 & $4^{28}$ & 56 & 39 \\
\hline & 17 & 759 & $1,13^{8}$ & 30 & $35^{\circ}$ & $48 \mathrm{I}$ & 602 & -333 & 250 \\
\hline & 1775 & 1,600 & 2,400 & 1,171 & 410 & 1,110 & 1,388 & 4 & \\
\hline & 1776 & 682 & 1,023 & & & $7^{81}$ & 976 & 24 & 18 \\
\hline & 8777 & 36 & $4^{8}$ & $1,55^{8}$ & 545 & 6,305 & 7,882 & 387 & 290 \\
\hline A & age, & 1,492 & 2,238 & 4,695 & 4 & 1,757 & 2,067 & 425 & $303^{*}$ \\
\hline
\end{tabular}

Value of the import per annum of $\}$ thefe articles in the laft feven years,

Ditto in the preceding feven years,

Here therefore we find that infead of a decreafe in the import the contrary has taken place.

Recapitulation of the total Value of Corn, Flour, \&c. imported.

* M S. communicated by the Right Hon. Ifaac Barrè. 


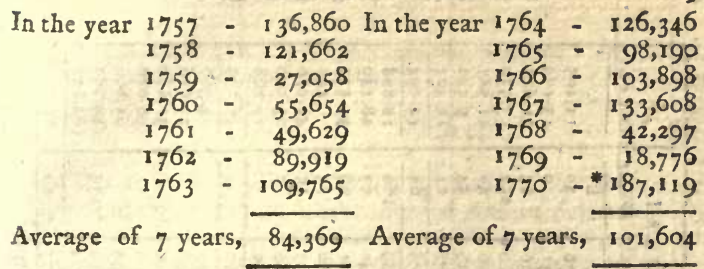

1.

$\begin{array}{rr}\text { In the year } 1771-265,897 \text { In the year } 1775-29,371 \\ 1772-91,14 & 1776-42,788 \\ 1773-22,780 & 1777-105,559 \\ 1774-25,34^{8} & \text { Average of feven years }-84,697\end{array}$

Second period, Lalt feven years,

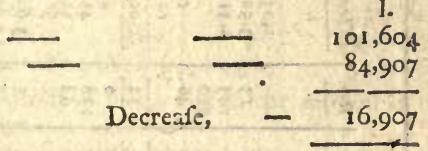

Here is the refult of the whole import account ; the balance of which in favour of the nation is no more than this trifling fum of fixteen thoufand pounds. The account however mult be farther examined; we mult take the export fide of the queftion, for there has been an export notwithftanding this great import. We fee fomething of this in the regifter of our Englifh corn trade, where is a confiderable fpeculative commerce in corn; but as no fuch thing exifts in Ireland, where the corn trade is a fimple import of a neceffary of life, it is a little furprizing if any great export appears. Let us however examine the account.

- The Dublin Society were not very accurate, when in their petition to parliament they fet forth, that in two years preceding. $177 \mathrm{i}$, the import amounted to upwards of 600,0001 . 


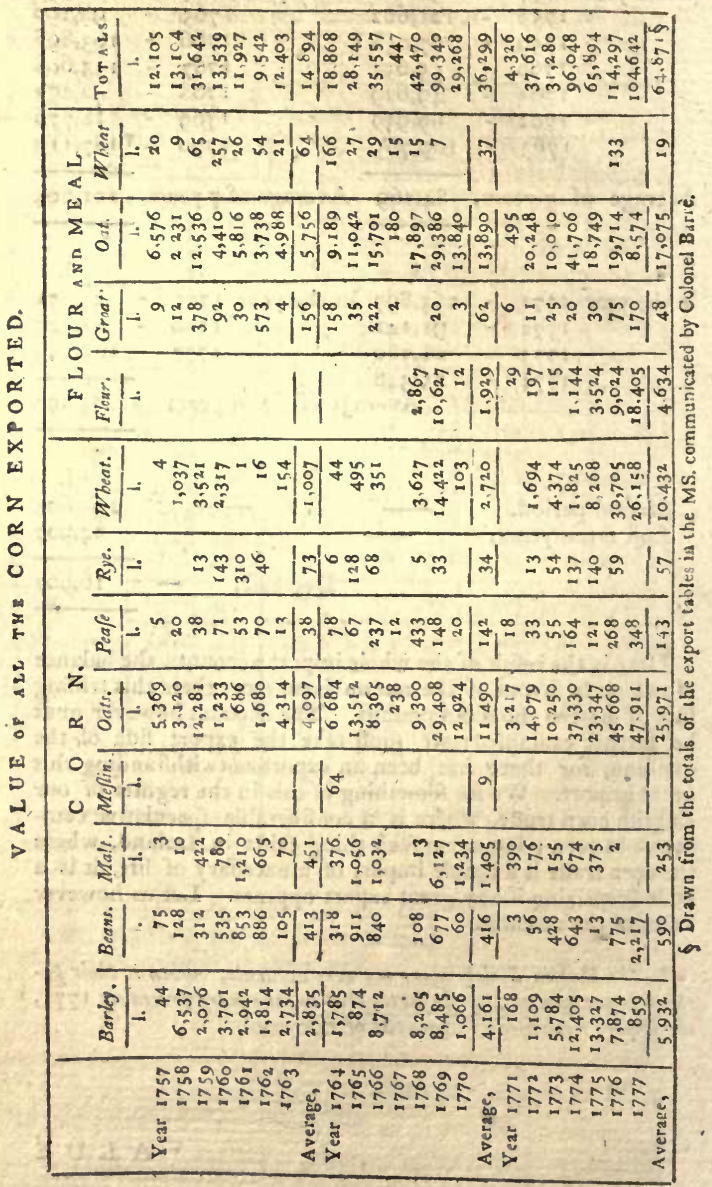


Exported in the laft feven years per annum,

But as the preceding table includes the export from all the ports in the kingdom, I have inferted it as an object of general information, not as immediately neceffary to the enquiry before us, which concerns the port of Dublin only. A meafure which draws the corn to that capital from all the ports in the kingdom, can never promote an export from them, but mult operate in a contrary manner: for this reafon I have drawn the export of the port of Dublin from the general tables for twenty-one years, and find the averages of the three periods, each of feren years, to be in value as follows: the table itfelf is too voluminous to infert.

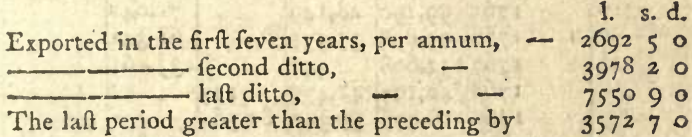

Which fum is the profit to be carried to the account of the inland carriage bounty.

I muft here obferve, that there was a bounty given on exportation, which took place the $24^{\text {th }}$ of June, 1774. viz. 3 s. $2 \mathrm{~d}$. on the quarter of wheat, ground wheat, meal, or wheat flour. 2s. 4 d. on the quarter of rye, peafe or beans ground or unground. 1s. 3 d. on the quarter of oats, which act declares the half quarter of wheat, rye, peafe, beans, meal, \&c. Thall be $224 \mathrm{lb}$. barley and malt were left out to enfure the acts paffing in England.

The following feffions an additional duty on the import was laid of 2s. a barrel on all wheat, and is. per hundred weight on all flour, meal, bread, and bifcuit, except of the produce of or manufacture of Great Britain, to be levied when the middle price of wheat at the port where imported Thall exceed 235. Englifh, the barrel of $280 \mathrm{lb}$. The old duty on wheat was 2 d. per barrel; on flour 1 s. from all ports, Great Britain included.

Decreafe in the import of the laft feven years, , $\quad 16,907$ Increafe in the export from Dublin, - $3,5,2$ Total gain per ann. according to this account in the

laft feven years,

The reader is not to imagine from hence, that the corn trade of Ireland yields a balance of profit; the advantage to be attributed to the bounty from this account is only a leflening of lofs, as will appear from the following ftate of export and import over the whole kingdoin. 


\section{IMPORT AND EXPORT COMPARED IN VALUE.}

\begin{tabular}{|c|c|c|c|c|}
\hline & Import. & Export. & $\begin{array}{l}\text { Balance } \\
\text { profit. }\end{array}$ & $\begin{array}{c}\text { Balance } \\
\text { lofs. }\end{array}$ \\
\hline & & & & $=10$ \\
\hline Year 1757 & 136,860 & 05 & & 124,75 \\
\hline & & & & 108,5 \\
\hline 1759 & & & $4,5^{8} 4$ & \\
\hline 1760 & & 13, & & 42,155 \\
\hline 1761 & & & & 37,702 \\
\hline 1762 & 89,919 & 12 & & 80,377 \\
\hline 1763 & 109,762 & 12, & & 97,359 \\
\hline Average, & 69 & 14,894 & 654 & 10,129 \\
\hline 1764 & & & & 07 \\
\hline 1765 & & & & 71,04 \\
\hline 1766 & & & & 68,34 \\
\hline 1767 & & & & 133,16 \\
\hline 1768 & & 42,470 & 173 & \\
\hline 1769 & & 99 , & 80,564 & \\
\hline 1770 & & & & $7,85^{1}$ \\
\hline Average, & 101,604 & 36,299 & 11,533 & 76,83 \\
\hline 1771 & & & & 261,57 \\
\hline 1772 & & & & $53.5^{2}$ \\
\hline 1773 & & & 493 & \\
\hline 1774 & & & & \\
\hline 1775 & & & $-36,523$ & \\
\hline 1776 & & & 71,509 & \\
\hline & & & & 17 \\
\hline & & & & \\
\hline
\end{tabular}

I.ofs per annum in the middle feven years, $\quad \ldots \quad 76,8,8$ Gain ditto,

Neat lofs per annum,

Lofs per annum in the laft feven years, - $\quad 45,144$ Gain ditto, 26,746

Neat lofs per annum,

It is a reduction of the lofs of $65,000 \mathrm{l}$. down to 18,0001 .

Having thus difcovered the advantage of the meafure, let ns in the next place examine, at what expenfe this benefit has been obtained. The following table thews the payments of the bounty to each county; the totals; the ftones of corn, and the cwts. of four brought. 


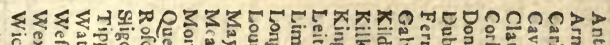

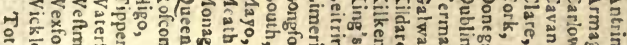

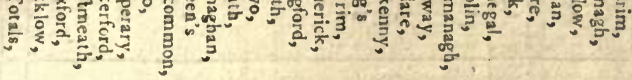
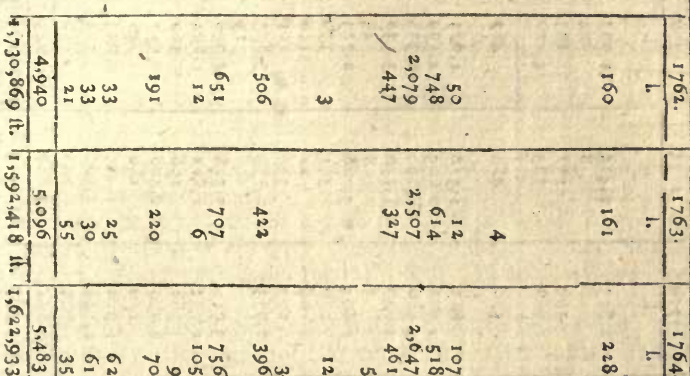

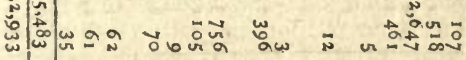

F)

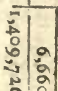

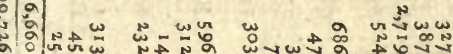

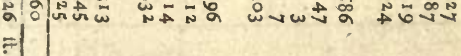

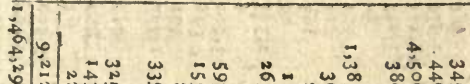

b N NEN

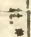

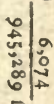

(19.20.

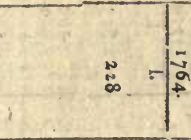




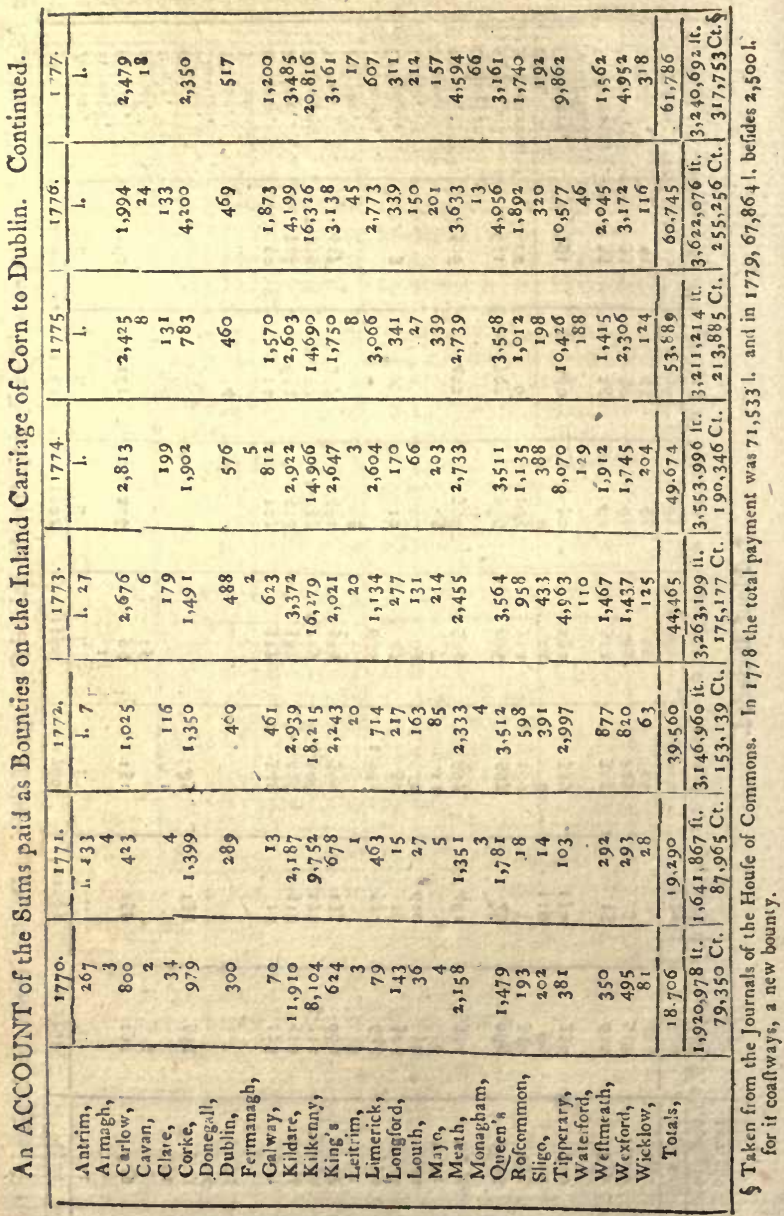




\begin{tabular}{rrrr} 
& I N A N D B O U N T Y. & 125 \\
Total pay- & 1. & Total pay- & 1. \\
ment in $1764-5,483$ & ment in $1771-19,290$ \\
$1765-6,660$ & $1772-39,560$ \\
$1766-9,212$ & $1773-44,465$ \\
$1767-6,074$ & $1774-49,674$ \\
$1768-13,675$ & $1775-53,889$ \\
$1769-25,225$ & $1776-60,745$ \\
$1770-18,706$ & $177-61,786$ \\
\hline
\end{tabular}

Paid in feven years, 85,038 Paid in feven years, 329,413

Which is, per ann. 12,i $4^{8}$ Which is, per ann. 47,059

If therefore the account was to be clofed here, it appears that forty-feven thoufand pounds per annum, have been given of the public money for a gain in the export and import account of corn of twenty thoufand pounds a year. Surely this is paying very dear for it! - but the account does not end here.

From this table the reader finds, that the bounty has been continually rifing, until it has exceeded fixty thoufand pounds a year. It alfo appears, that the encreafe of tillage has been chiefly in the counties of Kilkenny, Tipperary, Carlow, Meath, Kildare, King's, Wexford, Queen's, and Limerick, as will appear by contrafting the firft and the lalt years of thofe counties.

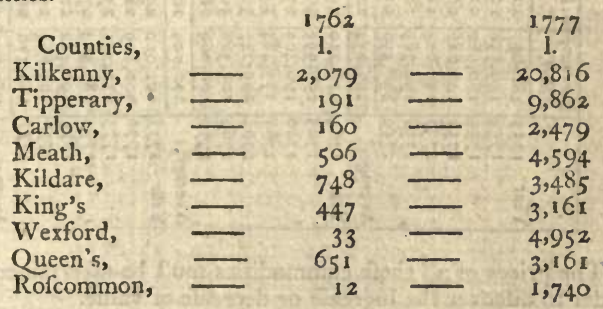

And Limerick arofe from nothing at all to 27731 . in the year 1776 ; from hence one fact clearly appears, that the increafe of tillage has by no means been in the poor counties, by breaking up uncultivated lands; on the contrary, it has been entirely in the richeft counties in the kingdom, which confirms the intelligence I received on the journey, that it was good fheep land that had principally been tilled. The bounty to Tipperary, Carlow, and Rofcommon, once the greateft fheep counties in Ireland, was infignificant at the beginning of the meafure, but has at laft become very grcat. This circumftance, fo cfiential in the fubject, renders it abfo- 
lutely neceffary to enlarge our enquiry, that we may examine, as well as our materials will permit, whether any national lofs, as well as profit, has refulted from converting fo much rich pafture land into tillage ; and in order to do this, it will be neceffary to lay before the reader the exports of the produce of pafturage from Ireland, during thefe two periods of feven years each, which ferve us for a comparifon.

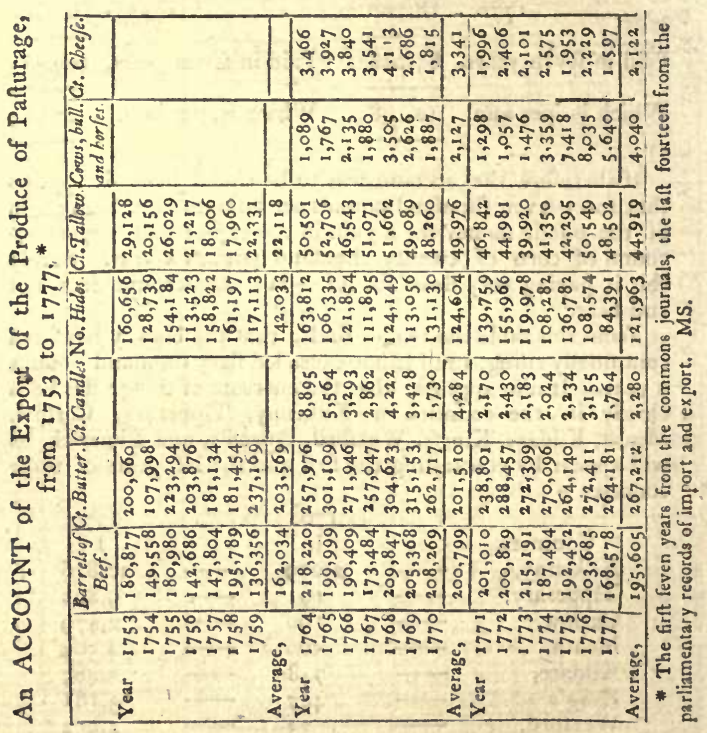

The prices of all thefe commodities muft be afcertained, in order to difcover the increafe or decreafe of value.

The cuftom-houfe price of beef is $11.6 \mathrm{~s} .8 \mathrm{~d}$. per barrel; but $I$ find that the average price at Waterford, from 1764 to 1776 , was 16 s. per cwt. or 11.12 s. the barrel. The cuftomhoufe rate of butter is 2l. per cwt. but by the fame authority, I find the real price on the average of the laft fourteen years to be 21. 5s. 6d. Candles at the cuftom-houfe 11. 15s. per cwt. the real price 2l. ros. Tallow at the cuftom-houfe 21. the true price 21.4 s. 6 d. 
Average Price of four and a half hundred Beef per Hundred Weight.

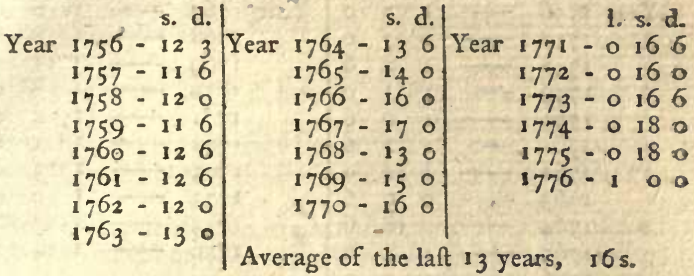

Shipping Prices of Butter, Tallow, Candles, and Pork, in Waterford, from the Year 1764 to 1777 , both inclufive t.

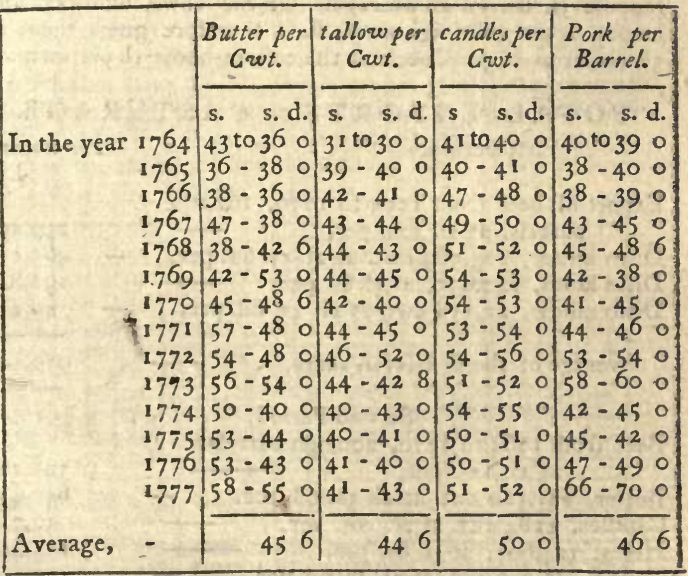

Thofe are the prices as they appeared at the beginning and at the end of the year.

\section{Prices}

+ MS. Communicated by Cornelius Bolton, ESq; menuber for that sity. 
Prices of $\mathrm{Ox}$ hides of $112 \mathrm{lb}$. from the Year 1756 to 1776 , both inclufive.

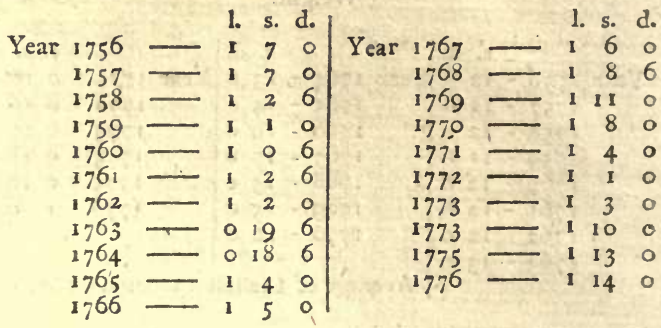

The real price of hides I was difappointed in at Corke, muft therefore take that of the cuftom-houfe, which is $11.13 .4 \mathrm{~d}$. tanned, and 11. 5s. untanned; as more of the latter, I fhall fuppofe $11.8 \mathrm{~s}$. on an average. Of the cows, bullocks, and horfes, I am quite ignorant, fhall therefore guefs them at 5l. on an average. Cheefe at the cuftom-houfe 11 . per cwt.

\section{TOTAL EXPORTS OF PASTURAGE.}

\section{Firlt Period.}

Per annum.

1.

259,254

463,119

198,845

49,211

Average of the firft feven rears,

970,429

Second Period.

Beef from 1764 to $1770,200,799$ barrels,

at 11. 12s. per,

Butter, 281,510 cwt. at 21 . 5s. 6 d. per.

321,277

Candles, 4284 cwt. at 21 . 10 s. per,

Hides, 124,604 , at $11.8 \mathrm{~s}$. per,

Tallow, 49,976 cwt. at 21. 4 s. $6 \mathrm{~d}$. per,

Live ftock, 2,1 $2 \%$, at 51 . per,

Cheefe, 3,341 cwt. at 11. per,

640,434

10,710

174,445

111,196

10,635

3,341

Average export of the fecond feren years,

$1,272,038$

Third Period.

Beef from 1771 to $1777,195,605$ barrels, at

Butter, 26, 11,212 civt. at 21.5. 6d. per, 
Candles, 2,280 cwt. at 21. 10s. per, Hides, 121,963 , at $11.8 \mathrm{~s}$. per, Tallow, 44,919 cwt. at 21.4 s. 6d. per, Live ftock, 4,040 , at 5 l. per, Cheefe, 2,12z ewt. at 11 . per,

Average export of the lant feven years, -

Second period greater than the firft by

Second period greater than the lalt by

$1,2,8,902$

$$
\begin{array}{r}
301,609 \\
-\quad 53,136
\end{array}
$$

The fecond period being greater than the firf by near three hundred thoufand pounds, and Ireland having bcen throughout all three periods on the advance in profperity, it follows, that the increafe fhould have continued, had not fome other reafon interfered, and occafioned, inftead of a fimilar increafe of three hundred thoufand pounds, a fallin off of above fifty thoufand. I cannot fupofe that the increafe of tillage did all this; I fhould fuppofe that impolfible. Moft of thele commodities are certainly confumed at home, which perlaps may account for there being no increafe; but the increafe of tillage mult inevitably have had its fhare, and it is afigning a very moderate one to $i t$, to fuppofe the amount no more than this. decreafe of fifty thoufand pounds a year. We come next to Theep, and the exports which depend on them. The follow-

\begin{tabular}{|c|c|c|c|c|c|c|c|c|}
\hline & $\begin{array}{l}W \text { col, } \\
\text { ftones. }\end{array}$ & $\begin{array}{l}\text { Value } \\
\text { at } 14 \text { s. }\end{array}$ & $\begin{array}{l}\text { Wolien } \\
\text { Yarn. }\end{array}$ & $\begin{array}{l}\text { value at } \\
17 \text { s } 6 d .\end{array}$ & $\begin{array}{l}\text { Worjed } \\
\text { yarn. }\end{array}$ & $\begin{array}{c}\text { Value at } \\
40 \mathrm{~s}\end{array}$ & $\begin{array}{l}\text { Tolal } \\
\text { fones. }\end{array}$ & $\begin{array}{l}\text { Iotal } \\
\text { value. }\end{array}$ \\
\hline & . & 1. & ftones. & 1.? & fiones.: & 1. & 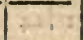 & 1. \\
\hline Yeari 764 & 10,128 & 7,089 & $9,99 \mathrm{I}$ & 8,742 & 139,412 & $27^{8}, 8 \div 4$ & 159.531 & 1294,655 \\
\hline $\begin{array}{l}1765 \\
1766\end{array}$ & 17.316 & 512,121 & 13,450 & $\begin{array}{r}1 \mathrm{1}, 768 \\
6,08\end{array}$ & 149,915 & $\begin{array}{l}299,830 \\
304,244\end{array}$ & 180,681 & 1323,719 \\
\hline 1767 & 48,733 & 34,113 & 7,553 & 6,603 & $151,94^{\circ}$ & $303,88 \mathrm{c}$ & 208,226 & 544.596 \\
\hline 1768 & 28,521 & 19,964 & 11,387 & 9.963 & 157,721 & 315,442 & 197,629 & 345,369 \\
\hline 1769 & 3,840 & 2,688 & 5,012 & 4,385 & 131,364 & 262,728 & $138,2,16$ & $6 \quad 269,801$ \\
\hline 1770 & 2,578 & 1,804 & 3,833 & 3,353 & 117,753 & 235,506 & $5|124,164|$ & 240,663 \\
\hline Average, & 18,976 & 13,283 & $8,45^{8}$ & 7,399 & $14^{2}, 889$ & 285 & 038 & 306,462 \\
\hline Year 1771 & 218 & 152 & 4,468 & 3,909 & 378 & 278,756 & 064 & 7282,817 \\
\hline 1772 & 2,045 & 1,431 & 5,947 & 5,203 & 115,904 & 808 & 123,896 & $2.38,44^{2}$ \\
\hline 1773 & 1,839 & 1,287 & & & 94,098 & 188,196 & 95,937 & 189,483 \\
\hline 1774 & 1,007 & $7 \circ 4$ & & & & 127,840 & 64,927 & 128.544 \\
\hline 1775 & 2,007 & 1,404 & & & 78,896 & 157.792 & $80,9 \circ 3$ & 159,196 \\
\hline 1776 & 1,059 & 741 & & & $86,5^{27}$ & 173,054 & 87,586 & 173.795 \\
\hline 1777 & 1,734 & $1,2,13$ & & & 114.703 & 229,406 & 116,437 & 230,619 \\
\hline verage. & 1.415 & 990 & 1,459 & 1,301 & & & & 1200,413 \\
\hline
\end{tabular}
ng table fhews the whole at one view:

Vor. II.

5 The quantities taken from the Parliament Records of Import and Export, MS. and the value added. 
In the laft century the quantity of wool, \&c. was much larger, indeed it was fo great, as will appear from the following table, as to form a confiderable proportion of the kingdom's exports.

\begin{tabular}{r|r|r||r|r|r} 
& $\begin{array}{c}\text { Wool. } \\
\text { ftones. }\end{array}$ & $\begin{array}{r}\text { Yarn. } \\
\text { ftones. }\end{array}$ & & $\begin{array}{c}\text { Wool. } \\
\text { tones. }\end{array}$ & $\begin{array}{r}\text { Yarn. } \\
\text { ftones. }\end{array}$ \\
Year 1687 & 256,592 & 3,668 & Year 1703 & 360,862 & 36,873 \\
\hline 1697 & 217,678 & 13,480 & 1711 & 310,136 & 55,273 \\
1700 & 336,292 & 26,617 & 1712 & 263,946 & 60,108 \\
1701 & 302,812 & 23,390 & 1713 & 171,871 & 68,548 \\
1702 & 315,473 & 43,148 & 1711 & 147,153 & 58,147
\end{tabular}

Relative to the prices I have charged, the following table is the authority.

Market Prices of Wool in the Fleece, per Stone of fixteen pounds; and of Bay Yarn, per Pack, containing fourteen great Stones, of eighteen pounds each.

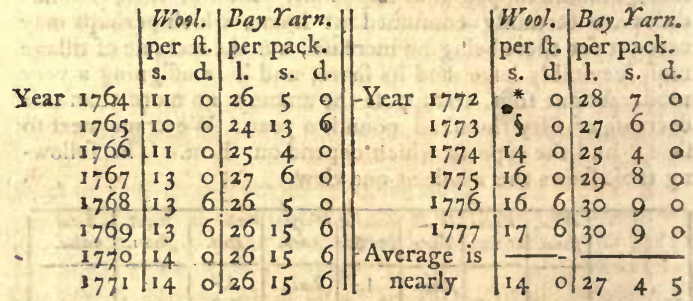

Wool is here rated at the market price for combing wool rough in the fleece; but na eftimate can be formed from this upon what has been exported, the fmall quantities whereof have been for the molt part wool upon fkins or coarfe fells, which muft have come much lower than the prices herein mentioned.

Woollen yarn for export has not been an article for fale in Ireland, what has been fent out was directly from the manufacturer, I prefume in very fmall quantities, and from the port of Corke only.

Worfted, or bay yarn, is fent principally to Norwich and Manchefter, it fells by the $\mathrm{kain}$ in Ireland, but in the preced-

Unfettled, but very ligh. - The pack of bay yarn is taken to contain 2100 Jkains.

$\$$ Communicated by Mr. Fofoua Pine, in the yarn trade. Tle euffom-houfe price of woot is 15 s. woollen yarn 17s. asd rworfects yarn 11. 13 s. 4 d. 
ing table it is rated by the pack; the colt at market is only noticed, the neceffary charges on fhipping amount to full two per cent. exclufive of commiffion which is two per cent. more.

Wool, woollen, and bay yarn, are exported by the great ftone, containing eighteen pounds weight. A licence for exporting mutt be procured from the lord lieutenant, the coft of which is nearly fourpence halfpenny per ftone $\oint$. From compariing the prices at different periods, exported woollen yarn may pretty fafely be rated at feventen fhillings and fixpence per ftone, of which five fhillings a ftone is labour.

Exported value in the firf period,

Ditto in the laft,

\section{Decreafe,}

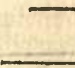

106,049

Whoever recurs to the minutes of the journcy, in the counties of Carlow, Tipperary, and Rofcommon, the great theepwalks of Ireland, will have no reafon to be furprized at this lofs of one hundred thoufand pounds a year. There are yet other fubjects fo connected with the prefent enquiry, that in order to have a clear and diftinet idea of it, we muft include in the account. I think it fair to give tillage credit for any increafe there may be in pork, bacon, lard, hogs, and bread; it is true they do not entirely belang to it, for dairies yield much; but to obviate objection's, I will fuppofe them totally connected with tillage. The following table includes all thefe articles. 
132, EXPORTSOF PORK.

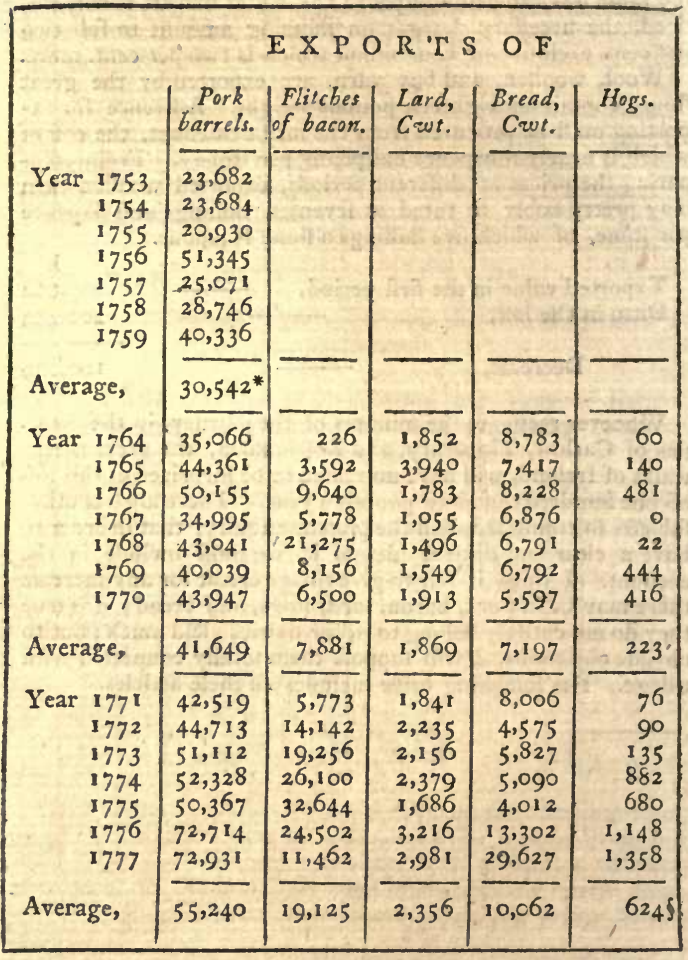

Export of pork per annum, from $176_{4}$ to 1770 ,

41,649 barrels, at $21.6 s .6$ d. per barrel t, 96,833

Bacon, $788 \mathrm{cwt}$. at I $5 \mathrm{~s}$. per cwt.

Lard, I 869 cwt. at i 1 . per. cwt.

Bread, $7197 \mathrm{cwt}$. at 1os. per cwt. $\|$

Ilogs, 223, at $15 s$. a piece $\ddagger$,

Average export of feven years,

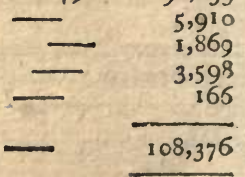

Export

* Fournals of the Houfe of Conmons. \& Parliament Record of Export and Import, IMS. + Waterford price. II Caftem: Houfe price. I Suppofed at that rate for want of authority. 
Export of pork per annum, from 1771 to 1777 ,

55,240 barrels, at 2l. 6 s. 6 d. per barrel, -

Bacon, 19,125 at 15 s.

1.

Lard, 2356 cwt. at il. per cwt.

Bread, 10,062 cwt. at 1os. per cwt.

Irogs, 624 , at $15 \mathrm{~s}$. a piece

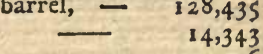

14,343

2,356

5,031

${ }_{4} 68$

Average exports of the laft feven years, - $\quad 150,631$

Increafe in the laft feven years,

$4^{2,255}$

The data are now very completely before the reader, from which the merit of this extraordinary meafure may be eftinated. I will not affert that any cuftom-houfe accounts are abfolutely authentic; I know the common objections to them, and that there is a foundation for thofe objections; but the point of confequence in the prefent enquiry does not depend on their abfolute, but comparative accuracy; that is to fay, if the errors objected to them exift, they will be found as great in one period as in another, confequently their authority is perfectly competent for the comparifon of different ones. Whoever will examine the entries with a minute attention, and compare them with a variety of other circumftances, will generally be able to diftinguifh the fufpicious articles. In the prefent enquiry I will venture to affert that they fpeak truth, for they correfpond exactly (as I thall by and by fhew) with many other caufes which could hardly have failed without a miracle of producing the effects they difplay. I hould further add, that or the greatelt number of the articles inferted in the preceding tables, there are duties paid on the export which exempt them from the common objection to the entries. But to reafon againt the accuracy of fuch accounts is perfectly ufelefs, while minifters in defence of their meafures, and patriots in oppofition to them found their arguments on them alone. Whoever attends either the Englifh or Irif houfe of commons will prefently fee this in a multiplicity of inftances. All who come to the bar of thofe houfes depend on thefe accounts; committees of parliament rely on them, and the beft political writers of every period, from Child and Davenant to Campbell and Whitworth, have agreed in the fame conduct, knowing the errors to which they are liable; but knowing alfo that there is no better authority, and that they are perfectly competent to comparifons.

Having thus clofed my authorities, I thall now draw them into one view, by fating the account of the inland carriage bounty, Debtor and Crcditor. 


\section{Bounty on the INLAND Carriage of Corn.}

Dr.

To payments of public money on the average of the laft 7 years,

To decreafe in the export of beef, butter, \&c.

To decreafe in the export of wool and yarn,

I.

By decreafe in the import of corn, \&c. - 16,907

By increafe in the export of corn, - 3,570 By increafe in the export of pork, hogs, bread, \&c. 42,255 62,734 Balance againft the bounty, $-\frac{143,510}{206,244}$

Thus far I have laid before the reader a connected chain of fuch facts as the records of the meafure, and the parliamentary accounts would permit : it appears as clearly as the tertimony of figures can fpeak, that it has had very ill effects upon the general national account. Had the effect we have feen taken place of itfelf without any artificial means to affift it, the friends of the public would perhaps have been well employed to remedy the evil : how abfurd therefore muft it appear to find that it has been brought about with the utmolt care and affiduity, and at an expence of near fifty thoufand pounds a year of the public money!

It is the intention and effect of this bounty, to turn every local advantage and natural fupply topfy turvy. We have had for feveral years in England, an importation of foreign corn more than proportioned (the kingdoms compared) to any thing the Irifh knew.t If any one to remedy this, propofed a bounty on bringing corn by land from Devonthire and Northumberland, $f o$ as to give it a preference in the London market to that of Kent and Effex, with what contempt would the propofer and propofition be treated! the corn counties of Louth and Kildare in the vicinity of Dublin are not to fupply that market, but it is to eat its bread from Corke and Wexford!

It muft alfo be brought by land carriage! the abfurdity and folly with which fuch an idea is pregnant in a country bleffed with fuch ports, and fuch a vaft extent of coaft, are fo glaring, that it is amazing that fophittry could blind the legiflature to fuch a degree as to permit a fecond thought of

+. In 1774 we imported to the value of $1,023,000 l$; and in $\$ 775$ to that of $1,265,562$. 
it. Why not carry the corn in fhips, as well as tear up all the roads leading to Dablin by cars? Why not increafe your failors inftead of horfes? Are they not as profitable an animal? If you muft have an inland bounty, why not to the ncareft port from which it could be carried with the molt eafe, and at the leatt cxpence to Dublin? This would have anfwered the fame end. The pretence for the meafure was the great import of foreign corn at Dublin; this is granting that there was a great demand at Dublin; and can any one fuppofe that if the corn was forced to Corke or Wexford, it would not find the way to fuch a demand as eafily as from the eaft of England, which is the only part of that kingdom which abounds with corn for exportation? But the very pretence was a falfhood, for with what regard to truth could it be afferted, that Dublin was fed with Englifh corn before this meafure took effect, when it appears by the preceding accounts, that the import of the whole kingdom from 1757 to 1763 was only 84,0001 . a year, and from 1764 to 1770 tho more than 101,604l.? This import account does not diftinguifh like the export one, the ports at which the foreign corn was reccived; if it did, I hould in all probability find but a moderate part of this total belonging to Dublin, as it is very well known that in the north there is always a confiderable import of oatmeal. Granting however the evil, ftill the plan of remedying it by a land carriage of 130 miles was abfird to the latt degree. But fuppofe fo confiderable a city as Dublin did import foreign corn to a large amount, is it wife to think this fo great a national evil, that all the principles of common policy are to be wounded in order to remedy it? Where is the country to be found that is free from confiderable importations even of the product of land? Has not Ireland a prodigious export of her foil's produce in the effects of pafturage, for which her climate is fingularly adapted? And while the lias that, of what little account is a trifing import of corn to feed her capital city? We have feen the undoubted lols that has accrued to the nation from a violent endeavour to counteract this import, yet the meafure has only leffened it to an inconfiderable degree.

I was at a mill on Corke harbour above 120 miles from Dublin, and faw cars loading for that market on the bounty, with a hip laying at the mill quay bound for Dublin, and waiting for a loading; could invention fuggeft any fcheme more prepolterous than thus to confoupd at the public expence all the ideas of common practice, and common fenfe! By means of this meafure I lave been affured it has happened, that the flour of Slaine mills has found its way to Carlow, and that of Laughlin Bridge to Drogheda : that is to fay, Mr. Jebb eats his bread of Captain Mercer's flour, and the latter makes his pudding with $\mathrm{Mr}$. Jebb's afliftance; they live 
1oo miles afunder, and the public pays the piper while the flour dalses the hay in this manner.

The raft difference between the expence of land and water carriage fhould cver induce the legiflature, thougl failors were not in queftion, to encourage the latter rather than the former. From Corke there is paid bounty 5 s. $6 \frac{x}{2} \mathrm{~d}$. yet the freight at 10s. aton is only $6 \mathrm{~d}$. The bounty from Laughlin Bridge is 2 s. $3 \frac{1}{2}$ d. yet Captain Mercer pays in fummer but Is. 4 d. and in winter no more than 1s. $6 \mathrm{~d}$. Mr. Moore at Marlefield receives 4 s. bcunty, but his carriage colt him only 2s. 6 d. in fummer, and 3 s. in winter; hence therefore we find that the bounty more than pays the expence, and that the profit is in proportion to the difance, i. e. the abfurdity.

In the year ending Scptember 1777, there were 34,598 barrels of malt brouglit from Wexford to Dublin by land, re-

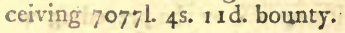

34,598 barrels are $51,897 \mathrm{Cwt}$. which at 6

Cwt. per horfe, would take for one day, 8,649 horfes. From Wexford to Dublin and back takes feven

days, or

One man to two horfes,

The horfes at $16 \mathrm{~d}$. a day,

Men at 9 d. a day,

Seven days men and horfes,

The freight of which to Dublin at 8 s. a ton

ti Thould be,

Saving by Sea, $\ddagger$
60,546 horfes. 30,273 men.

1. s. d. $4,3 c 6 \quad 8 \quad 0$ 1,13549

$5,17112 \quad 9$

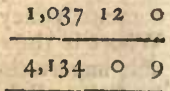

It is therefore a logs of about 80 per cent. purcbajed by the bounty.

In proportion as failors are leffened horfes are increafed. Suppofe common coafting veffels navigated at the rate of one man to twenty tons, it requires fixty-fix horfes to draw that burthen, and thirty three men : fo that for every failor loft, there are above threefcore of this worft of all ftock kept; which is of itfelf an enormous pational lofs. If the number of horfes kept at actual work by this bounty, with the mares, colts, \&c. to fupply them, were known, it might probably be found fo large as to leffen a little of the veneration with which this meafure is confidered in Ireland.

I find that in the feffions of 1769 and 1771 , there was a bounty paid on the carriage of corn coaftways to Dublin. It amounted

† MS. communicated by Ricbard Nevill, ESg; member for Wexford. 
amounted in the firft to $32781 .+$, and in the latter to 49731 . $\$$, the act lafted only thofe four years. It was an experiment which furely ought to have been continued; for if corn is to be forced to Dublin, this molt certainly is the only rational way of doing it.

By the following table the amount of this coafting trade will be feen, with and without that bounty.

Corn and Flour brought coaftways to Dublin from $175^{8}$ to $1777^{\circ}$

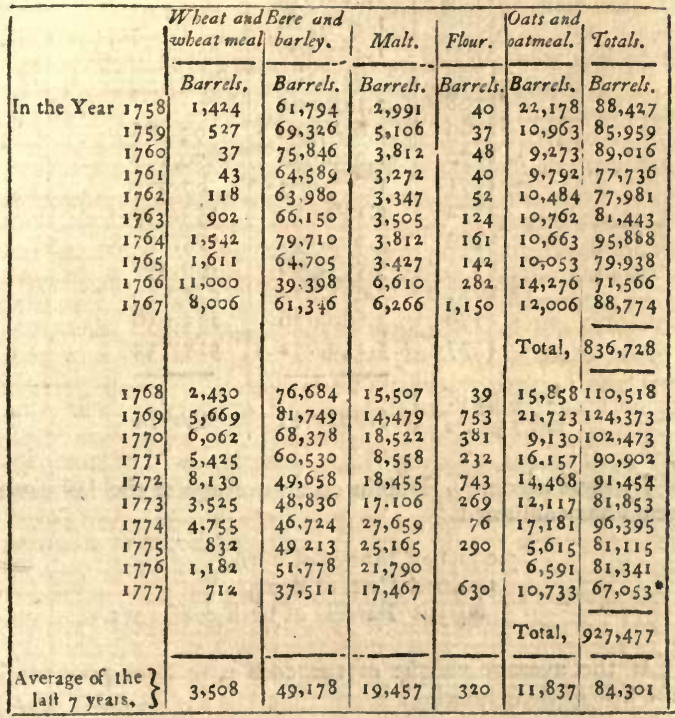

+ Fune 1, 1768. $7^{\text {th }}$ George III. chap. 24. $4 d$. per Cwt. corn of Irifb growth by water coaftways to Dublin, foutbward between Wicklow and the $T_{u}$ car ; north, betveen Drogbeda or Carrickfergus.

5 d. per Cwt. if Soutbward of Iufcar, or nortb of Carrick. fergus.

4d. per Cwt. Soutbward of Cooley point, to Newry, Belfaft, or Londonderry. Continued to $24 t$, Fune, 1771.

f MS. account of public premiums, communicated by the Right Lion. Fobn Forfter, member for the county of Louth.

* MIS. comnunicatsd by Rich. Nevill, Efq; member for IVexford. 
With the affifance of thefe particulars, united with the quantities on which the inland bounty is paid, given at page 127 and 128 , we fhall be able to fee the principal part of the confumption of the city of Dublin.

Brought by Land-carriage Bounty.

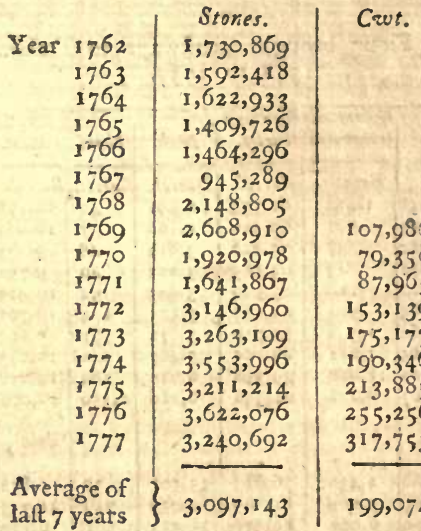

By thefe accounts, Dublin on an average of the latt feven years has confumed

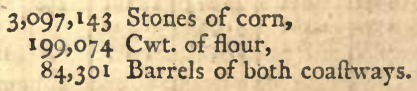

If the average weight of the corn is I 4 ftone per barrel, the firft of thefe articles

Will make in barrels,

The 199,074 Cwt. of flour may be called in barrels of wheat,

Add the above batrels coaftways,

221,224

180,000

$$
\text { Total, }-\underline{485,525}
$$

To this fhould be added the import of foreign corn, which is known to be confiderably more than the export, and it will appear that if there are 150,000 inhabitants in Dublin, they. muft confume above three barrels each of all forts of corrt in 
a year, which confidering that the mafs of the people live very much upon potatoes, is a great allowance, and fuggefts the idea either that the people are more numerous, or that more money is paid in bounties than there ought to be by the acts, which is probable.

I come now to confider one of the principal arguments ufed in favour of this meafure. It is the increafe of tillage being fo beneficial to the kingdom. Taken as a general pofition, there may or may not be truth in the affertion: I am apt to think rather more Atrefs is laid on it than there ought to be, and fome reafons for that opinion may be feen in Political Aritbmetic, p. $36_{3}$, \&cc. But not to enter into the general queftion at prefent, I have to obferve two circumftances upon the ftate of Ireland; firt the moiture of the climate, and fecondly the fort of tillage introduced.

That the climate is far moifter than that of England I have already given various reafons to conclude; but the amazing tendency of the foil to grafs would prove it if any proof was wanting. Let general Cunningham and Mr. Silver Oliver recollect the inftances they fhewed me of turnep land, and ftubble left without plonghing, and yielding the fucceeding fummer a full crop of hay. Thefe are fuch facts as we have not an idea of in England. Nature therefore points out in the clcaref manner, the application of the foil in Ireland moft fuitable to the climate. But this moiftere which is fo advantagcous to grafs, is pernicious to corn. The fineft. corn in Europe and the world is uniformly found in the drict countries; it is the weight of wheat which points out its goodnefs; which leffens per meafure gradually from Barbary to Poland. The wheat of Ireland has no weight compared with that of dry countries; and I have on another occalion obferved, that there is not a fample of a good colour in the whole kingdom. The crops are full of grafs and weeds, even in the beft management, and the harvefts are fo wet and tedious as greatly to damage the produce; but at the fame time, and for the fame reafon cattle of all forts look well, never failing of a full bite of excellent grafs : the very drieft fimmers do not affect the verdure as in England.

I do not make thefe obfervations, in order to conclude that tillage will not do in Ireland. I know it may be made to do; but I would leave the vibrations from corn to paturage, and from pafturage to corn, to the cultivators of the land to guide themfclves as prices and other circumftances direet, but by no means force an extended tillarire at the expence of bounties.

But what is the tillage gained by this meafure? It is that fyftem which formed the agriculture of England two hundred year's ago, and forms it yet in the wort of our common fields, but which all our cxertions of enclofing and improving are bent to extirpate. 1. Fallow. 2. Wheat; and then fpring corn until the foil is exhaufted: or elfe, 1. Fallow. 2. Wheat. 
3. Spring corn; and then fallow again. In this courfe the fpring corn goes to horfes, \&c. the fallow is a dead lofs, and the whole national gain the crop of wheat; one year in three yields nothing, and one a trifle, whereas the grafs yiclds a full crop every year. Let it not be imagined, that watte and defart tracts, that wanted cultivation, are only turned to this tillage. Nine tenths of the change is in the rich fheep walks of Rofrommon, Tipperary, Carlow, and Kilkenny. I have already proved this fact; the queftion therefore is reaced to this: Ought you to turn fome of the fineft paftures in the world, and which in Ireland yielded twenty fhillings an acre, into the moft execrable tillage that is to be found on the face of the globe? The comparifon is not between good grafs and good tillage; it is gosd grafs againft bad tillage. The tables I inferted prove, that Ireland has loft fifty-three thoufand pounds a year for feven years in the produce of cows and bullocks, and one hundred and fir thoufand pounds in that of theep; this is a prodigious lofs, but it is not the whole; there is the lofs of labour on above fifty thoufand ftones of woollen yarn annually, which is a great drawback from the fuperior population fuppofed, perhaps falfely, to flow from tillage. When thefe circumftances are therefore well confidered, the nation will not, I apprehend, be thought to have gained by having converted her rich theep walks, which yielded fo amply in wool, and in the labour which is annexed to wool, into fo execrable a tillage as is univerfally introduced.

Another circumftance of this meafure is, that of facrificing all the ports of the kingdom to Dublin; the natural trade, which ought to take a varicty of different little channels, proportioned to vicinity, was by this fyftem violently drawn away to the capital; a very ill fituated capital, the increafe of which, at the expence of the out ports, was by no means a national advantage.

A queftion naturally arifes from the premifes before us; frould the bounty be repealed? Abfurd as it is, I am free to declare, I think not at once. Upon the credit of the meafure great fums have been laid out in raifing mills, moft in fituations which render them dependant on this forced trade for work. Great lofs would accrue in this to individuals, and the public faith rather injured. The following tables will for that this is not a light confideration. 
The principal mills of Ireland, from June 1773 to June 1774 .

Cwt.

\begin{tabular}{|c|c|c|c|c|}
\hline efield, & - & Step & & \\
\hline Slane, & & D. Jebb, Efq; and Co & 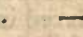 & \\
\hline Anner, & & Mr. J. Grub, & & \\
\hline Rathnally, & & J. Nicholfon, Efq; & & \\
\hline $\begin{array}{l}\text { Lodgc, } \\
\text { Kilkarn, }\end{array}$ & & Richard Mercer;Efq; & & \\
\hline $\begin{array}{l}\text { Kilkarn, } \\
\text { Carrick, }\end{array}$ & & $\begin{array}{l}\text { Wade and Williams, } \\
\text { D. Tighie, Efq; }\end{array}$ & & 6,9 \\
\hline Archer's Grove, & 7 & Mr. W. Ratican, & & 5.5 \\
\hline $\begin{array}{l}\text { Lock, } \\
\text { Ballykilc }\end{array}$ & & $\begin{array}{l}\text { Mr. H. Bready, } \\
\text { Doyle and Hofkins, }\end{array}$ & - & 3 \\
\hline & & H. O Brien, Efq; & & \\
\hline & & & & \\
\hline
\end{tabular}

The mof diftant mill from Dublin is that of Barnahely. Corke, one hundred and thirty miles. A prodigious number of men and horfes would be thrown at once out of cmploy * ment, which would have bad effects; and a fudden diverfion of that fupply, which has now flowed to Dublin for fo many years, would certainly have very ill confequences. The policy therefore to be embraced is this; lower the prefent bounty to the fimple expence of the carriage, and no more; and cointeract it by railing the bounty on the carriage of corn coaftwife, until it rivalled and gradually put down the land carriage. Perhaps it might be neceffary to accompany this meafure with a land carriage bounty from the mill to the neareft exporting port, the Dublin bounty would therefore ftand in order to prevent the evil of a fudden change, but when the other bounties had got fo far into effect, as to leffen the old one confiderably, then it flould be totally diccontinued; and it would then certainly be proper for the other bounties (having performed their office) to be difcontinued alfo. The prefent fyftem is fo undoubtedly abfurd, that the rival bounties fhould be raifed higher and higher until they had turned the commerce into the natural channel; an expreffion I am fenfible implies an apparent abfurdity, for a natural chiannel of conmerce docs not want fuch bountics, but a bad proceeding has made it fo exceedingly crooked, that a mere repeal, leaving the trade to itfelf, molt certainly would not do. You mult undo by art the mifchief which art has done; and the commercial capital in Ireland is too fmall to bear any violence.

United with the conduct I have rentured to recommend, in cafe the tillage fyitem was perfifted in, it would be very. well worth the attention of parliament, to annex fuch conditipns to the payment of any new bounties, as might have the effect of fecuring a good tillage inftead of a bad one. If it 
was found practicable, which I fhould think it might be, no public money thould ever be given for barley, bere, or oats, that did not fucceed turneps; nor for wheat, or rye, that did not follow beans, clover, or potatoes; by this means the nation would have the fatisfaction of knowing, that if the plough was introduced in valuable pafture land, it would at leaft be in a good fyftem.

Before I conclude this fubject, it may be proper to obferve a circumftance, which however ill it may be received in England, has, and ought to have this weight in Ireland. The revenue of that kingdom is under fome difadvantages which England is free from; the hereditary revenue is claimed in property by the crown; a great penfion lift is charged on it, and much of the amount paid out of the kingdom; there is no free trade to compenfate this; a large part of the military eftablifhment is taken out of the kingdom, and of late years the nation has run very much in debt 6 in fuch a fituation of affairs, it is thought wife and prudent to fecure the payment of fuch a fum as fifty or fixty thoufand pounds a year towards the internal improvement of the kingdom. Nobody can deny there being much good fenfe in this reafoning; but the argument is applicable to a well founded meafure, as ftrongiy as it is to an abfurd one; and I hould farther obferve, that if this or any bounty is the means of running the nation fo much in debt that new taxes are neceffarily the confequence, this idea is then vifionary; the people do not fecure an advantage but a burthen. I cannot here avoid $x$ comparifon of expending fo large a fum annually of the public money rationally, or in a meafure at beft fo very doubtful; for indulge the prejudices of gentlemen, and fuppofe for a moment, that all the proofs 1 have given do not amount to an abfolute condemnation, they certainly, even then, give it the moft dubious complexion that ever meafure had. But fuppofe from the beginning, the money which has been thus advanced, had been given in premiums of ten pounds per acre on all land abfolutely wafte, which was brought in and reclaimed. That fum I thewed on another occafion, will build excellent dwellings, fence, plant, drain, pare and burn lime, plough, fow, and complete an acre; the premium would therefore pay the whole, and leave to the proprietor no other bufinefs than to take the trouble of feeing the conditions of the premium complied with. The following table will thew what the effects of fuch a premium would have becn, calculating the annual produce at four pounds an acre, which is much under what it ought to be. The firf column thews the fums paid as bounty, the next the number of acres that fum would have improved at ten pounds per acre, and the third the produce at four pounds per acre, waiting three years at firft to give time for operations. Sums. 


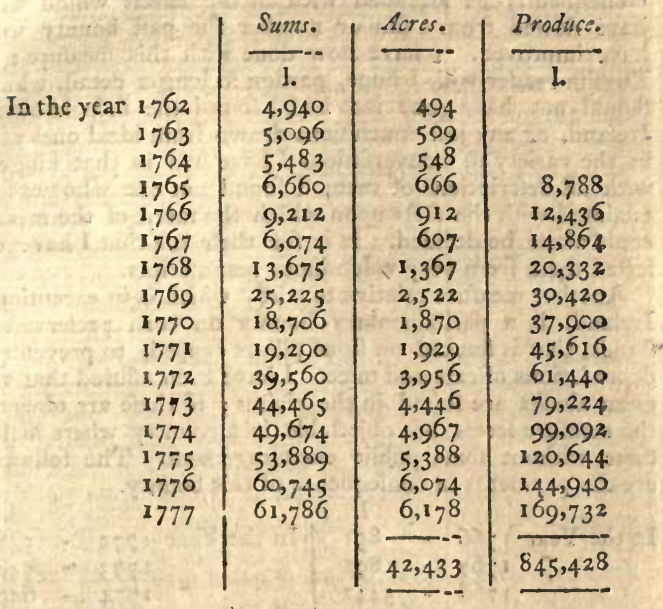

From hence we find, that at the end of the year $\mathbf{1 7 7 7}$, there would have been 42,433 acres improved in the complete and mafterly manner ten pounds an acre effects, the annual produce of which would be at four pounds an acre, 169,732l. all abfolute and undoubted profit to the kingdom: there would have been received in this manner no lefs than 845,000 . If the lands were thrown as they ought to be into the courfe of - 1. turneps; 2. barley; 3 . clover; 4. wheat; and reckoning the barley at ten barrels, and the wheat at fix, there would now be a produce every year of 63,649 barrels of wheat, and 186,082 of barley; and this from only half the land; the other half in turneps and clover would undoubtedly keep ten fhecp the year through, and - yield fifty pounds of wool, or in the whole 106,080 fheep and 33,150 ftones of wool, with all the employment and population which would refult from fuch excellent tillage, building, fencing, manuring, and fpinning. How different this effect from having in the laft feven ycars loft above a million fterling by the inland carriage; in that period the bounty has juft trebled; if it goes on fo it will be onc hundred and eigh-. ty thoufand pounds a year in feven years more, and by that time there will be neither fheep nor cows left in the king: dom; but fuppofe it to ftand at fixty thoufand pounds a year, that fum in feven years, applicd in a bounty on cultivating waftes, would improve forty-two thoufand acres, and confequently. 
confequently be attended with all the effects which would have flowed from a fimilar number the paft bounty would have improved. I have now done with this meafure; my Englifh reader will, I hope, pardon fo long a detail, which I thould not have gone into had I found the facts known in Ireland, or any juft conclufions drawn from ideal ones; but in the variety of converfations I have had in that kingdom with all defcriptions of men, I found not one who was acquainted with the facts upon which the merit of the meafure could alone be decided. It is for their ufe that I have collected them from very voluminous manufcripts.

Another meafure relative to corn, which is in execution in Ireland, is a parliamentary bounty on corn preferved on ftands, that is ftacked on ftone pillars capped, to prevent the depredations of rats and mice. I have been affured that very great abufes are found in the claims; if thefe are obviated, the meafure feems not objectable in a country where little is done without fome public encouragement. The following are the payments in confequence of this bounty.

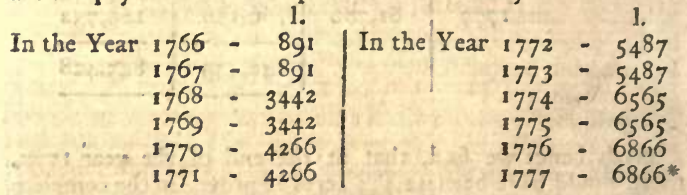

It would be a proper condition to annex to this bounty, that it be given only to corn preferved as required, and threfhed on boarded floors; the famples of Irifh wheat are exceedingly damaged by clay floors; an Englifh miller knows the moment he takes a fample in his hand if it came off a clay floor, and it is a deduction in the value. The floors fhould be of deal plank two inches thick, and laid on joifts two or three feet from the ground, for a frec current of air to preferve them from rotting.

\section{SE CTION XIX.}

\section{Manufaçures.}

THE only manufacture of confiderable importance in Ire1 land is that of linen, which the Irith have for near a century confidered as the great ftaple of the kingdom. The hiftory of it in its earlier periods is very little known; a committee of the houfe of commons, of which Sir Lucius O'Brien.

$$
\text { was }
$$

* The reafon of the fums being tive fame for two years through-. out, is their being retwened every fecend year to parliamert. 
was chairman, examized the national records wich great atteation, in order to difcover how loag they had been in it; all they difcovered was that by all aft pafted in 1542 , the $33 \mathrm{~d}$. of Henry 8. linen and woollen yarn were enumerated among the molt confiderable branches of trade poffetfed by the natives of Ireland in an act made againit grey merchants foreftalling. The ith of Queen Elizabeth the fame aet was revired, and a further law made againft watering hemp or flax, \&ce. in rivers. By the 13 th of Elizabeth all perfons were prohibited from exporting wool, flar, linen and woollen yarn, except merchants refiding in cities and boroughs; and by a further ast the fame year, a penalty of $12 \mathrm{~d}$. a pound was impofed on all flar or linen yarn exported, and $8 \mathrm{~d}$. more for the ufe of the town exported from. In this laft act it is recited, that the merchants of Ireland had been exporters of thofe articles in trade apwards of one hundred years preceding that period: and by many fublequent acts, and ptoclamations during the reigns of Charles I. and II. thofe manufactures were particularly atterided to; from wherce it evidently appeared that the kingdom poffeffed an export trade in thefe conomodicies at thoie early periods. The Earl of Strafford, Lord I.ieutenant in Charles I. reign, palfed feveral laws and took various meafures to encourage this manufacture, infomuch that he has by fome authors been faid to have eftablifhed it originally. At the end of the laft centory, in King William's reign, it arofe to be an object of confequence, but not fingly fo, for it appears from a variety of records in both king doms, that the lrif had then a confiderable woollen manufacture for exportation, which raifed the jealoufy of the Englifh manpfacturers in that commodity fo much, that they prefented fo many pecitions to both lords and commons, as to induce thofe bodies to enter fully into their jealoufies and illiteral views; which oecafioned the famous eompact between the two nations, brought on in the following manner.

$$
\text { Dis Fovis } 9^{\circ} \text {. Funii. } 1699 .
$$

The Earl of Stamford reported from the lords committees. (appointed to draw au addrefs to be prefented to his Majefty, relating to the woollen manufacture in Ireland) the following addrets, viz.

"W E the lords fpiritual and temporal in parliament affembled, Do hambly reprefent unto your Majefty, that the growing manufacture of cloth in Iroland, both by the cheapnefs of all forts of neceflaries fot life, and goodnefs of matezials for making of all manner of cloth, doth invite your fub. jeets of England, with their familics and fervants, to leavo their habitations to fettle there, to the increafe of the soollen 
manufacture in Ireland, which makes your loyal fubjects in this kingdom very apprehenfive that the further growth of it may greatly prejudice the faid manufacture here; by which the trade of this nation and the value of lands will very much decreafe, and the numbers of your people be much leffened here; wherefore wé do moft humbly befeech your moft facred majefty, that your majefty would be pleafed, in the moft public and effectual way that may be, to declare to all your fubjects of Ireland, that the growth and increafe of the woollen manufacture there hath long, and will ever be looked upor with great jealoufy, by all your fubjects of this kingdom : and if not timely remedied, may occafion very ftrict laws totally to prohibit and fupprefs the fame, and on the other hand, if they turn their induftry and fkill to the fettling and improving the linen manufacture, for which generally the lands of that kingdom are very proper, they fhall receive all countenance, favour, and protection from your royal influence, for the encouragement and promoting of the faid linen manufacture, to all the advantage and profit that kingdom can be capable of."

To which the houfe agreed.

It is ordered by the lords fpiritual and temporal in parliament affembled, That the lords with white ftaves do humbly attend his majefty with the addrefs of this houfe, concerning the woollen manufacture in Ireland.

$$
\text { Die Veneris } 10^{\circ} \text { Junij } 168^{\circ} \text {. }
$$

The Lord Steward reported his Majefty's anfwer to the addrefs, to this effect, viz.

" THAT his Majefty will take care to do what their lordthips have defited.

\section{A.SHLEY COWPER.}

Cler. Parliamentor."

\section{Fovis 30 Die Junii 1698.}

" Moft Gracious Sovereign,

" WWE your majelty's molt dutiful and loyal fubjects, the commons in parliament affembled, being very fenfible that the wealth and power of this kingdom do, in a great meafure, depend on the preferving the woollen manufacture as much as poffible entire to this realm, think it becomes us, like our anceftors, to be jealous of the eftablithment and increafe thereof elfewhere; and to ufe our utmolt endearours to prevent it. 
"And therefore we cannot without trouble obferve, that Ireland is dependant on, and protected by England in the enjoyment of all they have; and which is fo proper for the linen manufacture, the eftablifhment and growth of which there would be fo enriching to themfelves, and fo profitable to England ; thould, of late, apply itfelf to the woollen manufacture, to the great prejudice of the trade of this kingdom; and fo unwillingly promote the linen trade, which would benefit both them and us.

“The confequence whereof will neceffitate your parliament of England to interpofe to prevent the mifchief that threaten ${ }^{s}$ us, unlefs your majefty, by your authority and great wifdom, fhall find means to fecure the trade of England, by making your fubjects of Ireland to purfue the joint intereft of both kingdoms.

"And we do moft humbly implore your majefty's protection and favour in this matter; and that you will make it your royal care, and enjoin all thofe you employ in Ireland to make it their care, and ufe their utmolt diligence, to hinder the exportation of wool from Ireland, except to be imported hither, and for the difcouraging the woollen manufactures, and encouraging the linen manufactures in Ireland, to which we fhall always be ready to give our utmoft affiftance."

Refolved, That the faid addrefs be prefented to his majefty by the whole houfe.

\section{Sabbati. 2. die fulii.}

\section{H IS M A ESTY'S ANSWER.}

\section{"Gentlemen,}

"I thall do all that in me lies to difcourage the woollen manufacture in Ireland, and to encourage the linen manufacture there; and to promote the trade of England."

\section{Thurdday 27 th September, 1698.}

Part of the Lords Juftices Speech.

"AMONGST thefe bills there is one for the encouragement of the linen and hempen manufactures: at our firft meeting we recommended to you that matter, and we have now endeavoured to render that bill practicable and ufeful for that effect, and as fuch we now recommend it to you. The fettlement of this manufacture will contribute much to people the country, and will be found much more advanta- 
148 COMPACT WITH ENGIAND.

geous to this kingdom than the woollen manufacture, which being the fettled ftaple trade of England, from whence all foreign markets are fupplied, can never be encouraged here for that purpole; whereas the linen and hempen manufactures will not only be encouraged, as confiftent with the trade of England, but will render the trade of this kingdom both ufeful and neceffars to England."

The Commons of Ir e LAND returned the following Anfwer to the fpeech from the throne.

" WE pray leave to affure your excellencies, that we fhall heartily endeavour to eftablifh a lisen and hempen manufacture here, and to render the fame tufeful to England, as well as advantageoús to this kingdom, and that we hope to find fuch a temperament in refpect to the woollen trade here, that the fame may not be injurious to England."

And they paffed a law that feffion, commencing the 25 th of March, 1699 , leaving 45. additional duty on every 20 s. value of broad-cloth exported out of Ireland, and 25 . on every 20s. value of ferges, baize, kerfeys, fuffs, or any other fort of new drapery made of wool or mixed with wool, (frizes only excepted) which was in effect a prohibition. And in the fame feflion a law was paffed in England, reftraining Ireland from exporting thofe woollen manufactures, including frize, to any other parts except to England and Wales.

The addrelles of the two houfes to the king carry the cleareft evidence of their fource, the jealoufy of merchants and manufacturers; I might add their ignorance too, they are dictated upon the narrow idea that the profperity of the woollen fabrics of Ireland was inconfiftent with the welfare of thofe of England; it would at prefent be fortunate for both kingdoms if thefe errors had been confined to the laft century. There is an equal mixture alfo of fadhood in the reprefentations ; for they affert that the cheapnefs of neceffaries in Ireland drew from England the. woollen manufacturers, but they forgot the cheapnefs of labour in Ireland, to which no workman in the world ever yet emigrated. 'The Irilh were engaged in various flight fabrics not made in England; but had they been employed on broad cloth for exportation, the Englifh manufacture would well have bore it; they did at that time and afterwards bear a rapid encreafe of the French fabrics, and yet flourifhed themfelves. We have had fo long an experience of markets increafing with induftry and inventions, that the time ought to have come long ago for viewing competitors without the eye of jealoufy.

The memoirs of the time, as well as the expreflion in the above tranfaction, evidently prove, that it was underftood by both kingdoms to be a fort of compact, that if Ireland gave 
up her woollen manufacture, that of linen fhould be left $t^{\circ}$ her under every encouragement. I have however myfelf lieard it in the Brition parliament denied to have been any compaet; but fimply a promife of encouragement, not precluding a like or greater encouragement to the Britioh linens. This is certainly an error, for fo underfood, what is the meaning of the ample encouragenents promifed by the Britilh parliament? They could not mean internal encouragement or regulation, for they had nothing to do with either: it could fimply mean, as the purport of the words evidently fhew, that they would enter into no meafures which fhould fet up a linen manufacture to rival the Irifh. That woollens fhould be confidered and encouraged as the itaple of England, and linens as that of Ireland: it mult mean this or it meant notbing. That the Irifh underftood it fo cannot be doubted for a moment; for what did they in confequence? They were in poffeftion of a flourifhing woollen manufacture, which they actually put down and crippled by prohibiting exporta. tion. Let me afk thofe who affert there was no compact, why they did this? it was their own act. Did they cut their own throats without either reward or promife of reward? common fenfe tells us they did this under a perfect conviction, that they fhould receive ample encouragement from England in their linen tradc: but what moonhine would fuch encouragement prove if England, departing from the letter and ifirit of that compact, had encouraged her own linen manufacture to riyal the Irifh, after the lrifh had deftroyed their woollen fabrics to encourage thofe of England? Yet we did this in direct breach of the whole tranfaction, for the $23 \mathrm{~d}$ of George II. laid a tax on fail cloth made of Irith liemp. Bountics alfo have been given in England without extending fully to Irih linens. Checked, Itriped, printed, painted, ftained, or dyed linens of Irifh manufacture are not allowed to be imported into Britain. In which, and in other articles, we have done every thing poffible to extend and increafe our own linen manufacture, to rival that of Ircland.

I admit readily, that the apprehenfions of the Irifh at the progrefs of Britilh linens are in the fpirit of conmercial jealoufy, as well as our violence in relation to their woollens. But with this great difference; we forced them to put down a manufacture they were actually in poffefion of ; and we being the controuling power, do not leave them that freedom of market which we polfefs ourfelves, points which neccffarily place the two nations in this refpect upon very different footings. Give them as they ought to have, a free woollen trade, and they will then have no objection to any meafures for the encouragcment of our linens which do not abfolutely exclude theirs.

The following table will fhew the progrcfs of their linen manufacture through the prefent century. 
An ACCOUNT of the EXPORT of LINEN-CLOTH, and LINEN-YARN, from IRELAND.

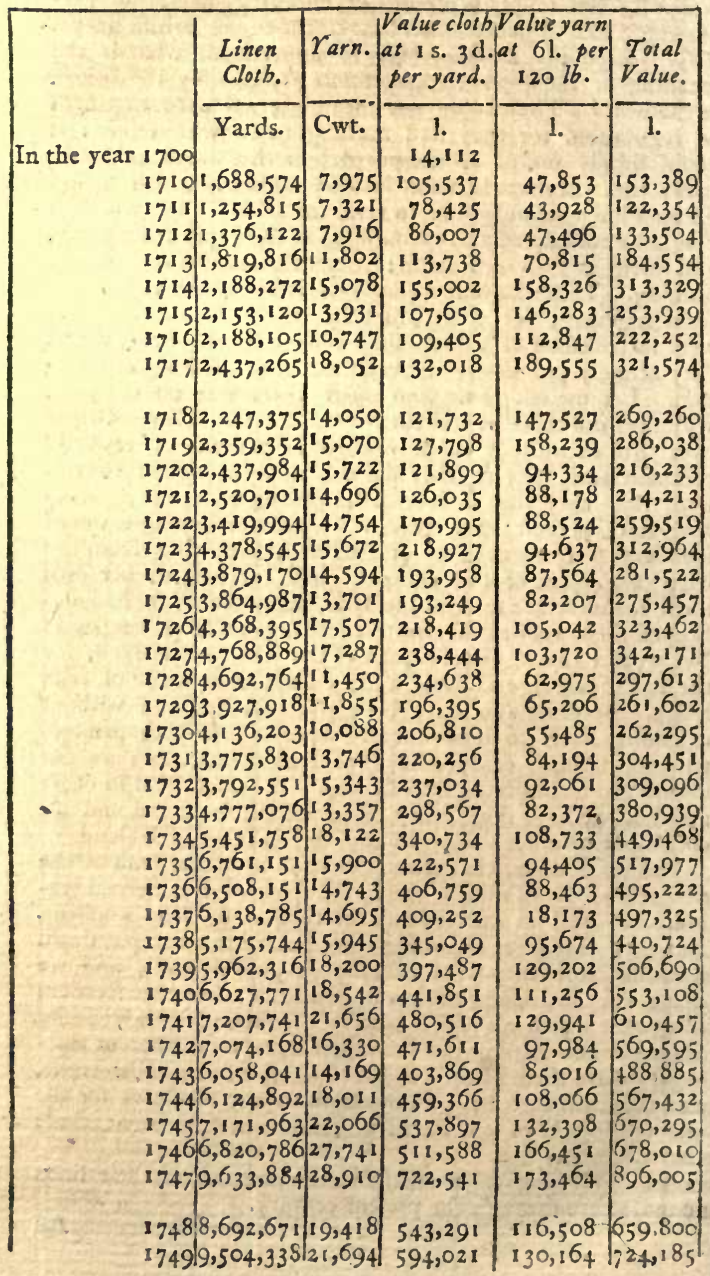


An ACCOUNT of the EXPORT of LINEN-CLOTH, and IINEN.YARN, from Ireland. Continued.

\begin{tabular}{|c|c|c|c|c|c|}
\hline & Limen Clotl:. & rarn. & $\begin{array}{l}\text { Valus Cloth } \\
\text { at is. } 3 \text { d. } \\
\text { per yard. }\end{array}$ & $\left\{\begin{array}{l}\text { Value yarn } \\
\text { at } 61 \text {. per } \\
\text { C. } 120.16 .\end{array}\right.$ & Totalvalue \\
\hline & Yards. & Crut. & 1. & 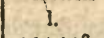 & \\
\hline a the year $175^{\circ}$ & $11,200,460$ & 22,373 & $\sigma_{53 \cdot 360}$ & 134,238 & $7^{87} 7,598$ \\
\hline 1751 & 18 & 43 & & 459 & 394,452 \\
\hline $175^{2}$ & & 3,407 & & 442 &, 042 \\
\hline 1753 & $7^{87}$ & $2.3 .23^{8}$ & 69 & &, 018 \\
\hline 1754 & 903 & 22,594 & & & 732 \\
\hline $\begin{array}{l}1755 \\
1756\end{array}$ & $\begin{array}{l}13,3 \\
11,5\end{array}$ & $\begin{array}{l}27,948 \\
26.997\end{array}$ & $\begin{array}{l}82 \\
88\end{array}$ & $\begin{array}{l}167,692 \\
161,982\end{array}$ & $\begin{array}{l}1,059,675 \\
1,046,841\end{array}$ \\
\hline Average, & $11,796,361$ & 24,328 & 745 & 145,972 & 904,479 \\
\hline ear 1757 & og & 31,078 & 13 & 18 & 387 \\
\hline $175^{8}$ & & 995 & & & 807 \\
\hline 1759 & 31 & 27,571 & & & 988 \\
\hline 1760 & & 042 & & & 951 \\
\hline 1761 & 881 & 699 & 51 & & \\
\hline 1762 & 15 & 35 & & & 014 \\
\hline 1763 & & & 40 & & \\
\hline Average, & $14.511,973$ & $33,1 \div 4$ & 967,445 & 19 & $1,166,136$ \\
\hline $\operatorname{car} 176+$ & 081 & & & & \\
\hline 1765 & 05 & & & & \\
\hline 1766 & 2 & & & & \\
\hline 1767 & & 74 & & & \\
\hline 1768 & & 90 & & & 294 \\
\hline 1769 & & 37 & & & 525 \\
\hline 1770 & $20,560,754$ & 33,417 & 16 & 0,502 & \\
\hline Average, & $17,776,862$ & 32,311 & $1,184,171$ & 193 & $1,379,512$ \\
\hline ear $177 i$ & 08 & 66 & & & \\
\hline $177^{2}$ & & 32 & & & \\
\hline 1773 & & 28,076 & & & \\
\hline 1774 & 6,674 & 29,194 & & & $64 i$ \\
\hline 1775 & $\log , 087$ & & & & 573 \\
\hline 1776 & 2,587 & 36,152 & & & 750 \\
\hline i777 & 19, & 29 & & & 1,4 \\
\hline Average, & $20,252,2,39$ & $3^{1,475}$ & $1,390,919$ & $188,8 \mathrm{ro}$ & $1,6\{5,654$ \\
\hline & \multicolumn{4}{|c|}{$\begin{array}{l}\text { Average of } 30 \text { years fince } 1748 \\
\text { Average of } 30 \text { years before, }\end{array}$} & 1,22 \\
\hline
\end{tabular}

Mr. Henry Archdall, in the year 1771 , afferted before a committee of the houfe of commons, that Ireland manufactrued for 
Exportation,

And for home confumption,

The latter article muft be a mere guefs; the firft we find contradicted in the preceding table, unlefs he meant cloth only.

This ample table calls for feveral obfervations. It firft appears that the manufacture has gone on in a regular increafe, until it has arrived in the laft feven years to be an objeet of prodigious confequence. The averages of each period of feven years are of particular importance; as there is one political leffon to be deduced from them which may be of great ufe hereafter: they prove in the clearelt manner that no judgment is ever to be formed of the ftate of the manufacture from one or two years, but on the contrary from feven year's alone. In 1774 it appears that the export was lower than it had been for nine years before, and we very well recollect the noife which this fall made in England. I was repeatedly in the gallery of the Englifh houfe of commons when they fat in a committee for months together upon the Itate of the linen trade, and from the evidence I heard at the bar I thought Ireland twas finking to nothing, and that all her fabrics were tumbling to pieces: the affertion of the linen fabrics declining a third was repeated violently, and it was very true. But they drew this conuparifon from 1771 , when we find from the preceding table that it was at its zenith, to appearance a very unnatural one, for it rofe at once five millions of yards which was unparalleled. It was ridiculous to draw a fudden ftart into precedent, for what manufacture in the world but experiences moments of uncommon profperity, the continuance of which is never to be expected; this fall of a third therefore though true in fact was utterly falfe in argument. In truth the fall was exceedingly trivial, for the only comparifon that ought to have been made was with the average of the preceding feven years, the decline then would have appeared only feven or eight hundred thoufind yards, that is, not a twentieth intead of a third. But becaufe the trade had ruin to a molt extraordinary height in 1771 , the manufacturess and merchants felt the fall the more, and were outrageoufty clamorous becaufe every year was not a jubilee one. It fuch were to be the confequences of an unufual demand, minifters and leginatures would have reafon to curfe any extraordinary profperity, and to prevent it if they could, under the conviction that the grafping avarice of commercial folly, would be growling and dunning them with complaints when the trade returned to its ufnal and natural courfe. In the year ${ }^{1773}$ and 4 , all' Ireland was undone; the linen manufasture

* Fournals of tie commons, vol. 16. page 368 . 
was to be at an end; but lo! at the end of the period of feven years upon examining the average it is found to be in as great a ftate of increafe as ever known before; for the four periods have all the fame rife one above another of thrce millions of yards each: confequently I fay, upon the evidence of the cleareft facts that there has been no declenfion but an INCREASE. And I thall draw this manifelt conclufion from it to difbelieve commercial complaints as long as 1 exilt, and put no credit in that fort of proof which is carried to parliament in fupport of fuch complaints. Fallhood and impofition I am confident find their way to the bar of a houfe, and I do not think it much for the credit of thofe who fupported the Irith complaints at the period above mentioned, that I fhould find in copying at Dublin part of this table from the parliamentary record of imports and exports, the export of the year 1775 erafed; the only confiderable crafure there is in thofe volumes, the total of particulars makes $19,447,250$ yards, but it now ftands written over that erafure $20,205,087$. It is eafily accounted for; if the trade had been known to have experienced fo immediate a revival, half their arguments a $_{4}$ ould have had no weight, it might therefore be convenient to fink the truth. If it was merely accidental in the clerk I can only fay it was at a molt unfortunate time and fubjes?*.

The following table will hew that England is the market for eighteen twentieths of the total Irifh exportation.

QUANTITIES of IRISH LINENS imported into ENGLAND from Chriftmas 1756, to Chritmas 1773.

$$
\text { rards. }
$$

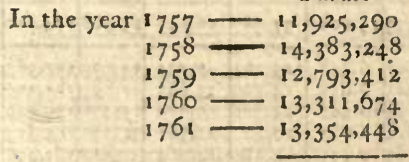

$65,766,072$ or per Annum $\mathbf{r}_{\mathfrak{j}, 153,614}$.

Tards.

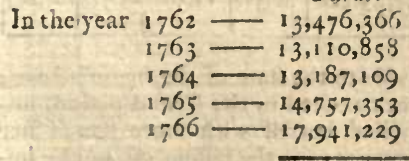

$72,472,915$ or per annum $14,494,583$.

- In the wollen manafacture of England tbe fame spirit of complaint and falfhosd bas at different times peffered both parliament and the public. See this point difcufed in my Political Arithmetic, page 152. + Subftance of Mr. Glover's evidence before the boufe of commons 1774 , page 60 . 
rards.

In the year $176_{7} \longrightarrow 16,500,755$

$1768-15,249,248$

$1769-16,496,271$

$1770-18,195,087$

$3771-20,622,217$

$87,063,578$ or per annum $17,612,715$.

In the year 1772

1773
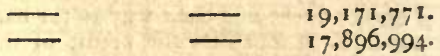

The following table will fhew the importation of the raw material for this fabric.

IMPORT of FLAX, HEMP, and FLA X$S E E D$, into I RELA N D.

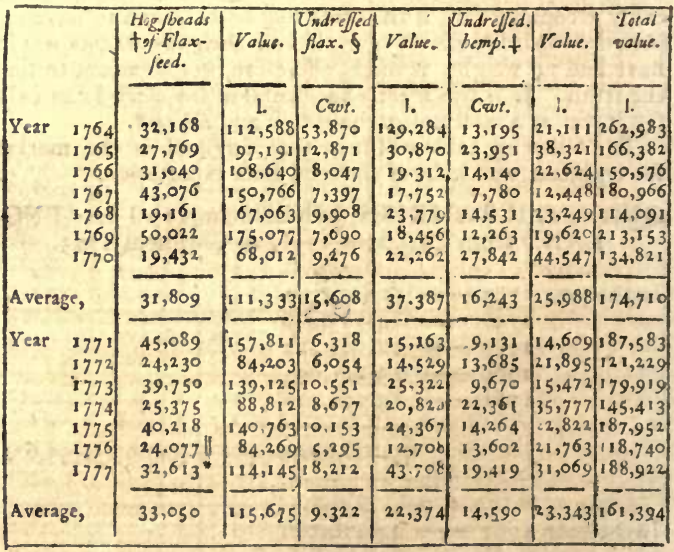

This account is favourable to the ftate of the manufacture; for the increafed import of flax-feed in the fecond period, implies that the country fupplied herfelf with more flax of her own producing, which accounts for the falling off in the import of undreffed fias: the perfons who have ftudied the manufacture,

+ At 3 l. 10s. a bogfhead from 2 s. $106 l$. \& At $48 \mathrm{~s}$. from $45 l .1052 l$. perton. +At 325 . from $24 l .1040 l$ per ton, average $32 l$. If From tbe plantations of this $12,44 \mathrm{l}$. - Ditto, 4,512 . 
nufacture in all its branches with the moft attention, agree there is no greater improvement to be wifhed for, than the raifing the flax inftead of importing foreign. It is mucls to be lamented, that the flax-hufbandry has not made a greater progrefs in the kingdon; for the profit of it is very great. The minutes of the tour furnith the following particulars:

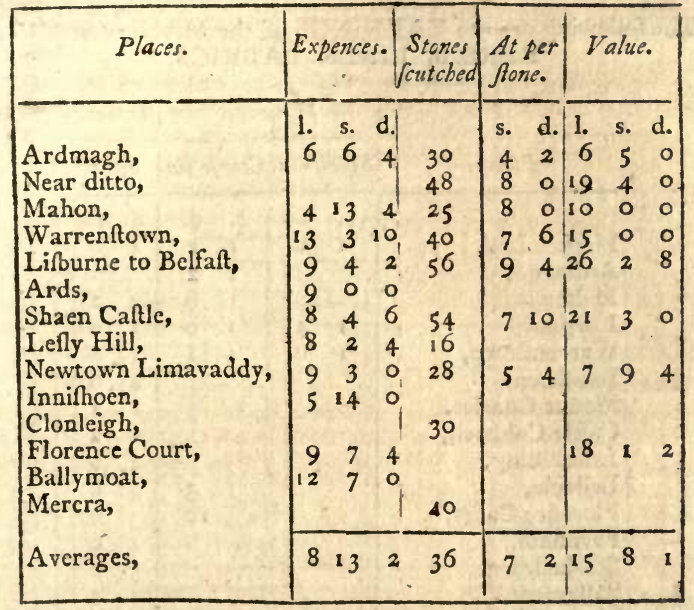

From hence we find, that the profit is near feven pounds an acre, clear, after paying large expences, and that on the Cunningham acre.

There is a notion common in the north of Ireland, which I fhould fuppofe muft be very prejudicial to the quality as well as the quantity of flax produced; it is, that rich land will not do for it, and that the foil thould be pretty much exhaufted by repeated crops of oats, in order to reduce it to a proper ftate for flax. The confequence of this is, as I every where faw full crops of weeds, and of poor half-ftarved fiax: the idea is abfurd; there is no land in the north of Ireland that I faw too rich for it. A very rich foil fown thin produces a branching harlh flax, but if very clear of weeds, and fown thick for the ftems to draw each other up, the crop will be in goodnefs, and quantity proportioned to the richnefs of the land. A poor exhaufted foil cannot produce a fiax of a ftrong good ftaple; it is the nourihment it receives from the fertility of the land which fills the plant with oil, and bleachers very well know that the oil is the frength of the ftaple, and unfortunately it is, that bleathing cannot be performed without an 
exhalation of this oil, and confequent weaknefs. But though it is neceffary for colour ta exhale a portion of the oil, flas that never had but little from the poverty of the foil it grew in, is of little worth, and will not bear the operation of bleaching like the other. Potatoes kept very clean under the plough are an excellent preparation for flax; and turaeps, well hoed, the fame.

The following are the EARNINGS of the MANUFACTL" RERS in LINEN FABRICS.

\begin{tabular}{|c|c|c|c|c|c|}
\hline \multirow{2}{*}{ Places. } & \multicolumn{3}{|c|}{ Weavers. } & \multicolumn{2}{|c|}{ Womes. } \\
\hline & Finelinen. & Courfe & E lin. & & pin. \\
\hline & s. d. & & & & $f$. \\
\hline Market Hiil, & & & & & \\
\hline Ardmagh, & & & & & \\
\hline Mahon, & & 1 & 0 & & \\
\hline Lurgan, & 14 & 1 & 0 & & \\
\hline Warrenftown, & & & & & 0 \\
\hline $\begin{array}{l}\text { Innifhoen, } \\
\text { Mount Charles, }\end{array}$ & 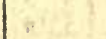 & & & & $\begin{array}{l}0 \\
2\end{array}$ \\
\hline Caftle Caldwell, & & & & & 2 \\
\hline Innilkilling, & & & & & \\
\hline Belleifle, & & $\mathbf{I}$ & 3 & & \\
\hline Florence Court, & & & 10 & & 0 \\
\hline Farnham, & & & & & 0 \\
\hline Strokeftown, & & & & & \\
\hline $\begin{array}{l}\text { Ballymoat, } \\
\text { Mercra, }\end{array}$ & & & & & $\begin{array}{l}2 \\
2\end{array}$ \\
\hline Sortland, & & & 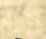 & 3 & 0 \\
\hline Weftport, & & & & & 0 \\
\hline Annfgrove, & & & & & \\
\hline Arèragcs, & 15 & 1 & $0 \frac{1}{2}$ & & 1 \\
\hline
\end{tabular}

Thefe earnings are from double to near treble thoie of hufbandry labour throughout the kingdom, and yet complaints of poverty are infinitely more common among thefe people than in thofe parts of the kingdom that have no fhare of the manufacture. It is fo in all countries; and ought to prevent too afliduous an attention to fuch complaints. Thofe who for the fake of great earnings will become weavers, muft do it under the knowledge that they embrace or continue in a life not of the fame regular tenour with the loweft fpecies of labourers. If they will not be more prudent and faving, they ought not to clamour and expect the public to turn things topfy turvy to foed them, who, with any degree of attention, 
might have fupported themfelves much better than another clals that never complains at all.

Having thus endeavoured to fliew the rife, progrefs, and prefent amount of this manufacture, it will be neceffary to lay before the reader fome account of the fums of public money which have, according to the fafhion of. Ireland, been expended in its encouraigement. 'This is not fo eafy to do fully and accurately as I could wifh, but the following papers are the beft authorities I could find,

An account of the nett produce of thed uties appropriated to the ufe of the hempen and linen manufactures from their commencement, and alfo the bounties from parliament.

\begin{tabular}{|c|c|c|c|c|c|c|c|}
\hline & & Velt duties. & Buntics. & & & Netrdaties. & Dounties. \\
\hline & & 1. & t. & & & 1. & 1. \\
\hline in she yea & 1721 & & 2,500 & In the year & 1758 & $9,77^{2}$ & \\
\hline & 1723 & & 5,500 & & 1759 & 8,933 & 8,000 \\
\hline$=$ & 1725 & & 4,000 & & 1700 & 6,581 & \\
\hline & 1727 & & 4,000 & & 1761 & 11,841 & 8,000 \\
\hline 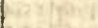 & 1729 & 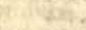 & 4,000 & & 1762 & 14,014 & \\
\hline 47 & & & & & 1763 & 15,064 & 8,000 \\
\hline & 1731 & 5,637 & 4,000 & & 1764 & 14,998 & \\
\hline$x^{2}$ & 1733 & 6.328 & 8,000 & & 1755 & 15,820 & 8,000 \\
\hline$+a$ & 1734 & 5,314 & & & 1766 & 18,634 & \\
\hline af weth & 1735 & $6,74^{8}$ & 8,000 & & 1767 & 12.717 & 8.000 \\
\hline whitry & $173^{6}$ & $9, i_{1}$ & & & 1768 & 10,414 & \\
\hline$=0$ & 1737 & 8,676 & 8,000 & & 1769 & $+2,181$ & 8,000 \\
\hline$=1$ & 2738 & 10,623 & & & 1770 & 1,635 & \\
\hline t & 1739 & 10.087 & 8,000 & & 1771 & 861 & 8,000 \\
\hline 27 & 1740 & 7,894 & & & 1772 & 1,348 & \\
\hline & 1741 & 13,180 & 8,540 & & 1773 & 1,700 & 8,000 \\
\hline & 1742 & 12,561 & & & 1774 & 580 & \\
\hline & 1743 & $13,77^{\circ}$ & 8,000 & & 1775 & 1,387 & 8,000 \\
\hline & 1744 & 14,844 & 8,000 & Totals & & 453,204 & 184,540 \\
\hline & $\begin{array}{l}1745 \\
1746\end{array}$ & $\begin{array}{l}18,066 \\
15,0,6\end{array}$ & & Nett tea du & ties for & $453, \pi 04$ & 184,540 \\
\hline & $\begin{array}{l}1740 \\
1747\end{array}$ & 17,922 & 8,000 & 7 years, & ending & $\{72,500$ & 184,540 \\
\hline & 1748 & 12,657 & & 2775 , & & & $1+0.0$ \\
\hline & 1749 & 18,335 & 8,000 & & & & \\
\hline & 1750 & 17,813 & & & & $710,2,44$ & \\
\hline & 1751 & 12,477 & 8,000 & & & & \\
\hline & $\begin{array}{l}1752 \\
1753\end{array}$ & $\begin{array}{l}17,175 \\
12,2,31\end{array}$ & 8,000 & $\begin{array}{l}\text { Average of } \\
7 \text { years d }\end{array}$ & $\begin{array}{l}\text { ehe lalt } \\
\text { uties }\end{array}$ & \}$^{1,3^{8} 5}$ & \\
\hline & 1754 & 12,884 & & Dittoof tea & duties, & 10,357 & \\
\hline & 1755 & 14,292 & 8,000 & & & & \\
\hline & 1756 & 12,239 & * 4,000 & Together, & - & 11,742 & \\
\hline & 1757 & 1,722 & 8,000 & & & & \\
\hline
\end{tabular}

The tea duties werc granted for the ufe of this manufacture. But that this account is not conplete appears by another $\ddagger$ to the following effect.

* By King's Letter.

t Here the tea ducies were feparated, and produced in $\frac{z}{4}$ gear is L. D, 72,5001 . and 10,0001 . a year each year attrr.

I Commons journals, vol. 17. p. 253 . 
An account of the feveral fums of money for which the vicetreafurers have claimed credit, as being paid by them for the ufe of the hempen and linen manufactures, from the 25th of March 1700 , to the 25 th of March 1775 , diftinguifhing each year, returned to the hon. houfe of commons purfuant to their order, November 25, 1775.

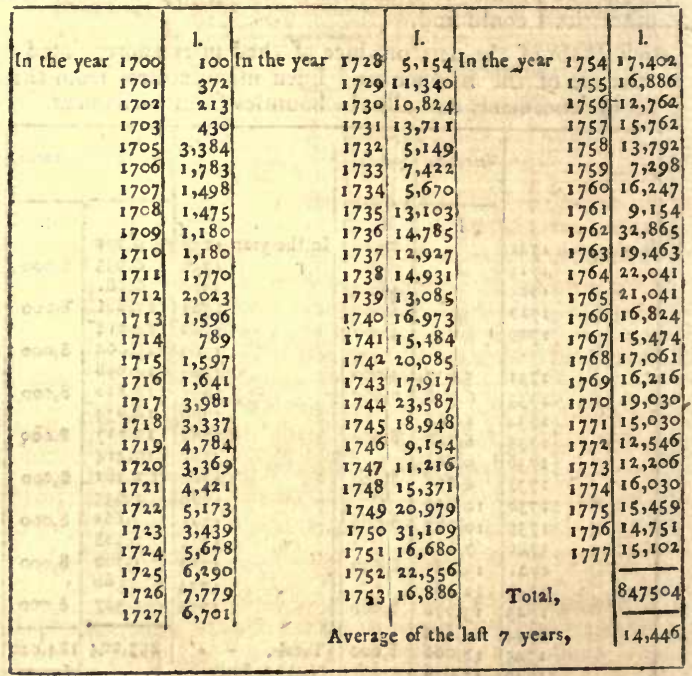

The expenditure of this money is under the direction of the linen board, upon a fimilar plan as the navigation board explained above. Their mode of applying it will be feen by the following account.

Difurfements of the Linen Truftees, from $175 \%$, to 1772 .

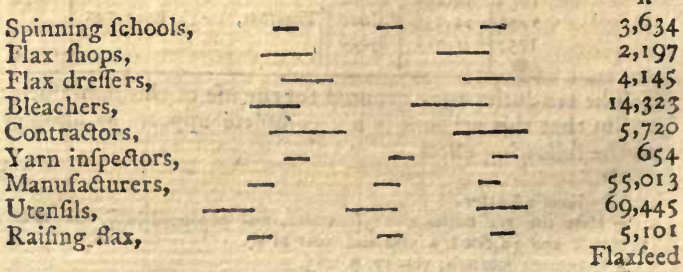


Flax-feed mixed with potatoes,

Fraudulent lapped linens,

Buildings and repairs,

Clerks, \&c. at linen office,

11,728

Ditto, linen and yarn halls,

Infpectors, itinerant men, and reed makers,

7,642

Incidental charges,

7,723

In fixteen years,

11,773

Or per annum,

225,606

Subfequent to 1698 Ireland, at an enormous expence to the public, made a progrefs in the linen manufacture, sct.

The truftees of the linen board expended near half a million of money to extend and promote the linen manufacture before the year 17501 .

But thefe accounts do not yet fhew the full amount of public money which has been granted for the ufe of this great manufacture ; to have this complete we muft take in the bounties on the import of feed, and on the export of canvas and fail cloth, which have been as follow:

\begin{tabular}{|c|c|c|c|c|c|}
\hline $\begin{array}{c}\text { rears, end- } \\
\text { ing Lady- } \\
\text { day. }\end{array}$ & $\begin{array}{l}\text { Import } \\
\text { hemp and } \\
\text { flax feed. }\end{array}$ & $\begin{array}{l}\text { Export can- } \\
\text { vas and } \\
\text { fail-cloth. }\end{array}$ & $\begin{array}{c}\text { Years, end- } \\
\text { ing Lady- } \\
\text { day. }\end{array}$ & $\begin{array}{l}\text { Import } \\
\text { bemp and } \\
\text { flaxjeed. }\end{array}$ & $\begin{array}{l}\text { Export can- } \\
\text { vas and } \\
\text { fail-cloth. }\end{array}$ \\
\hline & 1. & 1. & & 1. & 1. \\
\hline $173 \mathrm{I}$ & 1,211 & 1,446 & 1755 & 10,500 & $\int 73^{I}$ \\
\hline 1733 & 2,120 & 1,207 & 1757 & 9,873 & \\
\hline 1735 & $2,6,8$ & 1,301 & 1759 & $11,05^{8}$ & \\
\hline 1737 & 5,004 & 1,492 & 1761 & 11,273 & \\
\hline 1739 & $6,79^{2}$ & 3 , & 1763 & 9,187 & \\
\hline 1741 & 6,112 & 3 , & 1765 & 11,464 & \\
\hline 1743 & 5,911 & $I_{2}$ & 1767 & 15.894 & \\
\hline 1745 & 7,536 & 1,367 & 1769 & 16,810 & \\
\hline 747 & 4,482 & 2,283 & 1771 & 16,062 & \\
\hline 1749 & 7,939 & 3,416 & 1773 & 16,279 & \\
\hline $175^{1}$ & & & 1775 & 14,674 & \\
\hline 1753 & $11,48 i$ & 1,909 & 1777 & 14,479 & \\
\hline \multicolumn{2}{|c|}{ Totals, } & - & & 226,834 & 28,682 \\
\hline \multicolumn{4}{|c|}{ Average of the laft feven year's, } & & \\
\hline
\end{tabular}

By

* Tournal of the Houfe of Commons, vol. xv. P. 375 .

+ Report of Sir Lucius O'Brien's committee journals, vol. $x$. p. 396. I Ibid. p. 400 . \$This year this bounty ceafed. $\|$ Extraced from an account of national preniums, MS. Com. municated by the Right Hon. Fobn Forfier. 
By one of thefe accounts the annual net produce of thofe duties appropriated to this manufacture, on an average of the laft 7 years, is But by the other, the treafury charges the ma-

nufacture on the fame average with, - $\quad 14,446$ Difference,

2,704

The fact however is, that the larger of thefe fums is paid to this purpofe, and the account of the linen boards difurfe. unent amounts to 14,1001 .

The total annual fums at prefent applied appear to be thefe:

Produce of duties appropriated to the purpofe $-14,446$ Parliamentary bounty, Bounty on the import of flax feed,

Total per annum, 4,000 15,094 $33,54^{\circ}$

And that the total fums thus applied fince the year inoo have been :

Paid by the vice treafurers, Parliamentary bounty, Bounty on flas import, Ditto on export of canvas, 28,682

Total, $1,295,560$

The moft carelefs obferver cannot help remarking, the great amount of this total; and muft think that an annual grant of 33,0001 . a year in fupport of a manufacture which works to the annual amount of two millions fterling, an extraordinary meafurc. I muft be frec to own, that I cannot, upon any principles, fee the propriety of it. They cannot have done any confiderable mifchief I grant, but if they do no good there is a great evil in the mirapplication of fo much money. That a manufacture in its very cradle, if it happens to be of a fickly growth, may be benefited by bounties and premiums, is certain ; but that even in fuch a cafe it is wife to give them, I doubt, very much; for fabrics being fackly in their growth is a reafon againlt encouraging them. The truly valuable manufaetures, fuch as linen in Ireland, wool and hardware in England, and filk in France, want no help but a demand for their produce. Ireland has always hitherto had a demand for her linens, and having fo much longer than the beginning of this century been in the trade, would paturally 
increafe it in proportion to the demand; and the would have done that though no linen board nor bounties had exifted. It is contrary to all the principles of commerce to fuppofe, that fuch an increafing manufacture as this has been, would want flax or flax-feed without bounties on the import; or that manufacturers in it would not earn their bread without a prefent of 55,0001 . The only inftance in which thefe bounties would certainly have a confiderable effect is, the cafe of expenfive machines; the firt introduction of which are difficult to individuals in a poor country. But this article, in its fulleft extent, would have demanded but a fmall fum in the linen trade, for it by no means goes to common fpinning wheels, the conftruction of which is generally known. But if there is any reafon to fuppofe linen would, throughout the century have ftood upon its own legs, how much more is there for its doing fo at prefent! I will venture to affert, that there is not one yard of linen more made on account of the thirtythree thoufand pounds a year now expended. It is to fuch a great manufacture a drop of water in the ocean.-An object too contemptible to have any effects attributed to it. It is idle and vifionary to fuppofe, that a fabric which has employed a fourth part of the kingdom for 70 years, and exports to the amount of a million and a half annually, wants boards, and bounties, and premiums, and impertinence to fupport it. I have heard it faid more than once in Ireland, that a feat at the linen board might eafily be worth 3001 . a year; it is very well if the whole becomes a job, for it might juft as well as be applied to infpectors, itinerant men, builders and falaries.

1 before calculated the extent of wafte land, the bounty on the inland carriage of corn would have improved at rol. an acre, let me do the fame with the $1,300,000$ expended on linen. It would have improved 130,000 acres, which would now be yielding 520,0001 . a year, or a fourth part of the whole amount of all the linen manufacture of Ireland; fo infinitely more productive is money beftowed on the land than on the fabrics of a fatc.

I do not mean to find fault with the eftablifhment of this manufacture; it has grown to a great degree of national im. portance, but from fome unfortunate circumfances in the police of it (if I may ufe the expreffion) that importance is not nearly equal to what it ought to be, from the extent of country it abfolutely fills. It will be at leaft a curious enquiry to examine this point; from the beft information I can affert, that the linen and yarn made in Connaught, and part of Leinfter, vaftly exceed in value all the exports of Ulfter exclufive of thofe two commodities, which makes linen the whole exportable produce of that province, or $1,600,000)$. a year. Uliter contains $2,8,6,837$ plantation acres; Iuppofe that valt tract under theep, and feeding no more than two to an acre, 
their fleeces only at five fhillings each, would amount raw to $1,418,4$ 181. and fpun into bay yarn, without receiving any farther manufacture, the value would be $2,127,6221$. reckoning the labour half the value of the wool, that is to fay, the amount would be more than the whole value of the linen manufacture poth exported and confumed at home.

How exceeding different are the manufactures of England! That of the fingle city of Norwich amounts to near as much as the whole linen export of Ireland, but very far is that from being the whole exported produce of a province! It is not that of a fingle county, for Norfolk, befides feeding that city, Yarmouth and Lynn, two of the greateft ports in England, and a variety of other towns, exports I believe more corn than any other county in the kingdom; and whoever is acquainted with the fupply of the London markets, knows that there are thoufands of black cattle fattened every year on Norfolk turneps, and fent to Smithfield. What a fpectacle is this ! The agriculture in the world, the moft productive of wealth by exportation around one of the greateft manufactures in $\mathrm{Eu}$ rope. It is thus that manufactures become the beft friends to agriculture; that they animate the farmer's induftry by giving him ready markets, until he is able, not only to fupply them fully, but pufhes his exertions with fuch effect, that he finds a furplus in his hands to convert into gold in the national balance, by rendering foreigners tributary for their bread. Examine all the other fabrics in the kingdom, you fee them prodigious markets for the furrounding lands; you fee thofe lands doubling, trebling, quadrupling their rents, while the farmers of them increafe daily in wealth; thus you fee manufactures rearing up agriculture, and agriculture fupporting manufactures; you fee a reaction which gives a reciprocal animation to human indufry; great national profperity is the effeet; wealth pours in from the fabrics, which fpreading like a fertile ftream over all the furrounding lands, renders them, comparatively fpeaking, fo many gardens, the moft pleafing fpectacles of fuccefsful induftry.

Change the fcene, and view the North of Ireland; you there behold a whole province peopled by weavers; it is they who cultivate, or rather beggar the foil, as well as work the looms; agriculture is there in ruins; it is cut up by the root; extirpated; annihilated; the whole region is the difgrace of the kingdom; all the crops you fee are contemptible; are nothing but filth and weeds. No other part of Ireland can exhibit the foil in fuch a ftate of poverty and defolation. A farming traveller, who goes through that country with attention, will be flocked at feeing wretchednefs in the fhape of a few beggarly oats on a variety of molt fertile foils, which, were they in Norfolk, would foon rival the belt lands in that county. 
But the caufe of all thefe evils, which are abfolute exceptions to every thing elfe on the face of the globe, is eafily found - a molt profperons manufacture, fo contrived as to be the deftruction of agriculture, is certainly a fpectacle for which we muft go to lreland. It is owing to the fabric fpreading over all the country, inftead of being confined to tcwns. This in a certain degree is found in fome manufactures in England, but neyer to the exclufion of farmers; there, literally fpeaking, is not a farmer in a hundred miles of the linen country in Ireland. The lands are infinitely fubdivided, no weaver thinks of fupporting himfelf by his loom; he has always a piece of potatnes, a piece of oats, a patch of flax, and grafs or weeds for a cow, thus his time is divided between his farm and his loom. Ten acres are an uncommon quantity to be in one man's occupation; four, five, or fix, the com. mon extent. They fow their land with fucceffive crops of oats until it does not produce the feed again, and they leave it to become grafs as it may, in which ftate it is under weeds and rubbilh for four or five years. Such a wretched managemen is confant deftruction to the land; none of it becomes im. proved unlefs from a ftate of nature; all the reft is deftroyed, and does not produce a tenth of what it would if cultivated by farmers, who had nothing to do but mind their bufinels. As land thus managed will not yield rent, they depend for that on their web; if limen fells indifferently they pay their rents indifferently, and if it fells badly, they do not pay them at all. Rents in general, at their value, being worfe paid there than in any other part of Ireland.

Where agriculture is in fuch a ftate of ruin, the land canaot attain its true value; and in fact the linen counties, proportioned to their foil, are lower let than any others in Ireland. There has been a great rife on many eftates, and fo there has all over the kingdom, but not at all owwing to the manufacture; and I am confident, from having gone over the whole with attention, that any given trast of land in the linen country, if it could be moved to fome other part of the king. dom where there are no weavers, would let twenty per cent. higher than it does at prefent; and I am fo convinced of this, that if I had an eftate in the South of Ireland, I would as foon introduce peftilexce and famine as the linen manufacture upon it, carried on as it is at prefent in the North of that kingdom. Particular fpots may be, and are high let in the North, but I speak of the average of any large tract.

But if, inftead of the manufacture having fo diffufed itfelf as abfolutely to banif farmers, it had been confined to towns, swhich it might very eafily have been, the very contrary effest wonld have taken place, and all thofe vaft advantages to agriculture would have flowed, which flourifing manufactures io other countries occafion. The towns would have been 12 
large and numerous, and would have proved fuch ample markets to all the adjacent country, that it could not have failed becoming well cultivated, and letting probably at double the prefent rent. The manufacturers would have been confined to their own bufinefs, and the farmers to theirs; that both trades would have flourifhed the better for this, the minutes of the journey very generally fhew; a weaver who works at a fine cloth, can never take the plough or the fpade in hand without injury to his web.

I never heard but two objections to this : firt, That the weavers would be unhealthy in towns: and fecond, That the country would be lefs populons.

To the firft I reply, that ill health is the confequencr of a fedentary life and a bended pofture; whether the man has his farm or not, it is not a little work now and then that will remedy this cvil if he fupports himfelf by the loom. I was in feveral of the linen markets, and never faw more pallid pictures of difeafe; I defy any town to thew worfe. Robult, healthy, vigorous bodies, are not to be found at looms; if the health of the people is your object, you muft give up manufactares, and betake yourfelves to agriculture altogether; but this, in the prefent ftate of the world is vifionary. If the weavers were confined to towns, as I propofe, there would be a much greater aggregate of health than at prefent, for the country would be as healthy as it always is in the hands of farmers and labourers, but at prefent all is unhealthy as all are manufacturers.

The fecond objection I totally deny, for it is againft all the principles of population to affert, that a meafure, which is beneficial to both agriculture and manufactures, can be prejudicial to the increafe of people; more food would be raifed from well than from ill cultivated ground; a whole race of farmers and labourers would be employed in feeding the towns : to think that population could be injured by fuch an arrangement is an abfurdity too grofs to deferve attention.

That the circumftances of the Irifh manufacture are lamentable, when the extent of country is confidered, no man of reflection can doubt, for the value of it taken in that light. (important as it is in its total amount) appears to be comparatively trivial. Fortunately the evil is not without a remedy; the landlords of the country might, with no great difficulty, effect the change. Let them fteadily refufe to let an acre of land to any man that has a loom; the bufinefs would and ought to be gradual; but farms thould be thrown by degrees into the hands of real farmers, and weavers driven into towns, where a cabbage garden thould be the utmolt fpace of their Jand; and thofe gentlemen who are introducing the manufacture into other parts of the kingdom, fhould build the cabbins contiguous, and let the inhabitants on no account have any land. All encouragement, all attention, all bounty, all premium, 
premium, all reward, fhould go to thofe alone who lived by, and attended to their looms alone, not in a feparated cabbin, but in a ftreet. The more a perfon attends to the abominable Itate of land in the North of Ireland, the more he will be convinced of the propriety and even neceflity of this meafure; and if, contrary to common fenfe, a paltry board is permitted to exit, by way of promoting a fabric of two millions a year, let them have this object, and this only as their bufinefs. Let them devife the means of inducing landlords to drive their weavers into towns, and they will in a few years do more good to their country than all their infpectors, itinerant men, and fpinning wheels, will do in a century:

Relative to the other manufactures of Ireland, I am forry to fay they are too infignificant to merit a particular attention; upon the fubject of that of wool I muft however remark, that the policy of England, which has always hitherto been holtile to every appearance of an Irifh woollen manufacture, has been founded upon the mean contractions of illiberal jealoufy; it is a conduct that has been founded upon the ignorance and prejudices of mercantile people, who, knowing as they are in the fcience which teaches that two and two make four, are lolt in a labyrinth the moment they leave their counting-houfes and become ftatefmen; they are too apt to think of governing kingdoms upon the fame principles they conduct their private bufinefs on, thofe of monopoly, which though the foul of private intereft, is the bane of public commerce. It has been the mitaken policy of this country, to fuppofe that all Ireland gained by a woollen manufacture would be fo much lofs to England; this is the true monopolizing igroorance. We did not think proper to draw thefe bands of commercial tyranny fo tight as to interdict their linens; we gave them a free trade; nay we import an immenfe quantity of Ruffian and German linen, and yet between this double fire of the Irifh and foreigners, has our own linen manufacture flourifhed and increafed; it is the fpirit and effect of every fpecies of monopoly to counteract the defigns which dictate that mean policy. The rivalfhip of the Irifh (if a rivallhip was to enfue) would be beneficial to our woollen trade; as a faft friend to the intereft of my native country, I with fuccefs to thofe branches of the Irifh woollens which would rival our own; a thoufand beneficial confequences would flow from it; it would infpirit our manufacturers; it would awaken them from their lethargy, and give rife to the fpirit of invention and enterprize. How long did our old broad cloth trade fleep in the wett, without one fign of life ftrong enough to aninate a new purfuit; but a different fpirit breaking out in Yorkfhire and Scotland, new fabrics were invented, and new trades opened. A free Irifh woollen trade would put our manufacturers to their mettle, and would do more for the woollen trade of England than 
any other meafure whatever. Our merchants think fuch a rivalhip would ruin them; but do they think the French would not reafon for fuch fears alfo? Have we not loft the Levant and Turkey trade throuth the obftinacy of our mo. nopolifts? And why thould not Ireland have a chance for fuch a branch as well as Languedoc? But fuch has been our narrow policy with refpect to that kingdom, that we have for a century fat down more contented with the fuccefsful rival. Thip of France, than with the chance of an Irifh competitor.

Whenever any queftion, relative to commercial indulgence to Ireland, has come into the Britifh parliament, its friends have always urged the diffreffed ftate of Irelaind as a motive. This is taking the ground of duplicity, perhaps of fallhood, they ought to be more liberal, and avow that their principle is not to relax the prefent laws as a matter of humanity to Ircland, but of right and policy to themfelves; to demand a free trade to Ireland as the beft friends to Britain; to demand that France may be rivalled by the fubjects of the Britifh empire, if thofe of one kingdom cannot, or will not do it, that thofe of another may.

One would have reafon to fuppofe, from the fpirit of commercial jealoufy among our woollen towns, that whatever Ireland got was loft to England : I thall in a fucceeding fection infert a table, which will fhew that in exact proportion to the wealth of Ireland, is the balance of the Irifh trade in favour of England. That kingdom is one of the greateft curtomers we have upon the globe; is it good policy to wifh that our beft cuftomer may be poor? Do not the maxims of commercial life tell us that the richer he is the better? Can any one fuppofe that the immenfe wealth of Holland is not of vaft advantage to our manufactures; and though the Ruffia trade, upon the balance, is much againft us, who can fuppore that the increafing wealth of that valt empire, owing to the unparalleled wifdom of its prefent empress, the firft and molt able fovereign in the world, is not an increafing fund in favour of Britifh induftry?

The tabinets and poplins of Ireland (a fabric partly of woollen, partly of filk) did that ifland poffefs a greater freedom in the woollen trade, would find their way to a fuccefsful market throughout all the South of Europe. A friend of mine travelled France and Spain with a fuit of that pleafing fabric among others, and it was more admired and envied than any thing he carried with him. This is a manufacture of which we have not a veltige in England.

Under another head $I$ inferted the export of wool and yarn, and alfo the import of woollen goods from England; the following flight minute on the proportionate value of the la. bour to the material, will conclude what I have to fay on a manufacture, which working only for home confumption can zever thrive. 


\section{R E V E N U E.}

Bay yarn. A woman, on an average, fpins three fkains a day, which weigh a quarter of a pound, the value fpun is from ten pence to a fhilling, medium ten pence three farthings.

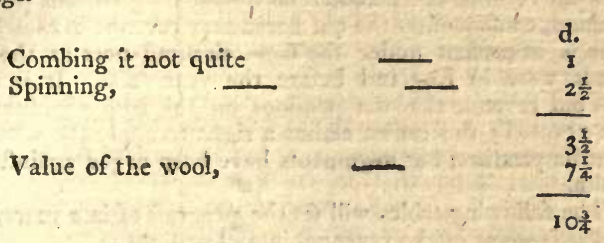

The balls are a pound and an half each of twelve fkains, the woman fpins a ball in four days, being paid ten pence; in Leinfter it is ten pence halfpenny, and in Munfter it is nine pence; average nine pence three farthings. Combing a ball is about three pence, which with fpinning nine pence three farthings, makes twelve pence three farthings labour on a ball; and the price of a ball, both wool and labour, in the year 1778, was three fhillings and fixpence, In a war the price of wool generally falls in Ireland. The laft French war did not fink prices in Ireland, but the Spanifh one did. The filk manufacture of Ireland has been already difcuffed in Section 16, and is a fabric that merits neither the encouragement of the natives, nor the attention of others.

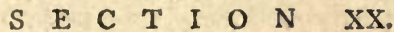

Revenue-Taxes.

THE rife, progrefs, and prefent ftate of the revenue of 1 Ireland, is very little underftood in England, though an object of confiderable importance to that kingdom. The variations of this revenue are ufeful marks, among many others, of the profperity or declenfion of the ifland, and every thing which enables us to judge of the real ftate of a country with which we are fo intimately connected, well deferves our attention.

The public revenue in that kingdom ftands upon a very different footing from ours in England, owing to the operations of the revolution relative to this object not having ex- 
tended to Ireland.' Before that epoch the two kingdons were in this refpect fimilar; but the old fubfidies and other duties which formed the hereditary revenue of the Stuarts in England, were purchafed of the crown at the revolution with the civil lift revenue of $700,000 \mathrm{l}$. no fimilar bargain took place in Ireland, confequently the old hereditary revenue in that kingdom is at prefent under the fame circumftances as the like funds were in England before the year ${ }^{1688}$. It is upon this old revenue that the penfions on the Irith eftablifhment are granted; the crown claims a right to apply the whole of it at its pleafure, but arguments have been urged againft that claim.

'The following tables will fet the progrefs of late years, and prefent receipt of the revenue, in a clear light. 
R E V E N U E:

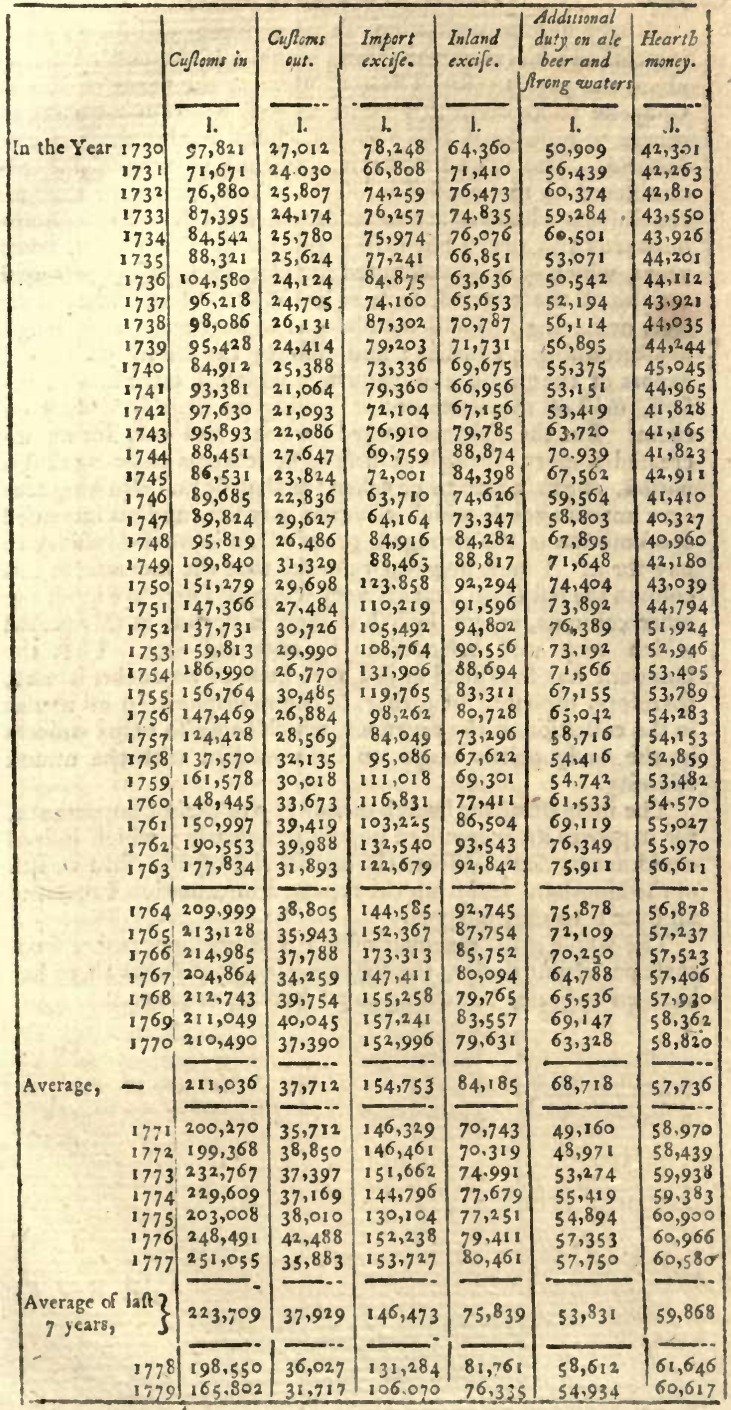


A very flight examination of thefe columns will fhew a great increafe in all (except the inland excife, and cuftoms outward) about the year 1748 . The conclufion of the peace of Aix la Chapelle feems from this table, as well as from a variety of others to have been the principal epoch in the profperity of Ireland. The inland excife is a revenue fo wretchedly adminiftered by the confeffion of the whole kingdom, that no conclufions whatever are to be drawn from it. The cuftoms outwards have rifen but little; and not at all in the laft feven years, which is to be accounted for from fome of the principal articles of the exports, fuch as linen, \&cc. being either duty free, or having fo fmall a cuftom as to be merely with defign of afcertaining quantities; and alfo by the falling off in the export of the produce of pafturage which I have thewred before, molt of the articles of it having an ill judged duty on them. But the cuittoms inwards is not a bad one, for an increafed import, though at firt fight it feems to be againt a nation, ought never to be taken in that light. No kingdom ever imports goods which it cannot pay for, and an increafed confumption is the ftrongelt proof of an increafed ability to pay for it. I muft however remark, that the increafe in this column the laft reven years is very trifling. There are in all the other columns, except hearth money, a decline in this period which very well deferves to be enquired into. That the kingdom has flourifhed in it I have little or no doubt, it may, therefore, probably be owing to the multiplication of abufes in the collection of the revenues, which being fo many cancers in the body politic ought to be remedied with the utmoft affiduity.

The increafe of the hearth money is a matter of importance, for it proves an increafe of population clearly; which indeed could not be doubted from the increafed profperity and wealth of the kingdom, and from the repeated information I received all over it to that purport.

The whole grofs revenues offer a different appearance from thefe particular duties, the following account fhews there has been an increafe, but owing to an increafe of taxes. 


\begin{tabular}{|c|c|c|c|c|}
\hline $\begin{array}{l}\text { Two years cnd- } \\
\text { ing Lady day. }\end{array}$ & $\begin{array}{c}\text { Heredita- } \\
\text { ry revenue } \\
\text { grofs. }\end{array}$ & $\left\{\begin{array}{l}\text { Old addi- } \\
\text { tional du- } \\
\text { ties grofs. }\end{array}\right.$ & $\begin{array}{l}\text { For receiving } \\
\text { revenue, pay- } \\
\text { ing drarw- } \\
\text { backs and pre- } \\
\text { miums oncorn } \\
\text { bc. }\end{array}$ & \begin{tabular}{|} 
Nett pro- \\
duce of the \\
hereditary \\
andold ad. \\
ditional \\
duties.
\end{tabular} \\
\hline $\begin{array}{r}\text { the year } 1751 \\
1753 \\
1755 \\
1757 \\
1759 \\
1761 \\
1763\end{array}$ & \begin{tabular}{|c|}
1. \\
$1,048,85^{8}$ \\
$1,047,062$ \\
$1,127,552$ \\
954,668 \\
989,937 \\
$1,053,939$ \\
$1,201,300$
\end{tabular} & $\begin{array}{c}1 . \\
366,462 \\
349,557 \\
367,980 \\
322,568 \\
320,4^{1} 5 \\
346,649 \\
418,25^{8}\end{array}$ & $\begin{array}{c}1 . \\
192,513 \\
185,766 \\
193,259 \\
191,357 \\
205,290 \\
234,077 \\
260,602\end{array}$ & $\begin{array}{c}1 . \\
1,233,943 \\
1,210,353 \\
1,302,274 \\
1,085,880 \\
1,105,062 \\
1,166,511 \\
1,358,956\end{array}$ \\
\hline Arerage, & $1,060,474$ & 355,698 & 81 & $, 209,068$ \\
\hline $\begin{array}{r}\text { n the Year } 1765 \\
1767 \\
1769 \\
1771 \\
1773 \\
1775 \\
1777\end{array}$ & $\begin{array}{l}1,299,165 \\
1,295,317 \\
1,309,828 \\
1,276,711 \\
1,288,094 \\
1,279,275 \\
1,388,044\end{array}$ & $\begin{array}{l}452,375 \\
471,240 \\
481,998 \\
454,955 \\
439,615 \\
404,415 \\
419,748\end{array}$ & $\begin{array}{l}273,010 \\
318,044 \\
347,943 \\
349,275 \\
398,380 \\
428,180 \\
464,762\end{array}$ & $\begin{array}{l}1,477,529 \\
1,448,513 \\
1,443,882 \\
1,382,391 \\
1,329,330 \\
1,255,509 \\
1,343,120\end{array}$ \\
\hline ráge, & $1,305,062$ & 446,335 & 368,786 & $1,3^{82}, 896$ \\
\hline In the & 1,1 & 346 & & \\
\hline
\end{tabular}

Thefe are for fellions not years. Befides thefe duties there are others appropriated by parliament to particular purpofes; thefe are for paying the intereft of loans, for the encouragement of the linen manufaeture, of tillage, of proteftant fchools, and the cambric manufacture.

The whole revenue of the kingdom for twenty years in two periods, of ten each with the averagcs, will fhew the general increafe, whether owing to new duties or an increafe of old ones. 
TOTAL REVENUE OF IRELAND.

1.

In the year $175^{8} \quad 650,76_{3}$ In the year 1768

1759

1760

$176 \mathrm{r}$

1762

1763

1764

- 1765

1766

1767
$714,9,8$

717,022

$74^{6,151}$

878,068

850,895

939, 139

948,251

950,744

$9^{10,780}$
1.

945,520

977,372

954,045 $900,9^{13}$ 897,395

955,074

* 957,498

$+930,228$

1,040,055

$1,093,881$

Average of ten years, 834,673 Average of ten years, 965,198

$$
\begin{gathered}
\text { Ditto of the former period, } \\
\text { Increafe, }
\end{gathered}
$$

But this revenue, confiderable as it is, has not been equal to the national expenditure. In the feflions of 1759 , there was a furplus in the treafury of 65,7741 . yet in the following one a confiderable debt was contracted, as will be feen by the progrefs of the incumbrance.

1.

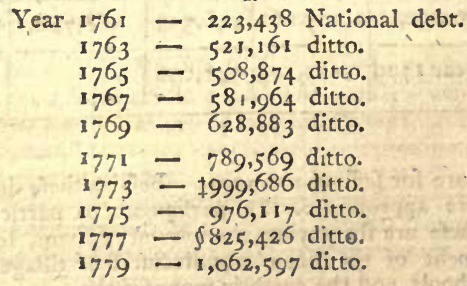

Suppofe the revenire a million, it is about a fixth part of the land rents of the kingdom. If there are three million of fouls in Ireland, they pay exactly $6 \mathrm{~s} .8 \mathrm{~d}$. a head. It appeared be-

- Additienal duties laid.

+ Stamps ditto.

\pm This does not agree wiih the fate in 201. 17 of the journals, nor the following year.

of Extraded from the national accounts laid before parliament every ferions. 
BRITISH AND IRISH TAXES COMPARED. 173 fore the export of linen, yarn, corn, woollen, pork, beef, \&c. \&c. amounted to $3,250,4711$. fuppofe all other exports would make it up three and a half millions, the revenue of the kingdom amounts not quite to $a$ third.

It will not be improper here to compare the burthens of Ireland with thofe of Great-Britain.

Britifh revenue of 13 millions paid by 1 . s. d.

9 millions of people is, - i 9 a head.

Irifh revenue of I million paid by 3
millions of people is,
- 68 a head.

Britifh revenue of 13 millions paid by
72 millions * of acres is,
- 36 each.

Irih revenue of 1 million paid by 25 millions of acres is,

o 0 ro each.

Britih revenue of 13 millions paid by

a rental t of 24 millions is, 010 to in the pound.

Irih revenue of 1 million paid by a rental of 6 millions is, - $\quad 34$ in the pound:

Britifh revenue of 13 millions paid by an export of $\ddagger 16$ millions is, $016 \quad 3$ in the pound. Irin revenue of $\mathrm{t}$ million paid by an export of $3 \frac{x}{2}$ millions is, - $\quad 0 \quad 5 \quad 9$ in the pound. Britifh revenue of 13 millions paid by a balance of trade of 5 millions is, 2120 in the pound. Irifh revenue of 1 million paid by a balance of trade of 1 million is, $\quad 00$ in the pound.

The inferiority of the taxes of Ireland to thofe of GreatBritain, upon every one of thefe comparifons is very great; the parallel is, however, certainly not complete : the fpecie of Ireland is i, $600,0 \mathrm{col}$. but it is difficult to fay what that of England is, the gold coinage proved our calculators to be fo amazingly out in their reckoning, but in this article, including paper lies, I apprehend the greater eafe in England of paying taxes, which are light or heavy, not perhaps io much in proportion to the income of a people as tothe eafe of circulation; that in England is out of all comparifon greater than in Ireland, which would make it impoffible for the preceding proportions to be raifed in that kingdom as high as they are in Britain. But fair allowances being made for this article, fill we may with great fafety conclude that this national burthen is vaftly lighter there than with us. If the advantages of fuch a fitua:

- The exact number at $\sigma_{4} 0$ to a mile is $71,979,848$.

2ol. that of England, and 4 l. allowed for Scotland. I The laft cuftom-houfe account. 
174

D U T I E S.

a fituation are not continued, it will certainly be owing to complaints of poverty, occafioning clofer fcrutinies into facts than have hitherto happened.

We come next to the expence which abforbs this income.

\begin{tabular}{|c|c|c|c|c|}
\hline $\begin{array}{c}\text { Troyears ending } \\
\text { Lady day. }\end{array}$ & Civil lift. & $\begin{array}{c}\text { Military } \\
\text { lift. }\end{array}$ & $\begin{array}{c}\text { Exitraordinary } \\
\text { charges,includ- } \\
\text { ing parliamen- } \\
\text { tary grants. }\end{array}$ & Totals. \\
\hline In the year 1751 & 146,134 & 766,151 & 126,356 & $1,038,643$ \\
1753 & 143,705 & 762,571 & 152,415 & $1,058,691$ \\
1755 & 144,602 & 795,182 & 169,276 & $1,109,061$ \\
1757 & 161,223 & 794,364 & 362,674 & $1,318,263$ \\
1759 & 181,964 & 820,383 & 298,173 & $1,300,521$ \\
1761 & 202,052 & 997,072 & 281,888 & $1,481,013$ \\
1763 & 221,365 & $1,124,743$ & 332,934 & $1,679,043$ \\
1765 & 241,271 & 988,535 & 275,955 & $1,505,761$ \\
1767 & 257,988 & 971,007 & 337,646 & $1,566,642$ \\
1769 & 270,040 & 954,426 & 327,094 & $1,551,561$ \\
1771 & 272,678 & 976,917 & 373,997 & $1,623,593$ \\
1773 & 323,833 & $1,172,723$ & 389,634 & $1,886,191$ \\
1775 & 366,838 & $1,223,326$ & 342,377 & $1,932,541$ \\
1777 & 410,904 & $1,112,682$ & 410,172 & $1,933,758$ \\
1779 & 336,475 & 937,679 & 432,474 & $1,706,628$ \\
& & & & \\
\hline
\end{tabular}

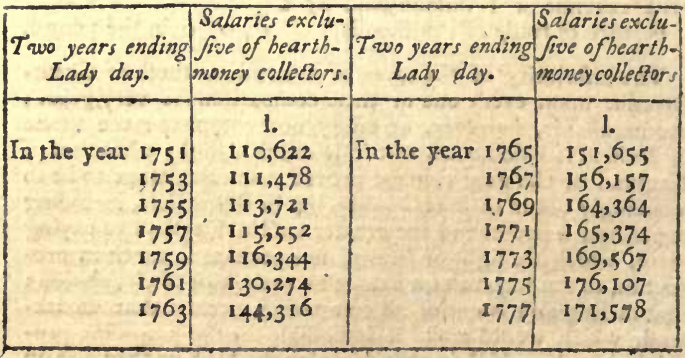


D U T I E. S.

Some of the particular duties which go towards raifing the above revenue will be feen among the following articles.

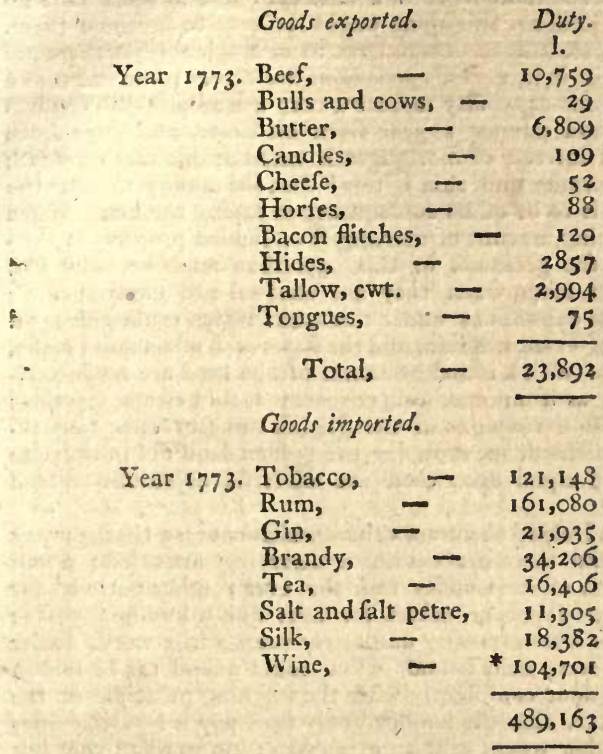

'To lay a duty of near $24,000 \mathrm{l}$. a year upon the export of the producc of pafturage is heavy and moft unpolitic, and ought to be abolifhed. The other articles in this lift are very proper ones to tax.

The decline in feveral branches of the revenue having united with an increafed expence to run the ration in debt as above mentioned, new taxes are of courfe in contemplation every feffions. A LAND TAX has been a matter of converfation in Ireland for fome years: fome increafe muft be made to the revenue, but in what mode is an enquiry of the molt incerefting vature to that kingdom; I fhall for this reafon offer a few remarks on the fate of the country relative to the taxes which would be moft proper for it.

There are a varicty of objections to land taxes in general, befides the particular ones which apply immediately to Ireland. Taxes ought all to be equal, but an equal land tax mult be a variable one which is at once a tythe, the moft pernicious burthen to which any nation can fubmit ; it is the taille, the equal land tax of France which is fo wcll known to be the ruin of 


\section{A LA N D T A X.}

the agriculture of that kingdom: hence therefore equality muft not be thought of in a land tax: and if there were no other objections, this alone ought for ever to preclude them. But fuppofe a fixed unequal tax as in England, yet there are great evils in it, a man's poffeffions are rarely to be taken as a proof of his capability to bear a tax; a landlord who receives a thoufand pounds a year from his eftate, and pays feven hundred intereft of mortgages is taxed at his whole rental; what enormity and ruin is this! that the ability to bear the burthen is to be of no confequence in laying the tax. When the amazing amount of mortgages on landed property is confidered, the greatnefs of this oppreffion mult be fully felt. But land taxes when they are unequal are unproductive; hence the oppreffions under this name which crufh the agriculture of France, Milan, and the ftates of Auftria and Pruffia, in moft of which actual valuations of the land are made periodically, as if no man's improvement fhould efcape taxation: hence alfo the defigns of the Englifh miniftry once remarkably manifefted, of dropping the prefent land tax in order to obtain an equal one: thefe are univerfal objections to land taxes.

But in Ireland there are others which concern that country fingly, and therefore the more deferving attention; a valt proportion of it is under leafe for ever; other parts let for five hundred years; others for lives and a hundred years; others for lives and fifty and thirty years; in a word, under leafes of every defcription. How could a land tax be laid in that kingdom confiftently with the reigning principle of the Englifk tax, that the landlord only fhall pay it ? Difficulties innumerable would arife at every ftep; no gordian knot but the fword of power can cut ; but the queftion is whether all the principles that have dirested a fimilar tas in England would not be cut with them: for the tax to be either equal or productive, it muft be laid on fome claffes of tenantry : it ought certainly to be laid on all who do not occupy; but from that moment there is an end of it as an Englith land tax, it is a taille, a tax on tenantry: break the limits, the great line between the owner of the land and the tenant, and who will fay how far the innovation will be carried, the moft dangerous that can ever be made in a kingdom? Adieu to all improvements in agriculture wherever fuch an one takes place.

Evils of this fort rarely make their full appearance at firft; a land tax in Ireland would probably come in under a very fair appearance; but the ftate of the country ought to tell its inhabitants that fuch a tax would be too unproductive to laft; the fucceffive alterations would do the fatal bufinefs, and produce the mifchief in its full deformity.

Adminitration have had experience in England of the lofs, as it has been called, to the revenue from a fixed tax : if ever therefors 
therefore they introduced it into Ireland, it would be in a form which admitted alterations, in order to avoid the circumftance which has more than once raifed a ftrong inclination to a new affeffment. For thefe and other reafons too numerous to give in detail here, I am convinced that Ircland can never experience a more pernicious tax than that on land.

But ás I obferved before, government muft go on, and mult be fupported at an increaling expence; new taxes muit confequently be had recourfe to, and I thall not hefitate a moment in recommending excifes as the only ones which can be much extended without any aational injury: an entire change in the adminiftration of them fhould take place; the monftrous abufes in them remedied, and new ones laid. The cheapnefs of whilkey with which a man may get dead drunk for two pence, is an enormity too great to be borne. The morals, health, peace, induftry, agriculture, manufactures, commerce, and wealth of the kingdom, are all materially injured, by the cheapnefs of this vile beverage: there is not an object in Ireland which would yield a more productive revenue, at the fame time that every fhilling government got would be half a crown benefit to the public: a judicious, and well collected excife on this liquor would raife an immenfe revenue. All other fpirits, wines and tobacco, ate alfo very well able to bear much heavier taxes than they labour under at prefent. An excife on tea alfo might be applicable ; but there is no want of objects; and if the legillature of the kingdom will not fet themfelves very fteadily to the bufinefs, a land tax will be the confequence, and in it all the mifchiefs that muft attend the meafure.

The propofition for a land tax on abfentees was very wifely rejected; the execution of it would have fmoothed fome of the difficulties, or at leaft rendered them familiar, and certainly have facilitated, a general tax of the fame nature.

The mode purfued in Ireland of raifing money by tontine, at an exceeding high intereft, fo high even as 7 per cent. is very mifchievous to the kingdom. The great want of that country is capital, confequently any meafure which tends to leffen capitals that are employed in any branch of induftry, is pernicious : feven per cent. intereft in national funds mult be a fevere blow to every branch of induftry, for who will lend moncy on private fecurity at fix per cent. while the public gives feven? And what man will undergo the trouble, and run the hazard of manufactures or commerce, while he can fit by bis fire fide with feven per cent. in his pocket. In England where the capital is fo immenfe, and with all that of Holland at command, fimilar tranfactions are found excecdingly detrimental, infomuch that no induftry can be carried on which will not yield very large profits; no money to be procured on bond; fearce any on mortgage; valt fums drawing out of the general induftry for inveltment. VOL. II. 
in the pablic funds, and a general fall in the value of that great portion of landed property which is obliged to be fold. But the fums borrowed in this country may be too large to raife by taxes; I do not think it is the fame in Ireland; and that kingdom had much better raife their fupplies within the felfion than leffen their little capital by tontines.

\section{S E C}

\section{Commerce - Fißheries - Embargoes.}

U

NFORTUNATELY for Ireland, the general commerce of it is to be fully treated in a very fmall compafs; and the facts which I have already had occafion to lay before the reader, in the two preceding fections, go very far towards completing the whole that is neceffary to explain its ftate. Being a dependent country, the Britin legiflature has upon all occafions controuled its commerce, fometimes vith a very high hand, but univerfally upon the principles of monopoly, as if the poverty of that country was to form the wealth of Britain, I have on every occafion endeavoured to fhew the futility of fuch an idea, and to prove from the evidence of invariable facts, that the wealth of Ireland has always been, and is, the wealth of England, that whatever fhe gets is expended in a very large proportion in the confumption of Britifh fabrics and commodities. The increafed profperity of Ireland, which the has experienced in fpite of our abfurd reftrictions on her commerce, has raifed her to be one of the greateft and beft markets this kingdom poffeffes in any part of the globe.

It is a remarkable fact which was pointed out to me by that very able politician, the Earl of Shelburne, that the narrownefs of our prohibitory laws in England is of late date ; from the old Engtith acts of parliament it appears, that before the reftoration the true fyftem of commerce was much better underftood than it has been of late days : if the tranfactions of the commonwealth are examined, there will appear great liberality and the foundeft principles in Cromwell and the leading men of thofe times; and that it was the clear determination of the protector as well as of the long parliament, tn make the trade of Ireland as free as poffible; nay, the act of navigation itfelf, at the reftoration, included Ireland upon the fame footing as England ; it was not till twelve years afterwards, that the exception crept in by a fingle claufe in an- 


\section{O M M E R C E.}

other act, which probably was paffed at the defire of fome merchant, without any perfon's caring about it, which has been the cafe with many an American act. The next prohibitory law, which declared the importation of Irifh cattle a nuifance, was a contefted job between the duke of Ormond and the duke of Lauderdale ; afterwards it became the farhion to pafs acts againft Ireland, which nobody had the knowledge or libe.rality to oppofe. In the full perfection of this fpirit it was, that a bill, which paffed in Ireland in $\mathbf{7 5 9}$, for reftricting the importation of damaged flour, was thrown out in England at the inftigation of a fingle miller at Chichelter.

Whenever old prejudices wear out, it will certainly be found for the intereft of England to give every freedom poffible to the trade of Ireland. I am convinced if this extended to its being an abfolute free port, no mifchief would refult from it; but as to a free export to all the world, not the fliadow of a good argument ever yet appeared againft it; for upon what principles of policy, or of common fenfe, can we found a conduct which reftrains our own fubjects from the free fale of their products and manufactures, when the returns of fuch fales mult flow into our own coffers by that extention of demand which has been infeparably connected with the wealth of Ireland, when the population and the power that rife upon fuch wealth are our own? A mercantile landlord at London might as well fay to his tenant in Yorkfhire, You fhall not fell your corn to whom you pleafe, you thall thip it to me s you fhall not convert your wool to the beft purpofes, you fhall fell it raw to me. This language might be that of his leafes, but it would be that of folly. Would he not foon find, that by leaving his tenants to make the beft of their own commodities, they would afford to pay him a better rent; their wealth becomes his, if he keeps them poor he muft be fo himfelf. The cafe of Ireland is exactly parallel; the inhabitants of that ifland, in their public revenue, in their military, by their abfentees, and in their commercial balance, pay to this kingdom a direet rent for it, which vibrates in its amount to the variations of their national wealth. While it was a wildernefs of favages it paid the rent which defarts every where yield; as it improved our receipt has been proportioned, until it has become a cultivated flourifhing eftate, and yields a rent which marks to an iata the cxtent of the cultivation, and. the degree of that profperity. Of what ufe is the experience of a century of facts, if we are not to open our eyes to the leffons they convey? Long experience has told us what the effects of Irifh wealth are; we fecl thofe effects flowing like vital warmth through the whole extent of our own territory, and fhall we yet hefitate to encourage and extend a profperity which is the fource and foundation of our own? 
I have taken the great line of leading principles; will the littlenefs of commercial jealoufy reply in its true fpirit, that this town will be hurt; that that manufacture will be loft; that Manchefter will be alarmed; and that Norwich will have apprehenfions : it is not a queftion for the weavers of one place and the merchants of another to decide, it is THE EMPIRE that is concerned; the general intereft demands the meafure, and ought to abforb every pitiful confideration: but all experience fpeaks only one language even to thefe mittaken individuals: 1 obferved it before, and gave initances of manufactures finking in the poffeffion of a monopoly, and thriving fróm a rivalry; of markets rifing to increafing induftry; of the welfare of one country rifing from the profperity of others: truths as univerfal as the world. And thall we deny the application to a fifter, but dependent kingtom, from whom we have fo many ways of gaining all the advantages of her wealth? But arguments are little wanted where facts are fo numerous; to thofe I have already inferted, let me add the following ftate of our imports and exports in the Irinh trade.

TRADE oF GREAT BRITAIN WITH IRELAND.

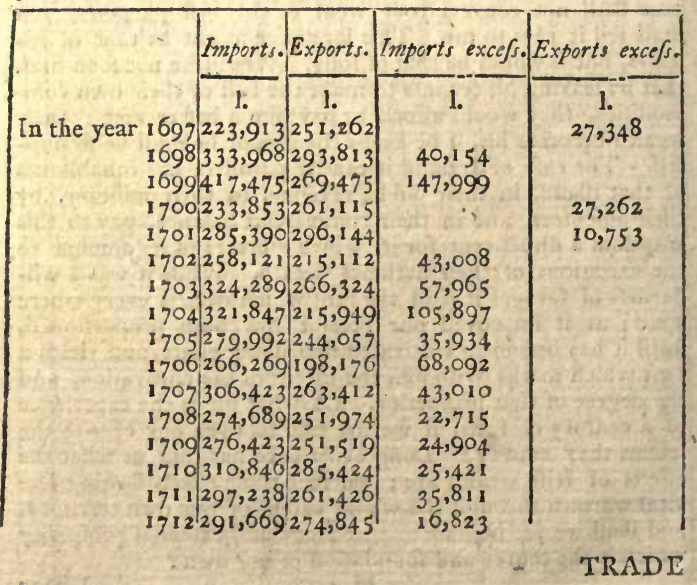


C O M M E R C E.

TRADE OF GREAT BRITAIN WITH IRELAND, Continued.

\begin{tabular}{|c|c|c|c|c|c|}
\hline & & Imports. & Exports. & $\begin{array}{c}\text { Imports } \\
\text { exce/s. }\end{array}$ & $\begin{array}{l}\text { Exports } \\
\text { excess. }\end{array}$ \\
\hline & & 1. & 1. & 1. & 1. \\
\hline In the & 1713 & 295,926 & $-306,964$ & & 11,038 \\
\hline & 1714 & 326,391 & 397,048 & & 70,656 \\
\hline & 1715 & $3^{8} 9,437$ & $4^{2} 0,062$ & & 30,625 \\
\hline & 1716 & 561,673 & 345,252 & 216,421 & \\
\hline & 1717 & $4^{6} 9,657$ & $4^{2} 9,880$ & 39,776 & \\
\hline & 1718 & 326,283 & 333,988 & & 7,704 \\
\hline & 1710 & $3^{80}, 130$ & $3^{87}, 460$ & & 7,329 \\
\hline & 1720 & 282,812 & $328,5^{8} 3$ & & 45,771 \\
\hline & 1721 & 332,882 & 378,838 & & 37,956 \\
\hline & 1722 & 356,095 & 488,370 & & 132,274 \\
\hline & 1723 & 360,526 & 553,945 & & 193,418 \\
\hline & 1724 & $3^{6} 7,889$ & 468,257 & & 100,367 \\
\hline & 1725 & 333,870 & 474,836 & & 140,965 \\
\hline & 1726 & 332,604 & 569,553 & & 236,949 \\
\hline & 1727 & 307,038 & 436,012 & & 128,973 \\
\hline & 1728 & 318,147 & 475,762 & & 157,615 \\
\hline & 1729 & 287,648 & 517,198 & & 229,549 \\
\hline & 1730 & 294,156 & 532,698 & 1 & $23^{8,542}$ \\
\hline & 1731 & 308,936 & $6,8,68_{4}$ & & 309,745 \\
\hline & 1732 & 294,484 & 614,754 & s & 225,731 \\
\hline & 1733 & 386,105 & 595,251 & & $35^{1,822}$ \\
\hline & 1734 & 401,422 & 627,154 & & 225,731 \\
\hline & 1735 & 417,421 & 769,244 & & $35^{1,822}$ \\
\hline & 1736 & 447,176 & 720,555 & & 273,378 \\
\hline & 1737 & $34^{6}, 476$ & 730,910 & & $3^{8} 4,433$ \\
\hline & $173^{8}$ & 381,372 & 696,590 & & 315,218 \\
\hline & 1739 & $4^{11}, 9^{24}$ & 673,621 & & $26 i, 697$ \\
\hline & 1740 & 390,565 & 628,288 & & 237,723 \\
\hline & 1741 & 404,863 & 698,715 & & 293,851 \\
\hline & 1742 & 346,814 & 775,650 & & 428,835 \\
\hline & 1743 & 816,797 & 860,178 & & $43,3^{80}$ \\
\hline & 1744 & 390,874 & 703,227 & & 312,353 \\
\hline & 1745 & $1,441,498$ & 910,920 & 530,578 & \\
\hline & 1746 & 532,686 & 796,157 & & $26_{3}, 471$ \\
\hline & 1747 & $54 \mathrm{r}, 393$ & 748,677 & 1 & 207,284 \\
\hline & 1748 & $4^{6} 4,4^{8} 9$ & 906,424 & & $44^{1}, 935$ \\
\hline & 1749 & 567,776 & $1,006,045$ & & $43^{8,268}$ \\
\hline & 1750 & 6 1 2,808 & $1,316,600$ & & 703,792 \\
\hline & 1751 & 664,484 & $1,174,493$ & & 510,008 \\
\hline & 1752 & 563,959 & $1,140,608$ & & 576,648 \\
\hline & 1753 & 561,489 & $1,149,55^{2}$ & & 588,063 \\
\hline & 1754 & & 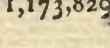 & & $\begin{array}{l}503,302 \\
\text { TRAD }\end{array}$ \\
\hline
\end{tabular}


182

C O M M E R C E.

TRADE OF GREAT BRITAIN WITH IREL A N D, Continued.

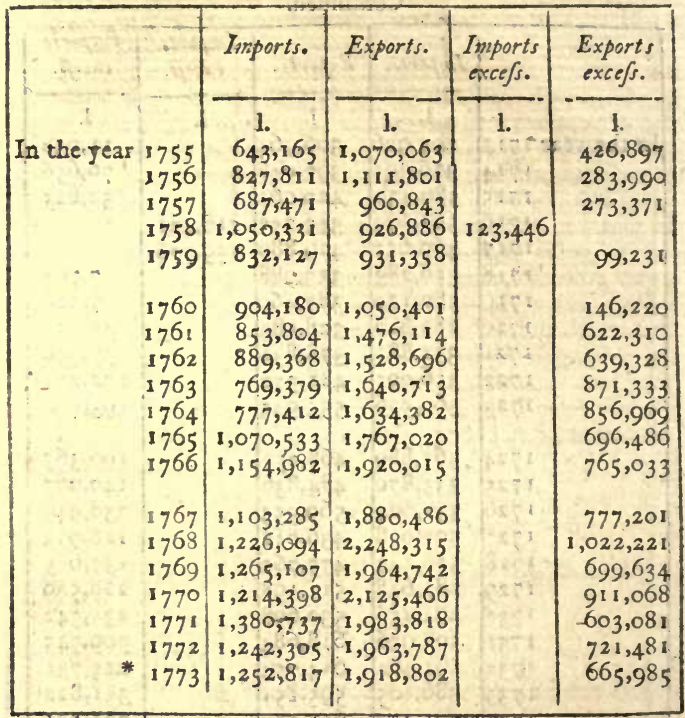

The reader will recollect that it was the general tenour of the information received in the journey, that the year 1748 was the epoch of the modern profperity of Ireland; all agree that after that peace, Ireland advanced greatly, her rife of rental will mark this clearly. The following is a review of the minutes:

\section{R I E O F R E N T S.}

Iord Longford more than doubled in thirty years.-Earl of Innifkilling quadrupled in ditto.-Mr. Cooper almoft treWed fince 1748.-Mayo trebled in forty years. - King's county

two

- Extracied from the accounts laid before the Britifb parlia ment.

It is a circumfiance very mucb to be regretted, that thefe ac. counts no longer fee the light; they bave not been laid before parliament fonce 1773, why bould a plactice ibat bad continued for above a century ceafe jufl then? If there were any trades like the Ameriean wbich did not offer a pleafing fpeciacle, there were otbers like thofe of Ireland, Ruflia, E'c. to make umends. 


\section{O M M E R C E.}

two thirds fince 1750 . -Tipperary doubled in twenty years. - Barony of Owna and Ara doubled in ditto.-Rich lands of Limerick rifen a fourth in twenty years, and two thirds fince 1748 .

In the preceding enquiries the truth of this is confirmed by every proof which authentic records can fhew; as the table now before us marks the commercial connection between Great Britain and Ireland, it is neceffary to divide it into periods, in order to fee the average of each. The table contains twenty-five years fince 1748 , during which period.

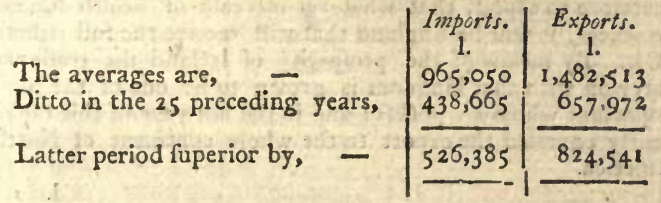

Here is an account that is worth a dozen arguments ! It is from hence cvident, that our exports to Ireland have in the laft twenty-five years confiderably more than doubled, almoft trebled; and this great rife has been exactly in the period of the internal profperity of that illand. If I did not know perfons of very refpectable characters in parliament, who think very differently upon this great queftion of the freedom of Irifh trade, I fhould be ahamed of dwelling a moment on the fubject. How would it have been poffible for that country to fupport fuch an increafed importation, unlefs the had increafed in wealth? And having proved that fuch advances in national profperity have been attended by this increafed demand for the manufactures and products of England, are we not perfectly founded in concluding, that future advantages to Ireland will alfo be attended by fimilar effects? The influx of wealth into that country brings a talte for the elegant luxuries with which we abound, and the capability of purchafing them enfures the purchafe. An Englifhman cannot go into a fingle houfe in Dublin, or fee a perfon dreffed, of either fex, without having this truth ftaring him in the face. But there is a circumftance in this account which deferves particular attention, and that is our import trade not having increafed fo much as the export one, from which this plain conclufion is to be drawn; that let Ireland get her wealth from where the will, it comes infallibly to England. The fourth column of the table which thews the balance the pays us, and which amounts of late years, from fix hundred thoufand to a million a year, could not poflibly be fupported with the abfentee drain, unlefs the made by her trade elfewhere. 


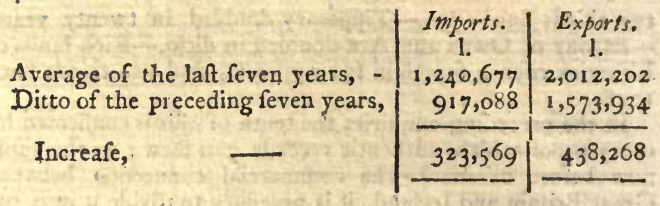

From this comparifon we find, that the rapid increafe of our exports to Ireland is in late years, the ftronger reafon therefore to expect, that whatever increafe of wealth the experiences, it will be England that will receive the full tribute of it. By means of the profperity of Ireland the trade we carry on with that kingdom is grown to be one of the molt important which we poffefs; and in the laft year of this table, nearly equalled the export to the whole continent of North America.

1.

Exports from England to the continent of North
America, from Chriftmas, 1772 , to 1773 , Ditto to Ireland,

Freight, infurance and profit on both twelve per cent. Hence therefore this nation has no demand of policy fo ftrong on her at prefent, as to encotirage lreland to the utmoft of her power, in order to increafe her own trade to that illand, that American loffes may be the lefs fenfibly felt; but this can only be done by embracing a fyftem totally it new. And here it is a tribute fairly due to genius long fince departed, to obferve, that the relative interefts of England and Ireland were better underftood by $\mathrm{Mr}$. Houghton in 1682, than by any later writer, whofe productions have come to my knowledge; and as 1 have mentioned him on this occafion, 1 muft remark, that he feems to me to have had jufter ideas of trade, manufactures, prices of provifions, enclofures, \&c. than nine tenths of the authors who have treated of thofe fubjects: "The richer Ireland grows the more wealth will the landlords have, and the more will they that live here fpend. I am told by an inquifitive and underftanding knight, that hath a great eftate there, and very well underftands the Irifh affairs, that what their gentry fpend here, with the penfions and the rent that are paid from thence to the city of London, amounts to about three hundred thoufand pounds per annum, and I fee no reafon why this expence fhould not increafe according to their thriving." - - Even in the woollen manufacture I queftion whether they could in cloth do more than the Dutch; and for otherr manufactures, why might it not put both nations at ftrife to find out 'fome nerv confumptions, and fo increafe tise trades of both? If there mult be but a fet quantity confumed, feeing. England bears up againt, and in cloathing outdoth Terra Firma, why may we not, IF IRELAND 
DE JOINEDTO US, fpoil the irade on the ctber fide, and fo be both enriched *?" Here is the intereft of England, relative to that country, explained upon the moft enlarged and moft liberal principles of freedom and of commerce. This penetrating genius, who faw deeper into the true Englifh interefts than half our modern politicians, was fenfible of no mifchiefs from a free Irifh woollen trade : the prevalence of commercial jeafoufy had not then arifen to the heights we have fince feen it. Without any hefitation, Ireland ought to have an abfolutely free trade of cxport and import to all our American colonies, and African fettlements; alfo a very confiderable freedom in her exports to Europe : but when this fubjeet was in converfation in the houfe of commons, I heard the minifter mention one circumftance, which feemed to ftand in the way of doing juftice to Ireland, that is to ourfelves: taxes there being fo much lower that their manufactures not being equalJy under the burthen of excifes, would have an unfair ftart of ours + . With great fubmiffion, I think this will not be found found doctrine either in fact or reafon. I might here go into the queltion of a poor and cheap country robbing a rich one of her manufactures, for the affertion comes directly to this; but Dr. Tucker has treated it in fo mafterly a manner, and has fo clearly proved the abfurdity of the idea, that what he has faid ought to be confidered as conclulive. But why give in linen what you deny in other fabrics? Irith linen has all the adrantages of a freedom from a great variety of excifes, which the manufacturers of Englifh linen labour under, and yet we not. only fupport the competition but thrive under it, from there being a difference in the fabrics, and as great a difference would be in all other fabrics. Their broad cloth, alfo, is made under the fame advantages, and compare it in both price and quality with that of England; I bought it at feventeen thillings and fixpence a yard at the Dublin fociety's warehoufe, without the mafter manufacturer's profit and expences, and I will venture to affert, from wearing both, twenty-three fhillings for Englifh cloth to be cheaper. The fame fact runs through a variety of their fabrics. The fixed trade, capital and fkill of England will for ever bid defiance to the no excifes of Ireland. But fomething was forced to be given-had woollens been put down and linens not permitted, the oppreffed and ruined people would have fought redrefs with arms in their hands. The monopolizing fpirit of commercial jealoufy gaye as little as poflible, and would not have given that little could the have helped it. But the argument fays, that Ireland having few excifes will get much trade and wealth: and is it not your defign that the thould? Ought pot this, in common fenfe, to be your with and aim? For whom

- Cotlecion of Hufbandry and Trade, vol. $4 \cdot p \cdot 48$.
+ Written in 7 .
+1779 . 
whom does fne grow rich? If I have not proved that point there is no proof in fact, nor truth in figures. Why cannot the rival France, Holland and Germany, as well as England? But we have ample experience to tell us that the may rival without impoverilhing us; that the may grow rich and we great by her wealth; that fhe may advance, and we be profperous. To affert becaufe there are not as many excifes in one part of one dominions as another, that therefore their trade fhall be cramped is exactly like faying, that labour is cheap there, and for that reafon fhall never be dear; making the poverty of the kingdom the motive for keeping it poor.

Taxes flow from trade and confumption, give them the wealth to confume, and never fear but taxes will follow.

\section{F I $S \mathrm{H} E \mathrm{E}$ I E $\mathrm{S}$.}

There is fcarcely a part of Ireland but what is well fituated for fome filhery of confequence; her coafts and innumerable creeks and rivers mouths are the refort of valt thoals of herring, cod, hake, mackarel, \&c. which might, with proper attention, be converted into funds of wealth ; but capital is fuch a univerfal want in Ireland, that very little is done. The minutes of the journey contain fome valuable information on this head, but the genreral picture is rather an exhibition of what ought to be done, than any thing that actually is executed ; nor have the meafures of the legiflature been attended with anv confiderable effect; fome of them feem to bave done mifchief, of which the following is an inftance.

By the 3 G. 3. c. 24.-Twenty Rillings, per ton on Englifh or Irith built veffels decked, after the commencement of this act, not under twenty tons, nor to be paid for more i. than one hundred, to proceed from fome port in Ireland.

Bounty of two fhillings a barrel on export of white, herrings.

Ditto of two Millings and fispence on mackarel.

Ditto of five fhillings for fix fcore of ling.

Ditto of three fhillings for hake, haddock, glaffing, and conger eel.

Ditto of four fhillings and three-pence halfpenny for every tierce, of 41 gallions of wet fith exported.

Ditto of three pourds per ton?

for whale oil,

Ditto of thirty fmillings ditto $>$ manufactured in Ireland.
for other oil of fith,

Ditto of four pounits per crrt. for whale bone,

"The following bas been the cffect of this meafure. 
F I S H E R I E S.

BARRELS OF HERRINGS IMPORTED INTO IRELAND FOR, EIGHTEEN YEARS.

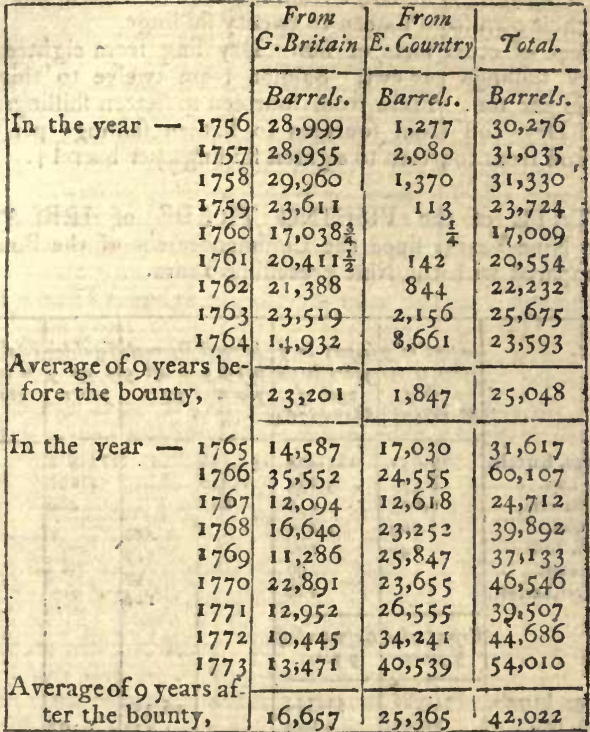

Import of herrings in the nine years fince the bounty exceed the preceding period in 155,156 barrels. Value at fifteen fhillings per barrel, _- _ 116,367 is 3

1. s. d.

Export lefs by 16,357 barrels, at twenty fhillings per barrel,

Lofs alfo on the export and import of dry cod, 1,298 cwt. at 14 s. per cwt. Ditto on barrelled cod, $16,357 \quad 150$ $\begin{array}{r}973100 \\ -\quad 364176 \\ \hline\end{array}$

Hake $9,566 \mathrm{cwt}$. at fifteen thillings par cwt.

134,063139 7,115 1 3 Salmon 1,108 tons, at twelve pounds per ton, $14,200 \quad 0$ Mackarel, 2,666 barrels at twenty thillings per barrel,

$\frac{2,666 \circ 0}{158,604150}$

Increafed import fince the bounty, 
Imported herrings for home confumption are from Scotland, for foreign ufe from Sweden. The former twenty thillings a barrel. The latter from fourteen to fixteen fhillings. And their own from fixteen to twenty fhillings.

Prices of other forts of fift. Dry ling from eighteen to twenty fhillings per cwt. Salmon from twelve to thirteen pounds per ton. Hake from fourteen to fixteen fhillings per cwt. Dry. cod from fourteen to fixteen fhillings per cwt. Wet cod from fourteen to eighten fhillings per barrel + .

A STATE of the FISHING TRADE of IRELAND, for Nine Years, fince the Commencement of the Bounty, compared with the Nine preceding Years.

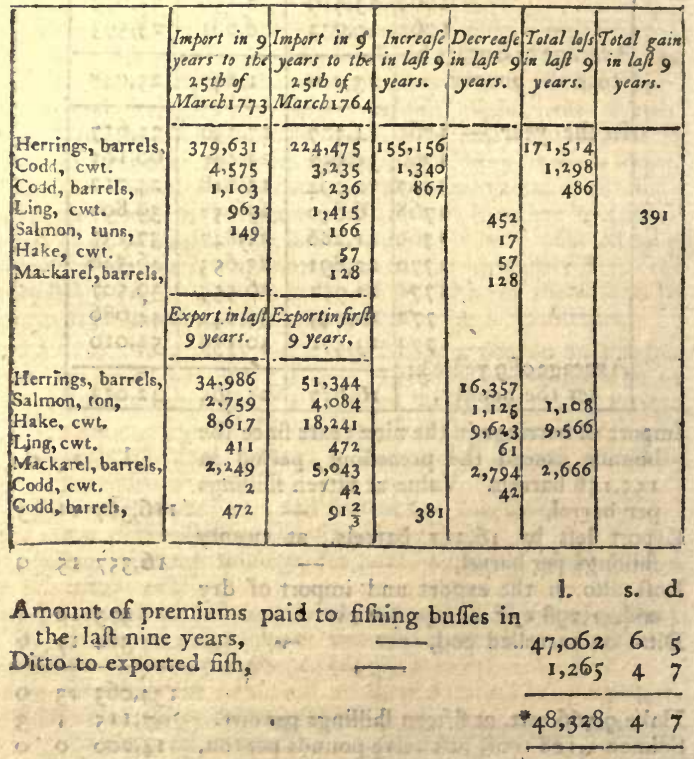

Before I quit this article of Irith fifheries, I thall obferve: that next to the cultivation of land there is no object in their national

+ Manufcript Report Com. communicated by tbe Right Hon, Wilian Eurtoiz. 
rational œconomy of fo much importance. No manufactures, no trade can be of half the confequence to Ireland, that many of her fifheries might prove if encouraged with jndgment. There is no undertaking whatever in which a fimall capital goes fo far; nor any in which the largeft will pay fuclr ample profits. Scotland has the herrings fomcwhat earlier, but they come in good time to Ireland for the Meditcrraneaz trade, and in a plenty that ought to make their capture a favourite object. The bounties hitherto given have been fo far from anfwering that they have in fome refpects done mifchief. I was prefent more than once at the meetings of the firhery committee of the Irith houfe of commons, and I found them making anxious enquiries how to avoid great frauds, from which 1 found that notorious ones had been committed; this is the great misfortune of bounties when they are not given with great judgment and care. Relative to the fiilferies the profit is fo great, that all acquainted with them will engage as far as their capital will admit, whatever bounties are given therefore fhould not be with a view to inftigate men poffeffed of capital, for they do not exift, but to put capitals into the hands of thofe who will certainly make ufe of them. it appeared in the minutes of the Loch Swilly filhery that one boat and the nets fufficient colt 201.; the beft bounty would be to give boats and nets to men ufed to the filhery, becaufe few are able to buy or build them. To give a premium on the export of the herrings or upon the tonnage of the boats will not anfwer, for it fuppofes them actually taken, and built, that is, it fuppofes the very difficulty got over which want of money makes perpetual. Before the boat is in the filhery it muft be built, and before the fifh are exported they muft be taken, thofe who have money to do either will go to work without any bounty, the profit alone being fuficient. In countries fo very poor, the firft fteps in fuch undertakings are the moft difficult; and to affit in overcoming the early difficulties is what the legiflature fhould aim at. Giving boats and nets to men that would certainly ufe them does this, and would be productive of great national good; always fuppofing that frauds and jobbing are guarded againf ; if they are permitted to creep in, as in giving fpinning wheels, the mirchief would be far more than the benefit. 20,000l. per annum thus expended would give 1000 boats, which would foon accumulate to a valt number, and if the effect was fo great as to find the herrings regorge in the home market, then would be the time to drive them out by a bounty on the export, if their owa cheapnefs did not bring the effect without-it. I am far from recommending a new fyftem of bounties upon an objeet that had not received them before, they have been long given or jobbed, all I mean is, that if the public is burthened with fuch payments, care fhould be taken that they are given in the mode that promifes to be molt advantageous. 


\section{E M B A R G O E S.}

OF all the reftrictions which England has at different times moft impoliticly laid upon the trade of Ireland, there is none more obnoxious than the embargoes on their provifion trade. The prohibitions on the export of woollens, and various other articles, have this pretence at leaft in their favonr, that they are advantageous to fimilar manufactures in England; and Ireland has long been trained to the facrifice of her national advantage as a dependant country ; but in refpect to ernbargoes even this fhallow pretence is wanting; a whole kingdom is facrificed and plundered, not to enrich England, but three or four London contractors! a fpecies of men of an odious calt as thriving only on the ruin and defolation of their country. It is well known that all the embargoes that have ever been laji, have been for the profit of thefe fellows, and that the government has not profited a fhilling by them. Whenever the affairs of Ireland come thoroughly to be confidered in England a new fyltem in this refpect muft be embraced. It may not be proper for the crown directly to give up the prerogative of laying them; but it ought never to be exerted in the cafes, and with the views with which we have feen it ufed. The fingle circumftance of facrificing the interefts of $\bar{a}$ whole people to a few monopolizing individuals in another country, is to make a nation the bealts of burthen to another people. But this is not the only point; the intereft of England and of government is equally facrificed, for their object is to have beef plentiful and cheap. But to reduce it fo low by embargoes as to difcourage the grazier, is to leffen the quantity; he increafes his theep or ploughs more, or is ruined by his bufinefs, which neceffarily renders the commodity too dear, from the very circumftance of having been too cheap. A fteady regular good price, from an active demand encourages the grazier fo much, that he will produce a quantity fufficient to keep the price from ever rifing unreafonably high, and government would be better fupplied. Another confideration is the lofs to the kingdom by not taking French money, and fending them to other markets; if it could be proved, or indeed if the fact was poffible, that you could keep their fleets in port for want of Irith beef there would be an argument for an embargo, perhaps, twice in half a century; but when all experience tells us that if they have not beef from Ireland they will get it from Holitein, from Denmark and elfewhere, is it not folly in the extreme to refufe their money, and fend them to other markets. The Dutch were ridiculed in Louis XIV's reign for felling the French, before a campaign, the powder and ball which were afterwards ufed againit themfelves: but they were wife in fo doing, they had not the univerfal monopoly of 
iron and gunpowder, as of fpices, and if they did not fupply the enemy others would, for no army ever yet ftaid at home in the heart of commercial countries for want of powder and ball : nor will a French fleet ever be confined to Breft for want of beef to feed the failors. Embargoes therefore cannot be laid with any ferious views of that fort, but when contracts are made, the contractors gaping for monopoly, raife a clamour, and pretend that no beef can be had if France is ferved, directly or indirectly, and in order to make their bargains fo much the more profitable, government gives them an embargo on the trade of a kingdom (like a lottery ticket to a fund fabfcriber) by way of douceur. 'This conduct is equally injurious to the true interelt of England, of Ireland and of government.

Before I conclude this fection, I muft obferve one circumfance, which though not important enough to ftop the progrefs of commercial improvement in Ireland, yet muft very much retard it, and that is the contempt in which trade is held by thofe who call themfelves gentlemen. I heard a language common in Ireland which if it was to become univerfal, would effectually prevent her ever attaining greatnefs. I have remarked the houfes of country gentlemen being full of brothers, coufins, \&c. idlers whofe beft employment is to follow a hare or a fox; why are they not brought up to trade or manufacture? 'TR $\triangle D E$ ! (the anfwer has been) THEY $\triangle R E$ GENTLEMEN ; - to be poor till doomfday : a tradefman has not a right to the point of honour - you may refufe his challenge. Trinity College at Dublin fwarms with lads who ought to be educated to the loom and the counting houfe. Many ill effects flow from thefe wretched prejudices; one confequence manifeft over the whole kingdom, is commercial people quitting trade or manufactures when they have made from five to ten thoufand pounds to become gentlemen; where trade is difhonourable it will not flourilh, this is taking people from induftry at the very moment they are the beft able to command fuccefs. Many quakers who are (take them for all in all the molt fenfible clafs of people in that kingdom) are exceptions to this folly: and mark the confequence, they are the only wealthy traders in the ifland. The Irifh are ready enough to imitate the vices and follies of England; let them imitate her virtues; her refpect for commercial induftry which has carried her fplendor and her powcr to the remotelt corners of the earth.

\section{S E C T I O N XXII.}

\section{Government-Unich.}

7 HERE never was a jufter idea than that whin I had did not extend to Jreland; the safe of the hereditary revenue 


\section{2 $\begin{array}{lllllllllll}\text { G } & \mathrm{O} & \mathrm{V} & \mathrm{E} & \mathrm{R} & \mathrm{N} & \mathrm{M} & \mathrm{E} & \mathrm{N} & \mathrm{T} & \end{array}$}

was a remarkable infance, but the whole government of that inland is one collective proof of it. The revolution was a moment in which all the forms of government were broken through in order to affert the fpirit of liberty, but Ireland loft that opportunity; meeting fecurity againft the Roman catholics in the victorious arms of king William, the refted fatisfied with a gorernment which fecured her againft the immediate enemy. It is certainly more a government of prerogative than that of England, and the law of the empire, the common law of the land is in favour of that prerogative; hence the abfurdity of proving the rights of Ireland in the details of common law, as Fitzgibbon and Mc. have done. Ireland from diftance and backwardnefs loft thofe fortuitous opportunities which proved fo important to the liberty of England; fhe could not claim the letter of the revolution, but fhe could have claimed the fpirit of it.

The contribution of that territory to the general wants of the empire is in two thapes. 1. By the penfion lift. 2 . By the military eftablifhment. The great liberal line for that kingdom to purfue is to examine not only the prefent amount of thefe articles, but what might be a fair eftimate for the future. To come openly to the Englifh government with an offer of an equal revenue applicable to whatever purpofes government fhould find molt beneficial for the intereft of the whole empire; with this neceffary condition that the military fhould be abfolutely in the power of the crown to remove and employ wherever it plealed. To think of tying down government, to keeping troops in any fpot, is an abfurdity. Government can alone be the judge where troops are moft wanting; it has an unlimited power in this refpect in England, and it ouglit to have the fame in Ireland; the good of the empire demands it. It is the fleet of England that has proved, and muft prove the real defence of Ireland, and that ifland Mould take its chance of defence in common with England. At the fame time any apprehenfions, that they would be left without troops, would be abfurd; fince it would be the king's interelt to keep a great body of forces there, for feveral reafons; among others, the cheapnefs of provifions, which would render their fubfiftence comparatively eafy; alfo, barracks being built all over the kingdom: another point which induce him, is the affiftance their circulation would be of to the kingdom, whereas in England they would be a burthen. But the point might as well be given up chearfully, as to have it carried by a majoricy in parliament. Penfions have been always on the increafe and will be fo; and as to the troops, government carries its point at prefent, and ought to do fo, why not therefore give up the point chearfully for a valuable confideration? As thefe things are managed now, government is forced to buy, at a great expence, the concurreaca of an Irifh parliament to what is really neceffary, would 
would it not be more for the public intereft to have a fixed permanent plan, than the prefent illiberal and injurious fyftcm? The military lift of Ireland, on an averge of the laft feven years, has amounted to 528,544 l. to which add 80,000 l. penfions, and the total makes 608,5441 . Would it not be wife in Ireland to fay to the Britifh government__ "I will pay you a neat feven or eight hundred thoufand pounds * a year, applicable to your annual fupplies, or paying off your debt, and leave the defence of the kingdom entirely to your own difcretion, on condition that I thall never have any military charge or penfions laid on me; the remainder of the revenue to be at the application of my own parliament, for the ufes of interior government only, and for the encouragement of the trade, manufactures and agriculture of the kingdom. That you thall give me a fpecified freedom of commerce, and come to a liberal explanation of the powers of your attorney general, the privy council, and Poyning's act." It would be the beft bargain that Ireland ever made.

If the government was once placed on fuch a footing, the office of lord lieutenant would be that of a liberal reprefentative of majefty, without any of thofe difagreeble confequences which flow from difficulties effentially neceffary for him to overcome; and the government of England having in Ireland no views, but the profperity of that kingdom, would neceffarily be revered by all ranks of people. The parliament of the kingdom would fill retain both importance and bufinefs, for all that at prefent comes before it, would then be within its province, except the military, and complaints of penfion lifts and reftricted commerce. Perhaps the advantages of a union would be enjoyed without its inconveniencies, for the parliament would remain for the civil protection of the kingdom, and the Britifh legiflature would not be deluged by an addition of Irith peers and commoners, one reafon among others, which made the late Earl of Chatham repeatedly dcclare himfelf againft fuch a meafure $t$.

The great object of a union is a free'trade, which appears to be of as much importance to England as to Ireland; if this was gained the ufes of an entire coalition would not be numerous to Ireland; and to England the certain revenue, without the neceflity of buying majorities in parliament, would be a great object. But as to the objections to a union, common in Ireland, I cannot fee their propriety; I have heard but three that have even the appearance of weight; thefe are: 1 . The Vor. II. $\mathrm{N}$

increafe

* I bave mentioned feven bundred iboufand pounds, but tbe fum would depend of courfe on the liberality of the return, a freetrade would be worth purchafing at a much bigher rate.

+ The Earl of Shelburne bas affured me of this fact; nor let me omit to add, that to tbat nobleman I am indeb:ed for the oxtline of the preceding plan. 
increafe of abfentees. 2. The want of a parliament for protection againft the officers of the crown. 3 . The increafe of taxation. To the firf and laft, fuppofing they followed, and were admitted evils, the queltion is, whether a free trade would not more than balance them; they imply the impoverithment of the kingdom, and were objected in Scotland againit that union which has taken place; but the fact has been directly otherwife, and Scotland has been continually on the increafe of wealth ever fince; nay Edinburgh itfelf, which was naturally expected molt to fuffer, feems to have gained as much as any other part of the kingdom. Nor can I upon any principles think, a nation is lofing, who exchanges the refidence of a fet of idle country gentlemen, for a numerous race of induftrious farmers, manufacturers, merchants, and failors. But the fact in the firt objection does not feem well founded; I cannot fee any inevitable neceffity for abfentees increafing; a family might refide the winter at London without becoming abfentees; and frequent journies to. England, where every branch of indultry and ufeful knowledge are in fuch perfection, conld not fail to enlarge the views and cure the prejudices which obftruct the improvement of Ireland. As to taxation, it ought to be confidered as a circumftance that always did, and always will follow profperity and wealth. Savages pay no taxes, but thofe who are hourly increafing in the conveniencies, luxuries, and enjoyments of Jife, do not by any means find taxes fuch a burthen as to make them with for poverty and barbarity, in order to avoid taxation. In refpect to the fecond objection, it feems, to bear nearly as ftrong in the cafe of Scotland, and yet the evil has had no exiftence, the four-courts at Dublin would of courfe remain, nor do I fee at prefent any great protection refulting to individuals from a parliament, which the law of the land does not give; it feems therefore to be an apprehenfion not very twell founded. So much in anfwer to objections; not by way of proving that an entire union is abfolutely neceffary, as without fuch a meafure Ireland wight certainly have great commercial freedom, and pay for it to the fatisfaction of England.

\section{S E C T I O N XXIII.}

General State of Ireland.

$\mathrm{T}$ may not be difadvantageous to a clear idea of the fubject 1 at large, to draw into one view the material facts difperfed in the preceding enquiry, which throw a light on the general ftate of the kingdom, and to add one or two others, which did not properly come in under any of the former heads, that we may be able to have a difinct notion of that degree of profperity which appears to have been, of late years, the inheritance of her rifing induftry.

BUIL D I N S 


\section{$B \quad U$ I $L$}

Thefe improving, or falling into decay, are unerring figns of a nation's increafing grandeur or declenfion: the minutes of the journey, as well as obfervations already made, fhew, that Ireland has been abfolutely new built within thefe twenty years, and in a manner far fuperior to any thing that was feen in it before; it is a fact univerfal over the whole kingdom; cities, towns, and country feats ; but the prefent is the æra for this improvement, there being now far more elegant feats rifing than ever were known before.

\section{$R$ O A D S.}

The roads of Ireland may be faid all to have originated from Mr. French's prefentment bill, and are now in a fate that do honour to the kingdom; there has been probably expended in confequence of that bill, confiderably above a mil lion fterling.

\section{T O W N S.}

The towns of Ireland have very much increafed in the laft twenty years ; all public regifters prove this, and it is a ftrong mark of rifing profperity. Towns are markets which enrich and cultivate the country, and can therefore never depopulate it, as fome vifionary theorifts have pretended. The country is always the moft populous within the fphere of great cities, if I may ufe the expreffion, and the increafed cultivation of the remoteft corners, fhew that this fphere extends like the circulating undulations of water until they reach the moft diftant fhores. . Befides towns can only increafe from an increafe of manufactures, commerce and luxury; all three are other words for riches and employment, and thefe again for a general increafe of people.

\section{RISE OF. RENTS.}

The minutes of the journey fhew, that the rents of land have at leaft doubled in twenty-five years, which is a moft onerring proof of a great profperity. The rife of rents proves a variety of circumitances all favourable; that there is more capital to cultivate land; that there is a greater demand for the products of the earth, and confequently a higher price; that towns thrive, and are therefore able to pay higher prices; that manufactures and foreign commerce increafe; the variations of the rent of land, from the boundlefs and fertile plains of the Miffiffippi, where it yields none, to the province of Holland, where every foot is valuable, fhews the gradations of wealth, power and importance, between the one territory and the other. The prefent rental of Ireland appeared to be $5,293,3121$. and for reafons before given, probably not lefs than fix millions. 


\section{A N U F C T UR E S.}

Linens the great fabric of the kingdom for exportation, have increafed rapidly.

The export from 1750 to 1756 , in value

of cloth and yarn was,

Ditto from 1757 to $176_{3}$,

Increafe,

From 1764 to 1770 ,

Increafe,

From 1771 to 1777 ,

Increafe,

From 1771 to 1777 ,

From 1750 to 1756 ,

Increafe,

Thirty years fince 1748 greater than thirty years before, by
1.

1.

\section{O M M E R C E.}

Trade in Ireland, in all its branches, has increafed greatly in twenty-five years; this has been a natural effect from the other articles of profperity already enumerated.

1.

The Irifh exports to Great-Britain, on an average of twenty-five years before 1748 , were, Ditto on twenty-five years fince, 438,665 965,050

Increafe, 526,385

This greateft article of her trade has therefore more than doubled.

Export to Great-Britain per annum for the laft feven years, The preceding feven years,

I, 240,677 917,088

323,569

The 
The greateft exports of Ireland, on an average of the laft feven years, are

Linen,

The product of oxen and cows, Ditto of theep, Ditto of hogs, Ditto of corn

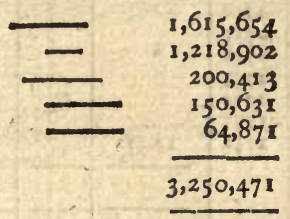

Her total exports are probably three millions and a half. The balance of trade in her favour muft be above a million.*

\section{O N S U M P T IO N.}

A people always confume in proportion to their wealth, hence an increafe in the one marks clearly that of the other. The following table will thew feveral of the principal articles of Irih confumption.

rears.

* Mr. Gordon, furveyor general of Munfer, favoured me with an account of the trade which made the total exports in 1772 to amount to

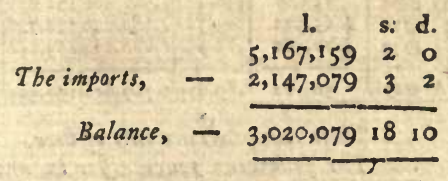

But the above table clearly proves that this is exaggerated, for tbe exports not included in my account can never amount to two millions.

If ber balance, bowever, was not above a million, it would be impofible for ber to pay $800,000 \%$ in abfentees and penfions, befides offices, intereft of money, Ecc. छ'c. to do that, and yet increafe as fbe bas done in wealth, it fbould be near $1,200,000 l$. 


\begin{tabular}{|c|c|c|c|c|c|c|c|}
\hline rears. & $\begin{array}{l}\text { Beer, ale and } \\
\text { porter barrels, } \\
\text { at } 3^{2} \text { gallons, }\end{array}$ & $\begin{array}{l}\text { Brandy, } \\
\text { gallins. }\end{array}$ & $\begin{array}{l}\text { Rum, } \\
\text { gallons. }\end{array}$ & $\begin{array}{l}\text { Sugar, } \\
\text { Muforov. }\end{array}$ & $\tau_{e a}$, lbs. & Tobaccs, $1 b_{s}$ & $\begin{array}{c}\text { Wine, } \\
\text { tons. }\end{array}$ \\
\hline $\begin{array}{l}1750 \\
1751 \\
1752 \\
1753 \\
1754 \\
1755 \\
1756\end{array}$ & $13,57^{2}$ & & $\begin{array}{l}439,302 \\
700,905 \\
513,266 \\
784,945 \\
987,122 \\
507,864 \\
815,887\end{array}$ & & $\mid \begin{array}{l}179,641 \\
130,306 \\
191,566 \\
140,465 \\
166,558 \\
199,938 \\
163,693\end{array}$ & \begin{tabular}{|l} 
\\
$* 3,574,037$ \\
$* 4,154,203$ \\
$* 3,424,359$
\end{tabular} & \\
\hline & . & & 678,470 & & 167,451 & & \\
\hline $\begin{array}{l}1757 \\
1758 \\
1759 \\
1760 \\
1761 \\
1762 \\
1763\end{array}$ & $\begin{array}{l}10,949 \\
15,222 \\
16,517 \\
13,500 \\
18,837 \\
18,007 \\
22,099 \\
\end{array}$ & & $\mid \begin{array}{r}511,682 \\
534,692 \\
820,915 \\
249,197 \\
341,97 \\
656,531 \\
691,027\end{array}$ & & 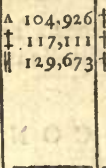 & $\begin{array}{r}+4,769,975 \\
+4,95^{8}, 721 \\
+3,662,246\end{array}$ & \\
\hline & $1^{6,447}$ & & 543,717 & & & & \\
\hline $\begin{array}{l}1764 \\
1765 \\
1766 \\
1767 \\
1768 \\
1769 \\
1770\end{array}$ & $\begin{array}{l}28,935 \\
27,787 \\
32,440 \\
29,487 \\
40,542 \\
45,452 \\
38,439\end{array}$ & $\begin{array}{l}6_{57}, 037 \\
757,105 \\
651,943 \\
770,319 \\
685,661 \\
420,584 \\
437,437\end{array}$ & $\begin{array}{r}913,120 \\
1,230,840 \\
1,480,697 \\
1,667,540 \\
1,873,273 \\
2,100,419 \\
1,640,791 \\
\end{array}$ & $\begin{array}{l}167,011 \\
129,331 \\
133,249 \\
133,829 \\
181,924 \\
183,337 \\
183,245\end{array}$ & \begin{tabular}{|}
204,891 \\
236,908 \\
297,988 \\
183,267 \\
239,800 \\
$1,007,693$ \\
$1,130,486$ \\
\end{tabular} & $\begin{array}{l}5,725,777 \\
4,431,801 \\
6,049,270 \\
4,083,379 \\
4,346,769 \\
4,84^{2}, 197 \\
5,445,94^{2}\end{array}$ & $\begin{array}{l}4,685 \\
6,416 \\
5,938 \\
5,683 \\
5,786 \\
5,870 \\
5,129\end{array}$ \\
\hline Average, & 34,726 & 525.726 & $1,55^{8}, 097$ & ${ }_{158,846}$ & $471,57^{6}$ & $4,988,162$ & 5,643 \\
\hline $\begin{array}{l}1771 \\
1772 \\
1773 \\
1774 \\
1775 \\
1776 \\
1777\end{array}$ & $\begin{array}{r}44,104 \\
47,735 \\
58,675 \\
51,995 \\
53,906 \\
+65,922 \\
+70,382 \\
\end{array}$ & $\begin{array}{l}708,011 \\
374, r_{44} \\
310,025 \\
395750 \\
556,133 \\
403,706 \\
479,996\end{array}$ & $\begin{array}{l}2,035,388 \\
1,973,731 \\
1,704,557 \\
1,503,086 \\
1,322,506 \\
1,888,068 \\
1,680.233\end{array}$ & $\begin{array}{l}176,924 \\
188,260 \\
201,109 \\
171,347 \\
205,858 \\
238,746 \\
193,25^{8}\end{array}$ & $\begin{array}{r}913,296 \\
741,762 \\
839,218 \\
1,207,764 \\
1,041,517 \\
680,526 \\
704,221 \\
\end{array}$ & \begin{tabular}{|l}
$5,012,979$ \\
$5,5^{2} 5,849$ \\
$5,231,714$ \\
$5,434,9^{2} 4$ \\
$3,949,740$ \\
$5,379,405$ \\
$3,916,409$
\end{tabular} & $\begin{array}{l}4,948 \\
4,63 \\
5,425 \\
5,709 \\
4,698 \\
4,521 \\
4,646\end{array}$ \\
\hline Average, & 56,102 & $1 / 89,67$ & 652 & 2196,500 & 875,472 & $4.921,572$ & 4.941 \\
\hline
\end{tabular}

$+T$ befe truo years are only of beer.

$\$$ The following years differ in anotber account, Com. Jour. vol. 14 . p. 141 .

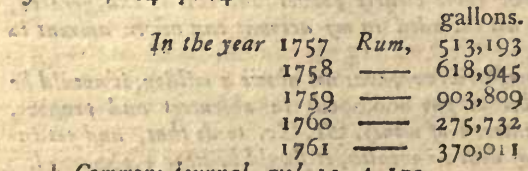

+ Commons journal, vol. 11. p. 179 .

H Ibid. p. 180.

$\ddagger$ lbid. p. 169 .

* 1bid. p. 169.

A Commons journals, vol.p. 318, 
The articles of beer, rum, and fugar, are greatly increafed; tea quadrupled; wine having leffened, is certainly owing to the increafed fobriety of the kingdom, which nuft have made a difference in the import. The imports of tilks and woollen goods given on a former occafion, fpoke the fame language of increared confumption.

\section{S P E C I E.}

The fpecie of Ireland, gold and filver, is calculated by the Dublin bankers at $1,600,0001$.

\section{P O P U I T I O N,}

This article, which in fo many treatifes is reckoned to be the only object worth attention, I put the laft of all, not as being unimportant, but depending totally on the preceding articles. It is perfectly needlefs to fpeak of population, after thewing that agriculture is improved, manufactures and commerce increafed, and the general appearance of the kingdom carrying the face of a rifing profperity; it follows inevitably from all this, that the people muft have increafed; and accordingly the information, from cne end of the ifland to the other, confirmed it : but no country fhould wifh for population in the firft inftance, let it flow from an increafe of induftry and employment, and it svill be valuable; but population that arifes, fuppofing it poffible, without it, fuch a caufe would, inftead of being valuable, prove ufelefs, probably pernicious: population therefore, fingly taken, ought never to be an enquiry at all ; there is not even any ltrength refulting from numbers without wealth, to arm, fupport, pay, and difcipline them. The hearth tax in 1778 produced 61,6461 . which cannot indicate a lefs population, exceptions included, than three miltions. The minutes of fouls, per cabbin, at Cafte Caldwell, Drumoland, and Kilfane, gave 6 and $6 \frac{x}{2}$.

Upon the whole, we may fafely determine, that judging by thofe appearances and circumftances which have been generally agreed to mark the profperity or declenfion of a country, that Ireland has fince the year $174^{8}$ made as grcat advances as could poffibly be expected, perhaps greater than any other country in Europe

Since that period her linen exports have juft TREBLED.

Her general exports to Great Britain more than DOU BLED.

The rental of the kingdom DOUBLED.

And I may add, that her linen and general exports have increafed proportionably to this in the laft feven years, confequently her wealth is at prefent on a like increafe. 


\section{$\begin{array}{lllllllll}\text { S } & \text { E } & \text { C } & \text { T } & \text { I } & \text { O } & \mathrm{N} & \text { XXIV. }\end{array}$}

State of Ireland, brought down to the End of the Year 1779-Difireffes - Free Trade-Obfervations - Armed Ajociations.

THE preceding fections have been written near a twelve1 month, events have fince happened which are of an importance that will not permit me to pafs them by in filence, much as I wifh to do it. The moment of national expectation and heat is feldom that of cool difcuffion. When the minds of men are in a ferment, queftions originally fimple, become complex from forced combinations. To publifh opinions, however candidly formed, at fuch times, is a molt unpleafant bufinefs, for it is almoft impoffible to avoid cenfure; but as a dead filence upon events of fuch importance would look either like ignorance or affectation, I thall lay before the reader the refult of my own refearches.

Upon the meeting of the Irith parliament in October laft, the great topic which feemed to engrofs all their attention was the diftrefs of the kingdom and the remedy demandedA free trade. In the preceding papers Ireland exhibits the picture of a country, perhaps the moft rifing in profperity of any in Europe, the data upon which that idea was formed, were brought down to Lady-day ${ }^{1778}$. I mult therefore na* turally enquire into the circumftances of a fituation which feems to have changed fo fuddenly, and to fo great a degree. I have taken every meafure to gain whatever proofs I could of the real declenfion in Ireland during this period, and I find the circumitance of the revenue producing fo much lefs than ufual, particularly infifted on, the following is the fate of it.

The greatelt declenfion is in thefe articles:

\begin{tabular}{|c|c|c|c|c|}
\hline years, & 10 & 1777 & $177^{8}$. & 1779. \\
\hline & & & 1. & \\
\hline ulto & 248,491 & 251,055 & $198,55^{\circ}$ & 165,802 \\
\hline Cultoms out & $4^{2}, 4^{88}$ & 35,883 & 36,027 & 31,717 \\
\hline Import excife, & 152,238 & 153,727 & 131,284 & 106,070 \\
\hline Wine, firft, & 15,825 & 16,124 & 13,497 & 8,933 \\
\hline
\end{tabular}

The totals are as follow, including the hereditary revenue, old and new additional duties, ftamps, and appropriated duties.

\begin{tabular}{l|c|c|c|c|} 
In the years, & $\frac{1776 .}{1 .}$ & $\frac{1777 .}{1 .}$ & $\frac{1778:}{1 .}$ & $\frac{1779}{1 .}$ \\
Totals, & $1,040,055$ & $1,093,881$ & 968,683 & 862,823
\end{tabular} \mid

The 
The total decline in the laft year amounts to about one hundred thoufand pounds, and from the particulars it appears to lie on the import account ; for as to the fall of five thoufand pounds on the export cuftons, it is very trivial, thofe diftreffes which have, by affociations or naturally, fo immediate an effect in cutting off the expences of importation, while exports remain nearly as they were, have a wonderful tendency to produce a cure the moment the difeafe is known; for that balance of wealth, arifing from fuch an dccount, muft animate every branch of induftry in a country, whofe greateft evil is the want of capital and circulation.

Generally fpeaking, a declining revenue is a proof of declining wealth; but the prefent cafe is fo trong an exception, that the very contrary is the fact; the Irifh were very free and liberal confumers of foreign commodities; they have greatly curtailed that confumption, not from poverty, for their exports have many of them increafed, and none declined comparably with their imports, circumftances marked by the courfe of exchange being much in their favour, as well as by thefe and other accounts; this liberal confumption being leffened from other motives, they are neceffarily accumulating a confiderable fuperlucration of wealth, which in fpite of fate will revive their revenues, while it increafes every exertion of their national induftry.

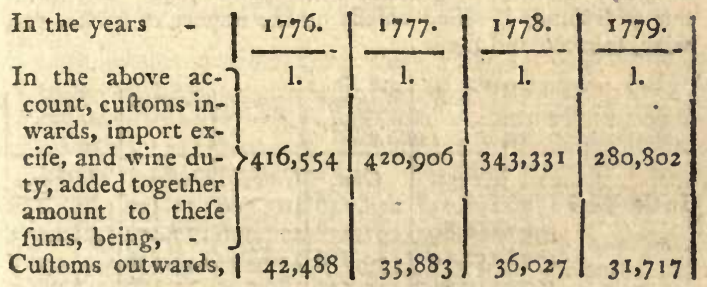

From 1777 to 1778 , the cuftoms on their exports increafed, but their cuftoms on imports declined above 77,0001. From 1778 to 1779 the former fell 4,3101 . or more than a ninth, at the fame time the import duty fell $6_{3}, 0001$. or a fifth; this difference in thefe articles is very great, and if all the heads of the revenue were included, it would be more fill.

It is not furprizing that the national debt fhould increafe while the revenue declines. At lady-day 1779 , it amounted to $1,062,5971$. which is more than in 1777 , by 237,1711 .

But the decline of the revenue has by no means been general, as will be feen by the following table of articles, which have been upon the rife. 


\begin{tabular}{l|r|r|r|r|} 
In the Years, & \multicolumn{1}{c}{1776} & 1777 & 1778 & 1779 \\
\hline Ale licences, - & \multicolumn{1}{c|}{1.} & \multicolumn{1}{c}{1.} & \multicolumn{1}{c}{1.} & \multicolumn{1}{c|}{1.} \\
Wine and ftrong wa- & 7,272 & 7,182 & 7,363 & 7,511 \\
ter ditto, & 19,563 & 19,984 & 20,823 & 20,298 \\
Hearth money, - & 60,966 & 60,580 & 61,646 & 60,617 \\
Tea duty refidues, & 4,404 & 4,590 & 7,300 & 5,747 \\
Tobacco, & 58,046 & 51,453 & 47,698 & 52,558 \\
Strong waters, third, & 5,659 & 18,586 & 18,782 & 18,233 \\
Stamps, - & 19,725 & 20,784 & 21,174 & 21,316 \\
Hops, - & 2,141 & 3,984 & 2,427 & 4,012
\end{tabular}

All of which, except the article of ftamps, are laid upon the great confumption of the common people; whatever diftrefs, therefore, is marked by a falling revenue, the lower claffes do not feem, fortunately, to have fuffered proportionably with the higher ones. But let us farther enquire how far the declenfion of revenue is owing to an increafe of poverty; and how far to a forced artificial meafure, that of affociations for non-import. Thefe have been very general in Ireland during 1779, and mutt have had a confiderable effeet. In order to underftand the queftion, the facts themfelves muft be feen; the following tables will explain them. The revenue of Ireland, is raifed chiefly on the import of fpirits, tea, wine, tobacco and fugar.

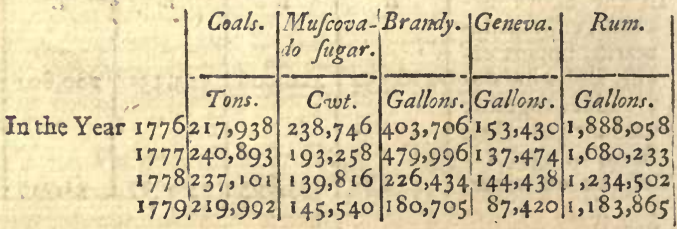

\begin{tabular}{|c|c|c|c|c|}
\hline & $\begin{array}{l}\text { Tea. } \\
\text { Bohea. }\end{array}$ & $\begin{array}{c}\text { Tea. } \\
\text { Green. }\end{array}$ & $\begin{array}{l}\text { Wines of } \\
a^{\prime} l \text { forts. }\end{array}$ & Tobacco. \\
\hline & & & & \\
\hline $17{ }^{2}$ & $308,55^{8}$ & $.371,968$ & & \\
\hline & 35 & 34 & 5 & \\
\hline & $\begin{array}{l}330 \\
402\end{array}$ & $\begin{array}{l}479,115 \\
375,269\end{array}$ & & $\begin{array}{l}3,029,0 \\
4,038,4\end{array}$ \\
\hline
\end{tabular}

The great decline is in fpirits and wine. Tea has not fallen upon the whole; and tobacco in 1779 is fuperior to 1778. Sugar fince 1776 is much fallen, but from 1778 to 1779 there is a rife. Coals are tolerably equal. The ftrongeft circum- 
ftance is that of wine, which has fallen very greatly indeed. The principal caufe of the decline of the revenue is to be found in thefe imports. The remark I made before feems to be ftrongly confirmed, that the diftrefs of Ireland feems more to have affected the higher than the lower claffes; wine, green tea and brandy, are fallen off confiderably, but tobacco, bohea tea, and mufcovado fugar, are increafed from 1778 to 1779 This is ftrongly confirmed by the import of loaf fugar having falling while mufcovado has rifen : the loaf in 1776 is $8,907 \mathrm{cwt}$. in 1777 it is $15,928 \mathrm{cwt}$. in 1778 it is $12,365 \mathrm{cwt}$. but in 1779 it is only 5,931 cwt. Other inftances may be produced : imported millenery, a mere article of luxury for people of fafhion, has fallen greatly : Englifh beer, confumed by the better ranks, declines much, but hops for lrifh beer, which is drank by the lower ones, has rifen exceedingly.

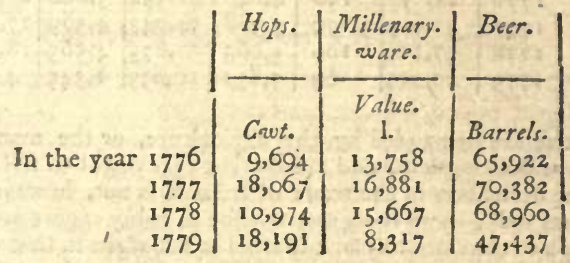

From this circumftance I draw a very ftrong conclufion, that rents are not paid as well as they ought, and that tenants and agents make a pretence of bad times to an extent far beyond the fact. The common expreffion of bad times does fome mifchief of this kind in England, but in Ireland it is much more effective, efpecially in excufes fent to abfentees inftead of remittances.

The great decline of the import of Britilh manufactures and goods, which is remarkable, muft be attributed to the non-import affociations bearing particularly againft them; they have dropped fo much, that we may hope the Irifh manufactures, they have interfered with, may have rifen in confequence,

\begin{tabular}{|c|c|c|c|c|}
\hline & $\begin{array}{c}\text { New } \\
\text { drapery. }\end{array}$ & $\begin{array}{c}\text { Old } \\
\text { drapery. }\end{array}$ & Muflin. & $\begin{array}{c}\text { Silk } \\
\text { manufac. }\end{array}$ \\
\hline $\arg 17$ & $r d s$ & $r d s$ & $r d s$ & 16. \\
\hline 1777 & 731,8 I 9 & $\begin{array}{l}290,215 \\
381,330\end{array}$ & $\begin{array}{l}110,55^{2} \\
162,663\end{array}$ & $\begin{array}{l}17,3<0 \\
24,187\end{array}$ \\
\hline 1778 & 741,426 & 378,077 & 121,934 & 27,223 \\
\hline 1779 & 270,839 & I 76,196 & 44,507 & 15,794 \\
\hline
\end{tabular}


In moft of thefe articles we find fuch a decline of import, that there is no wonder the revenue fhould have fuffered. If it is faid, that this decreafed import is to be attributed to a preceding poverty, it will only throw back the period of enquiry into the years difcuffed in a preceding fection, and from which no national decline can by any means be deduced.

Some articles of import, however, contain fuch a decline, as induces me to think there muft be more diftrefs than appears from others. The following are the objects I fix on.

\begin{tabular}{|c|c|c|c|c|c|c|}
\hline & $\begin{array}{l}\text { Flax- } \\
\text { Seed. }\end{array}$ & $\begin{array}{l}\text { Hemp- } \\
\text { Seed. }\end{array}$ & $\begin{array}{c}\text { Clover- } \\
\text { Seed. }\end{array}$ & $\mid \begin{array}{c}\text { Raw. } \\
\text { Silk. }\end{array}$ & $\begin{array}{l}\text { Cotton } \\
\text { Wool. }\end{array}$ & $\begin{array}{l}\text { Mohair } \\
\text { Yarn. }\end{array}$ \\
\hline & & $H$ & & & & \\
\hline 377 & 24,0 & 150 & $4^{8}$ & 41 & 3,860 & \\
\hline & 32,613 & 559 & 5, & & 4,569 & 27 \\
\hline & 37,211 & 106 & 5,664 & 51 & 4,565 & 18,327 \\
\hline & $20,4^{19}$ & 69 & 3,852 & & 1,3 & $4,55^{2}$ \\
\hline
\end{tabular}

There are demanded by the agriculture, or the manufactures of the kingdom, and are the latt that ought to fall.

The declenfion in the trade of Ireland is not, however, in imports only, there is a great decline in many export articles, enough to convince any one that all is not right in that country; the following particulars will fhew this.

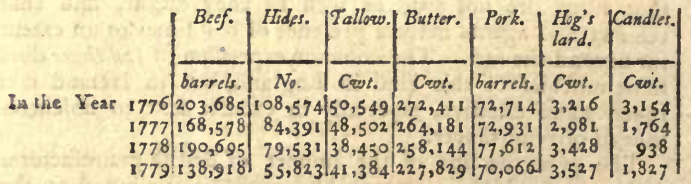

It is fome confolation that hogs have not experienced the declenfion which has attended oxen and cows. The article beef puzzles me. I have been informed, that for thefe two years, all government contracts for beef, \&c. have not been entered on the cuftomhoufe books, by an order of Mr. Gordon, the furveyor general; if this is the fact it accounts for the heavieft articles in this declenfion. The circumftance that the export of ox horns has fcarcely declined at all; that the export of ox guts has greatly increafed, and that glew has rifen, would juftify one in fuppofing that fomething of this fort mult bave affected the accounts of beef, \&c. 


\begin{tabular}{|c|c|c|c|}
\hline & Ox borns. & Ox guts. & Glew. \\
\hline & Cwt. & Barrels. & Cwt. \\
\hline In the year 1776 & 577 & 141 & 1,025 \\
\hline $\begin{array}{l}1777 \\
1778\end{array}$ & 338 & 243 & 1,215 \\
\hline $\begin{array}{l}1778 \\
1779\end{array}$ & 928 & 171 & 1,127 \\
\hline 1779 & 890 & 350 & $1,154^{*}$ \\
\hline
\end{tabular}

I need not obferve, that the greateft export of provifions from Ireland by far is to Great Britain, efpecially in time of war: now the accounts which have been laid on the table of our houfe of commons do not admit the fame conclufions as the Irifh accounts, owing probabiy to fome circumftances with which we are not fully acquainted, if not to the identical one I have mentioned. The following particulars are extracted from the accounts brought in by Lord North.

IMPORTS FROM IRELAND.

\begin{tabular}{|r|c|c|c|c|}
\hline & $\begin{array}{c}\text { Value of } \\
\text { beef. }\end{array}$ & $\begin{array}{c}\text { Value of } \\
\text { butter. }\end{array}$ & $\begin{array}{c}\text { Value of } \\
\text { tallow. }\end{array}$ & $\begin{array}{c}\text { Value of } \\
\text { pork. }\end{array}$ \\
\cline { 2 - 5 } In the year 1768 & 1. & 1. & 1. & 1 \\
1769 & 55,802 & 173,259 & 52,557 & 28,609 \\
1770 & 51,695 & 149,357 & 45,635 & 18,544 \\
1771 & 64,072 & 236,403 & 44,928 & 22,240 \\
1772 & 48,434 & 204,810 & 17,419 & 25,504 \\
1773 & 45,364 & 229,528 & 43,230 & 30,198 \\
1774 & 46,064 & 211,152 & 38,247 & 21,836 \\
1775 & 50,299 & 245,624 & 46,398 & 40,358 \\
1776 & 95,194 & 237,926 & 48,072 & 42,737 \\
1777 & 106,915 & 274,535 & 41,695 & 29,575 \\
1778 & 106,202 & 210,986 & 39,209 & 37,981 \\
\hline
\end{tabular}

As far as this account comes, for the year 1779 is not in it, here is almoft every appearance of increafe, or at leaft the decline where there is any, is much too inconfiderable to found any conclufions on. Let us examine manufacured exports from the fame account.

* The preceding tables in this fecion are taken from a $M S$. account of exp. and imp. communicated by W'illiam Eden, ESg. 


\begin{tabular}{|c|c|c|c|c|c|c|c|}
\hline \multirow[t]{2}{*}{ ' } & & \multicolumn{2}{|c|}{ Linen. } & \multicolumn{2}{|c|}{ Linen yarn raw. } & \multicolumn{2}{|c|}{ 'Bay yarn. } \\
\hline & & rards. & I Value. & lb. & Value. & Cwt. & Value. \\
\hline In the year & 1768 & $15,249,248$ & 500,778 & $4,794,926$ & $209,77^{8}$ & 21,043 & $47 \cdot 426$ \\
\hline & 1769 & $16,496,271$ & 549,875 & $4,107,478$ & 179,702 & 19,332 & 43 \\
\hline & 1770 & $18,195,087$ & 606,502 & $5,240,687$ & 229,280 & 19,903 & 64 \\
\hline & 1771 & $20,622,217$ & 687,407 & $4,035,756$ & $176,5^{6} 4$ & 18,598 & 94 \\
\hline & 1772 & $19,171,771$ & 639,059 & $3,608,424$ & 157,649 & 14,828 & 33,421 \\
\hline & 1773 & $17,876,617$ & 595,887 & $3,082,274$ & 134,869 & 11,073 & 24 \\
\hline & 1774 & 21,447 & 714,906 & $4,660,833$ & 203,911 & 12,549 & 3 \\
\hline 7 & $\begin{array}{l}1775 \\
1776\end{array}$ & $\begin{array}{l}21,910,171 \\
20,83\end{array}$ & $\begin{array}{l}730,539 \\
698,128\end{array}$ & $\begin{array}{l}4,3^{6} 3,5^{82} \\
3,914,351\end{array}$ & $\begin{array}{l}190,906 \\
171,252\end{array}$ & $\begin{array}{l}13,882 \\
18,091\end{array}$ & $\begin{array}{l}31,294 \\
40,778\end{array}$ \\
\hline & 1777 & $21,13^{2}, 54^{8}$ & 704,418 & $3,198,437$ & 139,931 & 17,897 & 40,269 \\
\hline & 1778 & $18,869,447$ & $628,98 \mathrm{I}$ & $3,788,603$ & 165,751 & 15,053 & 33,870 \\
\hline
\end{tabular}

From hence we find that thefe articles have not fallen off fo much as might from many reafons have been expected. Linen yarn has rifen from 1777 to 1778 confiderably. Cloth has fallen, but not enough to give any alarm. From 1770 to 1771 in linen yarn was almoft as great a fall without any ill effects enfuing. The following table contains the total export from Ireland.

EXPORT OF LINEN, YARN, \&c.

\begin{tabular}{r|r|r|r|} 
& Linen Cloth. & Linen rarn. & Worftedrarn \\
In the year 1776 & $20,502,587$ & 36,152 & 86,527 \\
1777 & $19,714,638$ & 29,698 & 114,703 \\
1778 & $21,945,729$ & 28,108 & 122,755 \\
1779 & $18,836,042$ & 35,673 & 100,939
\end{tabular}

Which does not mark any fuch decline as happened upon the bankruptcy of Mr. Fordyce. It is remarkable from thefe two accounts how great a proportion of the exported linen of Ireland is taken off by England, in the year 1776 it abforbed the whole. Indeed it appears to have more than done it, which apparent error arifes from the Irifh accounts ending at Lady day, and the Englifh ones the 3 ift of December. But in order to explain this bufinefs as much as poffible, I thall in the next place infert the Englifh account of all the exports and imports to and from Ireland. 


\begin{tabular}{|r|r|r|r|}
\hline & $\begin{array}{c}\text { Exports to Ireland } \\
\text { of Englifs mant- } \\
\text { facture, foreignt } \\
\text { goods and merchan- } \\
\text { dize, in and out of } \\
\text { time, and exported } \\
\text { from Scotland. }\end{array}$ & $\begin{array}{c}\text { Goods and } \\
\text { merchandize } \\
\text { imported } \\
\text { from Ireland } \\
\text { to England. }\end{array}$ & $\begin{array}{c}\text { Balance } \\
\text { againf Ire- } \\
\text { land. }\end{array}$ \\
\hline & 1. & 1. & 1. \\
In the year 1768 & $2,248,314$ & $1,226,094$ & $1,022,220$ \\
1769 & $2,347,801$ & $1,542,253$ & 805,548 \\
1770 & $2,544,737$ & $1,358,899$ & $1,185,838$ \\
1771 & $2,436,853$ & $1,547,237$ & 889,616 \\
1772 & $2,396,152$ & $1,416,285$ & 979,867 \\
1773 & $2,123,705$ & $1,392,759$ & 730,046 \\
1774 & $2,414,666$ & $1,573,345$ & 841,321 \\
1775 & $2,401,686$ & $1,641,069$ & 760,617 \\
1776 & $2,461,290$ & $1,654,226$ & 807,064 \\
1777 & $2,211,689$ & $1,639,871$ & 571,818 \\
1778 & $1,731,808$ & $1,510,881$ & 220,927 \\
\hline
\end{tabular}

In the year 1768 , the export and import between Scotland and Ireland is not included, but in the reft it is. This table is drawn from the accounts laid before parliament at the clore of the feffions of $177 \frac{8}{9}$, relative to the valuation here followed of the cuftomhoufe, I fhould remark it has been fuppofed, that the real balance is in favour of Ireland, nothwitliftanding the valuation fpeaks the contrary, and Lord North in December laft gave this as his information to the houfe of commons. But taking the account as it ftands here, it muf evidently appear that the diftreffes which have come upon lreland within the laft year or two, do not in the fmalleft degree originate in her commercial connections with England, for during the laft nine or ten years her balance has grown lefs and lefs. From 1776 to 77 it funk 230,0001.; and from 77 to 78 it fell 350,0001 . If therefore Ireland was profperous while the paid us a balance of 7,8 , and $900,0001$. a year, furely the ought not to be more diftreffed under lefs than a fourth of it? That kingdom muft upon the face of this account have had a fuperlucration of wealth arifing of late years upon this trade to a very great amount. Eut this account does not include the year 1779, of which upon the general payments between the two kingdoms I have no other authority than to mention the courfe of exchange. Mr. Eden obferves (Four letters to the Earl of Carlife) that during the year 1778 and 1779 , the exchange of Dublin on London has varied from $5 \frac{2}{4}$ to $7 \frac{2}{8}$ par is $8 \frac{1}{3}$. October 27,1779 it was at $6:$, which is remarkably low, and proves that Ireland mult have been accumulating wealth through that period. 
The reader will naturally remark, that thefe are all external authorities: fome of them feem to mark a difrefs in Ireland, but others fpeak very. frongly a direa contrary language; it remains to be obferved, that the interior authorities have been much infilted on. It has been afferted, and by very refpectable perfons, that rents have fallen, lands untemanted, prices low*, people unemployed, and poverty univerfal. The misfortune of thefe circumftances when produced as argument, is that they admit no proof. I afk for figures and you give me anecdote: my lord this is ruined the duke of $t$ 'other cannot afford to live at Dublin, the earl of A. has no remittances, Mr. C. has 18,00ol. arrears. This is a repetition of the complaints which the Englifh houfe of commons heard fo much of in 1773 . I am very far from denying them, but only defire that afertions may not be accepted as proofs. They are national complaints when a new fyltem of policy is called for, the palpable confequence of which is, that they are exaggerated-fuch complaints always were, and always will exceed the truth.

Let it not however be imagined, that I contend Ireland fuffers none, or very little diftrels: while we fee very great diftreffes in England we need not wonder that Ireland thould, though in a lefs degree, fuffer likewife. We fee the funds have in a few years fallen 27 per cent. The years purchafe of land reduced from 33 to 23 . The prices of all products fallen from 30 to 100 per cent. Wheat from 75 . to $3 \mathrm{~s}$. a buthel; other grain in proportion. Wool from $18 \mathrm{~s}$. to $12 \mathrm{~s}$. all greatly owing to the fcarcity of money arifing from the high intereft paid for the public loans: I can hardly conceive thofe operations to have drawn money from the channels of industry in every part of this ifland, without likewife affecting our neighbour, much of whofe national induftry was, if not Jupported, at leaft much affifted by Englifh capitals. Therefore, from reafoning, I fhould fuppofe they mult have been fomewhat diftreffed, but the preceding facts will not permit me to imagine, that diftrefs to be any thing like what is reprefented,

* Fanuary 24, 1780. I bave this minute received from my very obliging friend Mr. Bolton (member for Waterford) the following note:

"Butter bas been bere (Waterford) all this winter at 425 . per crut. Pork at the beginning of the winter 23s. to 23s. $9 d$. from that it rofe by degrees, and is now $26 \mathrm{~s}$. $6 d$. per cwet." The butter is very low, lower than for ten years; but pork keeps up its price. At Limerick tbe minutes few that 29s. 3 d. is a very bigh price, and that 125 . was the price only eleven years ago. I am yet in bopes, from an expreflion in Mr. Bolton's letter, to receive the price of otber commodities before the work is entirely finiped at press. 
fented, at the fame time that they thew it is in many articles wearing out even while the complaints are loudeft.

Admitting fome dittrefs, and connecting it with the general ftate of the kingdom rather than peculiarly to the prefent moment, I may be afked to what is it owing ? The preceding fections have been an anfwer to that queftion, but to bring their refult into a very thort compafs I thould here obierve, that the caufes which have impeded the progrefs of Irifh profperity are,

1. The oppreffinn of the catholics, which by loading the induftry of two millions of fubjects have done more to retard the progrefs of the kingdom than all other caufes put together.

II. The bounty on the inland carriage of corn to Dublin, which by changing a beneficial patturage to an execrable tillage at a heavy expence to the public, has done much mifchief to the kingdom, befides involving it in debt.

III. The perpetual interference of parliament in every branch of domettic induftry, either for laying reftrictions or giving bounties, but always doing mifchief.

IV. The mode of conducting the linen manufacture, which by fpreading over all the north has annihilated agriculture throughout a fourth part of the kingdom, and taken from a great and flourifhing manufacture the ufual effect of being an encouragement to every branch of hurbandry.

V. The ftoppage of emigrations for five years which has accumulated a furplus of population, and thereby diftreffed thofe who are rivalled by their ftaying at home $\oint$.

VI. The ill judged reftrictions laid by Great Britain on the commerce of Ireland. which have prevented the general induitry of the country from being auimated proportionably with that of others.

Vot. II.

VII. The

\$ This fingle circumftance is fufficient to account for any diftrefs that may be found in the north. Men who emigrate are from the nature of the circumflance the mof active, hardy, daring, bo!d, and refolute fpirits, and probably the moft mifchievous aljo. The intelligence in the minutes, fpeaks that language; it was ewery year ibe loofe, diforderly, ruortbless fellows tbut emigrated; upon an average of twenty years the number was four or five sboufand; but from tbe great increafing population of ibe country, the number in the four or five years laft pafi, would bave been greater. At any rate bere muft be from twenty-five to forty tbou. fand of the moft diforderly wortbless spirits accumulated, much againft their wills, a! bome, and are fully fufficient to account for wiolente and riots, mucb more for clamour and complaint. 
VII. The great drain of the rents of abfentees eftates being remitted to England, which has an effeet, but I believe not quite fo mifchievous as commonly fuppofed.

Is it upon the whole to be concluded, relative to the pre. fent moment, that the freedom of trade now giving to Ireland, is a wrong meafure? I by no means either think or affert fuch an opinion. In the preceding fections $I$ have repeatedly endeavoured to hew, that no policy was ever more abfurd than the reftrikting fyftem of England, which has been as prejudicial to herfelf as to Ireland; but becaufe a meafure is wife and prudent, is it proper to admit for truths facts which do not appear to be founded? The queltion of political prudence is a queftion only of the moment; but to admit circumftances to fpeak a national declenfion, which prove no fuch thing, is laying the foundation of future deception; it is bringing falfe principles into the political fcience, in a point than which none can be more important, afcertaining the circumftances relative to all future cafes as well as the prefent, which prove the profperity or declenfion of 2 kingdom. And here the reader will, I hope, pardon a digreffion on the conduct of one fet of men in the prefent noife of diftrefs; it is a circumftance in the ftate of Ireland, that fhould make more impreffion upon the country gentlemen of that kingdom than it does: they have united with merchants and manufacturers in the violent cry for a free trade, and they have regularly in parliament promoted all thofe vifionary and expenfive projects fet on foot by interefted people, for giving premiums and bounties, to the amount of above an hundred thoufand pounds a year, and which alone accounts for the whole of that national debt, and declining revente, which will make many new taxes neceffary. The Irith are a grateful and a loyal people, and will not receive this free trade without making a return for it; that can only be in taxation; nay, they already fpeak in parliament of a return. Thus have the country gentlemen of that kingdom been fuch dupes, as to agree to meafures for running themfelves in debt, and have joined in the cry for a favour, which I have thewn cannot be - of any confiderable ufe perhaps for half a century, but for which they are immediately to pay a folid return, and if that return takes the thape of a land tax, they have nobody to thank but themfelves. What I would conclude from this is, and would urge it as a lefion for the future, that it is always for the benefit of the landed intereft TO BE QUIET. Let merchants and manufacturers complain, riot, affociate, and do whatever they pleafe, but never unite with them, reftrain but never inflame them. The whole tenour of the preceding minutes proves that Ireland has flourifhed for thefe laft thirty years to an uncommon degree, I believe more than any coun- 
try in Europe. Was not this enough? Was not this a reafon for being filent and Atill? Why fubmit to a temporary diftrefs, rather than by loud complaints, bring the ftate and fituation of your country into queftion at all? Why demand ufelefs favours in order to pay folid returns? During the whole flow of your profperity what have been the additional burthens laid on you in taxation? Every country in Europe has added to thofe burthens confiderably, England immenfe$1 y$, but you not at all, or to fo trifling an amount as to be the fame thing. Could your moft fanguine hopes picture a more happy fituation? And yet to yourfelves are you indebted for bounties on the carriage of corn, for premiums on corn ftands, for ideal navigations through bogs to convey turf to Whitehaven, for collieries where there is no coal, for bridges where there are no rivers, navigable cuts where there is no water, harbours where there are no hips, and churches where there are no congregationsf. Party may have dictated fuch meafures, in order to render government poor and dependent; but rely on it, fuch a conduct was for their own, not your advantage, as the abfolute neceflity of new taxes will moft feelingly convince you. Thus have you been duped by one fet into meafures, which have impoverifhed the public and burthened you with a debt; and becaufe another defcription of men fuffer a diftrefs, in its very nature temporary, you join in their cry to buy that, which if any good arofe from it, would be theirs $\oint$, while you only are to pay the piper. Henceforward, therefore, execrate, filence, confound, and abath the men, who raife clamours at diftreffes, whether real or imaginary; you know from the progreflive profperity of your country, that fuch cannot be radical; weighty experience has told you alfo, that you may have to pay for relief that goes but imaginarily to others, in giving up your folid gold for their ideal profits. Reflect that the great period of your increating wealth was a time of quiet and filence, and that

$$
\mathrm{O}_{2}
$$

you

I The affertion is not founded on the following cbarge in the national accounts 1779 , thougb one might prefume fomething up sn it:

To the board of firft fruits for building new churches, and rebuilding old churches in fuch parifhes as no divine public fervice has been performed for twenty years palt,

$\oint I$ am well aware of what may be bere faid upon the advantage of landlords being in proportion to the profperity of manufactures and commerce : in gencral it certainly is $\int 0$, and always when things are left to take their natural courfe, but when they rife above tbe tenour of that fmoth quiet current, the conclufiow may not be juft: all the meafures condemned in the text are forced and artificial. 
you did not complain of poverty until you were proved to be a golden object of taxation. Ponder well on thefe facts and be in future filent.

That the meafure of giving freedom to the Irifh commerce is a wife one, I have not a doubt; but I muft own, I regret its not having been done upon principles of found policy, rather than at a time when it can bear the conftruction, true or falfe, of being extorted; and this leads me to one or two obfervations on the armed affociations, which have made too much noife in England.

If ill founded apprehenfions have led the legiflature of Britain to do now what it ought to have done long ago, the effect is beneficial to both countries; but I cannot admit that it is merely giving charity to a furdy beggar, who frightens us by the brandifhing and fize of his crutch. To fuppofe that Great Britain is at the mercy of Ireland, and that an Irilh congrefs may arife, fupported by forty thoufand bayonets, is mere idle declamation; we have the frongeft reafon entirely to reject fuch ideas, becauie it could not poffibly end in any thing but the ruin of Ireland; the very conflict would arreft all that profperity which has been gradually flowing in upon her for thefe thirty years paft, and leave her expofed, a divided $t$, weakencd people, open to the attack of every potent neighbour. What a fenfelefs, military mob, led by men who have nothing to lofe, would wifh or attempt, may be doubted; but that military affociations, officered and commanded by men of the firlt property, who have not named a grievance without redrefs following, and who have experienced more favour from three feffions of the Britifh parliament than from three centuries before.-To fuppofe that fuch men, having every thing to lofe by public confufion, but nothing to gain, would fo entirely turn their back to the moft powerful pleadings of their own intereft and that of their country, is to fuppofe a cafe which never did nor ever will bappen.

Apprehenfions of any extremities are idle, but there is this misfortune in a feries of conceffions, not given to reafon, but to clamour, that they rather invite new demands than fatisfy old ones; and from this circumitance refults the great fuperiority of coming at once to a univerfal explanation, and agreeing either to a union, or to fuch a modification of one, as I ftated in fection XXII.

In the next place let me enquire what degree of relief, (fuppofing the diftreffes of that kingdom to be as they may) will refult from the freedom lately given to the Irifh in refpect to their woollen and American trades, which will naturally lead

+ Thofe who are fo wild as for a moment to conceive an idea of this fort, muf furely have forgot the Roman catholics in that kingdom. It would be eafy to enlarge on this point, but for every reat fon improper. 
me to the queftion, whether any prejudice is likely to refult to England.

Whatever the diftrefs may be in Ireland, it appears that thefe freedoms will not ftrike immediately at the evil, nor bring any confiderable remedy; they are general favours, and not applicable to the diltrefs of the time; this ought to be well underftood in Ireland, becaufe fatfe hopes lead only to difappointment. It was highly proper to repeal thofe reltrictions; but it is every day in the power of the Irith to render to themfelves much more important fervices. In order to convert their new fituation to immediate advantage, they muft eftablih woollen fabrics for the new markets opened to them; thofe already in the kingdom I cannot fuppofe to be exported for this plain reafon-they are rivalled in their own markets by fimilar manufactures from England, I mean particularly fine broad clothes and ratteens; if the Irith $\mathrm{fa}$ brics cannot ftand the competition of ours in the market of Dublin, while they have a heavy land carriage in England, freight, commiffion, and duties on landing; and while the Irifh cloth has a great bounty by the Dublin Society to encourage it, they certainly will not be able to oppofe us in foreign markets, where we meet on equal terms; this removes the expected advantage to new fabrics, which, let me obferve, require new capitals, new eftablifhments, new exertions, and new difficulties to be overcome; and all this in a country where the old eftablifhed and flourifhing fabric could fcarcely be fupported without Englifh credit. It may farther be obferved, that the reafon why that credit and fupport have been given to the linen of Ireland, is its being a fabric not interfering with thofe of Britain, it is a different manufacture, demanded for different purpofes. Had it been otherwife, the fuperiority of Englifh capitals, and the advantage of long eftablifhed $\mathrm{fkill}$ and induftry, would have crufhed the competition of the Irifh linen; as in future they will cruph any competition in woollens if of the fame kinds we manufacture ourfelves. When the capital of Ireland becomes much larger, when new habits of induftry are introduced, and when time has eftablifhed new funds of Akill, then new fabrics may be undertaken with advantage, but it mult be a work of time, and can no more operate as a remedy to prefent evils, than any fcheme of the molt vifionary nature. Their Welt-India trade, I believe, will I believe be of as little fervice; every thing in commeree depends on capital; in order to fend thips freighted with Irith comodities to thofe colonies, reloaded with Weft.India goods, capital and credit are neceffary; they have it not for new trades; the progreffive profperity of the kingdom has increafed all the old branches of their commerce, but they all exhibit a proof that they are ftill cramped for want of greater exertions, which time is bringing. If new 


\section{INTEREST OF BRITAIN.}

fpeculations change the current of old capitals, the advantage may be very problematical; if this is not done new trades will demand new capitals, and I believe it will be difficult to point out three men in the kingdom with an unemployed wealth applicable to new undertakings.

But it is faid that Englifh capitals will be employed; an argument equally ufed to prove the gain of Ireland and the lofs of England; but in fact proving neither one nor the other. If the wealth of England is employed there, it will be for the benefit of England. Before the prefent troubles three fourths of the trade, induftry, and even agriculture of North-America were put in motion by Englifh capitals, but affuredly for our own benefit; the profit was remitted to England, and whenever the fund itfelf was withdrawn, it was to the fame country. Is it for the benefit of Portugal that Englifh factors refide at Oporto? Suppofing the fact fhould happen, that Englifh manufacturers or merchants thould eftablifh factors or partners at Corke or Waterford, to carry on woollen fabrics, I fee not a fhadow of objection; the profit of thofe undertakings would center moft affuredly in England; and if in doing it the Irith were benefited alfo, who can repine? Were not the Americans benefited in the fame manner? That England would fuffer no lofs if this was to happen is to me clear; but I believe Ireland has very little reafon to expect it for many years. I have thewn already that fuch a plan could never be thought of for fuch fabrics as are in Ireland rivalled by Englin goods of the fame fort; if it was to happen it muft be in new fabrics : but let me afk a fenfible manufacturer, whether it would not be eafier for him to eftablifh fuch amidit the long eftablifhed Rill and ing enuity of England, rather than go into a country where the whole muft be a creation; where cheapnefs of provifions, and the habit of fubfifting on potatoes, at fo fmall an expence, would baffle his endeavours for half an age, to make the people induftrious, and where, under that difadvantage, the price of his labour would be as high as in England ?. I have a right to conclude this, feeing the fact in the linen manufacture, throughout the North of Ireland, where the weavers earn on average 1s. 5 d. a day, and where alfo the cheapnefs of provifions proves very often detrimental to the fabric.

As a general queftion, there is nothing more mittaken than dearnefs and cheapnefs of labour. Artizans and manufacturers of all forts are as well paid by the day is in England, but the quantizy of work they give for it, and in many cafes the quality differ exceedingly. Hubandry labour is very low priced, but by no means cheap; I have in a preceding fection hew this, and afferted on experience that two fhillings a day in Syffolk is cheaper than fixpence in Corke. If a Huron would dig for twopence, I have little doubt but it might be dearer than the Irifhman's fixpence. 
If an Englih manufacturer could not attempt an Irih fabric for cheapnefs of labour, what other motive could influence him? Not the price of the raw material, for wool is on an average forty-feven per cent. dearer than in England, which alone is a moft heavy burthen. Other reafons, were the above not fufficient, would induce me to believe on the one hand, that the Irifh will not immediately reap any benefit from Englilh capitals employed in their woollen fabrics; and on the other, that if it was to happen, England would fuftain no lofs. What time may effect is another queftion; Ireland has been fo faft increafing in profperity, that the will gradually form a capital of her own for new trades, and I doubt not will flourifh in them without the leaft prejudice to Britain. Thofe who are apt to think the contrary, cannot confider with too much attention that cafe in poine : NorthBritain, which by means of cheap labour and provifions, has not been able to rival, with any dangerous fuccefs, one fingle Englith fabric, yet has the raifed many to a great degree of profperity; but the has flourifhed in them without injury to us; and her greateft manufactures, fuch as ftockings, linen, \&c. \&c. have grown with the unrivalled profperity of fimilar fabrics in England; if Englifh capitals have been affiftant, have we upon review a fingle reafon to regret it ? The plenty of coals in Scotland is an advantage that Ireland does not enjoy, where fuel is dearer than in England.

But let me fuppofe for a moment, that the contrary of all this was fact, that Englifh capitals would go, that Ireland would grin, and that England would lofe. Is it imagined that the account would ftop there? By no means. Why would Englifh capitals go? Becaufe they could be employed to more advantage; and will any one convince us, that it is not for the general benefit of the empire, that capitals fhould be employed where they will be moft productive? Is it even for the advantage of England, that a thoufand pounds thould here be employed in a fabric at twelve per cent. profit, if the fame could make twenty in Ireland? This is not at all clear; but no pofition is plainer than another, becaufe it is founded on uniform facts, that the wealth of Ireland is the wealth of England, and that the confumption in Ireland of Englifh manufactures thrives exactly in proportion to that wealth. While the great profit of the linen manufacture centers at lalt in England, and while Englifh capitals, and Englifh factors, and partners, have gone to the North of Ireland to advance that fabric, fo much to the benefit of England, what fhadow of an apprehenfion can arife, that other branches of Irifh profperity may arife by the fame means, and with the fame effect? Take into one general idea the confumption of Britifh goods in that kingdom; the interelt they pay us for money; and the remittances from abfentee eftates; and then let any one judge, if they can poffibly increafe in wealth without a valt proportion of every fhilling of that wealth at laft cen- 
tering here. It is for this reafon that I think mylelf the warmelt friend to Britain, by urging the importance of Irifh profperity; we can never thrive to the extent of our capacity till local prejudices are done away, and they are not done'away until we believe the advantage the fame, whether wealth arifes in Rofcommon or in Berkfhire.

Upon the whole it appears, that the Irifh have no reafon to look for relief from this new and liberal fyftem, to any diftrefs peculiar to the prefent moment; the filent progrefs of time is doing that for them, which they are much too apt to look for in ftatutes, regulations and repeals. Their diftrefs will moft affuredly be only temporary. The increafe of wealth, which has for fome time been flowing into that kingdom, will animate their induftry ; to put it in the future is improper, it muft be doing it at this moment, and he is no friend to Britain that does not wifh it may continue in the moft rapid progreffion; in this idea I thall not hefitate to declare, that the freedoms granted to Ireland, whenever they thall take effect to the benefit of that kingdom, will prove the wifeft meafures for enriching this. That all apprehenfions of ills arifing from them are equally contrary to the dictates of experience, and to the conclufions of the foundeft theory. 


\title{
MODES OF AGRICULTURE
}

\author{
RECOMMENDED TO THE
}

\section{GENTLEMEN OF IRELAND.}

HAVING been repeatedly requefted by gentlemen in all H parts of the kingdom, to name fuch courfes of crops as I thought would be advantageous ; I very readily complied to the beft of my judgment with the defire; but as it is neceffary to be more diffufe in explanations than poffible on the leaf of a pocket-book, I promifed many to be more particular in $\mathrm{my}$ intended publication; I fhall, therefore, venture to recommend fuch modes of cultivation as I think, after viewing the greateft part of the kingdom, will be found, moft advantageous.

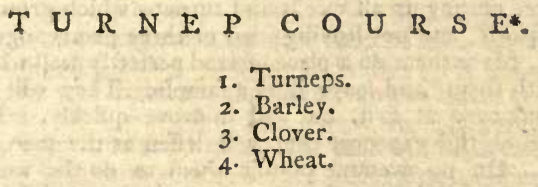

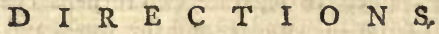

Plough the field once in Oetober into flat lands; give the fecond ploughing the beginning of March; a third in A pril ; a fourth in May; upon this fpread the manure, whatever it may be, if any is defigned for the crop; dung is the beft. About midfummer plough for the laft time. You muft be attentive in all thefe ploughings thoroughly to extirpste all root weeds, particularly couch (tritiam repens) and water grafs; the former is the white root, which is under grouñd, 
ground, the latter, which knots on the furface, and is, if pofible, more mifchievous than the former. Children, with bafkets, thould follow the plough in every furrow to pick it all up and burn it, and as faft as it is done fow and harrow in the turnep feed. The beft way of fowing is to provide a trough, from twelve to fixteen feet long, three inches wide and four deep, made of flit deal half an inch thick, let it have partitions twelve inches afunder, and a bottom of pierced tin to every other divifion, the holes in the tin thould be juft large enough for a feed to fall through with eafe, three of them to each tin; in the middle of the trough two circular handles of iron; the feed is to be put, a fmall quantity at a time, into the bottomed divifions, and a man taking the trough in his hands walks with a fteady pace over the land, fhaking it fideways as he goes: if he guides himfelf by the centers and furrows of the beds, he will be fure not to mifs any land; cover the feed with a light pair of harrows. A pint and half of feed the proper quantity for a plantation acre: the large globular white Norfolk fort, which grows above ground, yields the greateft produce.

As foon as the crop comes up, watch them well to fee if atracked by the fly, and if very large fpaces are quite eaten up, inftantly plough again, and fow and harrow as before. When the plant gets the third or rough leaf, they are fafe from the fly, and as focn as they fpread a diameter of three or four inches is the time to begin to hand hoe them, an operation fo indifpenfibly neceffary, that to cultivate turneps without it, is much worfe management than not to cultivate them at all. Pracure hand hoes frnm England eleven inches wide, and taking them into the field, make the men fet out the turneps to the diftance of from twelve to eighteen inches afunder, according to the richnefs of the foil; the richer the greater the diftance, cutting up all weeds and turneps which grow within thofe fpaces, and not leaving two or three plants together in knots. Make them do a piece of land perfectly well while you are with them, and leave it as a fample. They will be flow and aukward at fir $\mathrm{t}$, but will improve quickly. Do not apprehend the expence, that will leffen as the men become handy. On no account permit them to do the work with their fingers, unlefs to feparate two turneps clofe together, for they will never then underftand the work, and the expence will always be great. Employ hands enoughto finifh the field in three weeks. As foon as they have done it, they are to begin again, and hoe a fecond time to correct the deficiencies of the firt?; and for a few years, until the men become fkilful in the bufinefs, attend in the fame manner to remedy the emiftions of the fecond. And if afterwards, when the turncps are clofed, and excluded all hoeing, any weeds fhould rife and thew themfelves above the crop, children and women fhould be fent in to pull them by hand. 
In order to feed the crop where they grow, which is an effential article, herdles muft be procured; as a part therefore of the fyftem, plant two or three acres of the ftrait timber fally, in the fame manner as for a twig garden, only the plants not quite fo clofe, thefe at two years growth will make very good theep herales, they thould be 6 or 7 feet long and 3 feet high, the bottoms of the upright ftakes fharpened, and projecting from the wattle work 6 inches, they are fixed down by means of ftakes, one ftake to each herdle, and a band of year old fally goes over the two end ftakes of the herdle, and the moveable ftake they are fixed with: the herdles are very eafily made, but the beft way would be to fend over an Irifh labourer to England to become a malter of it, which he would do in a couple of months.

Being thus provided with herdles, and making fome other thift till the fallies are grown, you mutt feed your crop (if you would apply them to the beft advantage) with fat wethers, beginning the middle of November, or firt week in December, and herdling aff a piece proportioned to the number of your Theep, let them live there, night and day, when they have nearly eaten the piece up, give them another, and fo on while your crop lafts: when you come to have plenty of herdles, there fhould be a double row in order to let your lean fheep follow the fat ones, and eat up their leavings; by which means none will be loft. The great profit of this practice in Ireland is being able to fell your fat theep in the fpring when mutton almolt doubles its price. If you fat oxen with turneps they muft be given in theds, well littered, and kept clean, and the bealts fhould have good hay. Take care never to attempt to fatten either bealts or wethers with them that are lean at putting them to turneps; the application is profitable only for animals that are not lefs than half fat.

Upon the crop being eaten there is a variation of conduct founded on circumftances not eafy fully to defcribe, which is ploughing once, twice, or thrice for barley; the foil mut be dry, loofe, and friable for that grain, and as clover is always to be fown on it, it mult be fine, but if the firf ploughing is hit in proper time and weather, the land will be in finer order on many foils than after fuccefive ploughings. The farmer in his field mult be the judge of this : fuffice it to fay, that the right moment to fend the ploughs into a field is one of the mott difficult points to be learned in tillage, and which no inftructions can teach. It is practice alone that can do it. As to the time of fowing the barley in Ireland I fhould mifs no feafon after the middle of Fcbruary if I had my land in order. Sow three quarters of a barrel, or a barrel and quarter of barley to the plantation acre, according to the richnefs of the land, if it had a moderate manuring for turneps, and fed with fat fheep, three quarters or a whole one would be fufficient, but if you doubt your land being in heart, fow one and a quarter. Plough firt, (whether once, twice or thrice) and 
then fow and cover with harrows of middling weight, finifhing with a light harrow. When the barley is three inches high, fow not lefs than 2olb. of red clover to each plantation acre, if the feed is not very good do not fow lefs than $25 \mathrm{lb}$. and immediately run a light roller once over it; but take care that this in a dry day, and when the earth does not ftick at all to the roller. When the barley is cut, and carried from the field, feed the clover before winter, but not very bare, and do not let any cattle be on it in the winter. Early in the fpring before it fhoots pick up the ftones, clean off where you intend mowing it for hay, but if you feed it this is unneceflary. As to the application of che crop for hay or food it mult be directed by the occafions of the farmer; I fhall however remark, that it may be made exceedingly conducive to increafe the number of hogs in Ireland, as it will fingly fupport, all quarter, half, and full grown pigs. If mown it fhould be cut as foon as the field looks reddilh from the bloffoms : it will yield two full crops of hay.

Within the month of October let it be well ploughed, with an even regular furrow, and from half to three quarters of a barrel of wheat feed fown, according to the richnefs of the land, and harrowed well in. When this crop is reaped and cleared the courfe $\epsilon$ nds, and you begin again for turneps as before.

This fyltem is very well adapted to fheep, as the clovet fattens them in fummer, and the turneps in winter.-Excellent as it is for dry foils, it is not adapted to wet ones; the following is preferable.

\section{B E A N C OURS E*.}
1. Beans.
2. Oats.
3. Clover.
4. Wheat.

\section{I R E C T I O N S.}

WHATEVER the preceding crop, whether corn or old grafs, (for the firft manure is properly applied, but unneceffary on the latter) plough but once for planting beans, which fhould be performed from the middle of December to the middle of February, the earlier the better $t$, and chufe either the mazagan or the horfe bean according to your market; the fingle ploughing given muft be performed fo as to arch the land up, and leave deep furrows to ferve as open drains. Harrow the land after floughing. Provide flit planed deal

- For frong and ruet foils.

poles

+ In England it is proper to wait till the beary Chriflmas frolt breaks up, but as fucb are rare in Ireland tbe fame precautian is not necellary. 
poles ten feet long, an inch thick, and two inches broad, bore holes through them exactly at fixteen inches afunder, pafs pack-threads through thefe holes to the length of the lands you are about to plant, and there fhould be a pole at every fifty yards; four itakes at the corners of the extreme poles, faften them to the ground, the intention is to keep the lines every where at equal diftances and frait, which are great points in the bean hufbandry to facilitate horfe hoeing. This being ready, women take fome beans in their aprons, and with a dibber pointed with iron make the holes along the ftrings with their right hand, and put the bean in with their left; while they are doing one fet of lines, ancther fhould be prepared and fixed ready for them. Near London they are paid 3 s. and 3 s. $6 \mathrm{~d}$. a buftel for this work of planting; but where they are not accuftomed to it they do it by the day. The beans are put three inches afunder, and two or three inches deep. A barrel will plant a plantation acre. A light pair of harrows are ufed to cover the feed in the holes, ftuck with a few bufhes. By the time the cold eafterly winds come in the fpring they will be high enough to hand hoe, if they were early planted, and it is of confequence on Prong foils to catch every dry feafon for fuch operations. The hoes fhould be eight inches wide, and the whole furface of the fpace between the rows carefully cut, and every weed eradicated. This hoeing colts, near London, from 5s. to 75 . $6 \mathrm{~d}$. per Englifh acre, but with unfkilful hands in Ireland I fhould fuppofe it would coft from 12s. to 14s. per plantation acre, according to the lazinefs in working I have remarked there. When the beans are about fix inches high, they fhould be horfe hoed with a him, the cutting part ten or eleven inches wide. A plate of this tool is to be feen in my Eaftern Tour. It is cheap, fimple, and not apt to be out of order, one horfe draws it, which thould be led by a careful perfon, another fhould hold the fhim, and guide it carefully in the center between the rows. It cuts up all weeds effectually, and loofens the earth two or three inches deep; in a little time after this operation the hand hoe fhould be fent in again to cut any flips which the fhim might have paffed, and to extract the weeds that grew too near the plants for that tool to take them. This is but a flight hoeing. If the weather is dry enough a fecond horfe hoeing with the thim fhould follow when the beans are nine or ten inches high, but if the weather is wet it muft be omitted, the hand hoe however muft be kept at work enough to keep the beans perfectly free from weeds. Reap the crop as foon as a few of the pods turn darkifh, and while many of them are green, you had much better cut too foon than ton late. You may get them off in the month of Auguft, (in England the mazagans are reaped in July), which leares a fufficient feafon for half a tallow. Plough the ground directly if the weather is dry; and if dry feafons permit (but you mult 
be guided entirely by the ftate of the weather, taking care on this foil never to go on it when wet) give it two ploughings more before winter, leaving the lands rounded up fo as to thoot off all water, with deep and well cleanfed furrows for the winter. It is of particular confequence for an early fpring fowing, that not a drop of water reft on the land through winter.

The firt feafon dry enough after the middle of February, plough and fow the oats, harrowing them in, from three fourths of a barrel, to a barrel and a quarter according to the richnefs of the land. As the fowing muft be on this one ploughing, you mult be attentive to timing it right, and by no means to lofe a dry feafon; cleanfe the furrows, and leave the lands in fuch a round neat thape that no water can lodge; and when the oats are three or four inches high, as in the cafe before mentioned of barley, roll in the clover feed as before, taking care to do it in a dry feafon. I need not carry tlie direction farther, as thofe for the turnep courfe are to be applied to the clover and wheat.

The great object on thefe ftrong and wet foils is to be very careful never to let your horfes go on them in wet weather, and in the forming your lands always to keep them the fegment of a circle that water may no where reft, with cuts for conveying it away. Another courfe for this land is,

1. Beans.

2. Wheat.

In which the beans being managed exactly as before direeted, three ploughings are given to the land, the third of which covers the wheat feed: this is a very profitable courfe.

\section{POTATOE COURSE*.}

1. Potatoes.

2. Wheat.

3. Turneps.

4. Barley.

5. Clover.

6. Wheat.

\section{DIRE C T I O N S.}

I will fuppofe the land to be a ftubble, upon which fpread the dung or compoft equally over the whole field, in quantity not lefs than 60 cubical yards to a plantation. If the land be quite dry lay it flat, if inclinable to wetnefs arch it gently ; in this firft ploughing which fhould be given the latter end of February

- For light and dry foil; potatoes neoer anfwer on clays or frung wet foits. 
February or the beginning of March, the potatoes are to be planted. Women are tolay the fets in every other furrow, at the diftance of 12 inches from fet to fet clofe to the unploughed land, in order that the horfes may tread the lefs on them. There fhould be women enough to plant one furrow in the time the ploughman is turning another, the furrows fhould be not more than 5 inches deeep, nor broader than 9 inches, becaufe when the potatoes come up they fhould be in rows 18 inches afunder. The furrows thould alfo be fraight, that the rows may be fo for horfe hoeing. Having finifhed the field, harrow it well to lay the furface fmooth, and break all the clods, and if the weather be quite dry any time in a fortnight after planting run a light roller over it followed by a light harrow. About a fortnight before the potatoes appear, fhim over the whole furface of the field with one whofe cutting edge is 2 feet long, going not more than 2 inches deep; this loofens the furface mould, and cuts off all the young weeds that may be juft coming up. When the potatoes are three inches high horfe hoe them with a him as directed for beans that cuts 12 inches wide, and go 3 inches deep, and immediately after hand hoe the rows cutting the furface well between plant and plant, and alfo the fpace miffed by the flim. Repeat both thefe operations when the plants are fix or feven inches high; and in about three weeks after give a hand hoeing, directing the men gently to earth up the plants, but not to lay the mould higher to their ftems than three inches. After this nothing more is to be done than fending women in to draw out any weeds that may appear by hand. Take them up the beginning of October, firft carrying away all the ftalks to the farm yard to make dung: then plough them up across the field; making thefe new lands very wide, that is 4,5 , or 6 perch over, in order to leave as few furrows that way as poffible. Provide to every plough from ten to fifteen men with three pronged forks, and a boy or girl with a balket to every man, and difpofe eight or ten cars along the land to receive the crop, I ufed three wheeled carts, as they do not require a horfe while they are idle. Have your wheat feed ready brined, and limed, and the feedfman with his bafket in the field; as foon as the ploughman turns a furrow, the feeds man follows him clofe, fpraining the feed not into the furrow juft opened, but into the land thrown over by the plough, the fork men then divide themfelves at equal diftances along it, and thaking the mould which the ploughman turned over with their forks, the boys pick'up the potatoes. In ufing their forks they muft attend to leaving the land regular and handfome without holes or inequalities, as there is to be no other tillage for the wheat. They are alfo always to ftand and move on the part un ploughed, and never to tread on the other; they are alfo to break all the land in pieces which the ploughman turns over, not only for getting all the potatoes, but alfo for covering the wheat. And 


\section{MANAGEMENT OF LAND}

thus they are to go on till the field is finithed. If your men are lazy, and do not work hard enough to keep the plough conftantly going, you mult get-more, for they thould never ftand fill. The treacment of this wheat wants no directions, and the fucceeding crops of the courfe are to be managed exactly as before directed, only you need not manure for the turneps, if the potatoes had in that refpect juftice done them.

\section{FLA X COUR SE.}

5. Turneps.

2. Flax.

3. Clover.

4. Wheat.

\section{I R E C I O N S.}

This for flax on light and dry foils, the turneps to be managed exactly as before directed, and the remarks on the tillage of the turnep land for barley are all applicable to flax which requires the land to be very fine and friable; I would roll in the clover feed in the fame manner, and the weeding and pulling the flax will affift its growth. - Let the flax be faved and ftacked like corn, threfhed in the fpring, and the procefs of watering and dreffing gone through the lame as in the common way. This hupandry is exceedingly profitable.

1. Beans.

2. Flax.

3. Clover.

4. Wheat.

This for frong foils. The bean land to be prepared for the fax exactly in the fame manner as before directed for oats.

1. Potatoes.

2. Flax.

3. Clover.

4. Wheat.

For any foils except the very ftrong ones. The potatoes to be managed exactly as before directed, only upon taking them up the land to be left till fpring, but if wet no water to be fuffered on it in the winter. In the fpring to apply more or fewer ploughings as will beft enfure a fine friable furface to fow the flax in. 


\section{GENERAL OBSERVATIONS.}

In very ftoney foils, the implement called a fhim cannot be ufed to any advantage; in which cafe the operations directed for it mult be effected by extra hand hoeings. By land I mean thofe beds formed in ploughing by the finifhing open furrows: the face from furrow to furrow is the land.

In ploughing wet foils be attentive to get thefe lands gradually into a right thape, which is a direet fegment of a circle. A large fegment of a fmall circle raifes the centers too high, and makes the fides too fteep; but a fmall fegment of a large circle is the proper form-for inftance.
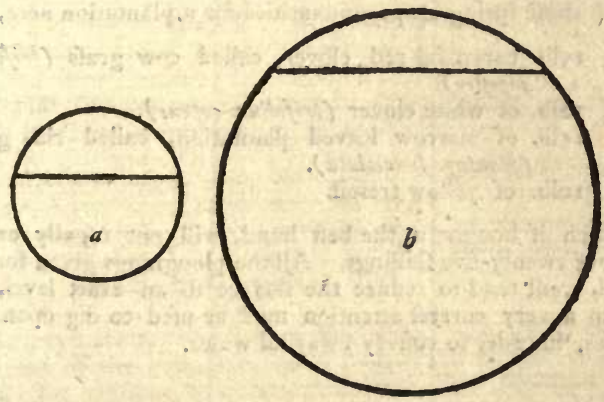

The fegment of $a$ appears at once to be an improper fhape for a broad land, but that of $b$ is the right form; keeping wet foils in that thape very much corrects the natural difadvantages. Permitting the teams to go on to wet foils in wet weather, is a moft mifchievous practice; but it is much worfe in the fpring than in the autumn. In all thefe courfes it is proper to remark, that keeping the fallow crops, that is the turneps, beans and potatoes, abfolutely free from all weeds, and in a loofe friable order, is effential to fuccefs. It is not neceffary only for thofe crops, but the fucceffive ones depend entirely on this conduct. It is the principle of this hußbandry to banifh fallows, which are equally expenfive and ufelefs, but then it is abfolutely neceffary to be affiduous to the laft degree in keeping thefe crops in the utmoft perfection of management, not a fhilling can be laid out on them that will not pay amply.

There are in the preceding courfes feveral refinements and practices, which I not only approve, but have practifed, but omitted here, as I do not think them likely to meet with the neceffary attention in Ireland.

Vol. II. 


\section{LAYING LAND TO GRASS.}

There is no part of hußbandry in Ireland lefs underftood than this branch, and yet where land is to be laid down, none is more important.

Begin according to the foil, with either turneps, beans or potatoes, and manage them as prefcribed in the preceding inftructions. If the land has been long under a bad fyftem, by which it has been exhaufted and filled with noxious weeds; take a fecond crop managed exactly like the firf, but one only to be manured. After this fow either barley, oats, or flax, according to the tenor of the preceding directions, but inftead of clover feed rolled in, harrow in the following feeds, with thofe fpring crops i quantities for a plantation acre,

15lb. perennial red clover, called cow grafs (trifoliume alpeftre).

32lb. of white clover (trifoliuns repens),

15lb. of narrow leaved plantation, called rib grafs 1olb. of yellow trefoil.

Which if bought at the beft hand, will not ufually exceed abote twenty-five fhillings. All the ploughings giver for this end, muft tend to reduce the furface to an exact level, but then a very correct attention muft be ufed to dig open furrows, in erder to convey away all water.
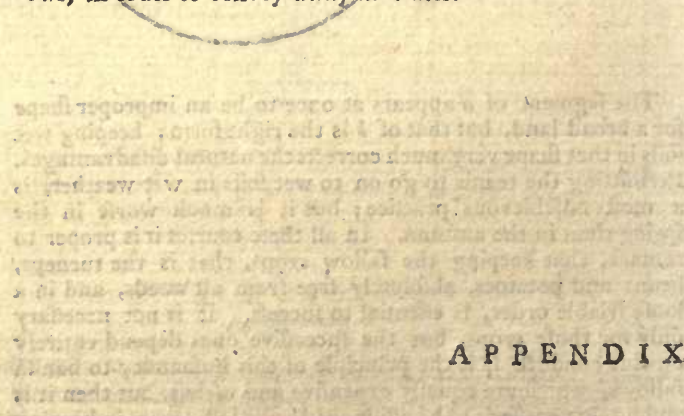


\section{$\begin{array}{llllllll}A & P & P & E & N & D & I & X\end{array}$}

The following particulars were omitted under their refpective heads.

\section{D $\quad E \quad R \quad R \quad$ Y.}

THE fhipping of this place in 1760 confifted of fixty 1 feven fail, from thirty to three hundred and fifty tons.

$$
\begin{aligned}
& 7 \text { of and above } 300 \text { tons, } 18 \text { to } 20 \text { men and boys. } \\
& 2100-14-16= \\
& 18-100-12-14 \\
& 21 \text { under } 100-\begin{array}{r}
10 \\
\text { Total, } 10,820 \text { tons. }
\end{array}
\end{aligned}
$$

In 1776 about two thirds of the above; the decline owing to that of the paffenger trade, and in the import of flaxfeed; for eighteen to twenty years back, two thoufand four hundred perfons went annually, not more in 1772 and 1773 than ufual.

\section{C $\quad \mathrm{O} \quad \mathrm{R} \quad \mathrm{K} \quad \mathrm{E}$.}

I was informed that there was no foundation for Dr. Campbell's affertion, that this city fuffers remarkably in time of war*.

\section{$E \quad X \quad T \quad E \quad N \quad T$.}

Dr. Grew calculated what the real contents of England and Wales were, not at the rate of the geographic mile, but real ftatute fquare, one containing 640 acres, and makes it $46,080,000$ acrest, inftead of the geographic content of 31,648,000. Ireland meafured in the fame manner, contains

$$
P_{2}
$$

about

* Political Surcey of Britain, vol. x. p. 243.

tPbil.Tranf. No. 330, P. 256. 
about twenty-five millions of Englifh acres, or fifteen millions and a half Irith, which at nine fhillings and feven pence an acre; make the rental $7,427,0831$. Thofe who confider this attentively, will not think $I$ am above the truth at fix millions, as all uncultivated bog, mountain and lake, are included in the valuations.

\section{R E $N$ T A L.}

The rental of England is ftated at page 11 of the fecond part to be thirteen fhillings, but it is not accurate to compare that with the $9 s .7 d$. Irioh rent. The latter is the grofs rent of all the inland, including every thing let or not, deductions being made for the portions of lake, bog, river, \&c. But that of England, at $13 \mathrm{~s}$. Only what is occupied by the farmers or landlords, and does not include large rivers, lakes, royal forefts, or common paftures (mountains, bogs, marfhes and moors not to be excluded, as they are parts of the lands let, from which the calculation was made). Upon a very large allowance, if thefe are eftimated at an eighth part of the whole, the account will be $7-8$ ths of England at 13 s. and 1.8 th at nothing, average $11 \mathrm{~s} .4 \mathrm{~d}$. per acre, inftead of $13 \mathrm{~s}$. the comparifon with Ireland then will be,

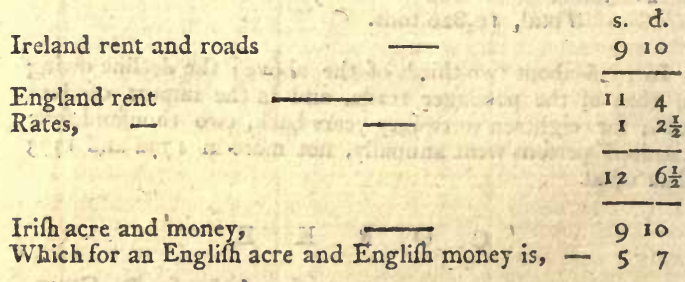

Inftead of which it is $12 \mathrm{~s} .6 \frac{1}{2} \mathrm{~d}$. confequently the proportion between the rent of land in England and Ireland is nearly as five to eleven; in other words that fpace of land, which in Ir eland lets for 5 s. would in England produce $11 \mathrm{~s}$.

DEANERIES OF IRELAND.

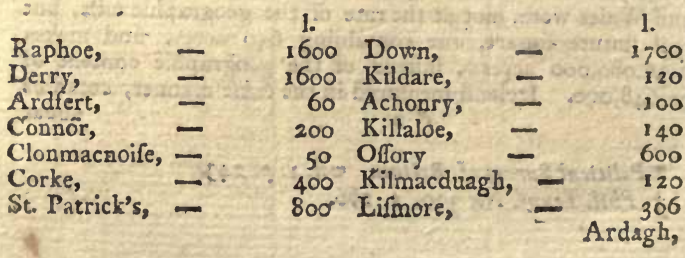




\section{A $\quad$ P $\quad P \quad E-N \quad D$ I $X$.}

\begin{tabular}{|c|c|c|c|c|c|}
\hline Ardagh, & - & 200 & Leighlin, & - & $\begin{array}{l}1 . \\
80\end{array}$ \\
\hline Emly & - & 100 & Ardmagh, & - & 150 \\
\hline & & 600 & Waterford, & - & 400 \\
\hline $\begin{array}{l}\text { Elphin, } \\
\text { ofs. }\end{array}$ & - & 250 & Chrift church, & - & 2000 \\
\hline $\begin{array}{l}\text { Rofs, } \\
\text { Killala, }\end{array}$ & - & 20 & Limerick, & - & 600 \\
\hline Cloyne, & 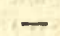 & 220 & Clogher, & I & $\begin{array}{l}200 \\
800\end{array}$ \\
\hline Kilfenora, & - & 210 & Tuam, & - & 300 \\
\hline & & 400 & Fern & - & 300 \\
\hline & & 20 & & & \\
\hline
\end{tabular}

\section{D L L E $N$ N E $\quad S \quad S$.}

La fociedad economica de Dublin ha levantado enteramente de nuevo las lencerias de Irlanda; cuyos habitantes efraban - pofeidos de gran indolencia. Han extendido fu agricultura, en lugar que antes vivian de ganados y paftos, como los tartaros. See the Appendice a la Educacion Popular. Parte Quarta, p. 35. Madrid 1777 , by Campomanes.

\section{FALL IN THE PRICE OF THE PRODUCTS OF LAND.}

Having in the preceding meets, mentioned much diftrefse being felt in England from the great fall in the price of all products, I think I may be pardoned one or two obfervations in defence of opinions I have formerly held, and which then fubjected me to much cenfure from the pens of a variety of pamphleteers:

From the conelufion of the laft peace in 1762 , to 1775 inclufive, the prices of all the produets of the earth were at fo high a price, that complaints were innumerable. I have a thelf in my ftudy almoft full of publications on the fubjeet, and parliament itfelf was employed more than once in enquiring into the caufes. The fuppofitions of the public were endlefs, there was fcarcely an objeet in the kingdom, which was not mentioned as a caufe, jobbers, regrators, foreftallers, fample felling, export bounty, poft horles, Atage coaches, hounds, \&c. \&c. but fome refpectable complainants fixed on great farms and inclofures. During that period I more than once endeavoured to perfuade the public, that the 'complaint itfelf was not well founded, that prices were not comparatively fo high as had been afferted; that the rife was not owing to any one of the caufes mentioned, and that a confiderable increafe of national wealth was fully fufficient to account for it.

In the years 1776,1777 , and 1778 , prices fell confiderably; and in 1779 fo low, that very general complaints have been 
heard of ruined farmers and diftreffed landlords, and at the time I am now writing the fact holds, that there is a very confiderable fall in all products, and great numbers of farmers ruined. I have the prices of wool now for forty years befote me, and that which from $175^{8}$ to 1767 was from 18 s. to $2 \mathrm{Is}$; a tod, is for 1779 only $12 \mathrm{~s}$. and was in 1778 but 14 s. We muft go back to 1754 to find a year fo low as the laft. Wheat and all forts of grain are greatly fallen *

In addition to thefe facts let me obferve, that great farms and cnclofures are now as prevalent as ever. If they were the occafion of high prices before, how come they not to have the fame effect now ? But it is quite unneceffary to dwell upon a fact, which at the firft blufh brings with it the molt complete conviction.

After the peace of $176_{2}$, there was a very great influx of wealth into this kingdom, which had the effect of nominally raifing all prices, not of corn and cattle only, but of land itflf; prices have declined in 1776,1777 , and 1778 , but greatly in 1779. I am very apt to believe, that as the former dearnefs, $2 s$ we called it, was owing to PLENTY of money, the prefent cheapnefs is owing to SCARCITY; not to a fcarcity, generally fpeaking, becaufe there is a proof that the fpecie of the kingdom was never greater than at prefent, but to a fcarcity in thefe innumerable channels, which like the finaller veins and ramifications of the human body, carry the blood to the leaft of the extremities. There is no fcarcity of money in London, as I am informed by feveral very confiderable bankers and merchants, But why is it fo plentiful there? In order to be applied at feven or eight per cent. intereft in public loans. This circumftance it is which collects it from every part of the country, from every branch of national induftry, and which occafons the effect now fo generally complained of, a fall in all prices. The reafon why the farners are ruined, which is really the cafe with numbers, is

The comparifon in general muft frand thus:

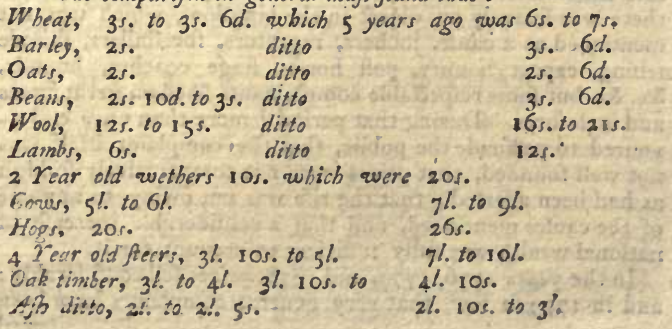


their having taken tenures of their lands at a rent proportioned to high prices; nor is this the only circumitance, labour ought to fall with other commodities, but government having four hundred thoufand men in pay, and confequently to be recruited, pids high in the market againft the farmer. Poor rates alfo ought to fall, but there is fo much folly, knavery, and infatuation, in every part of that abominable adininiftration, that I am not at all furprifed at feeing them rife, which is the fact. Thefe three circumftances eafily account for the ditrefs of the farmer.

We may in future, I apprehend, expect to fee more iccurate ideas of what has been called dear and cheap rates of products, and never more to hear of great farms, engroffers of farms, commanding and monopolizing markets, or enclofures condemned for doing that which we now find them fo utterly incapable of doing, that the farmers are ruined and in gaol for want of the power to effect matters, for which they were before fo execrated. We dt leaft gain fomething, if the prefent experience gives the lie direct to all that folly, nonfenfe and abfurdity, with which the public was fo repeatedly peftered. And there is the more reafon for this, becaufe if fuch a peace fucceeds the prefent war, as leaves us a wealthy and profperous people, prices will affuredly rife, when that folly might again be met with, if not at prefent difplayed ip the true colours.

I know there are perfons, who attribute both the former high, and the prefent low prices, to difference of crops, fpeaking much of plentiful and fcarce years; I have been uniform. ly of opinion, that the difference of product, upon an average of all foils, to be extremely fmall, fo fmall as not to operate upon price; and even upon particular fpots the difference is not nearly fo great, as to account for any confiderable rife or fall. If this was a proper place I could offer many reafons and facts for this opinion; but if we accept the idea, then there is at once an end to great farms and cnclofures as the caufe of the rife, which are the two circumftances the moft infifted on.

"I have lately received an account of a large common field in Leicefterfhire, which ufed to produce annually $800 \mathrm{qrs}$. of corn, befides maintaining 200 cattle, but which now in confequence of being inclofed and getting into few hands, produces little or no corn; and maintains no more cattle than before, though the rents are confiderably advanced." Dr. Price's Supp. to Obf. on Rev. Pay. p. 388. "In Northampton?hire and Liccefterfhire, enclofing has grcatly prevailed, and molt of the new enclofed lordhhips are turned into pafturage, in confequence of which many lordlhips have not now 50 acres ploughed yearly, in which 1500 , or at lealt 1000 werc plough- 
ed formerly; and fcarce an ear of corn is now to be feen in fome that bore hundreds of qrs. and fo feverely are the effects of this felt, that more wheat had been lately fold in thefe counties, on an average, at 75 . and $75.6 \mathrm{~d}$. the Winchefter bufhel, than ufed to be fold at 3s. 6d." Rev. Mr. Addington's reafons againft enclofing open fields. As enclofures have fince proceeded as rapidly as ever-Pray, why is wheat. down at 3 s. 6d. again, if it was enclofing that raifed it to 7 s. $6 \mathrm{~d}$. 


\section{I $\quad \mathrm{N} \quad \mathrm{D} \quad \mathrm{E} \quad \mathrm{X}$.}

Thofe marked thus * refer to the pages in Part II. at the end of Vol. II.

A.

A RDMAGH, i. 158. A Arran (ides) i. 388. Annfgrove, ii. 8. Abfentees, lift of, 82 *. Ardfert, ii. 127. Adair, ii. 135 .

B.

Bogs, 30. 52. 82. 218.241 . 310. 334. 342. 369. 395 . 72. * means of improving, $73 . *$

Ballyfhannon, i. 257.

Belleille, i. 271.

Ballynogh, i. 296.

Ballymoat, i. 310.

Ballyna, i. 344.

Baker, Wynn, i. 20.101*.
Ballynakil, i. 86.

Brownhill, i. 87.

Bargie and Forth, i. 108.

Ballygarth, i. 843 .

Boyne, battle of, i. 145 .

Belfaft, i. 202.

Blarney, ii. 33 .

Beans in Ireland, i. 109.ii. 197.

Bullocks, profit on, ii. $145.75^{\circ}$.

Bifhopricks, value of, $8 \mathrm{I}$ *

Bucks, $113^{*}$.

Bounty on inland carriage of corn, $114^{*} .124^{\circ}$. Its account ftated Dr. and Cr. $134^{*}$. Ill effects, ib. Beef, price of, $127^{\circ}$. Butter, price of, 127 * Ballycanvan, ii. 188. Buildings, $195 *$ 
D.

C. Dublin, inhabitants in, i. 2.

Cellbridge, i. 14 .

Carton, i. 23.

Caftletown, i. 22.

Cars, utility of, i. 40.212. 306. ii. 22.61*.

Courtown, i. 115 .

Cullen, i. 146.

Caftle Ward, i. 201.

Clay, burning of, i. 209.

Colerain, i. $219^{*}$.

Clonleigh, i. 236.

Caftle Caldwell, i. 258.

Carrots, i. 288.

Corn burned inftead of threfhing, i. 350.364 .

Conna Marra, i. 393 .

Corcaffes, i. 407 . ii. 1 .

Caftle Oliver, ii. 7.141.

Caftle Martyr, ii. 46 .

Caftle Mary, ii. 63 .

Corke, Neighbourhood, ii. 65. .75.

Coolmore, ii. 75 .

Climate of Ireland, 3 *.

Cloathing of the poor, $35^{*}$.

Cabbins, 35 *.

Catholicks, ttate of, 43 *.

Clergy, propofed improvements for them, $80 *$.

Coals, import of, $92 *$.

Cotton, import of, $99^{*}$.

Caftle ifand, ii. 121 ,

Candles, price of, $127^{*}$ :

Character of the lrifh, 106 *.

Corn trade, 114 *.

- experted, $120^{*}$.

$\rightarrow$ imported, 122 *.

on itands, 144 ,

Brgught coallways to Dublin, $137 .$.

Cuxraghmore, ii, 176.

Compact with Ireland relative to linens and woolleps, 146 *.

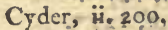

Cullen, ii, 256.

Confumption ${ }_{5}, 97$ *
Lodgings, i. 5. Opera, ib. Dublin fociety, $95^{*}$. Confumption of, 137 *.

Dolleftown, i. 24 .

Dangan, i. 31 .

Drueltown, i. 57 .

Dargle, i. 134 .

Derry, i. 229.

Drumoland, i. 406 .

Donneraile, ii. 18.

Dunkettle, ii. 38 .

Demefnes, 109 *.

Drinking, $110 *$.

Duelling, I $12 *$.

Dawfon court, ii. 214 .

E.

Emigrations, i. 168.203 .42 *.

Eyre Connaught, i. 388.

Extent of Ireland, $2 *$.

Education, 107 *.

Embargoes, 190*.

F.

Forfter, baron, his valt improvement, i. 146.

Flax, culture of, i. 207. 322. 394. 155 *.

Fifheries, i. *219.228. 242 . 244.392, ii. 194. $187^{*}$.

Florence court, 1. 276 .

Farnham, \& 285 :

Families, old, i. $305 \cdot 366$.

Foxford, i. 349 .

French, Mr. his bog improvement, i. 372 .

Food of the poor, 32 *.

Folding theep, it $\mathrm{r}+\%$. .

Turnefs, if. 206:

G.

Gibbftorn, i. 5 I.

Gowry, i. 114 .

Glen of Downs, i. 132 .

Glafslaugir, i. 170.

Giant's caufotray, is * 218 .

Gun 


\section{I $N \quad D \quad E \quad X$.}

Gun liarpoon for whales, Laughlin mills, i. 90. i. $25 \mathrm{x}$.

Grafs, tendency of the foil to, i. 131 .

Gillaroo trout, i. 351 .

Glolter, i. 215 .

Government, 19I*.

H.

Heaúfort, i. 54 .

Hampton, i. 139.

Hillnorough, i. 184.

Hearts of iteel, i. 217.

Horfes drawn by the tail, $i$. 292. 350.

Hollymount, i. 367 .

Hops, ii. 25 .

Hearth-money, exemptions

from, $87^{*}$.

Houfes, I 10*.

Hides, price of, $128 *$.

\section{I.}

Improvement of the kingdom in the laft twenty years,

i. 153. State of, compared with England II *.

Juries, 112 *.

Johnftown, ii. 227.

I.

Killadoon, i. 13 .

Kilfaine, i. 92.

Killrue, i. 137 .

Kington, i. 308.

Kilalla, i. 346 .

Kiltartan, i. 405 .

Kildining, ii. 62 .

Killarncy, ii. 90 .

King borough,Lord, his moun-

tain improvement, 69 *.

\section{L.}

Luttrel's town, i. 6.

Lucan, i. 21 .

Linen manufacture, account of, i 161. 172. 178. 316. 360. 385 .

- export of, $150 *$

- pretended decline in 1773 , $152 *$.

- importto England, 153 *. $161 *$.

Lurgan, i. 175.

Lifburne, i. 185.

Lecale, i. 196.

Leflyhill, i. 218.

Loch Swilly, i. 227.

Loch Earne, i. 268.

Limerick, ii. I.

Living, cheapnefs, ii. 6. 108 *.

Lime, ii. 10. 76. $67^{*}$. Kilns, ii. 25 .

Lota, ii. 65 .

Labour, payment of, 30 . Price of, i. 37.

Lixnaw, ii. 129.

Limerick, grazing, ii. 143 .

M.

Mahon, i. 170.

Magilligan, i. *22r.

Mount Charles, i. 242.

Mercra, i. 327 .

Mules, i. 343. ii. 28.

Moniva, i. $37 \%$.

Mallow, ii. 26.

Marino, i. 4.

Monknewtown, i. 46 .

Mullingar, i. 69 .

Mount Juliet, i. 92.

Mount Kennedy, i. 122.

Mountains, improvement of, i. 141.146 .352 .ii. 76.125 . $69 *$.

Market-hill, i. 156.

Middle men, 17 *.

Mountains, height of, ii. 113 .

Manners, $105^{*}$.

Mahaghrec illands, ii. 127.

Macarthy, of Spring-houfe, 


\section{N D E X.}

his farm the greateft in the Premiums propoled, $\mathrm{xO}_{2}$ *. world, ii. 157.

Mills of Ireland, $14^{1 *}$.

Manufactures, $144^{*}$.

Mitchelftown, ii. 269.

N.

Newrry, i. 155 .

Newtown Stewart, i. 188.

Newtown Limmovaddy,

* 221.

Newgrove, ii. 29.

Nedeen, ii. 83 .

Navigations, 90*. 93 *.

National debt, 172 .

O.

O'Connor, i. 305.

Orchards, i. 411 .

Oxen drawn by the horns, ii.

22. 55 .

Oppreffion, i. $3^{8}$.

\section{P.}

Packenham, i. 58 .

Poor, ftate of,'i. 68.98. 145.

151. $263.412 .25^{*}$. $36^{*}$. 40 *. ii. 222. 234. 247.

Portaferry, i. 190.

Products in Ireland, quantity of $13^{*}$.

Provifions, price of, 54 *.

Penfions, amount of, 85 *

Pcople, number in Ireland, 88 *.

Potatoes, oxen fattened on, i. 29.330 .

- hogs ditto, i. 34 .

- fort, ii, 24.63 .

i. 27 .

review of intelligence,

(1) 33 .

Population, i. 98. 263. 412. $85 \%$.

Powerfcourt, i. 133.

Planting, i. 303.62 *.

Public works, money granted for, 89 *.
Palatines, colonies of, ii. 123 . 138.151 .

People, race of, 106 *.

Pafturage, exports, 126 *. 128 *.

Pork, price of, $127^{*}$. Export of, $132 *$

Paffage from Waterford to Milford, ii. 203. Expence of, 206.

R.

Rents, rife of, i. 61. 278 . ii. 129. 147.

Rathan, i. 76 .

Rofs, i. 101.

Ravenfdale, i, 154.

Roftellan, ii. 64 .

Rental of Ireland, 6*.

Roads, 56 *.

Rapes, 112 *.

Revenue, $167 *$.

\section{S.}

Summer-hill, i. 28.

Slaine, i. 37: Mills, 43.

Suckling lambs, i. 126.

Sheep walks, i. $299 \cdot 306$.

Strokeftown, i. 297.

Sligo, i. 338.

Shaen Caftle, i. 78.

Shaen caftle, O'Neil, i. 210.

Silver firs, i. 289 .

Sheep, review of, $76 *$.

Sea weed, i, 342 .

Soil of Ireland, 3 *.

Society, Dublin, $95 *$. Their ridiculous conduct, 97 *

Silk, import of, $99^{*}$.

Stones; means of breaking, ii. 114.

Sheep, exports from, 129 *.

Shannon, fin in, ii. 238.

T.

Tullamore, i. $7 \mathrm{i}$.

Taghmon, i. 107.

Tinnyhinch, 


\section{I $\quad \mathrm{N} \quad \mathrm{D} \quad \mathrm{E} \quad \mathrm{X}$.}

Tinnyhinch, i. 133 .

Turneps, i. 288.405 .ii. 31 . 47.63 .

Tanrego, i. 339 .

Tuam, i. 368 .

Tallow, price of, $127^{*}$.

Townfhend, Mr. his eftabliflment of Englifh farmers, ii. 80 .

Tillage, $15^{*}$. Increafe of, where, $125^{*}$.

Tenantry, $17^{* *}$ Poverty of, 22*. Proper encouragement for, 23 *.

Timber, want of, $62 *$. To what owing, $65^{*}$. Means of preferving, $64 *$.

Tythes, 79*.

Tarbat, ii. 131.

Tipperary, fheep hufbandry, ii. 155 .

Tabinets, $166 *$.

Taxes of Ireland compared with thofe of Britain, 173*.

U.

Union, i. 8r.

Wooditock, i. 1 co.

Whiteboys, i. 102.119.

Wexford, i. 107.

Warrenftown, i. 177.

Weftport, i. 35 '.

Woodlawn, i. 395 .

Wool, imuggling, i. 413 . ii. 67.

Woollen manufacture, ii. 18. 34. 6 t. 68.

Wafte lands, 69 *.

Wool, price of, $130 *$. In Ireland compared with England, 76 *.

Woollen goods, import of, $99^{*}$.

Woodpark, ii. 120.

Woodford, ii. 130.

Waterford, ii. 184.

Weavers earnings, 156 *.

Y.

Yarn, export of, $129 *$. Price of, $130^{*}$.

Yelverton, his famous crop of wheat, ii. 230. 



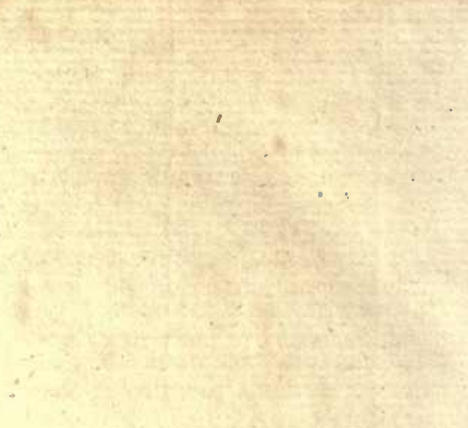




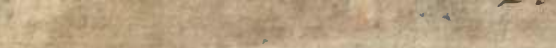


University of California

SOUTHERN REGIONAL LIBRARY FACILITY

405 Hilgard Avenue, Los Angeles, CA 90024-1388

Return this material to the library from which it was borrowed.

Fir. $=2-t$ RL

OCT O? 19911

FEB 131996

QL OCT 082 20O2 

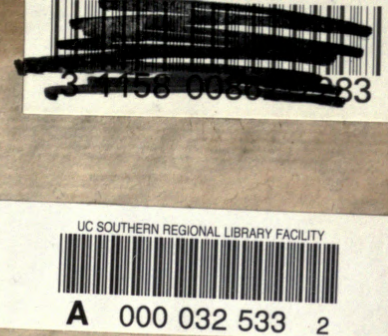


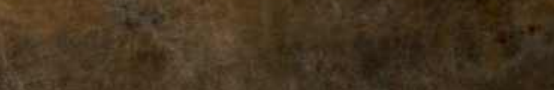

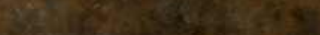

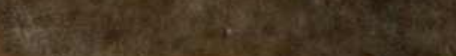

1.

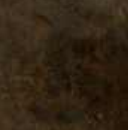

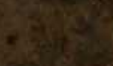

6.

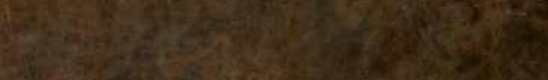

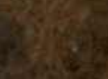

(1)

2

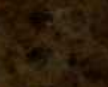

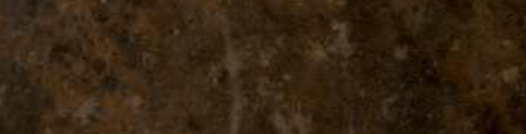

19.8.

$2 x^{2}$
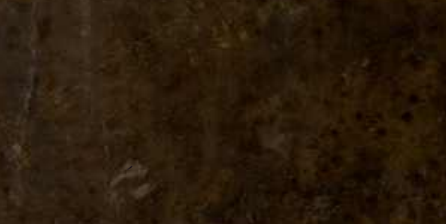

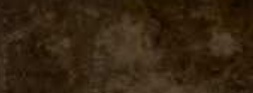

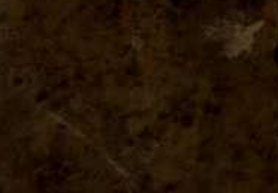

